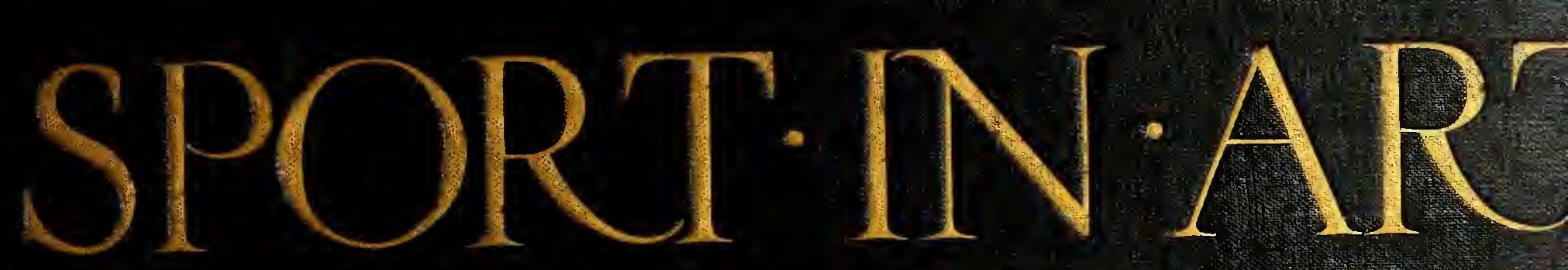

FROM THE FIFTEENTH T THE EIGHTEENTH CENTUR WILLIAM A.BAILLIE-GROHMA

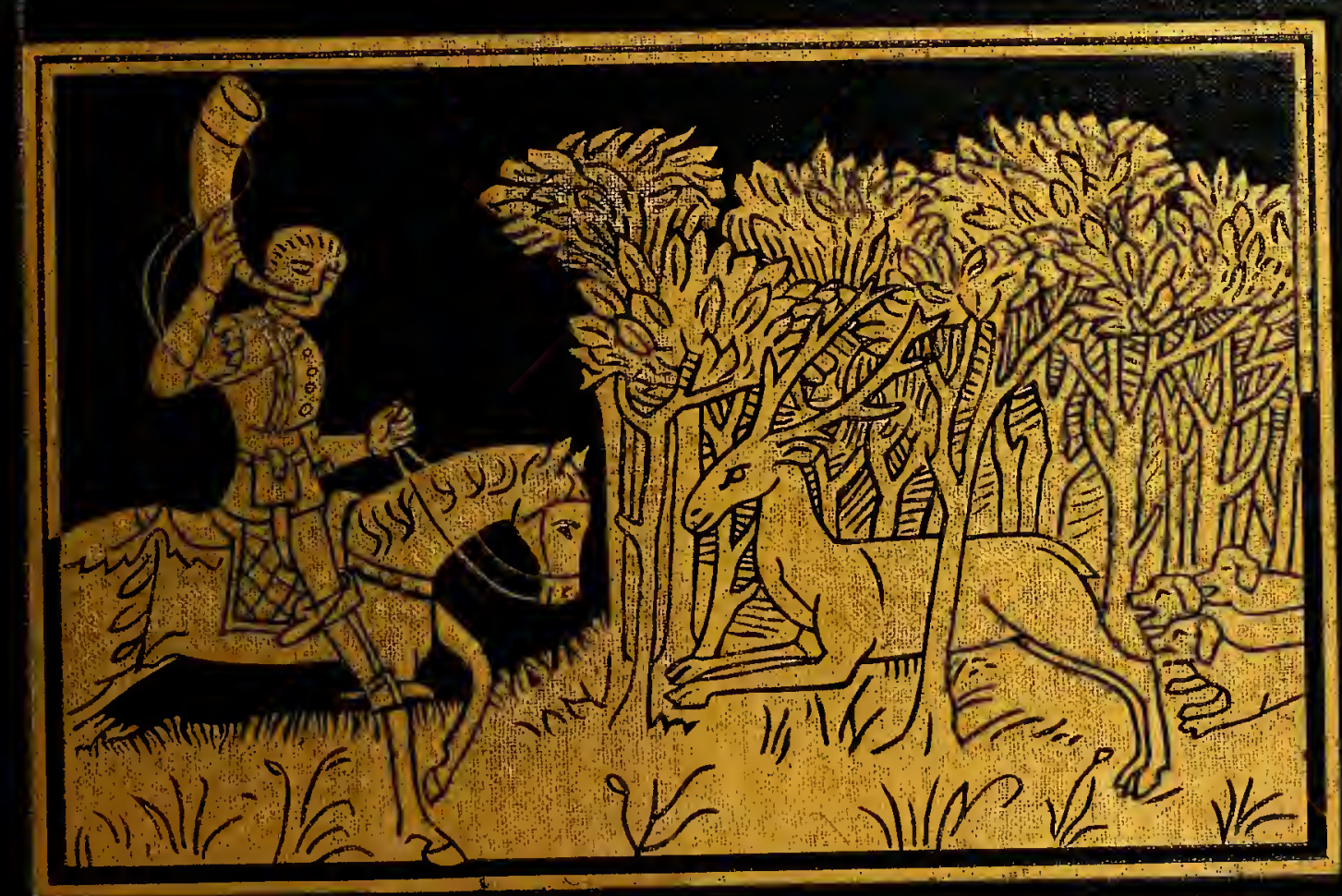




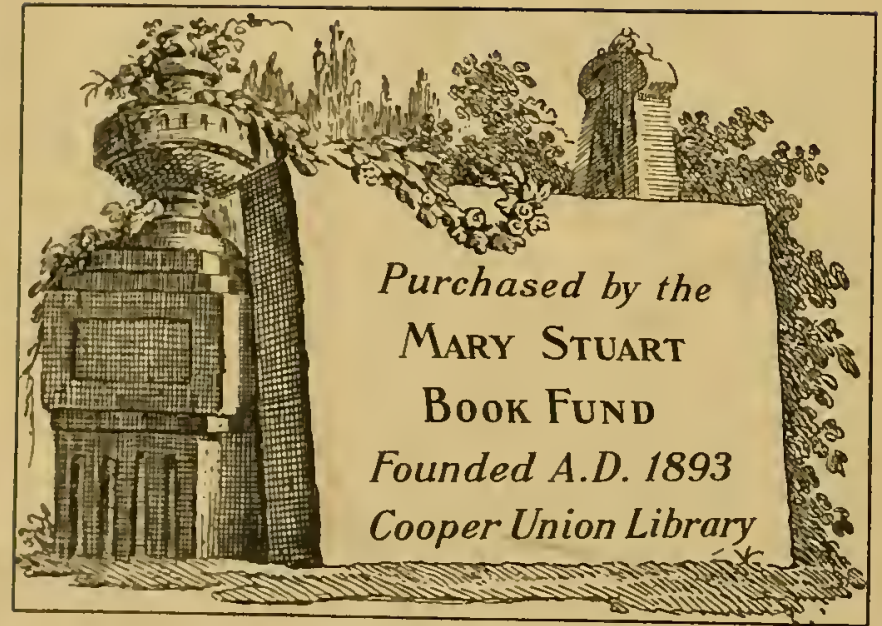




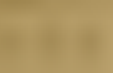

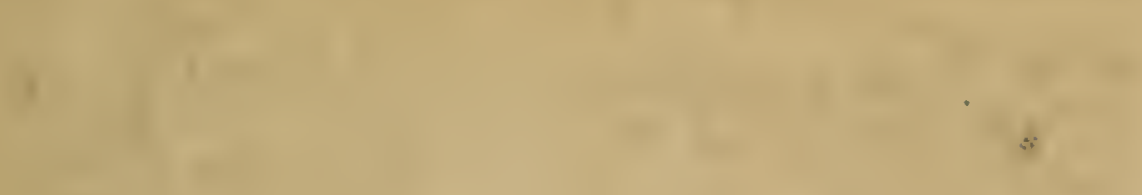

-

(1)

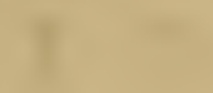

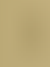

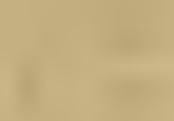

- 



\section{SPORT IN ART AN ICONOGRAPHY OF SPORT}


An Eudition de Luxe consisting of twenty-five copies in special binding is published at f. I $\mathrm{o}$ os, each copy being mumbered and signed 
a

(4)

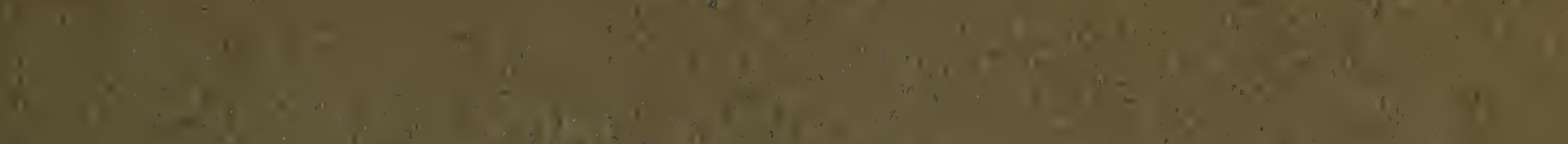

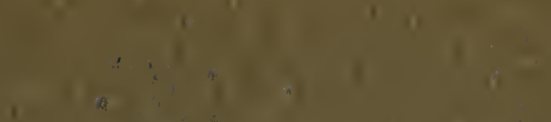

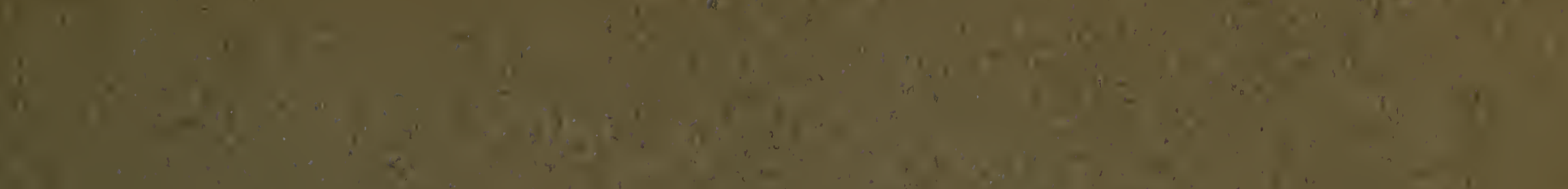

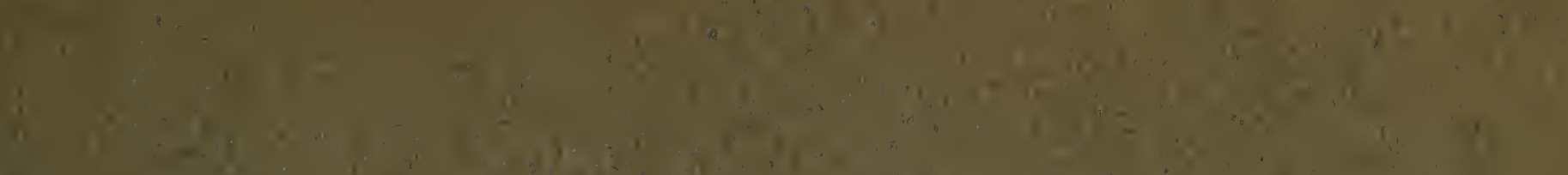

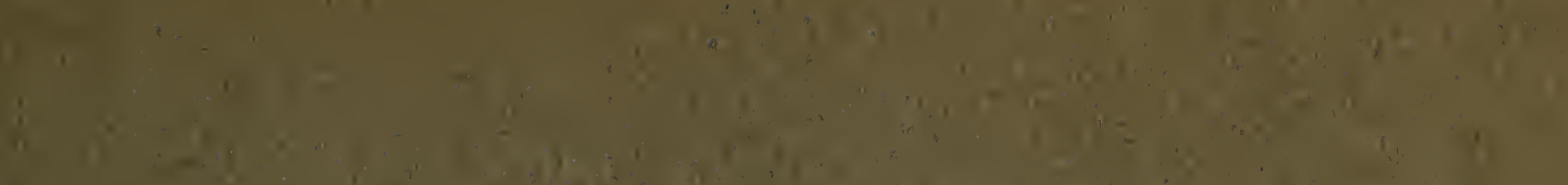

1. $\therefore i x+\cdots$

$\therefore+1+1+1$ (x)

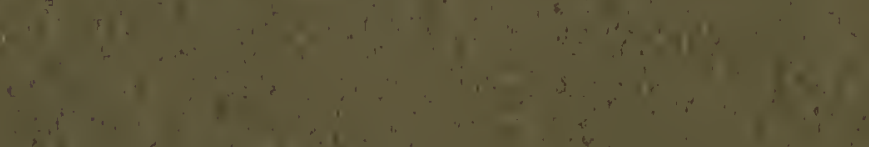

10 $\therefore ; i$

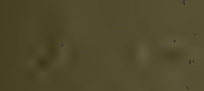

1.15

a

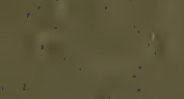

$(n+\infty)$

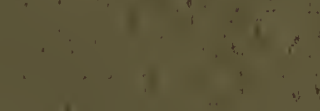

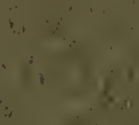

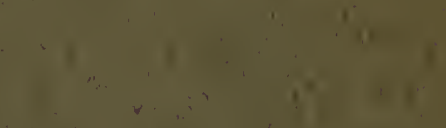




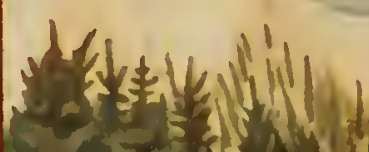

(a)

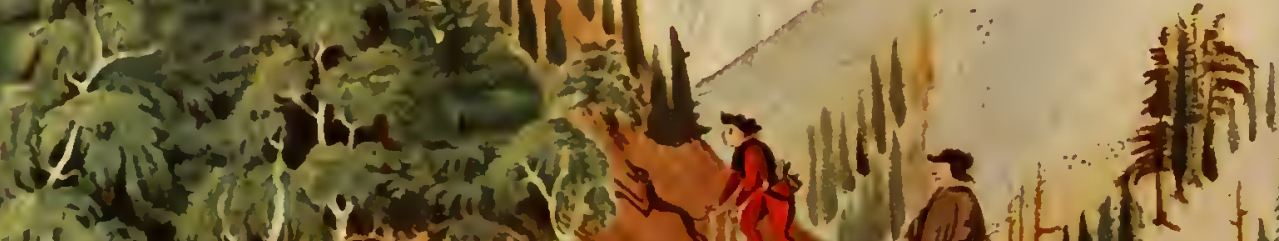

19.

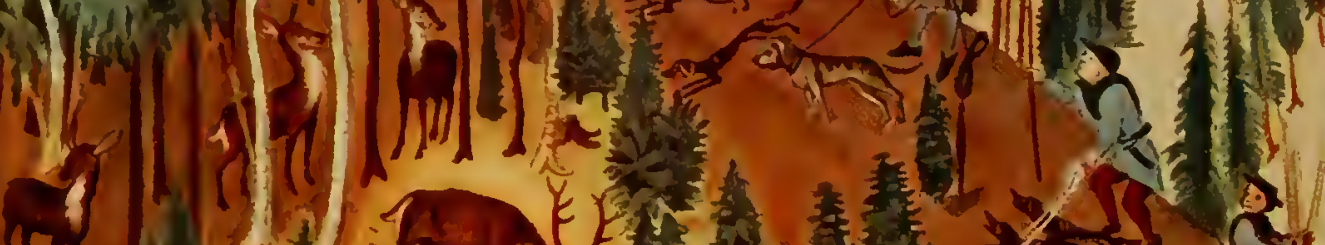

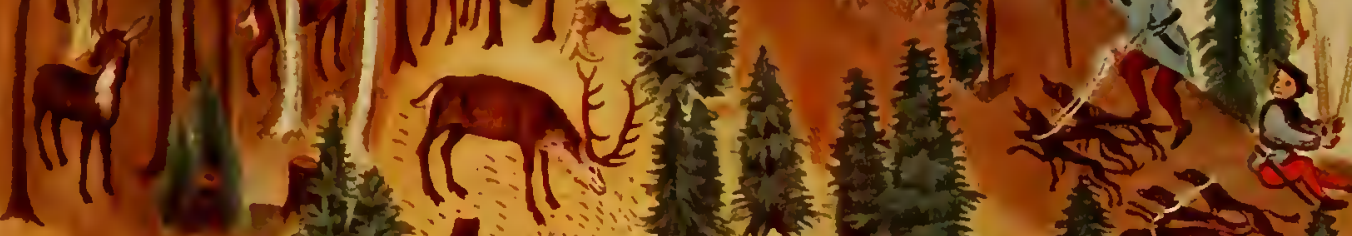

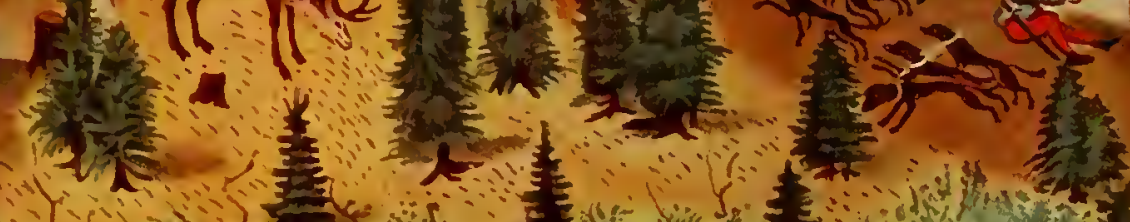

1

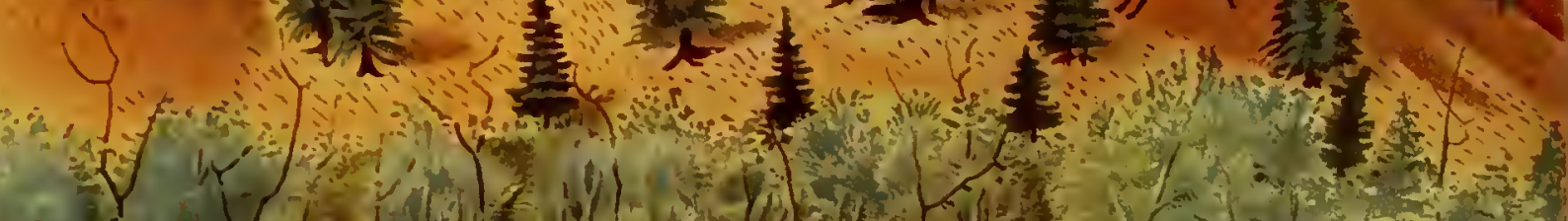
(1)

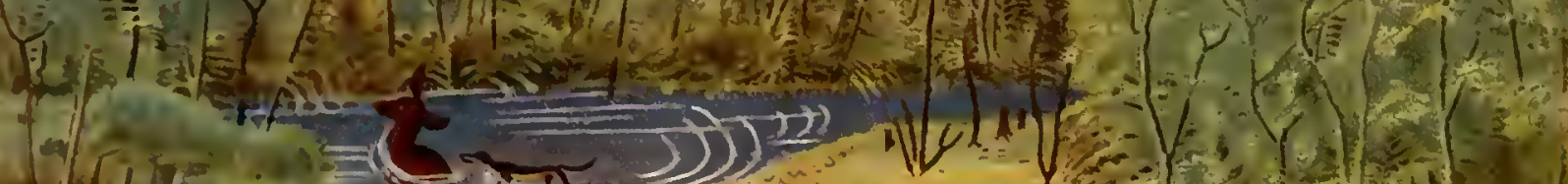

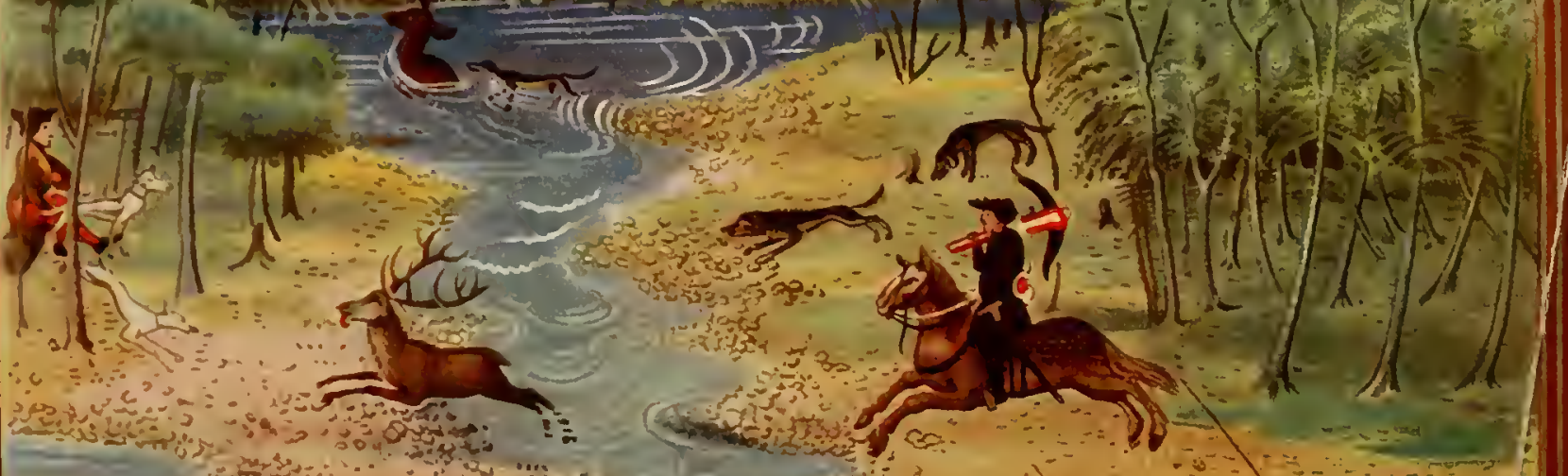
L( 


\section{SPORT IN ART AN ICONOGRAPHY OF SPORT}

DURING FOUR HUNDRED YEARS FROM THE BEGINNING OF THE FIFTEENTH TO THE END OF THE EIGHTEENTH CENTURIES BY WILLIAM A. BAILLIE-GROHMAN AUTHOR OF "SPORT IN THE ALPS," "THE MASTER OF GAME," ETC. ETC.

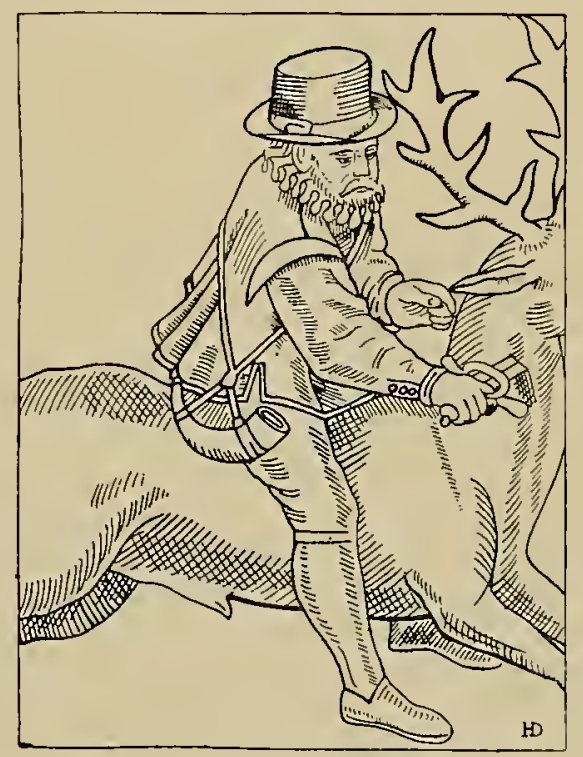

WITH TWO HUNDRED AND FORTY-THREE ILLUSTRATIONS

\section{BALLANTYNE AND CO LTD}

TAVISTOCK STREET COVENT GARDEN LONDON 



\section{PREFACE}

7 HE volume before the reader needs but a brief preamble, for the title tells its story. Pictorial records can under certain circumstances possess greater value than the written word, and the pencil, graver or brush, which produced these "books of a single page," has often rescued interesting incidents from oblivion. "Sport in Art" commences with the fifteenth century, just previous to the invention of printing, and ends with the French Revolution, thus taking in the four centuries that are as vital to the history of venery as they are to that of art.

The present pages do not pretend to give a connected history of field sports, for that would, of course, have demanded an even wider digression from the sphere of art than that of which the author has been guilty. What these pages propose is to let a selection from the available pictorial material tell to those interested in sport the story of the evolutions which hunting, shooting, falconry, and fishing underwent during the above-mentioned four hundred years. Some old pictures of horsemanship, and the first pictorial descriptions of mountain climbing have been included in the last chapters, but owing to the accumulation of matter all games and athletics have been excluded.

In these days of acute specialisation the writer will probably be blamed for attempting to cover such a large field, instead of confining his investigations to one particular kind of sport, or to one period, or to one school of art. The plan decided upon, after much deliberation, was to simplify matters as much as possible by linking together in chronological order the pictorial productions of various countries irrespective of other considerations, and to relegate to the Appendix the less important details regarding the artists and the prints themselves from the collector's point of view. In many cases the information that will be found there was obtained by the writer by personal research in the principal public and private collections abroad.

To avoid tiresome repetitions and yet to deal in a coherent manner with one given subject, all that is to be said about it will be found in the text massed together in one place, i.e. where the subject is first broached. The pictures, on the other hand, will be found in as strict chronological sequence of their production as it was possible to arrange them. Cross reterences will in such cases enable the reader to find that part of the text dealing with the picture in question. By this arrangement it is hoped that those who merely wish to follow the pictorial development of the chase without reference to the text will be enabled to gain a more comprehensive view, decade by decade, master by master, than if all the pictures of different periods concerning any one sport or any one special animal of the chase were put together.

As photography and cheap travelling rates have rendered familiar to most 


\section{PREFACE}

people the contents of the principal galleries of Europe, it has been the author's aim to deal with the lesser-known material stored in private collections, reproducing in the case of what might be termed the classics on the subject, a few of the most characteristic pictures from these tomes. If not otherwise mentioned the reproductions (243) are from drawings, engravings, etchings, and woodcuts in the writer's collection, which though it consists of over three thousand prints and represents many years' work, can claim to be but that of a one-sided amateur, and makes no pretension whatever to be a print collection in the usual sense of the word. For in forming it, the writer, with vandalism personified, was guided solely by the subject of the drawings and engravings and not by their merits from an artistic standpoint. It contains many prints which no self-respecting modern collector would deign to house in his portfolios.

As a rule the keen sportsman concerns himself little with art, and the artist generally lacks experience as well as the opportunity to depict correctly the incidents of sport; happily every century produced a few exceptions to this rule, and, equally happily, great sportsmen occasionally patronised art, while good artists devoted themselves to sport.

$\mathrm{U}_{p}$ to the eighties of last century the knowledge of, and interest in, ancient sporting prints was confined to a very small circle in this country. In those days when circumstances obliged a writer to refer to an old engraving even savants considered it sufficient to call it "A curious old print in the possession of the author." When and where it appeared, by whom the original was painted or designed, and who engraved it, and, finally, whether the scene it represented was an actuality, taken ad vivum as it were, or had sprung from an artist's fertile imagination, was all deemed information by far too unimportant to inflict upon the reader even if the writer happened to know these particulars, which few did. Worse even was the point of view taken by another class of writers. When the author of a more recent well-known standard work on our subject was roundly criticised in the press for the unwarranted exclusion of all essential information regarding the old prints with which he illustrated his chapters, his defence was that "the omission of all information about the prints was intentional," for otherwise, said he, he would be robbed of private information by what might be called legal piracy! Such selfish and unscientific reasoning is now happily a thing of the past.

Research was not encouraged: a well-known sporting weekly, in a leading article on sport in art, remarked not long ago, when referring to the class of prints with which these pages largely deal, that for them "there is no popular demand, because there are not many of them, and what there are are seldom to be bought. "They are therefore little known." There exist, as the reader shall see, some thousands. When the writer, five and twenty years ago, induced, not without some trouble, a friendly editor of a sporting weekly to publish a curious old print accompanied by a description of the same, followed up by some similar conviii 


\section{PREFACE}

tributions, more than one friend warned the writer that by such dry stuff he would lose his readers. "We want to know what we can shoot, when and where," said they, "and not what Noah shot when he came out of the Ark." But the experiment nevertheless succeeded, curiosity was awakened, and the ball was set rolling. To-day, one can scarcely open any sporting publication without finding in it reproductions of old prints. Abroad one such attempt to let selected old prints and pictures tell the story of the development of sport was made by a French writer, the Count de Chabot, who in I 898 published La Chasse à travers les Ages, but it dealt principally with French hunting. In respect to one gap which will be at once discovered by the reader on the look-out for the works of English animal painters of the eighteenth century, an explanatory word must be added. We have refrained from dealing with these well-known prints because abler writers have repeatedly described and republished them, Sir Walter Gilbey's publications and Mr. Ralph Nevill's "Old Sporting Prints" doing full justice to the subject. It is perhaps as well to say that when we speak of "old prints" we do not refer to the comparatively modern prints of the last century, sometimes called "old," much on the same principle that a chair or a table older than a generation or two is called "antique," but we mean pictures of preceding periods. Of these there is even to-day not a single collection in this country, at any rate none that is open to the student, and no publication has so far dealt with the subject in a collective manner.

That the present iconography of sport, for as such we may describe our attempt to bring a semblance of order into a vast mass of matter, will be found wanting in very many respects by sportsmen as well as by art lovers and collectors, goes without saying. Let us hope that it may lead to better things.

In conclusion, it must be mentioned that a number of the pictures reproduced in the present volume have appeared in various publications, such as Country Life, Burlington Magazine, Connoisseur, Magazine of Art, Monthly Review, Baily's Magazine, Gentury, Pall Mall Magazine, Land and Water, Illustrated English Magazime, Sporting and Dramatic, \&c., for, unlike the text of these pages, which is now presented in an entirely remodelled and connected shape, it was impossible to recast the pictorial material, though, in consequence of the increased size of the present pages, it was possible in some instances to reproduce drawings and prints in larger dimensions than those used for magazine articles. The writer's thanks for permission to reproduce previously published material are due not only to the Editors of the above illustrated periodicals, but also to the Editors of the Quarterly Review, Nineteenth Century, and Fortnightly Review, who at various times during the last quarter of a century have permitted contributions on old sport by the writer to appear in their pages.

Schloss Matzen, Trrol.

WILLIAM A. BAILLIE-GROHMAN 



\section{CONTENTS}

\section{PREFACE}

\section{CHAPTER I}

Illustrates the circumstance that, as bunting was made the subject of the earliest pictorial designs, bunters can rigbtly claim to have given the first impulse to art: Mousterian man in bis cave no self-assertive modern sportsman: Stone bammer imbedded in skull of "Megaceros Hibernicus" : Bear's skull with flnt arrow-bead sticking in it: The discoveries in the Altamira cave and in French caverns: Hunters of Assyria and Babylon : Greek training for sport and its literature: Xenopbon's "Cynegeticus" and the Gaul bunters in Casar"s time: Charles the Great and the various "Bestiaries": Saxon bunting with "bayas": The Bayeux Tapestry: The Teuton bunter: William the Conqueror and bis time: Gradual growth of material: What pictorial records show us, and for whom they are of interest

\section{CHAPTER II}

Gaston de Foix's great bunting-book, "La Livre de Chasse" : Where the finest copy is kept: Its exceptionally beautiful miniatures : Who possessed this copy, dramatic incidents connected with it, and the bistorical personages who owned it at different times: What Gaston de Foix tells us about writing it: Froissart's account of Gaston, bis castle of Orthez and bis bounds: The eigbty-eight miniatures it contains: What mediceval bunting was like, and the spirit of chivalry it evinced: The tufter or berner, and bis lymer or track-bound on the stag's line: The bunt breakfast or gathering and what was discussed there: The "laisser courre" or the use of running bounds: How the stag was undone and the "curée": Wild-boar bunting and the bounds used for it: Hare-bunting and various devices to net and trap bares: Hunting crops, use of them in thick coverts: Otter-bunting and the "baton fourcbie" : Wolf-bunting in France and the "louveterie": The "Hausse Pied" trap: Ibex-and chanois-bunting, sport for peasants : Stalking and shooting big game with crossbows and long-bows: The "Charrette" or stalking-cart : Reindeer-and bear-bunting : Gaston's 1600 bounds and what be says about their treatment: Five species employed for bunting : Gaston teaching bow the hunting-born was blown: Various bistorical borns

Pages 5 to 35

\section{CHAPTER III}

The "Treasury of Venery" and other ancient books on venery: The "Libro de la Monteria," written by King Alfonso of Spain : The "Master of Game" translated into English by Edward, second Duke of York: The aurochs and the bison, confusion between these two animals: Charlemagne's great bunts, during one of whicb be nearly waskilled by an aurochs: Earliest known pictures of them: Their presence in Crete: The "Chronicle of Constance," describing the aurochs sent from Poland to the King of England: T he Knossos fresco and the Ebsdorp map : The "Tresslerbuch" of the Teuton order, giving accounts bow aurochs were sent to monarchs : Albrecbt Diirer's designs for Emperor Maximilian's Prayer Book : "Adam and Eve": Hirschvogel and Baron Herberstein's travels in Russia: The last surviving 


\section{COXTEXTS}

herd of aurochs in Poland: Stradamus', Hans Bol's. Topsell's, and Clarke's pictures of the animals: The "American aurochs" of Hol balb: The Hamilton Smith picture: Ridinger's prints: Tohn van Eyck picture: The Duke of Devonshire's famous bunting tapestries: Lonis .I's bunts: The "Crimani Breviary" and other Books of Hours containing bunting scenes

Pages 36 to 55

\section{CHAPTER IV}

Emperor Maximilian as sportsman and author, bis modern ideas, variety of bis works, "Weisskunig" and "Thenerdank": His bunting-and bis fishing-book: Re-finding of the former: By zubom it was curitten and illustrated: Maximilian's sporting ardour and attention to details: His dislike to fire-arms for the chase: His "Secret Book of the Chase" : His chamois-bunts, and bow the animals were killed: How the stag was bunted: Maximilian's busy. days, fishing and shooting at the same tine: The Court few a necessary evil in the impecunious days of the great sportsman : Maximilian's fishing metbods, and what fish were known: Sporting feats narrated by bimself and curious incidents: His escapes from death and adventures while chamois-bunting : His son's dislike of mountain sport: A celebrated fresco in Castle Tratzberg with antlers of stags killed by bim: "Les belles Chasses de l'Empereur Maximilien," by Bernbard van Orley, with an account of the cartoons and the famous tapestries made after them: Maximilian's bunts in the forest of Soigne, near Brussels: Mary of Burgundy and ber sad deatb: The bunting lodges of the Dukes of Brabant and bow poachers were punished: Maximilian's boar-bunts and incidents of the chase

\section{CHAPTER V}

Pages 56 to 84

Albrecbt Diirer's engraving of St. Hubert, and other artists' representations of the same scene: Dïrer's designs for the Emperor's Prayer Book and who assisted in its completion: Goethe's "Dammbirsch" : Recent discoveries by Dr. Harry David: Dürer's picture of an elk : Germany's last elk: Dürer's woodcut of an Indian rbinoceros: Lucas Cranacb's sporting scenes and his stag-bunt, at which Charles $V$ was present : Combined weapons : Scotch bunting ordinances and date when fire-arms came into more general use in different countries: Mary Stuart as buntress: Facques du Fouilloux and bis "Sportsman's Bible" : His love for the chase and bis aniorous adventures: Fean de Clamorgan, the great wolf-bunter, and bis book: Badger-digging and opinions about it: The "Charrette": Turbervile's translation of du Fouilloux's "Vénerie," called "T Te Noble Arte of Venerie" : Description of the book and of its two editions, and points of difference: Its illustrations and the juggling that took place to alter pictures representing Queen Elizabeth into likenesses of Fames I : Quaint customs observed by the Queen; " taking assay" : Foreign princes visiting England and their accounts of the sport they enjoyed: French bunting experts called to England by fames 1, and their opinions of English sport: Fobn Selwyn's great feat in Oatland Park and its memorial : Baron Rothschild's engraved antlers, for which be paid $£ 600$

\section{CHAPTER VI}

Pages 85 to II 4

Stradamus" origin and change of name: The "Arazzia Medica" of Florence and bis employment there: Making a commercial success of the enbanced public demand for sporting pictures: Artists who worked after him: Stradanus" fine series called the "Venationes" xii set: The writer's collection of drawings by bim: Mountain sport not one about which 


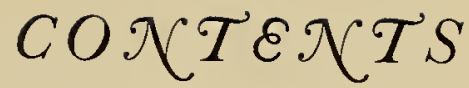

Stradanus knew much : chamois with reversed horns, and ibex as plentiful as rabbits: Men in armour fighting bears: Wild-fowling as depicted by Stradanus: Quail-netting : The "swift English dogs": The chase of the cony, and bare-bunting with leopards : Stradanus" pictures of African sport: His fishing pictures and the methods then entployed: The various series of engravings issued by Stradanus : Stradanus' drawing of Vespucci's Landfall, which is the earliest delineation of American fauna: White's pictures of America and incidents of sport

Pages I I 5 to I 45

\section{CHAPTER VII}

Hans Bol and bis "Venationis" set of pictures : The duck decoys, and wild-fowling : His fisbing pictures and drawing of aurocbs-baiting : Vincboons and other Dutch artists : Theodore de Bry and his works on American exploration: Le Moyne and White; Laudonniere, Hakluyt and Raleigh: A curious "off-take" : Indian sports as depicted by $T$ b. de Bry: Tempesta and bis productions : His aurocbs-bunt and picture of lady riding astride: Merian and Frisius

Pages I 46 to 168

\section{CHAPTER VIII}

The chase and art in the first half of the seventeenth century: Hendrik Goltzius: Martin de Vos and Crispin de Passe: Pieter de Witte or Candid, and bis influence on art in Bavaria : The "Hunting Chronicle" of the Duke of Coburg, drawn by Wolff Pirkner: The duke's bistory: His dwarfs and bis sport: The various metbods of bunting depicted in the Chronicle: Hunting ceremonies, and how stags were weighed and broken up: The Curée: Huge bags made in that century by German princes and particulars of same: The services of the chase which the peasants bad to render, and the cruel way the peasantry was abused: Ferocious punishments inflicted upon poacbers: The diaries of princes and their letters to each other: Sport in Spain: The art of shooting flying: Italian origin and the earliest picture of it drawn by the Venetian Giacomo Franco: The "chasse cuisiniere" in France, and some ferocious regulations: Blome's instructions to English sportsmen: Combats between wild animals and bow they were arranged: Presents of various wild animals exchanged by princes : T he pictures of great masters of little value in illustrating bunting customs : A curious bunting calendar and scoring appliance in the British Museum among the treasures in the Rotbschild Bequest

Pages 169 to 196

\section{CHAPTER IX}

Barlow's series the most interesting set of English bunting prints: He describes bare-bunting, cony-catching, river-fishing, salmon-fisbing, angling with the line, beron-bawking, pheasantbawking, partridge-bawking, otter-bunting, coursing fallow deer, stag- and fox-bunting : Other English artists and their pictures, amongst which Blome's contributions are the most important : Italian bunting a very degenerate sport; pictures of stoning a stag at bay and other unsportsmanlike proceedings in the "Venaria Reale": The extraordinary get-up of princes and princesses when bunting:Wouverman and van der Meule: Amling's drawings of Bavarian royalties going bawking

Pages 197 to 223 


\section{CO入TEגTS}

CHAPTER X

Wiltcull and Disportes: Louis. IIT's son and grandson as sportsmen: Eally mezzotints on sport by the Thomans of. Augsurg; chamois-bunting and smoking foxes out of the earths: Satirical Dutch sporting prints and bow they lampooned sport: Fleming's "Teutscher Yiger," Germany's most important work on sport of the eighteenth century: How they hunted at Girmain courts, and fort-tossing as a favourite amusement: How it was conducted ant the carions abuses it led to: A stag-bunt at the Bavarian court, where the "Bucentaur" " came into use: Hunting in France and Oudry's famous tapestries illustrating "Les Chasses de lonis $1 \%$ : II is position as artist: Carlo wan Loo, Boucher, Lancret, and the various inmons engracers sebo worked after them: The brothers Y an Haecken's work in England and tico portraits by them: The custom of branding bounds of German origin, when it came in and what English packs were so marked: Tcnier's pictures engraved by Thomas Major: Martin I"achsmutb: Discharges given to apprentices

Pages 224 to 256

\section{CIIAPTER XI}

Ridinger the most famous animal-panter of Germany: His work and life: How and where be liarnt bis art and bis gradual rise: His engravings as works of art, modern replicas: What Landscer thougbt of bim: His various series-"Gumers and bawkers," and the many interesting incidents the depict: His pictures of bawking, their merits and faults : Books on falconry: "The most wonderful stags" series; the great sixty-six pointer and what was obtuined in cxchange: Stags shot by the Dukes of IV iurttenberg : Proceedings during the rutting season; High Churcbmen as sportsmen: The rulers of Hesse and their white stags: thnormal antlers and the great esteem in which they were beld: The apocrypbal ariat stug of the Ardennes: Stags shot in Servia: Coats of mail used for bounds in wildboar bunting : Strange capture of a fox by a pike

Pages 257 to 305

\section{CHAPTER XII}

Other scts by Ridinger-"Curious events," "The manner of capturing wild animals," and "Sporting aumals and their tracks": "The fights of wild animals" and "Contemplation of culd animals." and the verses: Ridinger, a lover of borses, produces a great number of Dictures: His sets-." The borses of different nations," "I"arious operations on borses," "The ncw art of riding," and "The new riding-school" : In a series, "Description of the school and campaign borses," and in another. "The carousel," the artist deals with riding-school performances, but the best is bis fine set called "T be large riding-school": Reproductions from this sct coplain the art of training horses: "The Paradise" set and the "Four scasons of the Hound" : Ridinger"s drawings: "Par force" bunting, the French manner of stag-bunting; where it differed from otber bunting: How it came to be introduced into Germany; its unsuntableness for that country and how it impoverished the courts: The principal incidents of "par force" bunting and the terms in use as described by Ridnnger: The best pictorial account of French bunting designed by a German artist: Old French books on vencry: Mcntion of Irish bunters in French works: The bunting crop, and curious customs connected with it: Ridinger's mezatints-the great stag pulled down by four lynx: Ridinger's mezzotint portraits: English artists or foreignersliving in England engrawing after Ridinger; rare sets produced by them: The "American Buffalo," by $\mathcal{F}$. S.

1/iller: Ridinger's portrait : Delightful French prints of the eighteenth century depicting 


\section{COXTEXTS}

sport: Henry IV's adventure with the charcoal-burner : The Dauphin's sport: Hounds devouring their master

Pages 306 to 337

\section{CHAPTER XIII}

The pictures of de Saussure's ascent of Mont Blanc: Dr. Paccard and Facques Balniat: "La Montagne à travers les Ages": When was the name Mont Blanc first used? : Ch. de Mechel publishes first pictures of expedition: Siory of the two plates suppressed on account of undignified position of de Saussure: Question of who designed these plates-five aspirants, and opinions concerning them : Swiss bave done little to examine into question: Great stir made by de Saussure's feat: Mountaineering details seen from the pictures proving astonisbing ignorance of the first principles of mountaineering : "Fortune est nourrice de Folie" : Otber pictures of the conquest of the Alps: An earlier picture of the ascent of the Gross Glockner: The writer's inexperience, and ignorance of winter climbing when be made the first winter ascent of the Gross Glockner : Lucky escape fron death: The tribute exacted by great peaks

Pages 338 to $35 \mathrm{I}$

\section{APPENDIX}

Giving brief biograpbical notes about some of the artists mentioned in the text, arranged in alpbabetical order

Pages 353 to 410

INDEX

Pages 4 II to 422 



\section{LIST OF ILLUSTRATIONS}

EMIPEROR MIAXIMILIAN STAG-HUNTING. Out of bis "Hunting-Book," woritten I+99-I500 Frontispiece "[PaGe

Fig. I. THE TUFTER WITH HIS LYMER. From Gaston de Foix

To face p. 6

Fig. 2. THE HUNT BREAKFAST. From Gaston de Foix

Fig. 3. HOW THE STAG WAS ROUSED AND HUNTED. From Gaston de Foix

Fig. +. BREAKING UP THE STAG. From Gaston de Foix

To face p. то

Fig. 5. HARE-HUNTING IVITH GREYHOUNDS. From Gaston de Foix

Fic. 6. BUSTLING HARES OUT OF CORNFIELDS. From Gaston de Foix

Fig. 7. FOX-HUNTING ABOVE GROUND. From Gaston de Foix

To face p. 16

Fig. 8. OTTER-HUNTING. From Gaston de Foix.

Fig. 9. WOLF-HUNTING. From Gaston de Foix

FIG. Io. HOW THE WOLF-TRAP WAS WORKED. From Gaston de Foix

Fig. II. HUNTING THE IBEX AND CHAMOIS. From Gaston de Foi.x

Fig. I2. SHOOTING DEER IVITH BOIVS. From Gaston de Foix

FIG. I3. SPORTSMAN IN STALKING-CART. From Gaston de Foix

Fig. I4. CARE OF INJURED AND SICK HOUNDS. From Gaston de Foix

Fig. 15. THE RUNNING HOUND. From Gaston de Foix

Fig. 16. NETTING HARES WITH LOW-BELLS. From Gaston de Foix

Fig. 17. NETTING HARES AT CROSS-ROADS. From Gaston de Foix

Fig. 18. HOW TO BLOW THE HORN. From Gaston de Foix

Fig. 19. EIGHT HUNTING MINIATURES. Out of Fontaines-Guérin's IIS.

Frg. 20. DEAD AUROCHS SENT TO KING OF ENGLAND IN I +17

To face p. 36

Fig. 21. FALCONER. By Fobn wan Eyck

To face $p .3^{8}$

To face $p \cdot 4^{2}$

Fig. 22. FLEMISH TAPESTRY IVITH HUNTING SCENES

Frg. 23. FLEMISH TAPESTRY IVITH HUNTING SCENES

Fig. 24. BEARS AND WOLVES ATTACKING HUNTERS

FIG. 25. BREAKING UP THE BOAR. Out of the "Grimani Breviary"

Fig. 26. EMPEROR IIAXIMILIAN SHOOTING AND FISHING

To face p. 56

Fig. 27. A CHAMOIS DRIVE. Out of the "Hunting-Book"

FIG. 28. MIXED SPORT NEAR INNSBRUCK

FIg. 29. SHOOTING AND FISHING ON THE "PLAN SEE"

60

FIG. 30. TROUT-FISHING IN THE "WILD SEE"

6I

Fic. 31. FISHING WITH NETS

62

Fig. 32. CATCHING CRAYFISH 


\section{LIST OF ILLUSTRATIOXS}

FIC, 33. FRESCOES AND STAGS' ANTLERS IN CASTLE TRATZBERG

Fic. 34. THE HLNTS OF EMPEROR MILLAMLIAN. Tapestry

Fig. 35. THE HLXTS OF EMPEROR MAATMILIAN. Tapestry

Fic. 36. THE HUNTS OF EMPEROR MANIMILIAN. Cartoon

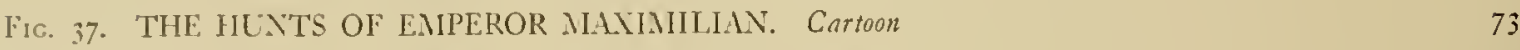

Fig. 38. THE HUNTS OF EMIPEROR MALTMILIAN. Cartoon 74

Fic. 39. THE HUNTS OF EMPEROR MILIMIILIAN. Cartoon 75

Fic. fo. THE HUNTS OF EMPEROR MLANTMILIAN. Cartoon 77

Fit. 4i. THE HLNTS OF EMIPEROR MALIMILIAN. Cartoon 78

Fic. t2. THE HUNTS OF EMPEROR MiAXIMILIAN. Cartoon $^{2}$

Fig. +3. TIHE HUNT'S OF EMIPEROR MLATIMILIAN. Cartoon 8I

FIG. H. DÜRER'S ARCHER. Painted about I 500

Fig. 45. DC̈RER'S "ST. HUBERT." Engraved about I505 89

Fic. +6. DÜRER'S DESIGN FOR EMPEROR MIAXINIILIAN'S PRAYER BOOK

FIG. 47. DÜRER'S DRAWING OF A BISON 93

FIG. + 8. DÜRER'S DRAWING OF A IOLNG ELK 93

Fic. 49. DÜRER'S WOODCL'T OF RHINOCEROS 94

Fig. jo. LLCAS CRANACH'S "ATONEMENT," Engraered I509 95

Fic. jI. LUCAS CRANACH'S PAINTING OF A STAG-HUNT

Fic. 52 . DELAUNE'S "COMBAT WTTH WILD ANIMIALS" 98

Fic. 53. GERMLAN WOODCUT, "PRESENTING THE DROPPINGS" 99

FiG. 5+. GERMAL WOODCUT, "GOING OUT BADGER-DIGGING" IOI

Fig. 5j. QUEEN EIIZABETH ON HER "STINDING" 103

Fig. 56. QLEEN ELIZABETH "TAKING ASSAY" IO6

FIG. 57. KING JAMES I "T.IKNG ASSAY"

Fig. 58. JOHN SELWYN'S FEAT IN O.ATLAND PARK IIO

Fig. 59. ENGRAIED ANTLERS BOUGHT BY BARON ROTHSCHILD II

Fig. 60. Chlinols-HLNTING. Dracuing by Stradanus $\quad$ i16

Fic. 6r. DEER-HLNTING. Sepia drawing by Stradanus $\quad$ To face p. 116

Fic. 62. BEAR-HUNTING. Sepia drawing by Stradanus $\quad$ II7

FIc. 63. MEN IN ARMOLR FIGHTING BE:IRS II8

Fig. 64. HERON-HAWKING. Draxing ly Stradanus 1

Fic. 65. DLCK-SHOOTHG. Dracting by Stradanus To face p. 120

Fig. 66. SWLN-SHOOTHNG. Draxing by Stradanus To face p. I20

xviii 


\section{LIST OF ILLUSTRATIOXS}

Fig. 67. PARTRIDGE-STALKING. Drawing by Stradanus

To face $p . \mathbf{I} 20$

Fig. 68. NETTING QUAIL. Engraved after Stradanus

Fig. 69. RABBITING WITH SIVIFT ENGLISH DOG. Engraved after Stradanus

Fig. 70. SMOKING OUT RABBITS IN A WARREN. Engraved after Stradamis

FIG. 7I. DIGGING OUT BADGERS. Tapestry after Stradanus

Fig. 72. HARE-HUNTING WITH THE LEOPARD. Engraved after Stradanus I29

Fig. 73. ELEPHANT-HUNTING. Drawing by Stradanus I30

Fig. 74. ELEPHANT-HUNTING. Engraved after Stradanus

FIG. 75. OSTRICH-HUN'TING. Drawing by Stradanus $\quad 133$

Fig. 76. FISHING BY NIGHT. Drawing by Stradanus $13+$

Fig. 77. FISHING WITH NETS. Drawing by Stradanus $\quad$ I35

FIg. 78. FISHING IN THE ARNO. Drawing by Stradanus ${ }_{1} 36$

Fig. 79. AN ARENA FIGHT BETIVEEN AUROCHS AND OTHER BEASTS. Drawing by Stradanus $\quad$ I37

FIG. 8o. FOX-AND HARE-HUNTJNG. Engraved after Stradanus $\quad{ }_{13} 8$

Fig. 8I. A SIXTEENTH-CENTURY DIANA. Engraved after Stradanus I I39

FIg. 82. HUNTING THE WILD CAT. Tapestry after Stradanus $\quad \mathrm{I}_{4} \mathrm{O}$

FIG. 83. PORCUPINE-HUNTING. Tapestry after Stradanus $\quad \mathbf{I}_{4} \mathrm{I}$

FIG. 84. WILD-BOAR HUNT. Tapestry after Stradamus I+3

Fig. 85. VESPUCCI'S LANDFALI. Drawing by Stradanus To face $p .14^{2}$

Fig. 86. A DUCK DECOY. By Hans Bol I+7

Fig. 87. DUCK-SHOOTING WITH SPANIELS. By Hans Bol $\quad{ }_{447}$

Fig. 88. AUROCHS-HUNTING. By Hans Bol $\quad$ I 47

Fig. 89. PARTRIDGE-SHOOTING AND HAWKING. By Hans Bol I5I

Fig. 9o. RIVER FISHING. By Hans Bol ${ }_{15} \mathrm{I}$

Fig. 9I. SALMON-NETTING. By Hans Bol $\quad{ }^{15}$ I

Fig. 92. FISHING IN STILL WATERS. Designed by David Vincboons

Fig. 93. DUTCH HAWKING. Designed by David Vincboons $\quad$ I55

FIG. 94. VARIOUS DUTCH SPORTS. Designed by David Vincboons $\quad{ }_{156}$

Fig. 95. HOW INDIANS APPROACHED DEER. By $T$ b. de Bry 157

Fig. 96. SEAL-HUNTING. By $\tau$ b. de Bry $15^{8}$

Frg. 97. HOW INDIANS CAUGHT WHALES. By Th. de Bry 159

Fig. 98. HOW INDIANS KILLED ALLIGATORS. By $T$ b. de Bry 160

Fig. 99. THE AMERICAN BISON. By $T$ b. de Bry I6I

FIG. IOO. T'HE LEGEND OF ST. HUBERT. Engraved after a painting by Muzuluio 162

xix 


\section{LIST OF ILLUSTRATIOXS}

Fis. IOI. BOAR-HLNIING. Disigned and engraed by Tempesta

FIG. 102. AN $\lambda$ LRCCHS HLNT. Designed and engrased by Tempesta

Fic. 103. $\triangle \mathrm{DLCK} \mathrm{DECOI}$. Disigned and cngraeed by $T_{\text {cmpesta }}$

FIG. 104. LADY RIDING ASTRIDE. Disigned and engraved by Tempesta

F1G. 105. GOLTZILS' ENGRIVING OF BOY WITH HOLND

FIG. 106. GOLTZILS' ENGRAIING, "HUNT AFTER WEALTH"

Fig. 107. ALIEGORIC:II, ENGRIVING. By Saenredam

Fic. 108. THE " SPORTS OF THE MIR." By M. de Voss; engraved by Crispin de Passe

Fig. rog. TAPLSTRY DEPICTING STAG-HUNTING. After P. de I" itte

Fic. IIO. BISON OUT OF TOPSELL'S "HISTORIE OF FOURE-FOOTED BEASTES"

FIC. II. COBURG CIIRONICI.E, SETTING UP THE SCREENS

FIC. I12. COBURG CHRONICLE, SHOOTING DEER

FIG. II3. COBURG CHRONICLE, WEIGHING OF STAGS

FIG. II . COBURG CHRONICLE, RETURNING FROM THE CHASE

FIG. 115. COBURG CHRONICLE, HOW STAGS WERE UNDONE

FIG. 116. COBURG CHRONICLE, "THE CUREE"

FIG. II. PAGE OUT OF HLNTING DIARY OF ELECTOR JOHN GEORGE

Fig. 118 . VENETIANS SHOOTING WILD FOWL. By G. Franco

Fig. IIg. COMBATS OF WILD ANIMALS IN DRESDEN

FIG. II9A. SCORING APPLIANCE IN THE ROTHSCHILD BEQUEST

FIG. 120. BARILIV'S PICTURE OF HARE-HUNTING

FIG. I21. BARLOW'S PICTURE OF CONY-CATCHING

FIG. 122. BARLOW'S PICTURE OF RIVER FISHING

FIG. 123. BARLOIW'S PICTURE OF SALMON-FISHING

FIG. I24. BARLOW'S PICTURE OF ANGLING

I'IG. 125. BARLOIV'S PICTURE OF HERON-HAWKING

Fig. 126. BARLOW'S PICTURE OF PHEASANT-HAWKING

F1c. 127. BARLOW'S PICTURE OF PARTRIDGE-HAWKING

Fic. 128. BARLOW'S PICTURE OF OTTER-HUNTING

FIG. I29. BARLOW'S PICTURE OF COURSING FALLOW DEER

I'Ic. 13०. BARLOW'S PICTURE OF STAG-HUNTING

FIG. I31. BARLOW'S PICTURE OF FOX-HUNTING

FIG. 132. THE I.EGEND OF ST. HLBERT

Fic. 133. THE WOLF-HCNT. Engraied afier A. wan der Mculen 


\section{LIST OF ILLUSTRATIOXS}

Fig. I34. STONING A STAG AT BAY. Designed by Branbil 212

Fig. I35. "LA VENARIA REALE," LADIES STARTING FOR THE HUNT. Engraved by G. Tasniere 213

Fic. 136. "LA VENARIA REALE," BOAR-HUNTING $2 \mathrm{I}_{4}$

Fig. I37. "PEARCHING" PHEASANTS. Out of Blonee 215

Fig. I38. OTTER-HUNTING. Out of Blome 215

Fig. I39. SHOOTING FROM HORSEBACK. Out of Blome 216

Fig. I40. SHOOTING ON THE WING. Out of Blome 216

Fig. I4I. THE ELECTRESS OF BAVARIA GOING HAWKING. By Amling To face p.216

Fig. I42. THE ELECTOR OF BAVARIA GOING HAWKING. By'Amling To face p. 220

Fig. 143. WATTEAU'S "RETURN FROM THE CHASE" To face p. 224.

Fig. I44. DESPORTES' PORTRAIT OF HIMSELF To face p. 224

Fig. 145. THE WOLF-HUNT. By Desportes 229

FiG. 146. THE DAUPHIN LOUIS. By B. Picard 230

Fig. 147. LOUIS OF FRANCE. By N. Arnoult 230

Fig. I48. CHAMOIS-HUNTING. By T.H. Thoman 23 I

Fig. I49. SMOKING OUT FOXES. By T. H. Thoman 232

Fig. 150. HERON-HAWKING. By T. H. Thoman 233

Fig. 151. THE AUROCHS. Out of Clarke's "Fulius Cresar" 234

Fic. I52. "THE ANTIENT HUNTING NOTES"

Fig. I53. DUTCH SKIT ON FOX-TOSSING ${ }_{236}$

FIG. 154. DUTCH SKIT ON FALCONRY 237

FIG. 155. A SHOW BOAR-HUNT. Out of Fleming's book 238

Fig. 156. A SHOW STAG-HUNT. Out of Flening's book 239

Fig. 157. WOLF-BAITING. Out of Fleming's book 240

FIG. 158. A WATER HUNT. Out of Fleming's book $24 \mathrm{I}$

FIg. 159. FOX-TOSSING AT GERMAN COURTS. From Fleming 242

FIG. I6o. SPORTING ARMS AND ACCOUTREMENTS. From Fleming 243

Fig. I6r. STAG-HUNT ON STARENBERG LAKE, NEAR MUNICH

Fig. I62. A PAGE OUT OF. EMPEROR CHARLES VI'S DIARY

FIG. I63. HUNTS OF LOUIS XV. Tapestry after Oudry 246

FIG. I64. HUNTS OF LOUIS XV. Tapestry after Oudry 247

Fig. 165. THE BEAR-HUNT. By Carlo Van Loo To face p. 248

Fic. I66. MR. SHARINGTON DAVENPORT. By Van Haecken $25 \mathrm{I}$

Fig. I67. MRS. SHARINGTON DAVENPORT. By Van Haecken 251

xxi 


\title{
LIST OF ILLUSTRATIOXS
}

\author{
FIG. 168. HOIY HOLNDS WERE BRAXDED \\ Fis. I6g. WILD-FOWLING. After Temiers \\ Fic. I7O. HEROX-HAII KING. Designed and engrased by Wacksmuth \\ FIC. 171. INDENTLRE FOR HLNTING APPRENTICE \\ Fic. 172. SHOOTING WII.D DLCK. By Ridinger \\ FIc, 173. LSE OI: THE STALKNG-HORSE. By Ridinger \\ FIc. 17t. SHOOTING FROM HORSEBACK. By Ridinger \\ FIC. 175. LSE OF THE POINTER. By Ridinger \\ Fic. 176. THE TRIIELLING PROFESSIONAL GUNNER. By Ridinger \\ Fic. 177 . THE O'TTER-TRIPPER. By Ridinger \\ Fic. 178. THE FALCONER. By Ridinger \\ FIc. 179. THE CADGE-BEARER. By Ridinger \\ FIc, Iso. THE FALCONER WITH THE "GRAND DUC." By Ridinger \\ Fic. 18. FALCONER PICKING LP THE "GRAND DUC." By Ridinger \\ FIc. 182. GOSHAIIK-STOOPING. By Ridinger \\ Fic. 183. THE FALCONER CASTING OFF. By Ridinger \\ Fic. 184. THE STOOP. By Ridinger \\ FIG. 185. REWARDING THE HAllK. By Ridinger \\ Fic. I86. THE USE OF THE GOSHAWK. By Ridinger \\ FIG. I87. LURING THE JERFALCON. By Ridinger \\ Fıc. I8s. THE BIRD-SNARER. By Ridinger \\ FIC. I89. THE BIRD-SNARER AT WORK. By Ridinger \\ Fıc. I90. THE "SINTY-SIX POINTER." By Ridinger \\ FIc. 19I. STAG WITH THREE ANTLERS. By Ridinger \\ Fic. 192. THO STAGS IITH MIALFORIIED HEADS, By Ridinger \\ FIc. 193. STAG WITH MLALFORMED ANTLERS. By Ridinger \\ Fic. I9t. FINE LIGHTEEN-POINTER. By Ridinger \\ FIc. 195. REILARKABLE THIRTY-TWO POINTER, By Ridinger \\ FIG. 196. RARE WHITE STAGS. By Ridinger \\ FIc. 197. STAG WITH THREE ANTLERS. By Ridinger \\ Fic. 198. "TWENTY-FOUR POINTER." by Ridinger \\ FIc. 199. STAG SHOT IN 1720. By Ridinger \\ F16. 200. ST.IG SHOT IN SERVIA IN 1729. By Ridinger \\ Fic. 201. SPOTTED STAG LEAPING THE "LAPPEN." By Ridinger \\ xxii
}




\section{LIST OF ILLUSTRATIOXS}

Fic. 202. STAG PLUNGING INTO THE DANUBE. By Ridinger 303

FIG. 203. HOUNDS IVEARING COATS OF MAIL. By Ridinger 304

FIG. 204. PIKE CATCHING A FOX. By Ridinger 305

FIG. 205. IBEX ESCAPING FROM LYNX. By Ridinger $\quad 307$

Fig. 206. IBEX CRUSHING LYNX TO DEATH. By Ridinger 307

Fig. 207. AMERICAN BISON FIGHTING BEAR. By Ridinger 308

Fig. 208. STALKER APPROACHING ȘTAG. By Ridinger $\quad 309$

Fig. 209. IBEX AND HIS TRACKS. By Ridinger 310

Fig. 2ro. AUROCHS AND TIGER. By Ridinger 31I

FIG. 2II. TRAINING YOUNG HORSES. By Ridinger $\quad 313$

FIG. 212. TEACHING HORSES. By Ridinger 314

FIG. 213. HOW HORSES WERE TAUGHT. By Ridinger 315

FIG. 214. LEARNING THE DOUBLE TURN. By Ridinger 316

FIG. 215. BEING TAUGHT THE "PESATE." By Ridinger 317

FIG. 216. ACCUSTOMING HORSES TO NOISE. By Ridinger 3

Fig. 217. POINTING A HARE. By Ridinger 320

FIG. 218. DRAWING. By Ridinger 321

Fig. 219. ROYALTY DRIVING TO THE MEET. By Ridinger 322

Fic. 220. GIVING THE COUP DE GRAACE. By Ridinger 323

FIG. 22I. THE "CURÉE." By Ridinger 324

FIG. 222. A GREAT HART OF TWENTY-TWO. By Ridinger 325

FIG. 223. MEZZOTINT PORTRAIT. By Ridinger $\quad 327$

FIG. 224. MEZZOTINT PORTRAIT. By Ridinger 327

Fig. 225. THE AMERICAN BUFFALO. After Ridinger 328

Fig. 226. PORTRAIT OF RIDINGER. By bimself 329

Fic. 227. THE "AMERICAN AUROCHS." By Holzhalb 33I

Fig. 228. HENRY IV'S ADVENTURE. By Guttenberg 333

Fig. 229. LOUIS XVI AS DAUPHIN. By Perrier. 335

Fig. 230. DE SAUSSURE'S ASCENT OF MONT BLANC 339

Fig. 23I. DE SAUSSURE'S DESCENT FROM MONT BLANC 34I

FIG. 232. DE SAUSSURE'S SUPPRESSED PLATE 343

FIG. 233. DE SAUSSURE'S EXPLORATION OF THE GRAND GEANT

FIG. 234. DE SAUSSURE'S EXPLORATION OF THE GRAND GEANT $3+9$ 

CHAPTER I : INTRODUCTION : SPORT IN ART IN PERIODS PRECEDING THOSE DEALT WITH IN THE SUBSEQUENT CHAPTERS

I

$\mathrm{T}$ has been said that as the chase of wild animals was made the subject of the very earliest pictorial designs, sportsmen can rightly claim to have given the first impulse to art. Unfortunately the skin-clad Mousterians who in the retirement of their caves incised on their walls and roofs writh nrimitive flint hurin nutlinedraxuinos of their fellnw creatures, the :uring for pict their

\section{ERRA'TA}

On p. 19 in legend underneath print, $\hat{B} A T O N$ should read BÂTON.

" +6 there should be a full stop after "Preuss" in second line of footnote.

" 72 on seventh line from bottom ausgerïllt should read ausgefüllt.

hambling refreshing ild a shelf -wielding lission on as to the low do we portrayed ;? Were

they not, perhaps, flying back to their caves in fearsome haste when their senses, which were still as unblunted and as keen as those of the sharp-eyed hawk or of the far-scenting deer, or of the acutely hearing wolverine, warned them of the approach of the gigantic foe? What more likely than that they drew those primitive tracings with trembling hand after a precipitate retreat? What evidence have we that these artists of the Middle Palæolithic age had already emerged from that primeval condition when men was still the hunted instead of the hunter? Indeed, there is evidence supporting such doubts, in the shape of a stone hammer found by a scientist, a generation or so ago, imbedded in the skull of a Megaceros Hibernicus. Had that blow been dealt to a wounded animal, in order to dispatch it, the precious flint tool would not have been left where Wauchoppe found it untold ages later. What more likely than that the blow was inflicted as a desperate act of self-defence on the part of the hard-pushed human quarry when the antlered pursuer, filled with blind rage, charged down upon him, crushing him to death before he had time to withdraw his feeble little weapon? Is not a similar tragic tale unfolded by the skull of a colossal prehistoric bear found in the Slauper cave in Bohemia with a flint arrow-head sticking in the frontal bone? From what one knows of the pigmy bear of to-day 


\section{SPORT IX ART}

and his tenacity to life, that arrow must have altogether failed to stop the onrush of the brute, and the cave-man probably came to a much more tragic end than did the bear, who possibly lived to a green old age, the bit of flint causing but occasional headaches. Were it not our wish to pass as quickly as possible to the very much later period with which this volume professedly deals, we might fill many pages with reproductions of rough but interesting pictorial material brought to light by recent discoveries, more particularly by French savants, such as the polychrome paintings in various shades of yellow, brown, red and black of bison and deer, and a great number of outline sketches of other wild beasts discovered, according to Professor W. J. Sollas's interesting "Ancient Hunters," by de Sautuola on the roof of the cavern of Altamira in Santander, and similar pictures in caves in the Ardeche, in the grottos of La Mouthe, Bernifol and Eyzies in the Dordogne, in the Pair-non-Pair cavern in the Gironde, and in some other Perigord caves.

Leaving this dark period when man was still the hunted, we reach the age when he had established his supremacy and was able to live in comparative security, although the chase still formed his principal means of existence, while the protection of flocks and crops occupied his time. After many centuries, what at one time had been the occupation of every adult male, under the law of "all that is best for the strongest " became gradually the privilege of the ruling classes, and under certain modern environments some forms of sport were evolved that could be enjoyed only by the wealthy, irrespective of bodily strength, knowledge of venery or woodcraft. Of the first stage no literature has come down to us; in the second period records by brush and chisel first take shape. From the monuments of Assyria and Babylon, and from the ancient Persian and other Oriental literature, one learns what important part the chase and hawking played in the life of the people in the East. In Europe we find the Greeks laying great stress on sport of every kind as a school for war. Lycurgus ordained that all children should be sent out early in the morning to hunt, and that every adult male and even the magistrates should exercise themselves in this manner in their leisure, so that they should not acquire habits of idleness and should keep fit for soldiering. In Macedonia nobody was allowed to take part in the public feasts unless he had killed a wild boar without nets. Although the Romans were not such ardent hunters as the Greeks, and preferred their cruel venationes - combats of wild animals in the arena-still the chase had its followers among both the patricians and the plebeians. For the literature of the chase in classic days the student must turn to his Iliad and the Odyssey and the friends, or perhaps enemies, of his youth, Horace, Virgil, Ovid and Tacitus, while the honour of having written the first book on hunting, Cynegeticus, belongs to Xenophon. Arrian and Oppian were both authors of works on our subject that are often quoted. Xenophon would urge men to the chase, for it accustoms them to rise early, to bear both heat and cold, it sharpens their wits, contributes to their 


\section{IXTRODUCTIOX: EARLY RECORTS}

health, perfects their senses of observation and hearing, retards and prevents the infirmities of old age, renders men robust and makes them able to support the fatigues of a military life. At this time, as in the days of Lycurgus and many succeeding centuries, honours were divided between the God of War and the Gods of the Chase, and it was customary to look upon the hunting field as the training ground for the soldier. Xenophon's arguments concerning the advantages of the chase were repeated with variations up to the fifteenth century by innumerable cynegetic authors until we have the worthy Gaston de Foix arguing that a good hunter is by far more likely to enter Paradise than any other man.

The Gauls were unquestionably the most sporting race in Europe, and Arrian says that they "coursed for the sport and not to live by what they caught." Cæsar leaves it on record that their young men were encouraged to attack the ferocious aurochs, and he was most honoured who brought home the greatest number and largest trophies of this gigantic ox. Trophies of the chase, as a sign of prowess, were always much prized; the antlers and horns as well as other parts were nailed to the doors of the hunters' habitations, or on to the trunk of some prominent forest tree. They were offered as sacrifices to their favourite gods and hung on the shrines of Diana and Apollo. In the Ardennes or Arduenna, the vast forest dedicated to Diana, her cult survived by centuries the christianising of the inhabitants, and it was long before good churchmen succeeded in substituting the veneration of St. Germain, St. Martin and St. Hubert as the patron saints of the chase. In the annual festivals of St. Hubert, which Continental nations still observe on November 3 , we have a slight echo of the sacrifices to Diana and of the orgies of wine and love held in her honour by the ancient Gauls.

Of the dark ages that followed the fall of Rome we have very little or no pictorial memorials.

With Charles the Great may be said to commence the era of mediæval sport, but there exists a deplorable paucity of graphic material also in this period. In the Gestes de Charlemagne, penned by the Monk of St. Gall, and in the Chronicle of Angilbert and Eginhard, there are found interesting descriptions of great hunts held by Charlemagne, to one of which we shall have to refer in Chapter III, but they all lack illustrations.* The revival of art under Charlemagne's wise and strong rule made itself more felt in respect to natural history, as we can observe in the Bestiaries, those primitive accounts of real and apocryphal animals. But even in the best of them, say Philippe de Thaun's curious MS., or Guillaume de Normandie's Le Bestiaire Divin, or Richard de Fournival's Le Bestiaire d'Amour, or in any of the other "illustrated "renderings of the original Physiologus, the pictures of existing animals of venery are so rudely drawn as to be practically worthless for our purpose, while the fantastic creations in the shape of grotesquely impossible creatures that occupy many parchment pages have even less claim to our space.

* From his Capitularies one can also gain information about the various statutes of the chase. 


\section{SPORT IX ART}

In England at this time the Saxons were hunting game in a very similar fashion to Charlemagne's battues. They erected hayas and made enclosures of wattles, and beaters with horns and shouts drove the game into these corrals, where it was killed with bows and arrows, clubs and spears. Of the Saxon days we have no pictorial matter. The Bayeux Tapestry, supposed to have been worked in Queen Matilda's time towards the end of the eleventh century, is one of if not the very earliest designs of the new age, where we see a sportsman with a hawk on his fist and representations of hounds. This famous embroidery may be said to mark the introduction into England of stag-hunting proper with running hounds. The Normans and the French favoured especially this kind of hunting rather than the huge beats and drives which flourished long after the Conqueror's day among their Teuton neighbours. To the French, true descendants of the sport-loving Gauls, the quantity of game slaughtered was a secondary matter; woodcraft and the working of the hunting hound came first; to the more stolid Teuton the pot simmering over the fire was not such a secondary consideration, and although they were great at woodcraft, they did not evince a craving for unnecessary exercise or pride themselves on their endurance in riding to hounds.

From IVilliam the Conqueror's time onward the searcher of MSS. will find scattered among breviaries, romances, and legends quaint illuminations picturing, in spite of a deplorable lack of perspective, hunting scenes; and from the thirteenth century onwards we find books on venery illustrated in this manner with archaic drawings too primitive to be instructive, but culminating in the beautiful miniatures of the fifteenth century with which we begin our series. It is from this time on that pictorial records claim our attention, and they appeal to more than one class of readers. They bring before our eyes, far better than any verbal description can do, the mise en scine of our forefathers' sport. They form a covert in which the student of sporting lore can draw to his heart's content. In it the lover of hound and horse can "harbour" many a long-forgotten secret of the kennel and of the stable. The naturalist obtains valuable material respecting the local distribution of the various beasts that were chased with such keenness by our ancestors, and he can learn little remembered details concerning their habits. The zoologist will discover unexpected data respecting the size, colouration and affinities of certain species that have since become rare, if not entirely extinct. To the connoisseur of old arms they present invaluable material respecting the weapons used for the chase at certain periods, or of their adaptation to a particular use. To the student of costumes they offer a rich field, probably the richest that exists; and to the collector of trophies they present a practically inexhaustible source of study and an inviting field for investigation. And finally, for the ordinary modern sportsman, who, as a rule, cares about as little concerning the doings, manners, appearance or ways of "musty old fogies" in long past days, as he does about what they bagged or how they bagged it, to hin the present volume is offered as a picture book to wile away an idle hour. 


\section{CHAPTER II : GASTON DE FOIX'S "LIVRE DE CHASSE"}

I

$F$ there is no figure on the stage of picturesque mediæval life that in point of romantic interest can equal the man whose knightly beauty gained him the sobriquet "Phœbus" and the distinction of being likened to the sun, there is also no treatise in the wide world of letters that stands quite so much by itself, and can claim to be the best in its particular branch, as does the work written by this same man, Gaston de Foix, more than five hundred years ago.

The praise meted out to this prince by his contemporaries, amongst whom the genial Froissart is probably the best known, cannot fail to find a ready echo in the modern sportsman's heart as he turns over the leaves of La Livre de Chasse, often called also Gaston Phobus, the name which is given indiscriminately to the book as well as to the author, treasured in the National Library of France at Paris. For "MS. 6r6," which is the official designation of this splendid parchment Codex, is without question, apart from its text, from the point of view of the artist, of the antiquary, of the naturalist and, above all, of the sportsman, the finest existing medixval volume of its kind. And, as one can honestly add, there are few books known to the bibliophile that have had a more adventurous career, that have passed through more romantic vicissitudes or peril, or whose beautiful mellow toned vellum leaves, profusely decorated with masterpieces of the illuminator's art, have been turned by the hands of so many men and women that have played prominent parts in history.

Each page is a masterpiece by itself. The miniature that adorns it, not standing alone or lost in the text like the illustrations of modern books, is surrounded as we see in Figs. I, 4, and 7, by ever-varying designs of graceful foliage framing it and connecting it with the clear and decorative text. Each miniature portrays in colours that have lost little of their beautiful freshness some hunting scene, be it the mere picture of the various animals of the chase and of venery, or the methods of their capture, or the different kinds of hounds then used by the sportsman, their kennels and their diseases. They stand out with unrivalled distinctness and with picturesque force against quaint patterned backgrounds lavishly decorated with burnished gold-in a word we are contemplating the absolute page beautiful and the perfect book.

As our illustrations are reproductions of these illuminations a glance at the history of this precious volume may be welcome.

It has been the delight of numerous antiquaries to search for the first owner of this volume. By the coat of arms emblazoned on the fly-leaf it has been discovered that, while it probably was originally made for one of the royal princes, or possibly for Charles VII himself, it belonged about 1470 to Aymar de Poitiers, 


\section{SPORT IX ART}

who had married one of the natural daughters of Louis XI. These Poitiers were Iimous sportsmen, and Jean of that ilk was the father of the beautiful and notorious Diane de Poitiers, the all-powerful mistress of Francis I and, strangely enough, also of his son Henry II. Diane, before she entered on her romantic career, had also married a famous sportsman, Louis de Brézé, Grand Seneschal of Normandie, who was a son of Charlotte of France, natural daughter of Charles VII. Returning home one day unexpectedly her husband surprised the love-lorn, though no longer young, Charlotte with her paramour, and forthwith killed them both. But there wis another tragedy in which the owner of our Codex came nigh figuring. Diane's father, Jean de Poitiers, became involved in the Connétable de Bourbon's treasonable machinations, and on the conspiracy being discovered, Jean was speedily sent to the scaffold.

At the very last moment, as he was in the act of kneeling down to receive the death-blow, the pardon obtained by his daughter from Francis I, her royal lover, saved his life. But his vast belongings, amongst which was almost certainly the book we are speaking of, were confiscated by the King. Scarce two years later we find it in his possession, and as one of his favourite books it accompanied him on his fateful invasion of Italy. Discovered after the battle of Pavia (1 525 ) by one of the looting Landsknechte in Francis' gold-laden tent, it was carried off by him to his native Tyrol, and there it became the property of the famous Bernard of Cles, Bishop of Trent, who presented it to the Archduke Ferdinand of Austria, the founder of the famous Ambras Collection. It remained in the hands of the Habsburgs for a century and a quarter; and after Turenne's victories in the Netherlands it became in some unknown way the property of the Marquis de Vigneau who presented it to Louis XIV, thus restoring it once more to the House of France. After various wanderings among the private royal libraries it finally, in 1848 , escaped in a marvellous manner revolution, plunder, and arson, to find what must be hoped will prove to be a final resting-place, in the great National Library of France.

Having cleared up who wrote the book and who owned this very special copy of it, the question whose hand designed these unusually interesting miniatures has so far defied expert research. The ascription to the masterhand of Foucquet does not find the support of Joseph Lavallée, the most dependable of the experts who have attempted to unravel this puzzle, but research may still throw light upon it. It is fairly certain that they were painted between the years 1440 and $145^{\circ}$, * some half a century after Gaston de Foix, its author, had commenced it on May 1, 1387 , as he tells us in his prologue. On a hot August day in the year 139 I he departed for happier hunting grounds at a bear-hunt in the forest of Sauveterre near Pampeluna. He had when this event happened but just completed

* Almost all English writers, even the very latest, declare that they date from the year 1359 , which for many reasons is impossible! 



\section{GASTOX DE FOIX}

his Livre de Chasse, which he wrote in the great hall in his famous stronghold Orthez, where, as Froissart describes, some years before, occurred one of the most tragic incidents of a dramatic period. It was there that Gaston de Foix, after

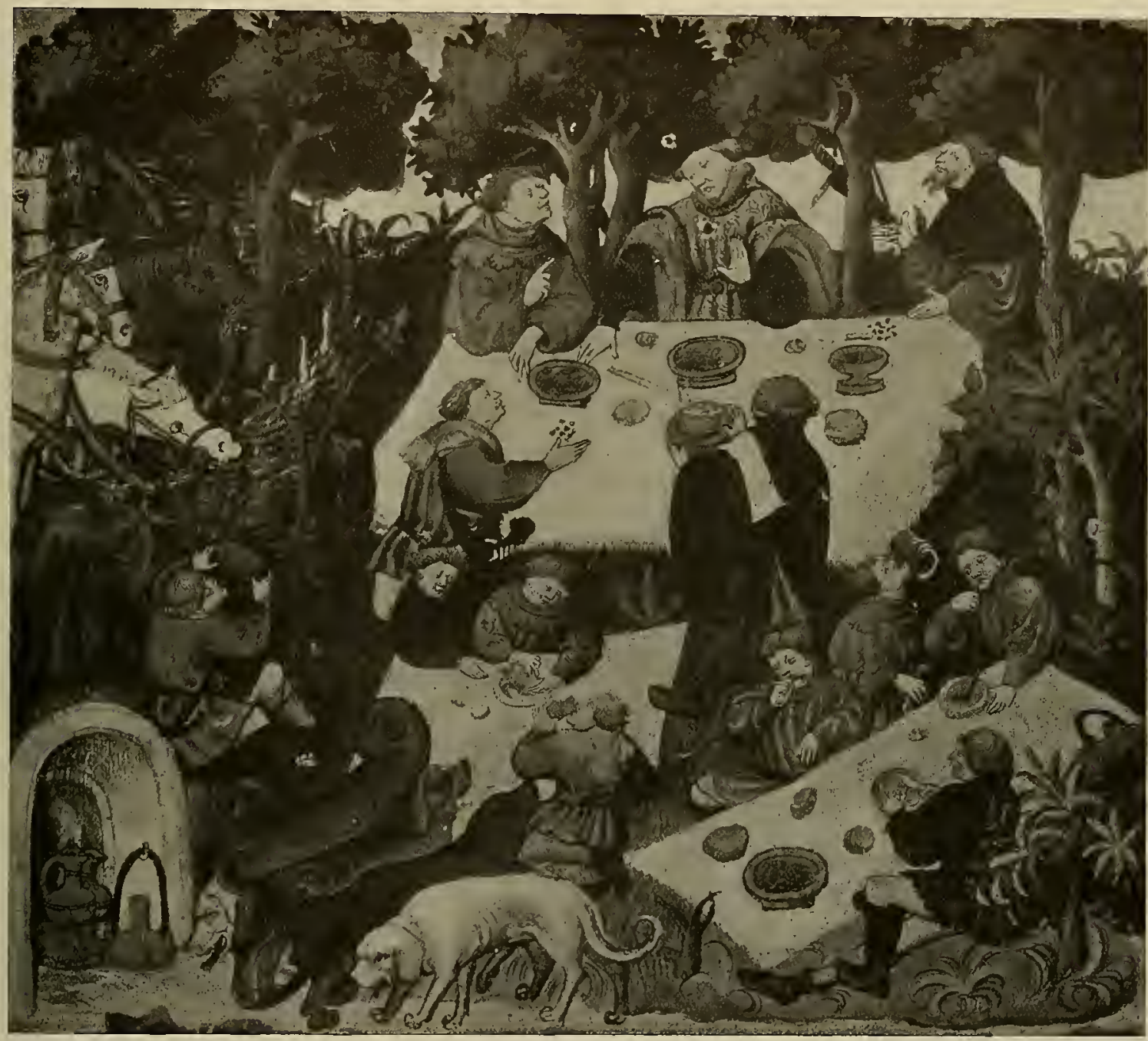

FIG. 2. THE HUNT BREAKFAST, RIVAL HUNTERS DISPLAYING THE FEWMETS (DROPPINGS) TO THEIR LORD. FROM GASTON DE FOIX'S MS. FIRST HALF OF FIFTEENTH CENTURY. See Page 16

finishing his supper-the only daily meal he partook of-which he did sitting in stately grandeur at a raised table, his knights and gentlemen-in-waiting holding flambeaux in their hands, would dictate to one of his four secretaries the chapters of his famous hunting-book, while the four historical greyhounds Tristan, Hector, Brun, and Rolland, which Froissart had brought him from England, lay stretched, 


\section{SPORT IX ART}

as we may presume, before the great fire on bearskins, trophies of their master's personal prowess.

The original MS. of the famous book was dedicated and sent by Gaston to his

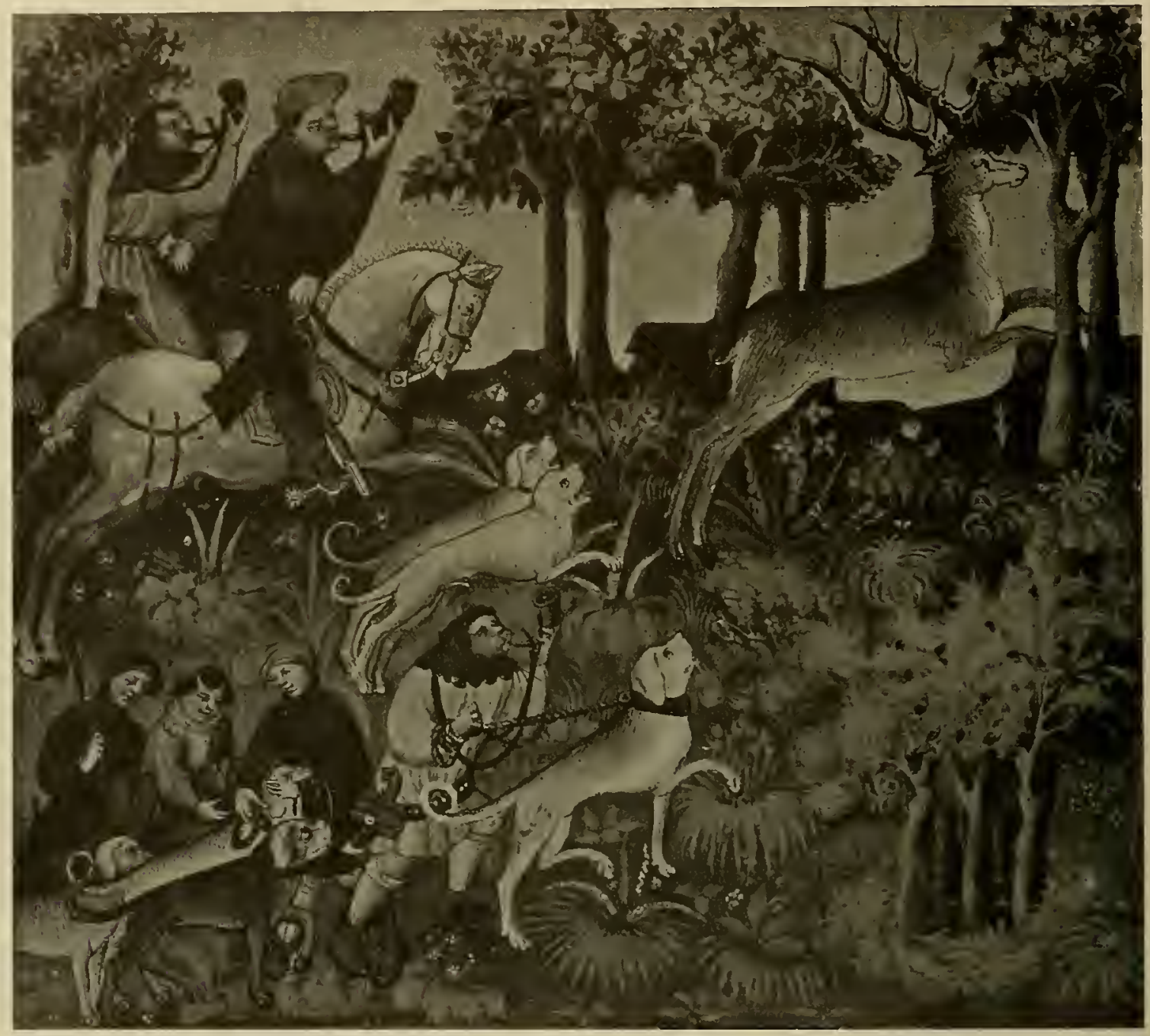

FIG. 3. HOW THE STAG WAS ROUSED AND HUNTED. FROM GASTON DE FOIX'S MS. See Page 20

lifelong friend Philip the Bold, the erstwhile English prisoner. It has, so far as one knows, totally disappeared, but there are thirty-nine or forty other ancient MS. copies of the book, some illuminated some not, preserved in various libraries; but none, except perhaps the Cheltenham MS. which the great bibliophile Sir Thomas Phillipps bought at a Fleet Street auction in the year I825, and which Io 


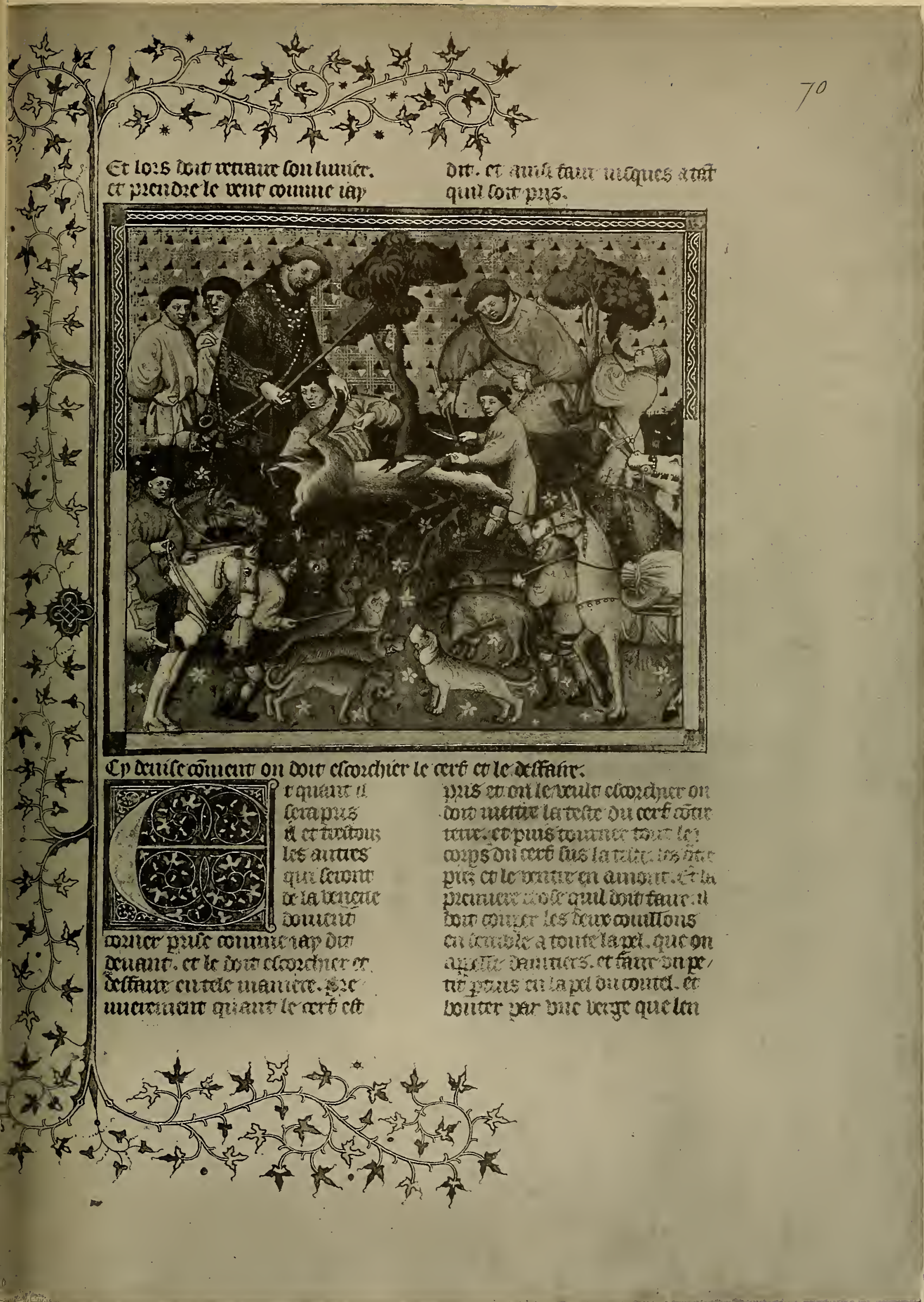

IG. 4. Breaking up the Stag. Illumination from Gaston de Foix's MIS. prainted about I $44 \mathrm{C}$. See Page 22 



\section{GASTOX DE FOIX}

was the copy made for Ferdinand the Catholic of Spain, can be spoken of in the same breath as the "MS. 6I6" from which the present illustrations have been reproduced.*

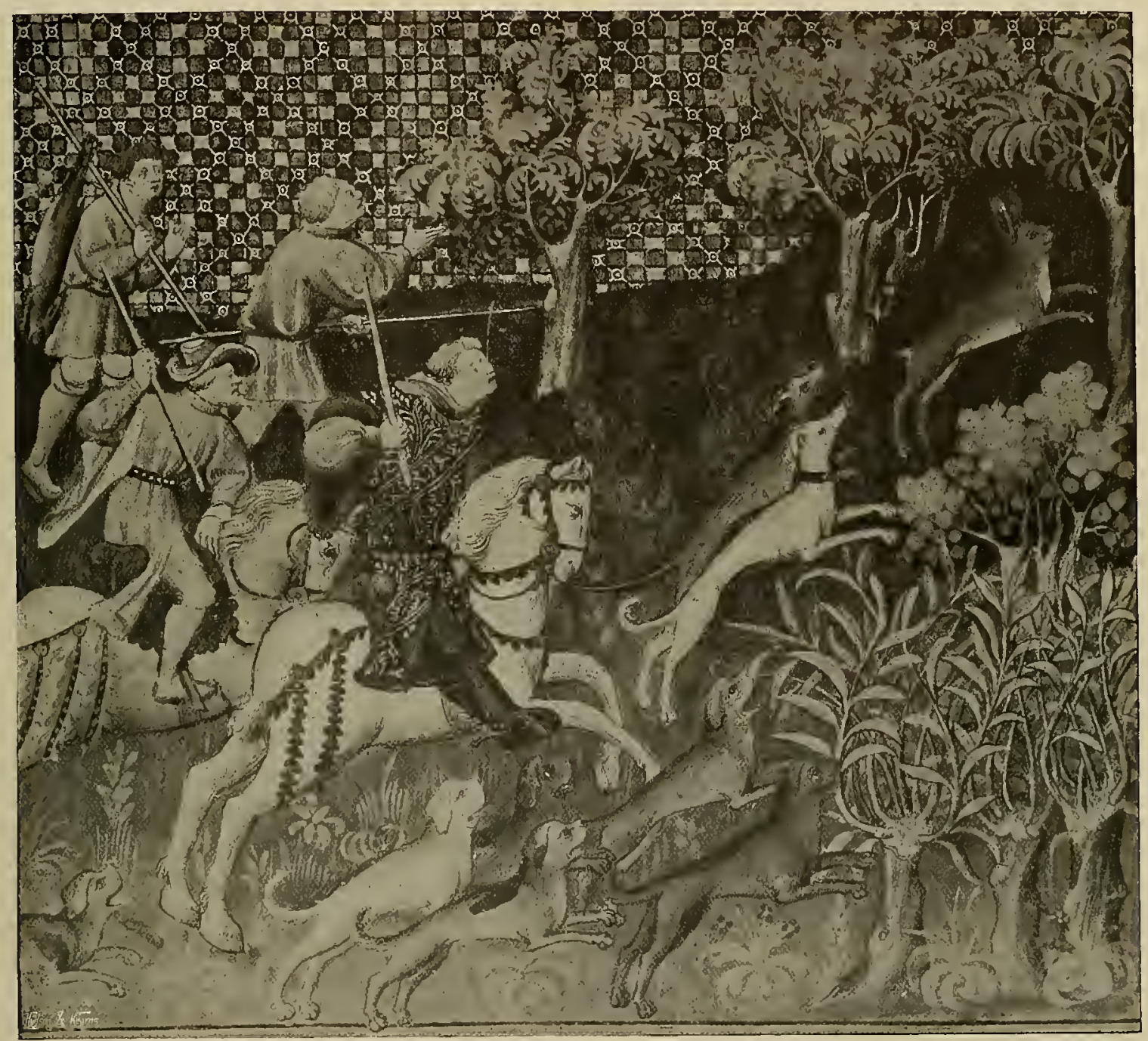

FIG. 5. HARE-HUNTING WITH GREYHOUNDS AND RUNNING HOUNDS. FROM GASTON DE FOIX'S MS. See Page 24

The "MS. 6 I 6 " contains eighty-eight miniatures representing the beasts of chase and of venery ; the different breeds of sporting dogs, their kennels, and treatment when sick or injured; the hunting of the different animals; as well as stalking and

* In the bibliography in the "Master of Game" the writer fully describes the Cheltenham MS. 


\section{SPORT IX ART}

shooting with cross-bows and long-bows, and finally, although the author says "Truly, I trow no good hunter would take his game falsely," he describes for the benefit of the "poor man" how the different traps, pitfalls, snares and nets, then so largely used, should be set or made.

Some of the pictures here reproduced may be already familiar to the reader, as the writer published forty-five out of eighty-eight to illustrate the earliest English hunting-book called the "Master of Game" written about 1406 by Edward second Duke of York. As with the exception of a few chapters it is a literal translation of Gaston de Foix's text, the use of the latter's illustrations was justified, for the different English MSS. of the Duke of York's translation contain no illuminations of any interest, England being then still far behind France in the fine arts.

In France there exist some hunting MSS. earlier by at least a century than the one with which we are here dealing; but although some of them, for instance MS. I 297 in the same great literary storehouse, contain quaint illuminations of the chase, they do not approach in quality or quantity those of MS. 6 I6.

Mediæval hunting had none of the steeplechase elements about it which are now a sine quâ non. Men went hunting in a leisurely manner, and they were out to enjoy a long day's sport; if night overtook them far from home in the depth of the forest, they knew how to make the best of an unpleasant incident. They knew much more than we moderns do of the "nature" of the beast they were hunting, of its habits and wiles, of its stratagems and ruses. They studied wild nature with a keenness unblunted by intellectual occupations, and they loved her with unstinted devotion. To see the play of the sun's rays in the forest's foliage, or to hear the song of the birds in the dewy morn delighted their senses, and they loved to listen to the brave music of their deep-toned hounds as they gave tongue in wooded glades. The chief pleasure did not lie in the slaying of the hart, but rather in the incidents that led up to it. To watch their pack at work, to cheer them on with their voices, chiding them when they ran riot or were at fault, checking them when they were hunting the change, these were the principal attractions. And when the great hart was at last at bay, or the fierce boar finally turned upon his relentless foes, the foam-flecked steed was pushed to a last effort, so as to be at their side before antlers or tusks could work havoc. And the killing itself was a true test of nerve, skill, and strength. It was done in a knightly fashion, without the use of unchivalrous wiles or taking refuge to cross-bow or long-bow. For the death-stroke had to be given with cold steel, and, needless to say, to approach close enough to a cornered hart, standing with lowered head, his rear guarded by rocks or by a big tree, so as to give the deadly thrust with a short hunting sword, was a feat that required grit of the true sort; while in the case of a big boar, dealing out strokes of his deadly tusks with lighining rapidity, it was, if it was performed on horseback, a deed requiring not only the above qualities but I 4 


\section{GASTOX DE FOIX}

perfect horsemanship. No one who deemed himself a veneur would dream of delegating the killing to a subordinate, as was done very generally later on when men grew soft, and the use of gunpowder removed many of the risks of the

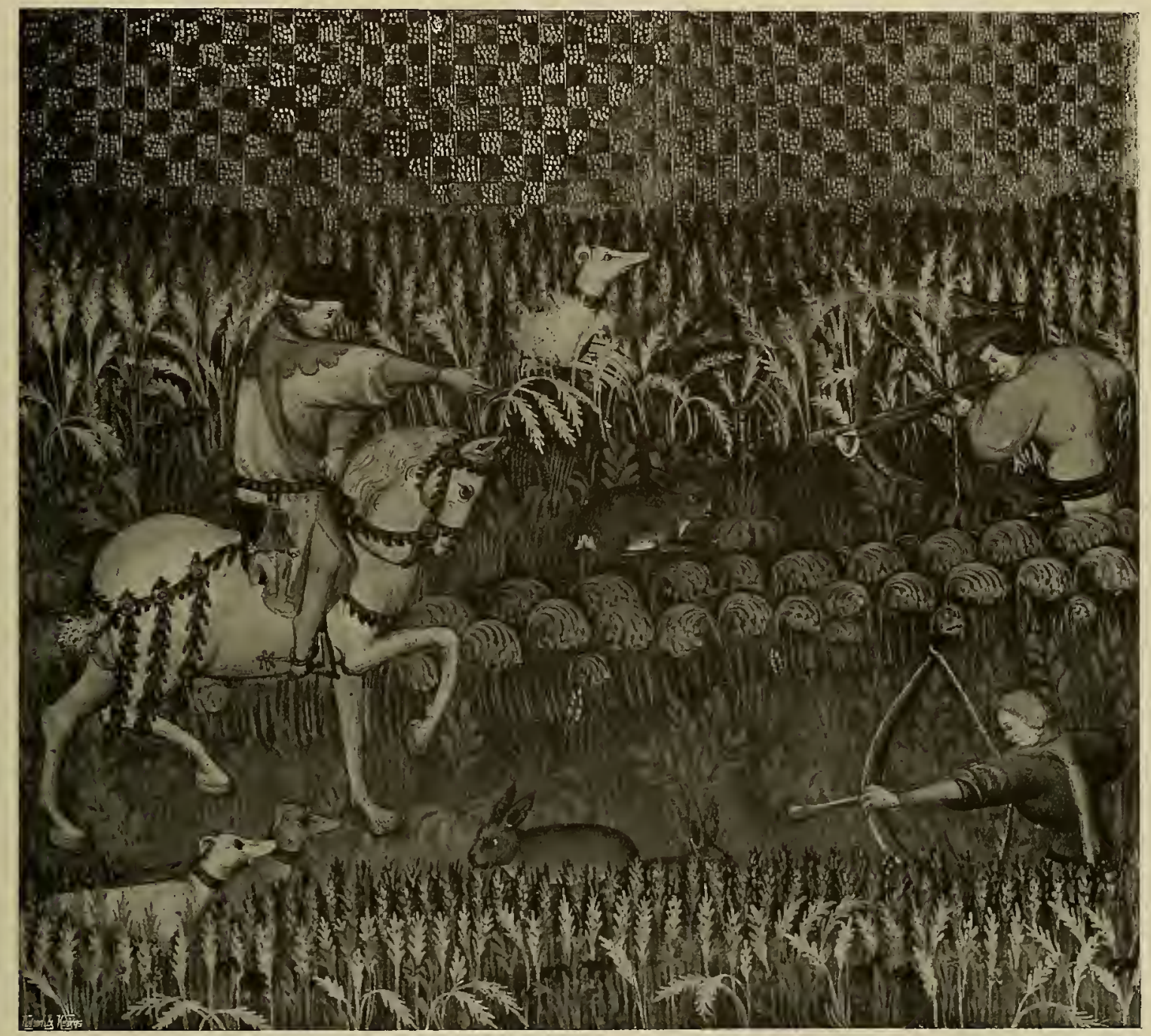

FIG. 6. BUSTLING HARES OUT OF CORNFIELDS AND SHOOTING THEM WITH BLUNT BOLTS FROM LONG-BOWS AND CROSS-BOWS. FROM GASTON DE FOIX'S MS. FIRST HALF OF FIFTEENTH CENTURY. See Page 25

chase, until, finally, sport was degraded to mere slaughter, and that by men securely ensconsed in danger-proof stands, to which they were driven in chariots or carried in litters.

As neither horses nor hounds were bred for speed, young and light deer were not 


\section{SPORT IX ART}

hunted, for they would not have found it difficult to get away from both; hence the bigger and heavier the stag, the more "their liking thereof," as the Duke of York expressed himself, and the larger the antlers the greater the honour.

The above brief remarks on the principal features of mediæval stag-hunting will have cleared the ground, so that we can now turn to the illuminations. Our first full-page reproduction of one of the inimitable leaves of Gaston de Foix's grand folio, Fig. I, does not introduce us actually to the very first incident of the staghunting day, for we see here not only the berner, or tufter as we now call him, with his lymer in leash, hot on the stag's line, but behind him a couple of hunt officials with six coupled running hounds. The turn of these latter would presently come, when the berner, after stealthily approaching the stag's lair, where some hours before he had harboured his unconscious victim, would put him to speedy flight. For after marking him down, soon after dawn, the berner had returned to the assembly, as was called the meeting-place, and had reported there to his master what signs he had discovered and what size he judged the stag to be. And only if his report sounded more promising than those of his rival berners, who had worked up other beats, would his particular stag be picked out for that day's hunting, thereby making him a happy individual. But woe to him if his signs played him false and his report proved untrue, or by some unlucky chance the stag in the interval of some hours had for some cause or other sneaked away or been alarmed by some unforeseen noise or whiff of humanity!

As delays caused by this harbouring were, of course, unavoidable, the assembly was not only the meet, but also the scene of the hunt breakfast. This al fresco meal, see Fig. 2, almost invariably preceded (up to the seventeenth century) the hunting proper, and, to judge by the lengthy descriptions, a good deal of importance was attached to this leisurely repast. Thanks to the invaluable work done by the Duke of York when translating Gaston de Foix's book, we have in the "Master of Game" the oldest and most authoritative source for old English hunting and for the terms then in use. According to it the proper English name was Gathering, "because," as the Duke explains, "all the men and the hounds for hunting gather thither . . . and the place where the Gathering shall be made should be in a fair mead, well green, where fair trees grow all about, the one far from the other, and a clear well or beside some running brook." And after instructing his readers how "all the officers from home should bring hither all that is needed well and plenteously, and should lay the towels and board-clothes all about upon the green grass, and set divers meats upon great platters after the lords power," follow some quaint instructions. "Some should eat sitting, and some standing, and some leaning upon their elbows, some should drink, some laugh, some jangle, some joke, and some play-in short, do all manners of disports of gladness, and when men be set at tables, ere they eat, then should come the lymerers and their grooms with their lymers, the which have been questing, and 16 



\section{GASTOX DE FOIX}

every one shall say his report to the lord of what they have done and found, and lay the furnes (droppings) before the lord, and then the lord or the master of the hunting, by the counsel of them all, shall choose which (stag) they will move and

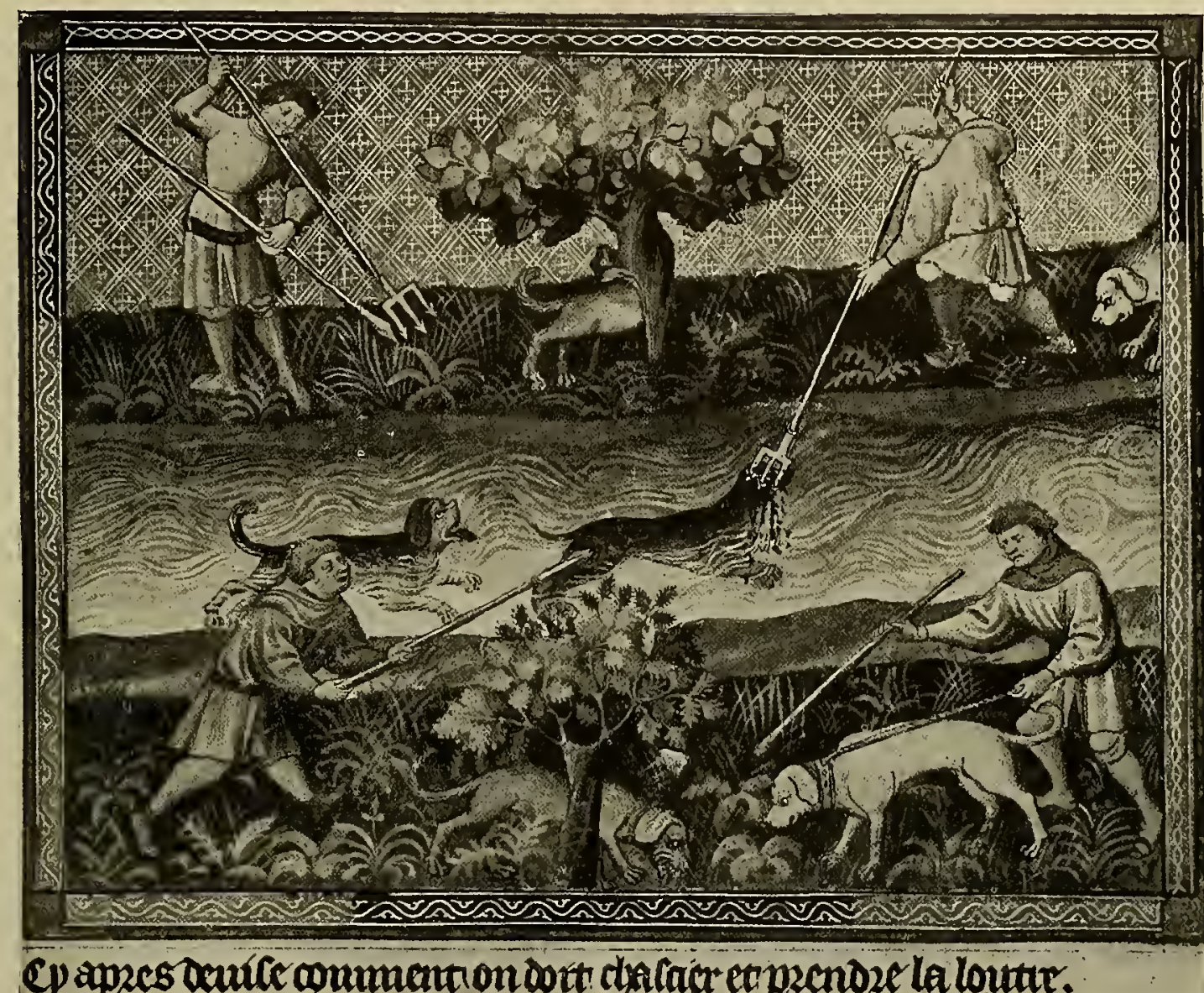

FIG. 8. OTTER-HUNTING. THE “ BATON FOURCHIE" OR SPEAR HAD THEN THREE PRONGS, LATER ON IT HAD BUT TWO. FROM GASTON DE FOIX'S MS. See Page 26

run to and which shall be the greatest hart and the highest deer. And when they shall have eaten, the lord shall devise where the relays shall go . . . and then shall every man speed him to his place and all haste them to go to the finding."

One incident in the above description is graphically depicted in Fig. 2, i.e. the bringing in and presentation of the fumes or droppings of two harts by rival berners. The little black dots spread out on the board-cloth had been carefully collected in proof of the size and condition of the respective harts tracked home by the two berners. Gaston's gestures and those of his adviser on his right, show that some 


\section{SPORT IX ART}

discussion has arisen respecting their merits. Gaston evidently does not intend to be hurried, for he has hung up his hunting sword on a branch of the tree behind him, and the matter is being discussed with due deliberation, although we cannot

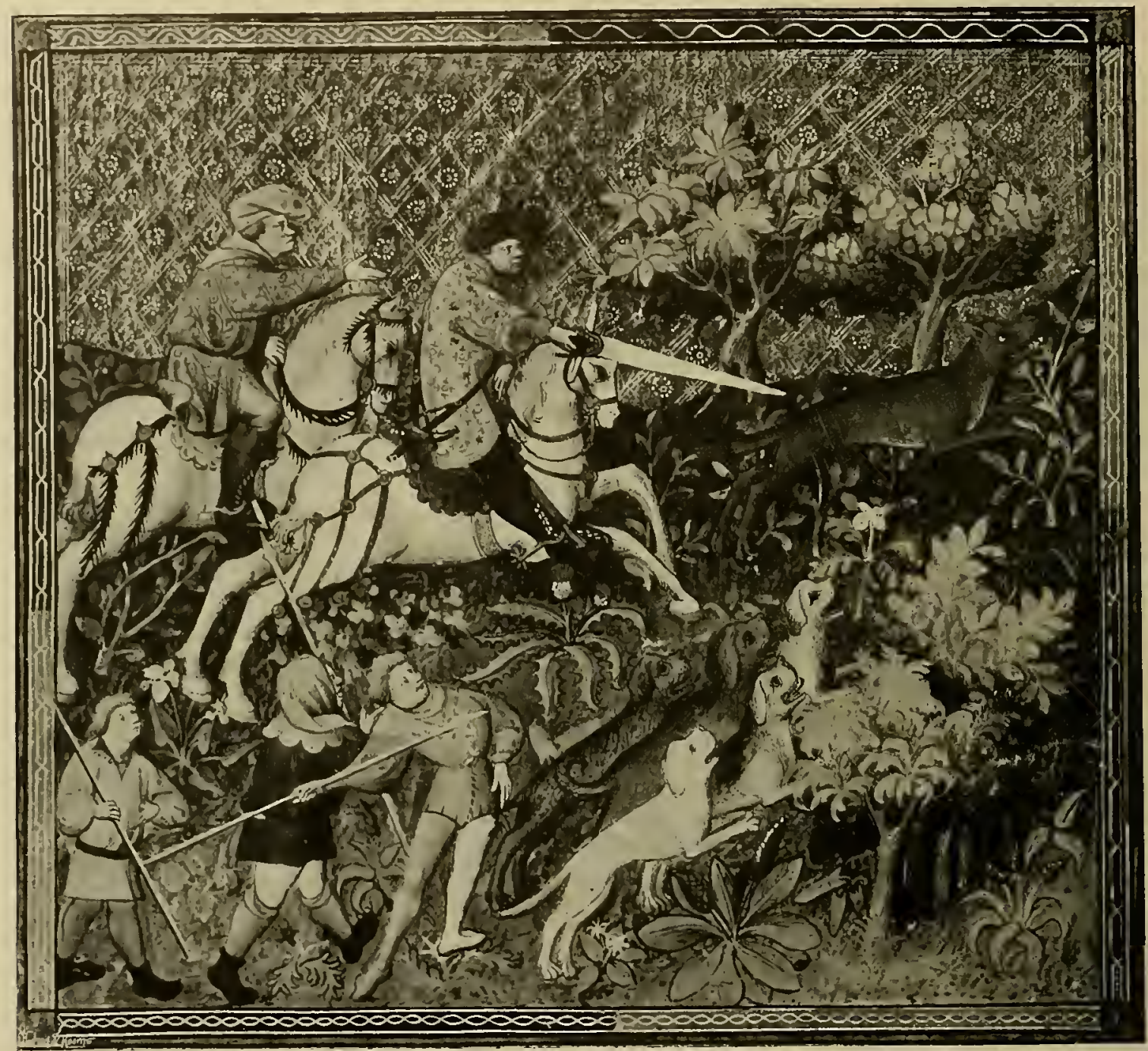

Fig. 9. WOlf-hunting, FROM GaSTON DE FOIX's MS. Sie Page 26

fail to notice that the lesser lights in Gaston's train are not observing very strictly his injunction that the question which hart is to be selected should be decided "ere they eat."

The next picture, Fig. 3, shows the hound in full cry and two huntsmen sounding on their horns the laisser courre. In the foreground we see the lymerer with his 20 


\section{GASTOX DE FOIX}

hound who has evidently just started his quarry. The type of hound is shown even better in Fig. I 5 ; it is probable that these "running hounds" sprung from the stock of the Abbey of St. Hubert, whose kennels were noted for supplying

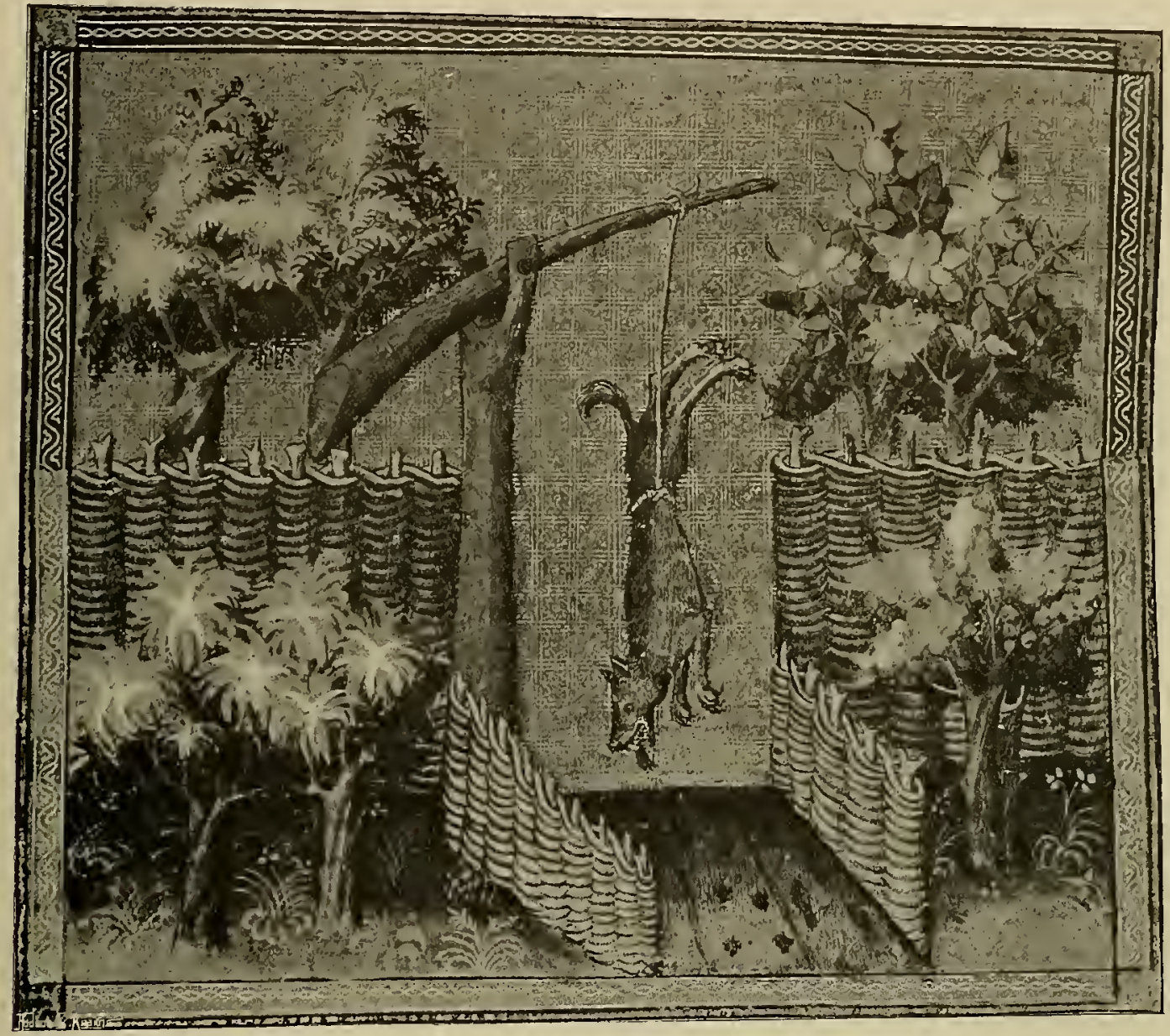

FIG. IO. HOW THE "HAUSSE PIED" OR WOLF-TRAP WAS WORKED. FROM GASTON DE FOIX'S MS. FIRST HALF OF THE FIFTEENTH CENTURY. See Page 27

good lymers for the royal kennels of France. The most usual colour was black and tan, although we are told that some of them were white, and the pictures in our MS. corroborate this. They were good scenting hounds, staunch but not fast. In Fig. 3, to the left in the illumination, we see other varlets with hounds of the pack " hardelled" in couples, for it was the custom to keep back relays, only a portion of the entire pack being put on the scent at first. The relays, in charge of picked berners, were posted along the probable line the stag would take, and were slipped when the hunted beast and the hounds already chasing him had passed. 


\section{SPORT IX ART}

Old French authorities on stag-hunting seemed to differ whether the staunchest and slowest hounds should be put into the first cry, or in the last. Roy Modus, writing half a century previous to Gaston de Foix, instructs the huntsman to uncouple the oldest and wisest first, saying that if one lets the younger and swifter hounds go first they are more likely to overshoot the line and take the change; but in Gaston's opinion, and in that of most of the more modern French authorities, the younger and swifter hounds should be put on the line first, the older and surer hounds being more fit to hunt a tired stag well, particularly if the scent be stained or cold. They are also better able to hold the stag at bay.

The discontinuing of relays seems to have begun in Normandy, and probably about the same time as in England. Lack of space prevents one going into further technical details, but they can be found in the work on English hunting, "Master of Game," already alluded to.

Now the stag was undone and prepared for the final ceremony, called the Curée or "rewarding" of the hounds, which was so called because the "reward " was given to the hounds on the hide or cuir of the stag. We see in Fig. 4 the dead quarry placed on his back, and in that position, under the direction of the prince or master, he was flayed and undone according to strict technical rules. One of the huntsmen is blowing the Mort, while others hold back the hounds until the mess, consisting of blood mixed with bread or flour with some tit-bits from their victim, is ready. It was then poured on the skin placed flesh side upwards on the sward. The sack on the mule's pack-saddle evidently contained either flour or bread to be used for the reward.

Next to stag-hunting the chase of the will boar appears to have been Gaston de Foix's favourite sport, for its danger evidently appealed to his sporting instincts. Wild boar waxed to an almost incredible size, old males attaining frequently, even in later centuries when their weights were carefully noted, to $500 \mathrm{lb}$. and $550 \mathrm{lb}$., and in isolated instances to over $700 \mathrm{lb}$. There are pictures of boars being chased on horseback with hounds, others show how they were shot with cross-bows and long-bows, while one miniature depicts a row of terribly fierce looking boars with tremendous tusks attacking a phalanx of hunters armed with the regulation boar spears. And finally we have pictures of wild boars being snared and trapped in pitfalls and also in nets. Any kind of contrivance was permissible to capture these depredators, who committed untold ravagesin the peasant's fields and among his roots. When the boar was hunted on horseback big powerful hounds were used, called $V$ eltres and Alauntes, also mastiffs, and in fact any large and courageous mongrel the loss of which the kennel would not miss. The boar was sometimes tracked and chased much in the same way as a stag, but when the quarry stood at bay, which would happen with the large and fierce males sooner than in the case of three and fouryear-olds, the hunters came up and killed him with their spears. The finest performance of all was to kill the beast from horseback with the sword. This 22 


\section{GASTOX DE FOIX}

was the most noble and knightly chase, in which Gaston de Foix delighted, and we can quite believe his remark that he has often seen men and horses killed by one stroke of a monster's tusks.

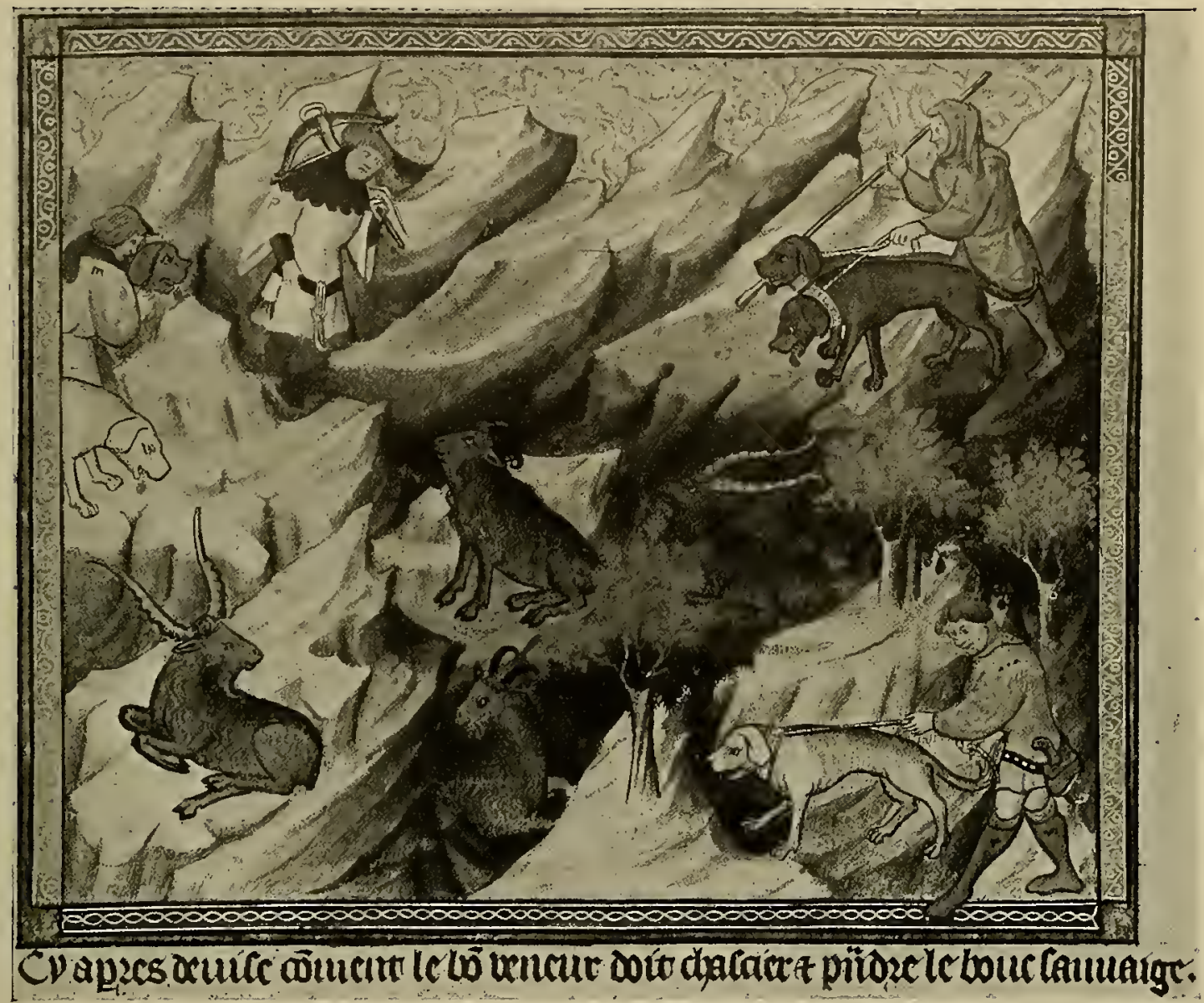

FIG. II. HUNTING THE “BOUC SAUAGE" OR IBEX, AND THE "BOUC YSARUS" OR CHAMOIS IN THE PYRENEES, WHERE THEY WERE THEN PLENTIFUL. FROM GASTON DE FOIX'S MS. FIRST HALF OF THE FIFTEENTH CENTURY. See Page 28

The full foliage depicted in all the illuminations of the boar-hunting we must regard as artistic license, for boar-hunting took place in late autumn and winter. Soon after Gaston's time the swords used for this chase were provided with a sort of guard consisting of a stout cross-pin about ten inches from the point, which prevented the sword penetrating too far into the body of the boar, and precluded its being quickly withdrawn. This form of mediæval pig-sticking must have 


\section{SPORT IX ART}

been most exciting sport, and good horsemanship was as essential as were strong hands and cool nerves.

Gaston does not give the prominent place to hare-hunting that the Duke of York

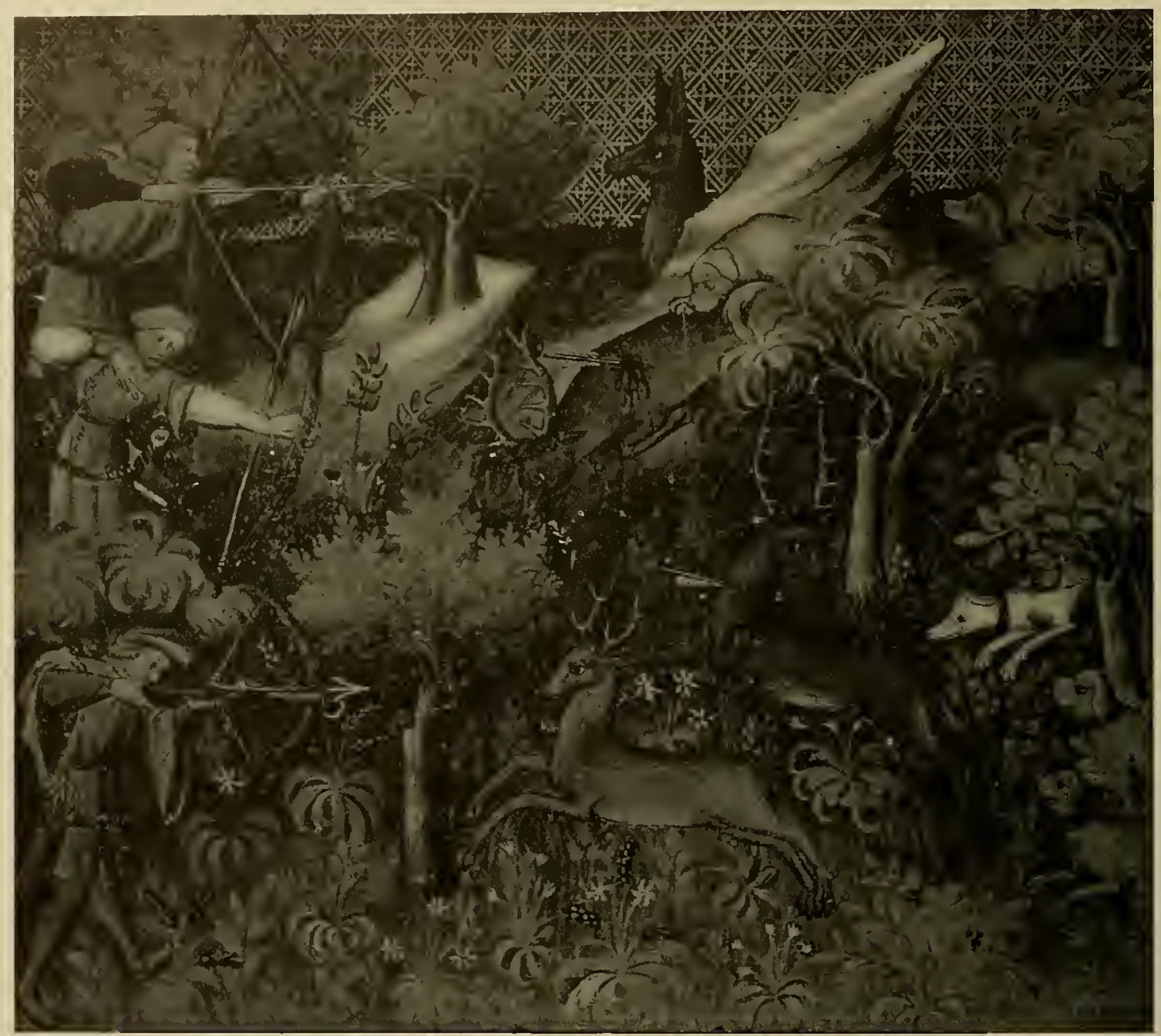

FIG. I2. SHOOTING DEER IVITH CROSS-BOWS AND LONG-BOWS. FROM GASTON DE FOIX'S MS. See Page 3 .

in his English translation does. He points out that hares can be hunted all the year round, and mentions six ways of taking them besides hunting; but although he gives elaborate instructions how to conduct what is practically pot-hunting, he does not, as a good sportsman, approve of these methods, and adds when speaking 24 


\section{GASTOX DE FOIX}

of the diverse ways of taking hares with cords (nets) that "I rould that they who take hares thus should have them (the cords) round their own necks."

One of the chief differences in the sport of hare-hunting as pursued then and now

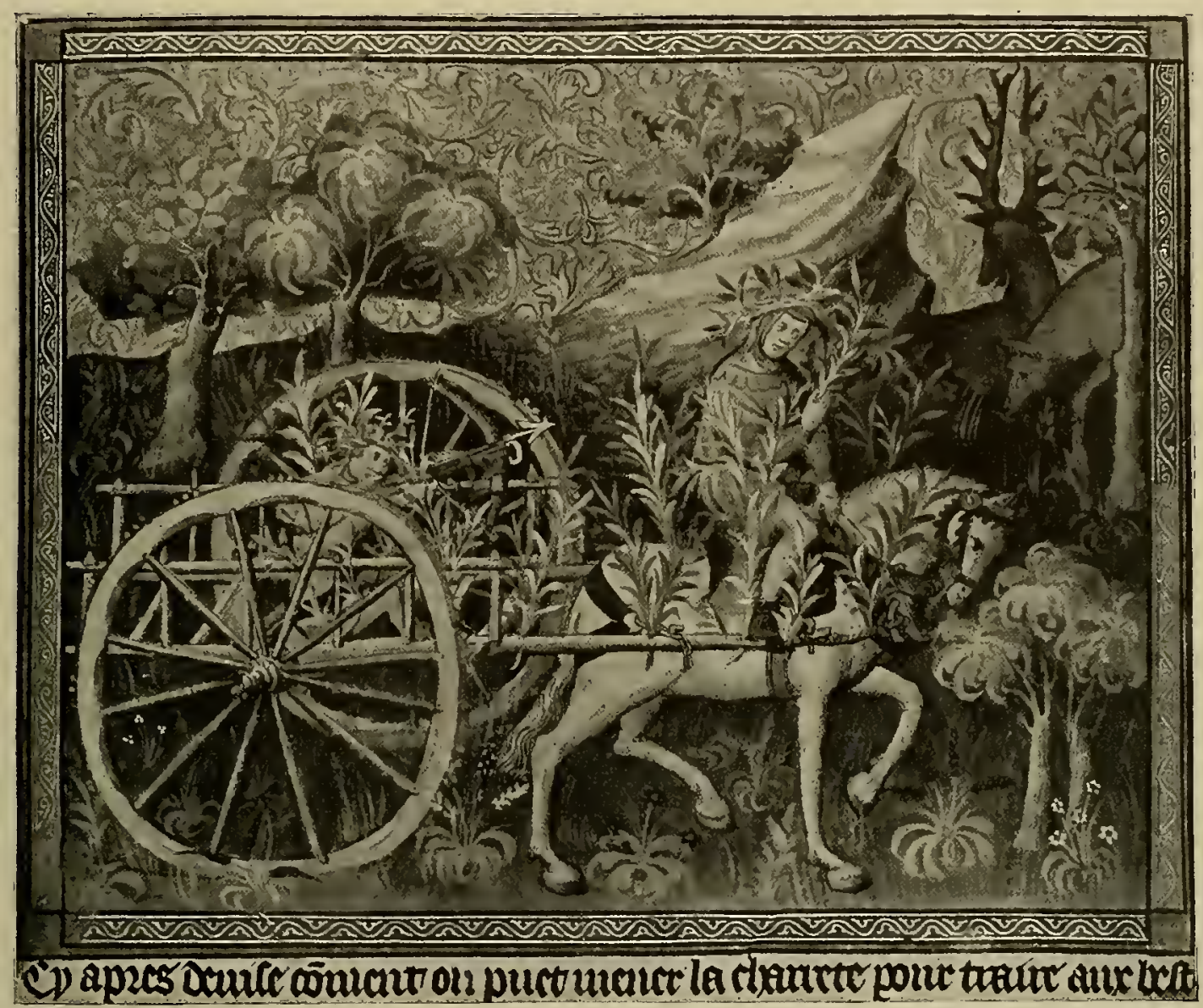

FIG. I3. HOW THE SPORTSMAN APPROACHED DEER IN HIS "CHARRETTE" OR STALKING-CART. FROM GASTON DE FOIX'S MS. See Page $3^{\circ}$

was that when the hare was once on foot greyhounds were also slipped at them. Our Fig. 5 shows greyhounds and running hounds hunting quite happily together! It must have been rather discouraging for the slow scenting hound to have the hare he had been diligently hunting suddenly "bitten" in front of him by the far swifter greyhound!

Another miniature, Fig. 6, depicts hares being bustled out of cornfields with greyhounds and shot with bows, the shape of the arrows being rather remarkable. Their knobby or turnip-shaped points prevented their penetrating into and spoiling 


\section{SPORT IX ART}

small game, the mere shock killing the animal. They were called Boson, and only a few specimens have come down to us. The forked or double-pointed arrowheads of which Shakespeare speaks two centuries later, do not seem to have been known in Gaston's time.

The fox was always considered in France as vermin, as he was in England up to the seventeenth century, and the animal was hunted chiefly for the sake of its pelt and to extirpate a thievish neighbour. The English country gentleman made more of a sport of it than ever did his French confrère. One notices in our Fig. 7 , as in others, that when the horsemen have no sword in their hands, they carry short sticks, about two feet and a half in length, in their right hands. These primitive hunting-crops were called destartoires or estortpoires. They were held before one's face to save it from tree-branches when riding through thick coverts, which, according to our pictures, seems to have been done constantly. As Gaston hints, they were also used for one's varlet, horse, or hound.

Otter-hunting, as Gaston writes, required "great mastery"; it required lymers and four experienced huntsmen, and he considered that it was a very fine chase and capital sport, an opinion many a modern brother of the craft will fully share. The baton fourchie, as we see in Fig. 8, carried still three iron prongs, while in later centuries the two-pronged iron came into use. The short spear carried by some of the hunters was probably used to throw in javelin fashion when the otter could not be reached with the other weapon.

Fig. 9 shows how the wolf was hunted. This chase was, on account of the fearful ravages committed by this pest of the late Middle Ages, quite a democratic sport, while stag-hunting was, of course, exclusively reserved for princes and great seigneurs. Indeed, the latter were, in some reigns, also excluded from hart-hunting, so keen were some royal veneurs.

Every district in France had its appointed wolf-hunters, or louveterie, since the days of the Capitian kings, and for the payment of these officials a levy was made to which every hearth had to contribute, not only a tax in money, but, when summoned, every man had to attend the wolf-hunt in person to help in the destruction. Besides hunting them, as we see in Fig. 9, with running hounds and trying, as the huntsmen in the picture are evidently doing, to attack them with swords or lances, every means were taken to get rid of these marauders. Traps of all sorts, pits, snares, poison, " needles," as a contrivance was called which was made of two pointed little sticks tied bow-like in such a manner together and hidden in a bait of flesh that, when swallowed by the wolf, the sticks would fly apart at right angles and pierce the entrails of the animal, were employed. Running hounds chased the cubs, large greyhounds coursed the old wolves. Nets were stretched round the coverts or forests where they were known to be ; greyhounds and archers were placed near the nets, and then armies of peasants beat the thickets till the wolves, flying before the unaccustomed noise, made for the open 26 


\section{GASTOX DE FOIX}

to find themselves caught in the nets, where they were killed with arrows or clubs; in fact they were slaughtered in any way possible without any law.

The term louvetrie, applied to wolf-hunting establishments later on, is not used by

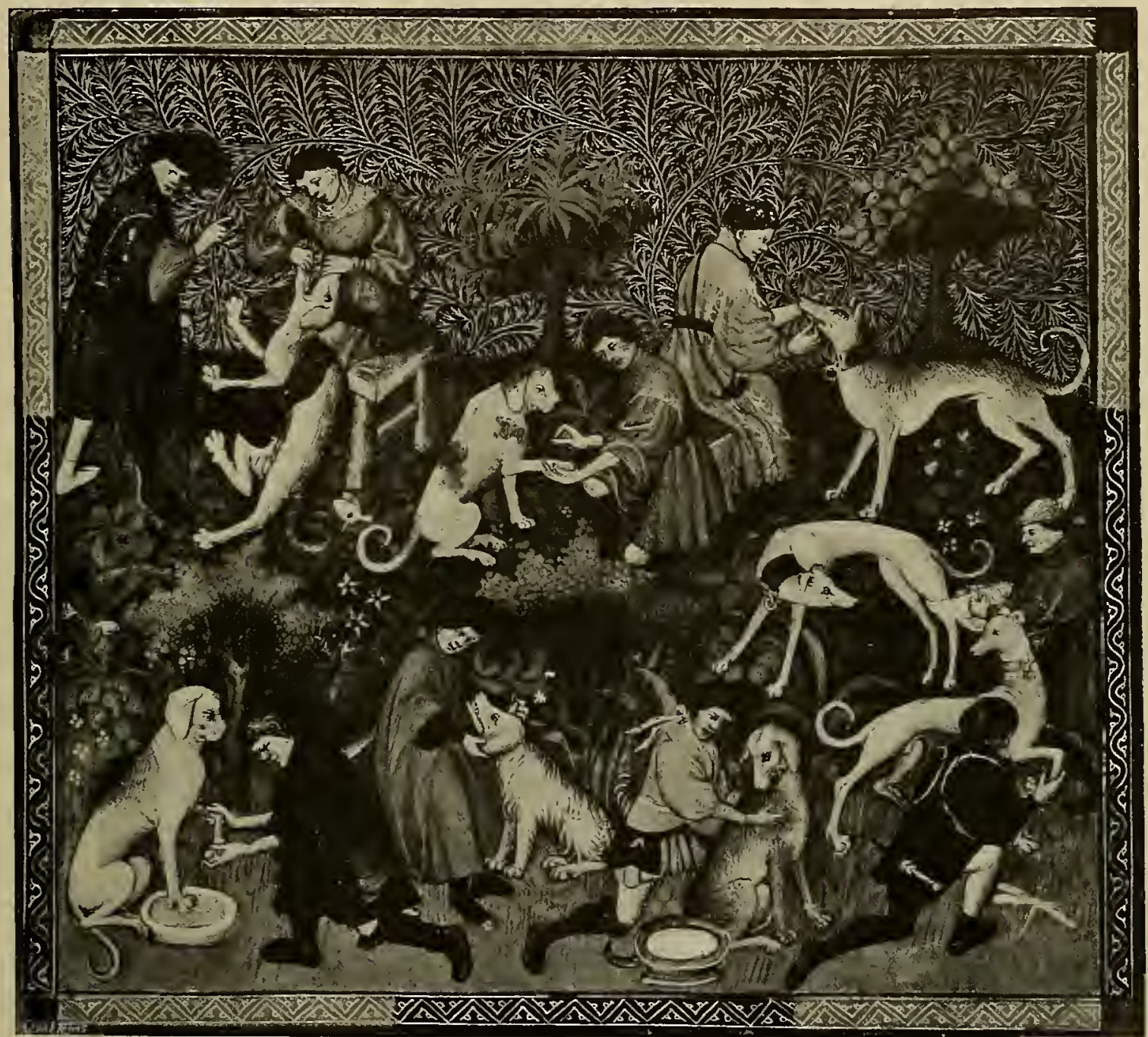

FIG. I4. CARE OF INJURED AND SICK HOUNDS. FROM GASTON DE FOIX'S MS. Page 32

Gaston de Foix in any of the eight chapters he devotes to the subject. One of these only is devoted to the hunting of the wolf, while another deals wirh the natural history of the animal, and six are on the various snares and traps employed for their destruction. One of these, the so-called Hausse-Pied, is shown in Fig. Io. 


\section{SPORT IX ART}

A chapter and picture which cannot fail to interest all big-game hunters relates to chamois-hunting, for it is, so far as I know, the oldest account of that sport that exists. The picture, Fig. I 1 , contains also a weird-looking representation of an ibex, and Gaston calls it bouc sauage or wild buck-goat, and the chamois he terms bouc ysarus, the latter designation being the name by which the Pyrenean representative of the agile mountain antelope is still known. Of these animals, the great peaks forming the southern boundaries of Count de Foix's principalities must have contained vast numbers, but their chase does not seem to have appealed overmuch to this great hunter, for he says: "In my mountains the dress of the people is more frequently of chamois skins than of scarlet, as are also their leggings and shoes, for of these beasts there is too great a multitude. At one view I once saw in the winter more than five hundred. Of these beasts every peasant is a good hunter for the sake of their venison as well as for their pelt, and there is no great skill in taking them "- an opinion which seems almost incredible, considering it refers to an age when fire-arms were unknown. Gaston de Foix says:

"When the hunter would hunt the wild goat or the goat ysarus he should go and remain the night before in high mountains in the huts where the shepherds live who guard the cattle, and he should have reconnoitred eight days before the whole country of the mountains, and all the runs and passes, and have made hays and have stretched nets in front of the rocks where they (chamois) will go to safety, just as one would do in front of the river for a stag. As soon as they are somewhat tired they go to take refuge on the rocks, and if hays cannot be made everywhere he should put on the highest rocks all the people he can get, who should throw stones of the cross-bow at them so that they come not thither or that they kill them with the cross-bows, or that the stones make them jump down the rocks. One should quest and start them with a lyner as one does a stag. And it suffices well to let run ten or twelve hounds of the pack, and to make at least four relays at the passes and at the highest mountains, about a league from one another. For when the hounds have climbed the mountains they cannot hunt for the great heat. Sometimes they go to some rivers if there be any at the foot of the mountains, and here a relay should be set, and he who gives the relay should not wait for the hounds that are hunting, for they may be hunting the forlogne (at a great distance behind the hunted game), but he should relay on sight as one does with greyhounds."

The picture of chamois-hunting gives us, with the usual quaint disregard of all laws of perspective, a view of how the lymer is led forth, how "the relays on the high mountains" are posted, and we see the berner, with an alpenstock in his hand, take profound chasms in his stride, while the animal in the centre of the picture, probably intended to represent a chamois buck, stares unflinchingly at the approaching veneur armed with a cross-bow. The squatting pose of this beast reminds one more of the curious habit of the rare white Rocky Mountain goat 28 


\section{GASTOX DE FOIX}

than of chamois, who, by the way, have long retired to regions where running hounds, lymers, and relays of greyhounds cannot bother them.

The ibex which our author seems to have hunted-to judge by the remark that

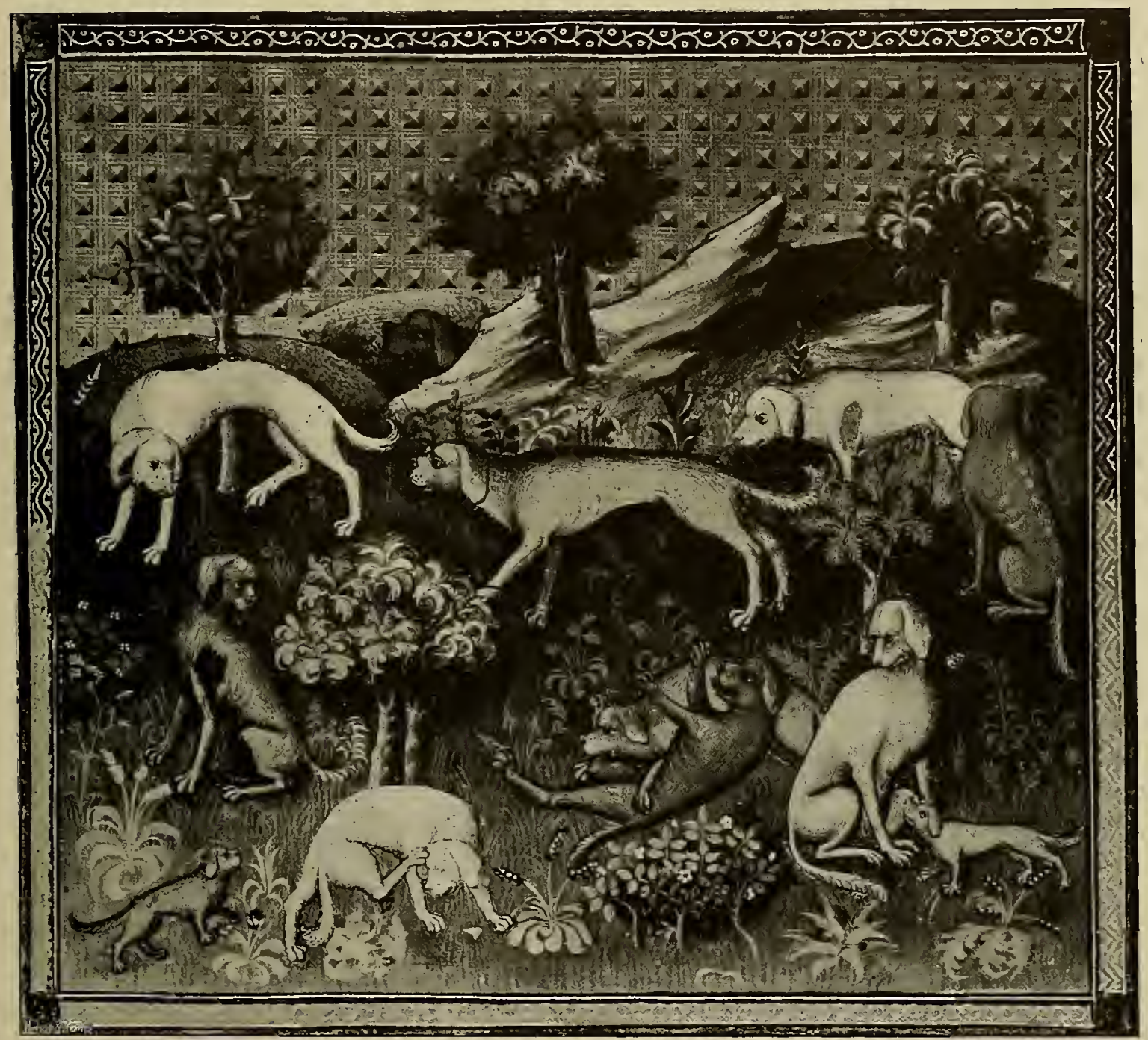

FIG. 15. THE RUNNING HOUND OF THE FIRST HALF OF THE FIFTEENTH CENTURY. Page 32

he had seen one buck jump down a height of ten fathoms without being killed or even injured-were probably the Spanish species. Though in one of the ibex pictures the artist gives in two instances fairly correct representations of their horns, others in the pictures we have reproduced are sadly incorrectly drawn. To the widely-spread mediæval legend that ibex pitch themselves down great 


\section{SPORT IX ART}

heights, breaking the descent by falling on their horns, Gaston gives quite a reasonable interpretation by explaining that on account of their heavy horns they now and again lose their balance when jumping down rocks and pitch forward on their horns, though "sometimes they failed in this and broke their necks, but not often."

Regarding stalking of big game and shooting it with cross-bows and long-bows, Gaston has comparatively little to say, for it was not a sport over which the author waxes very enthusiastic. Fig. I 2 illustrates one phase, viz. the slaying of stags with these cumbersome and comparatively ineffective weapons. Of the two, the cross-bow was in France the more generally used arm. It was provided with an iron stirrup in front, wherein the foot was placed, and the bow was bent by a winch, or lever, of which there were several types, one being called the goat's foot. The iron hook which we notice hanging from the belt of the man could be used without a winch and was called a baudre.

The Livre de Chasse contains a couple of chapters describing how game was to be approached under disguises. One of these miniatures, Fig. I 3, depicts a method which is as well known to-day as it was five hundred years ago. It is the use of the stalking cart, or, as Gaston calls it, Charrette. These carts are particularly effective in districts were game is accustomed to the sight of similar conveyances, and where the rumbling and creaking of their wheels are sounds frequently heard. Gaston is very particular in telling his readers that not only the horse, the cart, and the driver, but also the sportsman inside the vehicle, must be decked out with branches and green twigs, and that both men should be dressed in clothes of green colour, while the cart-wheels should be tightened up in such a manner that they will creak more loudly, for this noise will attract the attention of the deer so that they will pay less heed to the real danger. The cart was driven slowly in circles, gradually narrowing, round the herd, till it finally got close enough. for the sportsman to let off his cross-bow. It would be interesting to know why Gaston advised the men to bedeck themselves with green boughs, for inasmuch as the wood-fellers and charcoal burners, to whose sight the deer had become familiar, were not so disguised, it would appear on the face of it, that a bough-covered cart or man would sooner arouse the suspicion of game than the sight of individuals and carts such as they were accustomed to see. In the modern use of the stalkingcart the sportsman wears a woodman's blouse or peasant's smock-frock, and the vehicles used for stalking are those which are in ordinary use, and which therefore do not arouse the deer's suspicion. Emperor William and many other German sportsmen annually kill hundreds of roebucks, fallow deer, and also red deer by using stalkingcarts. Shirley, in his "Deer Parks," mentions that Lord Winchilsea used to shoot his fallow bucks in Eastwell Park by approaching them in a pony carriage with due attention to the wind, but adds that this device did not succeed more than once or twice.

30 


\section{GASTOX DE FOIX}

Another device was the stalking-horse, which consisted of a canvas or cloth cover, under which were hidden two men, the whole giving the impression of a grazing horse, under which guise the sportsmen approached their quarry to within bow-

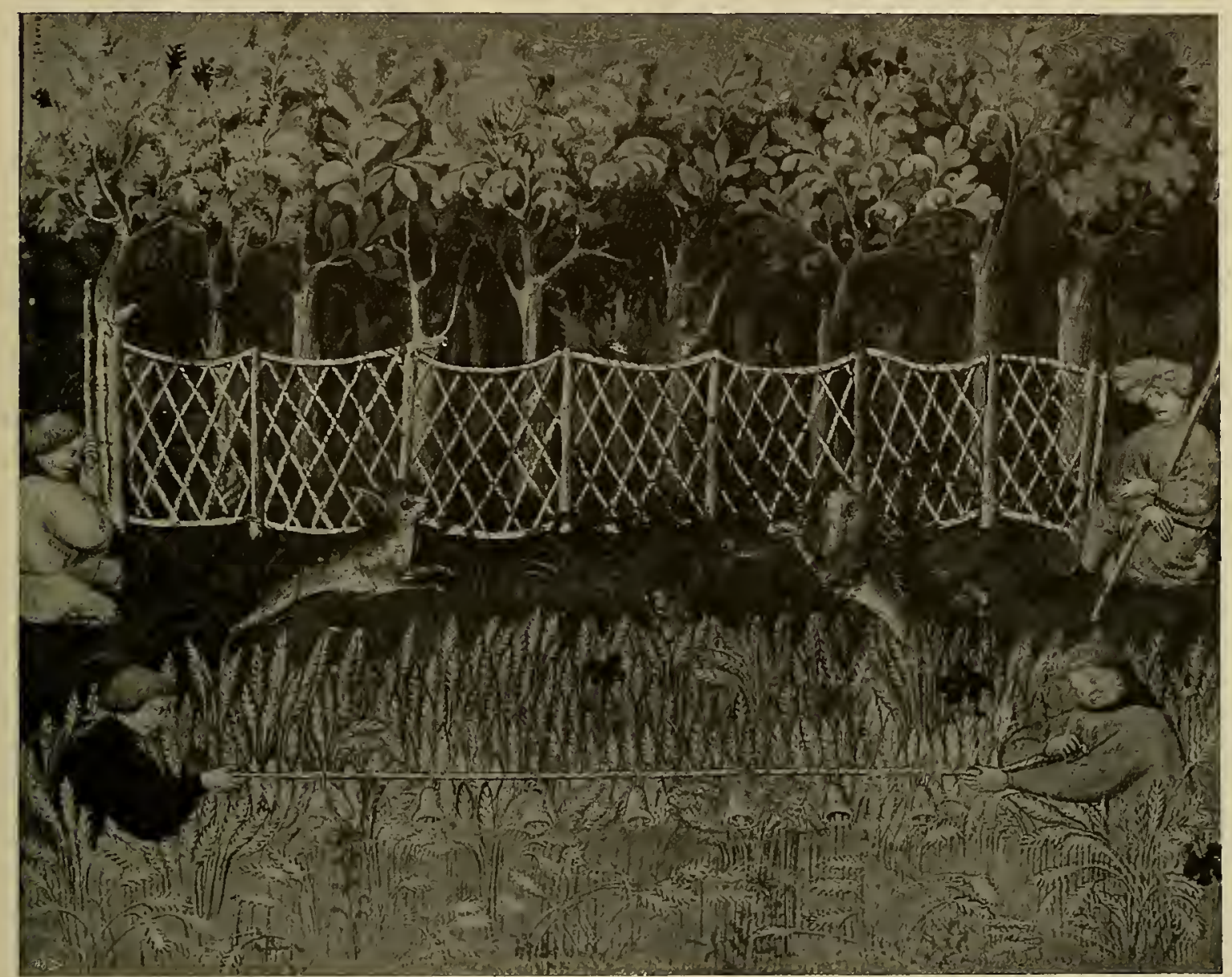

FIG. I6. NETTING HARES BY MEANS OF LOW-BELLS WHICH WERE DRAGGED OVER CORNFIELDS. FROM GASTON DE FOIX'S MS. See Page 32

shot. Sometimes the disguise consisted of a sham cow, and of this one of Stradanus' drawings, Fig. 67, gives us a good idea.

Of the hunting of game not indigenous in France, Gaston de Foix gives but a single example, that of the reindeer. He probably hunted this animal in Norway or Sweden, though he does not say so, but only remarks that he has seen them in those countries to which, we may presume, he paid a visit in the year I 3.58 , when he undertook an expedition to the shores of the Baltic to visit the Teutonic Knights. 


\section{SPORT IX ART}

According to his miniature, reindeer were hunted in much the same fashion as were deer, with running hounds; but in his text Gaston carefully excepts the use of the lymer to quest for and start the quarry. Greyhounds were taken into the middle of the woods, and nets were stretched across the different runs. "On account of his heavy antlers and grand gresse (great fatness), he is heavy and cannot run long before the hounds." Over the morassy ground where to-day the wild reindeer is chiefly found, this method of hunting could hardly have been adopted.

Buffon, it is curious to note, was led into an extraordinary error in making the reindeer an inhabitant of France in the fourteenth century. It was caused by an obvious printer's error in Verard's first edition of Gaston de Foix's book, where the author's words: "I'en ai vu en Nourvegue et Xuedene et en ha oultre mer, mes en romain pays en ay je pou veuz" is printed "J'en ai veu eis Morienne et Puede ne oultre mer, mais en romain pays en ay je plus veu."

Of the bear's nature Gaston writes a long chapter, and a somewhat shorter one than might be expected on the hunting of him, for he does not wax as enthusiastic over the chase of bruin as he does over that of the stag and the wild boar, for bruin does not run fast before the hounds (who therefore always hunt in view), nor does the chase last long, nor does the bear by ruse or stratagem try to deceive the hunter and his hounds, as does the wily old stag, nor does bruin turn on you and charge so sharply as does the fierce wild boar, the chase of which was considered the most dangerous, requiring, as we have heard, not only presence of mind, good horsemanship, and precision of eye, but also a strong and skilful arm.

Of hounds Gaston de Foix has of course a great deal to say, for not only was he passionately fond of them-Froissart tells us that he possessed sixteen hundredbut he was pastmaster in the training, and treatment of them. Lack of space forbids our giving more than a very brief summary of his dozen or so of chapters. His chapters on the medicinal treatment of hounds are of great length, and some of the recipes for cures betray considerable pharmacological knowledge, while others make one shudder. Fig. 14 shows how the kennelmen attended to sick hounds. In one corner a pill or draught is being administered, in another the hound's feet are being examined, while a third attendant is bandaging the leg of a greyhound, and a fourth appears to be doctoring a spaniel's ear.

There were in Gaston's time five kinds of hounds used for sporting purposes, viz. running hounds, to translate literally the French term; of these Fig. I 5 is a good picture. Then greyhounds, alaunts, spaniels, and mastiffs, or rather metifs, a mongrel breed chiefly used for such dangerous chases as that of the boar and bear, where, as de Fouilloux mentions, "out of a pack of fifty hounds that start on a boar chase often scarce a dozen return to the kennel whole and sound."

Netting hares and other small game came within the wide scope of Gaston de Foix's instructive treatise, and the pictures of it convince one that a good deal of skill and patience as well as knowledge were required. Fig. 16 shows one method, 32 


\section{GASTOX DE FOIX}

viz. hare-snaring with low-bells, as were called long strings from which were hung small bells. When dragged by men over the cornfields the hares would be scared up and dash into nets suitably placed at the end of the corn-patch.

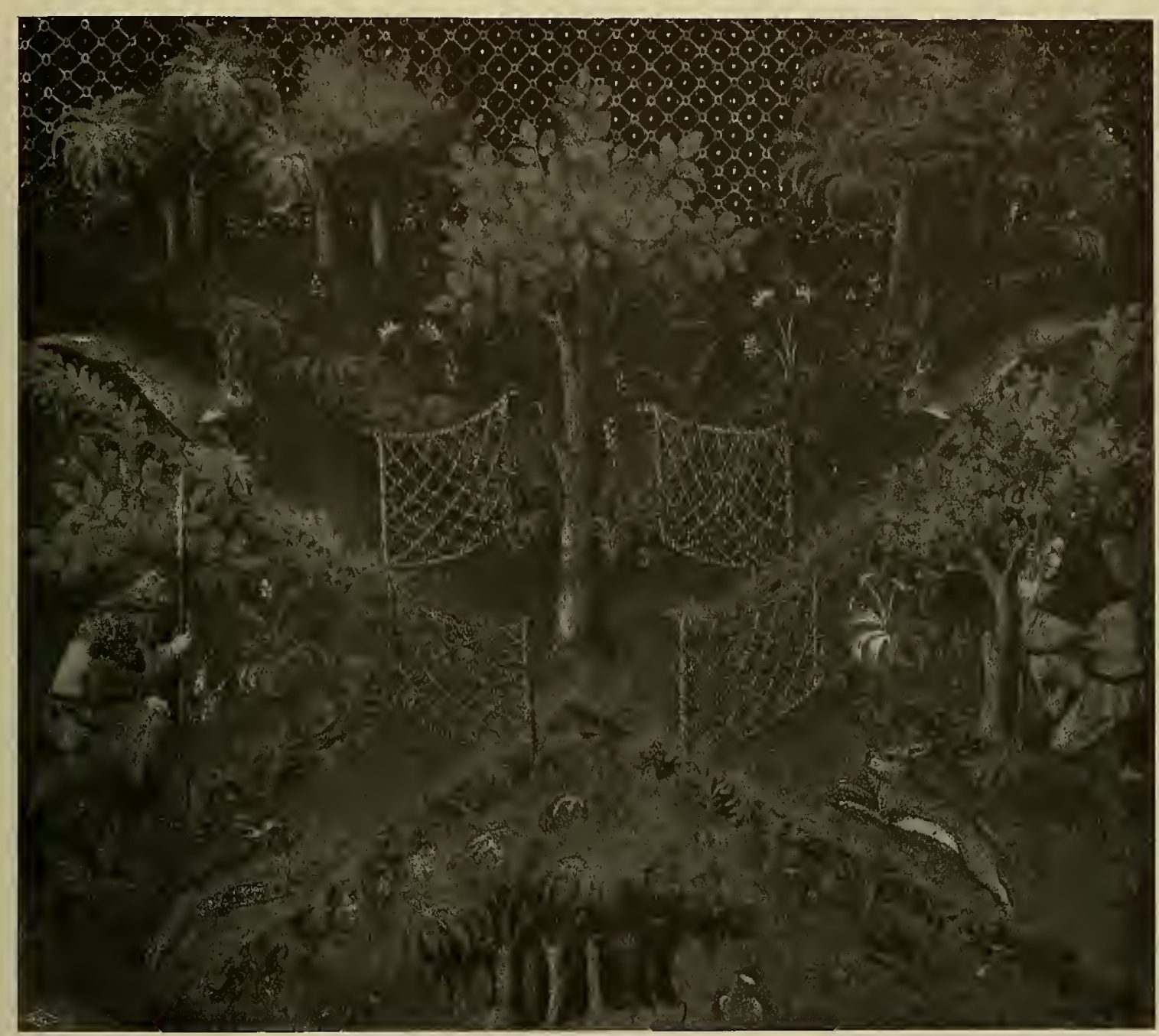

FIG. 17. NETTING HARES AT CROSS-ROADS. FROM GASTON DE FOIX'S MS. See Page 33

Fig. 17 illustrates another method of mounting nets at cross-roads, and hares being driven into them under cover of darkness. In this kind of poaching only the lower classes took a hand, or hunt servants when their master's larder wanted replenishing at short notice.

An amusing illumination in the Live de Chasse is reproduced in Fig. I8. Here we have the great Gaston himself attired in his stately gold-emblazoned surcoat 


\section{SPORT IX ART}

teaching his huntsmen how to blow. In his and in the Duke of York's time the hunting-horn was still of a curved primitive cow-horn shape; indeed most were actually made of the horn sheath of domestic or wild cattle; only those used by

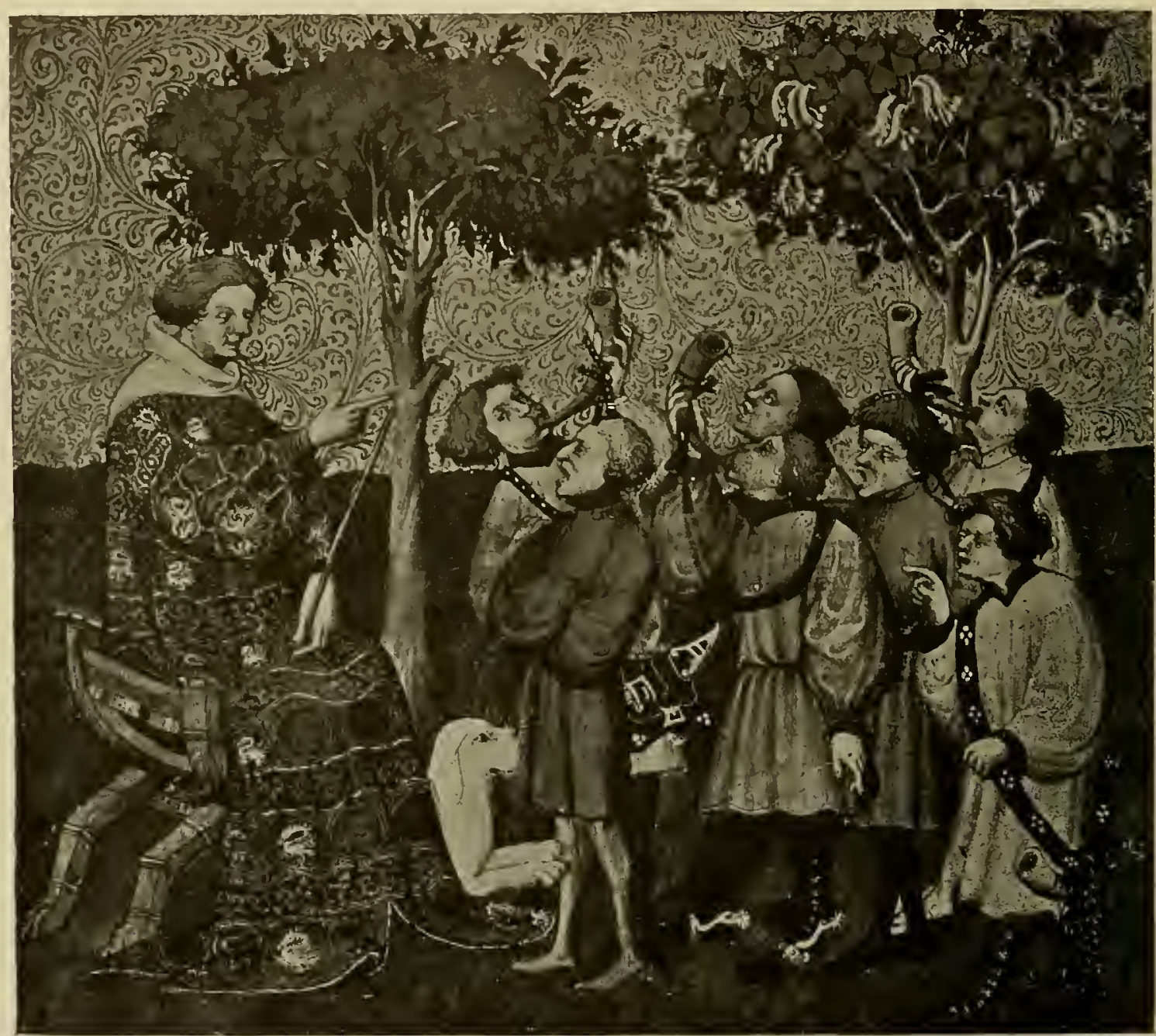

FIG. 18. COUNT GASTON DE FOIX INSTRUCTING HIS HUNTERS TO BLOW THE HORN. FROM GASTON DE FOIX'S MS. See Page 33

great seigneurs were fashioned of ivory, occasionally of ibex horn, and not infrequently of copper heavily gilt and richly engraved, and provided with gold or silver ferrules, and mouth-pieces. They were carried on broad leathern baldrics and appear to have hung down as far as the knee.

The Duke of York writes in his translation that there are "divers kinds of horns, 34 


\section{GASTOX DE FOIX}

that is to say bugles, great Abbot's, hunters' horns, ruets, small foresters' horns and meaner horns of two kinds. . . . The good hunter's horn should be two spans (eighteen inches) in length, and not much more nor much less, and not too crooked, neither too straight, but that the flue be three or four fingers uppermore than the head." "For the fewterers," who were the men who held the hounds in couples, "and woodmen any small or mean horn be good enough." There are a number of celebrated ancient horns in existence : thus the Borstal horn, also known as Nigel's horn, is two feet four inches long on the convex bend; the Corpus Christi (Cambridge) horn; and the fine Pusey horn (two feet and half an inch in length); but the two latter are drinking-horns, while others were horns of tenure. In the fourteenth and fifteenth centuries English hunting-horns enjoyed a great reputation abroad, and French lords sent to England to procure them. Thus the Duke of Burgundy, who had a fine collection, bought in I 394 un cor d'Angleterre garni d'argent doré for which he gave the large sum of 12 frcs. Soon afterwards Louis of Orleans paid I 7 frcs. for twenty-three English horns, and Henry Bolingbroke sent as a present three large silver-gilt hunting-horns to the latter's son. An ivory oliphant richly carved preserved in the British Museum is curious because the work was done by West African natives under Portuguese influence, the silver mounts being added in Europe in the year I 599. Of the changes in shape undergone by the hunting-horn we shall have to speak further on. In Tudor times the science of horn-blowing became decadent, to judge by the quaint plaint of du Fouilloux voiced in English by Turbervile, who writes: "In these days there are many men which bear horns and bewgles and yet cannot tell how to use them, neyther how to encourage and help theyr hounds therewith, but rather doe hinder than further them, having neither skill nor delight to use true measur in blowing." 


\section{CHAPTER III : THE CHASE AND ART IN THE FIFTEENTH CENTURY}

HE "Treasury of Venery" (Le Trésor de la Vénerie) by the Seigneur Hardouin de Fontaines-Guérin is, speaking chronologically, the next book that has to be cited. This poem was completed in the year I 394 , three years after Gaston Phœbus' death. Only one copy of it exists, and it is preserved in the same Paris repository that guards the last-named classic. Iis chief value for us are the twenty interesting illuminations with which a contemporary or slightly later miniaturist adorned its pages. Eight of these, massed upon one page, we reproduce in Fig. I 9.

Hardouin divided his poem into two parts; in the first he instructs his readers how the hunting-horn is to be sounded, while the second deals with stag-hunting proper. But as it is merely an amplification of the yet older La Chace dou Cerf, which dates from the end of the previous century, we need consider only the former, and that briefly. Hardouin's descriptions of the various signals are of too technical a character for explanation in this place, and the reader interested in the subject had best turn to the delightful modern edition prepared with loving care by the famous antiquary of the chase, Baron Pichon. The little blocks we perceive in the vignettes represent musical notes, the black ones being meant for short, the white ones for long notes. Hardouin proudly tells us that he learnt his art from that great master, Guillaume du Pont, the lonvetier, or wolf-hunter, of the forests of Anjou and subsequently first huntsman of Mary of Brittany. As he dedicated his treatise to the Princes Louis and Charles of Anjou, we may presume that he knew about what he wrote.* With the true sportsman's spirit he does not fail to do honour to the great master veneurs of his time. Amongst these we find the names of his contemporary Gaston de Foix, and of the famous Count Tancarville, to whom some ascribe the authorship of that forcrunner of Gaston de Foix's work, Le Roi Modus, and also Jehan de Brézé, an ancestor of the Brézé whose narrow escape from the scaffold we described in the last chapter. Hardouin was a typical sportsman of his day, and while still believing many of the popular fables, as for instance that stags attain the great age of 730 years, he shows a sportsmanlike anxiety that no hunting should go on out of season. The latter extended from the middle of May to the middle of September, and he prays those who have contravened these rules to do so no more. Against other unsportsmanlike actions he inveighs even more strongly-the crime of killing stags with "arrows barbed with iron," being denounced by him in the

* Louis II, King of Sicily, was only I 7 years of age when Fontaines-Guérin dedicated his book to him. But as Louis had hunted stags from his eighth year, as an entry in the journal of Jean Leferre of November 13,1385 shows, he no doubt understood all about venery. 36 

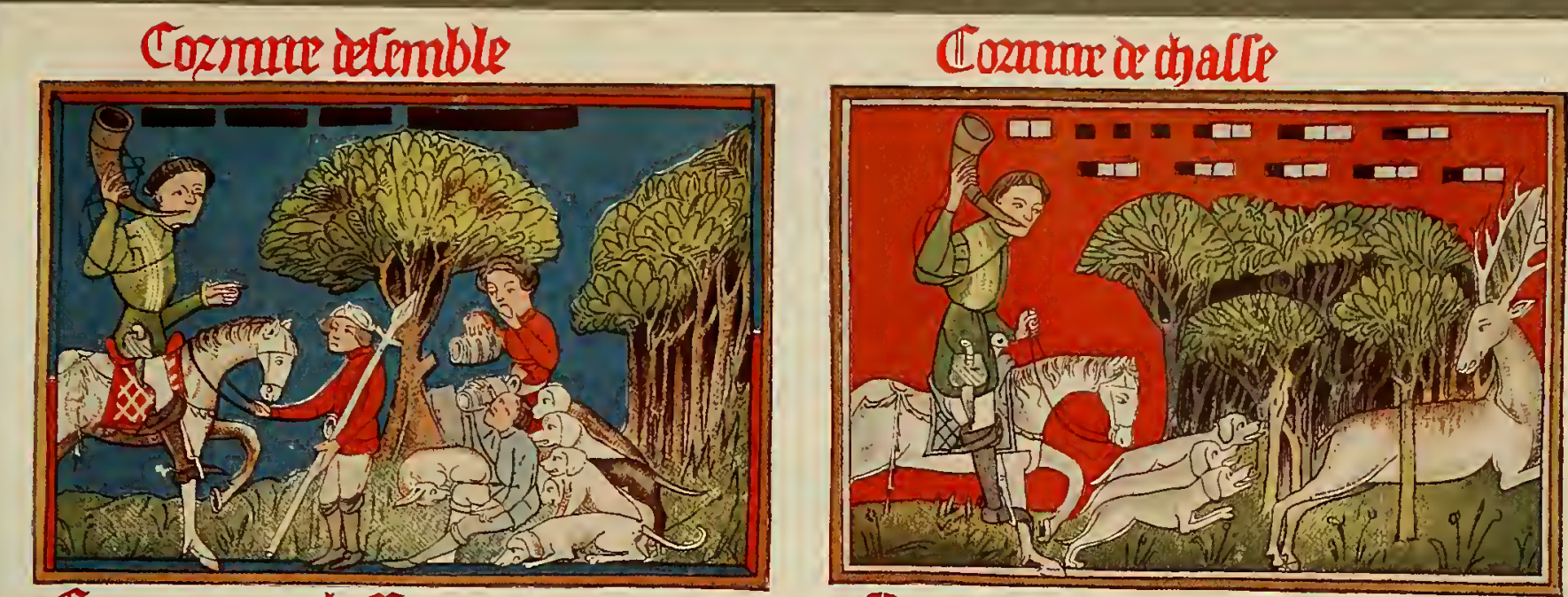

C oproundedalterume.
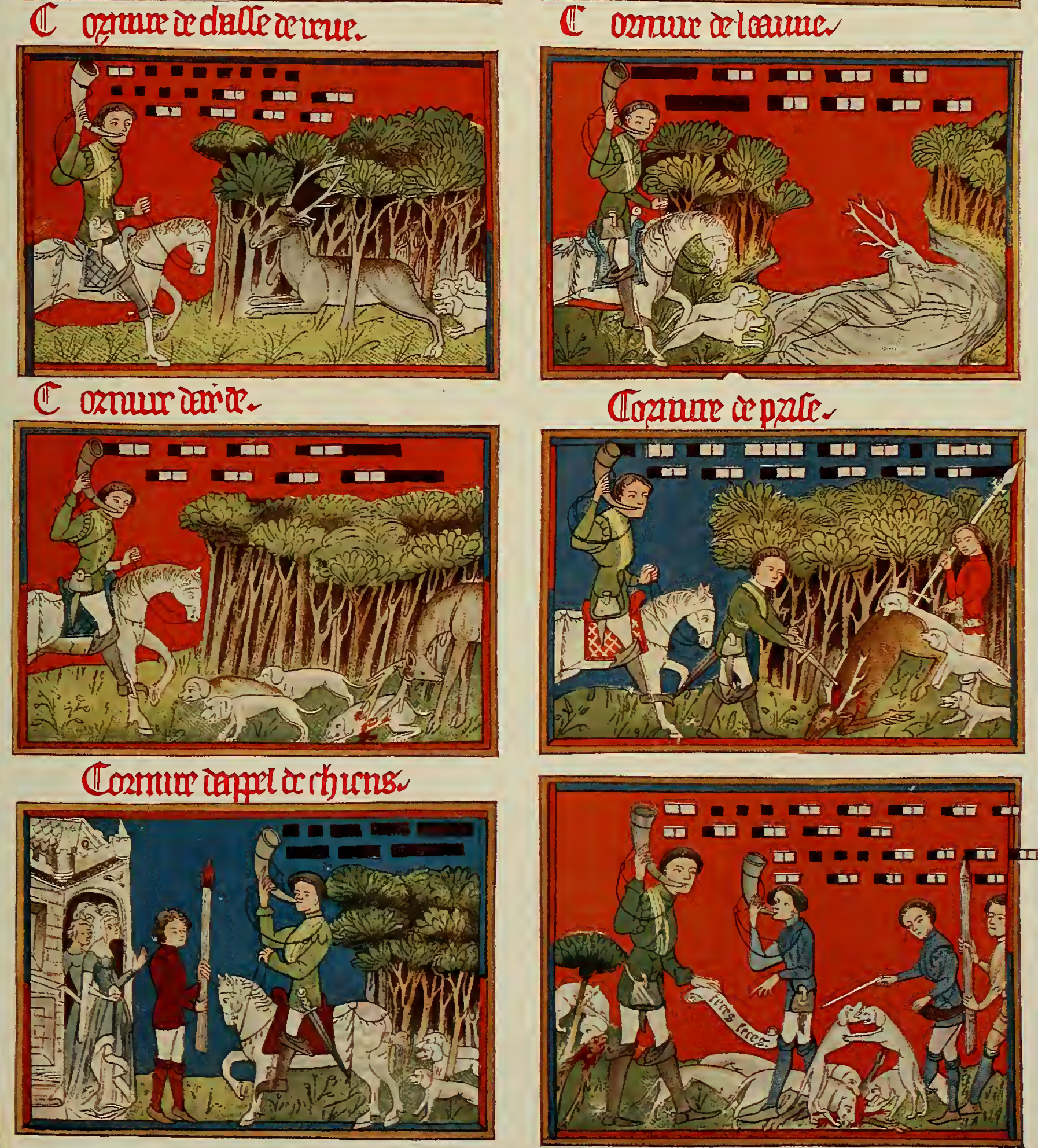

FIG. 19. Eight miniatures from the "Treasury of Venery," wntten circa 1394. See Page $3^{\circ}$ 



\section{LE TRÉSOR DE LAA VÉXERIE}

strongest terms. If he were consulted, he adds, such persons would receive no mercy or ransom, but he would have them hanged. He was himself not far from this fate when writing his poem in the donjons of the Castle of Mererques where the Countess of Turenne kept him in durance vile, though not for shooting stags. Hardouin must have been as keen a warrior as he was a sportsman. In a stubborn fight with the English, when the Duke of Clarence was killed ( 1421 ), he remained victor, but shared the latter's fate two years later at the battle of Gravant.

There is one circumstance which we must refer to in connection with illustrations in ancient venatorial literature. It is that in some cases the pictures are not as old by centuries as the text which they intend to explain, and hence their value for purposes of research is much reduced. This is the case in the Libro de la Monteria, the oldest Spanish book on hunting, written by King Alfonso XI about I 350. Though there exist some eight or nine MSS. of this work, they remained unpublished for almost two centuries and a half, for it was only in I 582 that Argote de Molina issued in Seville a very poorly illustrated impression. So primitive and uninstructive are these woodcuts that it would be doing the unknown artist whose unpractised graver produced them an unmerited honour to find space for them in their chronological order between the delicate little masterpieces of Hans $\mathrm{Bol}$ and the bolder, but not much less artistic productions of Theodore de Bry.

Of equally poor though coeval workmanship are the illustrations that adorn even the best of the nineteen existing manuscripts of the "Master of Game," translated from Gaston Phœbus about the year I 406 by Edward, second Duke of York. English art was then still inferior to that of France. None of these primitive pictures are reproduced here, for the reader interested in the study of early English venery will find reproductions in the modern edition published in I904, of which particulars will be found at the end of the present volume. This edition also contains the Bibliography of bcoks on hunting written before the year 1600 , to which we shall occasionally have to refer.

Let us now turn to a subject that will not fail to interest the naturalist-sportsman, namely, the aurochs and the bison. Most readers will probably be aware of the circumstance that from early mediæval days onwards these two animals have been constantly confused. Leading sportsmen, still in our midst, tell us in their books that they liave slain aurochs, whilst in reality the beasts they killed were the true European bison, the aurochs having become entirely extinct close upon three hundred years ago. For this reason it is perhaps permissible to say that the correct differentiation between these two animals is a subject of peculiar interest to the sportsman-naturalist.* If we want to trace the origin of this long-lived misconception, we

* Even in that recent and otherwise reliable work of reference, "The Century Dictionary," the aurochs is confused with the bison. It is perhaps hardly necessary to say that the chief structural difference between the two animals is that while the bison has fourteen pairs of ribs, the aurochs has only thirteen pairs. Of the existing relics of the latter, which consist mainly of skulls, to one of which, in the Magdeburg Museum, 


\section{SPORT IX ART}

have to dive into the not always limpid depths of early mediæval history. For the event which probably had more to do than any other with the promulgation of this error was the famous hunt given by Charlemagne to the ambassadors of Haroun-alRaschidin thedank Hercynian woods that surrounded his hunting-lodge, Heristallum. According to the original account by the monk Eginhard of St. Gall, the aurochs instilled such terror into the men from the East that they could not even bear their sight and fled from the Emperor's side. The latter, attacked by the fiercest of these huge brutes, missed the vital spot with the result that before brave Isambart could slay the fierce monster, the Emperor was slightly wounded in the thigh and had his nether garment torn into shreds, escaping death by a miracle. Rushing to his side the assembled courtiers offered to divest themselves of their own hose, but the Emperor laughingly rejected their offers, declaring that he intended to show himself in his sorry plight to the fair Hildegarde, who was a great huntress herself. Needless to say, this adventure went from mouth to mouth, and in the course of time, and of untold repetition, the aurochs became a Wisent, the name given to the European bison, and since that time a perplexing confusion has reigned between these two animals. That the true aurochs was an entirely different animal from the bison, whose name, alas! is also on the list of animals about to share the aurochs' fate, is now a fact known to all scientific men. To the writer the bison's pathetic fate appeals more particularly, for when shooting in the Rockies in the 'seventies of last century he still saw them in herds of ten thousands. But as the men who can claim to have witnessed this marvellous sight will before long follow these shaggy monsters to the happy hunting-grounds, the study of the past history of these two species may have attractions to wider circles. Of the earliest of all pictures of the two beasts the exceedingly interesting discoveries in the Altamira caves near Santander by Don Marcelino de Sautuola, the particulars of which are set forth in M. Emile Cartailhac and Abbé Breuil's La Caverne d'Altamira, , have disclosed pictorial records of great importance. For the palæolithic cave-men not only drew their fellow denizens in outline, which in most cases are surprisingly correct, but they coloured these sketches with the primitive pigments known to them. After a gap of centuries, the number of which is unknown to human ken, we reach the various pictorial records left to us by the chisels,

\footnotetext{
some reddish and some white hairs are still attached, all the larger specimens lack the horns. These were greatly prized as trophies or as driuking and hunting horns. Some must have been of extraordinary size. The Bishop of Strassburg's specimen holds, it is said, more than seven pints. Made into a drinking cup (A.D. I 586) by this church lord, it served as the token of a hard-drinking brotherhood, each member of which had to empty it at a draught. Unfortunately, like most of these horns, it disappeared in comparatively late years, the rich gold and silver mountings being probably the chief cause. That some of these aurochs horns are said to have measured 6 feet 6 inches each in length lacks confirmation, and would seem impossible.

* The Illustrated London News, of August 10, I912, brought some reproductions in colours of these unique delineations by Mousterian man.
} 38 



\section{THE AUROCHS AXD THE BISOX}

gravers, or brushes of the Classic ages. Among those who have made important discoveries respecting the distribution of the aurochs, Professor Conrad Keller, the well-known Zurich zoologist, occupies a prominent place. His discoveries in the ruins of the ancient palace of King Minos of Crete of no fewer than sixteen horn-cores and one skull of what unquestionably was the original wild ox of Europe, or aurochs, show that it lived there at one period, and that the famous legend of the Minotaur may well have a substratum of truth. Keller reproduces in one of his works* the fresco in Knossos depicting an aurochs in the act of impaling a helpless-looking victim, while a bold bull-fighter is actually turning a somersault over the back of the beast, a third, possibly female spectator, is attempting to seize the bull's tail. The scene was probably enacted in an arena. Another picture is of two aurochs on the run, the one in the rear tossing an unfortunate victim, is taken from a cup found in Haghia Triada (Crete) dating from the Minos period, i.e. between 2000 and 1500 B.C. Keller's highly instructive writings contain many other illustrations of Bos primigenius.

Skipping tens of centuries and passing over Cæsar's well-known remarks concerning the Urus, we reach the Bestiaries, but these primitive pictorial records do not add much to our information; "the choice hurts one," as Germans describe that state of uncertainty in regard to what the monastic artists meant to represent by their crude attempts. Skipping a few more centuries, we at last reach, in the beginning of the fifteenth century, fairly intelligent accounts of the animal's habitat, and are furnished with drawings presenting features sufficiently distinct to indicate the identity of the animal the picture means to represent. As such we can describe our Fig. 20, which is of interest in more respects than one. It is taken from the well-known Chronique du Concile de Constance, written, about I4I7, by Ulrich von Richenthal, who attended that celebrated Church Council. The animal which occupies the primitive cart in our picture is, we are told in the text, one of three aurochs caught alive in Lithuania and sent by the King of Poland to King Henry $V$ of England. The account tells us that it proved impossible to transport the three beasts alive, so they had to be killed, and while the flesh and skins of two were salted and put into big herring-barrels, which were to be given to the Polish bishops assembled at Constance, the third was carefully impregnated with spices and gunpowder and sent whole on its distant journey of some I 500 miles as a royal gift to King Henry. The latter, it was expected, would attend in person the great Council where the fate of the three antagonistic pontiffs was to be decided, but in the end he sent delegates and did not come himself, and our text, unfortunately, does not relate whether the precious carcass ever reached England.

The text above our pen-and-ink drawing, rendered into English, gives a fairly correct description of the aurochs: "It is like a very large black ox, with a larger 


\section{SPORT IX ART}

head and thicker neck and wide chest. It has two small pointed horns, and between the horns there is a space a foot in width, and it has a short tail, and is not unlike a piiffel, such as live in Italy." Püffel, or büffel, is in this instance rather misleading, for the animal the chronicler refers to is the wide-horned draught ox, still known by that name and so often seen in Italy working patiently under its heavy yoke. As to the aurochs' coloration, which we hear was black, there are other records to show that it varied like that of our domestic kine. In the Knossos fresco, and in what is known as the Ebsdorp map, the beast is represented as of a lightish red-brown. Cæsar stated that the aurochs of the Hercynian woods was like in colour to a taurus (bull), and one could quote quite a number of authorities in support of this fact.

As none of the French sporting books of the fourteenth and fifteenth centuries, such as Roy Modus, Gaston Phebus, Gace de la Buigne, and Fontaines-Guérin, mention either the aurochs or the bison by so much as a word, we may safely conclude that these animals had already then become quite extinct in IVestern Europe.

In the great swampy forests of Eastern Europe the aurochs survived quite two centuries longer than elsewhere, and one of the most interesting and hitherto unknown sources of information is the so-called Tresslerbuch or Diarium of Marienburg, near Dantzic, the headquarters of the famous Teutonic Order. In this book of daily expenditures, which has lately been published by Dr. Erich Joachim, we find a number of highly interesting entries relating to the bison, and more particularly to the aurochs. The entries begin with the year 1399 and end with 1409 , just prior to the disastrous battle of Griinwald (1410), when the forces of the Teutonic Knights were completely routed and the vast powers of the Order broken. The entries show that not only were live aurochs, bison and falcons sent to and received from friendly potentates as prized presents by the Grand Masters of the Order, but silver and gold-mounted aurochs and bison horns were despatched to great lords, who returned the offerings by other gifts, amongst which figures even a live lion which reached Marienburg in I 408 . Unfortunately we are not informed whence it came. Amongst the rulers to whom specimens of the above-named animals were sent we find the King of the Romans, the rulers of Hungary and of France, the Dukes of Burgundy, Austria, Orleans, Saxony, IVirttenberg, Geldern, Holland, the Prince Bishops of Mayence and Trier, the Counts of Bergen, Nürnberg and Katzenellbogen, and, most interesting for us, also the King of England, to whom were despatched several "convoys" of the highly prized Baltic falcons.

The entries deal with such minutix of expenditures as, f.i., the cost of two hundred bushels of oats and of the hay for feeding the four aurochs on the vessel that took them on their first stage from the port of Dantzig to distant Burgundy, the freight 


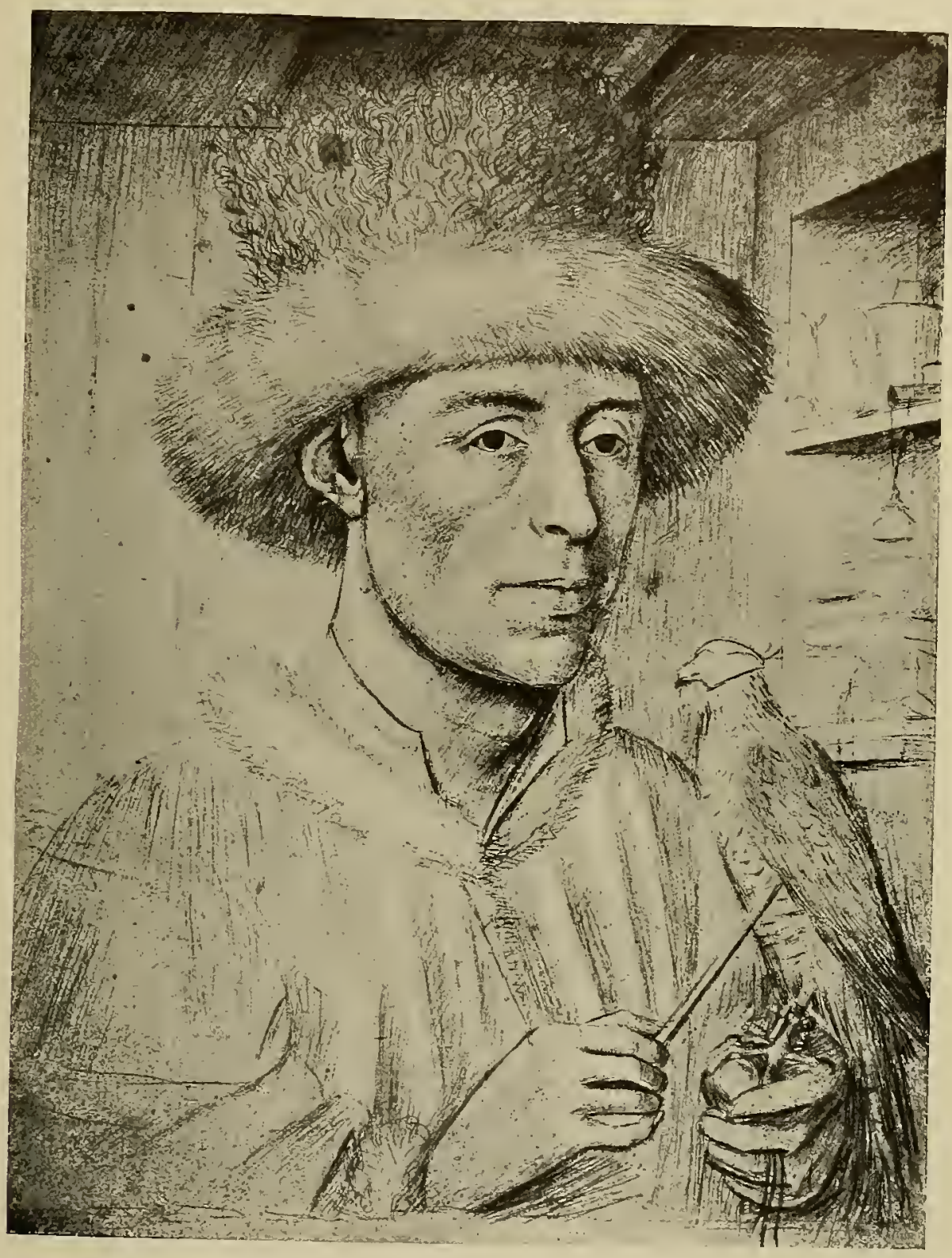

FlG. 2I. FALCONER, BY JOHN VAN EYCK, FIRST HALF OF FIFTEENTH CENTURY. See Page $5 \mathrm{I}$ 



\section{THE AUROCHS AXD THE BISOX}

that was paid for them and for the two "Russians" and the one "Goth" who attended to the animals, the tips for the "ships children," as were called the sailors, and to the crane men who assisted in loading the fierce beasts, for the ropes used in securing them on board ship, for canvas to cover their stalls, for the necessary water-barrels, troughs and buckets, for extra clothes for the Russians, for their two straw mattresses and blankets, and for their return fares. Other entries relate to the cost of mounting in silver and gold bison and aurochs' horns for presentation to the King of Hungary, for tips of a substantial nature, amounting sometimes to the equivalent of what a good knight's horse would cost, for the men who brought live aurochs from the King of Poland, or precious white jerfalcons from the Lithuanian coast. In fact this diarium written in quaint "Baltic" German, which the editor has left in its original form, proves a rich mine for the student of mediæval lore.

Albrecht Dürer ( $1471-1528$ ), of whom we shall have to speak at greater length in the fifth chapter, has left us a couple of drawings about which experts are at loggerheads. Some contend that both are intended to be bison, others that one is meant for an aurochs, while some will have it that both are to be regarded as aurochs. Goethe started the controversy more than a century ago by calling the beast depicted in Fig. 46 an aurochs. It is a reproduction of one of the beautiful pen-and-ink drawings with which Dürer adorned Emperor Maximilian's Prayer Book (see p. 86). Dürer's extreme accuracy when drawing animals from life is too well known to need comment, and as the beast lacks the characteristic features of the bison, i.e. the shaggy growth of hair round the base of the horns, the bison's hump, or in other words withers that are higher than the croup, and is distinguished by a rather long tail, it is likely that the artist intended it to be an aurochs, an animal he had almost certainly never seen, and which we may presume he drew from unreliable material or hearsay information. For by Dürer's time the fierce primeval ox had already become extinct in Germany and exceedingly scarce in the great forests of Eastern Europe. The other drawing by Dürer, reproduced in Fig. 47, which was recently discovered in the British Museum (see p. 93), is, on the other hand, we believe, unquestionably intended for a bison. We have here the typical hump, correctly drawn horns, while the absence of the shaggy tufts on the head may be explained by the circumstance that the animal Dürer had before him was probably a young bull in his summer coat. The vastly increased attention which Dürer's works are now receiving abroad has led some of the most recent writers to attempt to convince us that Dürer intended to represent either the bison or aurochs in his well-known engraving on copper of etdam and Ere of I 504 , and in his woodcut of the same subject in the "Little Passion" series made some years later, probably in 1509. As to the former, few unprejudiced observers will see in the animal depicted lying down behind Eve anything else than a common domestic cow. The animal occupying the same position in the 


\section{SPORT IX ART}

woodcut, with its whisker-like fringe of hair and spreading horns, was probably intended to represent an aurochs.**

In the sixteenth century there were produced quite a number of pictures of the aurochs by artists, very few of whom had ever set eyes upon a live wild specimen, though they may have seen captive ones. The one artist of whom we positively know that he had before him at least a stuffed specimen and probably sketches drawn from life, was the Viennese engraver Augustin Hirschvogel (born in Niirnberg about I 503 ), whose graver illustrated the famous travel-book of Baron Herberstein (1486-1566), the authority most frequently quoted in connection with the aurochs. For he was one of the last intelligent observers who saw the beast in its wild state, and absolutely the last who left pictorial records of his impressions. Herberstein was gifted not only with the powers of close observation and love of accuracy, but also with prescient eyes, for he foresaw that the aurochs was doomed to even speedier extinction than was the bison. The latter he had full opportunity to observe in the great preserve at Troki on the occasion of his return journey from his first expedition to Russia in 5 I 7 , and the aurochs he saw in the forest of Jaktorowka (Silva Hectorea, also called the Wiskitki forest), near Petrikau, which was thirty odd miles S.W.S. of Warsaw, on the occasion of his visit to that place with the Queen-Mother Bona of Poland between July 7 and $13,155^{\circ}$.

Herberstein's opportunities to gather records of these beasts were altogether exceptional, for his various diplomatic missions to Poland and Russia (he visited the former country no fewer than fifteen times) as ambassador, first of Emperor Maximilian, then of Charles V, and finally of King Ferdinand, brought him into close personal contact with the sovereigns of Russia and Poland, then two practically unexplored countries. $\uparrow$ From King Sigismund Augustus of Poland he received a dead aurochs, whose skin and head he took back with him to Vienna, + while Queen Bona presented him with two belts made of aurochs' skin which were believed to be specifics for women in travail. We read with some amusement

\footnotetext{
* Those interested in the Aurochs-Bison discussion will find instructive articles by Dr. Harry David in the Fahrbuch der König. Preuss Kunstsammlungen, Berlin, 1912, I. Heft; Dr. Seb. Killermann in Naturzissenschaftliche IV'ochenschrift, of 15 Dec. I 912 ; the same author's Dïrer's Pflanzen und Thierzeichnungen, I9IO; Scherer's Diurer, I 904 ; Wisent und Ur, in Verh. f. vaterl. Naturkunde in Wiurtenberg, 65. Jahrg. 1909; Dr. M. Auerbach's Aurochs und IV isent in Deutscliland, Karlsruhe, 1907.

† In those day's diplomats were frequently' employed to carry through very delicate duties, as Herberstein's very first miscion show's. King Christian II of Denmark had married a Spanish princess who had reason to complain to the head of her dynasty of her husband's shameless frolics with his former mistress, the fair but frail "Little Turtle Dove." It was to the as yet untried Herberstein that Emp. Maximilian entrusted the ticklish task of remonstrating with the erring $\mathrm{King}$. His unqualified success led to his being subsequently employed on more than one occasion on missions of even more delicate a nature, viz. to arrange royal marriages.

I In a poem De Uri et Bisante, by Caspar Betius (spelt also Pecius), which Herberstein published in his Gratae Posteritati (1558), particulars are given. 46
} 


\section{THE AUROGHS AXD THE BISOX}

that on returning to the Vienna court the Baron forthwith presented one of these precious belts to his sovereign lady, who, though she had been married twenty-nine years, had so far never had occasion to test the efficacy of such a gift. With the skin, horns, and hoofs of the King's aurochs Herberstein was less free, for he

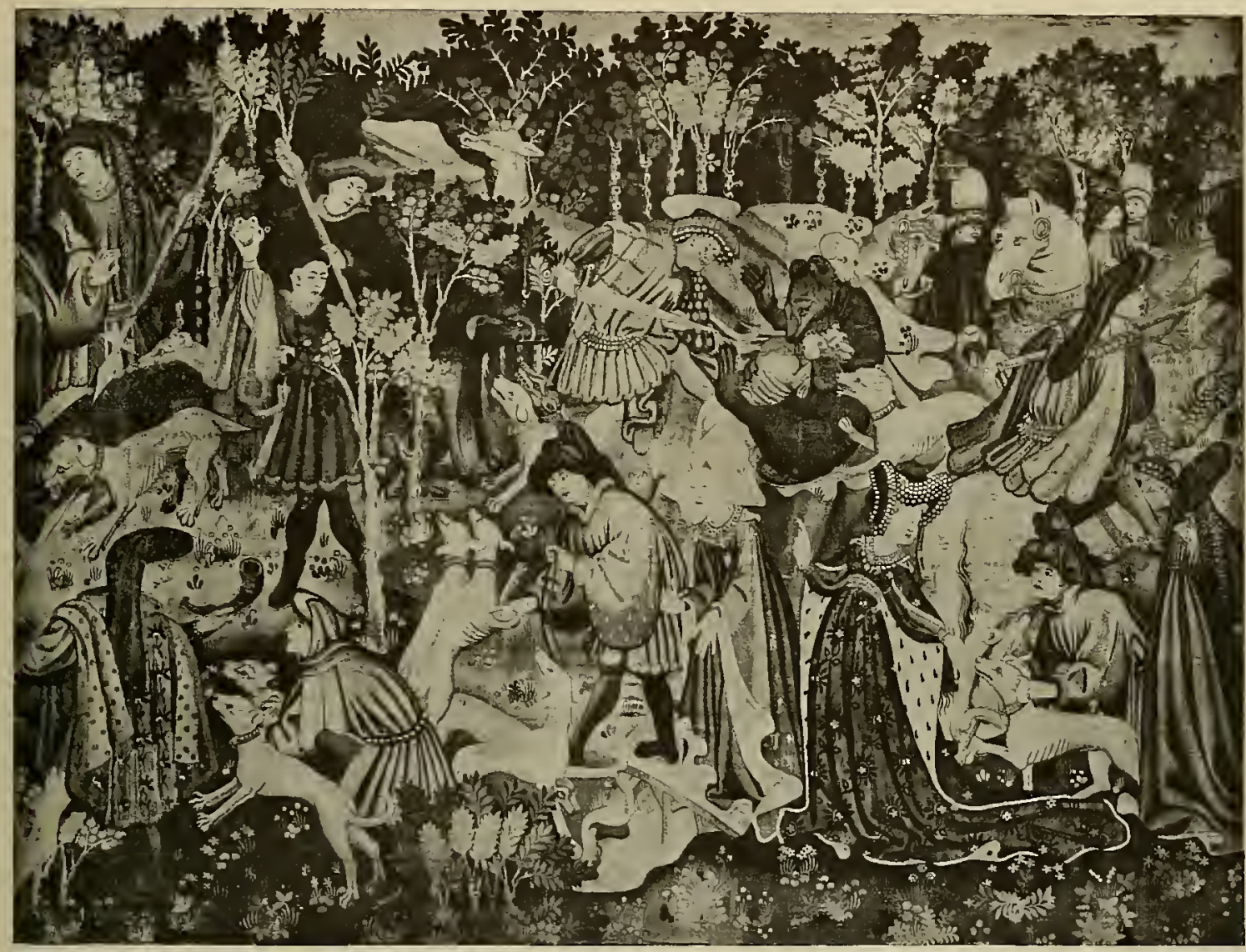

FIG, 22. TAPESTRY WOVEN ABOUT I 440 IN FLANDERS, BELONGING TO THE DUKE OF DEVONSHIRE, NOW LENT TO THE SOUTH KENSINGTON MUSEUM. IT REPRESENTS VARIOUS SPORTS. THE LADY WITH THE ERMINE CLOAK IS MARGUERITE OF ANJOU, HENRY II OF ENGLAND'S QUEEN. See Page 52

appears to have had them mounted and to have exhibited the trophy in his house in Vienna together with a similarly prepared specimen of the bison. The Herberstein house, to which all the curious wandered to inspect these rare exhibits, has now blossomed out into a fine palace (at the corner of the Herrengasse close to the Imperial Burg), while the family, since raised to the ranks of Counts, still flourishes. With this material before him, assisted probably by sketches brought back by the Baron, Hirschvogel drew and engraved his 


\section{SPORT IX ART}

celebrated pictures of the aurochs and bison that give Herberstein's Rerum Toscoviticarum Commentarii such unique interest and caused it to go through many editions and be translated into Italian and German. The best edition is the Vienna one of 1557 , where the two large woodcuts are placed in juxtaposition. Over them Herberstein, to differentiate the two animals, printed the following description :

The picture of the bison has the following: "I am a bison, am called by the Poles a Suber, by the Germans a Bisont or Damthier, and by the ignorant an aurochs." Over the woodcut of the aurochs: "I am an Urus, which is called by the Poles a Tur, by the Germans an aurochs, and until now by the ignorant a bison."

If Herberstein's pictoriai records of the wild aurochs were absolutely the last after life, there is one later written account of the beast. It is the very interesting diary kept by Cardinal Gaetano's secretary, Paul Mucante, during his master's mission to the Polish court in the year 1596 . * On September 30 of that year he states the King sent the Cardinal thirty fat oxen for his kitchen as well as "a grey beast called Tur of which the meat resembled ordinary beef only slightly drier and harder." On the following October 7 they witnessed a drive in a deer park near Warsau, but they saw no Tur only some Zubry (bison). As absolutely the last account of aurochs pemed by a person acquainted with their appearance must be described, Jarocki's report of the last censuses of the Jaktorowka herd. From this document it appears that in $5_{5} 6_{4}$ there existed still twenty-two old cows, three young bulls and five calves, while three old bulls were said to be roaming about singly. In 1599 there were left twenty-four head which had become reduced to four head in 1602 , and in the year 1620 there was left only one old cow. This beast, it appears, died in the year 1627 , as the last aurochs of which authentic records have come down to us.

A decade or so after Herberstein the Flemish painter Stradanus, who lived and worked for more than half a century in Florence, drew (Fig. 79) an interesting picture of an aurochs-baiting in an arena. Philip Galle of Antwerp soon afterwards reproduced it in an engraving, which he published with others in the year 1578 . While in our picture the aurochs is apparently having the best of the fight, the Latin inscription in the engraving gives the victory to the lion, who "lays low the wolves, defeats the 'taurus,' while the bear cowers away in terror." Whether the artist ever witnessed such a struggle cannot be ascertained, but as such baiting matches were exceedingly popular in the sixteenth and seventeenth centuries, it is quite likely that he drew the aurochs after a captive specimen that had been captured in a pitfall. However that may be, Stradanus gives us a fairly correct idea of what the beast was like, and in three other prints in the series we are alluding to, and of which we shall presently have much more to say, we get $4^{8}$

* According to Wrzesniowski the original MS. of this diary is in the hands of a Baron Potoki. 


\section{THE AUROCHS AXD THE BISOX}

portraits of the aurochs, while a fifth depicts the lassoing of the Bubalus in Sardinia.

A contemporary and countryman of Stradanus, one Hans Bol, produced also an interesting engraving of an aurochs hunt, Fig. 88, which forms the second print

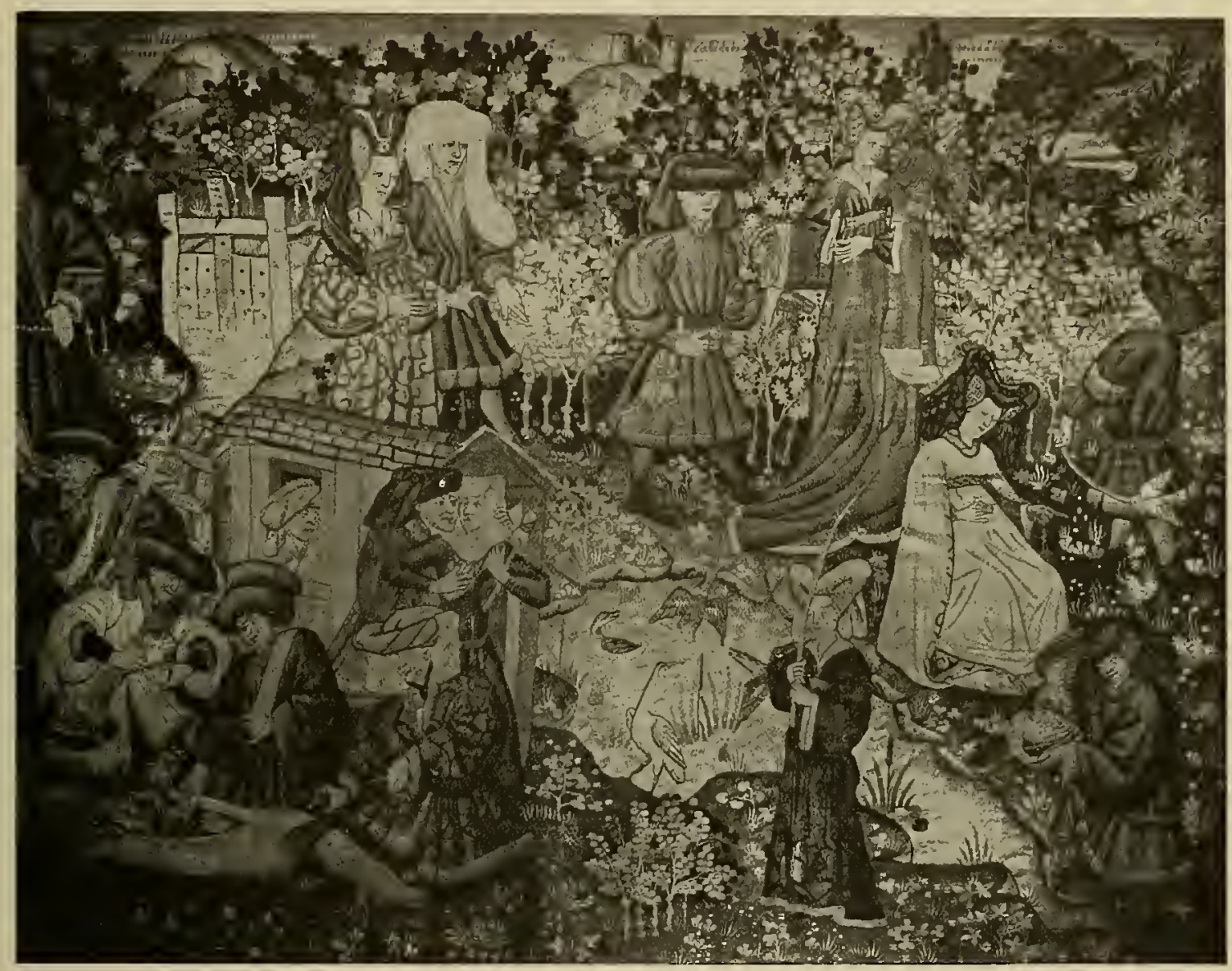

FIG. 23. TAPESTRY WOVEN ABOUT I 440 IN FLANDERS, PENDANT TO FIG. 22. THE PROPERTY OF THE DUKE OF DEVONSHIRE, NOW LENT TO THE SOUTH KENSINGTON MUSEUM. See Page 52

of an attractive little set of sporting prints published in 1532 by the same enterprising Antwerp publishers that gave the world the last-named collection. Beneath the aurochs picture we read in Latin elegaic couplets: "Thus with darts, swords, and light arrows men everywhere drive the horned aurochs into pits." A rather similar print was produced fourteen years later by the Nürnberg engraver Johann Sibmacher, who etched ten sporting plates. Then follow in 


\section{SPORT IX ART}

rapid succession half a dozen "portraits" by Tempesta, the pupil of Stradanus, one of which prints we reproduce in Fig. 102. It shows in what awe the gigantic wild bull was held, for it depicts a formidable-looking machine on wheels, wherewith the beast could be attacked and brought down. Some of Tempesta's pictures need not be taken seriously, for his Roman "studio" was nothing but a workshop where apprentice hands turned out a vast mass of prints of little or no value in an inquiry of this sort. His English contemporary of the pen, Edward Topsell, in his illustrated natural history hodge-podge called the "Historie of Foure-Footed Beastes" ( 1607 ), only added to the existing confusion. "A Bison," he says of Fig. I I 0 , is "a beast very strange, as may appear by his figure prefixed, which by many authors is taken for Urus, some for a Bugle or wild oxe, others for a Rangifer, and many for the beast Tarantus or Buffe." And to show that he really meant what he said, he affixes a picture of what is unmistakably a reindeer! Fortunately, however, he adds as pictures of the bison and of the aurochs, replicas of the two prints by Hirschvogel, out of Herberstein's book (badly copied), which, as we have already mentioned, are among the most correct representations published at a period when the aurochs still existed.

In England the belief that the aurochs was a bison-like creature continued throughout the eighteenth century. Fig. I 5 , taken from Samuel Clarke's "Julius Cæsar," published in I $7 \mathrm{I} 2$, shows what extraordinary ignorance still prevailed, the animal in the background, with antlers like an inverted umbrella, being a bison, or Bos Germanus, and the beast in the centre an aurochs!

Fig. 227, by the graver of I. R. Holzhalb of Zürich, continues the misconception, indeed it goes one better, for the bison is here turned into an "American aurochs."

There are numerous other illustrations of the two beasts ; some are fairly correct, and others very much the contrary, but of these we have not the space to speak at length. One of the former we may still mention, i.e. the so-called Hamilton Smith picture of the aurochs, too well known to be reproduced here. This painting, dating, it is believed, from the first quarter of the sixteenth century, an English colonel of that name discovered at an art dealer's in Augsburg not quite a hundred years ago. As it has mysteriously disappeared it was most fortunate that the colonel caused an accurate copy of it to be made, which was published for the first time in Cuvier's Règne Amimal, a translation of which appeared in London in 1827, published by W. Griffith.*

For the first fairly correct picture of the bison that appeared in England we have also to go to German sources, and strangely enough to the same city, for it was Augsburg's most famous animal-painter, Ridinger (1698-1767), who drew the earliest recognisable picture. A countryman of his, one J. S. Müller, who lived many years in London, engraved in 1748 a fine set of plates representing wild 


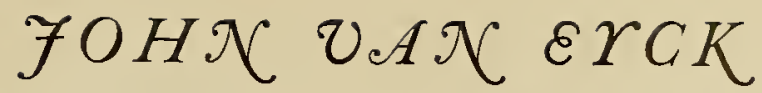

animals, after Ridinger's drawings, which were made from life. Among them is one of the bison, called by him the Buffalo (see Fig. 225), and underneath is a fairly correct description in English. With this picture we reach the chronological limit of the present enquiry; though the confusion between the two animals has continued unto our own day, as said at the outset.*

Here, to follow chronological sequence, we have to change the venue in order to make space for Fig. $2 \mathrm{I}$, a fine drawing of a falconer by John van Eyck. It is

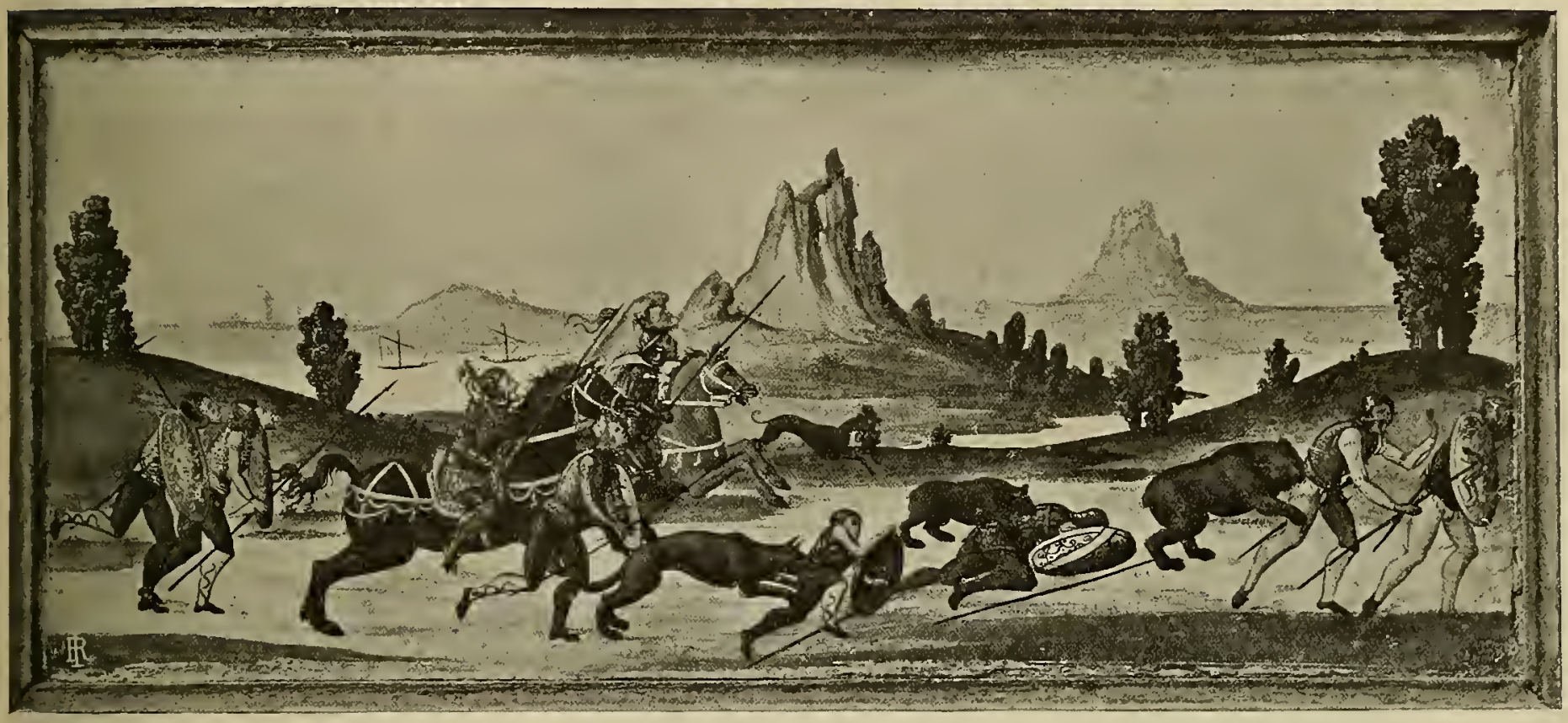

FIG. 24. BEARS AND WOLVES ATTACKING HUNTERS. SIENESE SCHOOL, SECOND HALF OF FIFTEENTH CENTURY. IN THE NATIONAL MUSEUM AT FLORENCE. AN EARLY PAINTING ON SPORT. See Page 33

the portrait of a relation of the artist, one Henry van Eyck, appointed in 1425 master huntsman to John IV, Duke of Brabant, as a reward for his faithful services to the Duke's uncle. Henry subsequently entered the service of Philip of Burgundy as varlet des faulçons, and his name, as $\mathrm{Mr}$. Weale in his beautiful

* As it may prove of use to those desirous of going into this subject more closely we may briefly quote the principal authorities consulted by the writer. Gesner, Baron Bonarus, Dr. Schneeberger, Count Ostrorog Wrzesniowski, Swiecicki, Dr. A. Luschin, Dr. A. Mertens, the late Prof. Dr. A. Nehring (3 treatises), Prof. Dr. C. Keller, and some notes received by the writer personally from a descendant of the adventurous Baron Herberstein. For English readers Lydekker's "The Ox and its Kindred," recently published, contains a useful résumé and reproductions of a few of the well-known pictures to which we have referred. 


\section{SPORT IX ART}

monograph on the van Eycks states, occurs in the list of the ducal household. The original is in the Staedel Institute in Frankfurt.

Proceeding in chronological order we now have to turn to another type of artistic rendering, viz. tapestry work. These are the hangings, reproduced in Figs. 22 and 23 , which were manufactured in the Netherlands about the year 1445 . Hardwicke Hall, as many will know without being told, is the home of these invaluable Gobelins, and they are now lent to the Victoria and Albert Museum by their public-spirited owners, the Duke and Duchess of Devonshire. The four panels are of enormous size-one measuring according to Mr. W. G. Thomson, the author of the "History of Tapestry," 37 feet in length and I4 feet in height. They are, to give the expert opinion of the just-named authority, the finest Flemish tapestry of that early period in England, and though they were not always in the nearly perfect condition in which they are to-day, having undergone considerable repairs, there are probably no finer examples of that epoch in any other country. Unfortunately the mass treatment and the absence of outline do not lend themselves to photographic reproduction, so that our copies appear bald and inartistic, and fail altogether to do justice to the wonderfully mellow effect of the sumptuous originals. The historian has not much trouble to discover that these hangings were woven for Marguerite of Anjou, who married Henry VI of England in 1445 , for on the horse trappings of what is evidently the leading personage there are several "M's," while the dress of the lady is embroidered with marguerites, a pattern which is repeated in the case of the lady bearing the erminelined mantle and the pearl-studded Hennin.

Mr. Weale expresses the opinion that they were woven by John le Vallois of Arras, while Mr. Thomson, being less definite, expresses the belief that they were productions of the looms of Tournai or of Arras. The latter authority considers that they were made after "cartoons inspired by illuminations of hunting scenes by a French artist such as the painter of the illuminations in the hunting-book of Gaston de Foix." As the reader has before him a number of these designs he can judge for himself. In our opinion they are not by a French artist, but by a Flemish designer, the one scene in Fig. 23 where an amorous sportsman is making violent love to a damsel who fails to make use of her distaff to ward him off, is so typical of the coarser Flemish artistic feeling as almost entirely to remove doubt. Another feature supporting our contention are certain details in the costume which are characteristically Burgundian, and would have been avoided by a French artist.

As to the details of hunting depicted by these four big panels, practically every kind of chase imaginable is included. We see heron and duck hawking, stag and wild boar hunting, encounters with bear, the chase of the otter, the use of ferrets, birds nesting, fishing with rod and line, hare coursing, together with pictures of how deer are undone, hounds rewarded and the hunting horn blown. These $5^{2}$ 


\section{EARLY ITALIAX PRIXTS}

sports are crowded together into a nigh inextricable medley of venery to which the presence of Saracens mounted on camels, throwing javelins at bear, give a weirdly outlandish effect. Leaving tapestries for the present, we come to the illustrations of sport by prints. The question from which hand or even from which country issued the first is difficult to answer, and any attempt to do so would oblige us to enter into technical details quite out of place in the present enquiry. Amongst the earliest can be cited two pictures in the "Florentine Picture Chronicle" by an unknown artist of the school of Maso Finiguerra (1 426-I 464), the Florentine goldsmith to whom the Italians are in the habit of ascribing the invention of copper engraving. Of slightly later date is the equally crude Doe at Rest and the print known as the Stag Browsing, both of which were attributed by Passavant to Giulio Campagnola, but which are probably the work of the master

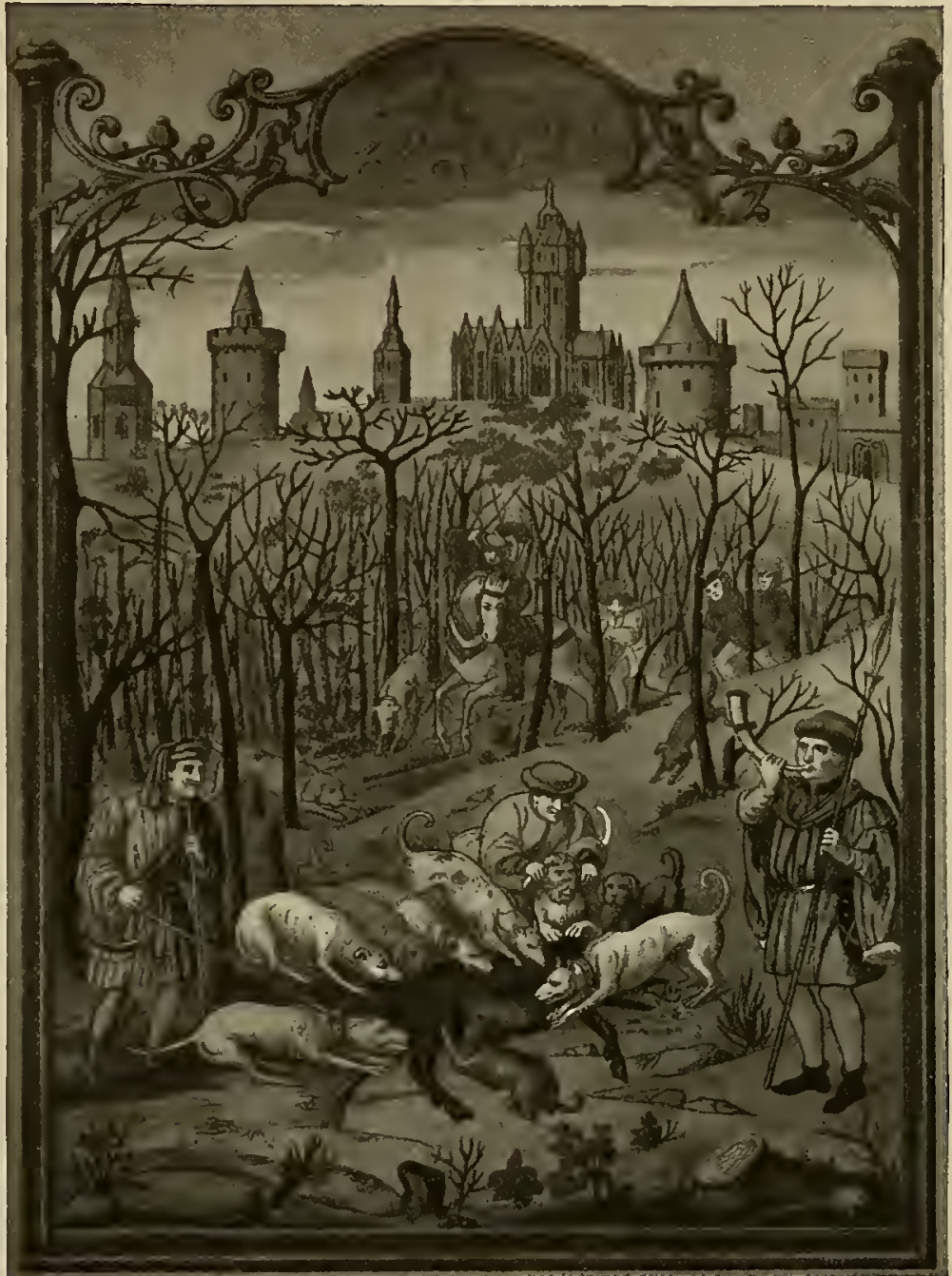

FIG. 25. FROM THE GRIMANI BREVIARY: UNDOING THE WILD BOAR, BY HANS MEMLING OF BRUGES, LAST QUARTER OF FIFTEENTH CENTURY. See Page 55 of the Beheading of John the Baptist." Another set of primitive sporting prints is the so-called "Otto" prints, so named after a well-known Leipzig collector. These are said to have issued from a Florentine workshop, possibly that of Finiguerra in the decade after that master's demise. These prints were used to decorate the covers * For further particulars consult Hind”s "Catalogue of Early Italian Engravings." 


\section{SPORT IX ART}

of toilet-boxes or work-boxes, and the details remind one in their rough delineation of a painting of the Sienese school (Fig. 24) preserved in the National Museum in Florence.

Another early Italian picture is the Pl. $7^{2}$ in La Caccia di Belfiori, a Florentine work, representing hunters spearing and beating to death what might be a wolf or a hind, so uncouth and rough is the drawing.

Another woodcut represents a knight in full armour with visor lowered fighting a lion. This may possibly have given Stradanus the idea of depicting a fight between armoured knights and bears, see Fig. 63 .

It is much to be regretted that even the last third of the fifteenth century failed to produce illustrations of any value on our subject, for how interesting would it not be were there pictorial descriptions of Louis XI hunts! Except a Book of Hours in the National Library in Paris, in which there are one or two illuminations depicting sporting scenes of his time, we possess nothing that throws light on his manner of conducting sport. However despicable this monarch may appear to the historian he was at least a keen sportsman. It is said of him that he did everything in its proper season; in summer and autumn he carried on his wars, in winter he hunted wild boar and stag, in spring he flew the falcon. In a letter to the Seigneur de Bressuire he once wrote: "In Normandy the army of the English is beaten and disbanded, and I am returning to Amboise or Plessis to take and kill wild boar, so that I may not miss the season while awaiting the other wherein to take and kill the English." Philippe de Commines, at whose manor of d'Argenton he often lodged, tells us of his passion for hunting in Touraine and the marshes of Anjou and Poitou. His daughter, Anne of France, who acted as Regent during the minority of her young brother Charles VIII, became an unusually bold and experienced huntress, and could undo a stag as deftly as the most practised veneur, as we know from the testimony of Jacques de Brézé, who was her Grand Veneur.

Mantegna has left us in his Triumph of Caesar (Hampton Court) some good pictures of elephants and other beasts, a more important contribution being one of his frescoes in the Camera degli Sposi in the Castello di Corte in Mantua. It is supposed to represent the hunting horse and two huge mastiffs of Lodovico Gonzaga.

Jean Duvet, one of, if not the first engraver on copper France produced, did some early work in our line, although he followed the fashion of depicting processional arrays of animals which Mantegna and Dürer had set. His allegorical apologue on Henry II and Diane de Poitiers, in which his favourite animal, the unicorn, largely figures, is perhaps for us the most noteworthy of his contributions.

Were we to attempt to do full justice to the title of this volume we should have to give also accounts of the productions of sculptors, and to refer to the more numerous frescoes dealing with sport. To do this we have not sufficient space. The 54 


\section{THREE FAMOUS BOOKS OF HOURS}

mural paintings, of which there exist a great many, are generally in a bad state of repair, and do not lend themselves to reproduction. Different is the case of the Books of Hours and Breviaries, which in some instances contain very beautiful illuminations treating of sport if the prince or great personage for whom the book was destined was known to be a veneur. There are two Livres d'heures which are specially fine examples; one is the well-known Brevarium Grimani, the illuminations of which used to be ascribed to Hans Memling, but late authorities do not agree with this. According to Thaussig and others Jan de Mabuse drew the majority. Our Fig. 25 is a reproduction of the leaf containing the picture of sport in the month of December, viz. wild-boar hunting. This wellknown treasure derived its name from the fact that Cardinal Grimani gave it in the year 1523 to the Library of St. Mark. A very sumptuous but also expensive reproduction of this famous devotional book has lately been published, so the art-lover need not travel to Venice to obtain a glimpse of these masterpieces. The reproduction fills twenty-five huge volumes weighing several hundredweight! The editors are Scato de Vries and Salomone Morpurgo, and an instructive introduction by Giulio Coggiola, which takes up one of the enormous volumes, deals separately with each of the 1662 pages. Unfortunately, only very few of the miniatures deal with our subject.

Another very fine Book of Hours is Les Très Riches Heures de Jean, duc de Berri, preserved in Chantilly (Musée Condé), painted about the year I 4 I 5 by Pol de Limbourg and his two brothers, Jean and Armand (Hermann) (see Appendix). The artist who designed Fig. 25 had unquestionably seen Limbourg's limning, for the mise en scene is very like that of a miniature in the Chantilly MS. The former artist, however, had a better eye for Nature, and, unlike Limbourg, who painted his trees in full leaf, improved upon the earlier illumination by showing his wooded background shorn of every leaf, except in the case of one tree, which he presumably intended to represent a pine or fir.

A third very remarkable Book of Hours, in which two of its forty-five miniatures related to sport, fishing, and falconry, was the one known as the Heures de Thurin, which unfortunately perished in the fire that destroyed the National Library of Turin in I904. Comte Paul Durrieu very fortunately had previously secured reproductions of these fine miniatures, and published them in 1902 . 


\section{CHAPTER IV : EMPEROR MAXIMILIANI AND BERNARD VAN ORLEY}

I

$\mathrm{T}$ would be difficult to pick out among historical characters a fitter personage to mark the state of transition from the medixval to the modern than is presented by the person of Emperor Maximilian I (1459-1519). While in every sense of the word, living up to the name with which history crowned him-the last knight-he equally deserves the distinction of being considered the first modern author. For in strange contrast to the modest writings of Gaston de Foix and other old authors on sport, which are singularly free from all self-advertising accounts of personal prowess, and breathe a spirit of calm reserve, Maximilian's works betray in a very striking manner the spirit of modern life, the restless rush and scramble of movement, and the craving to see himself in print. It is perfectly astonishing to notice what uncommon trouble he took to have his doughty deeds elaborately illustrated by the foremost artists of his day, and to get them published to the world by the most famous printers with founts of type specially cut by celebrated artists.

However great were his services to the arts and crafts of the day, which prospered greatly under his encouragement, the ulterior motive was ever the one of aggrandising either his personal fame or that of his ancestors to the remotest antiquity. No dynasty that ever occupied a throne had a son prouder of his progenitors than this Habsturg sportsman prince, and none, not even excepting late tenants of the German throne, assumed a master's erudition in regard to a greater variety of sciences.

Among the hundred or so of books that he either started, generally in the shape of notes he dictated to one or the other of his numerous secretaries, or carried through to completion, we find represented an extraordinary medley of subjects. Between a treatise on the fortification of castles, there would come notes respecting the seventy-two signs and other technicalities which a stag-hunter must know ere he can pass his apprenticeship to venery. These would be followed by pages of theological disquisitions regarding the sacraments, or by a learned dissertation on artillery, or the manufacture of Greek fire, or by a homily on astronomy, or a work on gardening, or the management of the kitchen. His attempt to add to his imperial crown the Pope's tiara was as characteristic of the versatility of his aims as were his flights into the field of politics. His popular reputation of considering the saddle his residence and the stirrups his home epitomised his kinetic restlessness, which is corroborated by the yet existing itineraries of his journeys. He might well have added "Here, there, and everywhere" to his motto: "Halt Mass" ("Restrain Yourself") repeatedly engraved on the gilt steel of his cro:s-bows and elsewhere.

Of his works on sport, of which there are some six or seven, the two largest, 56 


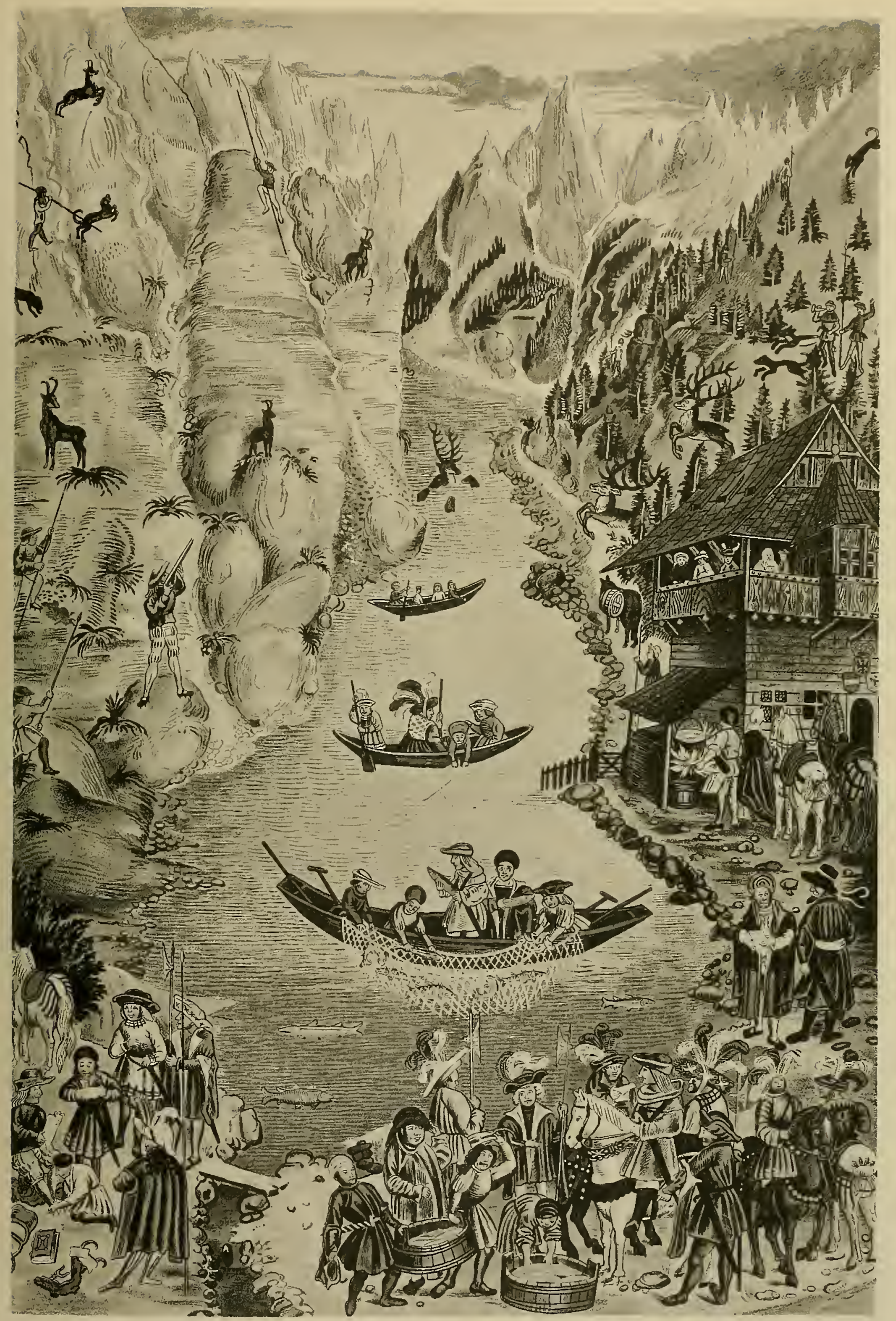

FIG. 26. EARLIEST PICTURE OF THE USE OF FIRE-ARMS FOR BIG GAME. OUT OF EMIPEROR MAXIMILIAN'S BOOK, CIRCA 1504. See Page 64 



\section{$\mathscr{M} A X I \mathscr{M} I L I \mathcal{A} ' S$ SPORTIXCG BOOKS}

Weisskunig and Theuerdank, are so well known that quite a brief reference must suffice. The former, a romance in stilted prose, relates in the style peculiar to medirval chronicles the happenings of his own reign and that of his father Frederick III, all the personages being disguised under allegorical names. Maximilian dictated it to his "Secret Secretary," Marx Treizsauerwein, between the years 1512 and 1517 . It is illustrated by 237 woodcuts, most of which are by the famous pupil of Dürer, Hans Burgkmair, but the book was not published until the year I775. Theuerdank, on the other hand, is written in verses of hard and forced metre and contains the adventures, told in an allegorical form, of that valiant hero Theuerdank by whom, of course, the Emperor meant himself. The I 17 wood engravings are by Schäuffelein, Burgkmair, and Leonhard Beck, and serve to illustrate his 117 adventures.* The dauntless hero is supposed to be surrounded by three evil spirits, personated pictorially by oddly dressed men, who persist in tempting him to perform all kinds of dangerous feats and to undertake riskful enterprises or perilous journeys, the hero's presence of mind or courage saving him invariably at the last moment. Most of the adventures described in Theuerdank are known to have really happened to Maximilian, and as a great number occurred while on his sporting expeditions-no fewer than sixteen happened while he was chamois-shooting-the book enables us to gain a good insight into his methods of conducting his sport.

Far less known, because only lately published, are his "Secret Book of the Chase" (Geheimes Jagdbuch), and the two works from which we publish all the illustrations, viz. the "Hunting-Book" and the "Fishing-Book."

To the "Secret Book of the Chase," of which the original manuscript was discovered only a few decades ago and immediately printed by a learned student of ancient venery, $\downarrow$ we shall have to refer on more than one occasion while treating the contents of Maximilian's "Hunting-Book," the original manuscript of which it fell to the present writer's lot to discover.

This Gejaid Buch was written for Maximilian by his master of game, Carl von Spaur, in the years I 499 and I 500, and illustrated by his court painter, Jörg Kölderer, whose quaint limnings show a decided lack of perspective.

That such a book had been written by the keen royal sportsman's orders was no secret to students, for there existed an unillustrated manuscript transcript preserved in the Stadthalterei Archiv in Innsbruck; but the original of the work had disappeared from Austria, and its whereabouts, in spite of many enquiries, remained unknown. Years ago, while on a round of visits to Continental archives, I

* A special fount was cut by the famous Formschneider Jost de Negkers or Dienecker of Antwerp, and the printing was entrusted to Hans Schönsperger the Elder of Augsburg. The ordinary copies of Theuerdank are on paper; then there are some on vellum, and there exist also three illuminated copies. One is in Windsor, a gift from the Duke of Brunswick to William IV (1836), while the two others are in the Royal libraries at Dresden and Wolffenbüttel.

† “Kaiser Maximilian's Geheimes Jagdbuch,” by Ch. G. von Karajan. Vienna, I859 and I88I. 


\section{SPORT IX ART}

happened to be examining some MSS. in the Burgundian Library in Brussels, and while so occupied came across a small folio, the plain vellum cover of which showed many traces of wear. A glance at its pages, and more particularly at the

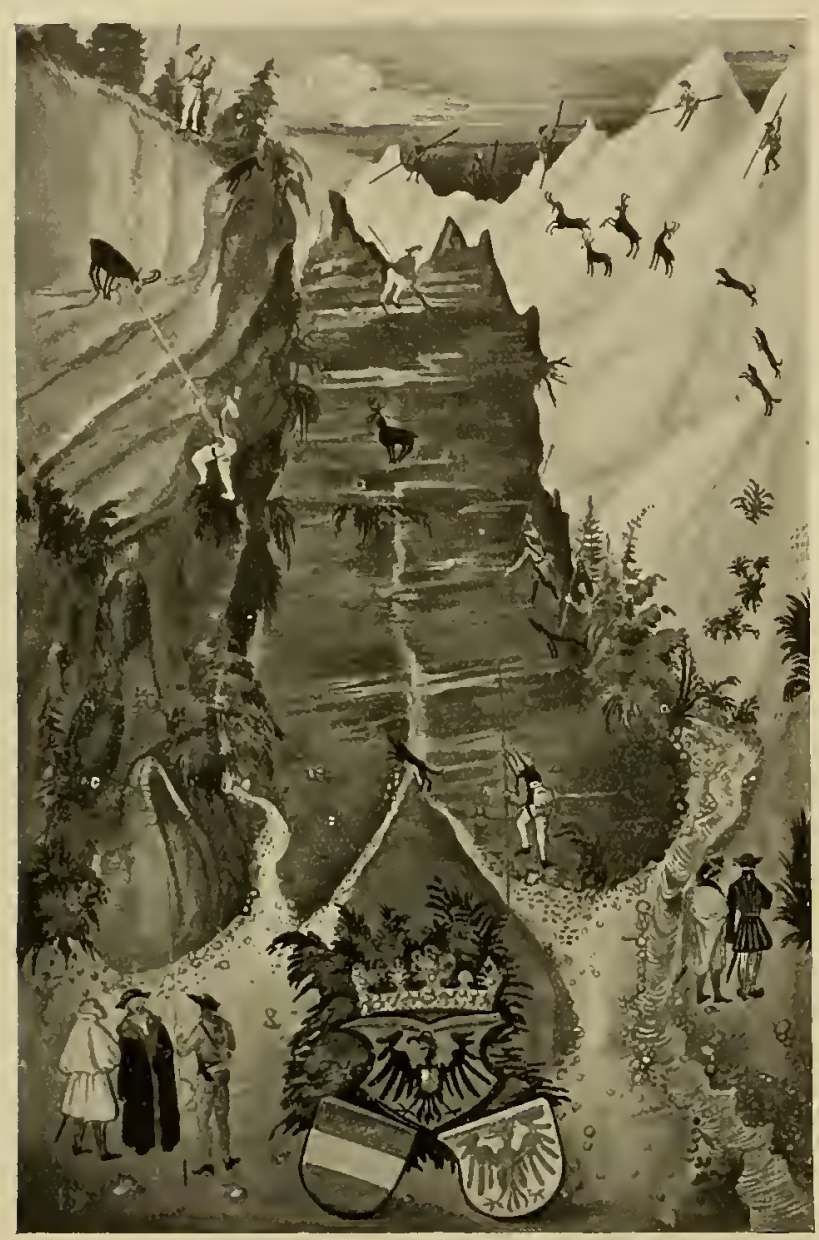

FIG. 27. A CHAMOIS DRIVE, A BUCK BEING "AUSGEFÄLLT" (SPEARED) AFTER HAVING BEEN CORNERED IN A PLACE FROM WHENCE IT COULD NOT ESCAPE. OUT OF MAXIMILIAN'S "HUNTING-BOOK," WRITTEN I4991500, AND ILLUSTRATED BY J. KÖLDERER. Page 6I finely executed illuminations illustrative of sporting scenes, thrust upon me the pleasurable conviction that I was holding in my hands the longlost original.

When it came to be published * it was thought a good opportunity to issue at the same time a very similar work, viz. Emperor Maximilian's "Fishing-Book," written four years later by the same scribe and illuminated even more profusely by the same artist who illustrated the Gejaid Buch. The original manuscript had long been known as one of the treasures of the Court Library in Vienna, whither it had been taken a century ago from the famous Tyrolese castle of Ambras, which in the sixteenth century was the home of what undoubtedly was the most precious collection of art objects and natural history curiosities then existing. Several of the illuminations in the "Fishing-Book," for reasons I shall presently explain, really relate more to hunting than they do to Walton's art. It would have proved too expensive to reproduce, except in the title-page, the rich colouring of the plates; hence the effect of these superb illuminations is lost.

And now let us proceed to examine

* Wagner's Library in Innsbruck, published (I gOI) both books. The Hunting-Book has prefaces by Count Wilczek, one of Austria's best-known sportsmen, and Dr. M. Mayr, Director of the Imperial Archives in Innsbruck, and an introduction by the present writer. It is dedicated by special permission to the venerable Emperor Francis Joseph, who is as ardent a sportsman as was his great ancestor, the author of the book. 58 


\section{$M A X I \mathscr{M} I L A \mathcal{X} I \mathcal{X}$ TRROL}

the ancient "Hunting-Book." It relates exclusively to mountain sport in the northern districts of Tyrol, which were the favourite resorts of Maximilian. By a glance at its pages he could at once ascertain the head of chamois and red deer in any of the two hundred and odd beats described therein. In the short introduction Carl von Spaur and Wolfgang Hohenleyter, his " game secretary," state that they exercised the greatest diligence in collecting all available information, and personally visited and explored all the glens and fastnesses appertaining to the King's* preserves, which in Maximilian's days practically included every glen and mountain range worth having for hunting purposes. When chamois or deer drives were to be arranged, the book gave the fullest topographical information, with useful directions concerning the posting of the sportsmen and hints as to the localities where their royal master could find quarters for the night. With regard to the latter, preference was, of course, given to any castle in the neighbourhood, though when in the more elevated regions, such as the famous Hinter-Riss, now the Duke of Coburg's celebrated preserve, Maximilian had faute de mieux to sleep in $\log$ alp-huts of the most primitive description. On many occasions, to avoid sleeping in such uncomfortable places, he covered

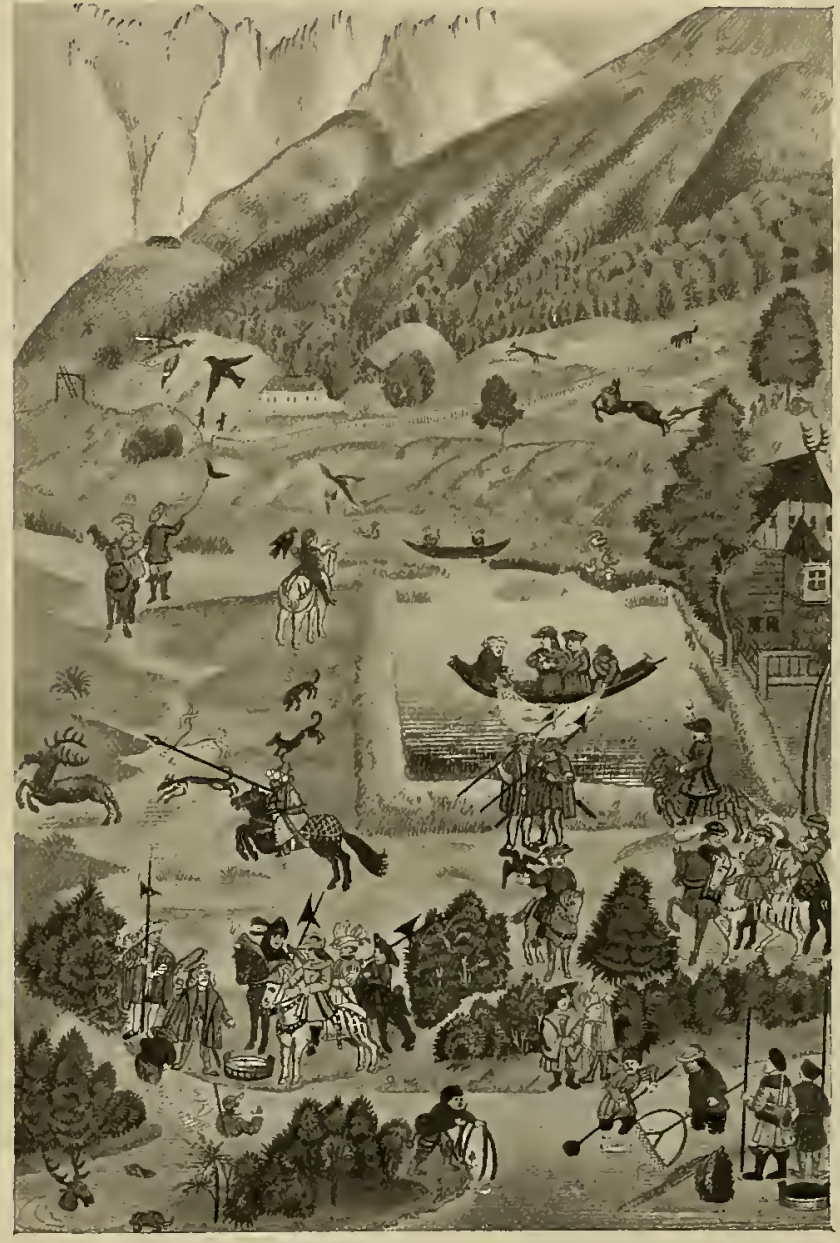

FIG. 28. MIXED SPORT ON THE LONG MEADOW NEAR INNSBRUCK. OUT OF MAXIMILIAN'S "FISHING-BOOK," WRITTEN 1504, ILLUSTRATED BY JÖRG KÖLDERER OF INNSBRUCK. S $s_{\varepsilon e}$ Page 66 extraordinarily long distances on horseback, for in those, days the remoter valleys were approachable only by miserably kept bridle-paths. On some occasions this indefatigable sportsman must have started from his headquarters in the middle of the night, getting back only after some thirty-six hours in the saddle.

* Maximilian did not assume the title of Emperor of Germany until the year 1508. 


\section{SPORT IX ART}

Though the Gejaid Buch is principally occupied with stag- and chamois-hunting, there are half a dozen highly interesting references to a yet rarer game, viz. the ibex, the chase of which was the object of Maximilian's highest ambition. These

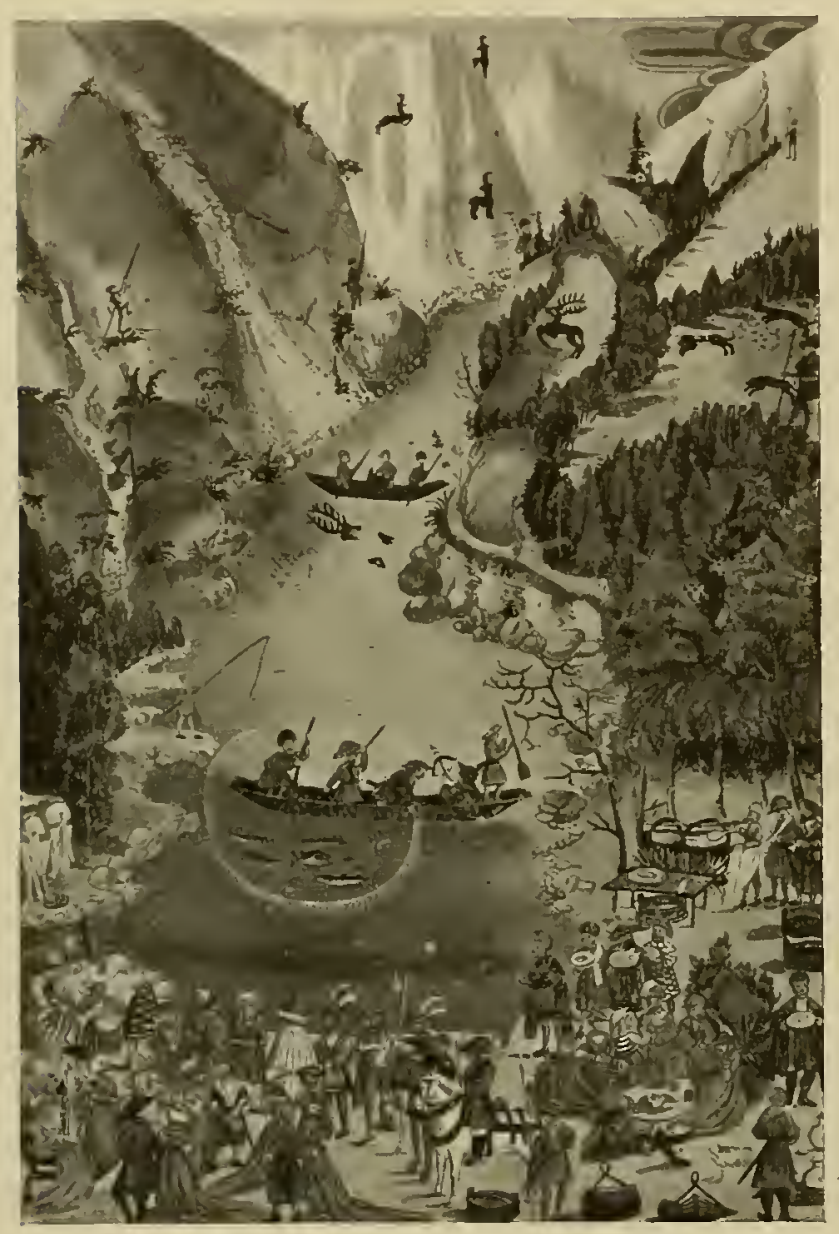

FIG. 29. SHOOTING AND FISHING ON THE PLAN SEE, FOLLOWED BY A RURAL FÊTE. MAXIMILIAN ON THE WHITE HORSE IN THE FOREGROUND. OUT OF THE "FISHING-BOOK," WRITTEN 1504, ILLUSTRATED BY JÖRG KÖLDERER OF INNSBRUCls. Sce Page 66 beasts were then still to be found in small bands in a few of the remotest districts of Tyrol, and Maximilian made strenuous efforts to prevent their complete extermination, and it is really wonderful, as we peruse his voluminous correspondence, to notice what close attention he paid to every detail connected with the chase. While engaged in weary campaigns in remote parts of Europe, or in the suppression of rebellions in distant provinces, or in the personal supervision of lengthy sieges, we find him writing letters about a young ibex buck some peasant women in a remote little Tyrolese valley were keeping for him; or promising in an autograph letter a silk dress to each of certain peasants' wives in an isolated glen in the same country as a reward for preventing their husbands from poaching this rare game; or giving minute instructions where a particular couple of hunting hounds were to be kept, and what was to be done with their puppies; or ordering that a batch of marmots from some isolated mountain glen should be sent him by special riders who would take months to reach the Netherlands.

To the general reader unacquainted with the localities referred to in the text of the Gejaid Buch the illustrations will be of far greater interest than the text. They betray, with one exception, the well-known disdain in which Maximilian held gunpowder, at least for sporting purposes. His field and siege artillery he was keenly eager to develop, but for sporting purposes gunpowder was 60 


\section{MAXIMILIAX'S HUXT METHODS}

taboo. Even in his later Theuerdank and Weisskunig he does not refer to the use of fire-arms for big-game shooting on more than a single occasion, when he tells the well-known story of his feat of hitting at the first shot with his cross-bow a chamois standing more than 200 yards above him, at which one of his men, versed in fire-arms, had vainly let off his "fire-tube." As our reproduction and the Theuerdank and Weisskunig pictures show, the method employed by Maximilian in the chase of the chamois was to approach them close enough to kill the beasts, either by throwing a short javelin-like lance, or to stick them with a long spear when, by means of hounds, they were cornered in some spot from which the animals could not escape. Both methods with an animal of the chamois' surefootedness and agility were necessarily of a precarious nature. Not only had the men to be fearless cragsmen, as surefooted, almost, as the game they wished to approach, but the nature of the ground had to be exceptionally favourable to this manner of cornering wily and fleet-footed beasts. In the piccure of the chamois-hunt, Fig. 27, we see the beaters with long Bergstöcke in their hands and crampons on their feet, lining the snowy ridge, while dogs are driving the chamois towards the place where it was known it was possible to approach them spear in hand. Maximilian had a great love for hounds, and we know he

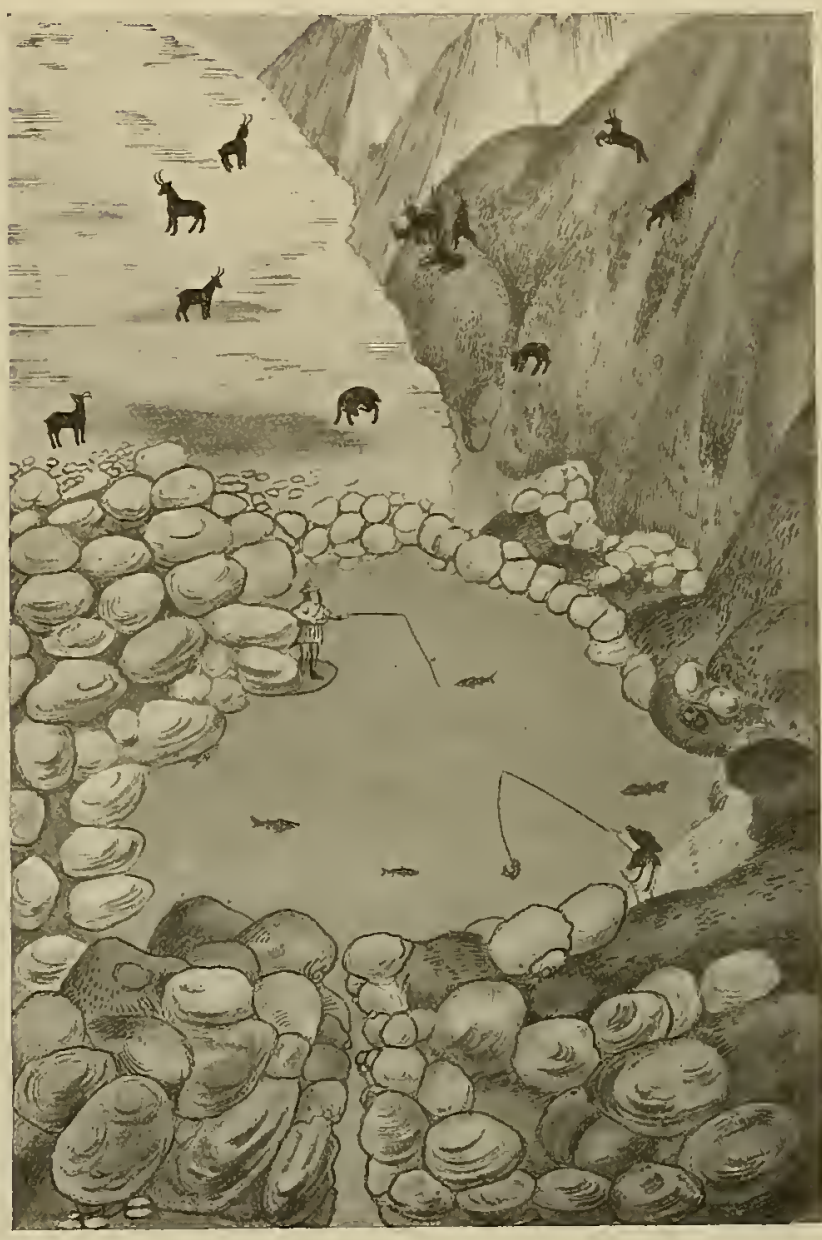

FIG. 30. TROUT-FISHING IN THE WILD SEE, NOTED FOR A SPECIAL KIND OF MOUNTAIN TROUT. OUT OF MAXIMILIAN"S "FISHINGBOOK," WRITTEN 1504, ILLUSTRATED BY JÖRG KÖLDERER. See Page 68 possessed some I 500 of them. For his methods of hunting the chamois they were probably quite indispensable, and numbers no doubt were killed every year by tumbling from cliffs, or by avalanches of stone let loose by chamois above. Nowadays, except in Albania and Spain, dogs are never used for chamois-hunting, for arms of precision 


\section{SPORT IX ART}

make their assistance unnecessary, and they frighten the game to a far greater degree than is expedient.

In the same picture we see the process of ansfällen-i.e. sticking a cornered beast

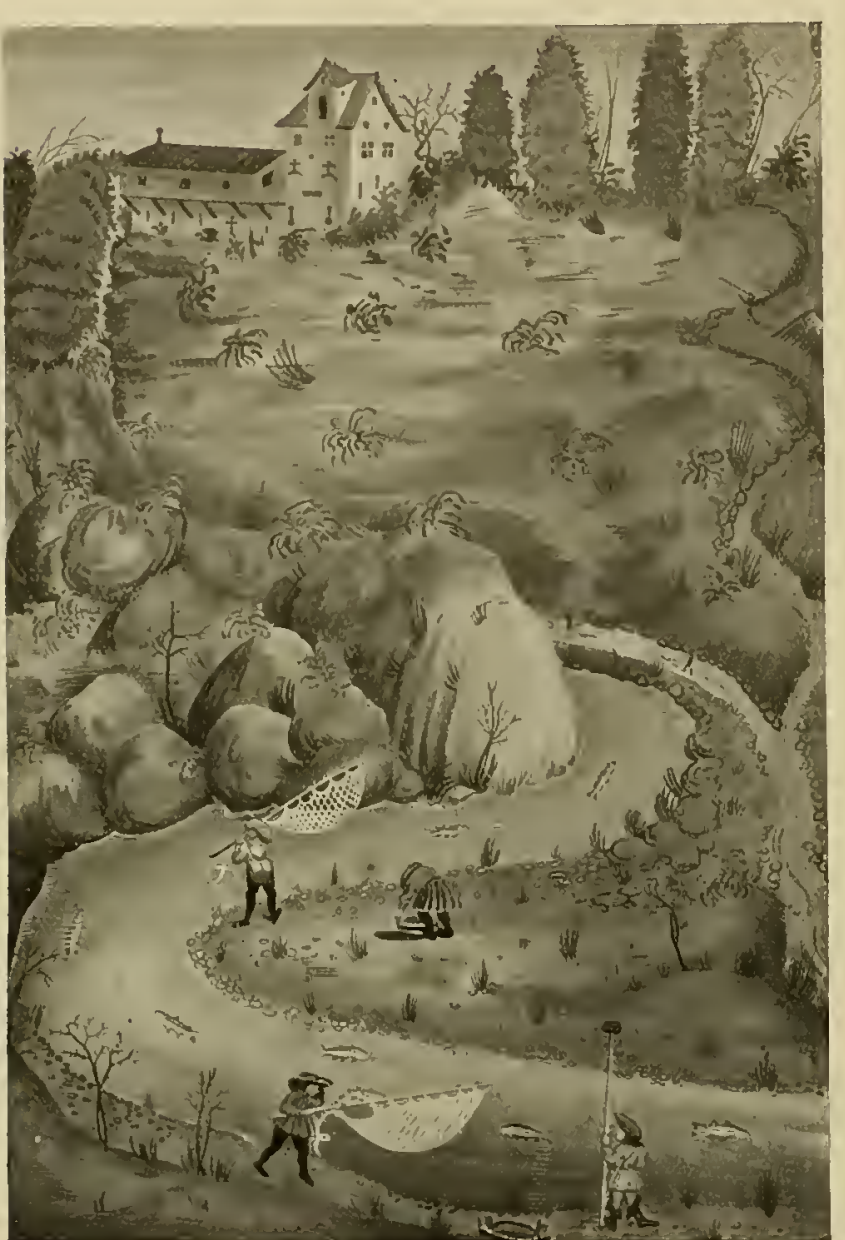

FIG. 31. FISHING WITH NETS NEAR MAXIMILIAN'S SHOOTING-BOX, SIGMUNDSWAID. OUT OF THE “FISHING-BOOK," IVRITTEN 1 ; $0_{4}$, ILLUSTRATED BY J. KÖLDERER OF INNSBRUCK. Page 68 with the immensely long fagdschaft, the hunter's position beneath the animal being, of course, a somewhat risky one, for the falling animal threatens to carry the hunter down the precipice. As he tells us in his Thenerdank, Maximilian had several very narrow escapes from death in consequence of chamois, or stones loosened by them, falling upon him.

As to the length of these spears, the "Secret Book of the Chase" we have spoken of contains some details that are almost incredible. Thus we are told that the length was four klafters, or more than twenty feet. How they handled these weapons on steep mountain sides, or when clinging to the face of giddy precipices, it is difficult to imagine. None of the pictures in Maximilian's works, or in other prints of the sixteenth century, such as Stradanus' and Bol's wellknown series, contain representations of spears of anything like that length, the usual size being from nine to twelve feet. For chamois they seem to have remained in use much later than for any other game. For ibex-hunting the hopelessness of pursuit with the

Fagdschaft seemed to have impressed itself upon all from early days, for in all old pictures of this sport we see either the cross-bow or the fire-tube in the hands of the ibex hunter. Indeed, we know from Maximilian's chronicles that ibex poachers made use of fire-arms much earlier than we have any trace of in any other form of chase: the Emperor's bitter complaint about the use of the "devilish 62 


\section{MAXIMILIAX'S TRROLESE HUXTS}

fire-guns" by peasants, and the harsh regulations which he consequently passed, bearing eloquent testimony to his anger.

In the picture of the stag-hunt, to which we have given the place of honour as title-page, we have more familiar surroundings before us. In the upper half of the print we see the making of the quéte or Suche by means of the lymer or lyam hound, by which the best stag was singled out. Upon his slot the "running hounds" were laid much in the fashion still in use on Exmoor. Behind the man who had the lymer in leash one sees two hardes, each consisting of three hounds, which were slipped when the "harbourer" had done his work."*

In the centre of the picture we see a stag of fourteen dash across a stream making straight for a wood, where, under the cover of trees, we see a Jagdknecht in red hose holding a coupled brace of greyhounds. The sport that would presently ensue when these fleet beasts were laid on-hunting by sight and not by scent-was called the Windhetz, and to judge by the frequency with which it occurs in the Gejaid Buch it must have been a favourite mode of chasing the hart. In the foreground a noble * stag of great head, who has "soiled"-i.e. taken to water-is being shot by Maximilian seated on his white hunting-horse. Several of

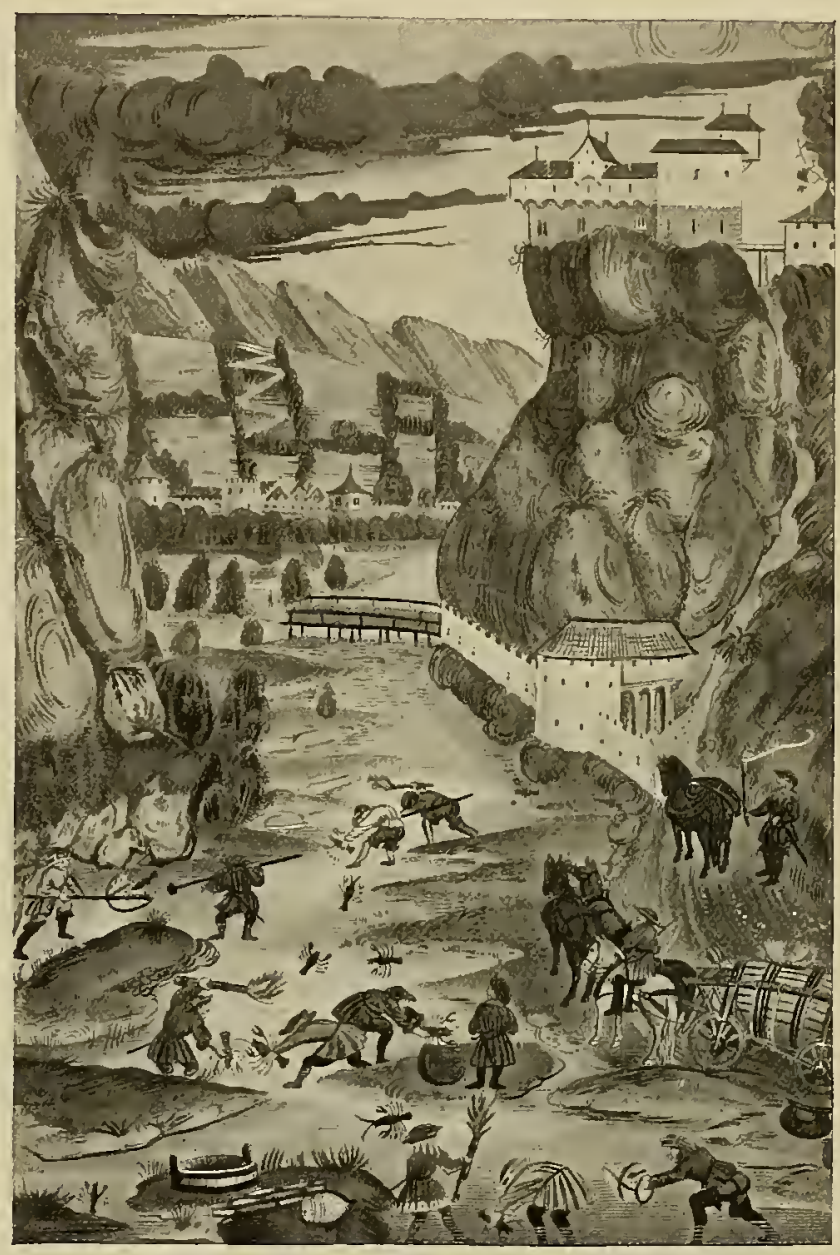

FIG. 32. CATCHING CRAYFISH AT NIGHT IN THE DRAU, NEAR LIENZ IN TYROL. OUT OF MAXIMILIAN'S “FISHING-BOOK," WRITTEN I504, ILLUSTRATED BY JÖRG KÖLDERER OF INNSBRUCK. See Page 68 Maximilian's hunting weapons are still preserved in the Vienna Imperial Collections, whither they were brought

* In the old days on Exmoor, when the hounds were taken to the meet, the coupling together was called "harling," a sporting term derived, no doubt, as most old English hunting terms were, from the French, which was the ruling tongue at the English Court well into the fourteenth century. 


\section{SPORT IX ART}

from Ambras, and amongst them are several of his cross-bows and his huntingsword. With the latter he used to tackle bear and wild boar when they had been brought to bay, or when, as these huge beasts often did, they charged their pursuers. In winter-time, when extreme cold makes steel brittle, a bow of horn replaced, according to the "Secret Book of the Chase," the metal one.

What the two men-at-arms, with huge halberts in their hands, had to do in a stag-hunt history does not relate; probably they were put in by the artist to indicate that the man on horseback was the Emperor.

To the critical eye of a modern artist these quaint drawings, void as they are of all regard to perspective, present, of course, many features that are ludicrous. In those days it was the artist's desire to convey to the reader, in as compact a form as possible, on one and the same canvas, various incidents which in later periods would have been represented in separate pictures. Hence we observe, crowded into one and the same canvas several scenes in which the central personage is shown occupied in different ways. In Fig. 26 we see the Emperor, or rather King, as he then was, in no less than four different positions. In the immediate foreground we observe him mounted on a white horse, probably in the act of arriving at the hunting rendezvous. Behind him is his secretary reading a report or petition to him; in front are two receptacles with fish, to which one of his attendants is drawing his royal master's attention by pointing at them. Then we see him in the boat on the lake superintending the working of a net, and holding in his hands a big trout, for which the lake in question-the Achen See, in North Tyrol-was at all times famous. We notice, however, that Maximilian, according to the artist, fails to follow his own advice, for his hands are ungloved. Long gloves, he tells us, reaching to the elbow, made of the skin of the seal, should be worn when this is being done, "so as not to get wet." A third time we recognise the King as, seated in the left-hand corner of the picture, he is being dressed for chamois-hunting, a valet strapping crampons to his feet after having taken off his long fishing-boots. One of his councillors is in the act of reading to him some document, for we know that State business was constantly being transacted by this ever-busy monarch while out on hunting expeditions, relays of messengers bringing him despatches and the latest news from the distant capital. In his "Secret Book of the Chase," which was avowedly written for his son's instruction, Maximilian is very particular about telling his successor that one of the advantages of sport for a ruler is the opportunity which it gives his subjects to come into closer touch with hin, thus enabling them to present their petitions in person.

In the fourth position in which we find the King in the picture before us (his identity being indicated in each case by the purple hunting-cap) he is shooting. with a "fire-tube" at a chamois. This is the occurrence to which reference has already been made, when alluding to the single exception to the rule that 64 


\section{$M \mathscr{M} X I \mathcal{M} I L I \mathscr{X} I \mathcal{X}$ TYROL}

Maximilian killed his chamois with the cross-bow, javelin or long Fagdschaft. So far as we are aware this is the earliest pictorial representation extant of the use of fire-arms in the chase of mountain game, and has therefore special interest.

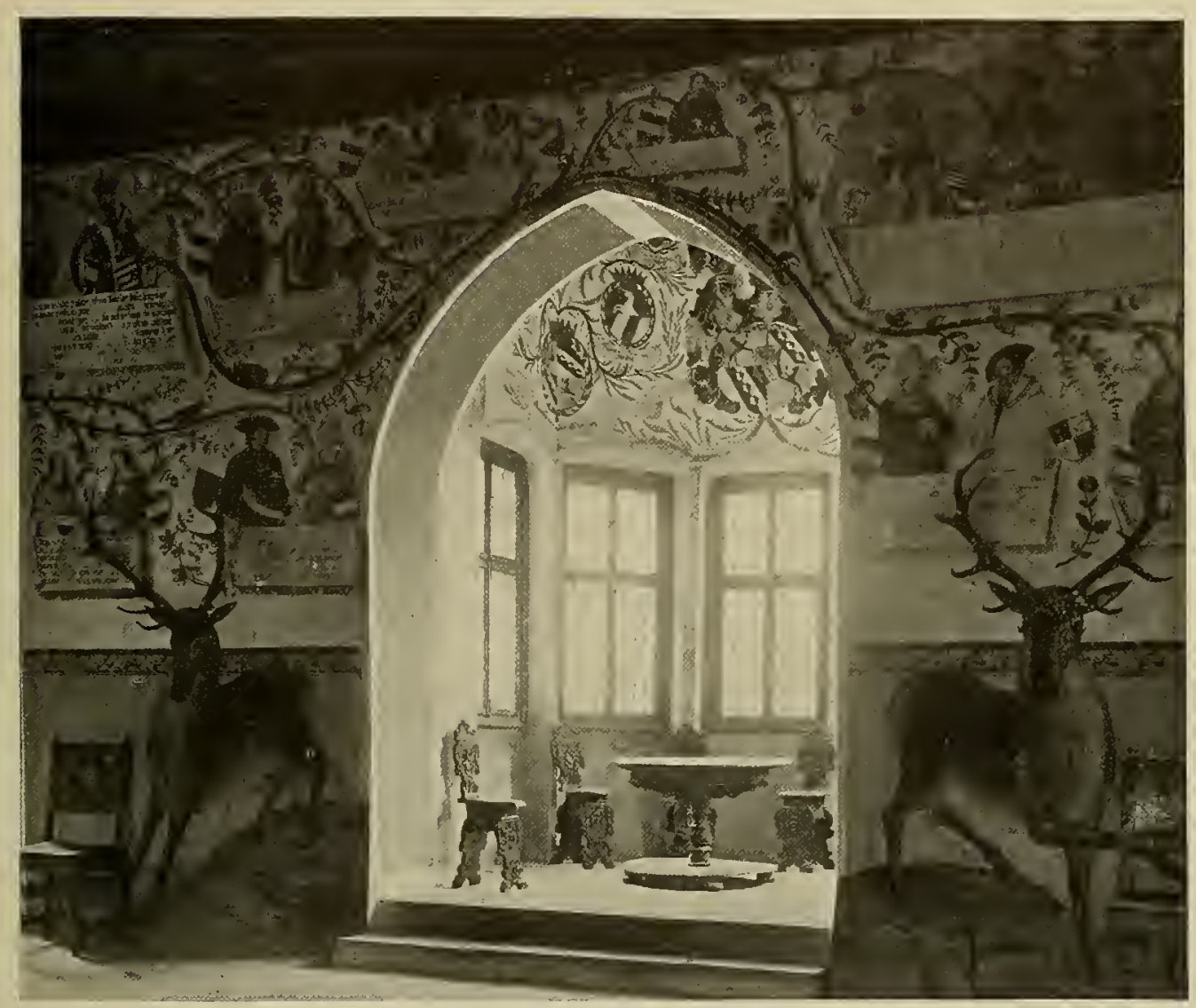

FIG. 33. FRESCO REPRESENTING THE PEDIGREE OF THE HABSBURGS. THE STAGS' ANTLERS ARE REAL, AND ARE SAID TO HAVE BEEN OBTAINED BY EMPEROR MAXIMILIAN IN THE NEIGHBOURHOOD. IT ADORNS THE HALL IN CASTLE TRATZBERG, IN TYROL. BEGINNING OF SIXTEENTH CENTURY. See Page 74

This spirited illustration has other points of interest about it. The Achen See, a fine sheet of mountain-enclesed water some four miles in length, was for the last six centuries a favourite resort of the rulers of Tyrol, and Maximilian, we know, visited it on many occasions, passing his time in shooting chamois and stags from a boat, from which in the intervals between the drives he used to fish. He himself narrates that once a chamois, while attempting to swim across the lake, was caught in a net! The quaintly gabled shooting-lodge we observe in

$$
\text { I } 65
$$




\section{SPORT IX ART}

the background is now, alas! the site of a huge ungainly summer hotel for tourists, whose presence in chattering shoals has spoilt the grand solitude that until recently reigned over a locality sacred to sport.

But let us resume our attempt to picture to ourselves the quaint scenes portrayed by the unconventional pencil of Kölderer, who, it is almost certain, was the originator of the pictures before us. One amusing detail must not be overlooked in this picture of sport on the Achen See. The figure of the man in a broadbrimmed wideawake hat, with a yellow sash and sword of Turkish pattern, who is standing in front of the shooting-lodge engaged in earnest converse with a be-nightcapped individual is nobody else than the Court Jew." Maximilian's finances were occasionally in a sadly disorganised condition, so much so that on more than one occasion the citizens of his provincial capitals refused to open their gates to their king till he had settled long-standing scores. This notorious failing is quaintly touched upon by the artist, for even for hunting expeditions ready cash had to be forthcoming, or sport would suffer; hence the presence of this "necessary evil." That the paper which the be-nightcapped personage is holding in his hand was probably a bill of exchange or other form of mediæval I.O.U. is a likely presumption, for we have evidence that the want of ready money obliged Maximilian to affix his sign-manual to such documents amid surroundings similar to those which we see here depicted. Another historical personage the artist has introduced in the picture of the hawking scene (Fig. 28) is the then Turkish ambassador, who about that time was paying a visit to Maximilian's court. The locality which this illumination represents is the "Long Meadow" near Innsbruck, and is identified by the gallows in the background. In this picture, hunting and fishing seem again to be progressing simultaneously, the identity of Maximilian on horseback and in the boat being as usual indicated by the purple hunting-dress. In Fig. 29, Master Kölderer did not forget to indicate the usual termination of the day's sport, viz. the al fresco banquet. Maximilian was in the habit of taking his queen-he was twice married, both consorts by a strange fatality succumbing to accidents in the hunting field-with some of the ladies of the court to witness his sport in localities that could easily be reached. In Theuerdank we have a picture of an assembly of ladies demurely seated near the foot of a cliff, high up on which the royal sportsman is shown in the act of spearing a chamois with the javelin. + In the picture before us a square dance to the music of fife and drum is progressing, the Turkish Ambassador being among the audience, while Maximilian on horseback is watching the pastoral fête, his queen being seated opposite to him.

To the right we notice the royal couple engaged in sampling the famous lake

* In many parts of South Germany the yellow sash was the distinguishing article of apparel which Jews were compelled to wear.

$\dagger$ This picture is in the writer's "Sport in the Alps" (A. \& C. Black : 1896). 66 


\section{$\mathscr{M} A X I \mathscr{M} I L I A \mathcal{X} S$ SPORTIXCG ARMS}

trout, Maximilian helping himself from the dish placed in the centre of the party, while three bearers under the guidance of the Master of the Table, with his chain of office round his neck and "wand of control" in his hand, are bringing a fresh relay of dishes. Seated in the bottom of the boat on the lake we again notice

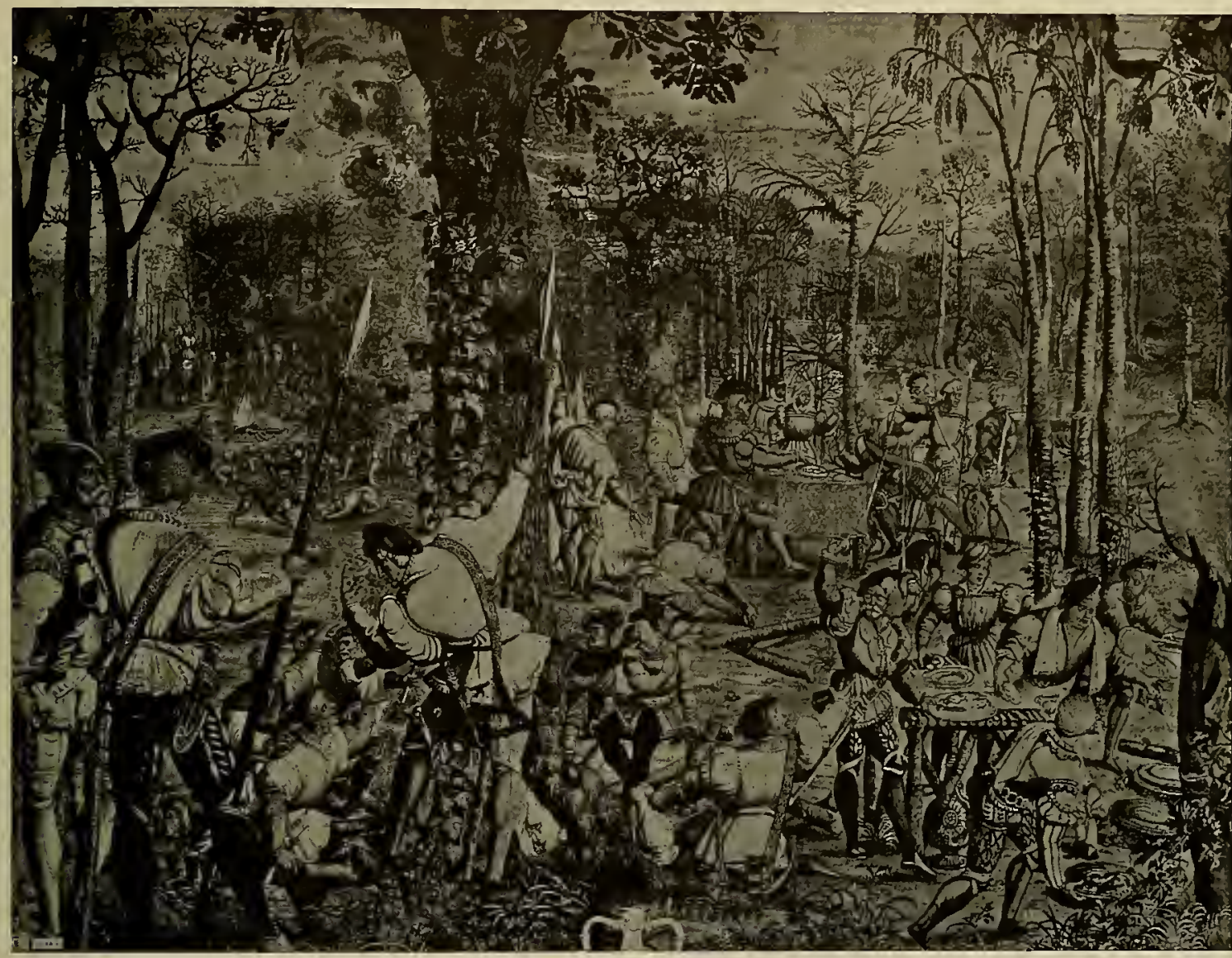

FIG. 34. “LES BELLES CHASSES DE L'EMPERFUR MAXIMILIEN," TAPESTRY COMMEMORATING MAXIMILIAN'S HUNTING FEATS, WOVEN IN BRUSSELS AFTER 1528, DESIGNED BY BERNARD VAN ORLEY SOON AFTER THE DEATH OF THE EMPEROR IN 1519. IT DEPICTS THE HUNT BREAKFAST IN THE FOREST OF SOIGNE, NEAR BRUSSELS. PRESERVED IN THE LOUVRE. See Pages $76-84$

Maximilian, with his cross-bow bent ready for a shot at a stag swimming across the lake.

In conclusion, it is of some antiquarian interest to know that in the Stadthalterei eArchiv in Innsbruck are preserved the original accounts relating to the writing of the Gejaid Buch, showing what was paid for the lodgment of the gam 


\section{SPORT IX ART}

secretary, Wolfgang Hohenleyter, that his salary was i 10 florins per annum, that he had candles, firewood, and stabling for his horse free, and even the cost of binding the book is not forgotten. And though Master Wolfgang apparently remained unpaid for more than a year, so that Maximilian had repeatedly to command the officers of his exchequer in Innsbruck to settle the reckoning, he seems to have received his money all right in the end.

Of the pictures in the Fishing-Book that deal specifically with the subject, two deal with trout-fishing, the third with crayfish. Fig. 30 is a picture of the $W$ ild See in the Unter-Innthal, and it marks a peculiarity of the trout inhabiting that elevated mountain tarn, viz., their particularly bright red spots. Small fish, such as the minnows and the miller's thumb, were used as bait." Fig. 3 I represents fishing with the net in the stream feeding the Plan See; the building in the background is the shooting-box Sigismundswaid, built by Maximilian's predecessor, Archduke Sigismund, an equally keen sportsman and Lord of Tyrol. Crayfishing (Fig. 32) was done at night by torchlight, and small hand-nets seem to have been used. The locality it represents is not named, but it is probably the river Drau in the Dolomite region of eastern Tyrol, the walled-in town in the background being perhaps Lienz. The four-horsed vehicle bears a big barrel wherein the crayfish were placed for transportation. This latter was a matter closely cousidered by the writer of the Fishing-Book, and we are repeatedly told how and at what season of the year fish bear transportation to various points principally visited by Maximilian; for as the fishing in practically all good waters was claimed as crown property by Maximilian, who was very fond of a fish diet, and the fish had to reach their destination alive, numerous instructions deal with this point.

A few more remarks elucidating how Maximilian conducted his sport may here be in place. "Slaughtering" hecatombs of game collected together in enclosures by hundreds or thousands of beaters, a method which became so popular among the rulers of Europe later on in the sixteenth century, was still unknown to the man, whose bringing up was of the old school, and who was still imbued with the old chivalrous spirit that led him to tackle a great bear or a fierce wild boar single-handed, armed only with the stout Bär Spiess or short Schweinsfeder, or boar-spear, relying solely on his own skill and strength. Stag and chamois shooting was also still a test of the sportsman's endurance and dexterity with the Schaft or with the cross-bow, and with very few exceptions the bags

* As it may be of interest to fishermen the following are the various fish mentioned; where there is any doubt as to the identity the scientific name is added. Two kinds of brook trout, the greyling, the char, the Danube salmon (Salmo hucho, Linn.). the tench, the bream, the perch, the roach (Leuciscus, Ag., or Telestes, Ag.), the carp, the pike, the dace, the gudgeon, the ling, or possibly the burbot (Lota vulgoris, Cuv.), the whitefish (Corigonus IV artmani), the bleak or blay (Alburnus lucidus); then among the small fish : the common minnow (Phoxinus lavis, Ag.), the miller's thumb (Cottus gobio, Linn.); then a fish for which we have been unable to discover the English name, its Latin one being Chondrostoma nasus. 68 


\section{SPORT IX ART}

with 104 shots, and that he bagged with one and the same cross-bow bolt 26 hares without missing. That both scores consisted probably of pot-shots at game is true, but still, considering the extraordinary unwieldiness of the fifteenthcentury cross-bow, which one cannot realise without actual trial, such shooting was marvellously good. Chamois shooting was of all sports the one he loved best, and mountain-girt Innsbruck, Tyrol's capital, was his headquarters for it. He expressly tells us in the last-named pages that there more than in any other place his Scliäfte, crampons of two different kinds, hunting garments, and other necessary gear are to be stowed, not forgetting to add that the first-named weapons are to be hung up so that they do not warp, the organ-lofts of churches being in his opinion the most suitable places!

In the same book the Emperor notes some curious occurrences that happened to him. He narrates them with the evident intention of mystifying his readers a bit, for he does not give the solutions. Thus he says that he once shot at a stag, but that he did not see him and did not hit him, yet the animal was killed by the shot! On another occasion he fired three times at a stag and each shot hit, though the stag was not walking, was not trotting nor running, and was not touching motherearth nor was he swimming! In this case one can make a shrewd guess that the stag had been caught by his antlers in the branches of a tree and was suspended in the air. A somewhat boastful tale he tells of his mountaineering experiences, for he states that he ascended the highest mountain in Europe, so that no man either before him or after him was nearer heaven than he was! The mystifying feature of the ascent being the circumstance that he reached the top of this great mountain without touching mother-earth! The probable explanation is that the mountain was covered with snow or ice. What peak it was that he considered the highest in Europe we are unfortunately not told, the probability being that it was the Gross Glockner. Another amusing entry relates the fact that in a wolf-pit in the Lechthal there were caught at one time a peasant, a horse, a wolf, a fox, and a wild duck!

Another mysterious occurrence was the shooting of a chamois by Maximilian, who writes: "Though he did not hit it, it yet was killed." Less singular was that once, while fishing, a chamois was caught in a net. But this is explained by Maximilian's predilection for crowding together the various kinds of sport in order to save valuable time. Thus he employed himself with lake-fishing while the chamois were being driven down to the shore where he would kill them, often while swimming. On this occasion his favourite, Count Henry Hardegg, was lucky enough to bring about the above. The desire to cram as much sport as possible into the day's work was a fad of Maximilian's which can only be explained by his extraordinarily busy career and his abnormal energy.

That Maximilian knew of the French manner of hunting the stag par force, i.e., by the strength of hounds, as the Duke of York called it, is shown by his descrip70 


\section{MAXIMILIAX'S "BOOK OF SPORT"}

tion of it, and his calling it "the new kind of hunting," though the "new" related only to his country, for in reality it was a very ancient sport. We must

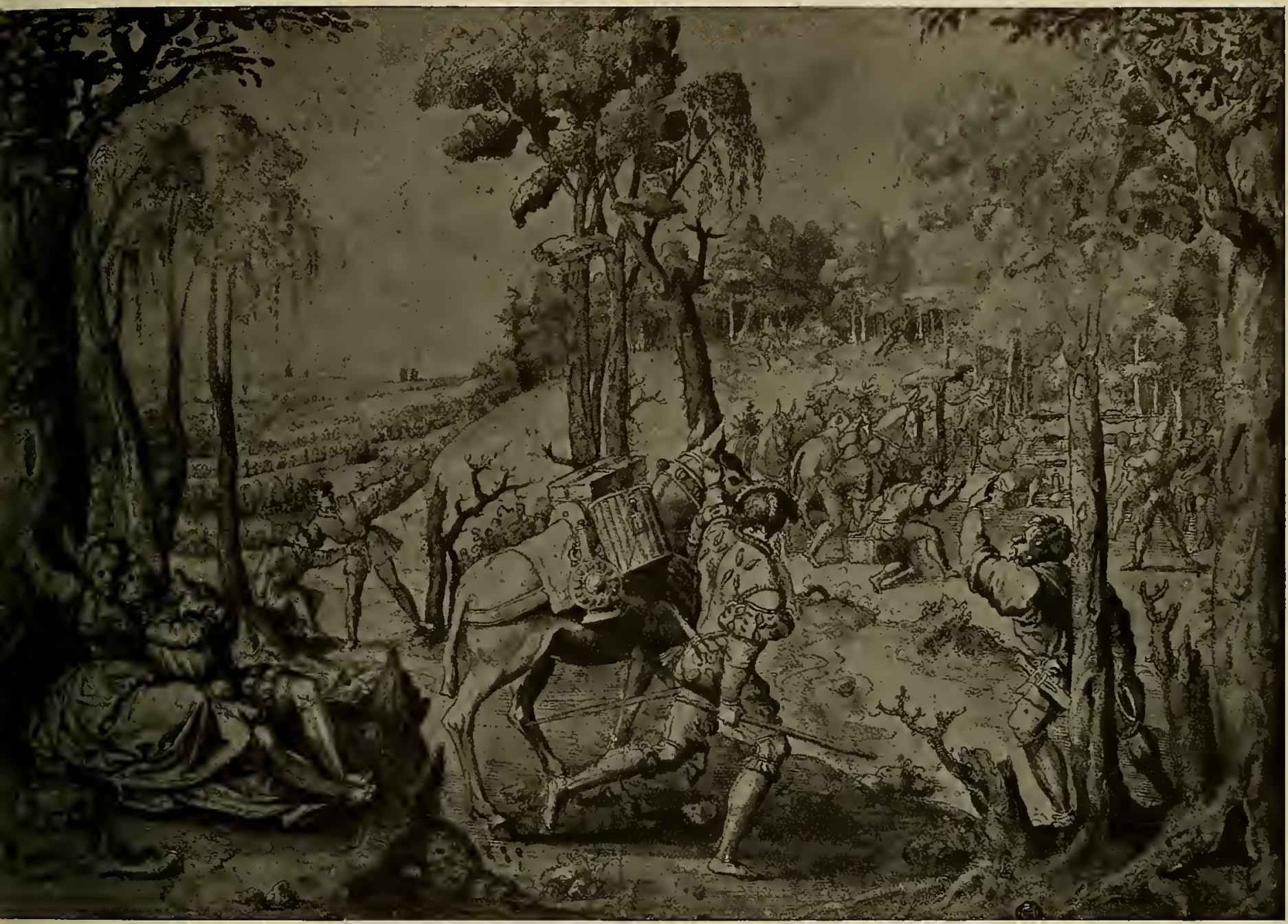

FIG. 36. CARTOON BY BERNARD VAN ORLEY AFTER WHICH “LES BELLES CHASSES DE L'EMPEREUR MAXIMILIEN" WERE WOVEN, DESIGNED SOON AFTER THE EMPEROR'S DEATH IN I5I9. PRESERVED IN THE LOUVRE. See Pages $76-84$

consider him, therefore, the sportsman who introduced par force hunting into Germany, but, as we shall see, it took two centuries to make it popular there, which it became temporarily in the beginning of the eighteenth century, when the German courts aped everything French.

The "Secret Book of Sport" contains also some Natural History notes that illustrate 


\section{SPORT IX ART}

Maximilian's intimate knowledge of the habits of his beloved stags and chamois; the only exception being his remark that chamois bucks, when they reach rery old age begin to rub off their horns in the middle, and when they do this they lose all desire to eat and starve to death. This fable was, however, not quite without some semblance of reason, for it is a fact often observed, and also by the writer, that old bucks rub their horns against rocks and trees, probably in consequence of some local irritation being set up between the sheath and the core.* It is also a fact that old bucks occasionally bear only stumps, two, three or four inches in length, but this injury is generally caused by stones falling from a height. Of the latter danger Maximilian had a not unnatural dread, for he had some very narrow escapes from death, and had men killed at his side by such stone-falls. In consequence of hounds being employed for the chase of chamois this danger was one by far more common than it is to-day, though fatal accidents still occur every year, an acquaintance of the writer coming to his end in that way while at his stand at a chamois drive, and he himself having had at least two narrow escapes.

Maximilian was most anxious that his only son, Philip the Handsome, should grow up a good sportsman, but in this he failed, to judge by an amusing account of the year 1496 , by Maximilian's Master of the Hunt, preserved in the Innsbruck archives. It appears that in that year Philip, then a youth of eighteen, passed through Tyrol, and, acting upon the emphatic orders of the absent Maximilian, the greatest efforts were made by the Tyrolese officials to show the young prince good sport. But to their great chagrin Philip seemed to care more about inspecting the famous silver mines of Schwaz and the salt mines at Hall and visiting shrines than for shooting chamois and stags. In fact, he refused point blank to participate at several drives which had been arranged for him, and at one which he did join he missed what he shot at. At another chamois drive which he condescended to attend, a big buck had been cornered on the face of the Hohe $W$ and, a vast precipice north of the town of Hall. In the course of the efforts, which were finally successful, of the men to get at the buck so as to show the young prince, who stood at the bottom of the cliff, how chamois were ausgerallt, or "thrown out," with Schäfte in the manner already described, one of the best tracking hounds was killed by falling down the face, the buck presently sharing the same fate, both being dashed to pieces. The account states that the prince was most profoundly astonished at the climbing feats of the keepers-and no wonder, for the place, well known to this day, where it happened seems absolutely unapproachable by anything without wings. Philip's bigoted Spanish education is betrayed in a

\footnotetext{
* Decidedly the oldest, and at the same time thinnest, of the five hundred and odd chamois killed by the writer, was a large buck he grassed in the Hinter Riss Mountains in 1903, the horns showing indisputable signs that the animal had been constantly rubbing them in one place (about one-third up) against some hard substance, so that the inner coze was already exposed to view.
} 


\section{PHILIP THE HaAXDSOME}

curious manner by the document, for it says that the prince after seeing the buck and hound killed returned to the town of Hall to pay his devout respects to the lady nuns at the cloister there.

Next day Philip showed that if he was an indifferent fäger, he was at least

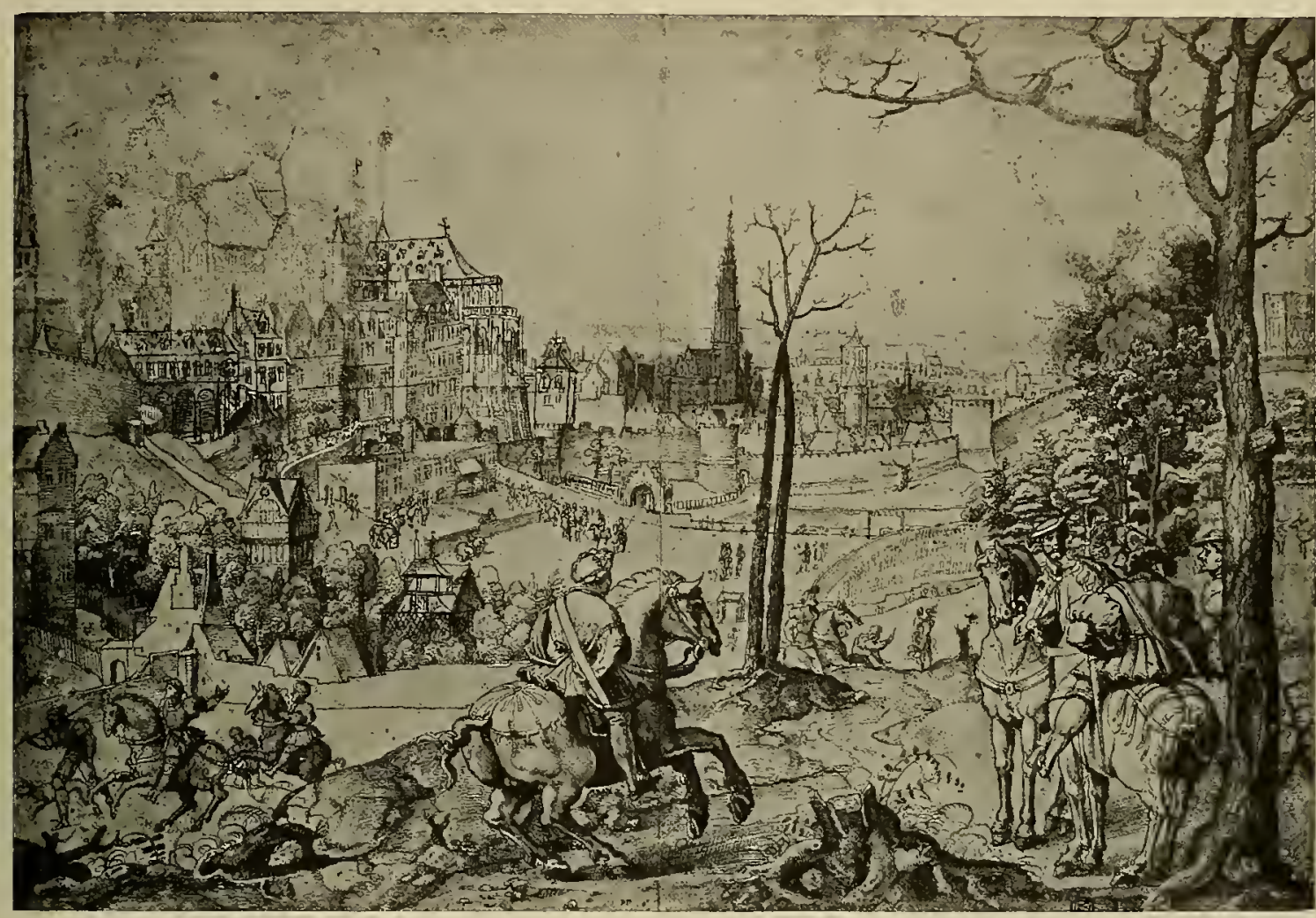

FIG. 37. CARTOON BY BERNARD VAN ORLEY, DESIGNED BEFORE 1525 AS CHAPEL ADDED TO ORIGINAL DRAWING WAS NOT COMMENCED UNTIL 1525. THE TAPESTRY WOVEN AFTER THIS CARTOON WAS FINISHED AFTER 1528. PRESERVED IN THE LOUVRE. See Pages 76-84

a good horseman, for we are told that he rode down a great stag of fourteen on the fields near Hall, killing him with his sword from horseback, at which the multitude were greatly astonished.

The latter remark shows that the surroundings of royal sport were not always what a good sportsman desired; the populace's inveterate curiosity to gaze upon royalty, more particularly when engaged in the spectacular court chases usually held near towns, but of which, as we know, Maximilian was by no means over fond, impeding the progress of sport. Thus we hear that when Prince Philip attended at one of these formal hunts at Igls, near Innsbruck, ladies accompanied the 


\section{SPORT IX ART}

sportsmen, and such multitudes of the common people persisted in following in the wake, and made so much noise, that the two stags that were in the drives would not go forward but broke out at the side and got away.

Here is the right place to say a few words about a characteristic production in Maximilian's honour in which nature as well as art had their share. This is the

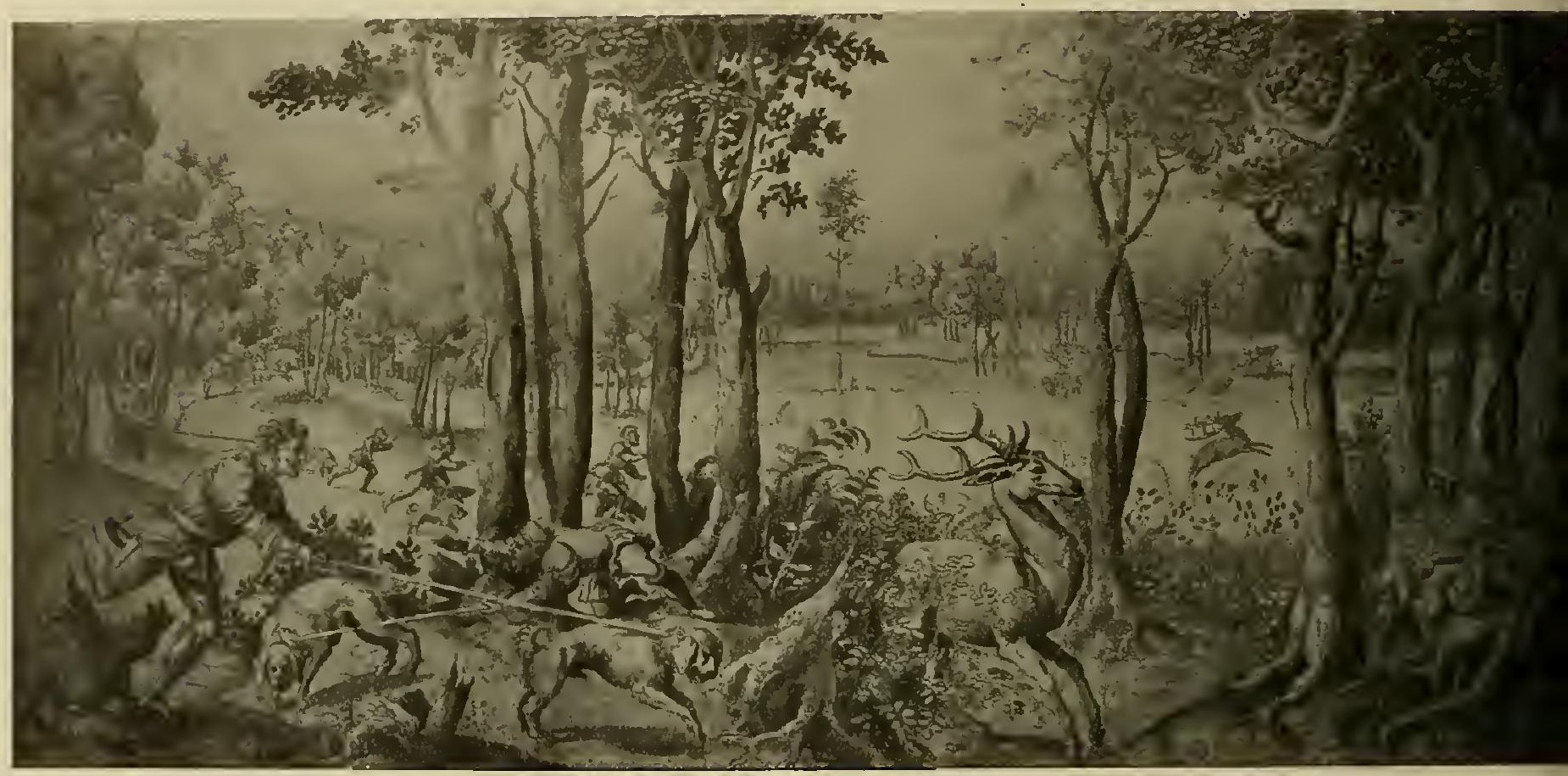

FIG. 38. BERNARD TAN ORLEY'S CARTOON : A STAG-HUNT IN THE FOREST, FOR EMPEROR MAXIMILIAN"S "BELLES CHASSES" TAPESTRIES. DRAWN IN OR BEFORE 1525. LOUVRE. Sec Pages $76-S_{+}$

mural adormment of the great hunting hall in the castle of Tratzberg, in Tyrol. This large and lofty chamber-it measures 52 feet in length and 26 feet in widthhas running round its four sides, in the manner shown in Fig. 33, painted in tempora, the genealogical pedigree of the Habsburg dynasty up to Philip, Maximilian's short-lived son. One hundred and forty-seven semi-life-size pictures -in some cases portraits-of the various members since the time of Rudolf fill the strip, which is some 150 feet in length. Acting as supporters, great stags are painted realistically at intervals below the pedigree, and real antlers fastened by iron stays into the wall in a natural position over the animals' heads, add to the curious effect of the whole. These antlers are remarkably fine specimens of huge beam, 74 


\section{SPORT IX ART}

to stalk chamois and stags, and one of the adventures described in his Theuerdank is known to have happened there.

Of another important work created by Maximilian-his Prayer Book, illustrated by Dürer and other great artists (to which we have already briefly referred on p. 45)-we shall have more to say in the next chapter (p. 86) when dealing with this celebrated designer's contributions to our subject.

Before we leave Maximilian we have to devote some space to the works of an interesting artist, who probably at the behest of Maximilian's daughter, Archduch. Margaret, Regent of the Netherlands, executed some famous cartoons immortalising the hunts of the great nimrod.* These drawings served as patterns for twelve huge panels of tapestry known as Les belles Chasses de l'Empereur Maximilien, woven in Brussels a decade or so after the death of the great sportsman and quite thirty years after the scenes they depict really occurred. For these relate to the early part of his life, when he passed some years in the Low Lands at the side of his pretty consort, Mary of Burgundy, who had brought him (I 477) that rich heritage.

Bernard van Orley, to use the now generally accepted spelling of his name, was, according to his biographer Wauters, an interesting personage, a friend and pupil of Raphael and patron of Dürer, who at an early age gained the favour of Archduchess Margaret. She made him her court painter, probably in consequence of a successful portrait he painted of Charles $V$ as a youth of fifteen. There exists a good deal of doubt as to the year when Van Orley was born, various authorities differing as much as twenty-one years, i.e. between 147 I and 1492 (see Appendix). What is certain is that he was a master of his guild in the year 15 I 5 , when he was honoured by the commission to paint the above portrait, and six years later, when Albrecht Dürer paid his memorable visit to Brussels, the great German speaks of him as a celebrated painter, and says that Van Orley gave in his honour a feast that must have cost him quite ten florins. We also know that Dürer painted two portraits of his host, one in charcoal, the other in oils; the former, it is almost certain, being the picture in the Dresden Gallery concerning which learned critics engaged not very long ago in a literary duel. Dürer, it will be remembered, had reason to complain that six personages in Brussels whose portraits he painted forgot to pay him, but his praise of Van Orley's hospitality makes it unlikely that he was one of the six unnamed forgetful ones. II we enquire how it happened that Van Orley became connected with the Belles Chasses tapestries, there is good reason to believe that it was in consequence of

\footnotetext{
* Vauters attributed the inception to Regent Mary, also a great huntress, but in this we feel convinced that he was wrong. For not only is it positively known that at least one of the designs originated more than five years before Margaret's death in December 1530, but her correspondence amply proves that she was exceedingly attached to her father, and was anxious that his feats should not be forgotten. 76
} 


\section{BERXARD VAX ORLETS CARTOOXS}

his having, a short time before, been selected by Raphael to superintend the manufacture of the world-famous "Acts of the Apostles" for Pope Leo X after

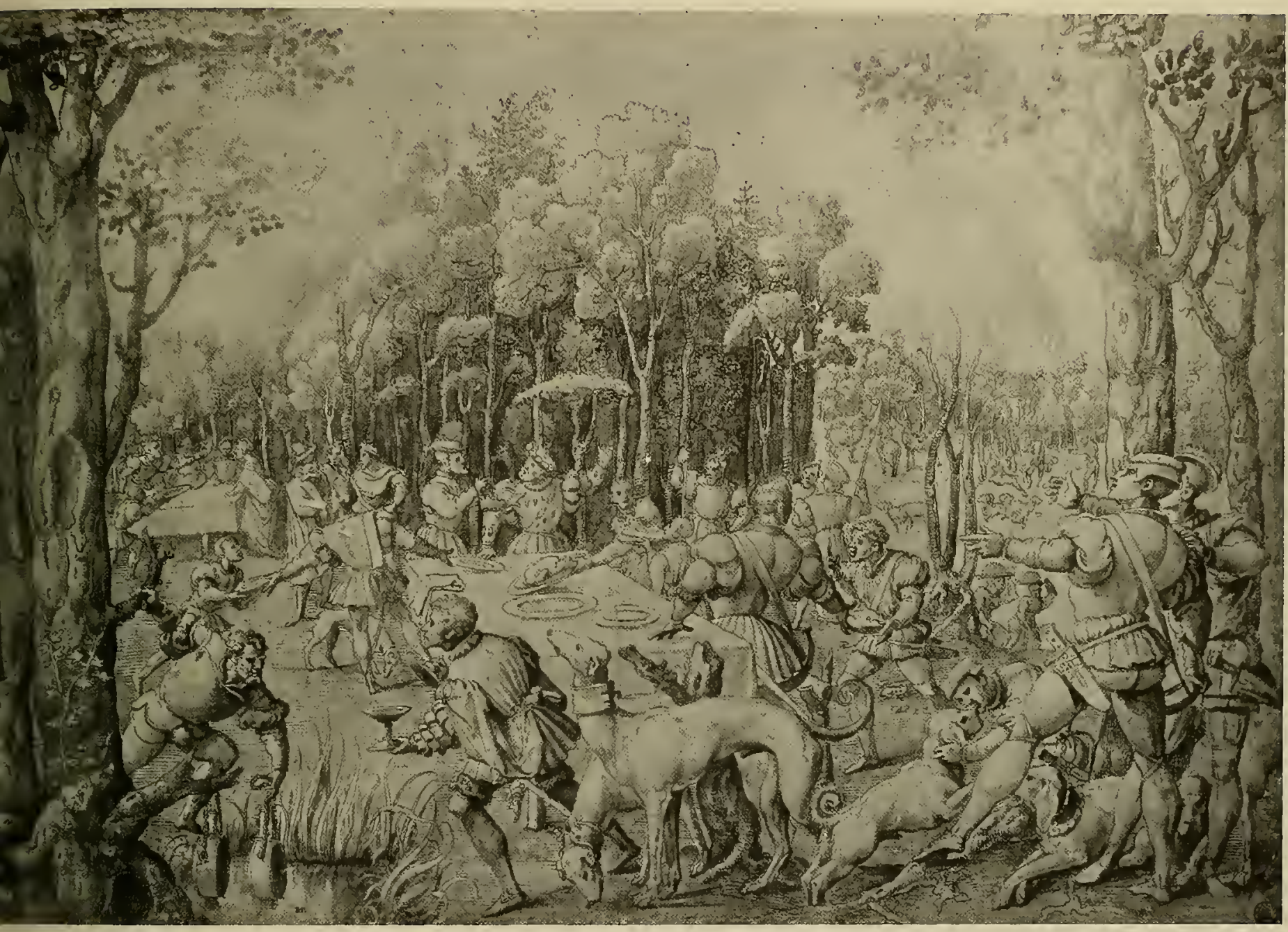

FIG. 4O. BERNARD VAN ORLEY'S CARTOON : THE HUNT BREAKFAST IN THE FOREST, FOR EMPEROR MAXIMILIAN’S “BELLES CHASSES.” DRAWN IN OR BEFORE 1525 . Pages $76-84$

the cartoons of which seven are now in the South Kensington Museum. When after four years P. van Aelst completed this great series in I 5 I 9 , they created such a stir in the art world that Archduchess Margaret decided to immortalise in a similar fashion the sporting feats of her father; and as her niece and successor, Mary Dowager Queen of Hungary, was filled with the same enthusiasm for her 


\section{SPORT IX ART}

grandfather's sporting feats, the great work which was inaugurated by the one was carried to completion by the other. Before we begin to describe the incidents

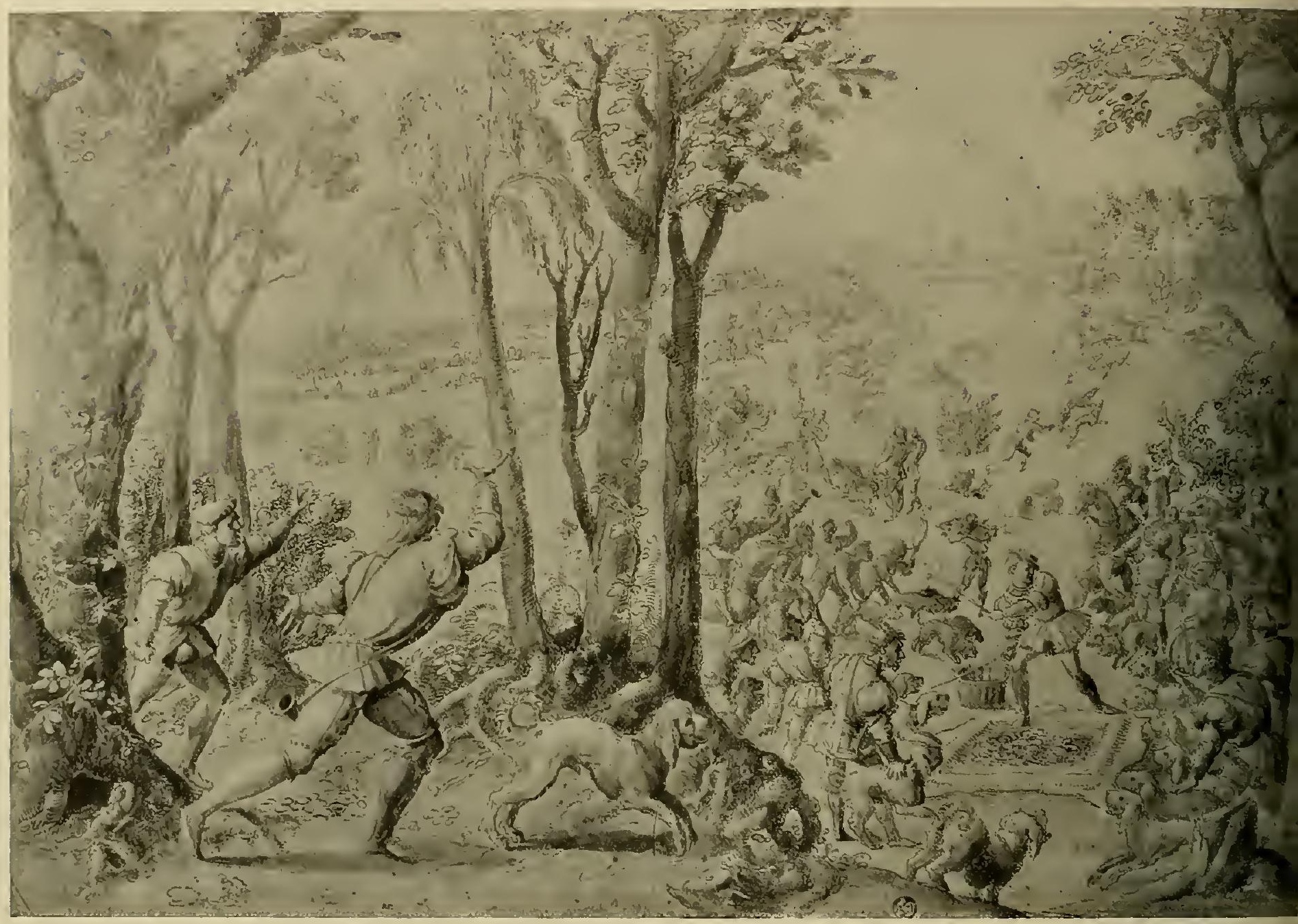

FIG. 4 $\mathrm{I}$. BERNARD VAN ORLEY'S CARTOON FOR THE “ BELLES CHASSES" TAPESTRIES : THE CURÉE, OR REWARDING THE HOUNDS. DRAWN IN OR BEFORF. 1525 . Pages $76-84$

depicted by Van Orley, a few remarks must be premised concerning the nature of our ten reproductions of Van Orley's works. Two of them (Figs. 34 and 35) are from the tapestries, while the other eight (Figs. 36-43) are reproductions of eight original cartoons designed by Van Orley. After these, Master Guillaume Geubels (the head of the famous Brussels Gobelin manufacture), who had but recently 78 


\section{SPORT IX ART}

The exact period when Van Orley drew these designs and Geubel's men completed the set is not known, but from internal evidence we can surmise that the former happened before the year 1525 , because the chapel of Coudenberg, which is in one of the drawings (Fig. 37) and was evidently added by him after the draving was finished, was not commenced until I 525. While the Brussels tapestry mark, which is on the panels, did not come into use betore 1528 , so that at any rate the weavers had not finished them before the latter year.

So admired were they that four copies were made at different subsequent periods. One in 1682 , a second in $1691-93$, of which we know the exact cost, viz. 33,170 livres - an enormous sum in those days, - the third by Leblond in 1705 . The latter hangs in Chantilly to-day. The fourth copy which hangs in La Muette, Louis XV's hunting-box in the woods of St. Germain-en-Laye, was produced in $1741-47$ by Oudry and Montmerque.

Looking at the vast size of most of the famous series of hangings, and taking into consideration that the yearly output of the most skilled weaver was about one square yard, it does not surprise one to hear that it took scores of men several years to finish one large panel. Thus we know that Pannemaker and eighty-four picked weavers were rather over five years in completing Charles V's triumphal "Conquest of Tunis," and how many years it took to finish the yet larger "A pocalypse" of King Réné at Angers, which measured 156 yards in length by 6 yards in height, or all told 936 square yards, history does not relate. And what enormous sums were spent upon them is attested by numerous instances of accurately kept accounts. In those days painters of the first rank received ludicrously small sums for their canvases; thus Van Orley's salary as court painter was 18 francs per annum, and for his portraits of royalties he received between 3 and 4 francs per square foot, which was, of course, much less than the cost of tapestry. For not only did one square yard represent a man's full year's wages, which in the case of tapestry weavers were higher than in any other branch, but the first cost of the gold and silver, as well as silk and the Arras thread, was very considerable.

It must still be mentioned that at one time this delightful series of hunting drawings was ascribed to Dïrer and by some even to Raphael, until Alphonse Wauters' researches incontestably proved them to be van Orley's work. Up to this point they were generally called the Belles Chasses de Guise, having for more than a century belonged to that famous family. The kind fate that brought both the cartoons and the tapestries under one and the same roof at the Louvre is a rare instance of good fortune, for in the old days it was a custom of the trade that the designs remained the property of the lisseurs. Had it not been so, we should not possess to-day Raphael's cartoons of the "Acts of the Apostles," for Rubens would not have seen them, and Charles I, acting upon his advice, would not have had the opportunity to enrich England's art treasures by their acquisition.

80 


\section{MART OF BURGUXTOYS DEATH}

Van Orley can at best have only been a boy when Maximilian hunted in the great forest of Soigne, which then more than half encircled Brussels, stretching

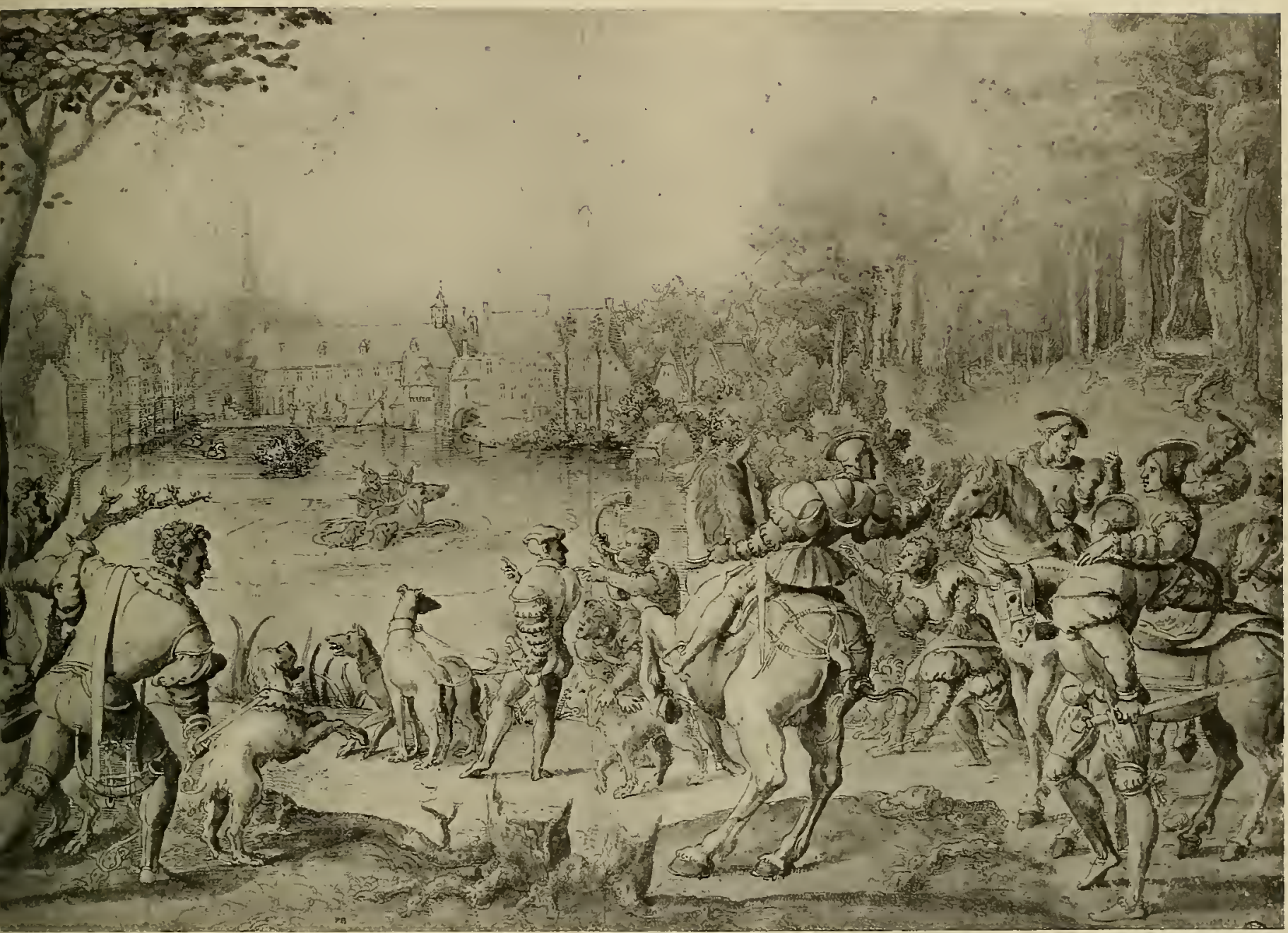

FIG. 43. BERNARD VAN ORLEY'S CARTOON FOR THE "BELLES CHASSES": DEATH OF THE STAG. IN THE BACKGROUND IS CHÂTEAU BOITSFORT. DRAIVN IN OR BEFORE 1525. LOUVRE. See Pages $76-8+$

for tens of miles nigh unto the sea, and making an incomparable hunting-ground filled with great stags, wild boar galore, and even bear. "Mary of the joyous spirit," Maximilian's lively consort, was herself passionately fond of hawking, a pastime which, alas! caused her to come to a sad end, as one day (March i 482 ) when flying her falcon in the woods of Winendael, near Bruges, her horse reared 


\section{SPORT IX ART}

and fell on her, killing both her and her unborn offspring.* Curiously enough, her fate was shared, a decade or two later, by Maximilian's second wife, the less beauteous Bianca of Milan.

In this vast forest of Soigne the old Dukes of Brabant had to good purpose established their Grande Vénerie. At Boitsfort, within sight almost of the great steeple of Saint Gudule, Brussels' chief landmark, which we see in the background in one of the panels, they had their château. Close by, at Trois Fontaines, was the prison sacred to poachers, or, rather, to those poor devils who were not immediately hanged, for there took place the cutting off of hands, gouging out of eyes, and other fiendish punishments. A little further off, nearer the eastern boundary of the great woods, lay Ter Vueren, the summer seat of the sovereigns of Brabant; while not far from it were the cloisters la Cambre and d'HertoginneDael, and a little further on the priory of Rouge Cloitre and the monasteries of Val Verd or Groenendael and Sept Fontaines, in any of which, in the free-and-easy ways of those days, the dukes and their followers and hounds did not scruple to demand night quarters when stress of weather or darkness overtook them in the forest. How terribly disconcerting the sudden appearance of a horde of hungry and noisy hunters and scores of hounds must have been to the gentle nuns or becowled monks, ill prepared for such guests, can be imagined. Nor need we enlarge upon the tales of carousals, not to call them by a harder name, that took place in these quiet retreats, to the horror of the inmates.

Turning now to some of the sporting details depicted by Van Orley, it is fairly probable that the lady immortalised by Van Orley in one or two of the panels is meant to represent Mary of Burgundy, as she is represented with a falcon on her fist, and on one of the hounds' collars we notice the arms of Burgundy.

In Fig. 34 we see Maximilian in his characteristic winter hunting-dress : a hood covering his head and shoulders as it does in his "Hunting-Book," written and illustrated under his own eyes about the year I 499. The ever-busy Maximilian is, in our picture, as usual doing three different things at one time: he is eating his breakfast, he is warming his back at the roaring fire behind him, and he is listening to the report of the eager hunter, who is probably

\footnotetext{
* It is somewhat curious that so few pictures exist of Mary of Burgundy's accident in the hunting-field. A small woodcut by Hans Weidlitz published in $155 \mathrm{I}$ in the Sanctorum et Martyrum is about the only one we can recall. It depicts Mary lying on the ground; Maximilian, who is wringing his hands, and a monk or saint, stand at her side. Campbell Dodgson in one of his most interesting papers reproduces a Flemish miniature in the style of the Breviarum Grimani. It depicts a mounted lady accompanied by two hunters, galloping along, while three skeletons, shrouded in winding-sheets, with darts in their hands, are pursuing the gay hunters, who are apparently quite unconscious of the threatening danger. As the letters M.M. are discernible on the saddlewurk, the miniature, which the author ascribes to a Bruges artist, almost certainly refers to Mary's accident.

† Quite possibly Van Orley used as guide for Maximilian's hunting-dress the very book discovered by the writer in the Burgundian library in Brussels, where it had lain, unknown, probably, to the world, ever since. $82^{\circ}$
} 


\section{THE HUXTS OF $\mathscr{M} A X I \mathscr{M} I L I \mathscr{A} \mathcal{X}$}

describing in a graphic manner the great head borne by the monster stag he has just harboured.

Bernard van Orley's dogs, stags, and horses might in some instances have been drawn more life-like; in the tapestries, thanks to the touches of skilful weavers, they appear rather more recognisable.* But we must remember that Van Orley's forte lay in portraits and landscapes, and that he does not appear to have had any actual experience as a hunter. He probably undertook this huge work at the pressing solicitation of Archduchess Margaret, who fully recognised her favourite painter's surpassing talent for picturesque grouping and fine landscape effects. Of the details of sport there was no better judge than the Grande Chasseresse herself, who could undo a boar or brittle a stag with her own fair hands, and whose ladiesin-waiting, before entering her service, had to testify their skill as horsewomen by being able to mount their steeds without any aid whatever.

In the boar-hunt picture, Fig. 42, Maximilian, mounted on a broad-backed Flemish steed, which is not unnaturally in a state of fright, is attacking a wild boar. The beast is but of moderate size if we can believe the records of weights sometimes attained by old boars. One of the pack is wearing a "coat of mail" made or several thicknesses of stout canvas and leather, wherewith the favourite hounds were protected. Maximilian's sword, as we perceive, if we examine the photograph under a microscope, is of the shape then in vogue for this particular sport. It has a very long blade-the Emperor's sword preserved in the Vienna Imperial Museum is forty-six inches long-with a cross-guard in the shape of a round or square steel pin, some ten or twelve inches from the point. This guard prevented the sword from penetrating too far into the boar's body, and thus prevented his tusks from getting within dangerous neighbourhood of the rider's legs. From the pin to the point the two-edged blade was a good deal broader than the rest, which generally consisted of a rectangular piece of steel without any edge. Sometimes the guard pin was held in position by a spring and could be removed by pressing the latter.

Maximilian, as we know from his Theuerdank, was possessed by the same passion for this type of sport, as was his great predecessor in authorship on biggame hunting, Gaston de Foix, who declared that to kill a boar from horseback armed only with a sword, when the animal was not "held" by hounds, was "a fairer and more noble feat than any other."

Fig. 36 needs no lengthy explanation. In the background burly cooks are busy roasting at an open fire sundry fowls and joints, and two mules laden with pewter

* There are a few incorrect technical details in the tapestries which are absent in the original designs. Thus Maximilian and the other hunters in Fig. 34 are wearing their swords and knives on their right sides, which of course was caused by an oversight on the part of Master Guillaume Geubels and his weavers, and probably roused the painter's ire. Then in Fig. 35 the kennelman in the foreground has four hounds on leash which are unmistakably lymers or track-hounds, while in Van Orley's design the four hounds are the ordinary hunting-hounds. 


\section{SPORT IX ART}

Hagons and paniers are hurrying their loads to the front. The couple philandering in true Flemish style in the foreground gives a characteristic tone to the whole, for, as we shall have occasion to notice on many occasions, hunting in the Low Lands included, if we can believe their artists, the pursuit of the fair sex. The remaining designs by Master Bernard are similar delightful renderings of hunting episodes: we are shown a stag-hunt in a forest with all the details of tracking, placing relays, and the stag soiling in a tree-embowered pond. In Fig. 39 we see the boar being singed before being roasted, while near by the boar's head, on a large platter, is being presented to a mounted sportsman. In the background is the château of Ter-Vueren surrounded by a broad moat upon which, so as to convey to the onlooker the impression of winter, some skating is going on. In another picture of a hunt, Fig. 43, in which the hart has taken to water, we see Boitsfort, and in others we have what is probably meant to be Groenendael and Rouge-Cloitre, ensconced in sylvan surroundings. Near the former Charles $V$ once made a very long successful shot with his rifle at a heron standing on the brink of the pond, a feat which the head of the order commemorated by erecting on the spot a column on the top of which a bronze heron was placed.

Our illustrations will bring home to the reader the evanescence of fashion in dress. IVe can be sure that our great-grandsons will be as much amused, and will find as much material for criticism, when they scan pictures showing how we conducted our sport as we, hypercritical moderns, do when we examine some early Plantagenet illumination of a hunting scene. Could we lieges of the Fifth George conjure the Second Edward's Chief Huntsman, Master Guilaume Twici, to appear before us from spirit-land, garbed in his quaint toggery, and jabbering Norman French, unintelligible to all but Channel lslanders, that worthy's attire would look no funnier to us than will our top-hat, scarlet coat, white leathers, and shining topboots appear to our descendants six hundred years hence. And would not the bluff-spoken Chief Huntsman give tongue to some unpleasant truths concerning our supine disregard of one and all of his venerated laws of venery? How indignant would he not wax to see the proceedings of the hunter of the "carted calf," or the preposterous hours and luxurious surroundings of the fashionable deer-stalker ! And would not a scowl of angry resentment mantle his face when viewing the puny head of some twentieth-century monarch of the glen, and overhearing us speaking of antlers as "horns." "Horins, indeed!" he would cry ; "horns! as if God's noblest trophy did not deserve to be distinguished from a cow's, or a goat's, or other dunghill beast's head-gear? Horns, indeed ! don't you miserable bungling duffers know enough to call by its right name a bit of bone which isn't a horn either in substance or appearance or growth ?" 


\section{CHAPTER V: ALBRECHT DÜRER, LUCAS CRANACH, JACQUES DU FOUILLOUX AND TURBERVILE}

$\mathrm{F}$

ROM an artistic standpoint it is a far cry from the primitive limnings by Jörg Kölderer to the work of his great contemporary Albrecht Dürer. And though we can hardly call him a cynegetic artist, there are a few pictures and engravings of his that deal with our subject. The six we reproduce are typical of his skill as a painter, designer and engraver on copper and wood. Fig. 44 was one of his least known pictures until it appeared in the Germanic Museum in his native town. The wonderful play of the archer's muscles makes it a masterpiece of its kind. The other print depicts that favourite subject, the Legend of St. Hubert, of which our National Gallery possesses two well-known examples in the panels of Vittore Pisano and the Master of Werden. But Dürer's chef d'cuvre, Fig. 45, is a more beautiful rendering. It is so well known that it was hardly necessary to reproduce it here, were it not for the purpose of comparing it with similar representations by later artists. Amongst these must not be forgotten the picture by the Italian Girolamo Muziano (written also Muciani) the idealist, who was so devoted to his craft that to avoid leaving his studio he had his head shaved. Cornelius Cort, the Dutch engraver and friend of Titian, translated Muziano's painting on copper, and Fig. 100 is a reproduction of the large plate $(39 \mathrm{~cm} . \times 54 \mathrm{~cm}$.$) . Albrecht Dïrer would hardly have approved of some of its$ details-the stag's antlers, the shape of the saint's Hirschfïnger, and, of course, St. Hubert's affected pose would probably have displeased the great master.

Fig. 132 shows us a yet later conception of the scene by an unknown Belgian artist, who engraved the plate in 1666 . An extraordinarily elaborate plate devoted to the same subject, two brothers, citizens of Augsburg, fabricated between them about the middle of the next century. Joseph Sebastian and Johann Baptist Klauber, who call themselves Catholic $i$ in the address on the plate $(7 \mathrm{I} \mathrm{cm} . \times 54 \mathrm{~cm}$.), must have regarded it as a tour de force, for a "fuller" engraving was assuredly never designed. Every square inch is occupied by hunting incidents, attributes of the chase, dead and live game, arms, nets, and traps. The centre is filled with the saint's figure arrayed in a Spanish costume with a cross-bow in his hand, kneeling in front of the sacred vision. Even the Christ on the crucifix, between the stag's antlers, is not allowed to remain silent, for from His mouth issues a long Latin pro memoria, which however fails to prevent various sportsmen from firing long fowling-pieces at game only a yard or two off. Stags and roebuck gambol wildly about, men in boats are killing swimming deer, hounds in full cry follow diverse beasts, and hunters spear, net, trap, slay, and otherwise do for hurrying and scurrying denizens of the forest! Johann Wolfgang Baumgärtner, a Tyrolese 


\section{SPORT IX ART}

artist, appears to have designed this strange picture, and as it is marked Cum Pr. S. C. Maj. it even received the Imperial hall-mark.

Emperor Maximilian, as everyone interested in the art of the late Middle Ages knows, was one of Dïrer's most munificent patrons, and one of this artist's masterpieces consists of the pen-and-ink designs with which he adorned the Emperor's Prayer Book, of which we have already had to speak. Fate did not deal kindly with this chef d'ceuve, for it has come down to us in two separate parts, the first portion, which contains Dürer's and Lucas Cranach's drawings, being preserved in the Hof und Staats Bibliothek in Munich, while the remainder, short of a few leaves which have disappeared altogether, is treasured by the Besançon Library, in the possession of which it came in the year 1694 . Speaking of the book as a whole, it marks the epoch of transition when the printed Livres d'Heures replaced the written ones, for the text of the Prayer Book, composed as it was by the Emperor himself, is printed, and represents one of the most perfect xylographic masterpieces ever produced. Our old friend Hans Schönsperger the Elder, of Augsburg, was the printer, and Jost de Negkers, the Antwerp Formschneider, who produced the font for "Theuerdank," cut also the extraordinarily fine types for the Prayer Book. Maximilian ordered the book already in 1508 , desiring two editions to be printed, "one an ordinary one, the other an extraordinary one," to use the Emperor's own words. The former he wanted for the members of the Order of St. George in connection with a scheme that lay ever near the Imperial heart, viz., a crusade against the Turks, who were then menacing Europe.* In spite of the Emperor's importunities, it took De Negkers and Schönsperger six years to cut the types and print the text, one copy being turned out with special care on vellum. It was to be the Emperor's own book. lt was this copy which he caused to be adorned by the first masters of the day, not with the usual miniatures in bright colours and encrusted with mellow gold, but with exquisite marginal pen-and-ink designs. While the lower part of the page is filled in with a picture or rich device, delicate scrollwork and foliated trellis designs, upon which are perched a variety of birds and animals, frame in with ever-varying imagery the centre block of the text. Its rubricated capitals are little masterpieces of the Formschneider's craft. Intricate volutes and boldly curved Hourishes, so characteristic of Dürer's free art, fill vacant spaces. What a wealth of imagination is represented by these pages can be seen from the circumstances that not any two of the 324 pages are in any way alike. The volume, which measures $7 \frac{5}{8} \times$ i i inches, can therefore well, be described as a unique production the like of which does not exist. $\dagger$

* Of the ordinary copies of the Prayer Book four of the ten copies ordered have come down to us, of which two are in England (British Museum and in Sir Thomas Brooke's library), the others being in the Vienna Court Library and in the Vatican. It was evidently the Emperor's intention to illustrate the ordinary copies with woodcuts or engravings as is shown by one of the existing copies.

$t$ An unusually fine reproduction of the Prayer Book costing several thousand pounds was published in I 908 by Karl Giehlow in Munich and Vienna. As we write this we have the precious original and the repro86 


\section{ALBRECHT DÜRER'S DESIGXS}

Maximilian's natural impetuosity did not always make him a pleasant patron, and the same intolerance of delay which caused him to ever urge his printers and typecutters to complete their jobs, marks also his relations with the artists who

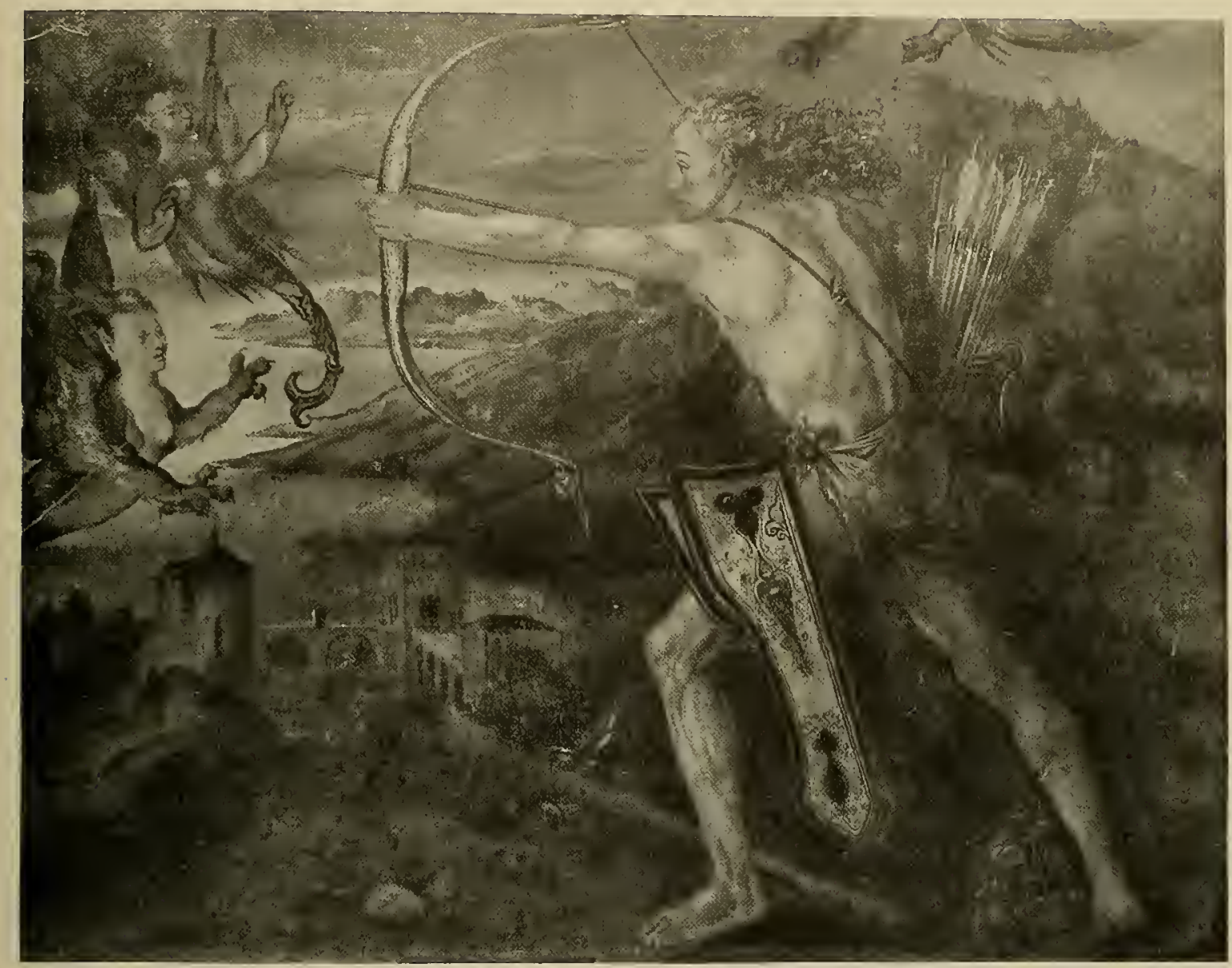

FIG. 44. DÜRER'S CONCEPTION OF THE USE OF THE LONG-BOW ; FROM HIS PAINTING "HERCULES AND THE STYMPHALIAN BIRDS" (1500) IN THE GERMANIC MUSEUM AT NÜRNBERG. See Page 85

were working for him. It was probably in consequence of this that Dürer, when he had completed some fifty of the pages of the Prayer Book, called in other artists to assist him. The first to do so were his brother Hans and his crony Lucas Cranach the Elder, and when even their progress failed to satisfy the impatient Emperor, Hans Burgkmair, Jörg Breu, and an artist whose identity is

duction before us, and in some respects the latter is clearer than the former, for where the intervening four centuries have slightly dimned pen lines the photographic lens has reproduced them in primary strength and brought out strokes which the human eye no longer could clearly detect. 


\section{SPORT IX ART}

not quite certain, but who probably was Albrecht Altdorfer, were all employed in completing the Prayer Book. Keeping strictly to Albrecht Dürer's scheme and style, it is perfectly marvellous how uniform and artistically complete are the contributions by these six artists.

The subjects of the pictures which occupy the lower part of each page are generally of a religious or mythological purport, and as such would not come within the sphere of our enquiry, but in a few cases animals of interest to the sportsman were made the subject of symbolic or allegorical renderings. They are occasionally in startling contrast to the devotional character of the work. Thus one prayer : "Do not lead us into temptation," is illustrated by a fox standing on his hind-legs blowing a flute to attract some foolish barn fowl! Two pages come more particularly within our observation ; one represents a deer of some sort in charging attitude with lowered head, the other, Fig. 46, an animal which might be a bison or it might be an aurochs. Of the latter we have already spoken in a previous chapter (p. 37), and we now want to make a few observations about the former beast, for it has aroused almost as much discussion as did that of the aurochs, and for the same reason. Goethe called it Dammhirsch or fallow buck. Now, if there is one thing that Dürer was master of it was the delineation of animals which he had actually seen, and in some instances, such as his hare in the Albertina, they are unequalled masterpieces. We can be sure that had he desired to draw such a common animal as a fallow deer, he would have hit off its likeness with the same skill that marks his pictures of other animals he drew ad vivum. The animal depicted in the Prayer Book has the head of a gigantic hare; from it sprout pilmated antlers that are distinctly not those of a fallow buck, and it is unlike anything that encumbered the earth at any period. It is for this reason alone that we nay assume that Dïrer here drew an animal he had at that time (15 I 5) never himself seen, viz., a Scandinavian elk. This surmise is supported not only by the likeness of the antlers to those of a young three-year-old eflces malchis, but by another detail which appears to have escaped the notice of Goethe and other critics. 1t is the presence of what are distinctly throat tassels, or "bells," characteristic of this species. And as Duirer had probably heard that the head of this northern deer was of extraordinary shape and ungainliness, he gave his elk the impossible profile which puzzled the Herr Rath.

A recent discovery, if so it can be called, by the Berlin Art historian, Dr. Harry David, of what is believed to be a drawing by Albrecht Dürer, which had lain neglected in one of the Sloane volumes in the British Museum, confirms what we have said of Dïrer's life-likedelineations of animals which he had actually seen himself. The drawing in question, Fig. 48, depicts a young Scandinavian elk with immature antlers, and is in every respect a perfect likeness of the animal, and must have been done from life. Dr. David expresses the belief that the date ( 5 I 9 ) and the monogran on this drawing, because written in paler ink, are not genuine; he 88 


\section{DÜRER'S DRAWIXTS}

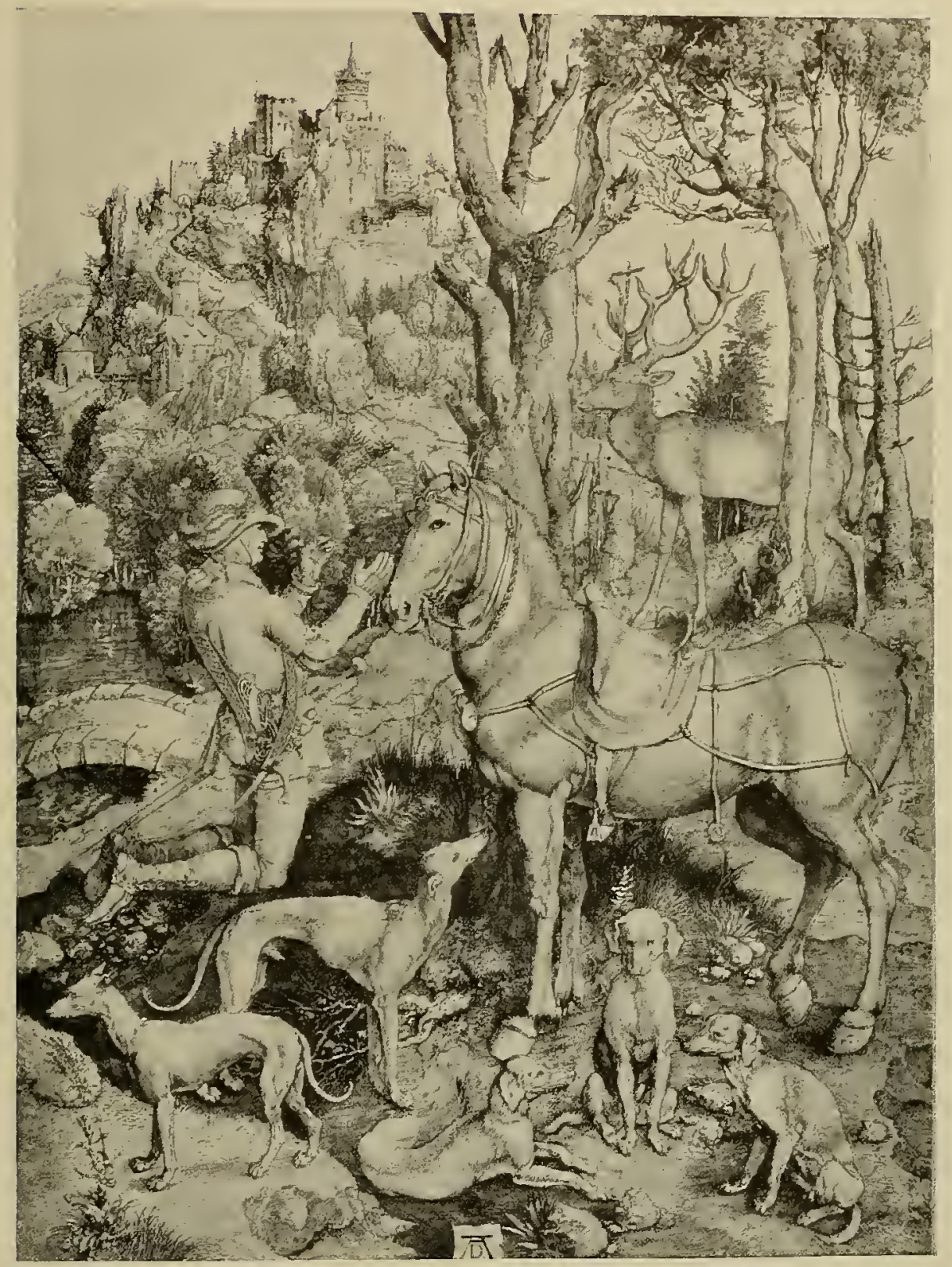

FIG. 45. THE LEGEND OF ST. HUBERT, DESIGNED AND ENGRAVED ON COPPER BY ALBRECHT DÜRER ABOUT 1505. Ste Page 85

considers that the drawing is unquestionably by Dürer, but that it was made at a much earlier period, possibly still in the fifteenth century. With this opinion few 


\section{SPORT IX ART}

will agree, for Dürer would have been the last man to draw in 15 I 5 the unreal picture in the Prayer Book after he had seen a live specimen. And we also fail to follow Dr. David's reasoning, which leads him to declare Dürer's monogram and date to be faked simply because they were written in paler ink than that used in the drawing. It will require more convincing proofs to make us doubt their genuineness. A glance at Dürer's much discussed copper engraving of Adam and Eve of 1504 , in which the stag-like animal behind Adam is now declared by Dr. David to be also an elk and not a red-deer stag, as was hitherto universally believed, confirms one's impression. For not only does the animal lack the chief characteristics of the elk, i.e. the high withers and lower hind quarters, but the antlers are also unlike an elk's. If Dürer intended this to be an elk and had drawn the British Museum sketch at a previous period, he would certainly have drawn it more in conformity with his sketch from life.

Dürer very probably saw the live specimen he depicted in the 15 I 9 drawing in that year or while he was travelling after finishing the Prayer Book in I515. For the species had not become quite extinct even in his native country at that period. History tells us that a large elk was killed more than a century later between U1m and Augsburg. It was shot by a Jäger named Suttele in 1629, the spot where this occurred being still marked by a memorial tablet. A drawing of the great beast was made, and when the Emperor came to the diet at Regensburg the feet of the elk were presented to him as curiosities. The drawing passed from hand to hand until it finally reached those of the great northern war-lord, Gustavus Adolphus. Asking where the beast had been killed, he was informed that it had been shot between Ulm and Augsburg in Suabia. Thereupon the King is said to have replied: "If this son of our northern forests managed to get so far south, then my men can also get there;" and they did get there, as the unfortunate inhabitants of Augsburg found out a year or two later. This ben trovato tale would appear to have a substratum of truth, for the chronicler from whom it is taken carefully mentions the various hands through which the drawing passed.* Another drawing by the great Nürnberg artist has lately led the same Berlin savant to make an amusing discovery, details of which he disclosed at a recent sitting of the Art-Historical Society in that city. It appears that Dürer's drawing and his well-known woodcut of a rhinoceros have incontestably proved that one of the most treasured Pompeian relics preserved in the National Museum in Naples is nothing but a clever modern fake. The marble in question formed the centre tablet of three reliefs which it was believed once graced the atrium of a fine Roman villa in the doomed city. On the centre tablet is sculptured the design of

* How often people confused the elk with other deer even in modern times is shown by the well-known mezzotint which W. Ward engraved in the last century after Rubens' picture in Sir Horace Walpole's collection at Houghton. It represents the death struggle of an ordinary red-deer stag, but nevertheless the print bears the title The Death of the Elk. 


\section{DÜRER'S RHIX⿻CEROS}

a rhinoceros, but curiously enough the head is not of the familiar African twohorned kind, but of the then less known one-horned Indian species. As the Romans were not supposed to have possessed intimate knowledge of the fauna of East India, much ink has been spilled by scientists in discussions over the question. It was more than wasted, for it now turns out that the sculptured rhino is an exact copy of the beast depicted by Dürer in the woodcut which he engraved in the year I5I5. Now this alone would, of course, not prove anything, for the Nürnberg master might possibly have drawn his somewhat fantastic "portrait" after a facsimile of the Roman carving seen by him in the course of his Italian travels. But unfortunately for the faker the British Museum possesses the original drawing by Dürer, and on it is written in the master's own hand that he drew it after a sketch sent him from "Lissabon," and that it represented an animal landed there on May I, I 5 I3, for King Emanuel of Portugal. So, of course, all possible doubt concerning the modern origin of the marble must vanish. Like so many other works by the immortal master, this woodcut made a great stir in

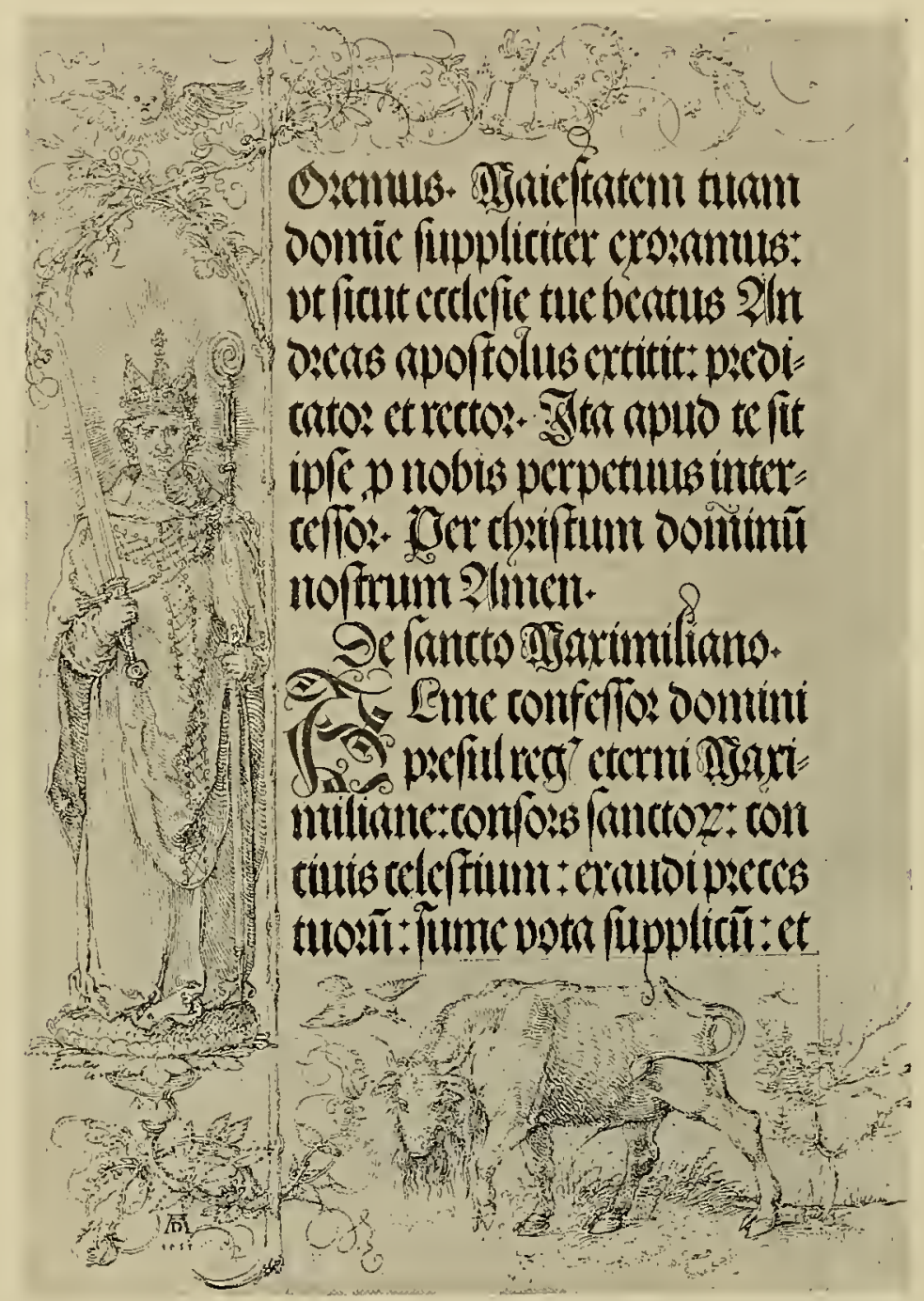

FIG. 46. PAGE OUT OF EMPEROR - MAXIMILIAN'S PRAYER BOOK ILLUSTRATED BY DÜRER! I5I5. · GÖTHE DECLARED THIS TO BE AN AUROCHS. See Page 45 those picture-starved days, and Dürer's rhino was copied and re-copied innumerable times ; in fact, until quite late into the eighteenth century hardly any other picture of this beast came to be published. Conrad Gesner was, of course, in this respect the chief sinner, for he gave it wide circulation by incorporating a copy of it in his 


\section{SPORT IX ART}

Historia SInimalium ( $1550-87$ ), that inexhaustible source for books on natural history for the next two hundred years. From him our garrulous Edward Topsell borrowed it, publishing a facsimile in his "Historie of Fourefooted Beastes," issued in 1607 , and it we reproduce in Fig. 49. The text accompanying the picture, based on information collected by Tertullian, Oppian, Pliny and Strabo, makes curious reading, not the least funny information being a remark taken from the last-named Greek geographer. According to it our pachyderm was a sort of winged beast : "The Rhinocerots. . hath also two girdles upon his body like the wings of a Dragon, comming from his backe downe to his belly, one toward his necke or mane, and the other toward his loines and hinder parts."

Before we proceed to touch upon the numerous artists that secured for the second half of the sixteenth century such lasting fame we must say a few words about Dürer's contemporary, Lucas Cranach the Elder (1473-1553), who has left us some curious paintings, one engraving and several woodcuts, dealing with sport or with animals of the chase. Fig. $5^{\circ}$ is a reproduction of the earliest of the half-dozen engravings produced by Lucas Cranach. It represents the Atonement of Saint Chrysostom, and we reproduce it on account of the quaint stag and roebuck that figure in this plate. Drawn in 1509 , when the artist was no longer a youth, these weird beasts make it difficult to believe that the artist acquired, later on in life, the extraordinary skill which he is reputed to have exhibited in the delineation of stags and other game animals. Thus it is said of a stag he piinted in Coburg that it was so life-like that all the hounds who saw it began to bay it; of a stag's antlers painted on a wall that birds wanted to build their nest in the cup formed by the uppermost tines; of a great wild boar that dogs, as soon as they saw, ran away from in terror, with bristling coats and tails between their legs; of some hares and partridges, painted in fresco in the dininghall at Torgau, that when the Chamberlain Count Schwarzburg entered the chamber he ordered the dead game to be removed lest it should begin to smell before the feast came to an end! Lucas Cranach was court painter to three successive Electors of Saxony, his devotion to Frederick the Magnanimous being so great that he followed him voluntarily into his five years' captivity. Of the opportunities to paint the court hunts, then becoming so popular in Germany, he availed himself as often as he could; and the many stag-hunting scenes that decorate the walls of Moritzburg, the ancient hunting-seat of the rulers of Saxony, and four similar canvases are typical samples of his brush. Two of the latter are in the Escurial, one in the Imperial Museum in Vienna, and the fourth is in Lord Powerscourt's collection, at his seat near Dublin. Of this picture Fig. 51 is a reproduction. It represents a large battue or stag drive given by John Frederick the Magnanimous to the Emperor Charles V after the diet of Spires in the previous vear. In the foreground we see the Emperor, his brother, Ferdinand King of the Romans, other princes of the Empire, and Sybilla of 92 


\section{LUCAS CRAX XACH'S PICTURES}

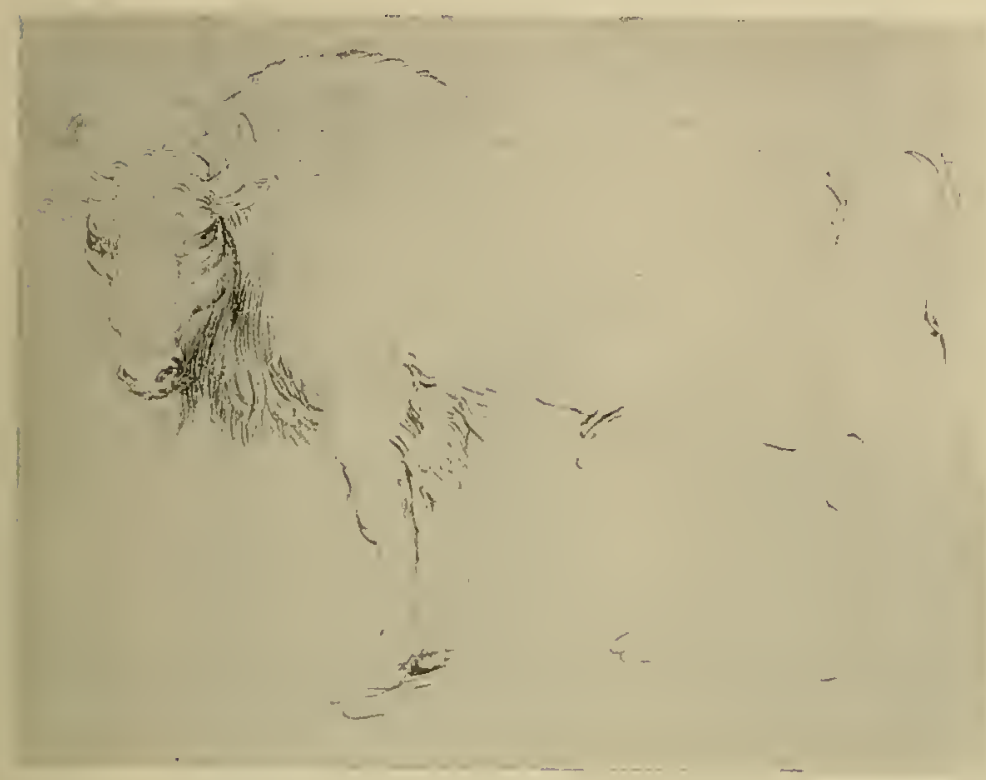

FIG. 47. DÜRER'S DRAWING OF A BISON, DISCOVERED RECENTLY IN THE SLOAN LIBRARY IN THE BRITISH MUSEUM. See Pages 37-51, 86-90
Cleves, Electress of Saxony; all are armed with crossbows, shooting at stags driven into a pond or lake, or possibly a backwater or arm of the Elbe, of grotesquely foreshortened perspective. In a boat on the right-hand side there are two men, possibly intended to represent the artist and his son; and on its side, invisible in the much reduced photograph, is Cranach's sign, a dragon, and the date I 545. The town in the background is Torgau on the Elbe, some hours' journey below Dresden. The tower on the

right of the castle is the Flaschenthurm or Bottle Tower, said to have derived its name from the fact that the Electors used to have great carousals in its upper room, while the lower chambers and cellars were filled with bottles and casks of choice vintages. Less than two years after this picture was finished the princes here depicted were fighting each other in mortal strife, and the chief guest had vanquished and taken prisoner his host. The late Lord Powerscourt, who was unaware of the picture's identity until the writer told

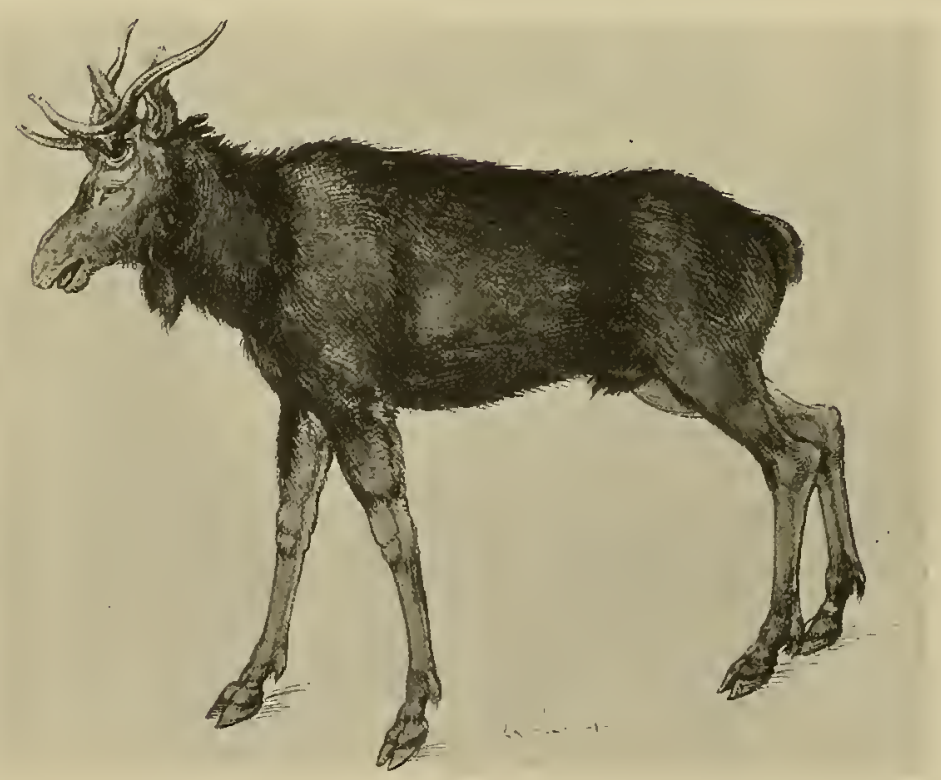

FIG. 48. DÜRER'S DRAWING (TINTED) OF A YOUNG SCANDINAIIAN ELK WITH IMMATURE ANTLERS. IN THE BRITISH MUSEUM. See Pages 88-90 


\section{SPORT IX ART}

him, bought this picture for a trifling sum at Christie's at the sale of the collection of Lord Breadalbane, who, it appears, had bought it when the gallery of Count de Survilliers - as Joseph Bonaparte called himself after his emigration to the United States-was brought back to Europe and dispersed after his death (1832). This much-travelled picture resembles the Vienna pendant, which is dated 1544 , in many details.*

At this period "combined" arms of the chase originated. These consisted either of cross-hows that were provided with a short barrel out of which a shot could

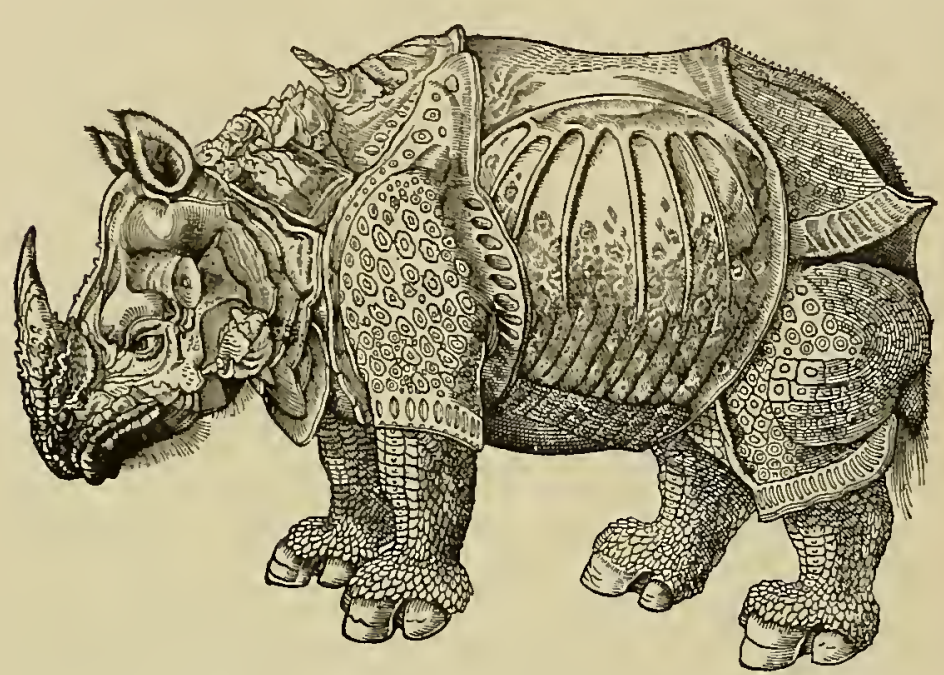

FIG. 49. DÜRER'S WOODCUT OF THE RHINOCEROS SENT FROM INDIA TO THE KING OF PORTUGAL AND LANDED AT LISBON MAY I5I3. ORIGINAL IN THE BRITISH MUSEUM WITH DÜRER'S NOTES. Sce Page 90 be fired, or of hunting halberts that had pistol barrels alongside of the blade. Of the latter combination Charles $\mathrm{V}$ possessed a beautifully gold inlaid specimen with two barrels. It perished with practically all of Charles's treasures in the fire which destroyed the Brussels Palace in $174 \mathrm{I}$. His successor Ferdinand, who was also present at the hunt depicted in Fig. $5 \mathrm{I}$, used one of the former combinations. The barrel of medium bore has a matchlock, and his initials and armorial bearings are displayed on the cross-bow. The specimen we allude to is preserved in the National Museum at Munich, while one of the former combinations is to be seen in the famous collection in the Veste at Coburg. It was exhibited at the Vienna Sport Exhibition in rgro.

Speaking of Lucas Cranach's work we might draw attention to another detail of art life which illustrates the low level at which stood the painter's craft even under the most favourable circumstances. Many of the receipts for payments doled out to Cranach while working at the Elector's Court are still extant, and they illustrate the miserable pay vouchsafed to this famous artist. Lacking other work, Cranach, fresh from painting a great canvas in which the Emperor and other

* The Archreological Fournal for I 850 (Vol. 7) contains a long account of this picture, in which the details, "admirably illustrative of the manners of the times, the costumes, and equipment for the chase" of this "highly curious painting," are fully described. At the time it was not yet in possession of Lord Powerscourt, and it appears to have been exhibited somewhere in London by a Mr. Henry Farrer. 94 


\section{LUGAS CRAX $\mathcal{X} A C H$}

leading personages of the realm are depicted, takes to wall-painting or to

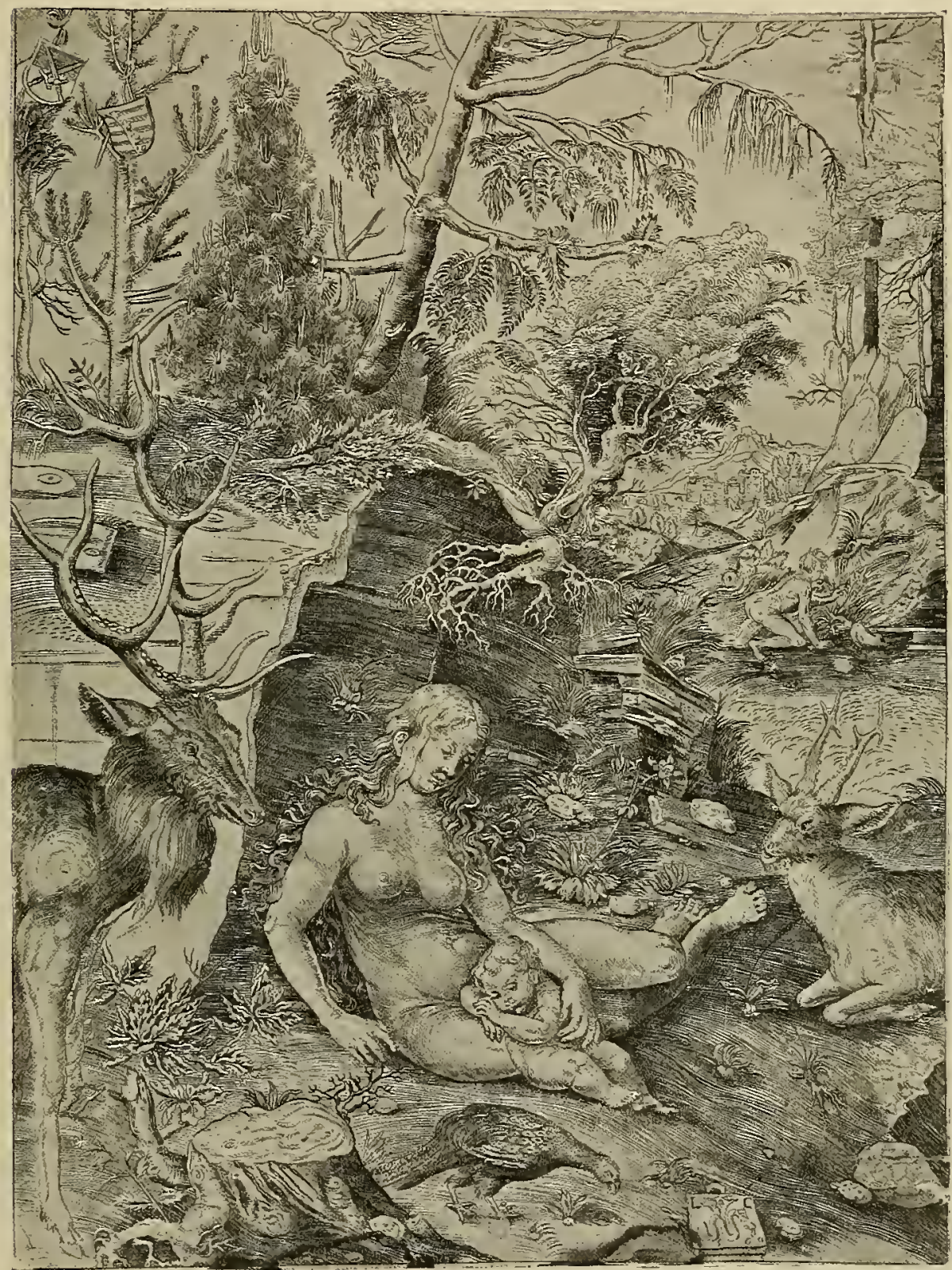

FIG. 50. "ST. CHRISOSTOM'S ATONEMENT" BY LUCAS CRANACH

THE ELDER, ENGRAVED 1509. See Page 92

designing the armorial bearings for some private customer, or to burnishing with gold the tines of deer antlers, or other work which to-day would be left to 


\section{SPORT IX ART}

the artisan rather than to a master of world-wide fame. Cranach received from the Elector an annual retaining fee of 100 florins, and his work for the court was paid separately-but what prices did he receive? For "painting two aurochs in the chamber above the great hall" he acknowledges the receipt of four florins. For the "great picture of the stag-hunt which my master the Elector gave to Elector Frederick" - possibly the very picture we have described-seventy thalers (ten guineas) were paid him ; for a smaller one, "The Chase in Boats," the fee was twenty florins; and for the aforesaid "gilding of six pairs of great antlers in the chamber of my royal mistress the Electress" the payment was but two florins! Considering that such a large sum as 500 florins was in one case refused for a single pair of antlers of great size, one can form some idea of the relative value of works of art when compared with trophies of the chase that had about them anything out of the common.

Of the hundreds of woodcuts designed by Lucas Cranach only a few relate to the chase. A large one (described by Bartsch, I I g) depicts mounted men shooting at running or swimming stags with cross-bows, in the manner Maximilian is represented doing in our title-page. One cannot refrain from expressing surprise that such keen sportsmen should not have at an earlier date abandoned such old-fashioned weapons, and used fire-arms also for the chase. Let a few facts bearing upon the slow progress of the latter for sporting purposes be here interpolated. We have seen that a picture (Fig. 26) produced not later than ${ }^{5} 0_{3}$ or 1504 , contains the first pictorial record of the use of fire-arms for big game. The next reference to their use occurs in a poem composed by the Cardinal Adrian de Saint-Chrysogone, printed in Venice in I 505 , in which, in elegant Latin, a "wonderfully horrible engin" is described which "projects a ball of lead at game, striking it with the force of lightning." It is not illustrated, but a reprint, published by S. Feyerabend of Frankfurt in 1582 , has woodcuts by Jost Amman, but of course they are of no assistance in throwing light upon the date when fire-arms came into use for the chase. About this time, the first decade of the sixteenth century, Benvenuto Cellini used an arquebus to kill a wild boar, and we know from his own writings that he was an early believer in the invention. He did his share in perfecting it, as well as in improving gunpowder by making it of a finer grain. If he did not exaggerate he must have been a good marksman, for at the siege of Rome he managed to wound the Connétable de Bourbon mortally, and to wing the Prince of Orleans.

A Flemish broad-sheet of $15 \mathrm{I} 4$ forbids people to use the "couleuvrine" to kill red and black game (deer and wild boar), hares, rabbits, partridges, pheasants, herons and other wild fowl, this being the earliest reference we have come across to the use of fire-arms for killing wild fowl. Unfortunately it leaves us in the dark whether it referred to the use of shot or only to ball--most probably to the latter only.

96 


\section{QUEEX MART STUART'S ACT}

In Scotland the use of fire-arms for purposes of the chase seems to have been known some little time before the middle of the sixteenth century. According to an Act of Queen Mary's Fourth Parliament, which was held in May r 55 I, under cap. 9, "Anent them that schuttis with gunnis at Deare and Wilde-Fowle,"

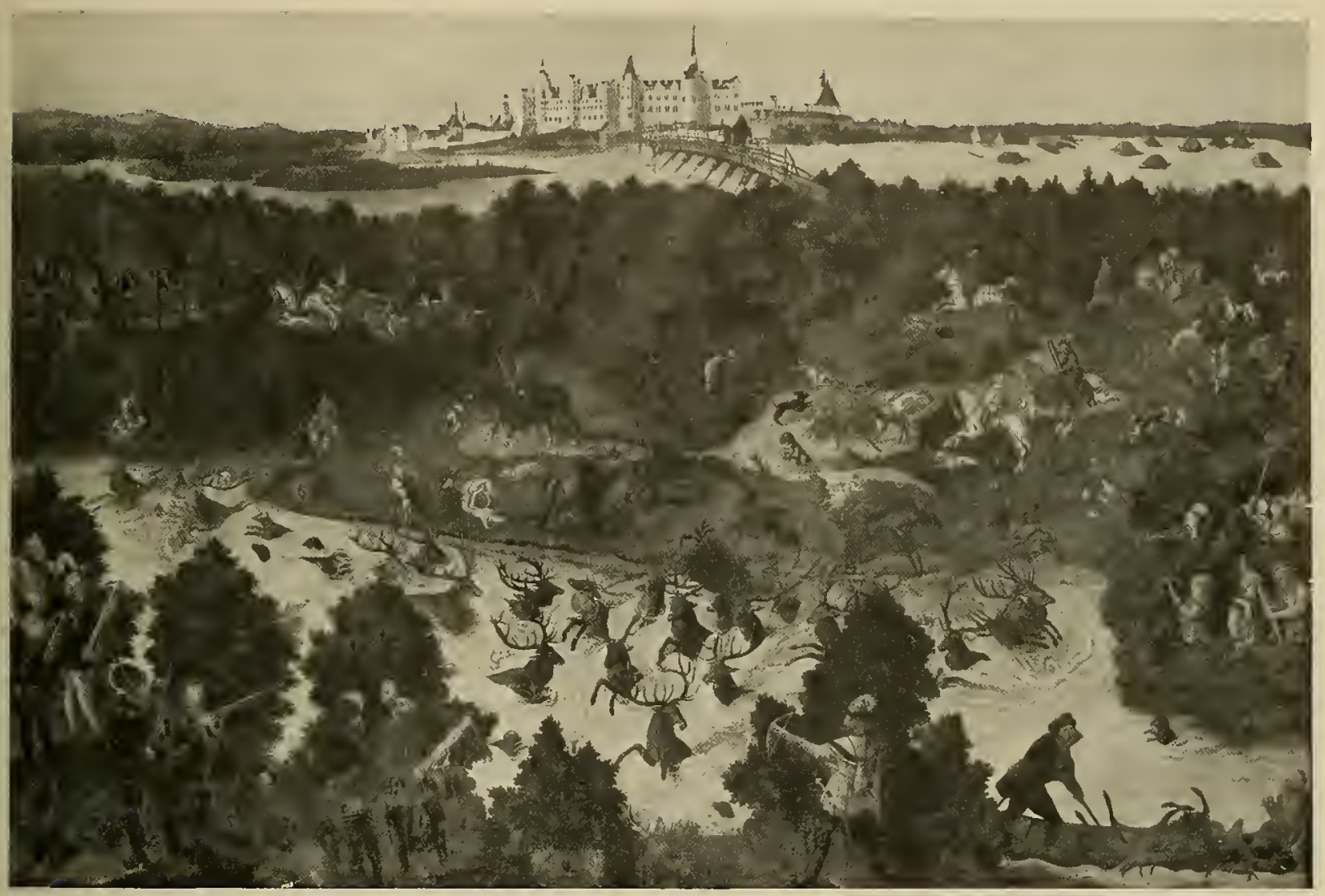

FIG. 5I. EMPEROR CHARLES $V$ AND SEIERAL ELECTORS SHOOTING STAGS AT A DRIVE NEAR TORGAU, ONE OF THE LAST GREAT COURT HUNTS AT WHICH THE CROSS-BOW WAS EXCLUSIVELY USED. PAINTING BY LUCAS CRANACH THE ELDER I5+5, IN THE POSSESSION OF LORD POWERSCOURT. See Pages 92-94

it was provided that no liege should "shutte with the half-hag, culvering or pistolet at Deare, Rae, Wilde beastes or Wilde Fowles in any time to come under the pain of death and confiscation of all their gudes for their contemption." Once in this Act the weapon is called half-hag, and on a second occasion it is spelt halse-hag. Culverings was probably derived from, and meant, a diminutive culverine, as field-guns were called in the sixteenth century. Anyhow, both seem to have come under the general term of gunnis, as the title of the Act shows. Queen Mary was in 155 I only nine years old, and since October I 548 


\section{SPORT IX ART}

had been living in France as Queen of Francis II, so the measure was enacted not by her, but by the Lord Governor, the Earl of Arran.*

It seems probable that the great court hunt depicted in Fig. $5^{\mathrm{I}}$ was one of the very last at which the cross-bow was used exclusively by all the sportsmen. From an entry in the diary of the Duke of Hesse made in 1573 , we gather that this sportsman had not used a cross-bow for the preceding twenty years. And to judge by one of Lucas Cranach's own notes the middle of the sixteenth century witnessed considerable changes, at least on the Continent. For he tells us that while he was sharing the Elector John Frederick's confinement (1547-52) in Innsbruck they used to pass the time by going out shooting with the long and with the short Pürschrohr or rifle. A model shooting diary kept by Duke Albrecht $V$ of Bavaria is

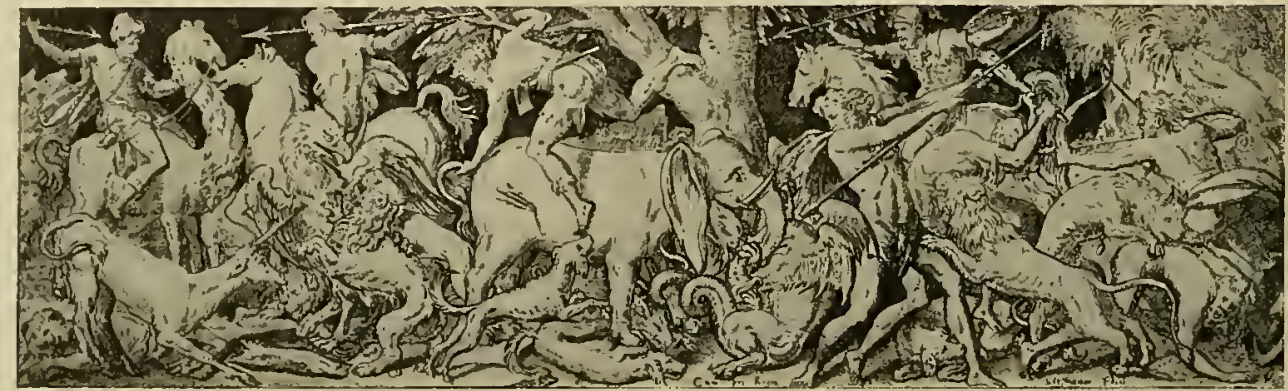

FIG. 52. FRIEZE DEPICTING COMBATS WITH WILD ANIMALS AND GRIFFINS. ENGRAVED BY E. DELAUNE (STEPHANUS, 1519-1583). Sce Tage 99

preserved in the Court Library in Munich. It showed what he killed with his own hands day by day between 1555 and I 579, when he died. The chief item was $47^{8} 3$ red deer which he appears to have shot with fire-arms, his Duchess also being passionately fond of stalking. She also used rifles, as is shown by a bill for "two special Birschbixen" for her highness, costing 60 florins, which is also extant. Game seasons were not kept very strictly, for the diary shows that the Duke killed a few stags also in the months of March, April and May! In England the use of fire-arms for shooting game seems to have become general at a later date than abroad, the bow retaining its popularity to the end of the sixteenth century. We know, f.i., that Lord Gilbert Shrewsbury killed three stags at Hatfield with his bow as late as I6I6, and that in 1624 the Archbishop of Canterbury while shooting fallow buck inadvertently killed a keeper with his bow.

But we must return to our artists who worked about the middle of the sixteenth century. One was Virgil Solis (1514-62), who amongst other fine work executed a set of twelve plates depicting the respective sports of the months of

* Henry VIII's statutes directed against "Cros-bowes and handguns," and Edward VI's "Acte against the shootinge of Hayle shott," also bear upon the matter.

98 


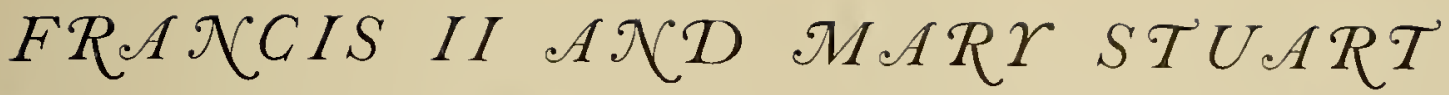

the year. He cannot have known much about the subject, for in the "April" plate he pictures stag-hunting, the hunted animal being depicted with fullydeveloped antlers! This plate is, however, of interest for another reason. It must evidently have taken the fancy of Francis II's "sweet little Scotch Queenlet," as the youthful King of France was wont to call his pretty royal spouse, Mary Stuart, of whom we have just had occasion to speak. For there exists a panel of tapestry closely copied from this plate, the only important difference being that the Queen is represented there as seated pillion behind the King, with her one arm akimbo, while with the other she holds on to Francis, whose head is turned backwards as if he were talking to her. Thus mounted $\grave{a}$ deux, the boy King and his youthful Queen are pursuing the fleet stag. Originally Mary Stuart desired that four panels should be woven to represent the four seasons, to

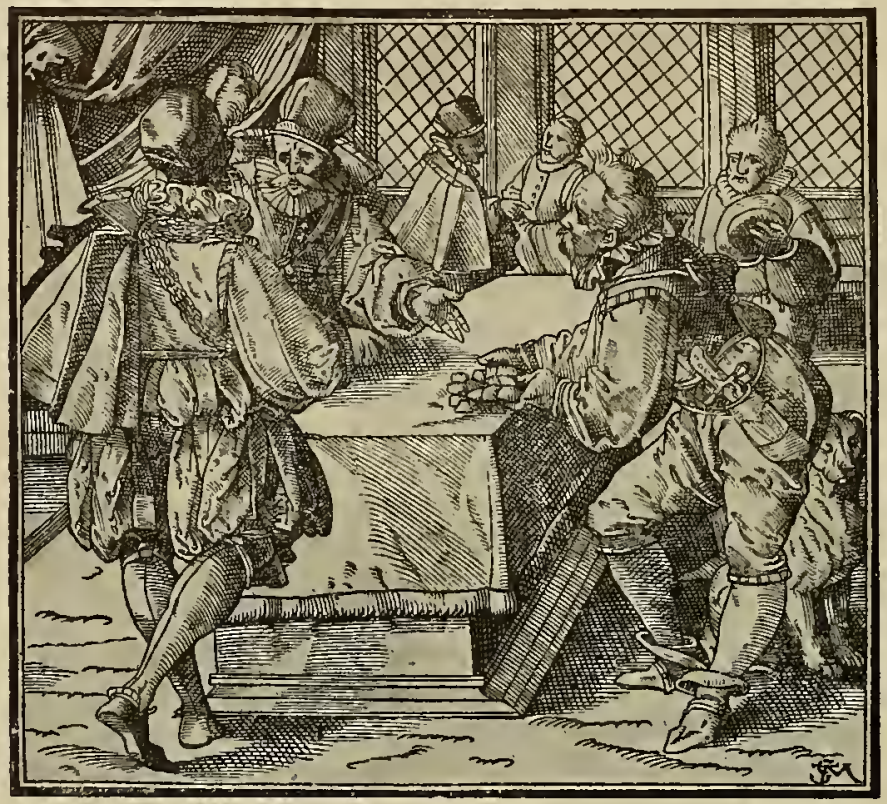

FIG. 53. PRESENTING THE STAG'S DROPPINGS TO THE LORD. WOODCUT BY TOBIAS STIMMER AND MAURER. GERMAN EDITION OF DU FOUILLOUX'S "VENERIE," PUBLISHED BY S. FEYERABEND IN 1582. See Fig. 2, and Page IoI adorn her chambers in the Pavillon des Chasses at Fontainebleau; and in the Bibliotheque Nationale in Paris are still preserved the designs for them, but only the one we have spoken of was actually made. It used to hang in the Queen's Room in Fontainebleau.

Etienne Delaune (I 5 (9-83), a Paris engraver, was imbued with a love of gladiatorial encounters between human beings and mythical as well as real animals characteristic of Antonio Pollaiolo's style. He depicted these scenes in oblong frieze-shaped prints, reminding one of the latter's Combat of ten mude men. Their execution shows uncommon talent, and they are most effective. Fig. 52 is a typical print of this sort, where wild men are engaged in deadly encounters with griffins, unicorns, lions, and elephants. The man leaping upon the back of an uncommonly patient elephant, holding on by his tail, is probably intent upon hamstringing the beast, of which manner of capturing them an artist of a slightly later date has left us an amusing picture in Fig. 74 . 


\section{SPORT IX ART}

About this time one of the great French classics was being written by Jacques du Fouilloux. La Vénerie, illustrated by an unknown artist with a large number of rough woodcuts in simple outline, and of little artistic merit, was published 1561. It was a most popular work, and evidently filled a long-felt want, for not only did it go through twenty-four French editions, but it was translated into German, Italian, and English. As we shall give a full description of the latter, we will not go into a detailed description of the parent work, but confine ourselves to the briefest possible account of the author of the "Sportsman's Bible," as the book was lovingly called by generation after generation of French ieneurs.

Born about the year 1520, "Seigneur and Gentleman of Gastine in the County of Poitou," as du Fouilloux describes himself, he passed his youth from his fifth to his twentieth year under the guardianship of relatives at the Castle of Liniers in the county of Deux Sèvres, a country which he tells us was then full of stags and wild boars. His education was of the usual type, making him chiefly conversant with the arts of gallantry, arms, and venery. That he was not idle in acquiring other knowledge is best shown by the charming manner with which he relates his sporting adventures and the excellent verses in which, with much poetical skill, he tells the story of his youth. At the age of twenty, longing for freedom, he roams away from his guardian back to his beloved Gastine: "N'oubliant rien, sinon à dire à Dieux," for, says he, "as a boar of three years leaves the sounder, so should a man of twenty be free to stray alone." His achievements in the field of sport were indeed great, but also those in matters of gallantry were remarkable, for his biographer informs us, that when on the occasion of a royal progress Jacques du Fouilloux was among the notables who received their sovereign at the gates of Poitiers, du Fouilloux was accompanied by fifty of his sons, of whom only one was his legitimate offspring!

Here must be interpolated, so as to keep to our chronological order, another very favourite French hunting-book, which was published in 1566 , five years after La Vénerie. This was Jean de Clamorgan's La Chasse du Loup, which attained an even larger number of editions, for there exist no fewer than one hundred and ten French, German, and Italian impressions, of which a great number were published in conjunction with du Fouilloux's book, and bound together in one and the same covers.

Clamorgan, as he tells us in his dedication to Charles IX of France, had served in the French navy forty-five years, but had spent all his leisure in wolf-hunting, which he declares une belle chasse sur toutes les autres, an opinion which, to judge by the enduring popularity of his work, seems to have been shared by a great many of his countrymen.

For the Continental artists of the time both La Vénerie, and Clamorgan's book provided a wide field, and were one to describe fully the origin of the I 00 


\section{FACQUES DU FOUILLOUX}

hundreds of illustrations in the various editions of these classics one would fill a book. To the well-known Frankfurt artist and publisher Sigismund Feyerabend they proved a rich mine, and his assistants Jobst Amman, Christian and Tobias Stimmer, Boxberger, Christian Maurer, and four relations of his own, all set to work to illustrate the German translations, while the rival establishment of Bernhart Jobin in Strassburg even managed to forestall Feyerabend by getting out an edition of Clamorgan a couple of years earlier. In some cases two artists co-operated in the production of a plate, Fig. 53 being an instance of this. This print and Fig. 54 will probably suffice to give the reader some idea of the class of work in these books. Whatever we may think of its quality, there can be but one opinion in regard to the diligence some of the above-named artists exhibited. Thus of Jobst Amman his pupil Jörg Keller reported that during the four years of his apprenticeship with Amman the latter produced more wood-blocks than a hay-waggon could draw away!

The scenes depicted in Figs. 53 and 54 do not need long description. The first depicts the presentation of the stag's fewmets

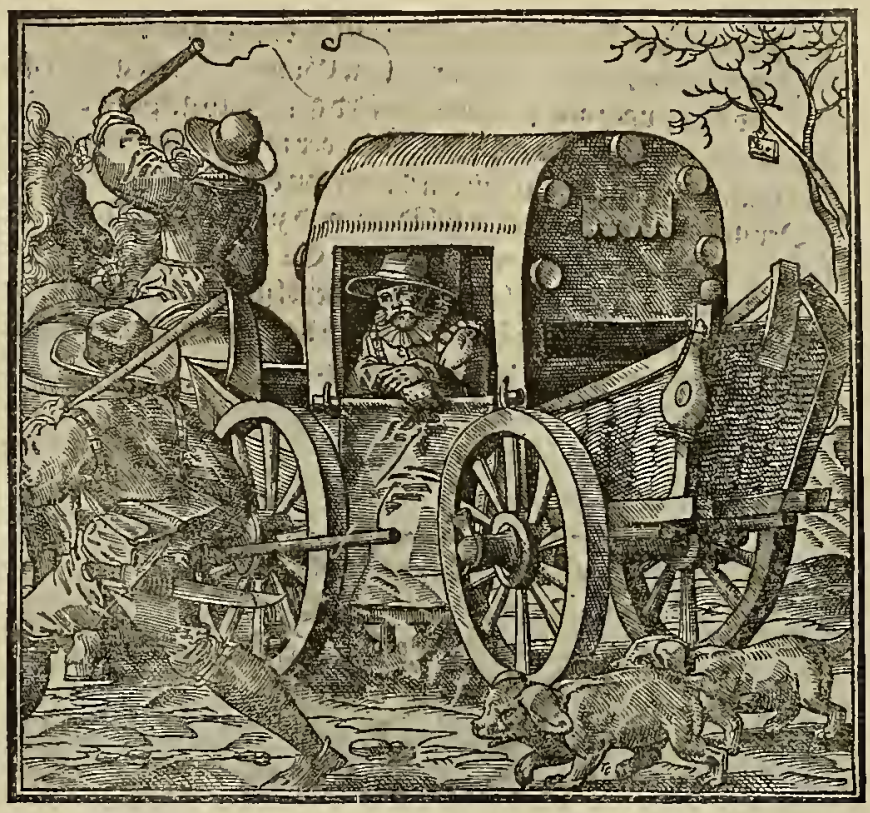

FIG. 54. SPORTSMAN IN HIS "CHARRETTE DE CHASSE" GOING OUT BADGER-DIGGING. WOODCUT OUT OF FEYERABEND'S GERMAN EDITION OF DU FOUILLOUX'S “VENERIE." See Page IOI (droppings) by the huntsman to

his lord, a proceeding to which, as we shall presently see, good Queen Bess was no stranger. Fig. 54 depicts the manner in which a lord went out to dig for badgers, driving to the scene of his sport in his chariot. Du Fouilloux gives us a characteristic and amusing account of what a seigneur required for that "sport," if an amusement which made no great claim upon a veneur's activity or suppleness of limb could be called by that name. The whilom badger-hunter started from his castle ensconced, as we see him, in his charrette de chasse. This vehicle exhibits an entire absence of springs, which accounts probably for the somewhat forlorn look upon the sportsman's visage, as he leans contemplatively over the apron which takes the place of the carriage door. Sticking out from the basketwork rumble we see two of the many tools required for digging out the badger, and of which the 


\section{SPORT IX ART}

English translation gives us the technical names then in use in Britain. There were needed, we are told by Turbervile, "sharp-pointed, round-hallowed flat and broad spades, howes and mattocks, shovels, pickaxes, tolerakes, and clamps or 'holdfasts' [tormidable-looking tongs with sharp teeth to seize and hold the squirming badger]"; then there were required half-a-dozen leathern mats to lay on the ground for the sportsman to lie upon when listening to the terriers at work in the badger's earth. Sometimes these mattresses were made so that they could be inflated by a pipe in one corner, "to blow it as you would blowe a Baggepipe," for "a lord or gentleman can not take too great heed of the colde and moysture of the earth." And "thirsty throates and typpling tongs," as the English version has it, were not forgotten, for the lord or gentleman is admonished "to cause his cooke and butler to hang good store of bags and bottels about the carriage on the pins so that it be both comely and comfortable. And thus in this order of battell a nobleman or gentleman may march to besiege the fox and badger in their strongest holes and may breake their casmats, platforms, parapets and worke to them with mynes and countermines untill they get their skins to make furres and mittens."

In the French parent work the seigneur is advised to furnish his charrette with yet another article, viz. a sprightly lass of sixteen or seventeen to scratch his head to while away the weariness of the road-quaint counsel in keeping with the easy morals of the sixteenth century and what might be expected from jovial old du Fouilloux, who gives us such inimitable pictures of country life in the sunny land of Poitou.

Having cleared the ground regarding the various editions of La Vénerie abroad, we now must turn to the English translation of this classic, commonly known as Turbervile. To appreciate the circumstances that surrounded its publication we must remember that British art was then still in a hopelessly stagnant condition. We were then busying ourselves with more important and pressing matters, sowing the seeds of our empire overseas. Neither Henry VIII nor Elizabeth distinguished themselves by encouraging art; so it came to pass that the craft of engraving was taken up in England a century later than abroad. Mantegna, Lucas van Leyden, and Diirer, to name only three masters who were by no means the first to practise it in their respective countries, were long dead by the time the first copper-plate was engraved in England, * and even that was not by the graver of an Englishman. As Salaman has pointed out, the first native engraver of any importance was William Rogers, whose earliest copper-plate bears the date of I 589 , more than a hundred years after early Continental masters bad reached their zenith.

This retarded development of artistic activity strikes one forcibly when searching for early prints on our subject. While the first decade of the sixteenth century had given the French a charmingly illustrated edition of Gaston de Foix, and the

* The illustrations of Thomas Reynold's "The Byrth of Mankind," a translation on Midwifery published in 1540 .

102 


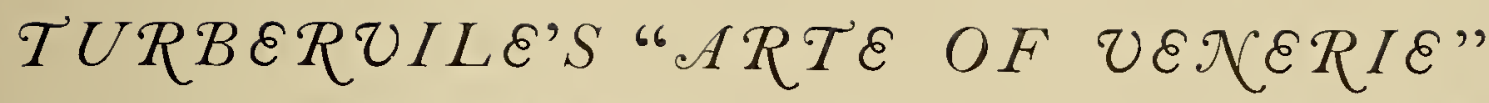

year $15 \mathrm{I} 7$ had presented to an already critical German public that xylographic masterpiece, Theuerdank, with its i 7 folio woodcuts, the first English illustrated hunting book, which is none other than the translation of "La Vénerie," did not leave the presses until the year I $575-76$. And even then only five of its fiftyfour illustrations are of British origin, the rest being taken bodily from the French parent work, notwithstanding the fact that the new designs are much superior to the French blocks. Unfortunately the identity of the graver that produced the pictures is in both cases unknown, hence we cannot even with safety claim that the five illustrations, three of which we reproduce, were cut by an English artist. As nine-tenths of the text in the "Arte of Venerie" is a word-forword translation of Jacques du Fouilloux's work, there is really very little about the book to which English writers or artists can lay claim. Nor is our respect for literary morals in those remote days increased by the circumstance that the publishers of both editions betray consummate care in

The booke ofHunting.

The report of a Huntefman vpon the fight of an Hare, in pride of greace. Chap. 36 .

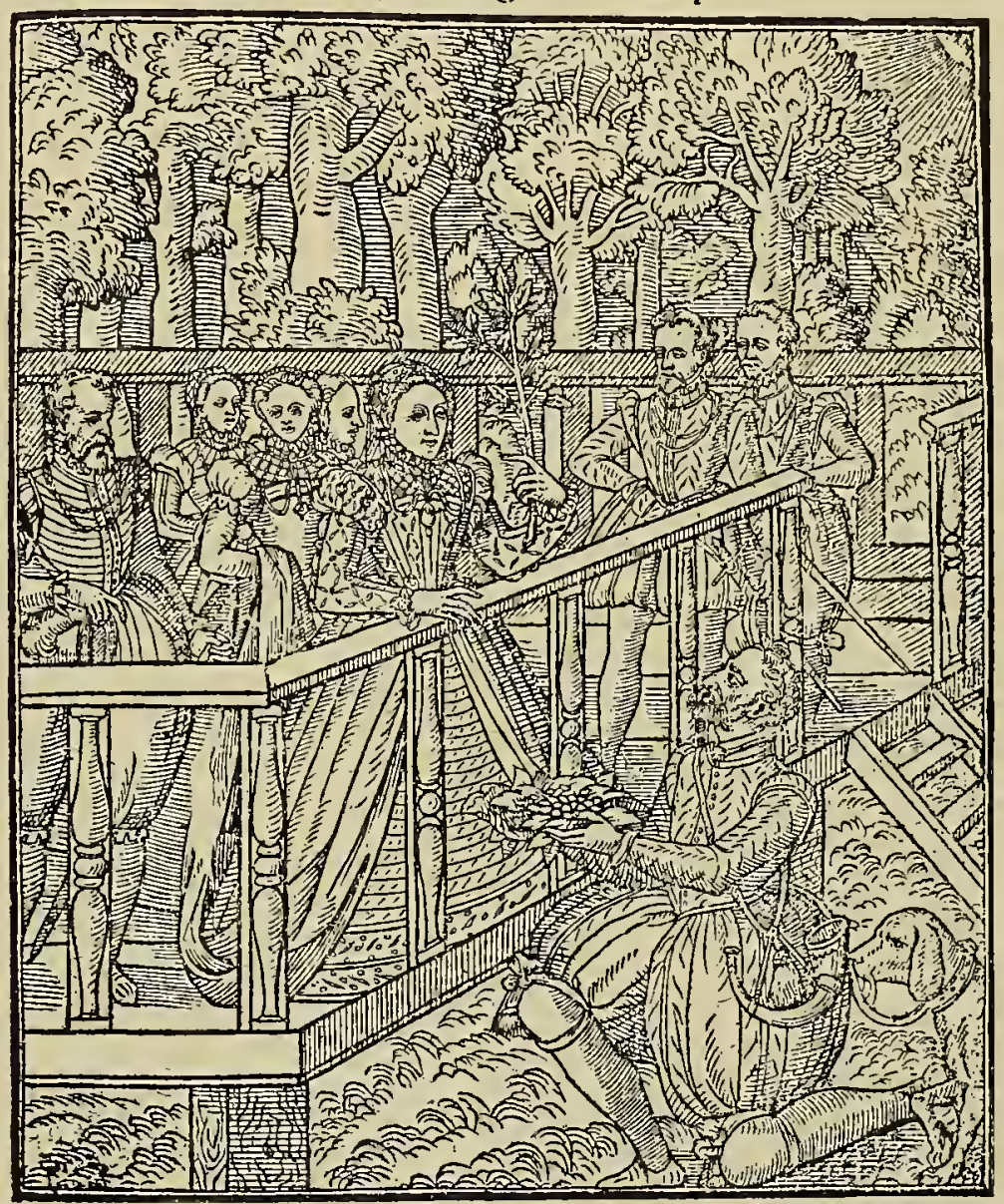

FIG. 55. QUEEN ELIZABETH RECEIVING THE -REPORT. THE MASTER OF GAME PRESENTING TO HER ON FRESH LEAVES THE STAG'S FEWMETS (DROPPINGS). FROM TURBERVILE, 1575-6. See Pages Ic 3-108 withholding from their readers the name of the author and of the book, although they do acknowledge in quaint words that they "hath spared neither English, French, Latine, Italian nor Dutche author to search as it were in the bowels of the same." The little black-letter quarto in its dingy brown calf binding, containing 264 pages, has now become a costly acquisition, its price at recent sales running to as many 


\section{SPORT IX ART}

five-pound notes as it originally cost shillings. It bears the title " The Noble Arte of Venerie or Hunting, wherein is handled and set out the Vertues, Nature, and Properties of fiveteene sundrie Chaces, together with the Order and maner how to Hunte and kill every one of them."

Below it, on the title-page, is a woodcut representing a kennel, hounds, and two "varlets," leading out a couple of hounds each, the man in front sounding a hunting-horn of old-fashioned shape. Their costume, which resembles that depicted in Figs. 55, 56, and 57 , is of the later Elizabethan period.

The information usually given by the title-page of a book concerning the name of its author, that of its publisher or printer, as well as the date of its publication, is not given in this instance; nor does the colophon contain more than one of these desired items of information. And even that is not in its usual place, but precedes "The measures of blowing," which fill the last four pages of the text. What the colophon tells us is little enough: "Imprinted by Henry Bynneman for Christopher Barker." That the book was probably commenced to be printed in the year I 575 we learn from a sort of introduction: "The Translator to the Reader," ending with a pathetic farewell, "From my chamber this XVI. June 1575." In it the author, or translator, or publisher, or whatever else we like to call the person responsible for this treatise, commends the work unto the gentle reader with a servile modesty characteristic of a period when bookmaking was already experiencing the unholy influences of Grubstreet.

To-day the "Arte of Venerie" is, as has been mentioned, a rare little book. Occasionally one comes across a copy of it bound by itself, but usually it is found under one cover with another treatise on a similar subject-namely, the "Booke of Faulconrie or Hawking." This issued from the same establishment and in the same year in which the compiler of Venerie dated his introduction, i.e. I 575 , and it is probably safe to assume, as do also the authorities at the British Museum, that the first edition of our treatise saw the light of day in that year and not in the following one.

This book on Hawking, imprinted, as we are told it is, "at the signe of the Grashopper in Paule's Churchyarde" is not shrouded in the anonymity which perplexes the student of our treatise on Venery. On the title-page it says that "George Turbervile, Gentleman," published it, while the introductory verses, as well as the "Epilogue unto the Reader," with which it concludes, are both signed with the same name.

It is not easy to explain why, if George Turbervile also compiled, or rather translated, our treatise on Venery, he suppressed his name, for his book on Hawking is also by no means original, though he tells us that the latter sport was the one he cared for most, and relating to which he could give some personal experiences, 104 


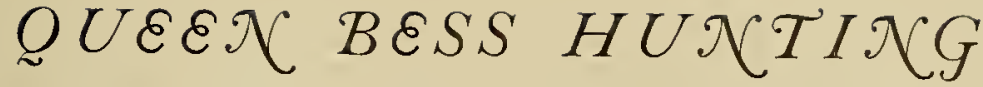

which, with the single exception of some remarks on Coursing, he appears to have been unable to do in connection with Venery.*

Perhaps the most interesting illustration in the book is Fig. 55-one of the five original woodcuts-which represents, as the legend explains: "The report of a Huntesman upon the sight of an Hart in pride of greace." In this full-page picture the artist represents Queen Elizabeth occupying her "standing" or hunting platform; from it she shot the deer as they were driven past her. She is in the act of receiving, as a preliminary ceremony of the day's chase, her Master of the Hunt's report. The latter, with bared head and on bended knee, is about to present to his royal mistress, on a tray formed of fresh leaves, the ferwmets (droppings) of the good hart, whose fate it was to be hunted that day. Tracked in the early dawn by the stealthy "harbourer" and his sagacious lymer, it became the former's duty to collect for his inaster's inspection these proofs of the stag's great size and good condition. No false prudery prevented good Queen Bess from observing this ancient custom! The next illustration, which we are not reproducing, represents the Queen partaking of the hunt breakfast in the woods in picnic fashion. She is seated on a raised sod seat with her back to a tree, two ladies in waiting standing behind her; in front of her, on a cloth spread on the sward, is her repast, consisting apparently of various kinds of fowl. We again see the busy Master of the Hunt, distinguished by the hunting horn at his side, waiting on her Majesty, one knee on the ground, in humble pose. The gentlemen of her suite, seated round a similar al fresco repast, are enjoying the contents of great baskets filled with roast fowl, and of two costrels and a number of flagons of considerable size. In verses, too long to quote entirely, the reader is told how "assembly" is made :

Who list (by me) to learne Assembly for to make,

For Keysar, King, or comely Queene, for Lord or Ladies sake :

Or where and in what sort it should prepared be,

Marke well my words, and thank me then, for thanks I crave in fee.

We are further informed that stags were said to be in "pride of greace" in the beginning of September, the period of the year when they are in the best condition. "On pleasant gladsome greene, under the shade of stately trees where little sun is seen, where fresh and fragrant flowers shall need no courtier's trick to daube himself with sweet musk, where beauty need not quake for cold, nor yet by the sun be tanned"-such be the spot selected for the assembly. If the company be great, "some wagons, cartes, some mules or jades come laden, till they sweat, with many a medicine made for thirsty throats and tippling tongues," while the doctor brings " his drugs to counterpose all quarrels." These drugs, we are told, did not consist

* In "English Poets," Alexander Chalmers, writing of T urbervile, says that he descended from a family of note in Dorsetshire, and was the younger son of Nicholas Turbervile, of Whitchurch, and was supposed to have been born about 1530 . 


\section{SPORT IX ART}

of "rotten drams, but noble wine which makes men's hearts to swell." In like poetical language does the rhyming Turbervile describe to us the goodly fare, wherewith the "Captain Cook doth hunger fight," the cold loins of veal, cold

The booke of Hunting.

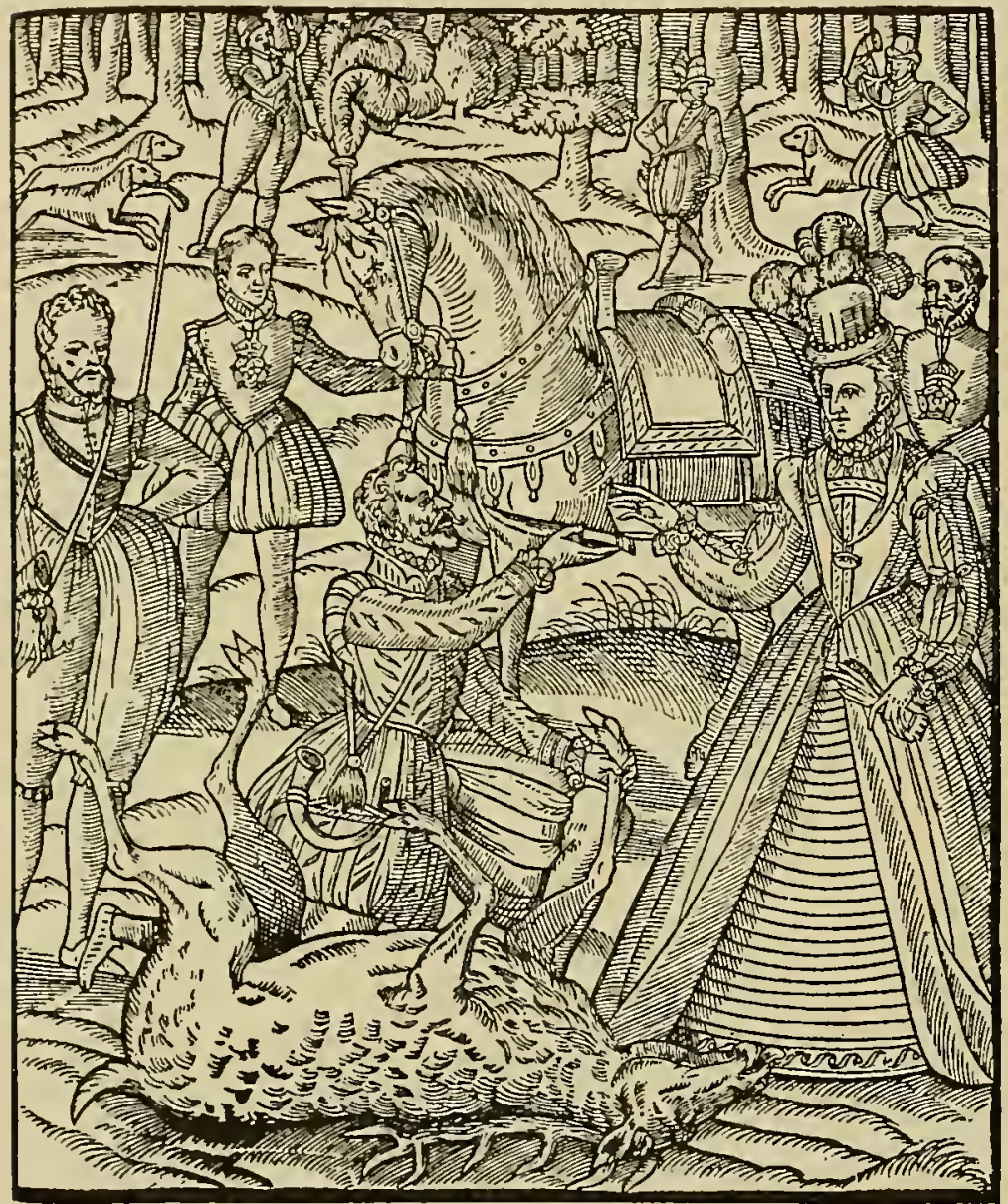

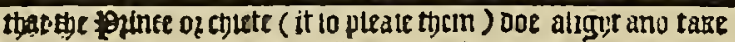

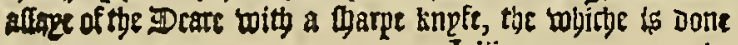
I.iij。

133 eon-pie and mutton cold, then neat's tongue powdered well, and "gambones of the hogge," or "sausages and savoury knacks to set men's minds on gogge."

Such, we see, were the comfortably substantial luncheons in shady glade to which Queen Bess seems to have been as partial as she was to the chase itself.

Fig. 56 shows us the Virgin Queen habited as usual in the stiff farthingale, the upper part of her body encased in a cuirass of whalebone, while at her side, held by a page, is her palfrey. Lying dead at her feet is the extended body of a stag. At the latter's side, next to the Queen, we again perceive the kneeling. Master of the Hunt, who is presenting to his royal mistress a knife wherewith she is to "take assay." This ceremony consisted in cutting one deep gash along the brisket of the stag towards the belly, for the purpose of disclosing the condition and the thickness of the layer of fat. To the thickness of the latter at the brisket great importance was attached by the sportsmen of that time.

That Queen Bess was too true a sportswoman to forego this "taking of the assay" we see by the picture; she has rid her right hand of the gauntlet, now held 106 


\section{CEREMOXIES OF THE CHASE}

in her left, and is stretching forth her right to grasp the knife. The cut being made, Turbervile proceeds to tell us in one of the few original passages which his book contains, that in England it was the custom to cut off the deer's head. "This is commonly done also by the chief personage; for they take delight to cut off his head with their woodknives, skaynes or swords, to try their edge and the goodness or strength of their arm." Then the head, we are told, was "cabbaged," under which was understood the process of cutting off the antlers in the orthodox manner prescribed by the laws of venery, i.e. by cutting through the brain-pan across the orbital cavity.

We are not informed whether Queen Elizabeth performed also the former somewhat unfeminine function, being one which required a good deal of physical strength. It is probable that "taking the assay" sufficed her. In France, it is perhaps as well to mention, the latter ceremony was unknown, la curée replaced it. This

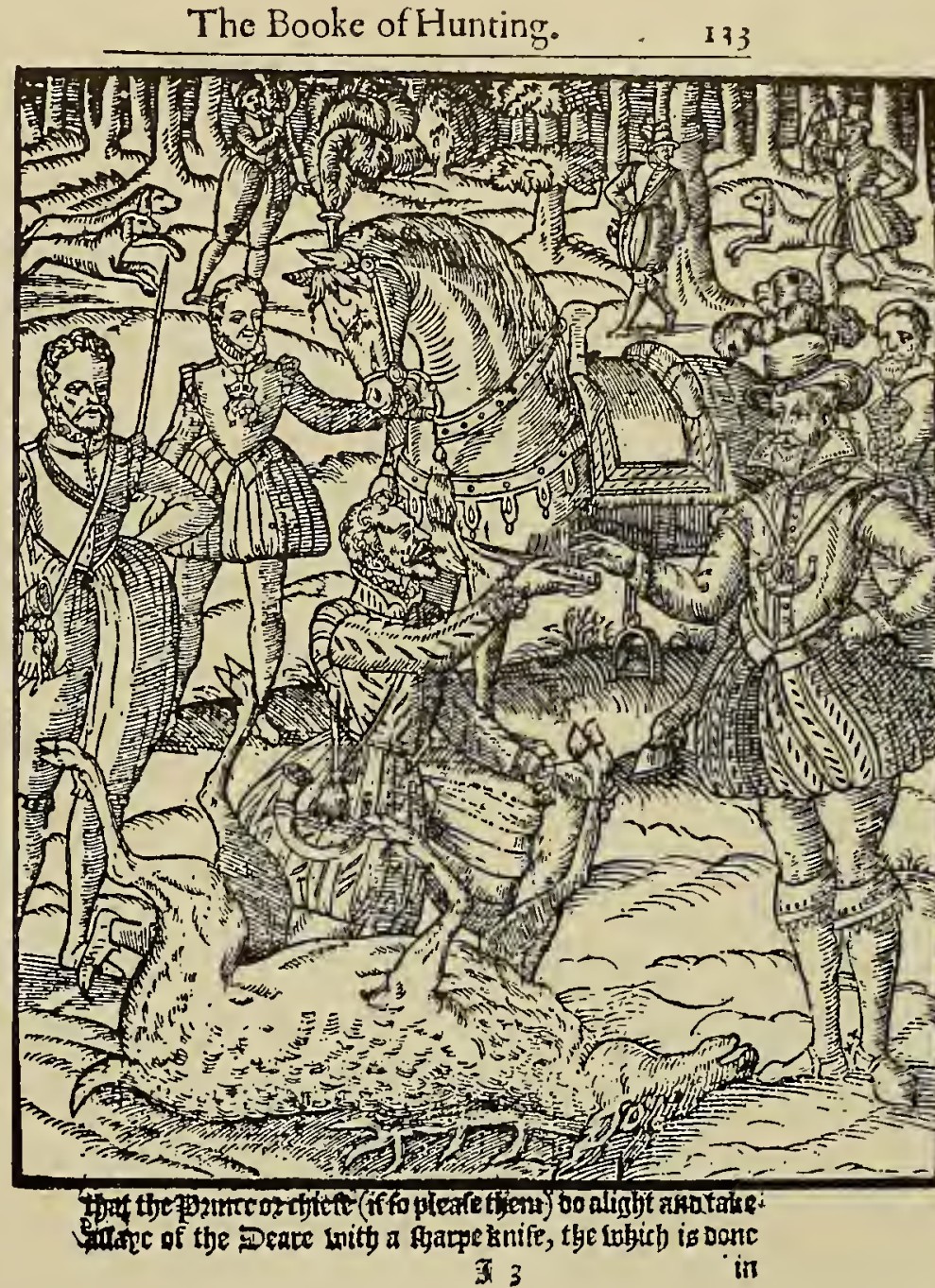

FIG. 57. KING JAMES I “TAKING ASSAY." FROM SECOND EDITION OF "THE NOBLE ARTE OF VENERIE," I6Ir. FOR THIS PRINT THE SAME BLOCK WAS USED, BUT A FRESH PIECE WITH THE FIGURE OF THE KING WAS LET INTO IT. See Page; ro3-108 was a function more in accord with the sentiment of the French chase, and its observance did not oblige. the lord to stain his hand with gore or turn amateur butcher. In one other respect the ceremonies of the two countries still resembled each other, i.e. in the cutting off of the right front leg at the knee-ioint, and the presenting of it to 


\section{SPORT IX ART}

the master or mistress by the huntsman-also humbly kneeling-who had harboured the hart, or by the Master of the Hunt.

With our next and last reproduction of Turbervile's woodcuts, Fig. 57, we reach a matter of some interest to the bibliophile as well as to the sportsman. It has already been mentioned that a second edition of Turbervile was published in the year 1611. But in the generation that had intervened momentous changes had occurred; James I had succeeded Elizabeth, and the Union had fused the two kingdoms. For reasons unknown to us the printer or publisher of the second edition, one Thomas Purfoot, rather than have fresh blocks made, resorted to a then often practised artifice in order to substitute the figure of his liege lord for that of the late Queen. This was achieved by the palimpsest trick of cutting out of the original wood-block the Queen's figure and substituting for it the King's portrait. This has been done in Fig. 57, a close examination of the woodcuts showing plainly the lines made by the insertion beginning at the horn of the saddle. The same jugglery occurred in the case of the hunt breakfast, the King and two gentlemen-in-waiting being substituted for the Queen and her two ladies. The rest of the picture remained the same: the feasting courtiers, the wine-swilling pages, the kneeling Master of the Hunt, even the horse in the background, are all left as they were, though a critical eye will quickly detect that the careless artist omitted to change into a man's saddle the trappings on Queen Bess's horse with its lady's footboard on the off side. On the title-page notice is taken of the political changes, for we fiud that the "Noble Realme of England" has become in I 6 I 1 the "Noble Realme of Great Britaine."

As so much of the book is a word-for-word translation, it is a disappointing source in respect to English hunting. The casual reader picking up the book, knowing nothing of its origin, is, of course, easily misled, for he naturally would not know whether the passage he is reading relates to French or to English customs. And into this pitfall even scores of English writers have tumbled headlong.

Speaking generally, we become impressed with the fact that the sixteenth century failed to produce a single original English work on hunting, while as to illustrations on our subject, excepting the woodcuts we have been describing, there existed a similar deplorable dearth. Indeed, had we not some fairly full accounts of how hunting was conducted at the Courts of Elizabeth and James I, written by foreign princes or ambassadors visiting England, we would know comparatively little about hunting as pursued by the ruling classes in England. And even these accounts we cannot always regard as descriptions of the national type of sport, for about royal pastimes there is ever something unnatural and artificial. It was the sport pursued by the hard-riding country gentlemen and the sport-loving yeomen of England, and not that at which princes of the blood and their courtiers played, of which we should like to possess ampler records. Lacking these we must be satisfied with the diaries of foreigners.

I 08 


\section{FOREIGX PRIXCES IX EX $\mathcal{X} L A \mathcal{X}$}

We will commence with the visit paid in I 592 by Duke Frederick of Württenberg to Queen Elizabeth, as narrated by the former's secretary Rathgeb in his diary, of which Rye published an English version.

"It had pleased her Majesty to depute a distinguished English lord to attend his Highness, and she had commissioned and directed him not only to show his Highness the splendid royal Castle at Windsor, but also to amuse him by the way with shooting and hunting red deer ; for you must know that in the vicinity of this same place Windsor, there are upwards of sixty parks which are full of game of various kinds, and they are so contiguous, that in order to have a glorious and royal sport the animals can be driven out of one inclosure into another, and so on ; all which inclosures are encompassed by fences. And thus it happened; the huntsmen who had been ordered for the occasion, and who live in splendid separate lodges in these parks, made some capital sport for his Highness. In the first inclosure his Highness shot off the leg of a fallow deer, and the dogs soon after caught the animal. In the second, they chased a stag for a long time backwards and forwards with particularly good hounds, over an extensive and delightful plain; at length his Highness shot him in front with an English cross-bow, and this deer the dogs finally worried and caught. In the third, the greyhounds chased a deer, but much too soon, for they caught it directly, even before it could get out into the open plain. These three stags were brought to Windsor and presented to his Highness; one of them was taken to his lodging, and sent as a present to the aforesaid Monsr. de Beauvois. . . . The next day, August 21, he departed from Windsor, and by the way had pleasant pastime in the parks with the game: in one of the parks his Highness shot two fallow deer, one with a gun, the other with an English crossbow ; the latter deer we were obliged to follow a very long while, until at length an unleashed track or bloodhound as they are called, by its wonderful quality and peculiar nature, singled out the deer from several hundred others, and pursued it so long, till at last the wounded deer was found on one side of a brook, and the $\mathrm{dog}$, quite exhausted, on the other ; and the stag, which could go no further, was taken by huntsmen, and the hound feasted with its blood."

Another German prince who visited England soon afterwards has left us some interesting notes upon sport. It was Duke John Ernest of Saxe-Weimar, who stayed in England as a guest of James I at Theobalds from August 24 to October 23, 16 1 3 : "The King and Prince then went down and out through the pleasure ground where horses and carriages were waiting. The King and young Prince seated themselves in one carriage, his Highness took his place in another; and thus they proceeded to the hunt. The other earls and lords rode on horseback. When they came to the hunting ground, the King, the Prince and his Highness also mounted on horseback; his Majesty had provided a fine palfrey for his Highness. The hunt generally comes off in this way: the huntsmen remain on the spot where the game is to be found, with 20 or 30 dogs; if the King fancies 


\section{SPORT IX ART}

any in particular among the herd, he causes his pleasure to be signified to the huntsmen who forthwith proceed to mark the place where the animal stood; they then lead the dogs thither, which are taught to follow this one animal only, and accordingly away they run straight upon his track; and even should there be

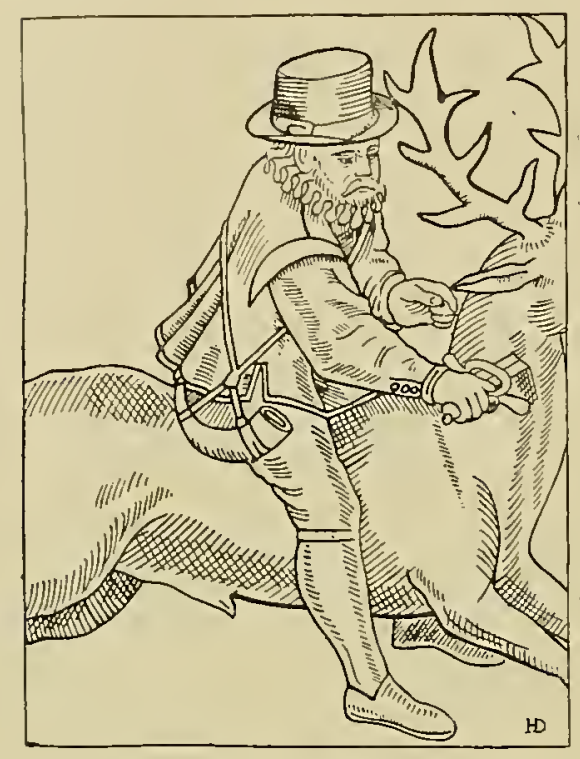

FIG. 58. BRASS TABLET COMMEMORATING JOHN SELWYN'S FEAT IN OATLAND PARK OF RIDING A STAG AND KILLING IT SO THAT IT FELL AT THE FEET OF QUEEN ELIZABETH. IN OR BEFORE THE YEAR 1587. See Pages I I 2-I I 4 40 or 50 deer together, they do nothing to them, but chase only the one, and never give up till they have overtaken and brought it down. Meanwhile the King hurries incessantly after the dogs until they have caught the game. There is therefore no particular enjoyment in this sport. Two animals only were caught on this occasion: one was presented by the King to his Highness, which was eaten at his lodging. His Majesty, however, now and then uses long bows and arrows, and when he is disposed he shoots a deer. There are no large stags to be found in England, but only Fallow deer."

James's Queen, Anne of Denmark, at times indulged in hunting. The following anecdote is amusing; the scene being Theobalds, the time a few weeks prior to above visit of the German prince, and the account is taken from a letter from a Mr. Chamberlain dated from Ware Park, August I, I6r 3 :

"At their last being at Theobalds which was a fortnight since, the Queen, shooting at a deer, mistook her mark, and killed Jewel, the King's most principal and special hound; at which he stormed exceedingly awhile; but after he knew who did it, he was soon pacified, and with much kindness wished her not to be troubled with it, for he should love her never the worse; and the next day sent her a diamond, worth $\oint_{2} 2000$, as a legacy from his dead dog."

Anne of Denmark's portrait at the age of forty-three hangs in Hampton Court. She is attired in a hunting dress, and wears a smart hat with red feathers : a negro is holding her richly caparisoned horse, while five small greyhounds are capering about ; in the distance is a view of the palace at Oatlands.

Some of the details given in the above extracts are corroborated by the oft-quoted criticism on the part of Marshal de Vieilleville, Henri II's ambassador to England : "The English are not so skilled in taking the stag as they are in marine matters." "They took me," he reported, "to a great park full of fallow-deer and roedeer, where I mounted a Sardinian horse, richly caparisoned; and in company of 110 


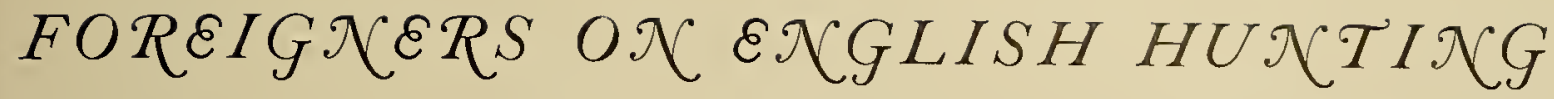

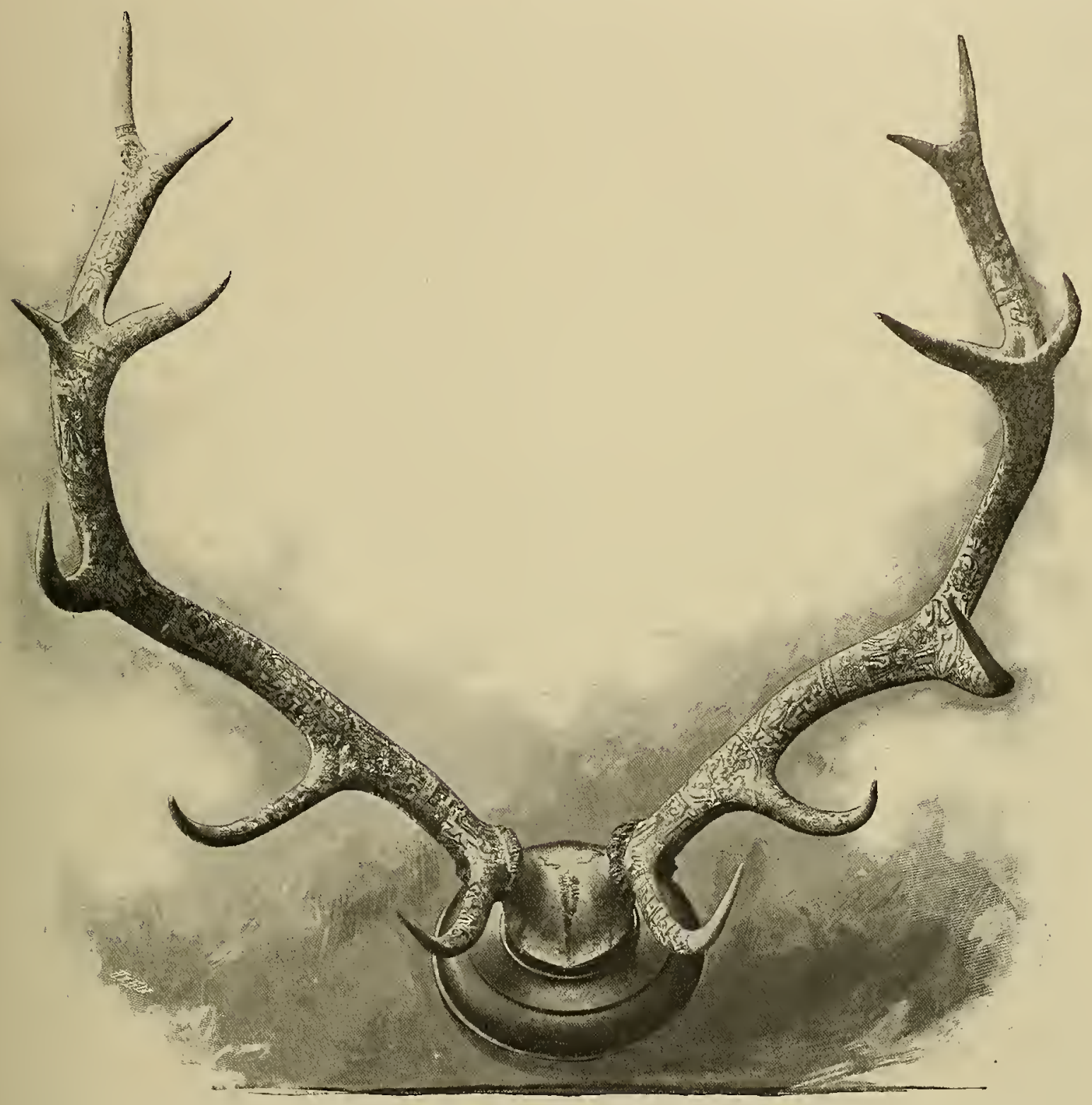

FIG. 59. ENGRAVED ANTLERS DATED I563. IN THE COLLECTION OF THE LATE BARON NATHANIEL ROTHSCHILD OF VIENNA, WHO PAID $\oint_{6} 600$ FOR THEM. Page II 4

forty or fifty lords and gentlemen we hunted and killed fifteen or twenty beasts. It amused me to see the English ride at full tilt in this hunt, the hanger in their hand; and they could not have shouted louder had they been following an enemy after a hardwon victory." 


\section{SPORT IX ART}

With the accession of James I stag-hunting in the French fashions suddenly became popular in England. Physically unfit as that monarch was for feats of endurance or for hard riding, this sport appealed to the love of pomp and to the vanity of a sovereign who was fully persuaded of a king's divine rights, among which was not least the royal prerogative of hunting where he listed in the forests of his subjects. James constituted himself a patron of venery, and one of his first acts after his accession to the throne was to beg his ally, Henry IV of France, to send him the most skilful of his huntsmen, in order that " he might henceforth hunt in the forests of his realm rather than in inclosures and parks, such as was hitherto the fashion, when one hunted the stag only as long as he was in sight." The Marquis de Vitry, one of the French king's most renowned veneurs, was immediately despatched to England; and soon afterward De Beaumont and De Moustier, two of Henry's officers of the hunt, with several ralets de chiens, or kennelmen, and presently, also, the Sieur de Saint-Ravy, followed the Marquis across the Channel. Saint-Ravy became permanently attached to the English court in the chalacter of grand veneur, or master of the hunt, to James's Danish queen. Other sportsmen of renown followed suit: thus Ligniville, the author of a wellknown work on venery, was sent from Lorraine to the English court to co-operate with the others in the introduction of the French chasse $a$ courre on English soil. And there is no doubt that in consequence of the pronounced favour shown by James for French hunting institutions, a considerable number of French nobles came over to England to sun themselves in the favour of the vain monarch. To such extremes did James drive his predilection that he imported red deer from France; and we are told that Saint-Ravy annually visited France for this purpose, collecting on a single occasion as many as forty and fifty in the forests of Fontainebleau. These stags, according to Maricourt, only the King hunted. He adds that, considering what game they have, the "English acquit themselves very well in the chase of the hare and of the fallow deer."

Stag-hunting in the French fashion does not seem to have remained popular for very long, for Ligniville already complains that the English were introducing the custom of killing the stag with a "harquebus" when the hounds had at last succeeded in bringing him to bay, while the French continued much longer to consider it a point of honour to despatch the stag with the hanger, a proceeding to which, of course, considerable danger to the unskilful or careless was attached.

Neither Cromwell's wars nor the rapid deforestation of England, which we know began about the middle of the seventeenth century, assisted in the development of English hunting institutions, which throughout that century retained a inore modest and also less typical aspect than those of France and Germany.

This is perhaps a fit place to revert to a type of record descriptive of ancient sport which, though not strictly pictorial, cannot be passed over in entire silence, 112 


\section{FOHX SELWTX'S DARIX F FEAT}

i.e. the sepulchral monuments of distinguished sportsmen or of persons of humbler rank connected with hunting. To enumerate all the existing brasses, carved effigies, or stone monuments commemorating the lives or deeds of departed sportsmen would lead us far beyond the limits of the present work, even if we restricted ourselves to those in the British Isles; and as moreover Miss Alice Dryden has added in her excellent edition of Twici, * first published by her father, the late Sir Henry Dryden, Bart., a valuable summary of such sepulchral monuments in England dating from the twelfth to the sixteenth centuries, a lisi it would be difficult to improve upon, the reader interested in this branch of sporting records has ready at hand the means to gain full information. To one monument of this kind we, however, propose to give a brief space, for it is of peculiar interest, and though of comparatively late date, it illustrates the great changes the last three or four centuries have worked in the immediate environment of London. The monument we allude to, though no longer in its original position, is in the parish church of Walton-on-Thames, and commemorates an extraordinary feat of skill and daring performed by John Selwyn, who died in $15^{87}$ and had been Keeper of Oatland Park. The monument in question consisted in the year I775, when it was first described by Francis Grose, of five brass tablets which had once laid nver a gravestone. Four of these brasses still exist, and are at present fixed into the wall of the church vestry; while the fifth, consisting of the inscription, has been lost. Fortunately, Grose in his article in the first volume of "Antequarian Repertory "preserved the text of the tablet that has disappeared, hence all doubt respecting the personages depicted in the four existing brasses is removed. It gives us the following pithy record of the redoubtable John Selwyn and his family. It runs: "Here lyeth ye bodye of John Selwyn, Gent Keeper of her Ma'ties Park of Otelande under ye Right honourable Charles Howward, Lord Admyral of England, his good Lord \& Mr. [Master] Who had issue by Susan his wyfe V sunes et VI daughters all lyving at his death and departed out of this world the 22 nd daye of Marche, anno Domini I 587." One of the brasses represents John Selwyn, standing, with his horn of office hanging from his right side by the baudric, with his hands folded as if praying; the second his wife, with a widebrimmed hat on her head, in the same devout attitude; the third the eleven children, the five sons on the right side, the six daughters on the left side, while the fourth brass, of which Fig. $5^{8}$ is a reproduction, depicts the feat which secured for the bold Selwyn such enduring fame. Famous for his strength, agility, and horsemanship, he appears to have had an opportunity of exhibiting them before Queen Elizabeth on the occasion of a grand stag-hunt in Oatland Park. There, while in hot pursuit of a stag he suddenly leapt from his horse on to the back of the hart while both were at full speed, and not only kept his seat

* "The Art of Hunting," by W. Twici, Huntsman to King Edward II, by H. Dryden, I 843 ; edited by Alice Dryden, Northampton, I 908. 


\section{SPORT IX ART}

in spite of every effort of the frightened beast, but drawing his hanger with it guided it towards the Queen. Coming near her he plunged his weapon into the stag's throat so that the animal fell dead at her feet.

In the year 1563 there was created a somewhat unusual work of art that can claim to come within our sphere, i.e. the beautifully engraved stag's antlers of which Fig. 59 is a reproduction. It is one of the gems of the Rothschilds' collection in Vienna, where its late owner, Baron Nathaniel, many years ago showed it me with much pride as a recent acquisition. As he paid close upon $f_{0} 600$ for this curiosity, it may claim to be one of the costliest pair of antlers of modern times. The antlers are of very regular growth and fair size, and bear fourteen points; they are attached to a piece of the skull bone. With the exception of about 4 in. or 5 in. at the extreme tips of the tines, the designs, which are engraved in black lines, cover every inch of the antlers. From the burrs, which the artist left in their natural state of pearly roughness, upwards the antlers have been smoothed and polished to resemble white bone, so that at a distance they look more like antlers made of ivory than the genuine article. Upon this white background, slightly tinged yellow with age, the designs of various armorial bearings, surrounded by fantastic arabesques and masks such as distinguish the Renaissance art period, stand forth with great clearness, and form a whole the artistic elegance of which it is hard to describe. On the right antler, occupying, as it were, the place of honour close above the brow tine, are the arms of Count Oswald Trab (the name is now written Trap), a member of a Tyrolese family of great antiquity, for whom this rare and curious work of art was probably executed. Above it, and also on the left antler, are the arms and national emblems of Italy, Spain, Portugal, \&c. The artist's initials, "G.H.," are to be seen close to the Trab crest, and next to it is the date ${ }_{5} 6_{3}$.

Engraved antlers of this sort are extremely rare; only two other specimens are known to collectors, one of these being in the possession of the late Lord Tweedmouth at Guisachan, in Scotland. It is a fine wide pair of over 40 in., with thirteen points. The date upon this specimen, curiously enough, is the same as the one on Baron Rothschild's set. Lord Tweedmouth informed me that it is said to have been engraved by a pupil of Albrecht Dürer, the style of engraving being quite in character with that of the well-known master. The principal subjects engraved are figures representing the different countries of Europe, together with some grotesque and sporting subjects.

Who the G.H. was who produced the Rothschild curiosity it is impossible to say with certainty, but there exist some indications that it might have been Joris or Georgius Hufnagel, an Antwerp artist who travelled extensively, and of whom we know that he lived eight years at Innsbruck working for Archduke Ferdinand. 


\section{CHAPTER VI : $7 O A N N E S$ STRADANUS}

T $\mathrm{N}$ the second half of the cinque cento, our subject was receiving in all parts of the civilised world much increased attention, and it becomes more and more difficult to follow in chronological order the various artists who, as representatives of their respective schools, deserve to be mentioned. It will, perhaps, be least confusing if, in approaching that period of vast activity, we first describe the works of the man who proved more prolific in our line than any of his contemporaries. This was Joannes van der Straet, commonly known as Stradanus ( $523-1605$ ) a native of beautiful, sad Bruges. For unknown reasons, possibly in consequence of the odium attached to his patronymic since the day when a forbear was mixed up with the murder of Charles the Good of Flanders, Stradanus put aside his own aristocratic name and, following the then fashionable fad, latinised it. But he was destined to become known under a third name, for the Florentines, amongst whom he lived for upwards of fifty years, insisted on calling him Giovanni della Strada. Particulars of this interesting man's career will be found in the Appendix ; for present purposes it will suffice to say that all his fellow artists and writers on art agreed that he was a great designer with a free, spirited style, wonderful imagination, power of invention and extraordinary diligence. His fame at the time was great, and he was among the elect that adorned the monument of his immortal master, Michael Angelo. In Mid-Victorian days a certain school of critics made a dead set at Stradanus, writing him down as an incompetent, talentless and decadent artist, but to-day the pendulum is swinging back more normally, and in the latest technical treatises his work as designer is coupled with that of Van der Weyden, Mantegna, Bernard van Orley and Leonardo da Vinci ; and, as the reader will have full opportunity of forming an independent opinion regarding this italianised Fleming's talents, no more need be said.

Stradanus came to Florence in the year 1553 , at the height of the great art-loving Duke Cosimo de Medici's career, and until 1571 when he resigned his post of designer to the celebrated Arazzia Medica, the tapestry works at Florence which Cosimo had called into being, Stradanus was principally engaged in decorative work which was either reproduced by the looms of his famous countrymen Roost and Karcher, who had also settled in Florence, or in painting frescoes for the palaces of the Grand Duke and for two of the art-loving Popes who had called him to Rome. Some of his tapestry designs, as we shall presently hear, dealt with sport, and it was probably the almost instantaneous success of these more or less novel designs that led him to throw up his engagements at the Arazzia Medica, and devote himself to the subject that had made him suddenly famous. The world had grown weary of contemplating. sentimental, allegorical, or legendary fables or incidents of ancient history, and the spiritedly drawn stag-hunt or the lively encounter with lions or elephants in African jungles that issued from Stradanus' studio in 


\section{SPORT IX ART}

endless variety, took the world by storm. He seems to have been the first artist who realised the commercial advantages that could be derived from a businesslike exploitation of this newly arisen craving for sporting pictures. Up to then even such great artists as Dürer, Cranach, Burgkmaier, and Van Orley found purchasers for their productions without much system, dealing, as hucksters would, directly with

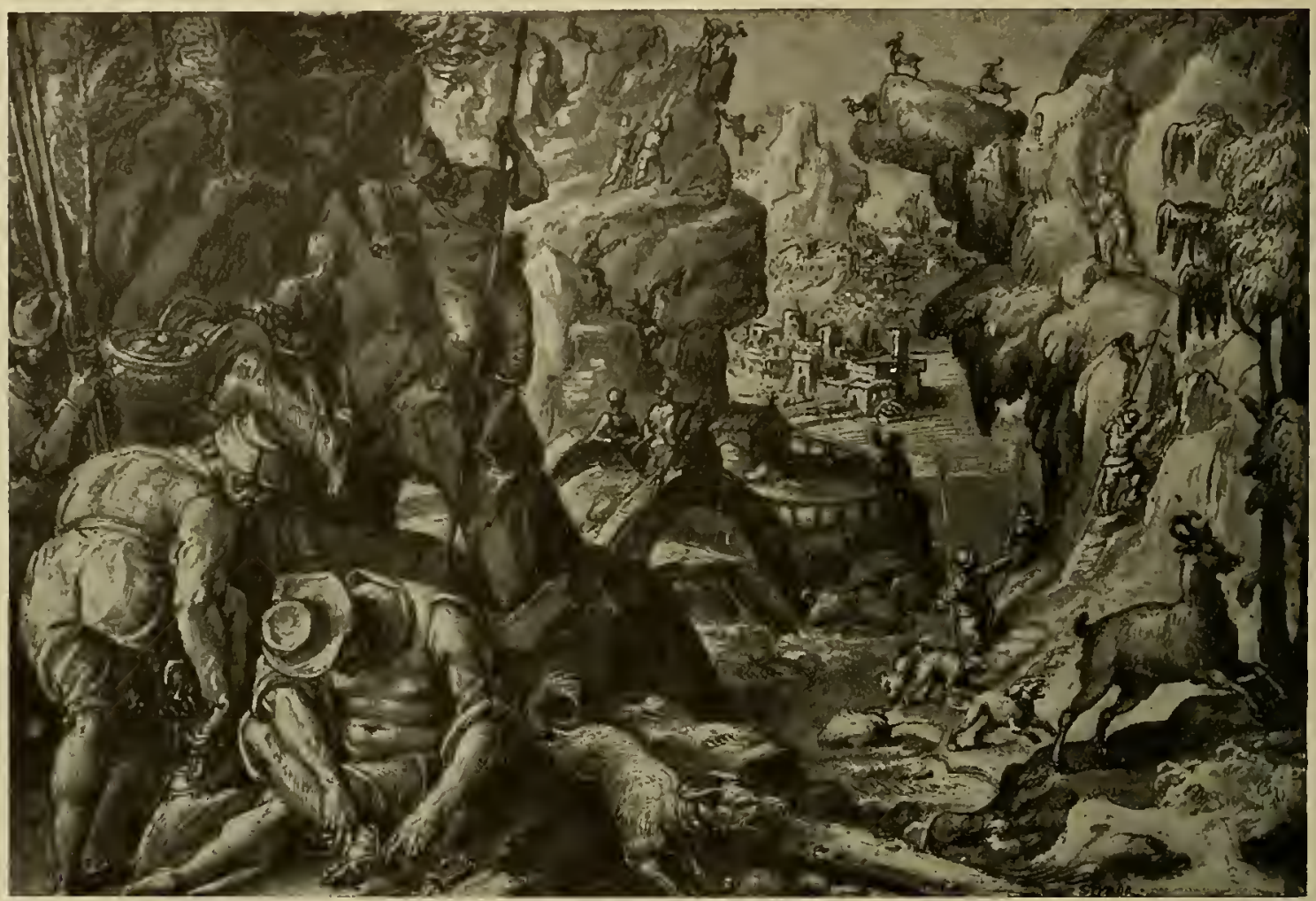

FIG. 60. CHAMOIS-HUNTING. SEPIA DRAWING BY STRADANUS CIRCA i 570 . Sce Page I 20

their customer, i.e. bartering the portrait, or saint, or whatever it happened to be, for silver ware, or a curiosity of some kind, or cash. To this Stradanus put an end by entering into a partnership with Antwerp's then most famous engraver, one Hieronymus Cock and, on his death soon afterwards, with a yet more strenuous family of artists and art publishers, the Galle, who were then coming greatly to the fore. It is a moot question how Stradanus sent his drawings from the banks of the Arno to distant Antwerp. Some of the engravers who chiefly worked for Stradanus, such as Philip and Cornelius Galle, Collaert, Goltzius and the Sadelers, did visit Italy, but at quite irregular intervals, and as it is almost certain that Stradanus never revisited the land of his birth, it seems more probable that the I 16 


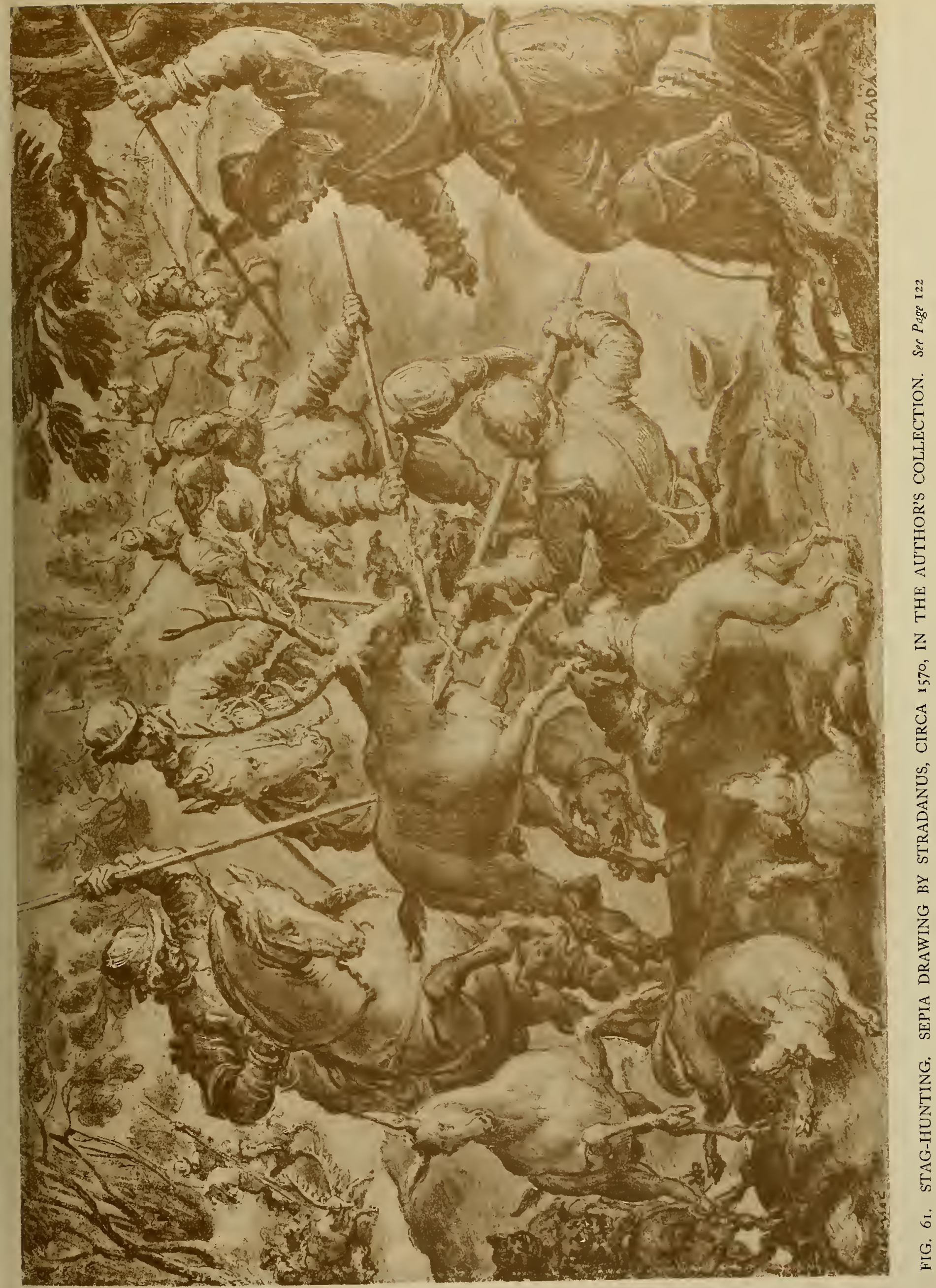





\section{STRADAXUS' ACTIUITT}

drawings were sent to Antwerp over the Brenner via Augsburg or Nürnberg, between which towns and Italy there existed a flourishing trade and constant intercourse. When the designs, after an adventurous journey over the snowy passes of the Central Alps, finally reached the Galle establishment they were engraved either by some member of that family, or by one or the other cf the numerous artists who worked for them (see Appendix); while later on, when the demand grew

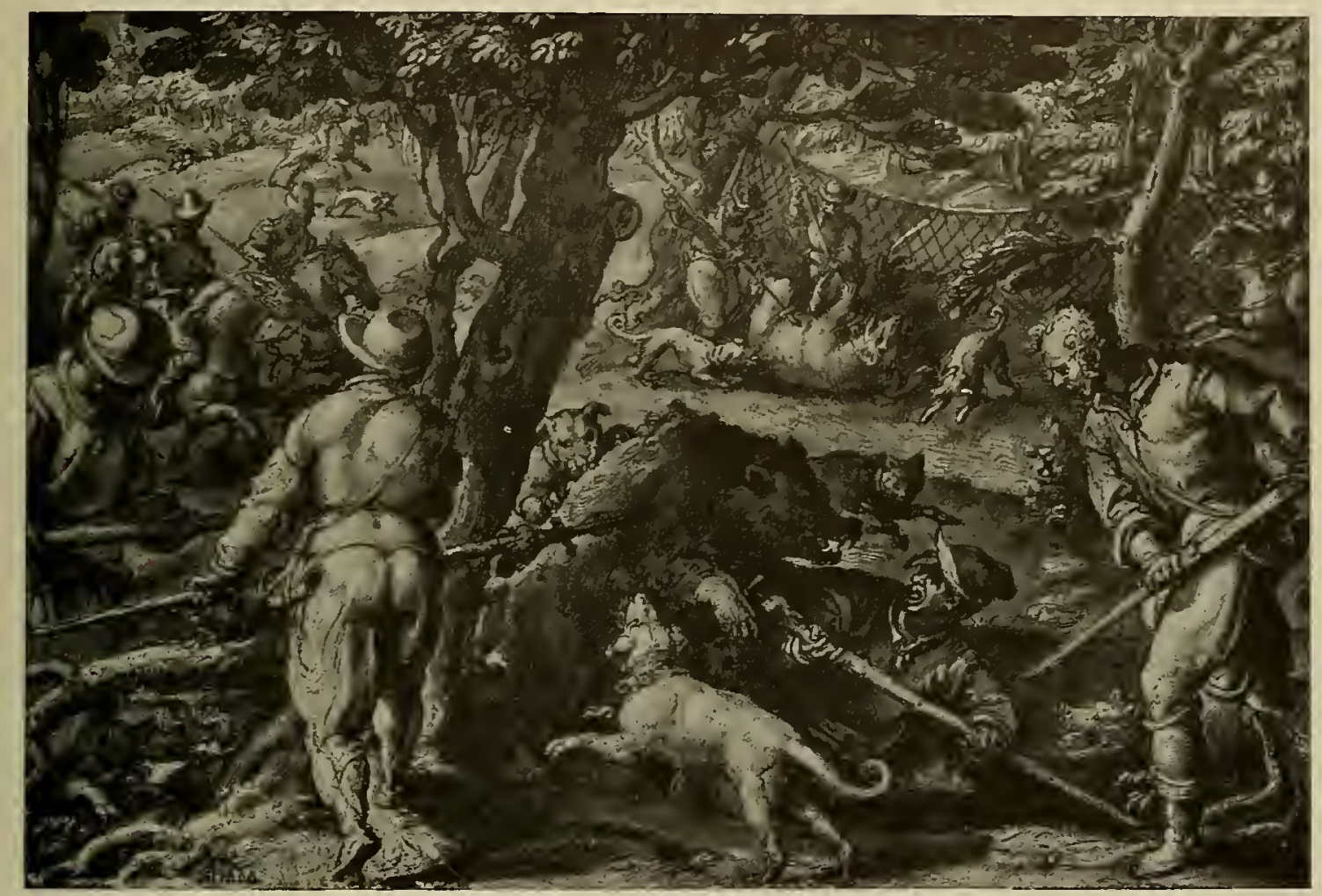

FIG. 62. BEAR-HUNTING IN A DRIVE WITH NETS. SEPIA DRAWING BY STRADANUS CIRCA 1570. SIGNED. See Page II9

greater, apprentices and indifferent artists were pressed into service, in consequence of which many of the later plates after Stradanus show all the signs of hasty shopwork by unskilled hands.

Before publication each picture was provided, in the fashion of the time, with a Latin inscription, sometimes in prose, occasionally in hexameters, occupying from two to four lines. In most cases, the doggerel Latin betrays their origin at the hands of some hackwriter who turned them out by the score.

At the beginning the sets consisted of only four or six prints. They were executed with much care, and each picture was surrounded, in the fashion of tapestry panels, 


\section{SPORT IX ART}

with a framework of artistically arranged trophies of dead game, or garlands of fruit, or scrollwork decorations depicting weapons of the chase, \&c. As great, or nearly as great, care was expended upon the border as upon the picture itself.

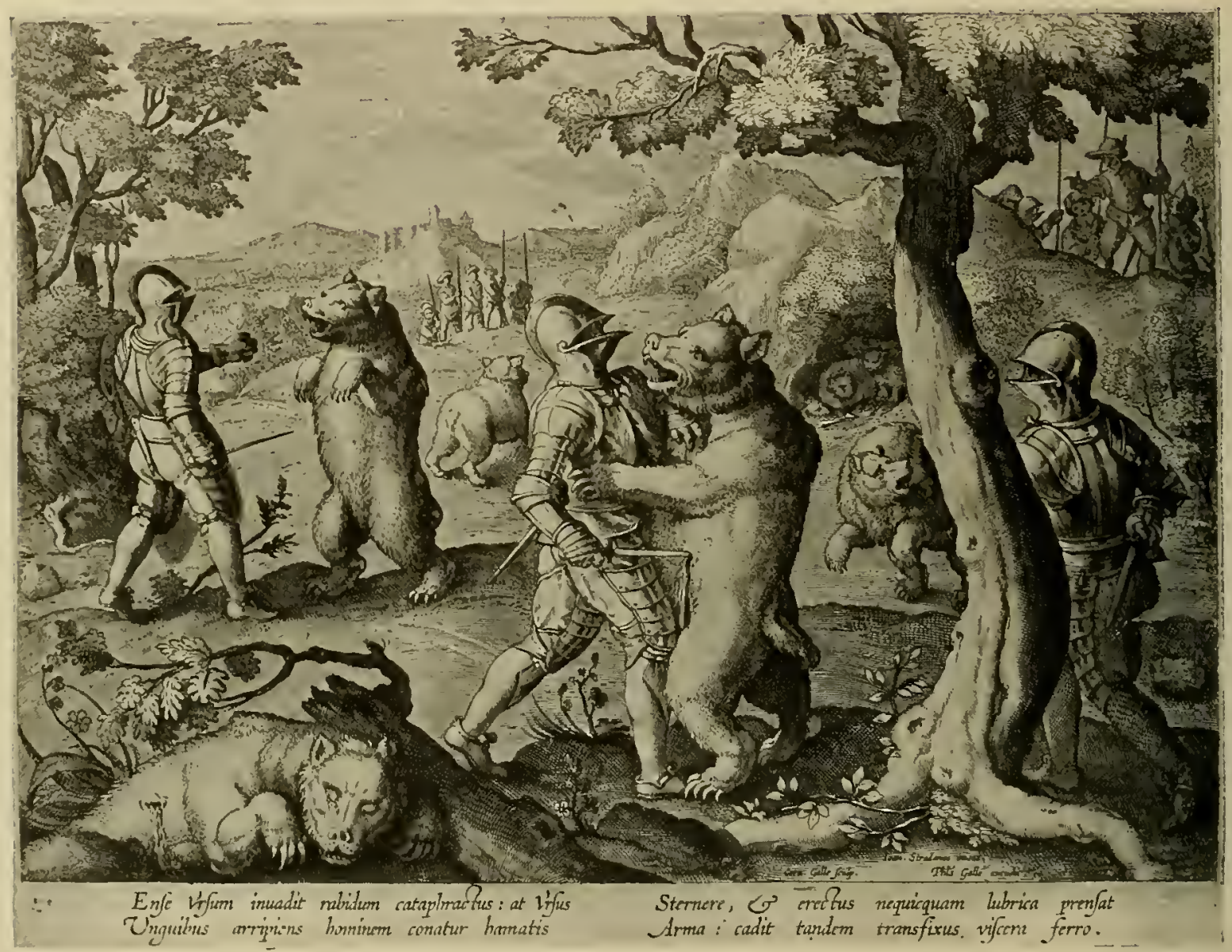

FIG. 63. MEN IN ARMOUR HUNT BEARS. ENGRAVING BY CORNELIUS GALLE AFTER STRADANUS, OUT OF THE "VENATIONES" SET, PUBLISHED 1578 . See Page I 22

Soon the demand for these small sets became so great that, in new sets, the framework was either left out altogether, or much reduced, or done by inexperienced apprentice hands. The number of pictures in a set was increased, and impressions were printed off in much larger editions, or old plates were touched up time after time, or new plates made when the old ones became worn down. The climax in this respect was reached in the case of the celebrated Venationes series, consisting of no less than 104 plates. Of these a number are reproduced in these pages, as well 1 I 8 


\section{STRADAXUS' DRAWIX $A S$}

as many of the original drawings by Stradanus, which form part of the writer's collection.*

If we can judge by the great number of stray copies of Venationes prints to be found, generally in a deplorably thumbed and dirty condition, in print-shops all over the world, an extraordinary number of editions of this mediæval sporting

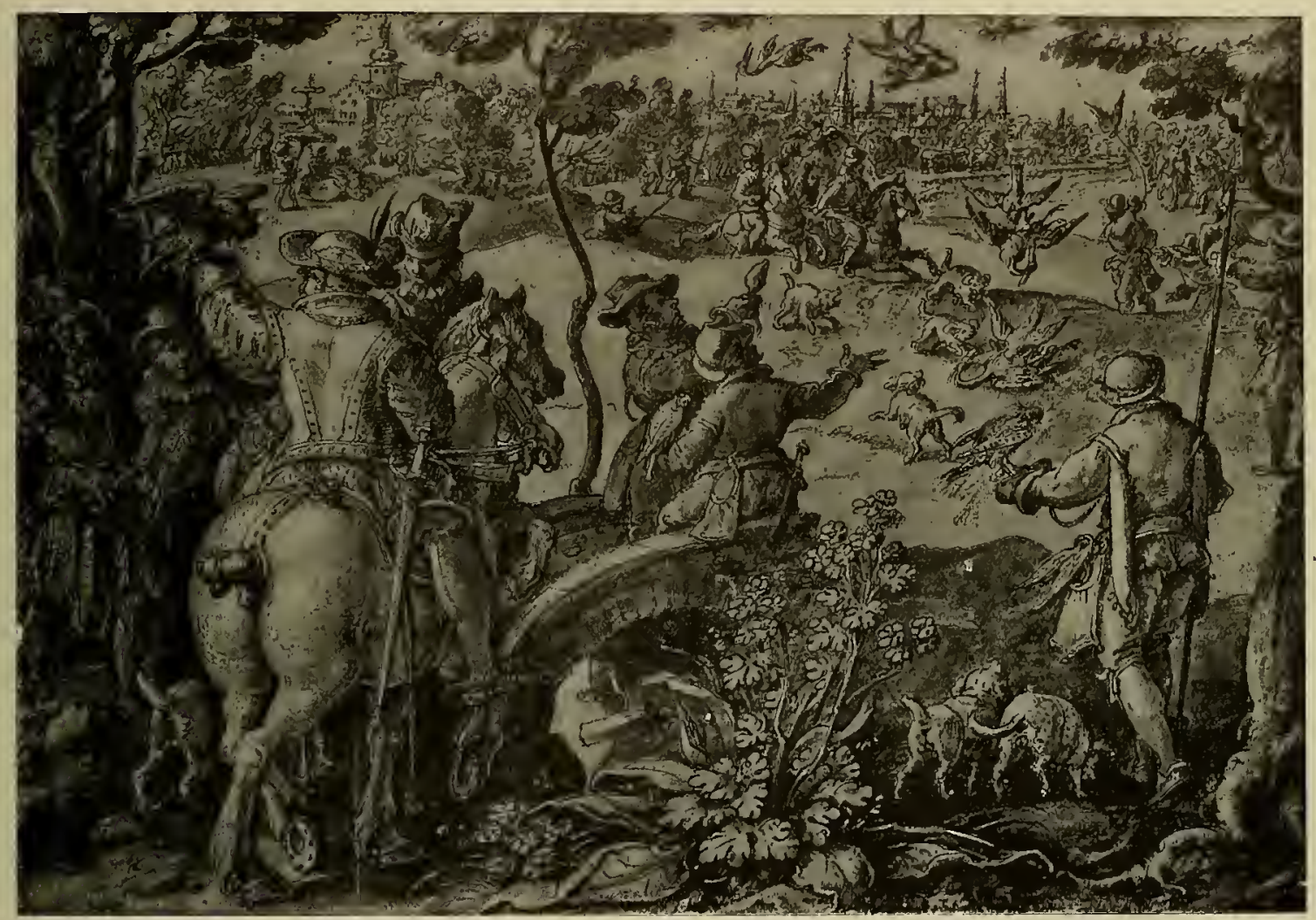

- FIG. 64. HERON-HAWKING. DRAWING BY STRADANUS CIRCA I570. SIGNED. Page I22

picture-book must have been struck off in the century following its first appearance, and many a primitive hand printing-press, such as we still see in the Maison Plantin at Antwerp, must have become worn out in the rush caused by an unprecedented demand.

In dealing with Stradanus' pictures of sport in the Venationes set we must remember that incredible ignorance concerning natural history was still prevalent, and though the days were past when the Bestiaries of the early Middle Ages formed the only

* It contains fifty-six of the original sepia or tinted pen-and-ink drawings by Stradanus, nearly all of which are signed. It is the largest number of his works to be found in any of the collections or museums in Europe or reported upon in literature. They are of a fairly uniform size, about $28 \times 19 \mathrm{~cm}$. 


\section{SPORT IX ART}

existing literature on the subject, yet people still believed in the existence of the Virgin-hunting Monosceros, the crocodile-devouring Idrus, the sickle-horned Aptaleon, the Onocentaur, in shape half-man half-donkey, the sly monster of the sea known as the Cetus, the living peripatetic root called Mandragore, whose plaintive cry meant sudden death to those who heard it, and other like strange creatures. It is not our object to deal with legendary sport described by some of Stradanus' pictures but to confine ourselves to those delineations which represented sport that actually prevailed in his day, and though, as we shall see, many of his details are faulty, yet there exists no work of that day which gives a more complete picture of what the chase of wild animals was like in the second half of the sixteenth century, and none that give more details regarding the arms of the chase.

Taking Alpine sport first Stradanus seems to have drawn largely upon his imagination when depicting the chase of the two typical mountain animals, the chamois and the ibex. Fig. 6o represents a scene which he or his collaborator, the Grand Duke Cosimo of Tuscany, may have seen on their journeys across the Alps; other details his versatile pencil found it easy to put in with good effect." When the writer many years ago first saw the print after Fig. 60 in which, strange to relate, the chamois carries horns that are crooked forward instead of backward, he naturally assumed that this extraordinary mistake was made by a careless engraver who had never seen a specimen. In this, however, he did the busy Antwerp art-shop an injustice, as was disclosed when the original drawing, here reproduced, came into his possession. For there, immortalised by master-hand, prance about not one but several chamois with reversed horns! In the foreground a hunter is buckling on his crampons, or Steigeisen, to his bare feet, while the men in the background, engaged in hunting, employ much the same methods which the Emperor Maximilian followed three-quarters of a century earlier, viz. they are represented as killing their prey by "ausfallen," spearing the chamois with long lances when they had them cornered in places whence the animals could not escape. In the print engraved after this drawing, the wielder of the graver on the shores of the North Sea took a liberty with the master's design, for he deliberately altered the rifle-like firearm which the man on the right-hand side of the drawing is holding in his hands, into a long spear: he probably had never heard, even at that comparatively late date, of the use of fire-arms in the chase of the nimble Alpine antelope.

There is rather a curious circumstance connected with the mistake made by Stradanus respecting the chamois' horns. His design for the title-page of the Venationes, which is among the writer's drawings, contains many animals, forming a sort of frame for the centre cartouche reserved for the title. Amongst them there is also a chamois, and in this instance its head is quite correctly drawn. From this it would appear that the painter designed the title-page some time after drawing Fig. 60 and had in the meanwhile informed himself respecting the correct position of the

*Vasari tells us (see App.) that Stradanus designed his hunting-pieces after the invention of Cosimo. 120 


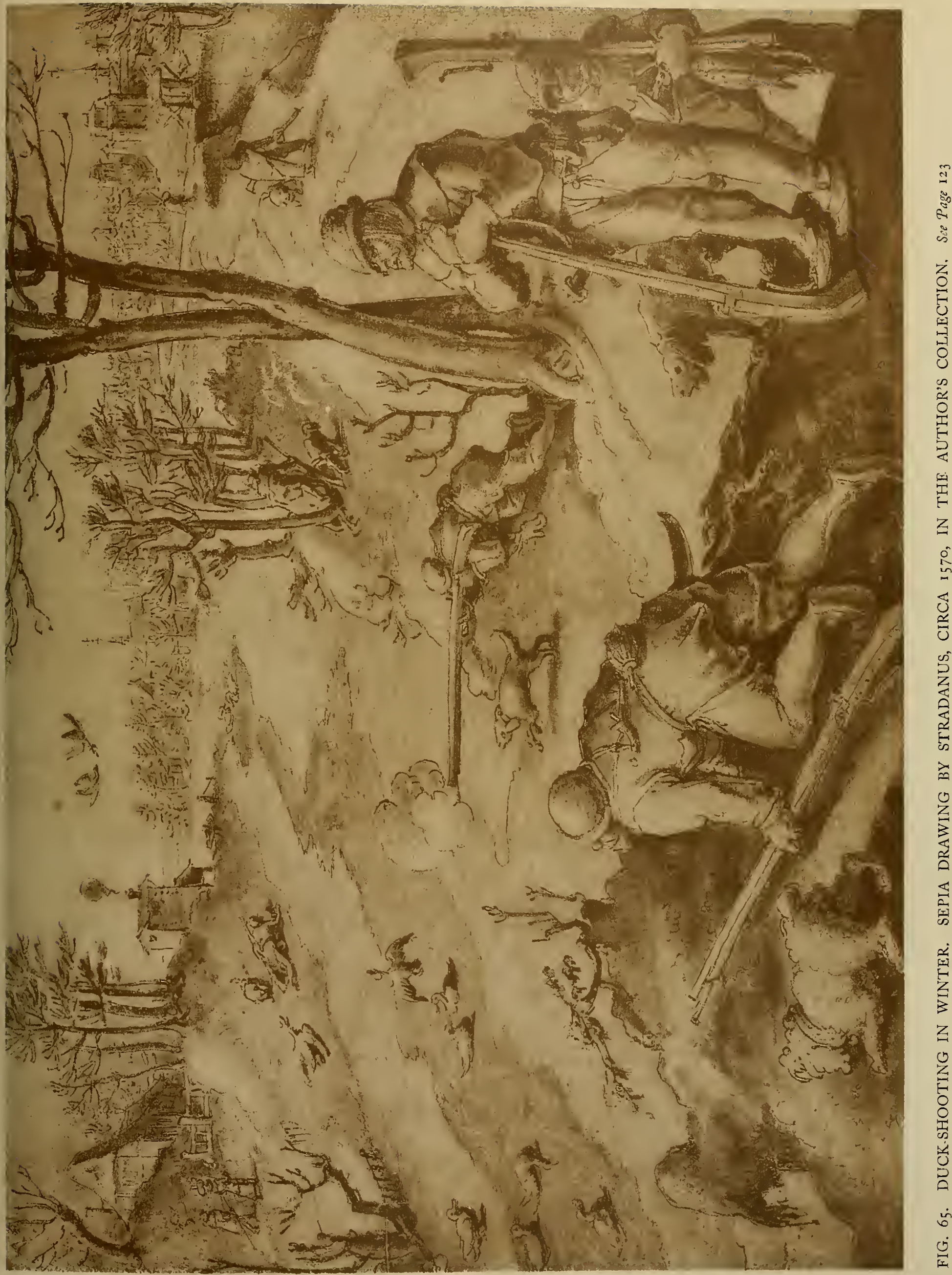





\section{6indey \\ and}

Min.

\section{site \\ and \\ .}

4.

8

$36 x-13$

(1)

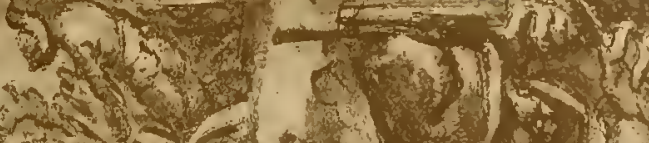

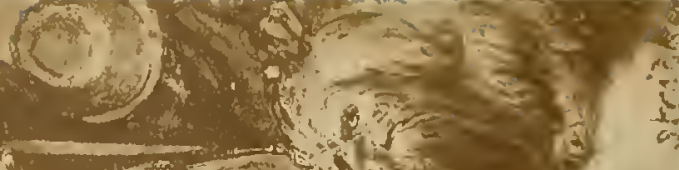

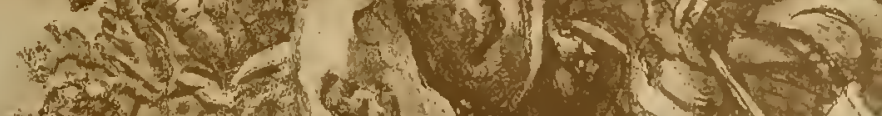

(20) 2.

$\left(1+\frac{1}{(-2)}\right)$

\section{ied.}

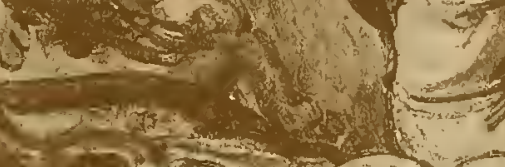

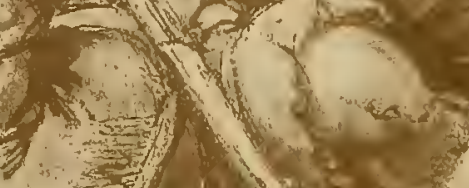

$\frac{2}{4}$

(n)

$\sin 2=$

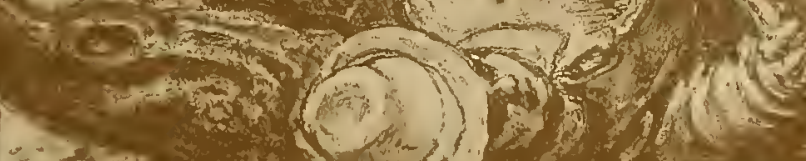

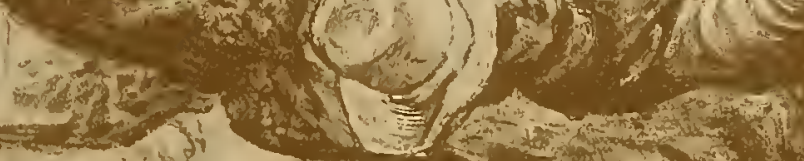

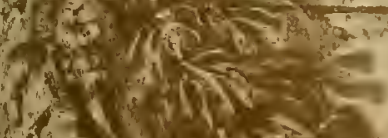

$2 x^{2} x^{2}$ and

wing a arses.

(1) Q) 1,15

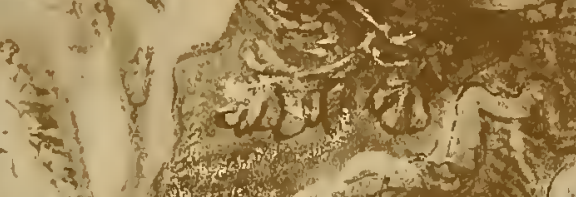
$x^{2} y^{2}$

$3^{2}+1$

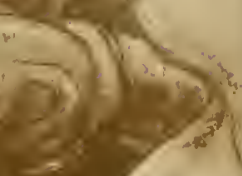

\section{4. \\ Hot

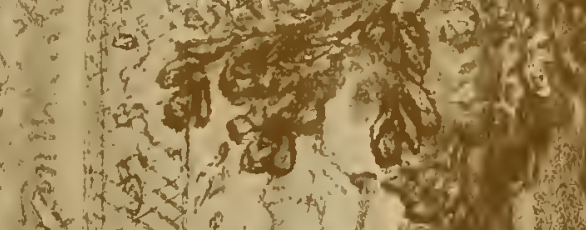 \\ 3. 100

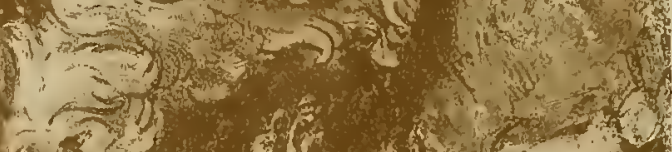

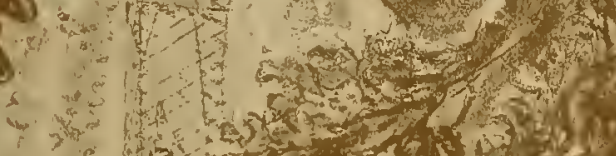

$(2,-2=-2(5)$

$-3)$

(s)

2
0
0
0
0
0
0
0
0
0
0
0

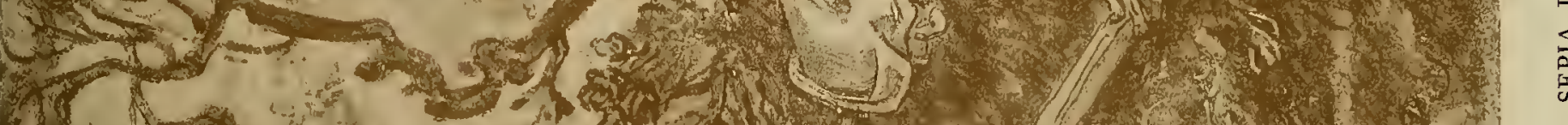

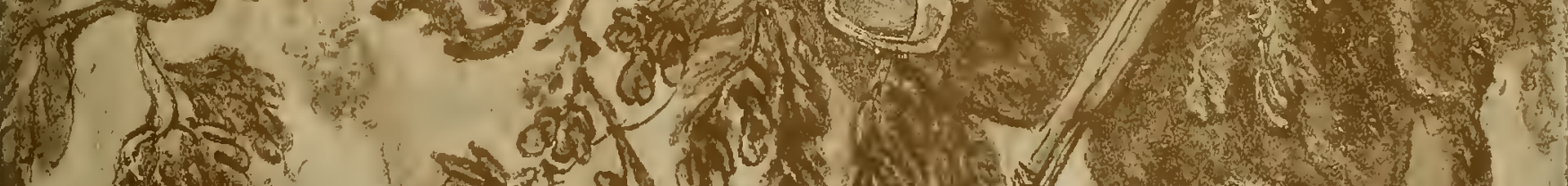

Hont

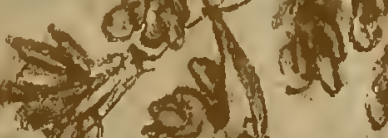

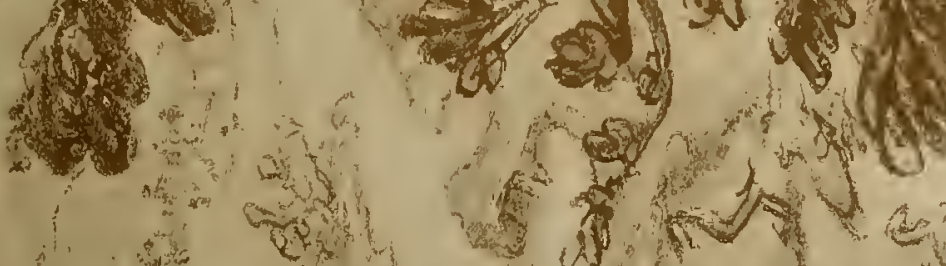

$\therefore$ on

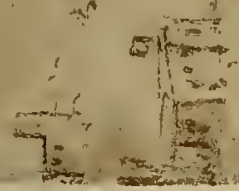

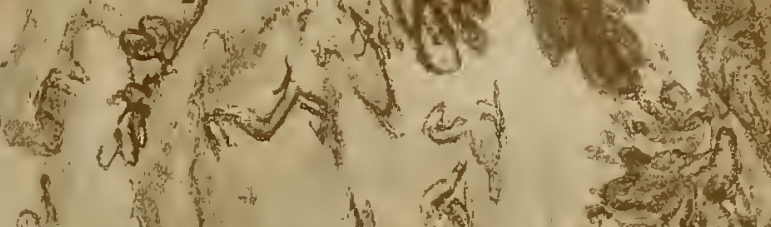





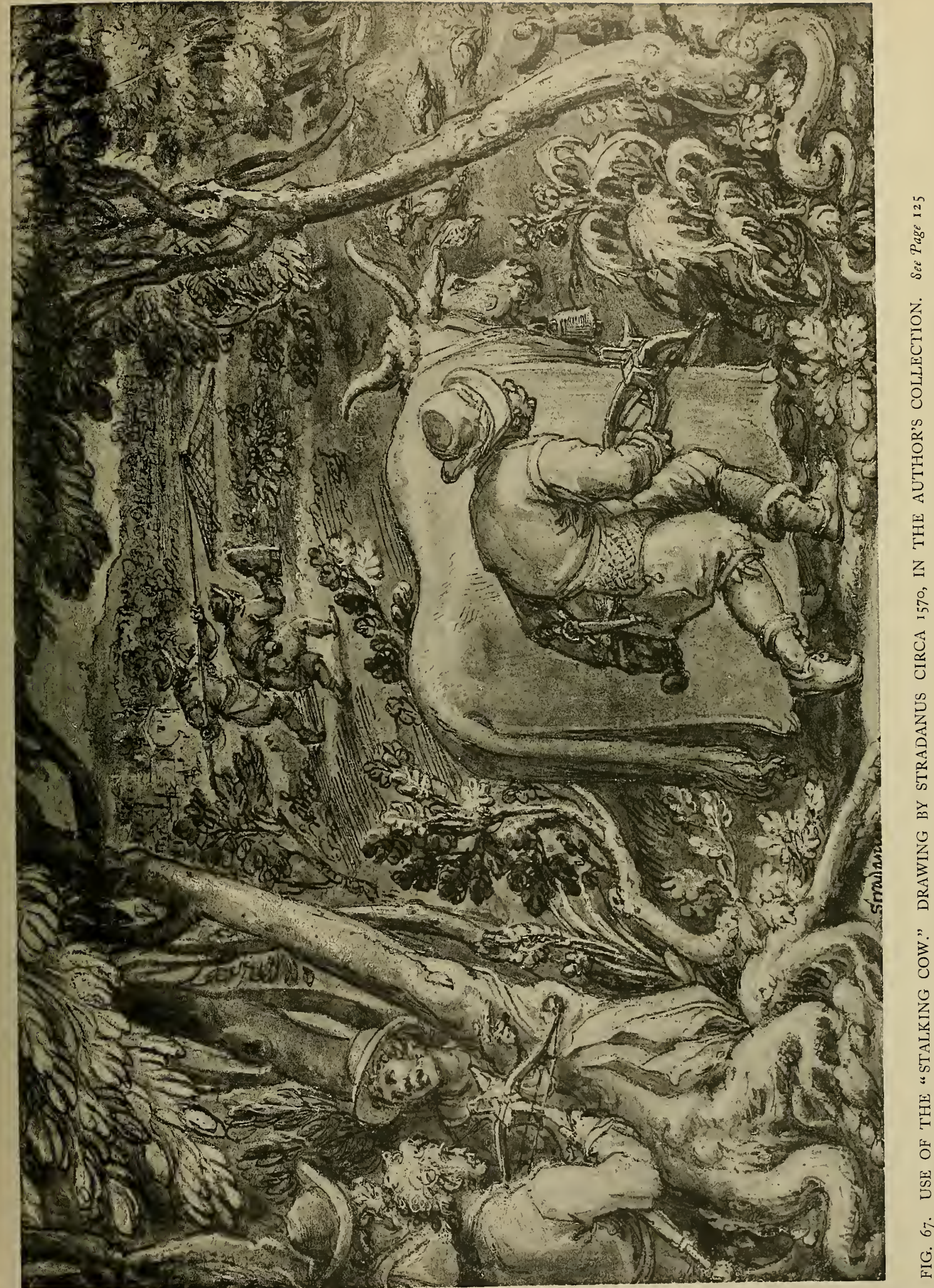





\section{$S \mathcal{T R A D A X U S}$ IDEAS OF SPORT}

horns. In a preceding set of six somewhat larger prints after his designs, engraved about 1570 , the chamois is also incorrectly drawn.

The picture of ibex-hunting shows an equal lack of experience. Numerous ibex are seen capering about low hills, much as were they tame, indeed very tame,

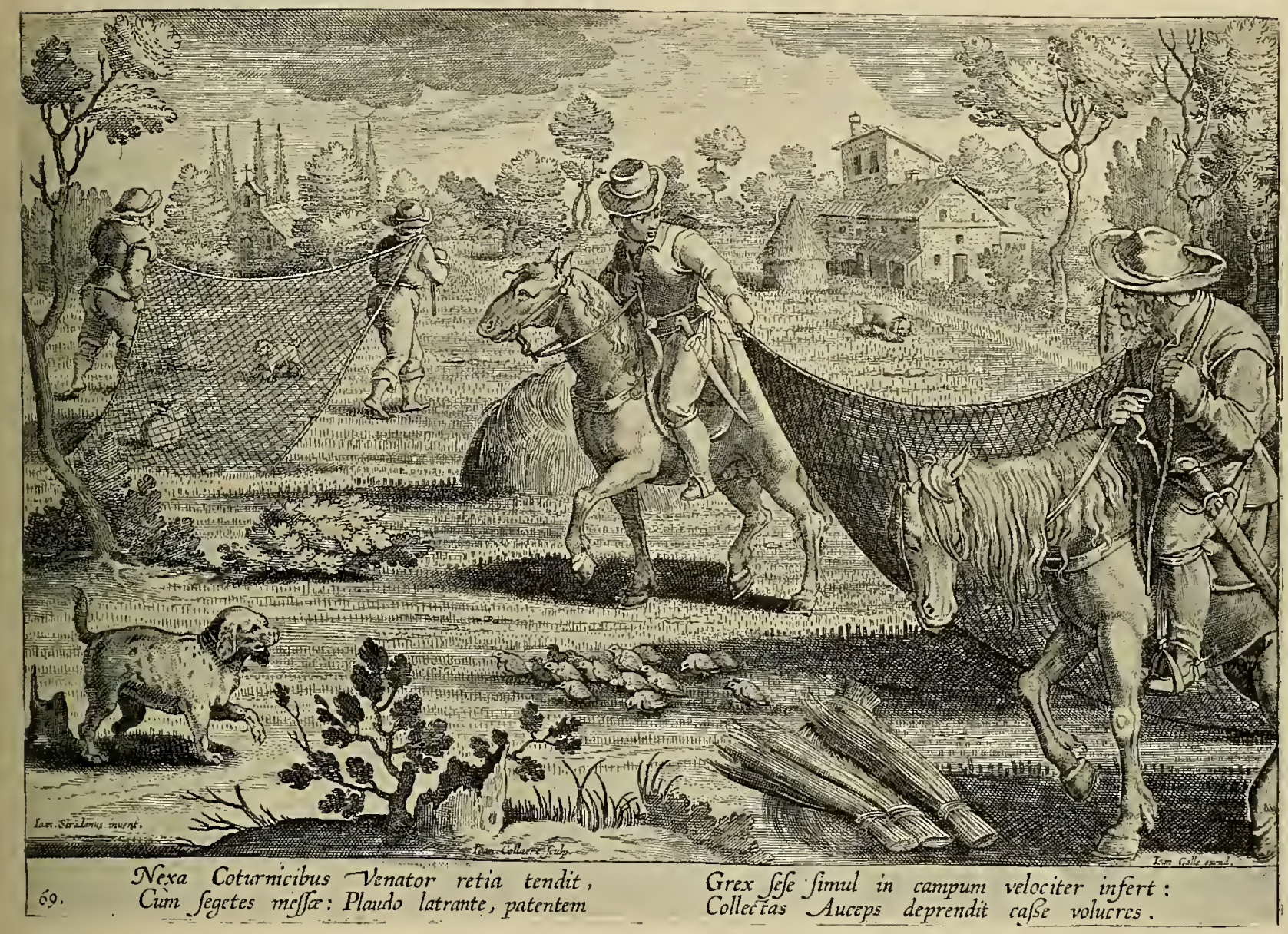

FIG. 68. CATCHING QUAIL WITH THE TIRASSE NET. ENGRAVING AFTER STRADANUS. OUT OF THE "VENATIONES," PUBLISHED 1578. See Page I 26

goats. Dogs are baying a couple, while in the foreground two mighty males with horns of gigantic size lie at the feet of a chasseur mounted on a mule. Near him stand four hunters, one of whom holds in both hands a match-lock of tremendous proportions. In the background a mule laden with two dead ibex is in the act of crossing an arched bridge.

Considering how scarce the ibex had already become in the beginning of that century, Stradanus' picture can hardly be called in any way true to life. 


\section{SPORT IX ART}

Of another type of sport, deer-hunting, we are able to reproduce a spirited drawing, Fig. 6r, which evidently must have pleased both master and public, for there exist three different engravings after it. The print in the Venationes has the inscription "Here they are hunting with hounds the stags through the open meadows, and striking them with their iron spear-points." The spectre-like beast intended to represent a fallow buck which Master Joannes Galle engraved into this plate in addition to what Stradanus had drawn, shows at the first glance that the Antwerp artist can also not have had any practical experience. There is a great deal of life about this drawing, though it also contains incorrect details, such as the stag's "single," but considering Landseer's sketches were not beyond reproach in this same respect, we must not blame Stradanus too severely. Of the three engravings after this drawing the No. 4 of the Quatre Vents series is the absolute replica, the two others differing more or less. As one plate of this set is dated 1576 , our drawing was made before that year.

In Fig. 62 we have the details of a bear-hunt, and one victim of bruin's prowess is evidently having a bad time. Another and more amusing picture of a bear-hunt of which we can reproduce only the engraving is seen in Fig. 63, but we would not like to say that this method of attacking bears was ever really in use. The inscription: "Men in full armour attack the savage bears with swords. The bears, clutching the men with their hooked claws, try to get them down, and standing upright grasp the slippery armour in vain, till at last they fall pierced through the entrails," tells us what one can see for oneself.

A more peaceful sporting scene is depicted in Fig. 64, reproducing a drawing or heron-hawking, which was considered the noblest of all falconry. In this country it has shared the fate of so many sports that have become impossible by the decimation or complete extinction of certain species. No doubt Stradanus had often witnessed this sport as a youth before he left his home, where it is still kept up, though the celebrated Hawking Club at the Loo near Apeldoorn, which two English sportsmen, the Duke of Leeds and Mr. Stuart Wortley, had helped to form in 1832 , was dissolved in the very year it had reached its majority.

One detail in Stradanus' drawing deserves special notice, i.e. the turned-up heads of the two herons at which hawks are about to stoop. It shows that the artist fully believed the legend, sanctioned even by such late writers as Walter Scott, that the heron, when hard pressed and stooped at by the hawk, will point his beak upwards and thus receive the descending enemy upon its point, thereby inflicting serious injury, if not killing him outright. According to modern experts this pretty story has no foundation in fact. It seems extraordinary that for centuries artists went on painting incidents which they could never have seen ; scores, if not hundreds, of pictures of what was once a favourite and aristocratic sport depicting this very occurrence.

Stradanus' predilection for portly men and women, as well as for steeds of the cart122 


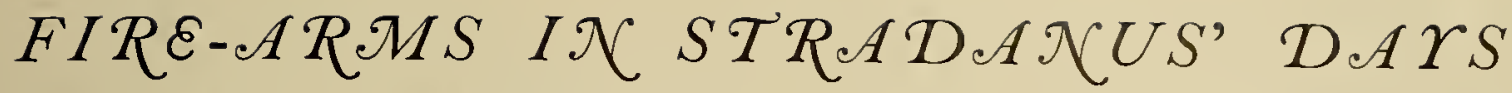

horse type, and for unwieldy fat spaniels and hounds, betrays his Dutch origin, and perhaps also a businesslike desire to please his principal public in the Lowlands and in Northern Germany.

More truthfully drawn in all its details, if we overlook the perspective, is Fig. 65

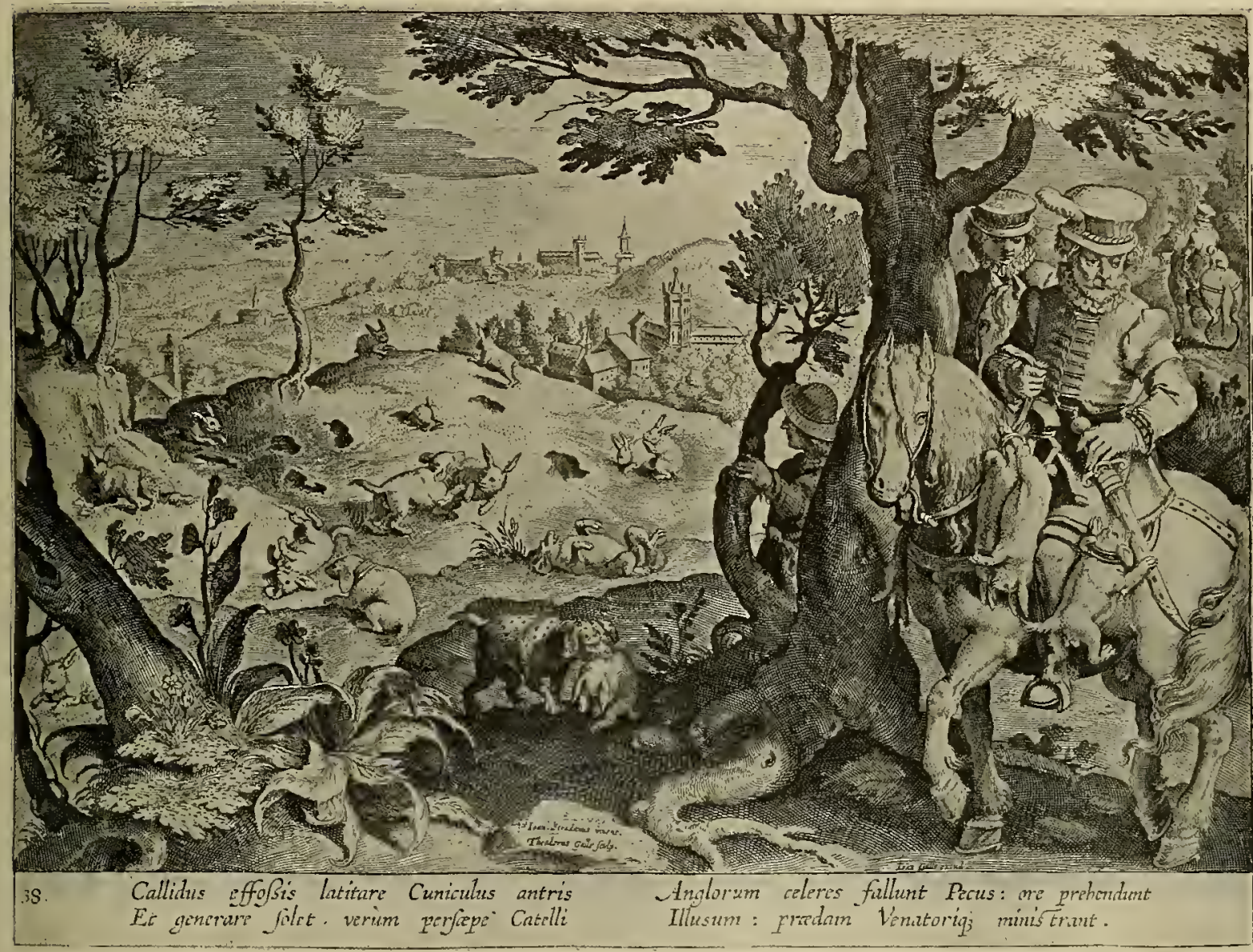

FIG. 69. RABBITING WITH "THE SWIFT ENGLISH SMALL DOG." ENGRAVING AFTER STRADANUS. OUT OF THE "VENATIONES," PUBLISHED 1578. See Page 126

representing duck-shooting in winter. Its details throw light upon the type of sporting arm then in use. It is perhaps hardly necessary to explain here that in the early days the stock of the gun was laid on the shoulder, not held against it, for the obvious reason that, as a man has only two hands and one of them had to hold the slow-match, the gun had to be held in such a manner that it could not slip. The guns in this drawing represent the earliest form of wheel-locks which superseded the match-locks, for there is no sign of a slow-match being carried by 


\section{SPORT IX ART}

any of the men, the habit of placing the gun on the shoulder being, however, still prevalent. The fact that the man in the background, who is just letting off his gun, holds it over his left shoulder, is of course not be taken as an oversight on Stradanus' part, but was done intentionally to bring it right in the print. The same is the case in respect to other drawings where the men carry swords on their right sides.

The shape of the guns, the knobs on the ramrods, or scouring sticks, as they were called, the lever-like trigger as well as the snake-shaped hammer in which the match was held protected by a short tube, hardly come up to what one might expect to see in the hands of sportsmen in the second half of the sixteenth century. The wheel-lock had been invented in Nürnberg quite half a century earlier (in I 5 I7), and the guns we see here show no improvements whatsoever. The men here depicted were evidently using "hail," as shot was called, out of their smooth bore "fire-tubes." An arm of this type is preserved in the Ambraser collection in Vienna. It bears the date $157 \mathrm{r}$, which is about the period we are dealing with here. Its length is four feet eight inches, the barrel alone measuring over forty inches, and it weighs close upon thirty pounds.

The next picture, Fig. 66, represents a similar scene, the descriptive text underneath the print engraved after this drawing, running, "Here rushing through the thickets the hunter catches unawares the ducks and marsh-loving coots" can hardly be said to be of a very informatory nature, while the birds here depicted are in size more like wild swans than coots. The curious-looking dogs were evidently a kind of rough-coated water-spaniel. Dogs were much used by wild-fowlers, and specially by those practising the art of netting water-fowl. For this sport dogs were trained to swim about the entrance of decoys, where tamed wild ducks were afloat, thus attracting the victims. Small shaggy-coated dogs of reddish colour to resemble as much as possible the fox, the arch foe of all wild fowl, were principally used, the sight of the swimming "fox" acting upon flighting water-fowl much in the same way that the sight of an owl acts upon crows, jays, and such-like birds, who flock round their dread enemy with a persistency that is taken advantage of to this day in some Continental countries. Slung over his back the sportsman in the centre of the drawing carries the large and the small powder-horns then in use, for in the latter was carried the fine-grained priming-powder or pulverin, while the larger receptacle held the very coarse article for the charge itself. To load one of these fearfully cumbersome weapons, which one of the men is doing, must have been a weary and time-robbing business; and what about miss-fires in damp weather? From an account of a battle fought fifty or more years later (Wittenweyer, I 638 ) we learn that although it lasted nine hours some of the musqueteers managed to let off their arms six or seven times only! We can gather from this what rapidity of fire was attainable. In the background we see a decoy pond with a net-trap, and two men, hiding behind bushes, working the rope that closes the trap. 


\section{SPORTIX ARMS AXD SXCARS}

Among the poaching contrivances used by sportsmen of the late Middle Ages was the stalking-horse and stalking-cow, and our drawing, Fig. 67, shows us how they were used. It is also in other respects an interesting picture, for it depicts the Arbalete a Falet or latch or stone-bow, a sporting weapon much used in that century,

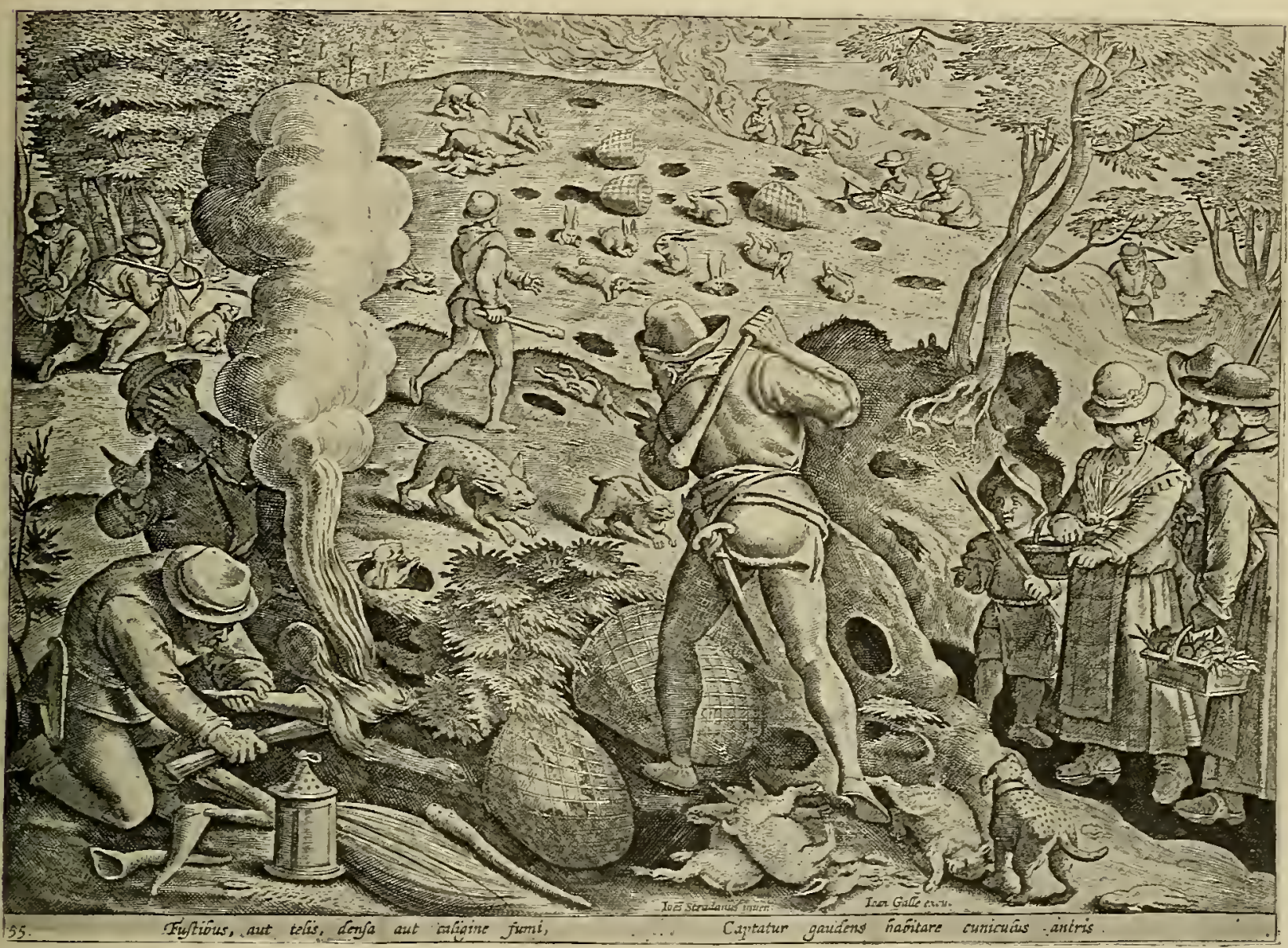

FIG. 70. SMOKING OUT RABBITS IN A WARREN. ENGRAVING AFTER STRADANUS. OUT OF THE "VENATIONES," PUBLISHED 1578 . See Page 127

particularly in Italy. The descriptive legend underneath the print made after this drawing is rather obscure ; literally translated it runs: "The hunter throws a cloth over the back of a cow, and so screened takes the greedy starling, while a noisy partridge from an oak-tree makes the cry of a starling." There can be little doubt, however, that whatever the composer of this inscription meant to say, Stradanus 


\section{SPORT IX ART}

intended to draw partridges.* In the background we see some nocturnal netting going on. The net, shaped like a dish-cover mounted at the end of a long pole, was used in conjunction with the fuée, a powerful shaded lantern provided with a strong reflector. Of the use of this fuée Stradanus has quite a number of illustrations, it being used even for fishing. Curiously enough the only picture of English sport represented in the Venationes set is bat-fowling, where artificial light was also used. As the print is rather uninteresting it will suffice if we give the inscription : "On a dark night an English fowler scares the surprised birds out of their nests, and to prevent them settling on the branches drives them with sticks and chases them with torches, until he can capture his tired prey."

A few words may still be added regarding the stone-bow, which also was called "prodd." With us they came under Henry VIII's ban when he forbade the use of all such bows in order that the use of the long-bow, our national weapon, might not go out of fashion. The bullets or pellets the latch propelled were made of lead or baked clay.

Our next reproduction of a print, Fig. 68, shows us the use of the tirasse net explained by the inscription: "The quail catcher stretches nets when the crops have been gathered. When the dog barks the flock makes into the open field and the fowler gathers them en masse in his net." A similar state of mental hallucination seems to be overtaking some rabbits in the background of the picture, the "fat boy " setter, or whatever one feels inclined to call this over-fed canine specimen, being employed for both species of game. Whether the name tirasse was then already known and used is doubtful, as one has failed to find it in any sixteenth-century author. Probably the nets were much wider than here depicted. Ridinger, who wrote about their use a century and a half later, describes them as being very much larger. Their use in France in the sixteenth century was so much abused that the Legislature of Toulouse, as Noirmont tells us, had to prohibit them for quail. In Louis XIV's time tirassing pheasants and partridges was a sport which the king and his ladies often witnessed, while Ronsard praises it in rhymes as calling for a clever dog, and, on the part of the men engaged in it, the skill of long practice.

Drag-nets of this kind are still used in Hungary and Bohemia to gather in live partridges, and also pheasants for export.

An amusing picture, Fig. 69, is the one depicting the chase of the rabbit by means of the "swift English small dogs"; as we are told in the description below the print : "The cunning rabbit burrows and breeds in holes, but very often the swift English breed of small dogs is too much for it. They seize them in their mouths when they have been snared, and bring their prey to the huntsman." What breed exactly these grossly over-fed creatures were intended to represent it is hard

\footnotetext{
* Sir Ralph Payne-Gallwey in his interesting work, "The Crossbow," reproduces the print after this original, and though he does not quote the inscription, he raises no question as to the birds being partridges.

I 26
} 


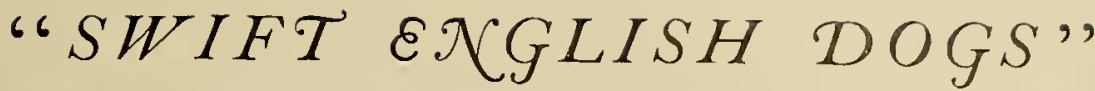

to say, more particularly if we observe the specimen seated behind the huntsman on the broad back of his horse in the background of the picture. It is a position which the creature jumping up on the horse in the foreground is apparently also,

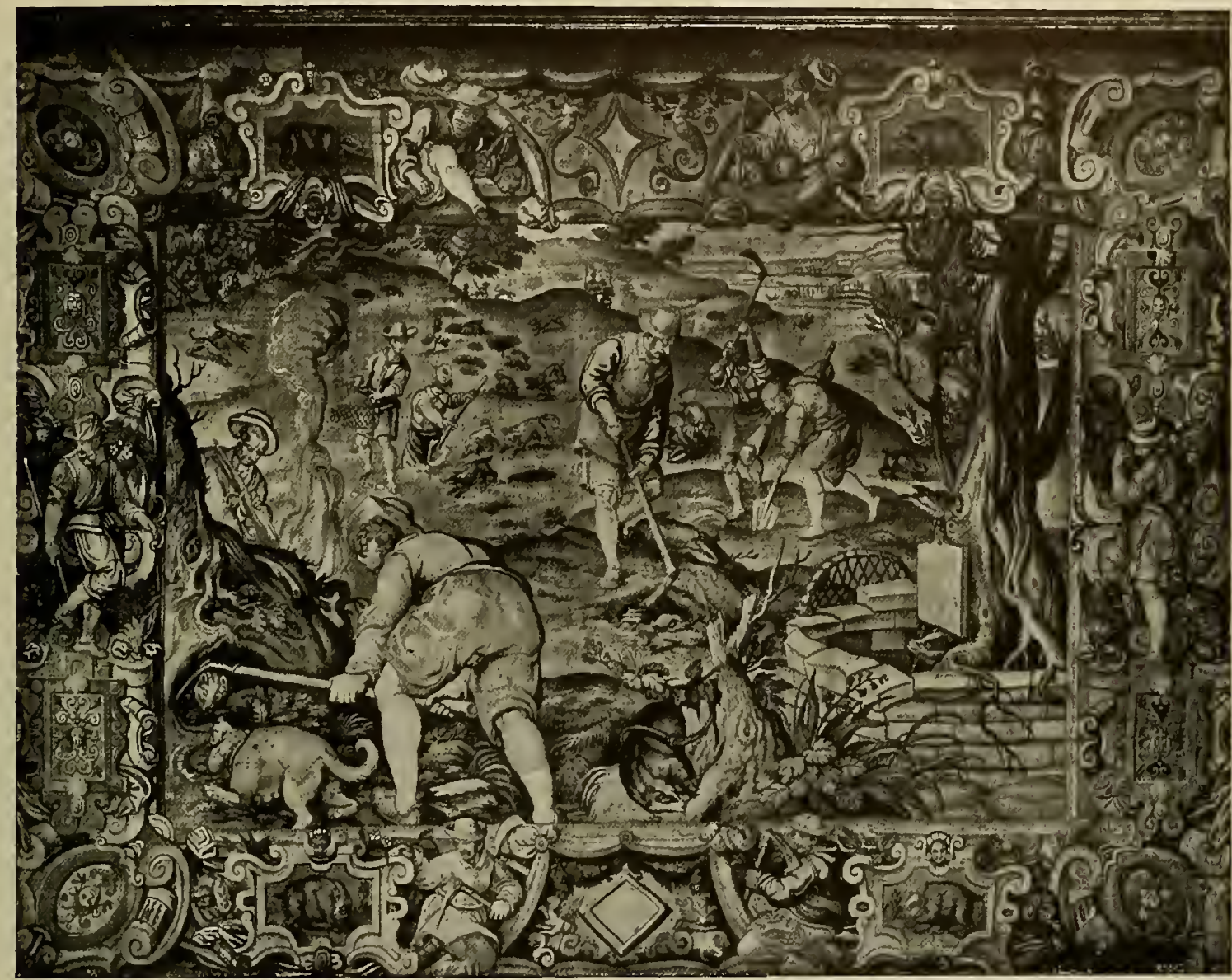

FIG. 71. DIGGING OUT BADGERS. TAPESTRY DESIGNED BY STRADANUS I 568 , IN THE PALAZZO VECCHIO IN FLORENCE. WOVEN AT THE ARAZZIA MEDICAE. See Page I 29

though vainly, endeavouring to occupy. The former evidently has had enough of this exciting sport, and is riding home behind its master.

Stradanus has left us also a picture, Fig. 70, of a scene in a rabbit-warren which has a familiar air about it, though we miss the smart fox-terrier and other attributes of modern days. The methods of capturing rabbits have varied perhaps less than those of any other chase, and though we do not know who introduced ferrets, they were already used in Pliny's time. For when he mentions what a plague the rabbits had become on the Balearic Isles, he tells us at the same time how highly the 


\section{SPORT IX ART}

ferret was esteemed by the population of the islands. The inhabitants of Minorca are even said to have petitioned the Emperor Augustus to send troops to aid in the destruction of these pests, that were undermining their houses and destroying their trees. It is amusing to imagine the Roman legionaries engaged in this, to us, homely and modern sport. Was it to Cæsar's soldiers, versed in the handling of ferrets, that the ancient Britons were indebted for initiating them in the way of making rabbits bolt from their burrows? Or was the method first imported many centuries later with other forms of chase from Normandy? However that may be, when it came it came to stay, and as long as there are rabbits there will be but few country youths who will not at some time or other enjoy what an old writer has called "one of the coldest and unpleasantest chases that can be followed."

In the Middle Ages, the flesh of the rabbit was considered to be better than that of the hare, which latter was believed to conduce to "melancholicke," while the former figured at all great feasts as a delicacy. In the early days of France, under the Capetian kings, there was a special Court "ferreter." In the reign of St. Louis (1226) the ferreter "shall have 18 den. wages, and when he and his varlet come to Court they shall eat there." In the accounts of Louis' grandson Philip, we hear of "Perrotus Picardus, furetarius ... I 8 den. Pro robis pro toto anno... 6os."

A quaint passage quoted from the "Arte of Venerie" (I 575-76) will show the procedure of coney hunting at that period. "He that would take conies must hunt with two or three spanels or curres made for ye purpose, amongst ye hedges and bushes where he knoweth that ye conies do lie; he may also have small greyhounds for the purpose to course at them, but in their default, the spaneils or curres will drive them into theyr burrowes; then set pursenetts upon al ye holes, or as many of them as you can find, and put in a ferret close muzled, and shee wil make the conies bolt out againe into your pursenets, and so you shall take them. Remember your ferret be close muzled, for else she will kill the conie in the ground, and peradventure will not come out againe of three or foure daies after. For default of a ferret, you may make the conies come cut of their burrowes with the powder of Orpine and Brimstone, to make a smother with them, and it will make the conies bolte out of the earth, and so you shall take them in your pursenetts." The translator of this passage remarks that the Frenchman seems not to be acquainted with English warrens, and that there are "Sundry lords and gentlemen in England, thanked be God, that would give a man but small thanks which should so smother their burrowes with Brimstone or Orpiment, for indeed it will mar a burrow and drive the conies cleane from it" (I6 I I edition).

But evidently the gentlemen of France did not waste their time in hunting conies, for the latter increased vastly, and they must have become more than a nuisance to induce Louis XVI to issue an ordinance, as he did in 1776 , giving permission to all peasants to kill rabbits for the protection of their crops. I 28 


\section{$S T R A D A \mathcal{X} U S$, BADGER-HUXTS}

In Fig. 7 I , representing badger-drawing, one is struck by the quantities of badgers ; they seem to have been as plentiful as rabbits in a warren.

Perhaps Stradanus had in his mind the legend told by a twelfth-century chronicler,

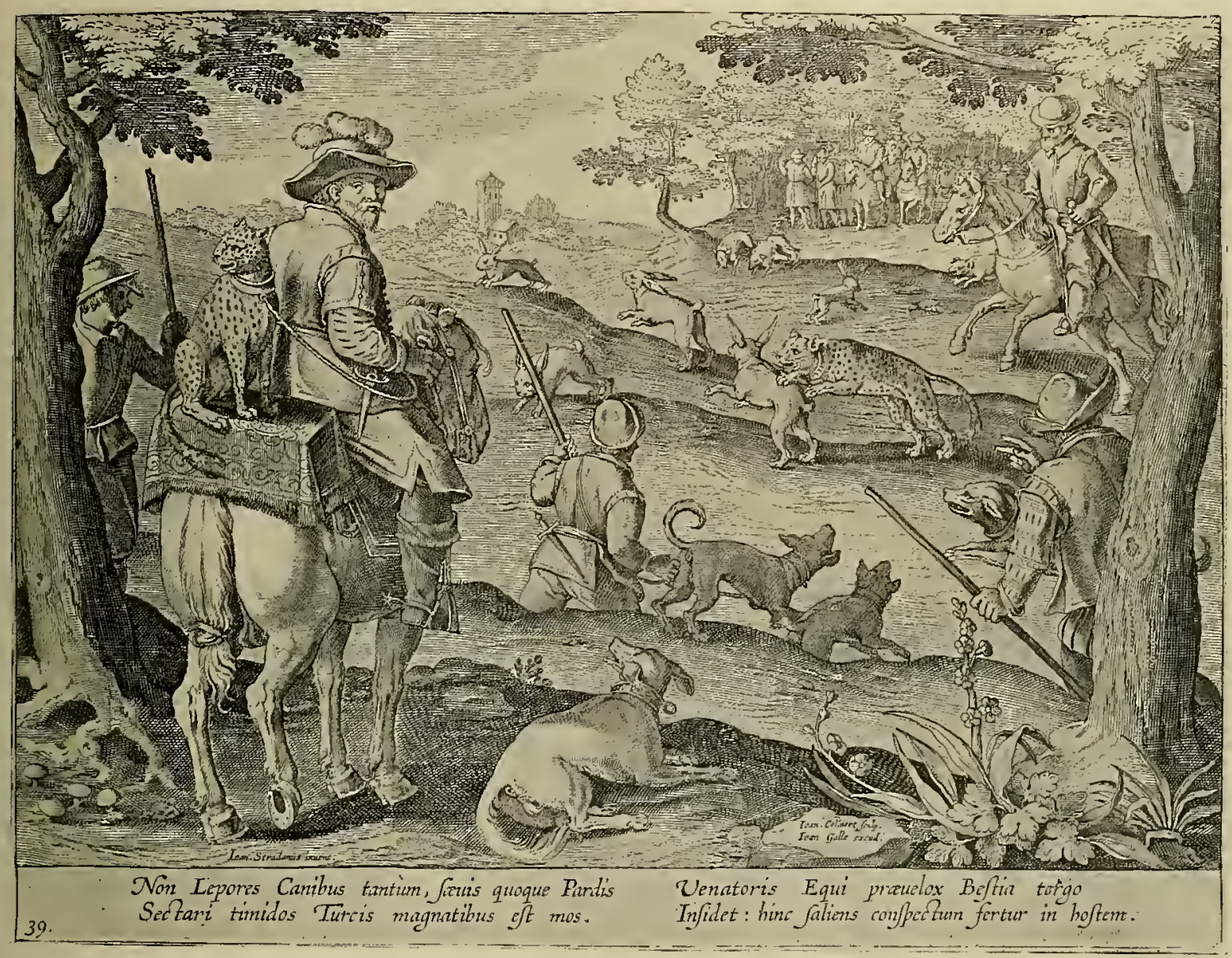

FIG. 72. HARE, - HUNTING WITH THE TRAINED LEOPARD. ENGRAVING AFTER STRADANUS CIRCA I 570 . OUT OF THE “VENATIONES," PUBLISHED I 578 . See Page 72

who relates that some noblemen went out badger-hunting and, having drawn one from his earth, put him into a sack, intending to carry him home. The badger appeared to them uncommonly heavy, and no wonder, for it was the Devil himself whom they had bagged in this guise. All the friends of the Evil One promptly came to his rescue, and the forest seemed filled with swarms of infuriated badgers, who gave battle.

Less familiar to us than the chases already described is that depicted in Fig. 72 , 


\section{SPORT IX ART}

for the essentially Oriental sport of hunting with the trained leopard (Felis jubata, the cheetah of the Hindoos) never became acclimatised in England, although it seems at one period to have been in vogue on the Continent. We are told by the

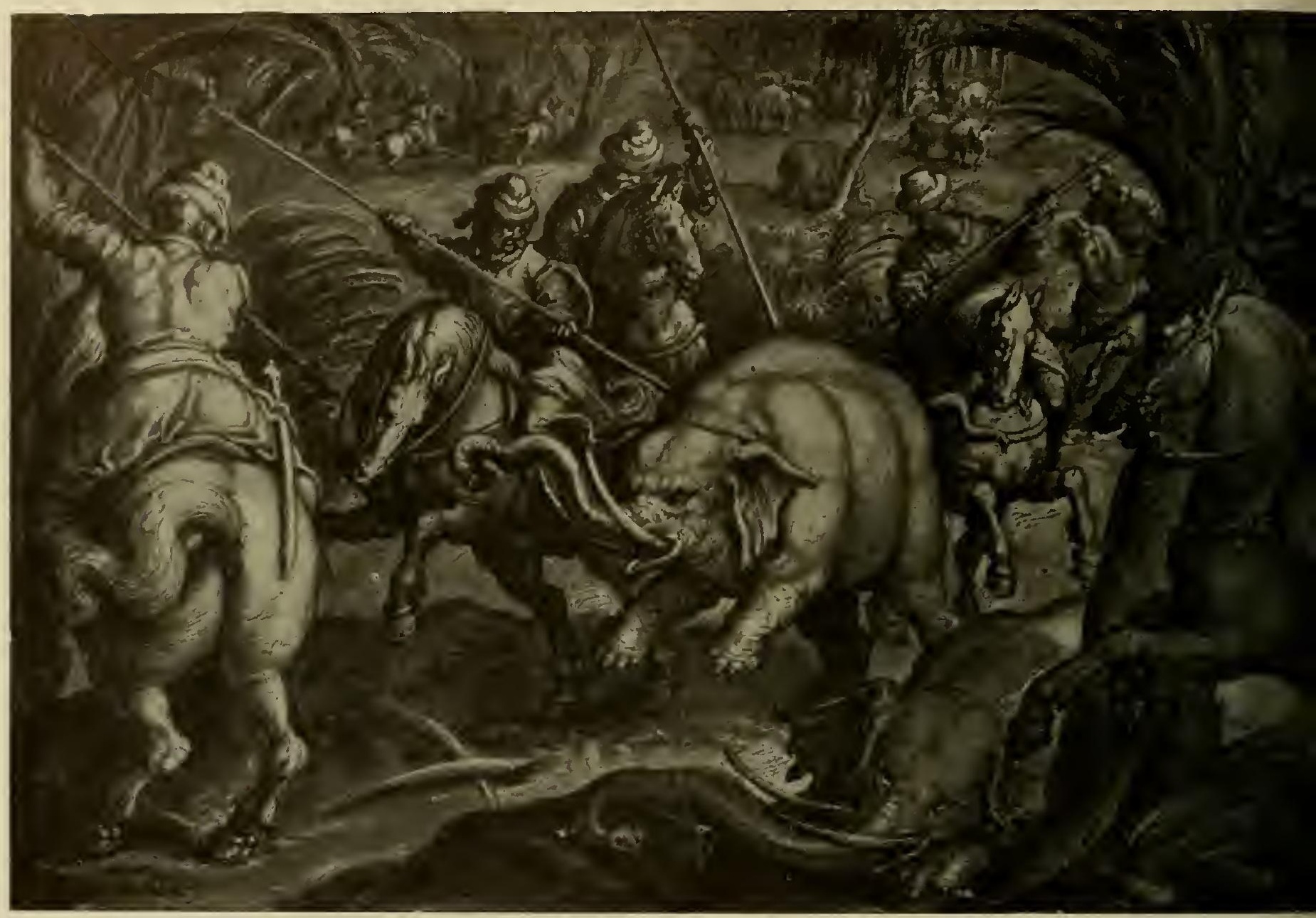

FIG. 73. ELEPHANT HUNTING IN AFRICA. ORIGINAL DRAWING BY STRADANUS CIRCA 1570. SIGNED. See Page 132

Latin inscription beneath the picture that it represents a hare-hunting party of Turkish grandees. Stradanus had probably heard that this was the favourite sport of the Turks, and no doubt the fame of the Great Mogul Akbar's hunting establishment had reached him. For Akbar, who lived at the close of the fifteenth and the beginning of the sixteenth century, is said to have kept over one thousand leopards for the chase. I 30 


\section{STRADAXUS' IDEAS ABOUT SPORT}

The Italians, who, through their commercial connections, were brought into constant relations with the East, seem first to have introduced this form of chase into Europe, and the Franks probably brought back some practical knowledge of the subject from the first Crusades, having seen how the Syrians, who were great adepts in training the cheetah, used it in hunting deer and antelope.*

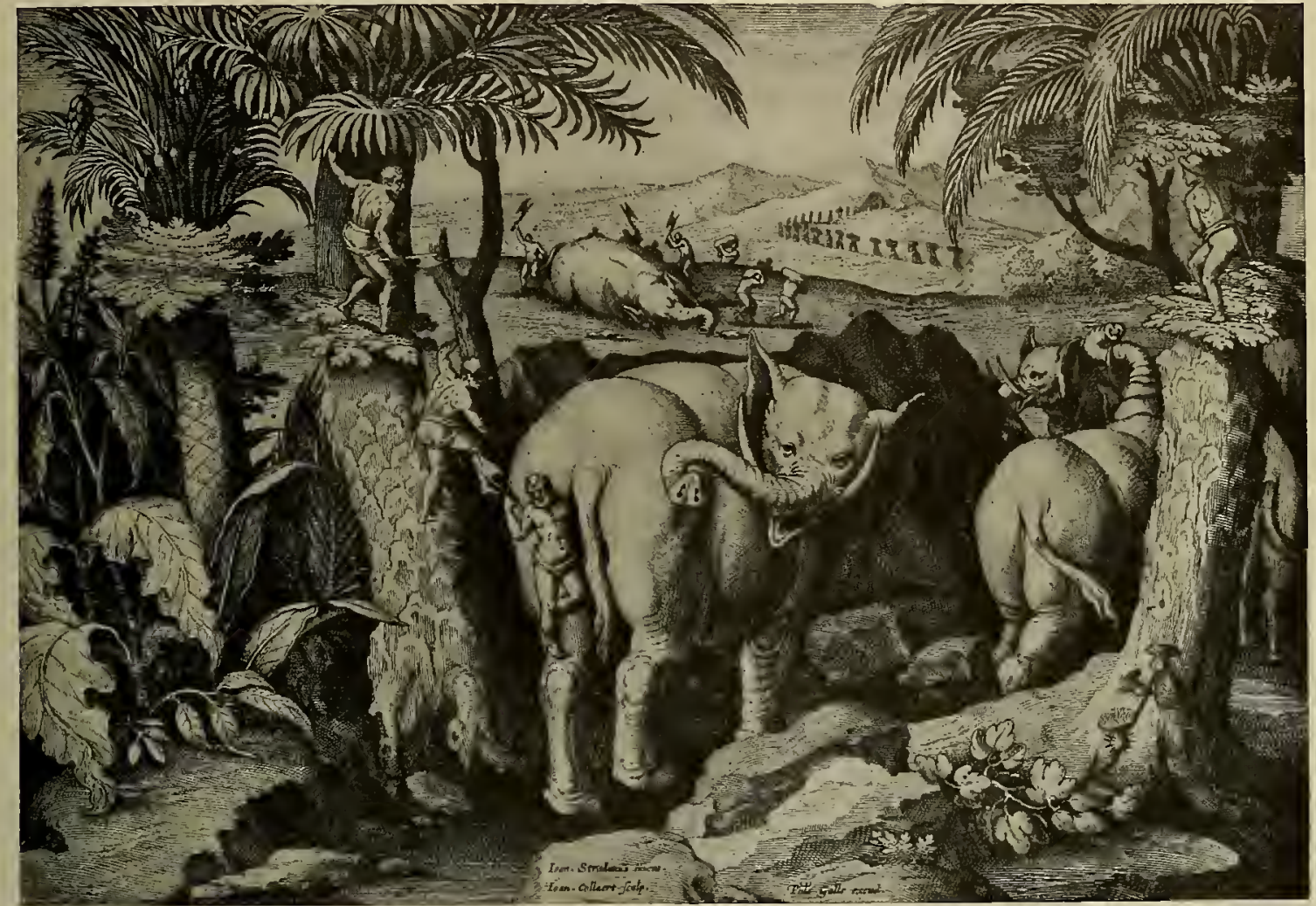

FIG. 74. ELEPHANT HUNTING BY TROGLODYTES IN AFRICA. ENGRAVING AFTER STRADANUS. OUT OF THE “VENATIONES," PUBLISHED 1578. See Page 132

Francis I had many trained leopards, and the naturalist Gesner describes the manner in which he says he saw them used at this monarch's court. The leopard sat on a cushion behind a mounted huntsman (just as the artist shows us), the huntsman holding him by a chain till the quarry was viewed; then the chain was loosed, and with a few prodigious bounds the leopard had reached his prey and strangled it. A piece of meat had then to be presented to him, to make him release his capture. To do this, the huntsman held the meat between his legs and walked * That the use of the hunting leopard was known also in the fifteenth century in Italy is shown by a fresco by Benozzo Gozzoli (1424-85) depicting one of them being held by a chain, while in the distance another is pursuing a roebuck. 


\section{SPORT IX ART}

backwards towards him, tempting him with the meat till he was in this manner enabled to capture him again. This, Gesner says, he was told was necessary, for if the huntsman had faced the leopard, he would spring on to the man and tear him. However that might be, the naturalist remarks that the animal was docile enough as soon as he was once more on his chain, and jumped up quite willingly on to his seat on the horse. In the seventeenth century the training of leopards was given up in France, and in Germany the Emperor Leopold I (I658-1705) seems to have been the last monarch to keep these animals. He was constantly to be seen riding out with one en croupe.

Of A frican sport Stradanus drew quite a number of pictures. The majority of them deal, however, with what one might call legendary sport, and it will suffice for our purpose if we reproduce only those dealing with elephant and ostrich hunting. In the drawing of the former, Fig. 73, Stradanus drew his quarry as of somewhat undersized dimensions, a mistake not usually made either by him or by other artists of his age, who, as a rule, magnified the size of foreign animals. Take as an instance our reproduction of an engraving, Fig. 74, after another drawing by him. Here we have elephants which, if we accept the ordinary human form as our scale, must have stood something like eighteen feet high, though probably, as the inscription below tells us that the man in the act of hamstringing his quarry is a troglodyte or cave-dweller, a race who were believed to be of dwarf stature, the disproportion is intended to be as great as it is. As an early picture of elephant hunting its amusing details, such as the long file of natives carrying off loads of dismembered elephant on their heads and shoulders to their caves, are curious enough. The four lines of inscription below this print run: "The cave-dwellers who are expert at snaring elephants grasp their tails, hamstring the beasts, and kill them when thus maimed. Next they cut them into portions and each man promptly carries off to his cave the booty he has acquired." **

Ostrich hunting, Fig. 75 , reproduced from the original drawing, is explained in the print made after it by : "The Moors hunt the ostrich with swift hounds, and wear its feathers in their turbans, as a mark of distinction." Some doubt is permissible concerning the swiftness of Stradanus' hounds ; canine specimens more unlikely to overtake these giant birds were surely never drawn.

Quite a number, about ten in all, of the Venationes prints relate to fishing, and as there are comparatively very few pictures illustrative of the gentle art that have come down to us from the late Middle Ages, $\uparrow$ we propose to reproduce here three of the six drawings by Stradanus in the writer's collection. They will convey

\footnotetext{
* Stradanus provided some of his elephants with bushy tails, by which he probably desired to differentiate between the African and the Indian species, less fantastic distinctions being probably unknown to him. + The earliest English fishing picture in print is the quaint woodcut in the I 496 Wynkyn de Worde's edition of the "Boke of St. Albans" which is coeval or possibly slightly older than Kölderer's more elaborately finis!hed illuminations in Emperor Maximilian's Fishing-Book reproduced in a previous chapter. 132
} 


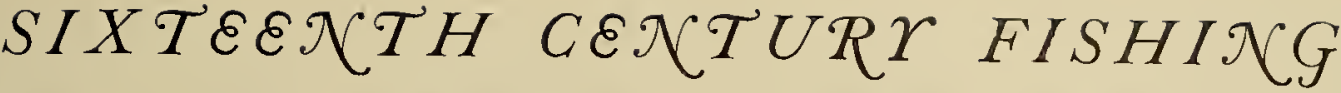

better than any words the extraordinary crude ideas then still prevalent and also show what arrant poachers Stradanus' contemporaries were.

The print engraved after our first drawing, Fig. 76, furnishes us in its inscription

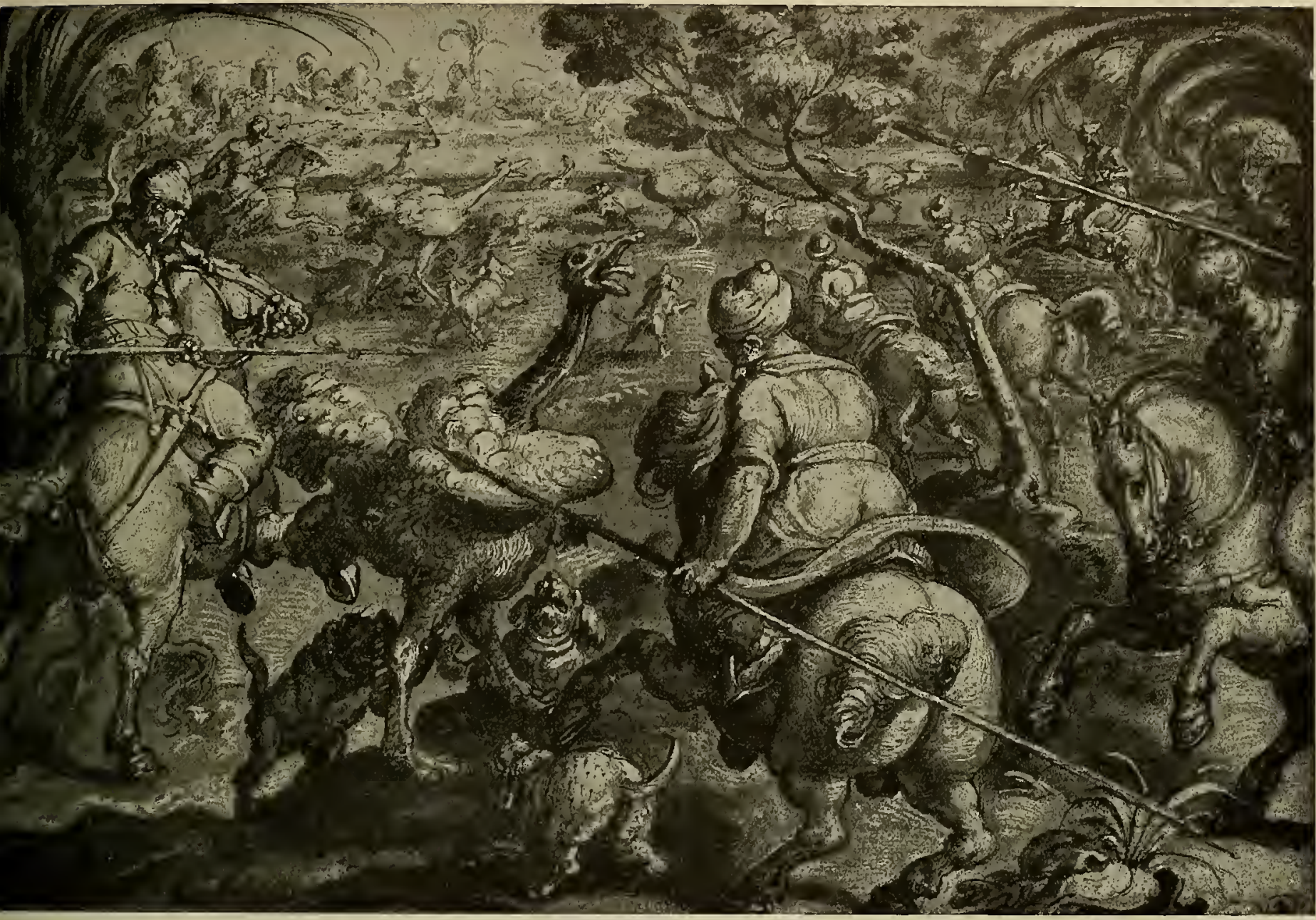

FIG. 75. OSTRICH HUNTING IN AFRICA. DRAWING BY STRADANUS CIRCA i570. Page I32

with the information that "this is how the fish is caught by lamplight at night, but when the sun is shining it hangs from the treacherous hook!" The allegorical group is meant to indicate day and night, while the landscape depicted by Stradanus, who, as a good Florentine, dearly loved his Arno, represented probably what he saw out of the windows of his studio.

The second picture is explained by : "The fish, deafened by tapping on the rocks, rises from the water and is caught without any effort." Whether the artist, by 


\section{SPORT IX ART}

again bringing in the crescent-crowned goddess, desired to indicate that this kind of "knock-me-out" fishing could only be indulged in during nocturnal hours, we can only guess. There is a tired air about the old gentleman that suggests a night

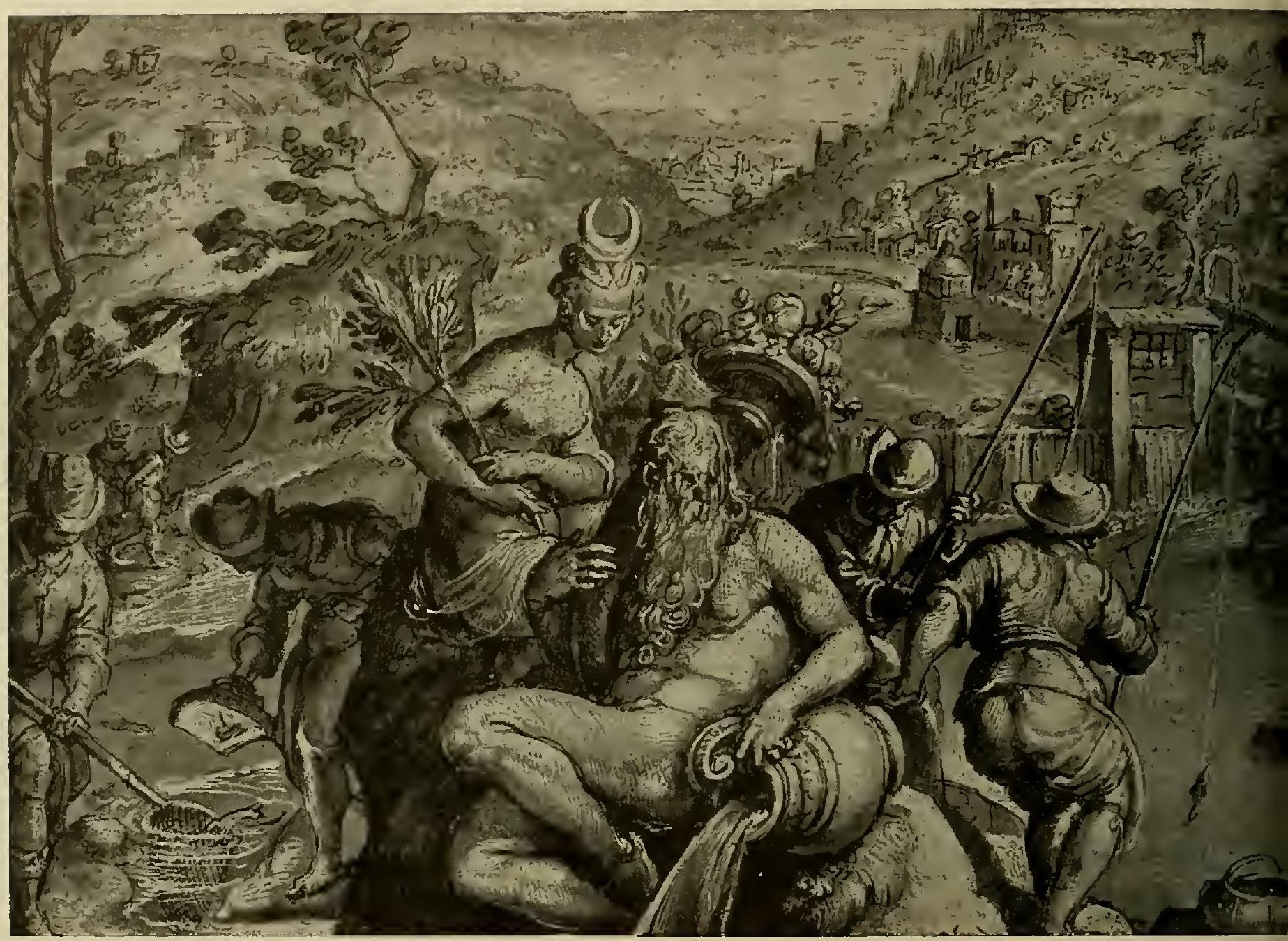

FIG. 76. FISHING BY NIGHT, AND WITH THE HOOK̄ AND LINE. DRAWING BY STRADANUS CIRCA 1570. SIGNED. See Pages I 32-135

out, and the fact that the young lady is pointing, in rather a reproachful manner, to herself makes one believe that he has been reproaching her; whether for late hours or the smallness of the bag in Fig. 77 the reader must judge.

Our third picture, Fig. 78 , again indicates that Stradanus could not get away from his beloved Florentine river. "When the Arno is in flood, this is the way they urge I 34 


\section{SPORT IX ART}

In the Appendix will be found a list of the various sets of Stradanus' sporting prints of which there were a number. To illustrate the fact that more care was expended upon the earlier ones we reproduce a spirited representation of fox-hunting, Fig. 80,

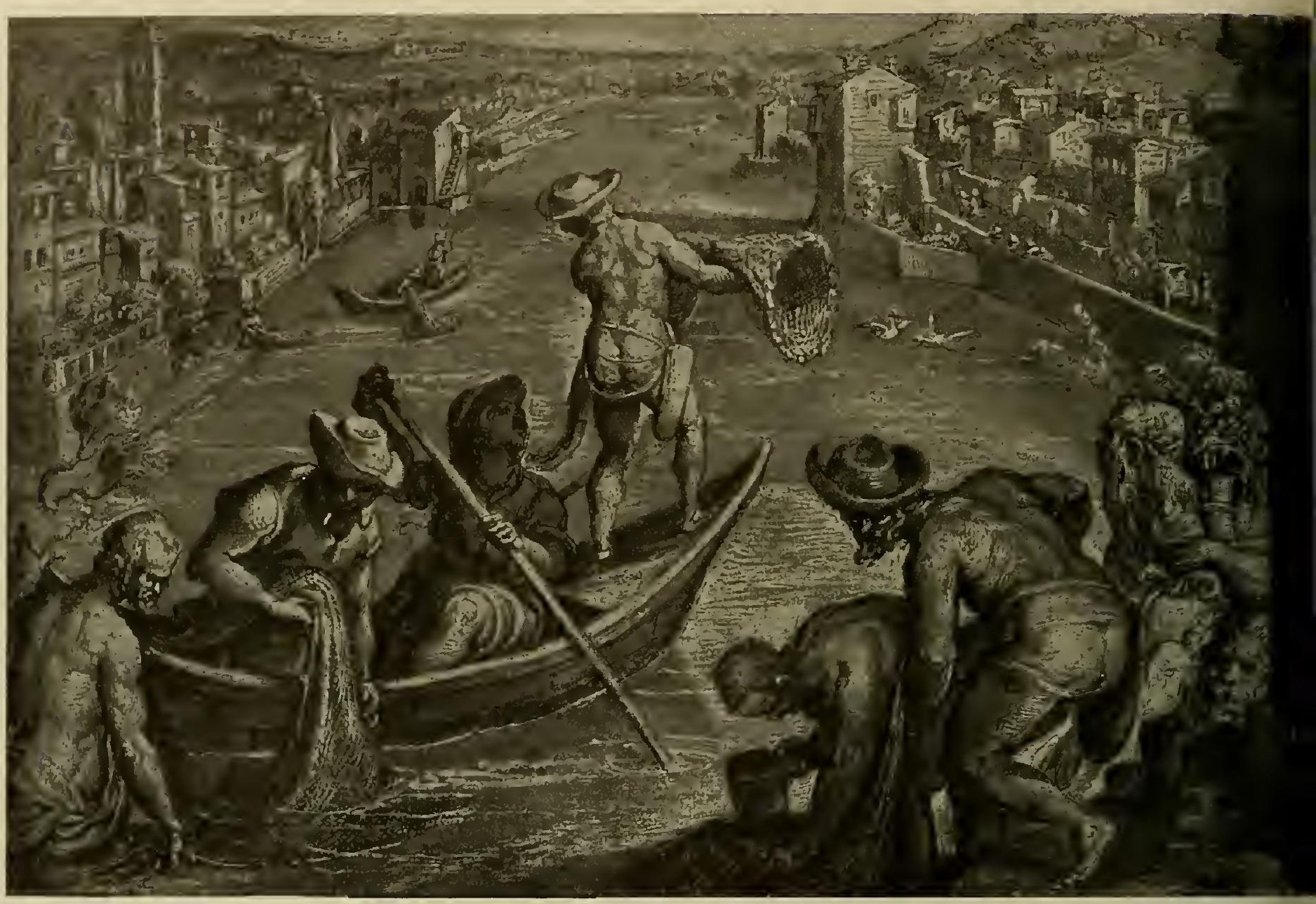

FIG. 78. FISHING IN THE ARNO WITH ROUND NETS. DRAWING BY STRADANUS CIRCA 1570. SIGNED. See Pages $132-135$

which forms part of the several Aux Quntre Vents sets, the one in question being dated I 576, while others were issued in I 570 and I 574 . These small collections, consisting of from four to six prints each, are much rarer than the more carelessly executed Venationes series.

That some engravers did better justice to Stradanus' designs than others will be seen by a glance at Fig. $8 \mathrm{I}$. This beautiful engraving, representing Diana surrounded 136 


\section{SPORT IX ART}

up sport as a subject for his designs. This appears to have been about the year 1567 , for the tapestry Caccia dedaini, delle Chamozzi was commenced that year and completed in 1568 , and probably the panels, of which we reproduce three more in Figs. 82,83 , and 84 , were designed, if not completed, before the year I 57 I when

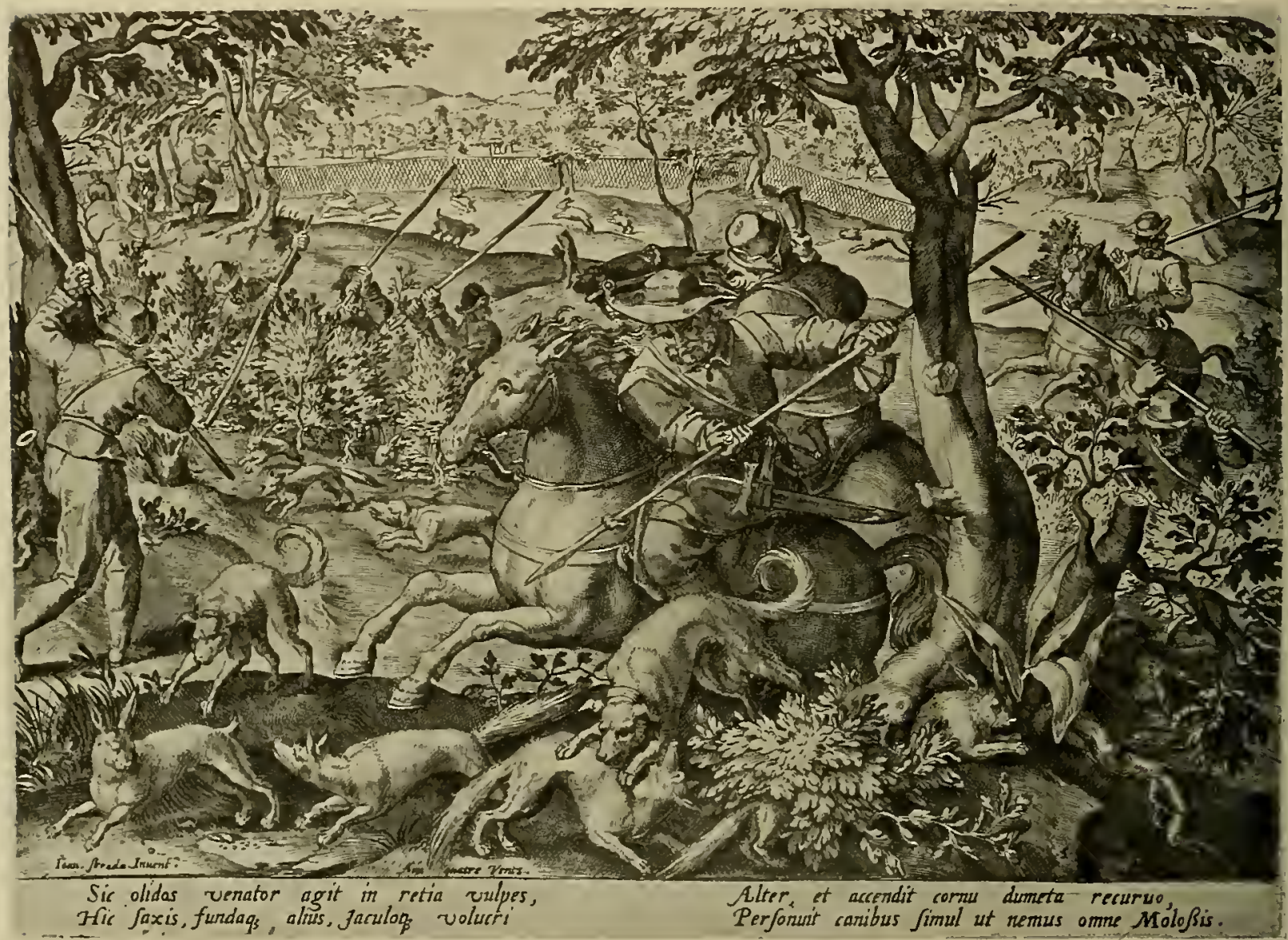

FIG. 80. FOX AND HARE HUNTING. ENGRAVING AFTER STRADANUS. OUT OF THE EARLY SMALL SET PUBLISHED BY H. COCK'S FIRM “AUX QUATRE VENTS" IN 1576. Page I 36

Stradanus left Florence. They were much admired by the above art critics and by Borghini, and also by Montaigne who saw them in $1580-1$.

Before bidding good-bye to the Flemish master's studio on the Arno, the scene of an extraordinary activity in art productions, we desire to devote a little space to the one drawing of his to which of all others the greatest interest, we think, attaches, although, it must be confessed, it relates only in an indirect manner to sport. This is his picture of Vespucci's landfall, Fig. 85, a drawing which, as the following will ${ }_{1} 3^{8}$ 


\section{VESPUCGI'S LAAXPF.ALL}

show, can claim the distinction of being the oldest existing picture of America's fauna.* It is executed in sepia, the lights being heightened in white ; it measures $10 \frac{3}{4}$ inches in width by $7 \frac{1}{4}$ inches in height. Underneath Vespucci's mailclad figure are written the words Americus Vespuccius Florentinus 1497, and in the

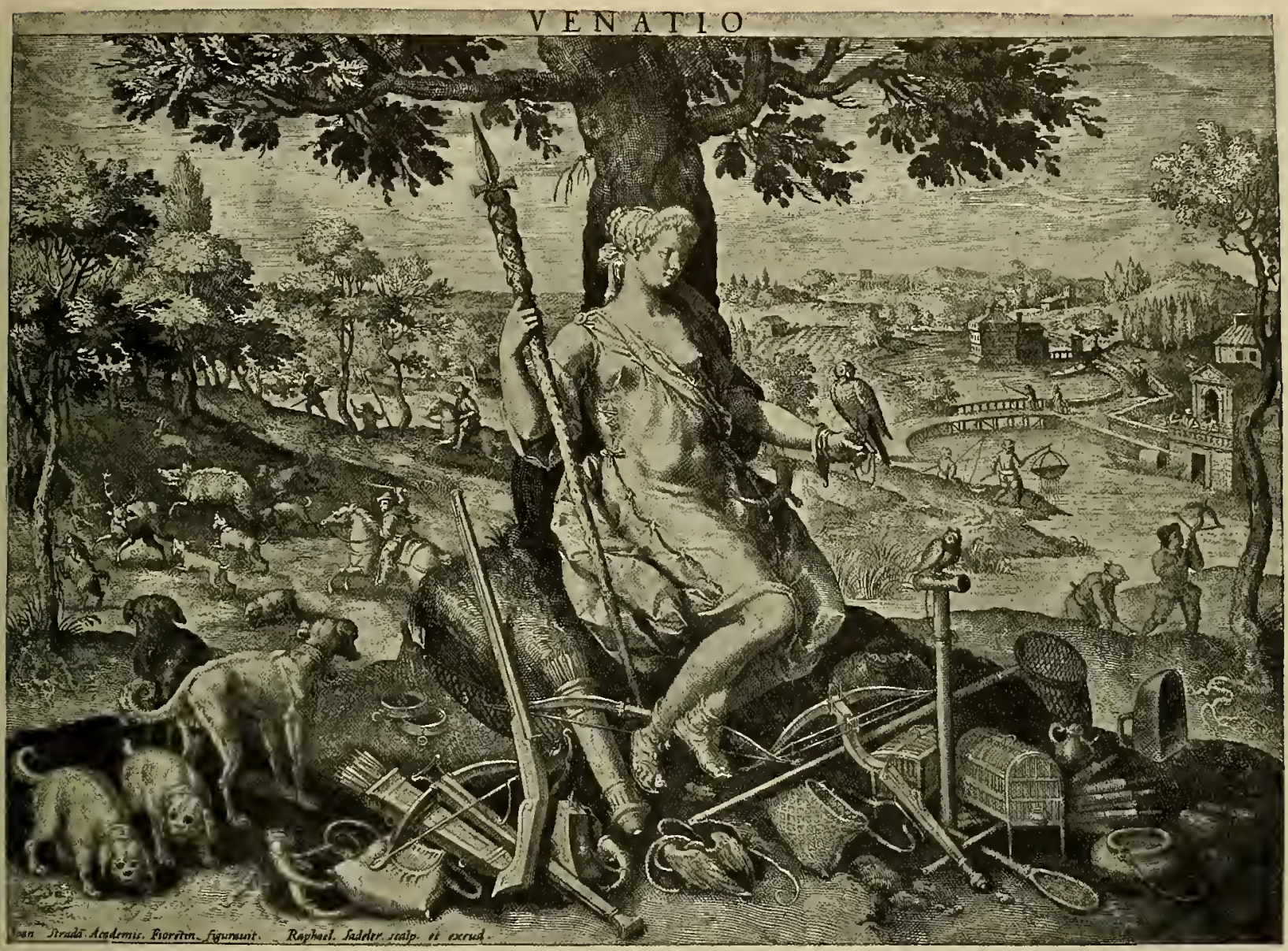

FIG. 81. A SIXTEENTH CENTURY DIANA. ENGRAVING AFTER STRADANUS BY RAPHAEL SADELER. See Page 136

right-hand corner is the artist's signature Foannes Stradanus. Underneath the picture in the print runs a Latin inscription Americen Americus retexit, Semel vocavit inde Semper excitam. It will be best first to examine the picture from the standpoint of

* The engraving after this drawing forms part of the set called Nova Reperta dealing with new discoveries, consisting of twenty plates drawn by Stradanus and engraved by the Galle, which was published by them in Antwerp soon after the exceedingly successful issue of the Venationes. It is of great interest and throws valuable light upon the lives of sixteenth-century craftsmen in Italian towns. 


\section{SPORT IX ART}

the sportsman, zoologist, and botanist. To do so we must remind the reader of the extraordinary nescience concerning America's fauna and flora prevalent in Europe for the first six or seven decades of the sixteenth century. Pictorial representations there were absolutely none during the first seventy years after Columbus set foot on Watling Island, for the rude woodcut which can claim the honour of being the

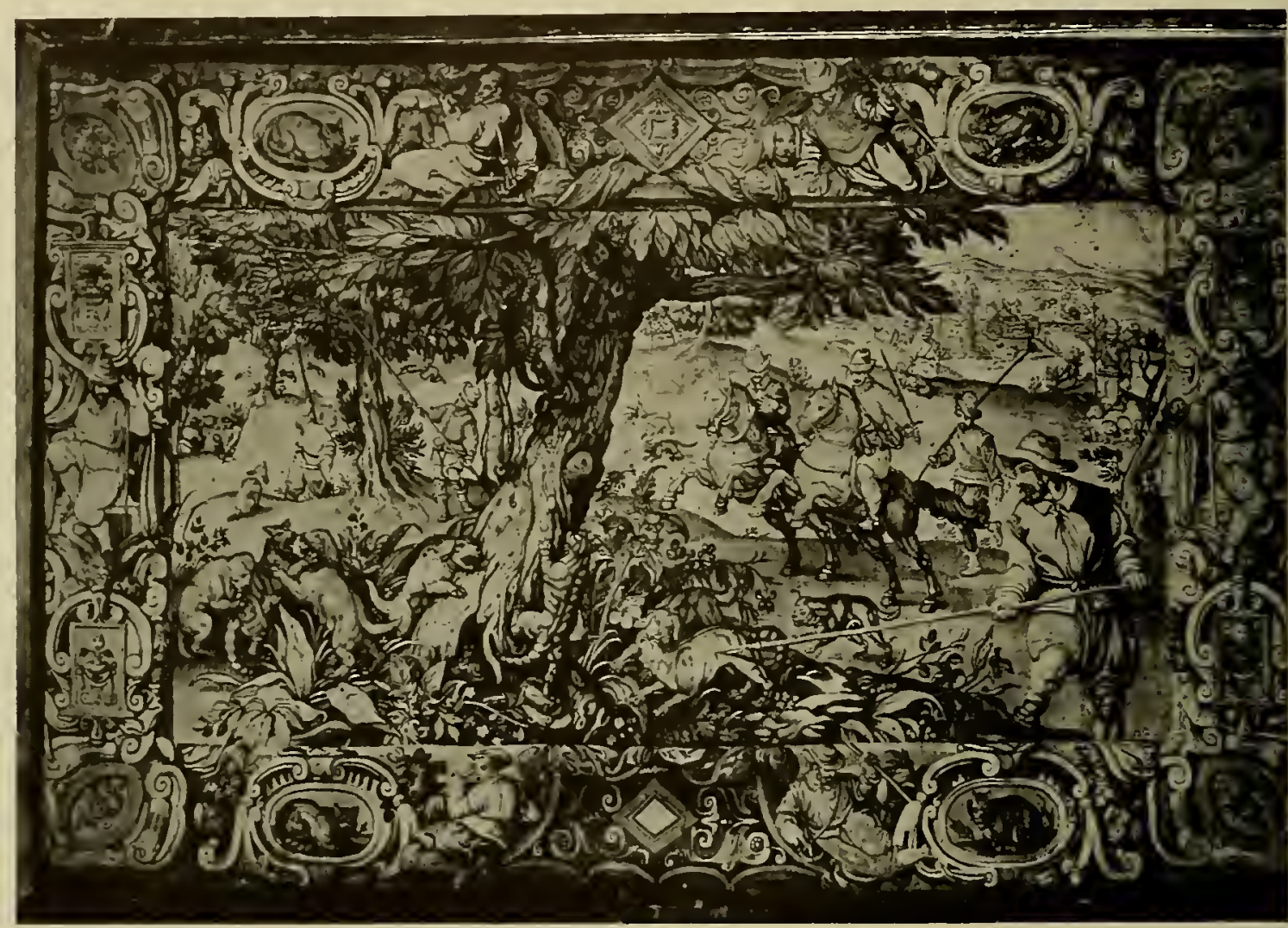

FIG. 82. HUNTING THE WILD CAT. TAPESTRY DESIGNED BY STRADANUS CIRCA 1569. IN THE PALAZZO VECCHIO IN FLORENCE, AND WOVEN AT THE ARAZZIA MEDICAE. See Page 138

first picture of an American subject, issued by an unknown printer in Augsburg five years after the latter event, deals with the natives (it represents the inhabitants of the West Indies preparing a cannibal's feast) and has no bearing upon America's fauna and flora. Indeed, we might extend this period of nescience, so far as pictorial representations are concerned, to almost a full century after the eventful year 1492 which gave the human race a New World. For it was only in the year I 590 that Thomas Hariot's first illustrated edition of "A brief and true report of the new found land Virginia," amazed the civilised world. It is illustrated with engravings 140 


\section{PICTURES OF A MERIGA'S FAUXCA}

" cott in copper the most diligentlye" by Theodore de Bry at Frankfort, after the famous designs drawn by John White in 1585 while he was residing on the island of Roanoke-England's first settlement on what is now United States territory. John White's pencil, de Bry's masterly graver, and Hakluyt's enthusiasm for the new discoveries, combined, produced the first illustrated work of travel in America. Of

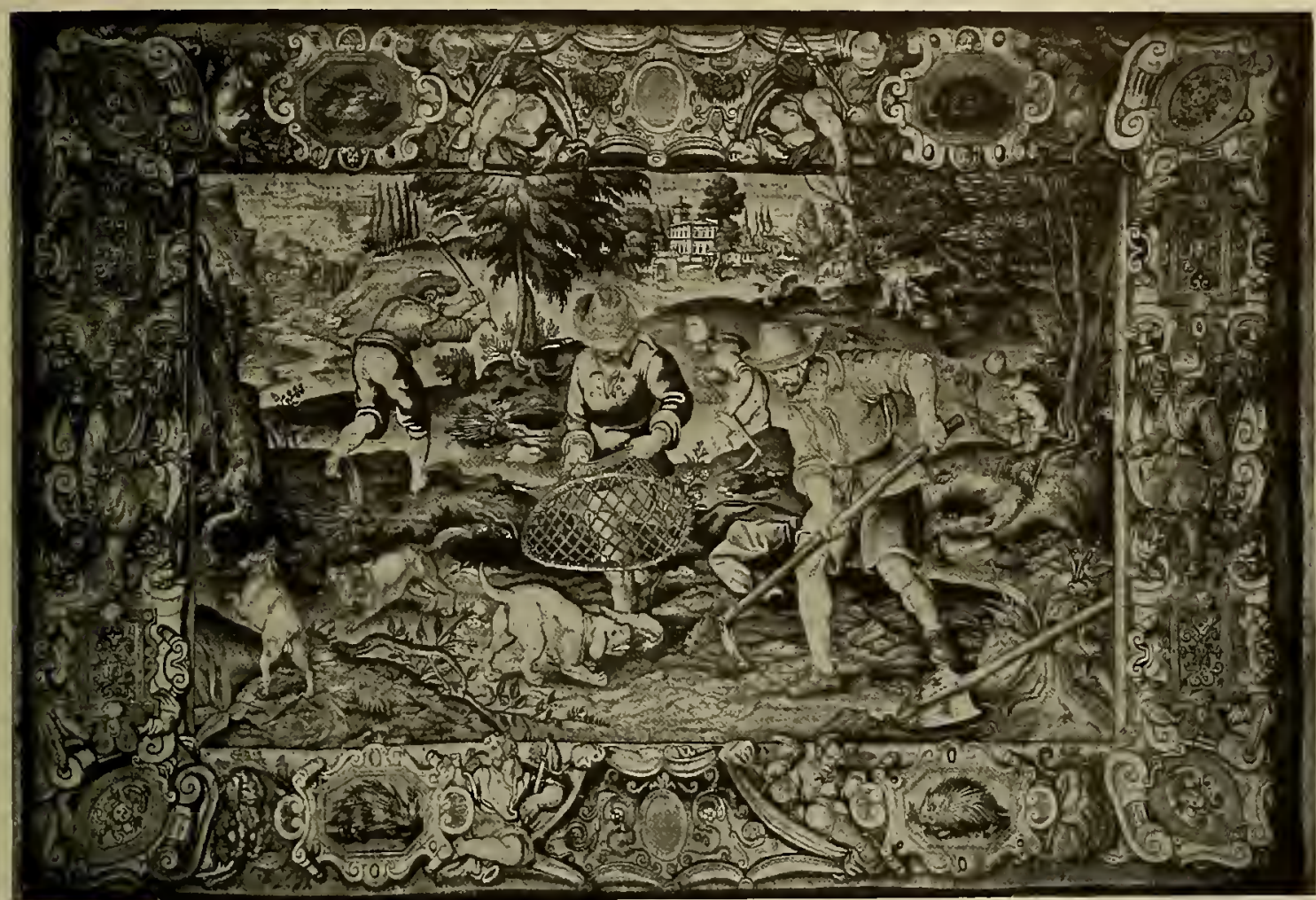

FIG. 83. PORCUPINE HUNTING. TAPESTRY DESIGNED BY STRADANUS CIRCA 1569.

IN THE PALAZZO VECCHIO IN FLORENCE. See Page 138

de Bry's designs we shall presentiy reproduce a few, as the majority relate to the aborigines and their ceremonies, feasts, and dwelling-places, to the exclusion of the fauna and flora, except where White could not well avoid bringing in specimens of either or both. In his text Hariot speaks occasionally of animals and plants, mentioning " eight-and-twenty sortes of beastes which I have heard of to be here," and of "foure score and six kinds of Foule," but White's artist's eye was evidently much more captivated, if not entirely engrossed, by his strange human surroundings, and so he greatly neglected animal and plant-life.

As shall be shown presently, there exist good reasons to suppose that Stradanus drew 


\section{SPORT IX ART}

his landfall of Vespucci at some time prior to White's pictorial efforts, and though the Florentine's picture was not drawn on the spot, as were White's, he had doubtlessly genuine material before him in his studio on the Arno, supplied, we may conjecture, by some of the numerous Florentine or Genoese adventurers who had visited the land of wonders, and had brought back sketches, not only of the natives, but also of animals, plants, and other natural features.

In his drawing the careful Stradanus wrote its name beside each of the animals and plants he depicted; thus, over the anteater standing at the base of the tree in the left-hand corner, he wrote Tamandoa- in the somewhat reduced reproduction the writing is invisible; over the bear-like creature above it the name Cerigon; over the horse-like tapir in the background is the name Anta; next to the sloth climbing the tree we read Pigritia, and finally over the pineapple plant at the base of the tree stands the name Anamaze. These five names were evidently written after the engraving had been finished, as was also probably the case with the word America, written in reversed form between Vespucci's figure, and the scantily clad native queen in the act of welcoming the navigator with outstretched hand. For had these writings been there when the drawing was sent to the Antwerp art establishment for reproduction, the Galles would certainly not have failed to add such interesting information, and would have copied the names on the engraving. Now, as the following shows, the picture must have existed and have been sent to Antwerp in or before the year I 588, for in that year was published in Florence the well-known work Historiarum Indicarum by the Jesuit father Petrus Moffe. A glance at the back of our drawing explains the connection between it and this book. Covering a considerable part of the blank paper, there is a mass of minute writing in Stradanus' hand descriptive of the animals depicted in the drawing on the other side of the paper. Below this writing, which is in Flemish and Latin, are the words "Compare Petrus Moffe the Fesuit's Historiarum Indicarum in the second book." As this work was published in Florence, Stradanus no doubt became acquainted with it in the year of its publication, if not earlier in MS. form, so that the engraving after this original cannot have been executed later than 1588 , and therefore preceded de Bry's publication by at least a couple of years and probably by more. For the interval between the execution of a drawing and the publication of the print after it, was in those days always considerable. Moffe's nomenclature is also of considerable interest as the first attempt in this direction. Assisted by Imperial Counsellor Professor von Wieser, one of the greatest authorities now living on this subject, who, as editor of the famous Cosmographice Introductio, dealt with the world-renowned Waldseemüller Mappemonde, where (I 507) the name America is used for the first time, the writer is enabled to give a brief explanation of Stradanus' minute notes written in Dutch on the back of the drawing. Of the Anteater, he says that it "is as large as a sheep; it has broad feet with which it scratches ants together; it has a large slit instead of a mouth, a long 142 


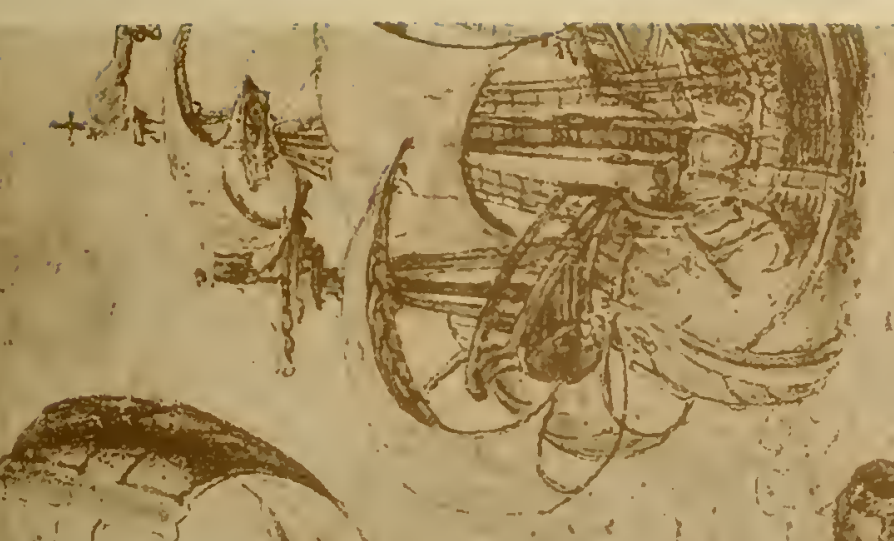

$(2)+10$

4. Dan a

(3) and -

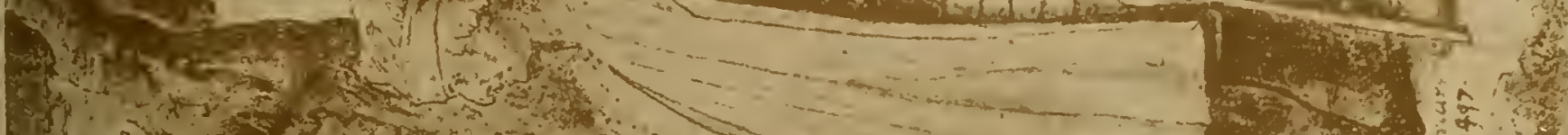

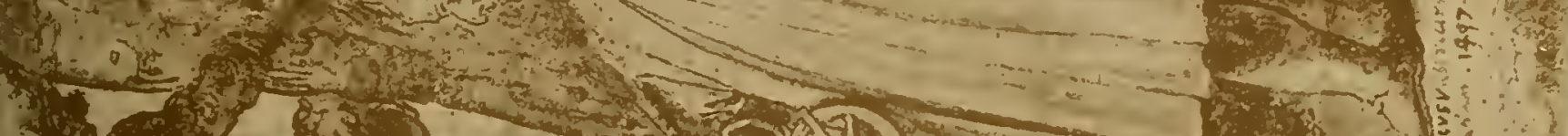

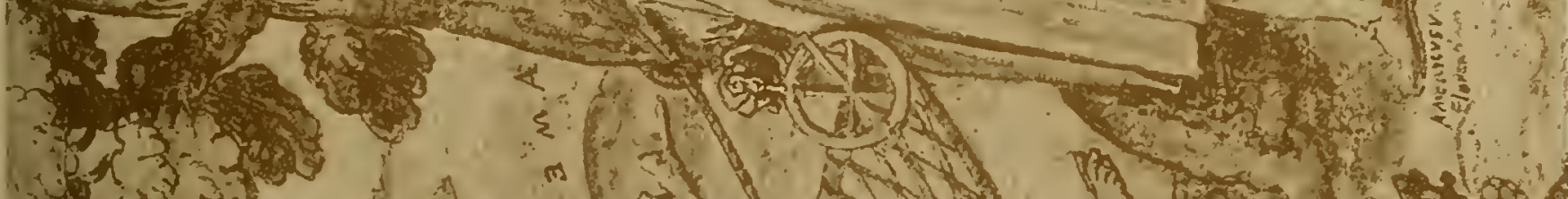

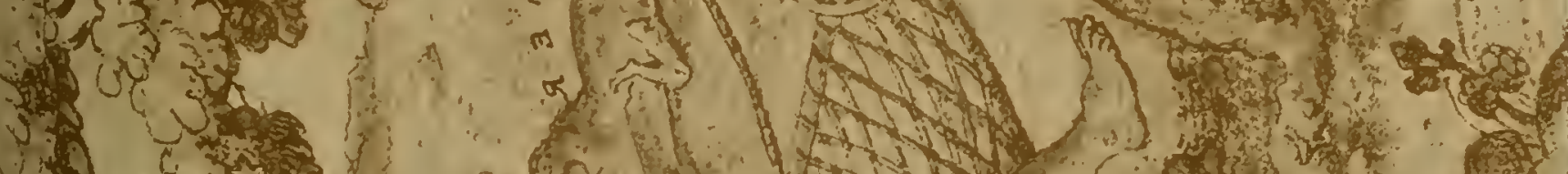

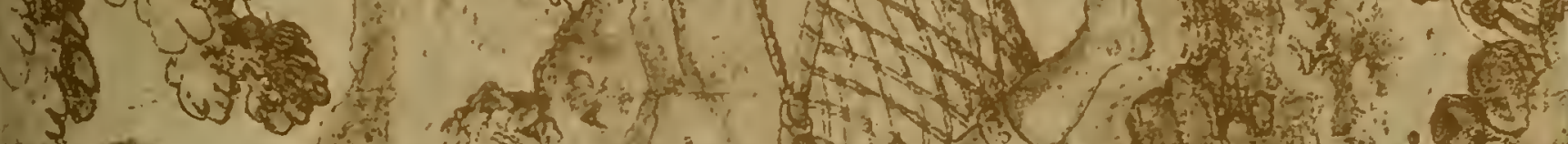

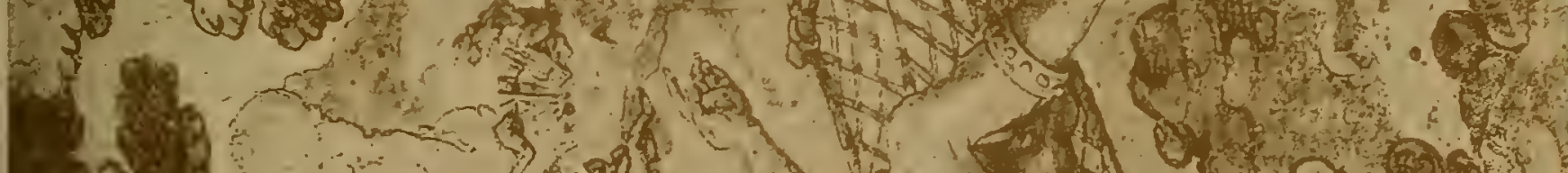

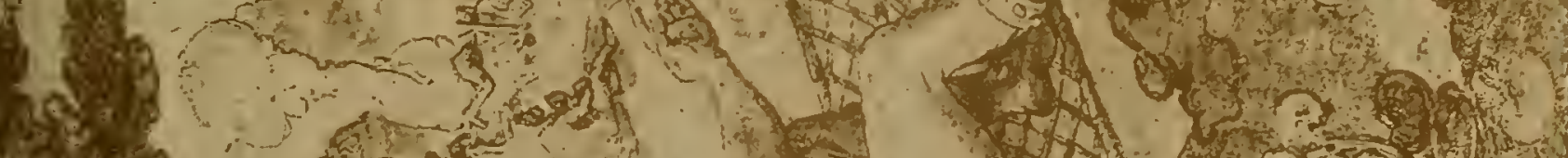

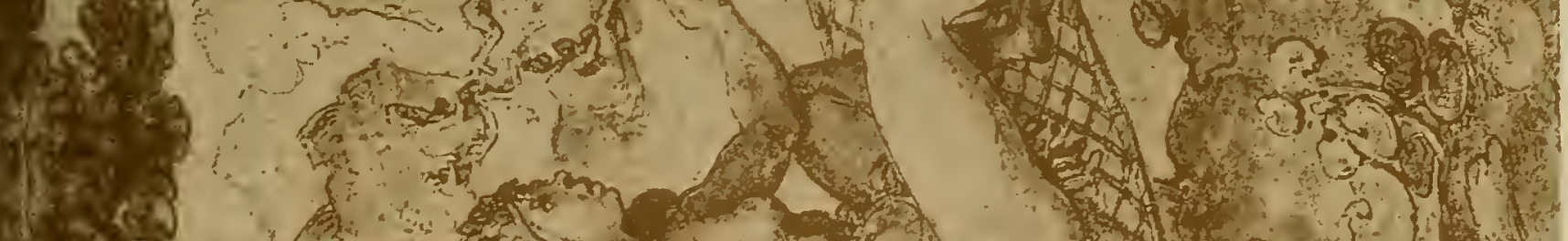

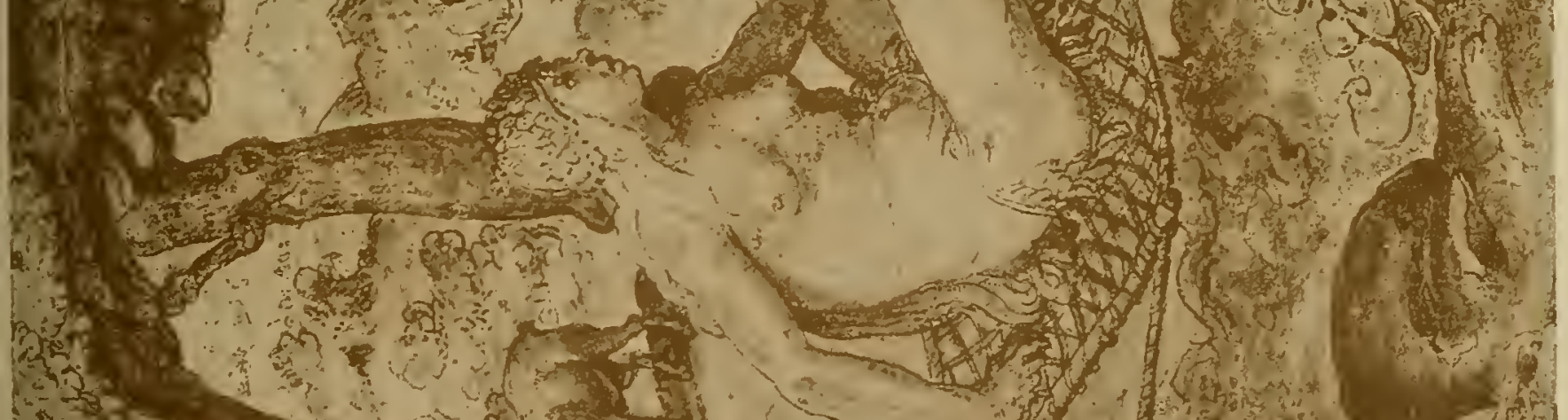
(n)

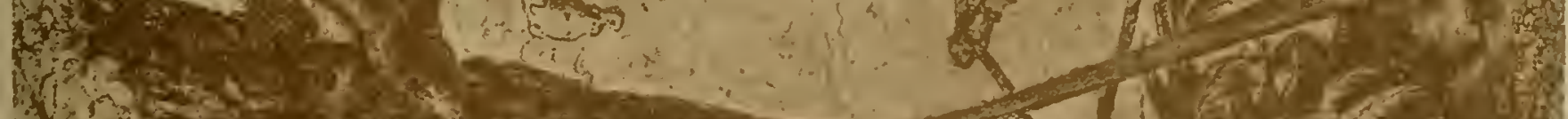

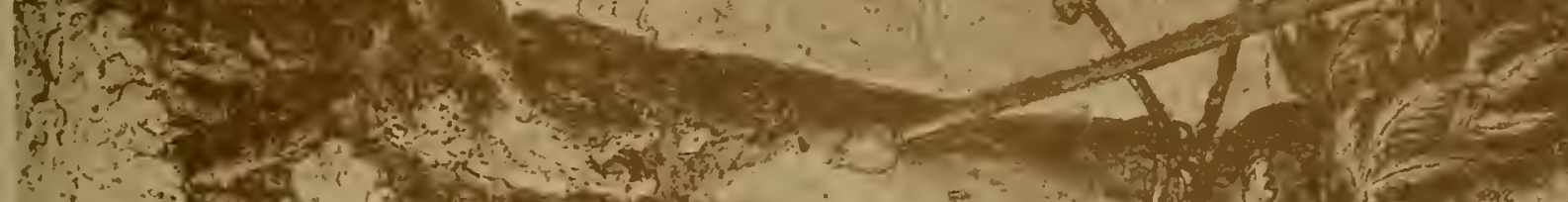

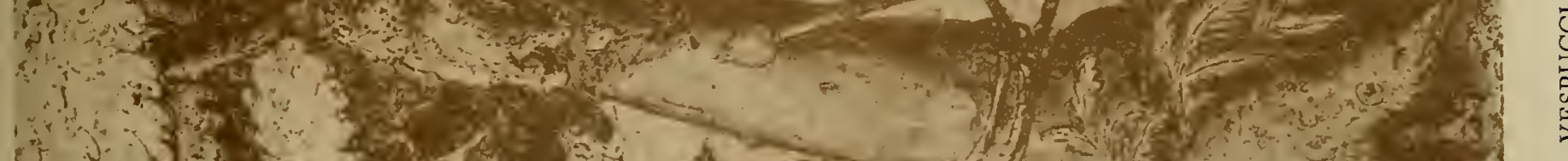
(f)

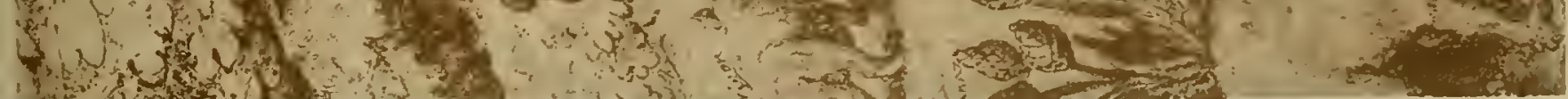





\section{PICTURES OF ARERICA'S FAUXA}

tongue to lick up ants, and a round stern." Of the Cerigon, he writes that it is a beast of the size of a fox, with a hide like a bootlace (sic); it has two bags below at its stomach in which it carries its young who hold on by sucking."

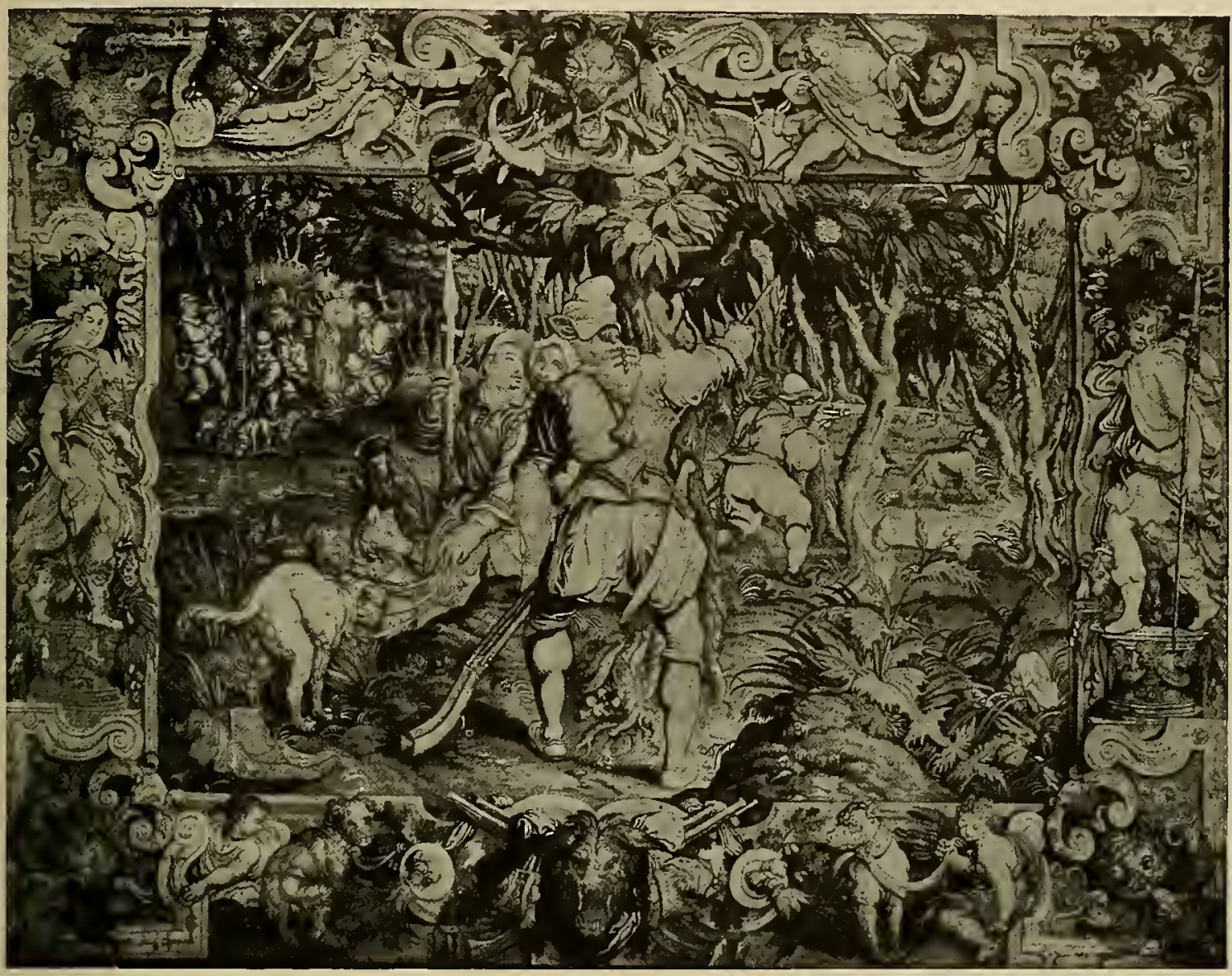

FIG. 84. WILD-BOAR HUNT IN WINTER. TAPESTRY DESIGNED BY STRADANUS CIRCA I569. IN THE PALAZZO VECCHIO IN FLORENCE. See Page 138

"The Anta (tapir) is large as a donkey or a small mule; it has a short tail, round ears, the lower lip round and long."

"Pigritia (sloth) is large as a fox, climbs trees, has fingers on its feet; because of its big belly it walks in fifteen days not further than one can throw a stone."

As an after-thought, probably, for there is no reference to it on the back of the drawing, Stradanus wrote its name above one plant which he depicts, viz. the word! Ananaze by which he quite correctly designated the small West Indian pineapple, called to this day by that name.

Those who are acquainted with White's drawings in the original, or with the 


\section{SPORT IX ART}

twenty-three plates made after them which serve to illustrate Hariot's work, will agree that Stradanus' picture has not a single feature at all resembling anything contained in White's designs. All the animals depicted by Stradanus are indigenous to regions more southerly than Virginia which were discovered by the earlier explorers. The net hammock in which the female is seated corresponds with those described by the latter, and of which no trace can be found in White's illustrations. On the contrary, on the only occasion where White and Hariot refer to the manner in which the natives sleep the former draws a deer's skin bed on the ground, and the latter declares that for a bed the native "hath two deares skinnes spredd on the grownde."

Another detail pointing the same way is that Stradanus makes cannibals of his aborigines, the two trussed human legs, one roasting over the fire, the other lying more in the foreground of the picture, leaving no doubt on that head. This clearly indicates that the artist had in his mind the earlier accounts of Aztec customs of which Prescott and others speak at length, while White's pictorical matter has not a single reference to such habits. We gather, therefore, that there is no trace of Stradanus having copied White's or any other known draughtsman's work, when composing his landfall. Throughout the sixteenth and seventeenth centuries artists copied details in their predecessors' or contemporaries' works in the most barefaced manner, the dearth that prevailed in those days in respect to original material illustrative of foreign countries, and especially in respect to that land of wonders, America, explaining if not excusing the prevalence of this custom. One is therefore fairly safe in assuming that had Stradanus, when he drew his landfall, seen John White's work or its reproductions by Th. de Bry he would have surely betrayed that fact and would not have given us such entirely original impressions of America.

Having said so much concerning this drawing's claim to be the earliest pictorial record of Ainerica's fauna and flora, we still have to revert to another, for artists, interesting fact, i.e. that its principal figure assists us materially in identifying the only existing portrait of Vespucci. Besides the rough marginal woodcut in the framework of Waldseemüller's Mappemonde, supposedly representing the navigator's features, and several quite apocryphal portraits, only one quite authentic picture of Vespucci from life has come down to us. It is, as is probably needless to say, the fresco painted by Ghirlandajo on an arch in what was then the Vespucci family chapel in the Church of Ognissanti in Florence. More than a century after the great master had completed his fresco, the chapel was ceded in 16 I 6 to another prominent Florentine family, the Baldovinettis, and as a consequence the Vespucci picture was whitewashed over. In this condition it remained hidden for nearly three hundred years, when in the spring of 1898 , on the eve of the Vespucci quatro-centenary, a learned enthusiast, Father Razzoli, after lengthy searches in the archives, rediscovered the interesting painting, sending, as many will remember, a thrill of excitement through the art world.

I 44 


\section{VESPUCCI'S LAXX D FALL}

The fresco represents the Vespucci family: the six males being grouped on the one side, the females on the other side of the Madonna of Mercy. When Vasari, in I $55^{\circ}$, in pursuit of his studies concerning Ghirlandajo's works, examined this fresco and described it in his life of that artist, he failed to particularise which of the six males is meant to represent Amerigo Vespucci, "who made the voyage to the Indies." Hence, as no other means exist to identify the hero, nothing positive could be said on this head ; but the following remarks will show that Stradanus' landfall materially assists in identifying which of the males in the fresco is intended to represent the Florentine whose good fortune it was to have a vast continent named in his honour.

Ghirlandajo painted the picture before 1480 , probably about the year 1475 , when Amerigo, who was born in the year I 454 (our style), was a young man of twenty-one. As might be supposed, the ages of the four sons (the fifth figure is that of the father Ser Anastagio Vespucci, the sixth that of the latter's brother, a Dominican dignitary of the Church with a mitre on his head) who are depicted in the fresco would assist one in determining which of them was meant for Amerigo. But this is not so, for the latter's brothers, Antonio, Giralamo, and Bernardo, differed in age from him by one or two years only, and as ali four are represented with clean-shaven faces, the picture furnishes no decisive clue. The Art Commissioners, consisting of famous experts, that soon after Father Razzoli's memorable discovery, examined the fresco with a view of determining this very question, were unable to arrive at decisive conclusions, but they expressed the belief that it was probably the youngest looking of the four Vespucci sons-the one standing between the white-locked father and the Madonna-who was meant for Amerigo. Now if we examine Stradanus' landfall and compare Vespucci's face with the physiognomies of the four youthful personages in the fresco, all doubt is at once removed. For among the latter there is only one-that of the youth standing between the father and the Madonna-which could possibly, in after age, develop into the aquiline-nosed, strongly marked features or Vespucci as Stradanus has represented him.

As Vespucci died in 15 I 2 , eleven years before Stradanus was born, the latter's picture of his famous townsman can make no claim, of course, to be a portrait in the true sense of the word; but, on the other hand, it is more than likely that real portraits were then still in existence, and were before Stradanus when he drew the landfall. For as one of the first artists of Florence, Stradanus would have hardly dared to palm off an imaginary portrait of a local celebrity whom some of his fellow citizens must have still seen in the flesh.

The strong family resemblance between Amerigo's father in Ghirlandajo's fresco and Stradanus' Vespucci is but another link in the chain of evidence that lends importance to our drawing. 


\section{CHAPTER VII : HANS BOL, VINCBOONS, THEODORE DE BRY AND ANTONIO TEMPESTA}

$\mathrm{T}$

HOUGH our last chapter took us several times into the seventeenth century we have to retrace our steps before we can say good-bye to the preceding one. And it is with one of our favourite Little Masters that we propose to commence. Hans Bol, born in Malins in 1534 , has left us some charming contributions which, according to Carel van Mander, placed him in the front rank among the one hundred and fifty artists who were making Malins one of the great art centres of the time.* His work is distinguished by its free touch and minuteness, his delicate drawings resembling fine miniatures. The wide-spread demand for pictorial series descriptive of field sports caused also this artist to take up our subject, probably at the instigation of that very "live" Antwerp art publisher, Philip Galle. Though hardly four years had elapsed since the latter had sent forth Stradanus' Venationes, and his presses were still busy producing fresh editions of it, his picture-loving customers received very favourably Hans Bol's charming series, consisting of forty-eight engravings, entitled Venationis, Piscationis, et eAucupii Typi. The first edition, which bears the date I 582 , is dedicated to the Brabant noble Paul de Kempenare, a compliment by which the artist probably desired to show some recognition of favours received. Further particulars about this set will be found in the Appendix.

An interesting little picture in this series is Fig. 86, depicting a duck-decoy ; for we do not think we go wrong in saying that this is the oldest picture of these once fashionable contrivances, if we except the drawing of what is more a ducktrap than a decoy which occupies the background of Stradanus' Fig. 66.

Sir Ralph P. Gallwey, in his book on "Duck Decoys" (1 886), states that the earliest sketch of a decoy and its pipes is to be found in Ogilby's "Fables of Æsop," published in 1665 , and he also says that the first and most reliable description of a decoy in England is Evelyn's account of Charles II's decoy in St. James's Park made in 1665 . Mr. Harting, in a capital paper in the "Zoologist," I 886 , pp. $382-4$, corrects these statements by pointing out that much earlier pictures were published by Tempesta in his Venationes Ferarum, citing three editions, Rome 1602 and 1605 , and Amsterdam 1627, as well as in his eAucupationis multifariae effigies, Amsterdam I 639, see Fig. I03, adding that another like picture by Hans Bol was published 1582 by Philip Galle, which is none other than our Fig. 86. He describes this picture as representing a dog who "is swimming and driving the fowl towards the pipe" ; this he declares quite rightly to be a mistake, 


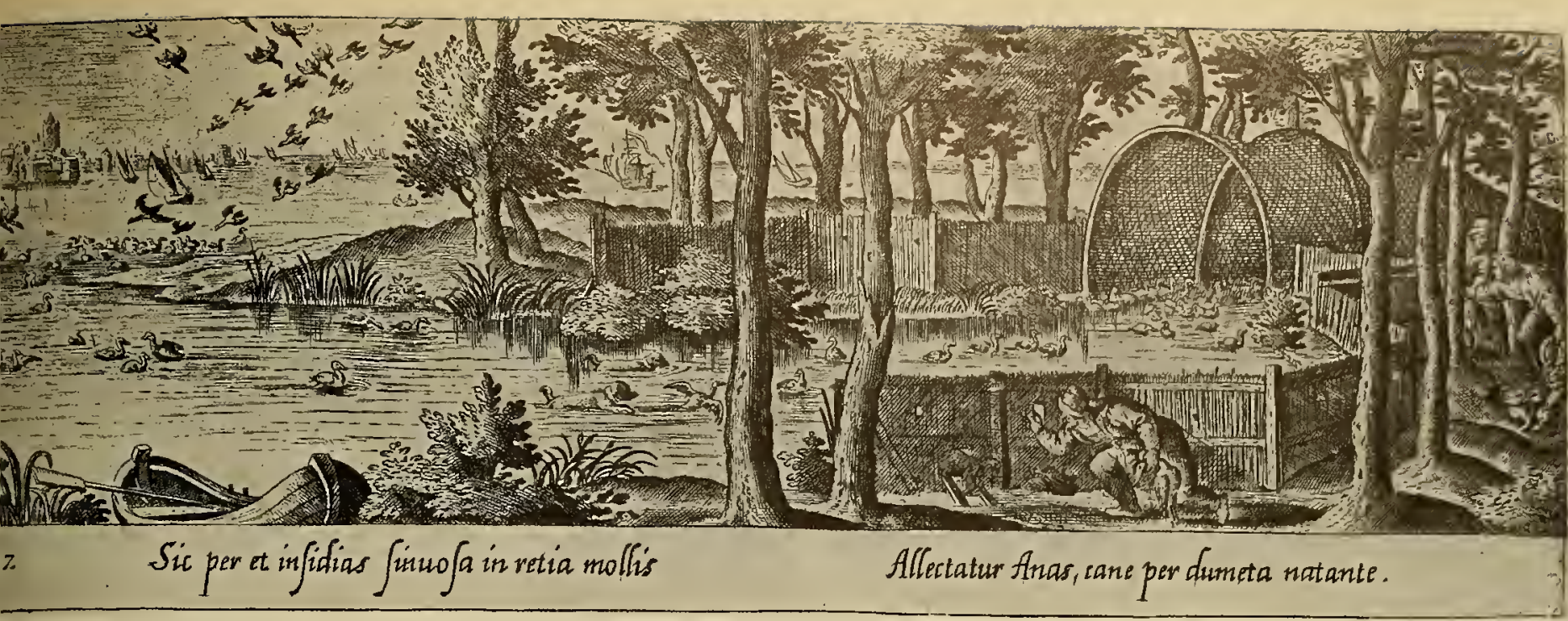

3. 86. A DUCK DECOY; THE DUCKS IN FRONT OF THE TWO DOGS ARE TAME “TRAITORS," WHILE E DUCKS FOLLOWING THE DOGS ARE WILD BIRDS, WHO ARE THUS SNARED. DESIGNED BY HANS BOL; BLISHED 1 58z. OUT OF HIS “VENATIONIS" SERIES. See Fig. 103, and Pages $146-149$

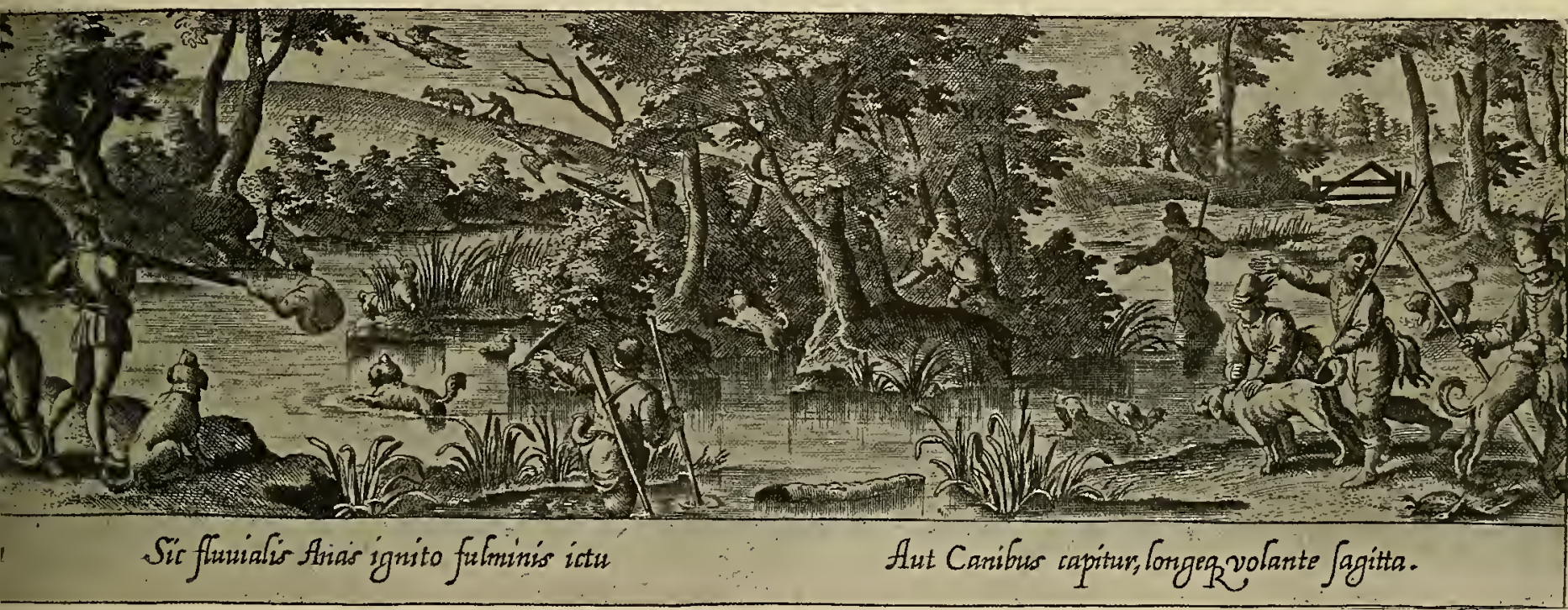

3. 87. DUCK SHOOTING WITH SPANIELS. DESIGNED BY HANS BOL; PUBLISHED A.D. I582. See Page 149

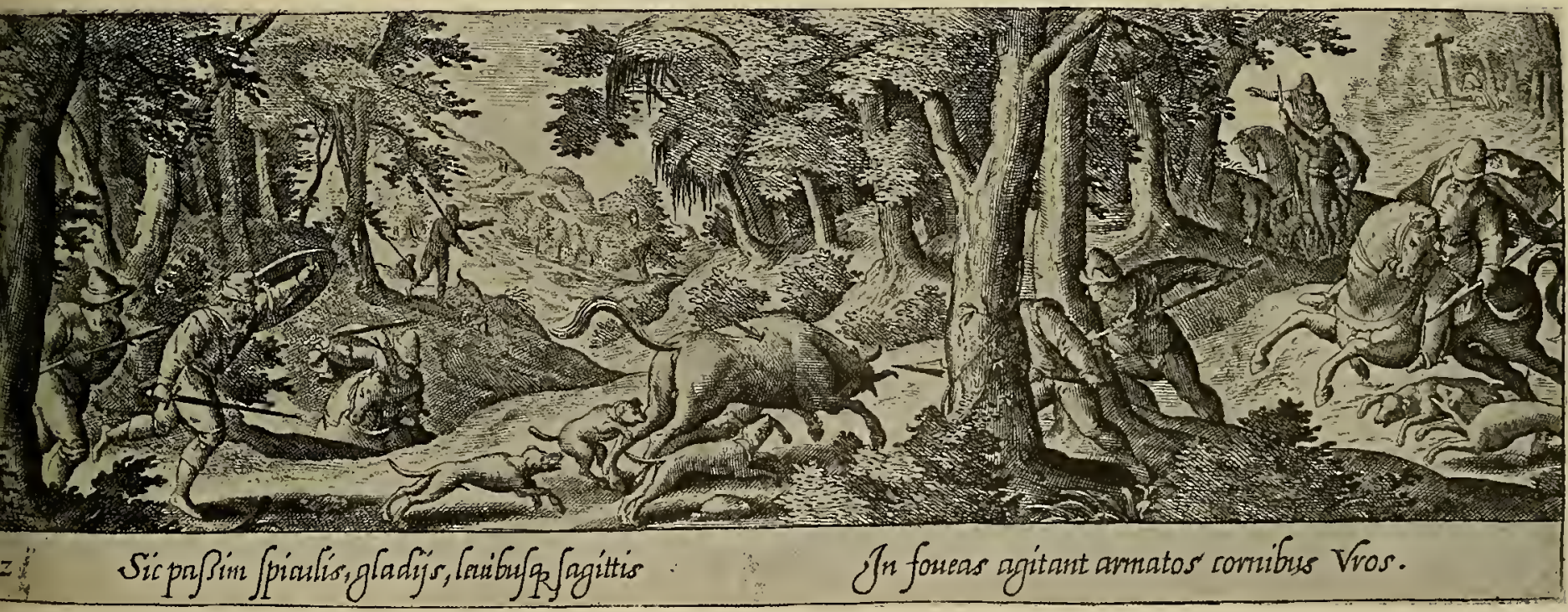

8. 8. AUROCHS HUNTING. DESIGNED BY HANS BOL; A.D. 158z. See Figs. 20, 46, 47, 79, 88, 99, 102, I10, I5I, 210, 227 ; also Pages 37-5 I, 86-90, 149 



\section{DUCK-DECORS}

owing to the artist's evidently not understanding the modus operandi. Now, while it is quite true that it would be a mistake to represent dogs driving ducks into the pipe-an error, by the way, into which Tempesta fell-dogs being used to entice ducks gradually to approach the pipes and not to drive them, we do not quite agree with Mr. Harting when he says that Bol made this mistake. The two dogs in Fig. 86 are not driving wild ducks, for the birds which are in front of them are evidently tame decoy-birds, so-called "traitors," trained to the work.* These, as well as the dogs, are luring on the wild ones, which we see swimming behind the dogs. That this was the artist's intention is shown by the Latin inscription below the engraving, which reads: "Also by means of a dog swimming in the shady pools, the gentle duck is thus lured into winding nets." + Tempesta, on the other hand, as we have already said, did fall into this mistake, and there is no doubt that in his engraving, Fig. 103 , the swimming dog is driving before him a flock of wild duck, no other birds being behind him. The "Book of Duck Decoys" contains ample proof that these appliances were introduced into England from the Netherlands, and that even as late as 1678 they were still spoken of as "new artifices lately introduced by the Dutch." Sir William Wodehouse $(1603-25)$ seems to have made the first Koye, as duck-decoys were then called after their Dutch name in England, and great catches were made-Daniels mentioning one of 3000 mallards at one drive, and Willughby mentions that 4000 duck were taken at Deeping on a similar occasion.

Fig. 87 is another picture by the same artist, which also deals with wild fowl. The inscription below : "The river-duck is thus captured, either by gun-shot, or by dogs, or by the far-flying arrow," covers the ground. If the man in the bushes on the island is raising his fire-arm to take a flying shot, it would be a very early picture of that proceeding, but it seems more likely that he is intent upon an easier task, i.e. attempting a pot-shot at the fowl in the reeds in front of him.

Of Fig. 88, describing an aurochs hunt, we have already spoken in a previous chapter (p. $\left.3^{8}\right)$ and we need say here no more about it.

A really interesting engraving is Fig. 8y, showing how partridges were shot with the cross-bow as well as captured with the goshawk; though we must not understand that the two were carried on at the same time, for naturally one form of sport would interfere with the other. The correct rendering of the faulty Latin inscription caused trouble to more than one expert classical scholar to whom the writer submitted these brief lines. Mr. Harting, at last, was able to solve the difficulty by suggesting that by the substitution of certain corrections the rendering is made to read: "Thus in the furrows

* Where the use of "traitors"-i.e. tame ducks attached by their legs to some stone or stick under water-originated is not known. The use of tame ducks to attrace wild fowl is alluded to in Epigrammata Selecta, Basel, I 529.

† Mr. Harting speaks of this Bol print as No. "27" ; it should be "22." 


\section{SPORT IX ART}

of the cornland is taken the wily partridge with her long train (or flock) of small young." It will be noticed that the three goshawks about to be Hown are, as it were, on leash-an altogether unusual proceeding. Mr. Harting explains this by suggesting that the hawk has varvels at the end of the jesses instead of a sivivel, and the man taking hold of the button-end of the leash is allowing it to run through the varvels, with the result that the hawk will fly away without it. Goshawks, Mr. Harting says, were often flown in this way as a saving of time, instead of detaching both jesses from the swivel, which would take longer.

Of fishing $\mathrm{Hans} \mathrm{Bol}$ presents us with no very exciting pictures, so we have selected but two, Figs. 90 and 91 , not to leave his treatment of Walton's art entirely unnoticed. The inscriptions, however, are too quaint to be passed over. Under the one we read: "Scaly fish are thus caught with a hook, a waxed line being attached to a quivering rod." The other one runs: "Thus the artful fisherman drives the large salmon from the open sea to the mouths of a river." Fishing the tunny, the haddock, the carp, the turbot, the cod, the sea-turtle, the anchovy, the crab and shell-fish, have each an engraving, while to the fish-market is devoted a particularly charming print, full of the most life-like details.

A little known Malins artist has left us a few delightful little sporting prints, i.e. David Vincboons, spelt also Vincboins and Vinckboons, whose work resembles Hans Bol's, though he was of a younger generation. For when Vincboons was born in I 582 Bol was already close on fifty. Vincboons designed a charming set of ten sporting prints from which we reproduce two, Figs. 92 and 93 . The former gives us a characteristic picture of fishing in the still waters of a canal in the vicinity of a Dutch town, a sport that delighted the phlegmatic burghers of the Netherlands. This set was published in I6 I 2 by a rival Antwerp establishment of the Galle, i.e. the Visschers who following the fashion of the day latinized their name into Piscator. One of them, Claes Ian of that ilk, is mentioned as publisher, and another, Nicolaus, as the engraver ; but this holds good only for a few of the set, for Fig. 83 , a charmingly composed hawking scene, and six others of the set, were engraved, as the signatures show, not by him but by a little known artist named $P$. Serwout, whose clever work deserves greater fame than it has hitherto received. Again we see amatory felicity brought into familiar touch with sport, and such homely scenes of placid domestic bliss were probably often witnessed in the outskirts of Flemish towns. Fig. 94 is a reproduction of a far larger plate and depicts a very kaleidoscope of sport in the environs of a Dutch town. Vincboons painted chiefly in oil, and his canvases enjoyed a great reputation. Like Van Dyck, he visited England, his stay there probably falling in the

* For terre there should be substituted terrae; for orne, ornae; for sobolis, subolis; for parue, parvae ; for Dedala, Daedala. Subolis in the sense Horace gives it, lascivi subolis gregis, would make sense, and the last word means the personification of artifice.

I 50 



\section{THEODORE DE BRT}

same year (I620-2I) in which his famous countryman paid his first visit to our shores. A picture of Richmond Palace seems to be the only remaining proof of his short stay in England.

In now turning to Theodore de Bry's work we reach a topic already touched upon in the previous chapter, which is of interest to the naturalist as well as to the sportsman. It will probably never be cleared up how it came that a Frankfurt engraver dwelling in a dull country town in the interior of Germany, far from seaports and persons engaged in over-sea commerce, should be the man to collect together and with the aid of his wife, his two sons, and his two sons-in-law, Matthew Merian and William Fitzer, illustrate and publish that famous set of the Major and Minor Voyages to America and the Indies, consisting of no fewer than twenty-five volumes in Latin, twenty-seven volumes in German, and like numbers in English and French, adorned with hundreds of engravings, woodcuts and maps. It was altogether a unique performance! Theodore de Bry, as his name indicates, sprung, however, from an adventure-loving stock, and left his native town of Liège, where he was born in 1528 , because of the persecution his Protestant proclivities had called down on his head. But his artistic talents alone would not have sufficed to create this library of Voyages had he not possessed an even more essential gift, viz. of discovering the requisite material. This he did in the shape of drawings made by the Huguenot, Morgues Le Moine or Le Moyne, one of the first settlers in Florida, and the Englishman John White, who was one of the founders of Roanoke, Britain's first colony on what is now U.S. territory. The former drew his pictures in I 564, the other twenty-one years later. Morgues Le Moyne, we must mention, was one of the few who escaped the fearful massacre by Mendez which was the death-blow to Coligny's attempt to establish Huguenot settlements in Florida under Ribault and Laudonnière in I 562-64. Le Moyne after this tragic episode entered the service of Raleigh, and no doubt it was he who influenced Raleigh to induce Hakluyt to publish in 1584 his "Particular Discourse concerning Western Discoveries," in which attention was drawn to the importance of exploring the countries just north of that which Laudonniere described in his journals and which was pictured in the maps and drawings of Le Moyne. It was in consequence of this treatise that Queen Elizabeth granted to Raleigh the desired charter to make discoveries and found plantations during the next six years. Raleigh very promptly sent out an expedition to this promised land, which was none other than Virginia. The little fleet of seven sail, under the command of Sir Richard Grenville, left Plymouth on April 9, 1585 , and the principal result it achieved was the establishment of the already mentioned colony. Among the I 08 settlers left there when Grenville returned to England was this very John White, or as Theodore de Bry called him, Joanne With,* a skilful draughtsman who during

* On the map drawn bv John White with the word "Virginia" across it, engraved by de Bry, the latter wrote "Autore Foanne IV ith Sculptore Theodore de Bry Qui et excud." 


\section{SPORT IX ART}

the twelve months he resided there drew what are without question by far the most important pictorial contributions to our early knowledge of America that have come down to us. For the earlier drawings by Le Moyne have perished, so that we know them only from the engravings made after them by de Bry.

One circumstance that might possibly explain why Theodore de Bry took such an absorbing interest in America, is the fact that among the eleven or twelve men who, with Le Moyne, escaped the Florida massacre in 1564 , was a young man

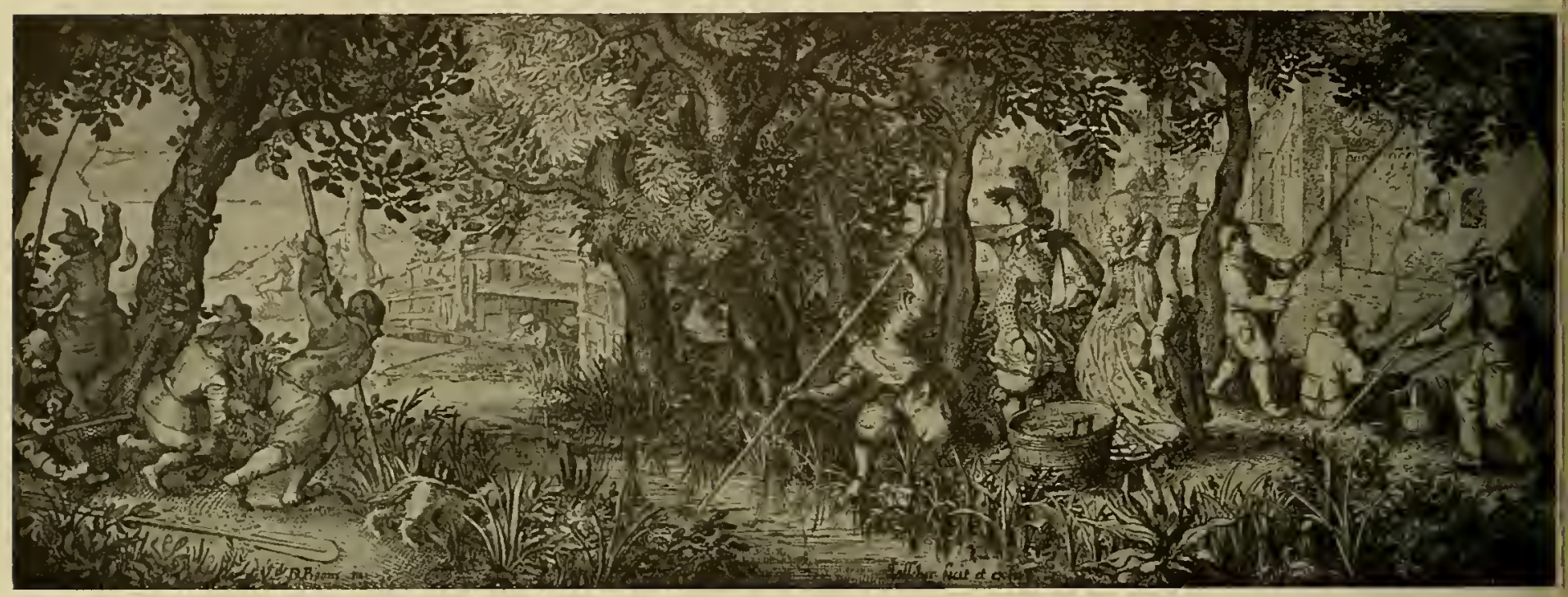

FIG. 92. FISHING IN STILL WATERS; SCENE ON A DUTCH CANAL. DESIGNED BY D. IINCBOONS (1572-1629); ENGRAVED BY C. VISSCHER; PUBLISHED IN I6I2. See Page I 50

named de Bry, who may have been a brother or near relation of Theodore, or possibly, but not likely, he himself. Theodore de Bry paid two visits to London, the first in 1587 and the next in 1588 . On the first visit he went to see Le Moyne, who was living in Blackfriars, and endeavoured to obtain from him his invaluable drawings, but he failed in this. When Le Moyne died, which he did a few months later, de Bry hurried over to London, and succeeded in purchasing these invaluable drawings from the widow. It was on this second visit that de Bry was introduced to John White, and the whole big project of publishing a great illustrated work on the Voyages to America, which was to be dedicated to Raleigh, took shape and was thoroughly gone into by the four persons chiefly concerned, i.e. Theodore de Bry, Hakluyt, John White, and Thomas Hariot, the latter's companion and author of the "Narrative of the First English Plantation of Virginia." When de Bry returned to Frankfurt he had in his possession accurate copies of White's maps and drawings, and the I 54 


\section{LE MORXE'S DRAWIX}

whole of Le Moyne's original pictures-treasure trove of quite unique value and interest. Two years later ( 1590 ) the first parts dealing with Virginia appeared, the description of Florida following the next year; and from that time on until I634 this extraordinarily diligent and intelligent family-old de Bry died in I 598 - published to an eager world the volumes of Voyages already enumerated.

In whose hands White's original drawings remained for the intervening two hundred and seventy-five years is not known, but on August 11, 1865, these priceless

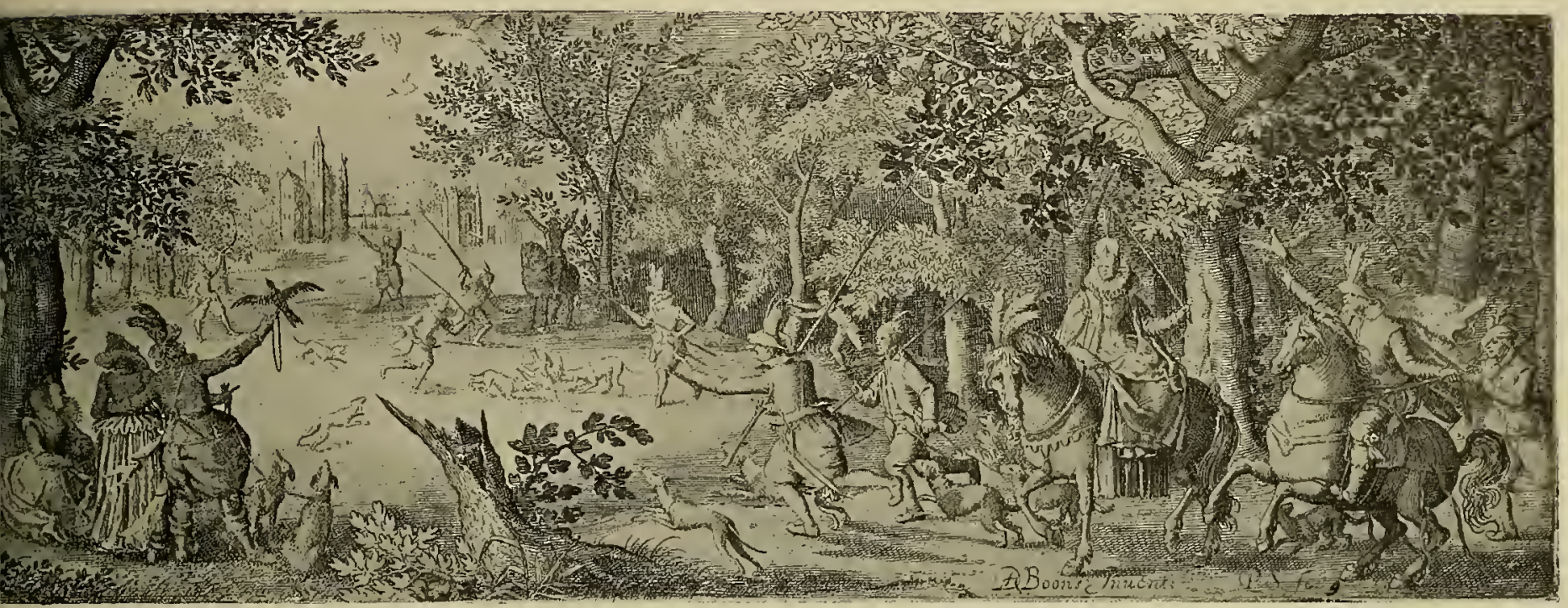

FIG. 93. DUTCH HAWKING. DESIGNED BY DAVID VINCBOONS (1572-1629), AND ENGRAVED BY P. VAN SERWOUTERS; PUBLISHED I612 BY CLAES VISSCHER. See Page 150

sketches turned up at Sotheby's rooms when Lord Charlemont's library came to be sold. Incredible as it sounds, a private purchaser, Mr. Henry Stevens, secured for a very trifling sum ( $\left.f_{0}, 25\right)$ what to American collectors, who willingly give hundreds of thousands for foreign canvases that have no bearing whatever on the history of their own country, should have proved of supreme value. And still more extraordinary, the purchaser's efforts in America to dispose of these, the earliest pictorial records of America's discovery, proved unsuccessful, and a kindly providence caused them to be secured for all time to the Motherland, the British Museum securing them in 1866 for a sum but slightly in advance of the price paid for them the year before!

There is one exceedingly curious circumstance connected with the smaller of the two volumes in which they have been bound. On opening it one discovers a number-there are seventy-three to be exact-of faint copies of the drawings that occupy the larger volume, and these replicas seem all the more inexplicable as they 


\section{SPORT IX ART}

are all reversed, i.e. as if they were printed off from the originals. The following is the explanation, which shows how near it came that these treasures shared the fate of Le Moyne's sketches, though on a different occasion. At the great fire at

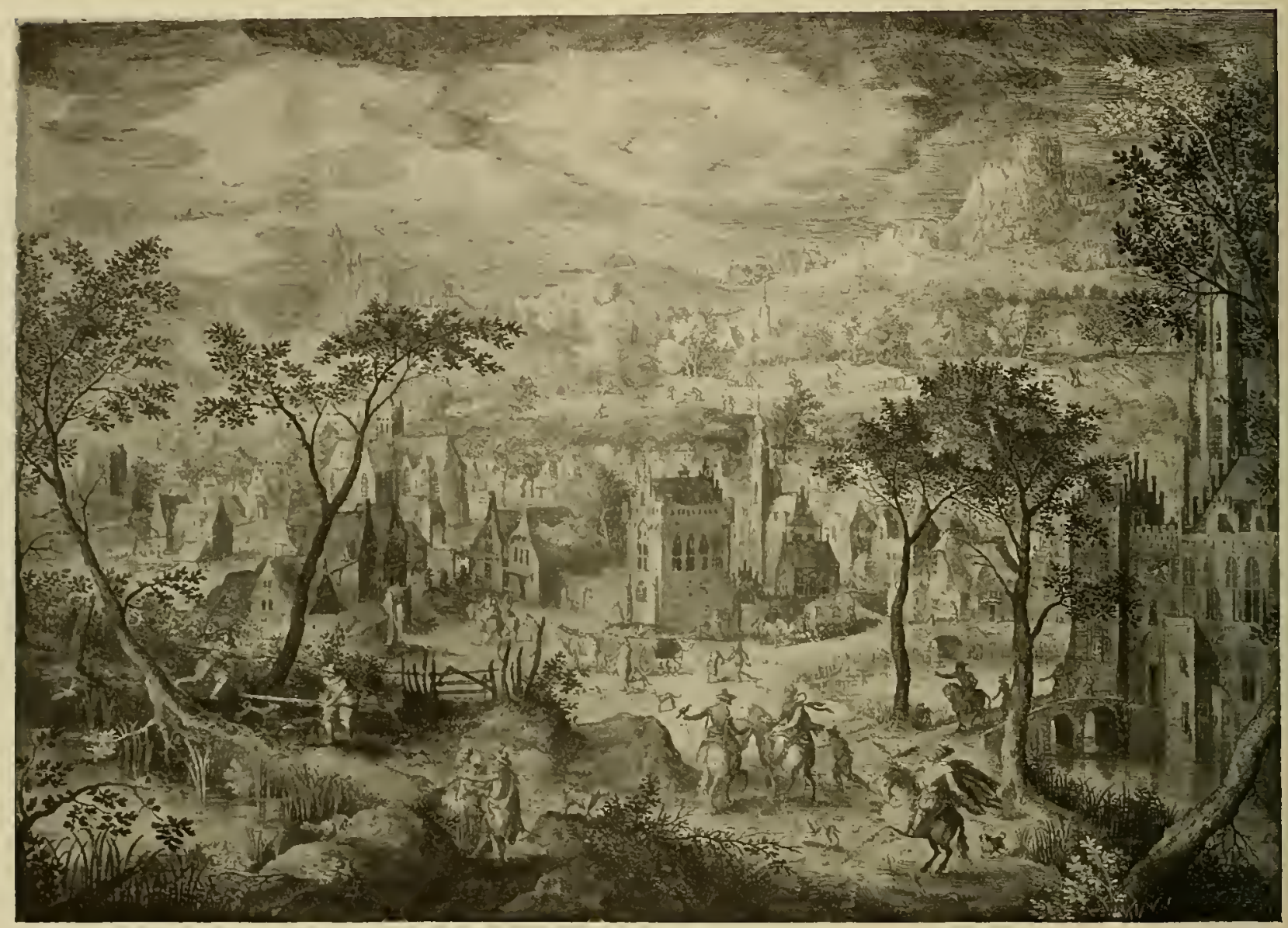

FIG. 9f. VARIOUS DUTCH SPORTS IN THE OUTSKIRTS OF A TOWN. DESIGNED BY Dayjd Vincboons, BeginNing of Seventeenth CENTURy. See Page 150

Sotheby's in June I $86_{5}$, a few weeks previous to the sale, the drawings were saturated with water and remained so for three weeks, the heavy pressure under which they rested producing these remarkable "off-takes" or reversed replicas. These Mr. Stevens carefully preserved, reversed in the binding and sized at considerable cost of time and money. Though they are not as distinct, of course, as the originals, some of these self-printed copies are quite sharp and clear.

Our first picture (Fig. 95), engraved by de Bry after Le Moyne's sketch, depicts an Indian ruse by which native hunters approached deer in the wilds of Florida. 156 


\section{IXDIA $\mathcal{X} S$ ST ALKIX DE DER}

Neither from this drawing nor from the text does it become clear to us what species of deer this picture means to represent. We are told that of "deare in some places there are great store: neere unto the sea coast they are of the ordinarie bignes as ours in England \& some lesse : but further up into the countrey where

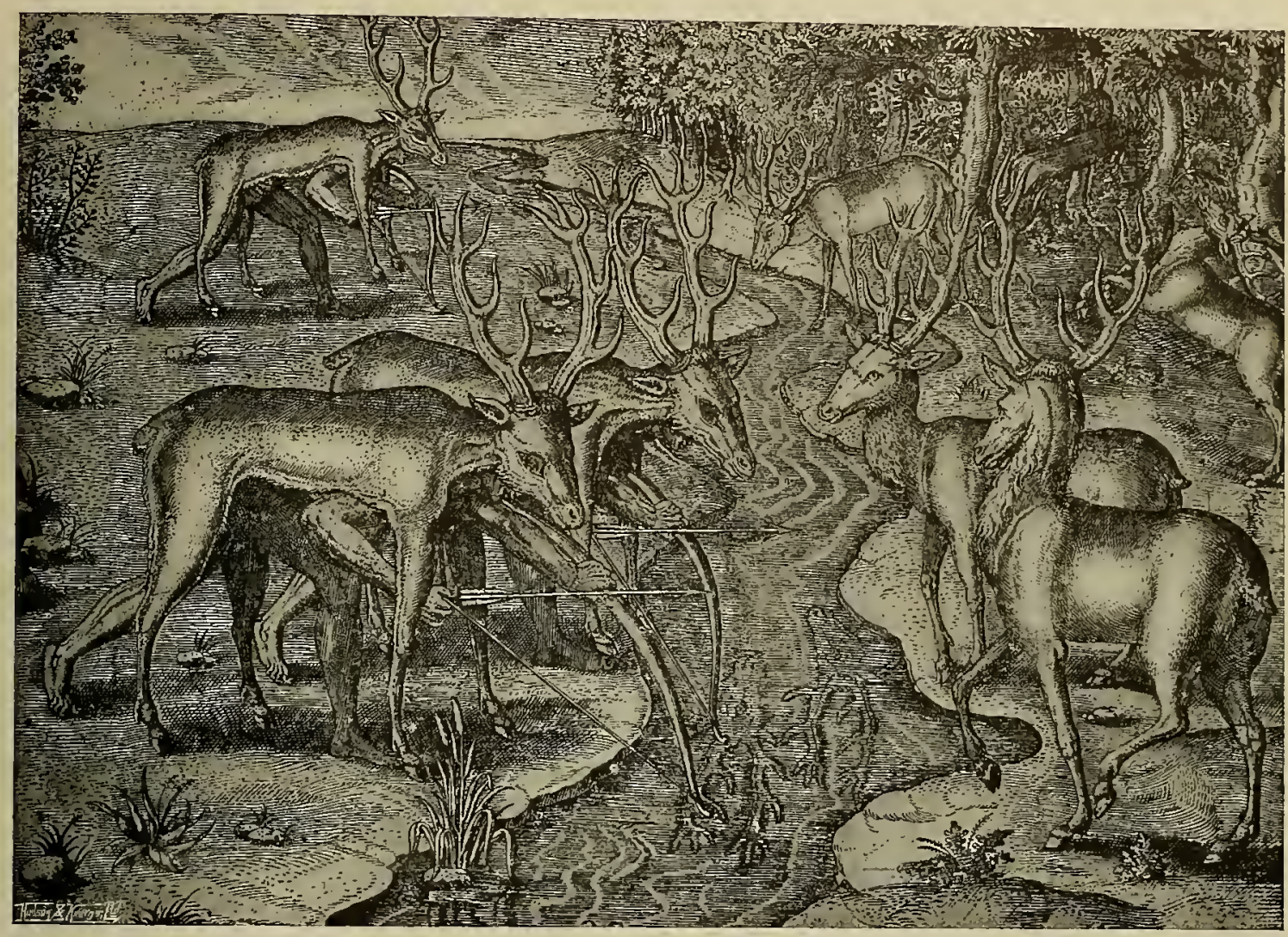

FIG. 95. HOW INDIANS APPROACHED DEER. FROM LE MOYNE'S “TRAVELS IN FLORIDA.” ILLUSTRATED BY TH. DE BRY OF FRANKFURT. EDITION 1591. Pages 153-159

there is better seed they are greater : they differ from ours onely in this, their tailes are longer and the snags of their hornes looke backward." Lacking further information we must conclude that they are meant to be white-tailed deer, and not wapiti, although the formation of the antlers is decidedly more like the wapiti's than that of the much smaller $C$. Virginianus; though, on the other hand, wapiti never have "royals" or three tines on top as some of the antlers in the picture bear.

The other three engravings (Figs. 96, 97, and 98) by de Bry tell their own tale; they are, unfortunately, the only "sporting" subjects engraved by de Bry, for the 


$$
\text { SPORT IX ART }
$$

fascination exercised upon the artists' minds by the strange customs, religious observances, domestic habits, queer costumes, \&c. of the natives proved too great, and both Le Moyne and White failed to record any other types of sport than

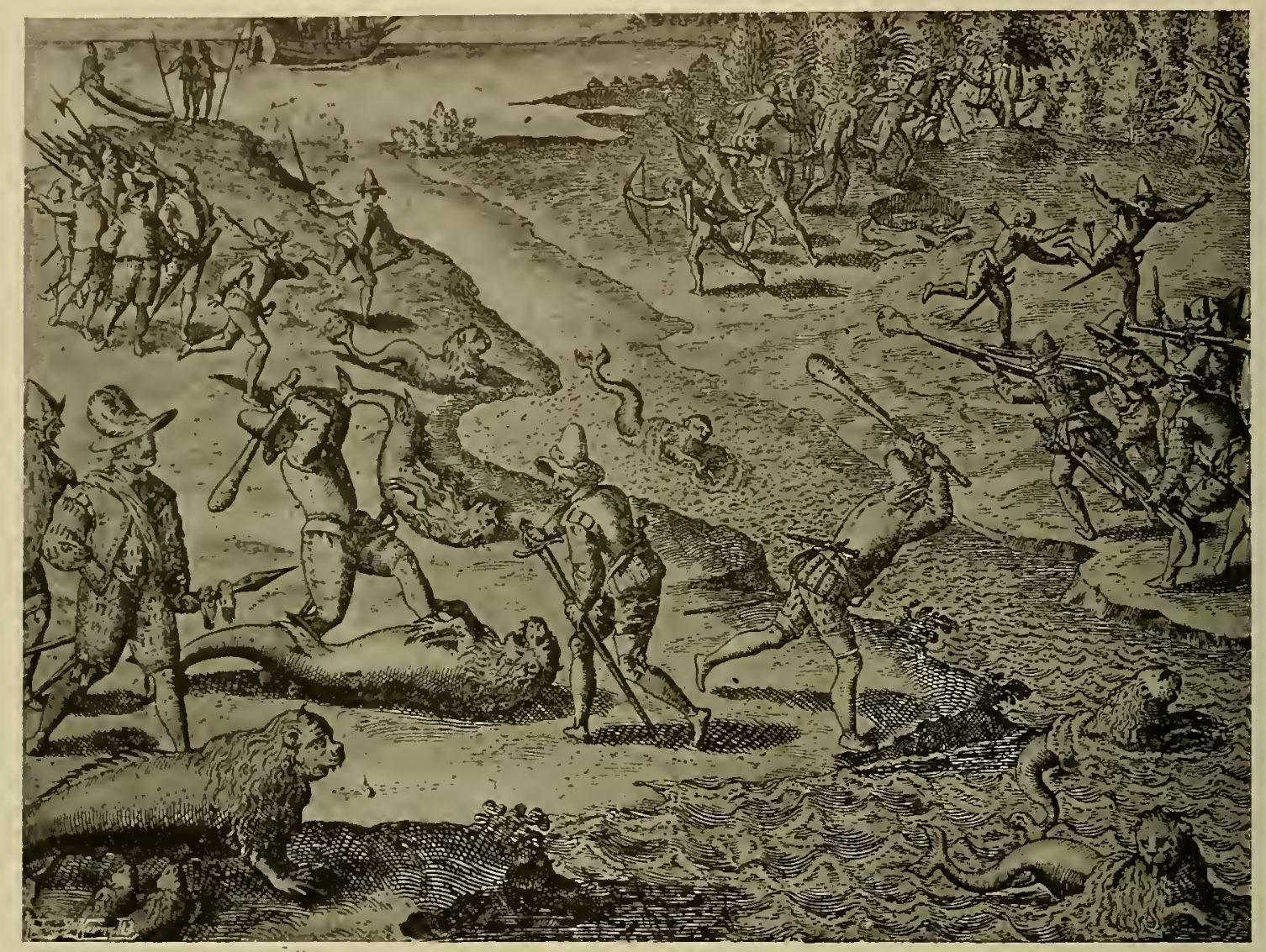

FIG. 96. SEAL-HUNTING UNDER THE SPANIARDS. OUT OF TH. DE BRY'S EARLIEST ILLUSTRATED BOOK ON EXPLORATION AND SPORT IN AMERICA. See Pages I53-I59

those we have seen. The only exception, perhaps, is a picture of the natives fishing with nets and their manner of making canoes, which is described in the text as "verye wonderfull," but as neither engravings lend themselves for reproduction we shall merely quote from the English edition a passage, leaving it in its quaint Elizabethan garb, which illustrates that the subject of fishing even in those far-off days presented irresistible temptations to indulge in philosophic moralising. "They have likewise a notable way to catche fishe in their Rivers, for whear as they lacke both yron and steele, they fasten unto their reedes or longe rodds the hollowe tayle of a certaine fishe like to a sea crabb in steede of a poynte whereI 58 


\section{THEODORE DE BRT'S VOYAGES}

with by night or day they strike fishes and take them opp into their boates. ... Ther was never seene amonge us soe cunninge a way to take fishe withall. Dowbtless yt is a pleasant sighte to see the people somtymes wadinge, and goinge

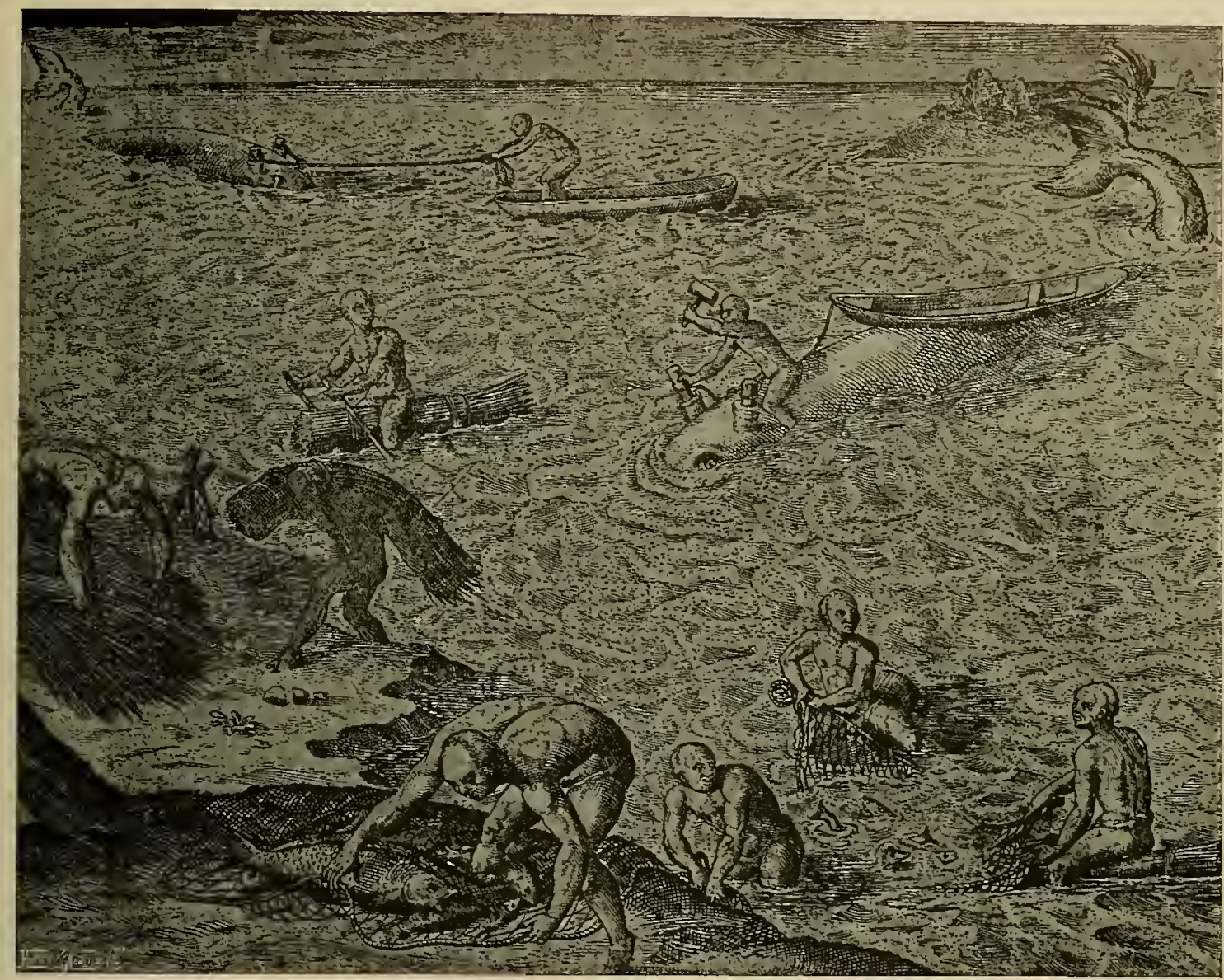

FIG. 97. HOW INDIANS CAUGHT WHALES : OBSERVE THE NATIVES PLUGGING THE BLOWHOLES. FROM TH. DE BRY'S “AMERICAN VOYAGES:" r590-r59r. See Pages I53-r 59

somtymes sailinge in those Rivers which are shallow and not deepe, free from all care of heapinge opp Riches for their posterite, content with their state and livinge frendlye together of those thinges which god of his bountye hath given unto them, yet without givinge hym any thankes according to his desarte."

Fig. 99 is also borrowed from de Bry's Voyages, where it is engraved on one of the many maps. It is probably the oldest existing picture of the American bison, described as a "a slow kind of cattell as bigge as kine with good meate." The 


\section{SPORT IX ART}

first white man who saw a buffalo (bison) of America was probably Cortez, to whom a specimen was shown in Mexico in 1521 . Less than twenty years later, during Francisco de Coronado's expedition into New Mexico, the vast ranges of

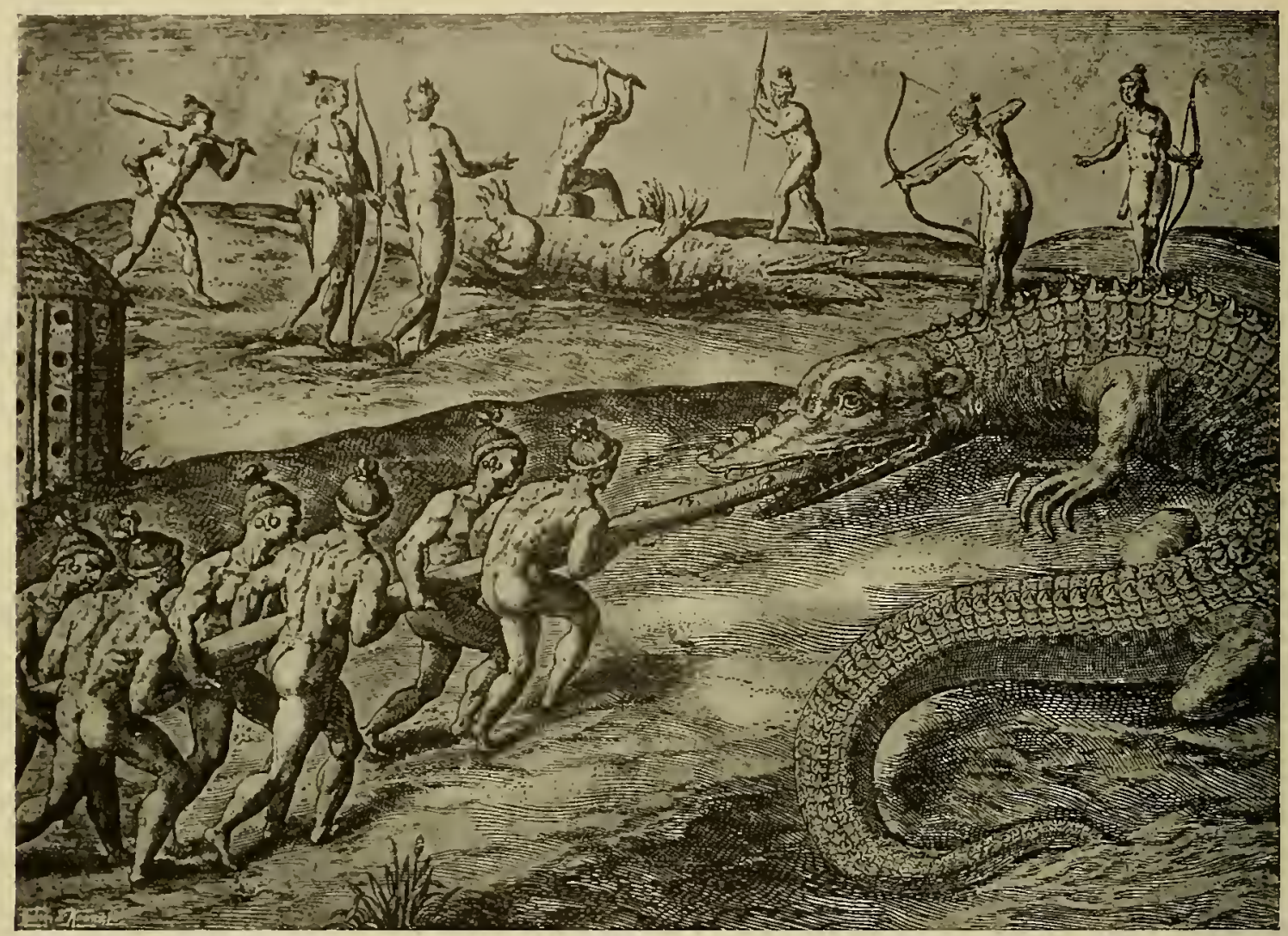

FIG. 98. HOW INDIANS KILLED ALLIGATORS FROM TH. DE BRY'S “VOYAGES TO AMERICA," 1590-1591. See Pages 153-159

the bison were first revealed to Europeans, and, as Castenado's narrative has it, "they traversed immense plains seeing nothing for miles together but skies and herds of bison." De Soto called them vaca, and subsequently they were called beufs by the French.

Antonio Tempesta ( $555^{-16} 30$ ), the Italian contemporary of the three last-named Flemish and German artists, and the most talented of Stradanus' pupils, may fitly be included in the present chapter. By some critics this Florentine, who worked for many years in Rome, is considered to have been a very able etcher, but somehow his work lacks the personal note, and acids having been used to an unusual I 60 


\section{TEMPEST A'S DESIGXNS}

extent by him his etchings appear dark and harsh, however spiritedly they are designed, and however deft the touch of the graver enhancing the "bite." There is a tiresome sameness about his engravings which, were it not for one circumstance, would tempt us to dismiss his productions with a briefer notice than we are giving him. It is, that a study of them brings forcibly home to one the creation and rise of the print publisher's profession in the last quarter of the sixteenth and first quarter of the seventeenth centuries. Though we have already touched upon this topic when dealing with Stradanus, we should like to say a few words more regarding the new relations between commerce and art brought about on the one hand by an immensely increased demand for prints, and on the other by the amazing sterility and lack of creative powers that had sunk like a cloud of poisonous gases upon the world of pictorial art, paralysing if not totally asphyxiating, the grand achievements of the Renaissance.

Tempesta sitting in his Roman workshop, for studio would be giving too grand a name to the Bottega where he and his assistants and pupils turned

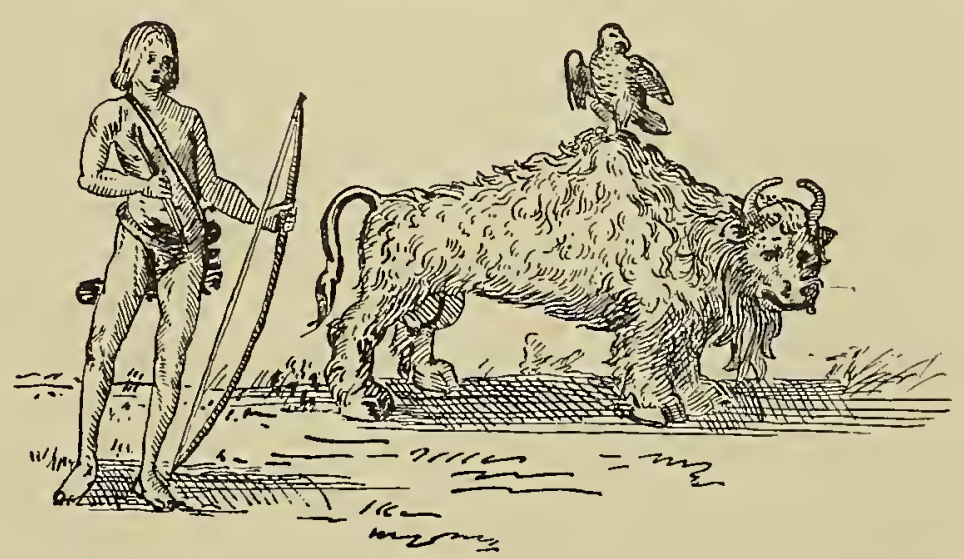

FIG. 99. THE OLDEST KNOWN PICTURE OF THE AMERICAN BISON. OUT OF TH. DE BRY'S EARLIEST ILLUSTRATED BOOK ON EXPLORATION IN AMERICA. I 595 EDITION OF "AMERICAN VOYAGES." See Pages 1 53-1 59 out some 1700 or 1800 plates, had established for himself an European reputation. In all art centres on the Continent scores of engravers, amongst them the Merians, the Savary, the Wierix, the Visscher, van Sondersell, Leon. Gaultier, van Aelst, Peter Aubry and Peter Goos, with their multitude of pupils, were busily providing the printsellers of Rome, Basel, Frankfurt, Cologne. Paris, Brussels, Amsterdam and Antwerp with wares that were nothing but cribs from Tempesta's "originals," if one can so call his plates which were so obviously inspired by his erstwhile master's works. Another detail we discover, i.e. the numerous tricks of the trade, that juggling escamoterie, which the profession of printsellers was practising to take in a confiding and picture-hungry public, whose demands for prints far exceeded the supply. When plates became worn down they were vamped up, re-touched and re-hatched, fascinating new titles were given to the series, possibly in German or in Dutch in place of the Italian or Latin of Tempesta's originals; or some fresh art patron, after having been "tapped" in approved fashion, had permitted his name to appear on the title-page to give fresh lustre to the faked-up 


\section{SPORT IX ART}

old prints, an honour which of course was bought by financial sacrifices; $;$ or new addresses, or fresh numbers, or different underlines were provided, or the more interesting plates were picked out of long series and lumped together into smaller

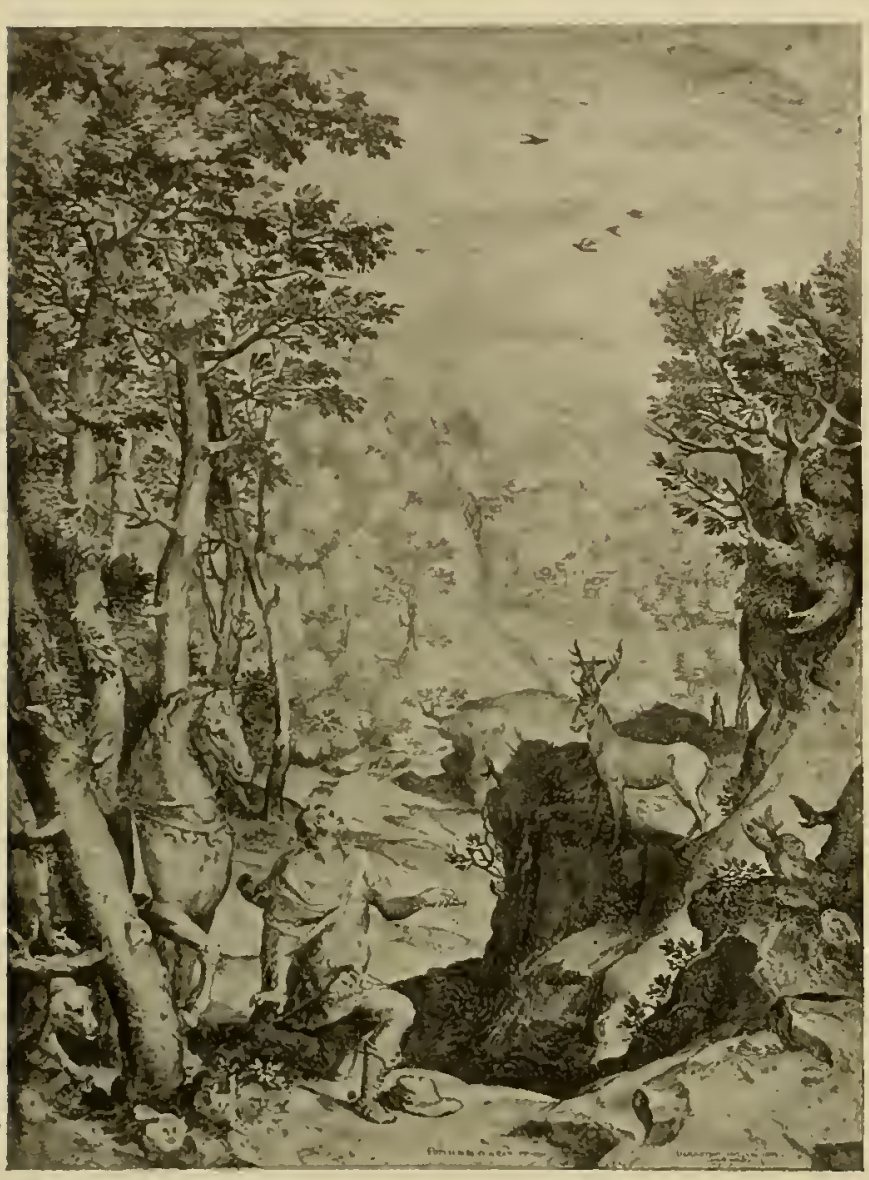

FIG. 100. THE LEGEND OF S. HUBERTUS. DESIGNED BY GIROLAMO MUZIANO, AND ENGRAVED (I 573 ) BY CORNELIUS CORT. See Page 85 spite of his mark on the plate. This we see by the distorted deer and swan-necked hounds in Fig. I01, a plate which shows faults also in the design, for it is evident that the horseman, as Tempesta represents him, has missed his chance, and that

* Tempesta seems to have had no trouble in finding art-loving and, what was more important, rich patrons willing to pay for the honour of figuring in his titles. Thus were immortalized the Duke of Valois, the Duke of Ursino, the Molto Mllustris. Signore Giovanni Leoncini, the lords Neri Dragomanno, Giov. Orlandi, Antonio Ubertino, J. Senesio, and others.

162

was given. And when this trickery began to pall mirror replicas of Tempesta's originals were mechanically engraved with the absurd result that the men's swords were transferred from the left to the right side of the wearer, and all the sportsmen figuring in the scene were suddenly rendered left-handed. We see them throwing their javelins and wielding their spears with the left hand, and mounting their steeds on the off side. So sinister had the world suddenly become that one old writer was taken in by these reversed pictures and built up ridiculous theories on what was believed to be strange phenomena of foreign countries.

Like his erstwhile master Tempesta was an exceedingly industrious artist ; but, as we can easily see from the faulty details perceptible in some of his plates, the commercial spirit of the age tainted also his artistic activity, for there can be no question that many of his designs were engraved by apprentice hands in 


\section{TEMPEST A'S DESIGXNS}

his leg or the horse are about to make the acquaintance of the boar's tusks in no pleasant manner. That Fig. 102 is altogether a fanciful drawing we have already

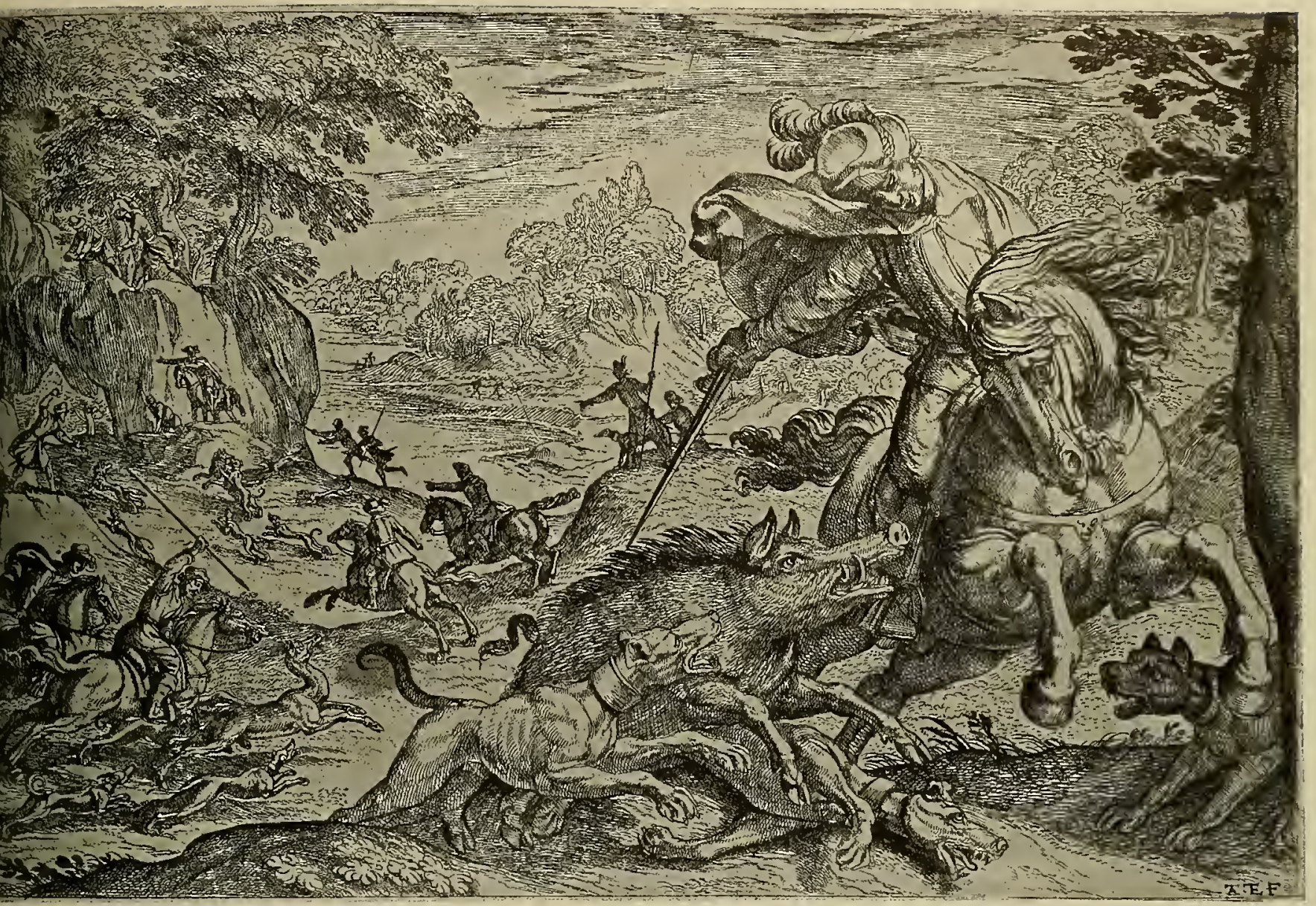

FIG. IOI. BOAR-HUNTING : “MISSING HIS CHANCE.” DESIGNED AND ENGRAVED BY ANTONIO TEMPESTA (1555-1630), A PROLIFIC ROMAN ARTIST. See Pages 160-I64

remarked when speaking of the aurochs (p. 37). Much the same faulty presentation is noticeable in Fig. I03, where the dog is undertaking the impossible feat of driving wild fowl into a decoy, instead of luring them in as we see in Bol's more correct plate depicting the same proceeding, Fig. 88. A more interesting etching of his we reproduce in Fig. 104. It is the earliest picture known to us that shows a lady riding astride, habited specially for this purpose in what one must describe as most practical garments. At the risk of being long-winded, a few remarks about the introduction of the side-saddle and women riding astride when hunting may be added. 


\section{SPORT IX ART}

It is generally believed that Anne of Bohemia, Richard II's Queen, introduced the siddle saddle into England. This attribution can only be correct if the word be understood in the modern sense, i.e. a saddle provided with a horn or other contrivance over which the right leg is placed. And though this early ascription is in conflict with Brantôme's assertion that Catherine de Medicis was the first woman to use such a contrivance, the fact that women's saddles underwent a very gradual development may partly explain and reconcile these contradictions. It is certain that women rode both ways at much earlier periods: when they travelled they sat either "pillion" or, as the Anglo-Norman historian Odericus Vitalis has it, "in female fashion on women's saddles"; when they hunted they rode as often as not astride of their mounts. Chaucer's description of the Wife of Bath who had a "foot mantel" round her hips, which is one of our earliest allusions to a riding-habit, can hardly have applied to the ancient side-seat saddle where the feet rested on a footboard, such as we see in the pictures of Queen Elizabeth in Turbervile's "Arte of Venerie," for we are told in the Canterbury Tales that the wife wore sharp spurs on both feet.

One serious difficulty in any enquiry as to the period when the modern side-saddle was introduced, arises from the crude nature of early pictures, and it is not until we get to the second half of the sixteenth century that we reach a development of art which permits us to make use of such evidence. The earliest picture dealing intelligently with our subject is the aforesaid etching by Tempesta. It is the fourth of a set of ten plates dealing with various forms of sport which Tempesta published in Rome A.D. 1609. But as he had gone there more than five-andtwenty years earlier, in response to a flattering call by Gregory XIII, and our etching is really an enlarged elaboration of an earlier and smaller print in which the lady appears on the right-hand side of the picture, it is almost certain that Tempesta depicted something which he had seen some years, possibly a quarter of a century earlier. The picture is one at which Diana would have turned pale, for the attendant running beside the horse, holding it by the bridle, is evidently there to stay, and the fair one's grip with both hands on the high saddle-bow in front of her does not increase our respect for her equestrian skill. But what it lacks in sporting spirit it atones for respecting costume. In what region of Italy the artist had visualised this shapely leg garbed in so altogether useful a manner, or what fair aspirant to Diana's graces had served as model for that graceful garter-sash with pendant ends, and for the knickerbocker inexpressibles, we unfortunately are not told. The print, unlike most others of that time, lacks the descriptive underlines which usually afford some clue. The slipping of the greyhound, the use of lances by the hunters in the distance, no less than the badly-drawn knobber tempt one to doubt the reality of the scene, were it not that the Italians of that period were a decidedly unsportsmanlike race who lacked to an extraordinary degree the true instincts of venery. Two other illustrations, Figs. 135 and 136 , afford proof of 164 


\section{SPORT IX ART}

by the fair ladies, and if we examine some of the other illustrations to which we shall have to refer again in a subsequent chapter, we perceive to what incredible depths sport had sunk in ltaly.

Of frankly satirical import is Fig. 154 , a reproduction of a very rare Dutch print published two hundred years ago, about the time when certain more common Italian and French series of satirical prints were published to amuse the world

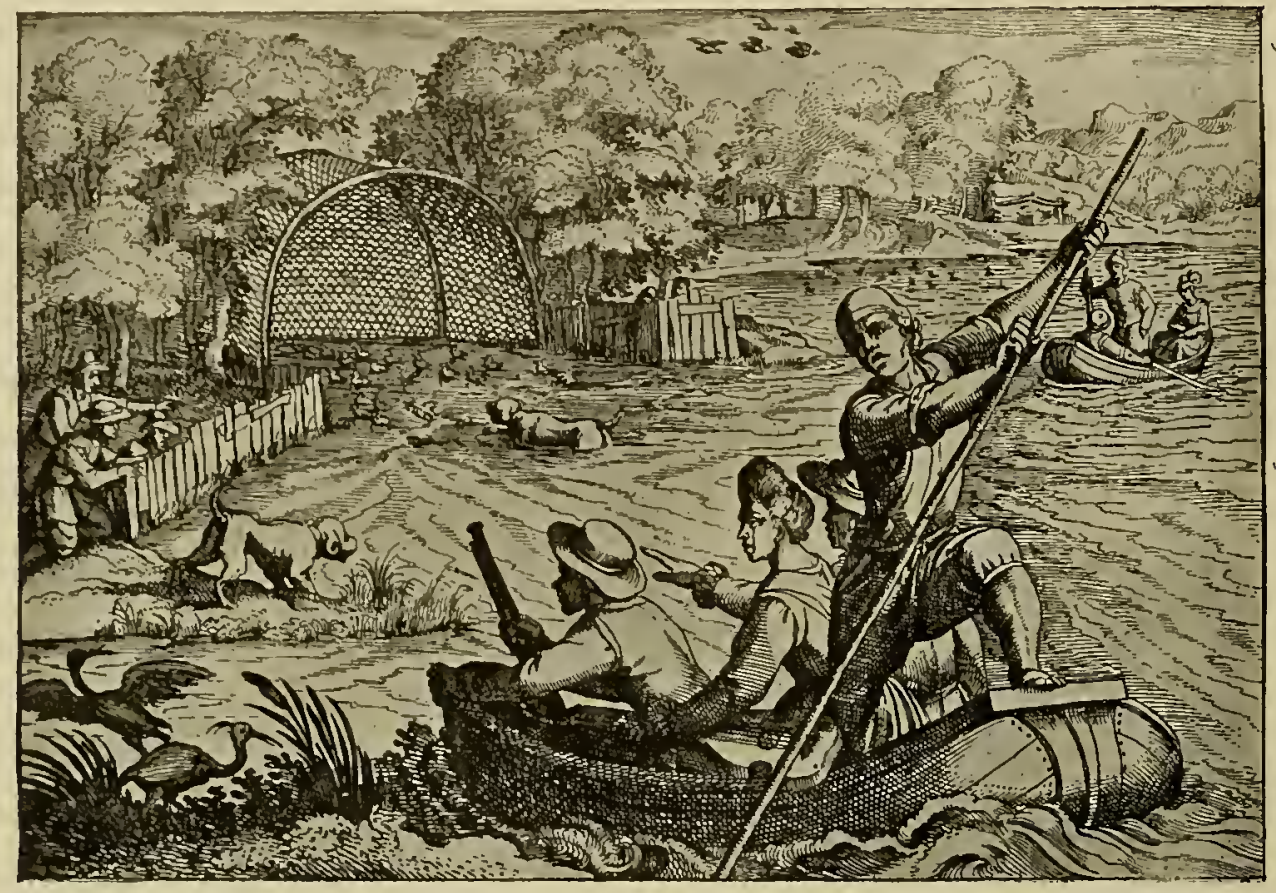

FIG. 103. A DUCK DECOY. DESIGNED AND ENGRAVED BY ANT. TEMPESTA (1555-1630). AN INCORRECTLY RENDERED INCIDENT. Fig. 86 and Pages $146-1+9$

after the harrowing experiences which the War of the Spanish Succession had imposed upon Europe. We have here what is probably quite a truthful or only slightly exaggerated fashion-plate, for of course the fact that the actors in the scene before us are dwarfs does not detract from the picture's veracity in respect to the costume, however much it may increase the comical effect. Thus the prince astride of a prancing steed is wearing the dress commonly worn by the sportsmen who hunted in Herrenhausen with George I of blessed memory before he betook himself to Britain. We can therefore take it that fair amazons were garbed in those days as we see the buxom lady in the picture before us.

Of similar ironical import is an amusing print of English origin, called Sporting Ladies or the 'Jockey's Downfall, published half a century or so later, in the year 166 


\section{LADIES RIDIX ASTRID E}

I777. The habits worn by what we might describe as suffragette jockeys are probably less exaggerated than their toupees and feathered panaches.

"Hoops and wigs" on horseback, as might be called a satirical fashion-plate issued a decade or two earlier from a German workshop, probably an Augsburg one employing artists that had been apprenticed to the celebrated animal painter of that town, J. E. Ridinger. For the touch strongly reminds one of his school. The chair-like saddle in which the fair huntress is comfortably seated is on the

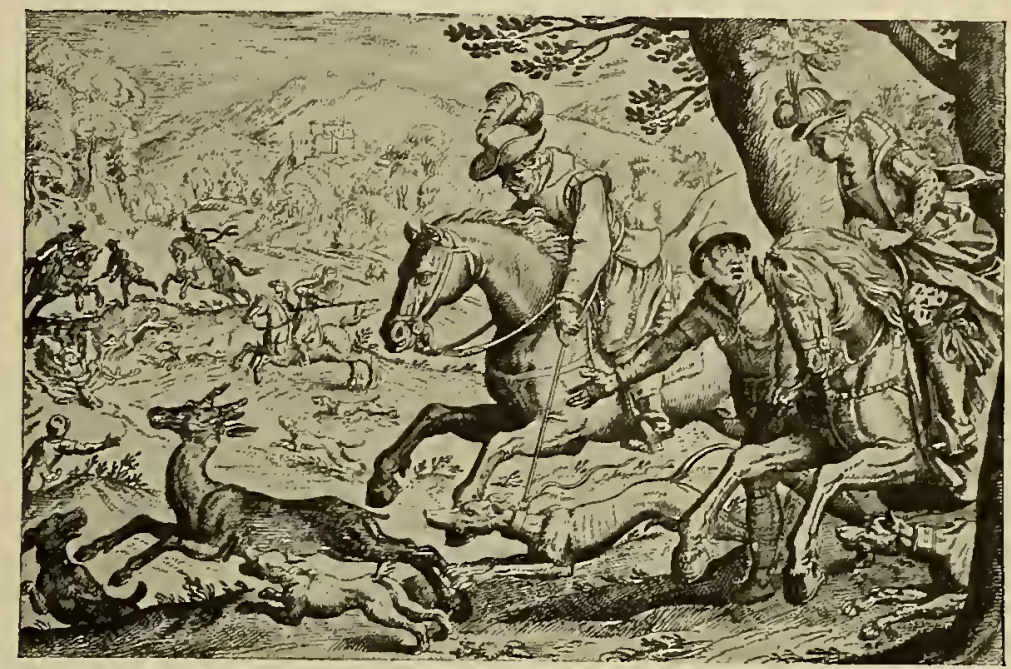

FIG. 104. EARLIEST PICTURE OF LADY RIDING ASTRIDE IN COSTUME SPECIALLY DESIGNED FOR THAT PURPOSE. DESIGNED AND ETCHED BY ANT. TEMPESTA (I555-1630). See Page ${ }_{1} 6_{3}$

wrong side of the horse according to modern ideas, and what would happen if those two little feet resting, as they evidently do, side by side on the footboard, should be jerked from their rest by any unexpected movement of the horse can better be imagined than described.

Of Tempesta's contemporary and Theodore de Bry's son-in-law, Matthew Merian the elder (I 593-I650), a few words must be added, for he engraved several little sporting series. One nice little set of six plates he evidently executed after some Netherland designer, probably during the year or two of his stay in that country. P. Aubry published the set, and of another series engraved by Merian we have given the particulars in the Appendix when enumerating Tempesta's various productions. About all these multifarious series, produced by the two last-named artists, there hangs a depressing pall of uniformity and lack of individuality that does not tempt one to extend research beyond the necessary limits. 


\section{SPORT IX ART}

Before concluding this chapter a Frisian contemporary of the last-named artist must be briefly mentioned. This was Simon Frisius (1580-1628 ?), a designer and etcher of considerable skill, who produced some exceedingly delicate work. Sporting subjects he treated allegorically, but there are only a few, and those are rare. In the writer's collection there are four small oblong etchings with corners rounded off $\left(6 \frac{1}{2} \times 5 \frac{1}{2} \mathrm{~cm}\right.$. $)$, three of which depict boar- and wolf-hunts of classic times, while the fourth represents the interior of a stable, with Latin inscriptions running round the oviform pictures. They bear the artist's initials S. F. 


\section{CHAPTER VIII: THE CHASE AND ART IN THE FIRST HALF OF THE SEVENTEENTH CENTURY}

7 HE extraordinary impulse which art of every kind received during the last three decades of the sixteenth century was nowhere more apparent than in the Netherlands. There artists continued to thrive in spite of wars, sieges, pestilence, and religious persecution. Sculptors, painters, designers and weavers of tapestry, engravers and etchers seemed to sprout in rich profusion out of a fertile soil, and nothing seemed to be able to impede that exuberant growth. Great wide-branching families of artists appeared, and fathers, brothers, sisters, and sons-in-law seemed filled with an unquenchable devotion to art and self-sacrificing diligence. They worked together, one painting the figures, the other putting in the landscape or animals; they sat to each other as models; they intermarried, * they painted each other's portraits, they acted as witnesses at each other's marriages, and as godfathers at christenings, and when they grew old they knew they could entrust their affairs to their brothers in art and could safely appoint them guardians of their children. We come upon few traces of jealous rivalry; and of the bitter feuds that were such a feature in Italian art circles, there is hardly any record in the temperate northern climate.

Hendrik Goltzius (1558-16r7) of whom we have already spoken briefly when dealing with Stradanus, was among those who intermarried in the manner we have described, but his was one of the few unhappy experiences that are recorded. When only twenty-one years of age he linked himself to the rich widow Matham, mother of a fellow-artist, and though by this step he acquired the means of establishing printing works of his own, his spouse soon drove him to forsake his hearth, and to seek peace by extensive travels. He visited many of the great art centres of Europe, and there he acquired the skill that made him a famous engraver. One of his most sought for plates is reproduced in Fig. 105, the portrait of the son of his friend Theodore Frisius, with a bird perched on his fist, playing with a big Frisian hound. Engraved in the year 1599 it may well serve as marking the transition between the period with which we lately dealt, and the one now to be touched upon. Fig. Io6 is already of the latter, and is a curious allegorical engraving by the same graver illustrating the "Hunt after Wealth," in which the characteristic attributes of the chase are cleverly brought in. The strutting fowl with a coin as body represents

* De Jode's daughter married Brueghel the Elder, Ryckaert gave his to Coques, "Velvet" Brueghel his two daughters to Teniers and Van Kessel, Van Ulden his to Biset, Van Noort his to Jordaens, Van Balen his to Theodore Van Thulden, while Quellinus tecame the son-in-law of Teniers, Snyders was brother-in-law of M. de Vos, Simon de Vos of A. Van Utrecht, Rambouts of Van Thielen, Van Cartbende of Van Hoecke, \&c. 


\section{SPORT IX ART}

wealth, while the hounds indicate labour, industry, parsimony, \&c. The prone figure of Justice is being overridden by mounted lady who is emptying herwell-filled purse to represent prodigality. The man on his knees with a fox's brush held behind his back stands for wily adulation, and the old hag hiding behind the tree represents avariciousness, while the two hounds she holds in leash typify usury and fraud. One of Goltzius' pupils, Ioannes Saenredam (1565-1607), a Dutch artist of considerable repute, followed his master's footsteps and has left us an allegorical design in which sport assists in glorifying Maurice of Orange, the heroic deliverer of the seven Provinces from the Spanish yoke. This large plate, Fig. 107, was also engraved by him, and its size $\left(55^{\frac{1}{2}}\right.$ by $42 \frac{1}{2} \mathrm{~cm}$.) allows its decorative qualities to shine. Saenredam acquired many of his master's mannerisms, but also his delightful grace and freedom of line. It was published in Amsterdam by Hermann Alardi in the year 1602 .

Martin de Vos (1531-1603-4), the Antwerp painter and friend of Tintoretto, did not concern himself much with sport; the one plate produced by him (Fig. 108) represents the aerial sport of falconry. In this attractive print the artist remains true to his countryman's characteristic devotion to the fair sex. It was engraved by his young friend Crispin de Passe the Elder, born about 156.5, the founder of another famous artist family some of whom worked in England.* His son, Crispin the Younger, contributed one important work in our line, Pluvinel's Art of Riding (1626), which was published by the father. Three sons as well as the daughter Magdalena were all pupils of the latter, doing him great credit, but they left little that is of interest to us.

It would be easy to cull dozens of pictures dealing with sport in allegorical fashion from the swelling portfolios containing the engravings of these prolific Little Masters, but it would serve no useful purpose so far as the practical issues are concerned. One little collection by an unknown master of interest to the collector but otherwise unimportant, may still be mentioned, for it shows considerable resemblance to Hans Bol's sets. The eight nice pictures, published by $\mathrm{F}$. de Widt, and also oblong in shape $\left(21\right.$ by $6 \frac{1}{2} \mathrm{~cm}$.), represent the chase of the wolf, fox, wild boar, bear, aurochs, hare, and rabbit, the latter being rather remarkable because the sportsmen are using guns and cross-bows. The title-page, which forms the first of the eight plates, has the usual cartouche surrounded by emblems of the chase. In the centre of the shield is printed: Animalium Quadrupedum Venatus in usum Pictorum Aurifabrumgue. The edition in the writer's collection is of the year 1631 , but possibly there are earlier ones.

\footnotetext{
* In the eyes of some critics the two de Passes' work equals that of Golezius, Crispin the Elder's celebrated full-length portrait of Queen Elizabeth being considered as fine as anything turned out by Goltzius, while Simon de Passe's portrait of Queen Anne on horseback is also of considerable merit. As the various members, more particularly the two Crispins, did not differentiate their productions, there exists some confusion regarding their respective work. 170
} 


\section{PIETER DE WITTE}

Of the same period with which we have been dealing is Fig. 109, a reproduction of one of the fine tapestries designed by Pieter de Witte, better known as Candito or Candid, as he is usually called in Germany. Born about the year I 548 he studied under Vasari in Florence, and presently followed a call to Munich where he became the court painter of three successive art-loving Dukes of Bavaria. His versatility was great; he designed a number of large tapestries which the skilful Hans van der Biest, who had also been summoned to Munich,* wove into very beautiful panels; he painted pictures in oil, and, finally, he gained his art-loving patron's high favour by designing architectural plans that were successfully used in the construction of the new ducal palace in Munich. Fig. Io9 is a reproduction of one of the "Months" set of Gobelins preserved in the National Museum in Munich. It depicts the type of sport obtainable in July, the seventh month of the year: stag-hunting. At the top we notice the armorial bearings of Bavaria and Lorraine; the lady on horseback is probably meant to

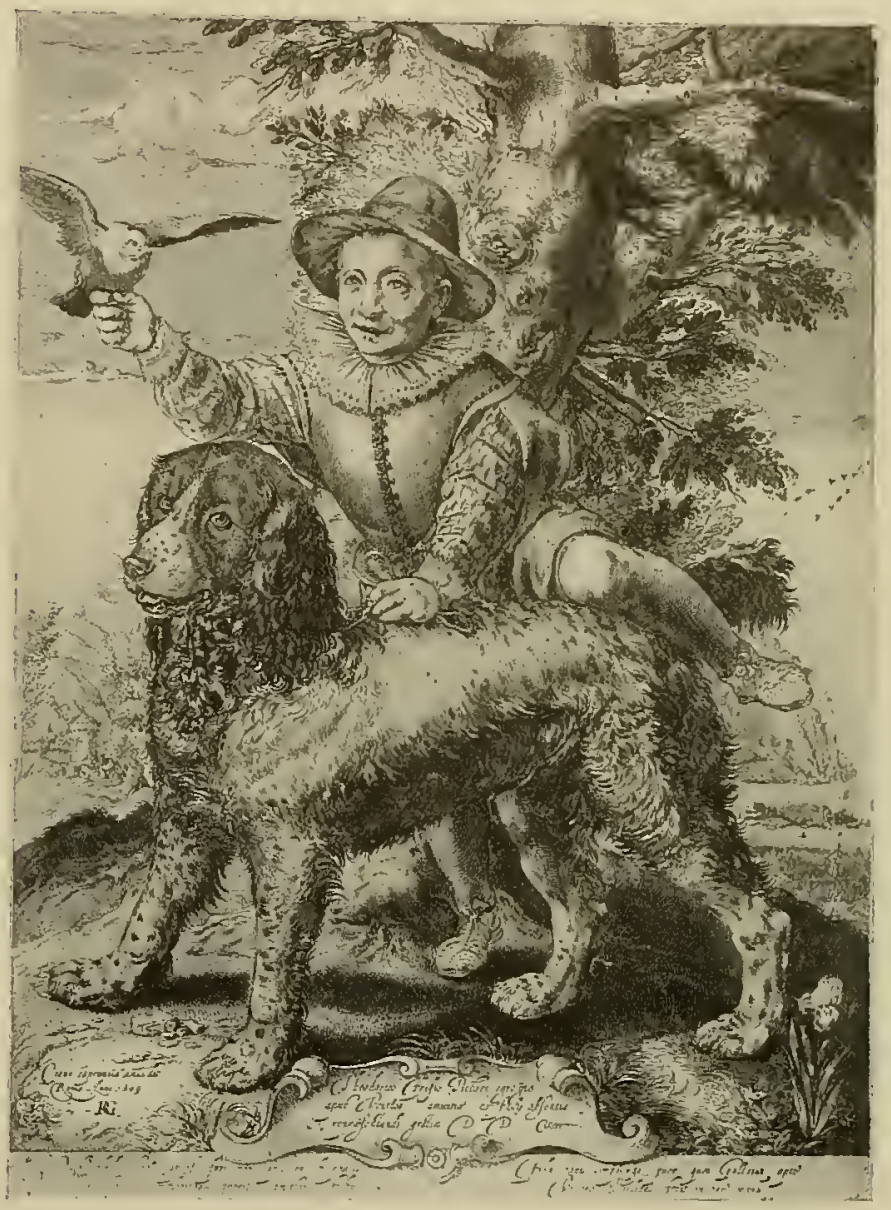

FIG. 105. GOLTZIUS' CELEBRATED ENGRAVING OF THE SON OF HIS FRIEND THEODORE FRISIUS PLAYING WITH HIS FRISIAN HOUND. PUBLISHED ROME 1599. See Page I69 represent Duchess Elizabeth, wife of Duke Maximilian of Bavaria, as is indicated by the interlaced $M$ and $E$ in the base of the two pillars at the sides.

* Duke Maximilian started tapestry works in Munich in 1603 by summoning Dirk Vouters and in the following year Hans van der Biest, a Brussels master weaver, to his capital. Under the latter's guidance, assisted by Flemish workmen, three beautiful series of hangings were comple:ed in the comparatively short period of seven years. 


\section{SPORT IX ART}

\section{THE HUNTING CHRONICLE OF THE DUKE OF COBURG}

Amongst ancient illustrated records of the chase executed by the order and under the eye of sovereigns, the Jacht Buch of Duke John Casimir of Saxe-Coburg

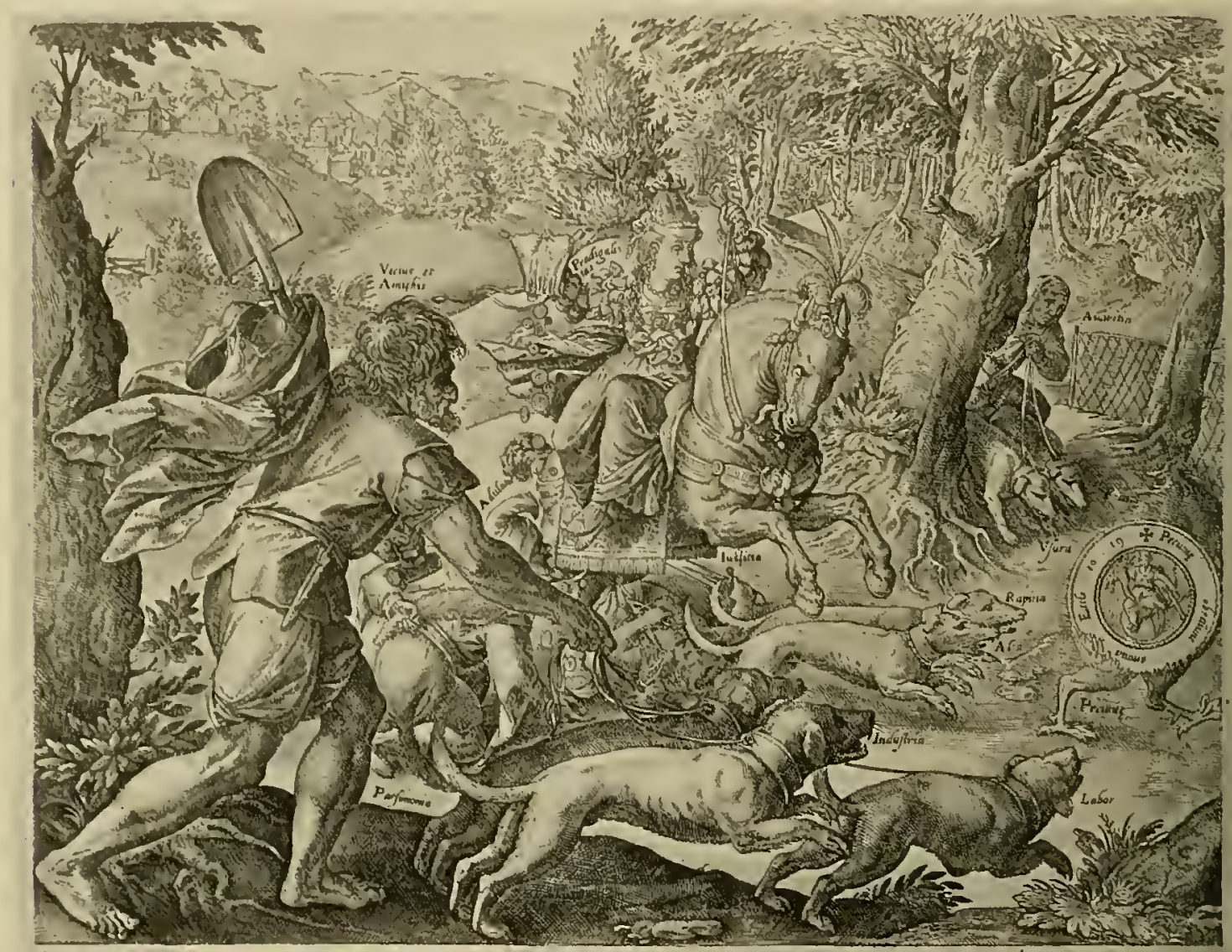

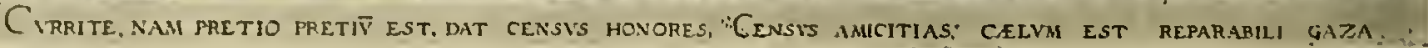

FIG. 10'. ALLEGORICAL ENGRAVING BY HENDRIK GOLTZIUS (1558-1617) ILLUSTRATING THE HUNT AFTER WEALTH. Sï Page I 69

(1564-1633) by Wolff Pirkner takes a high rank. For the illustrations were drawn from life by one who, as he shows us in the drawing, evidently witnessed the scenes which he depicts with his own eyes. These old princely nimrods were often exacting masters, for they insisted that the descriptions of their sport should be accurate in every detail, and we occasionally meet with complaints on the part of artists in regard to the hardships to which their lords 172 


\section{COBURG HUXTIXG GHROXIGLE}

unrelentingly exposed them in making them share the discomforts incidental to their indefatigable pursuit of wild animals.

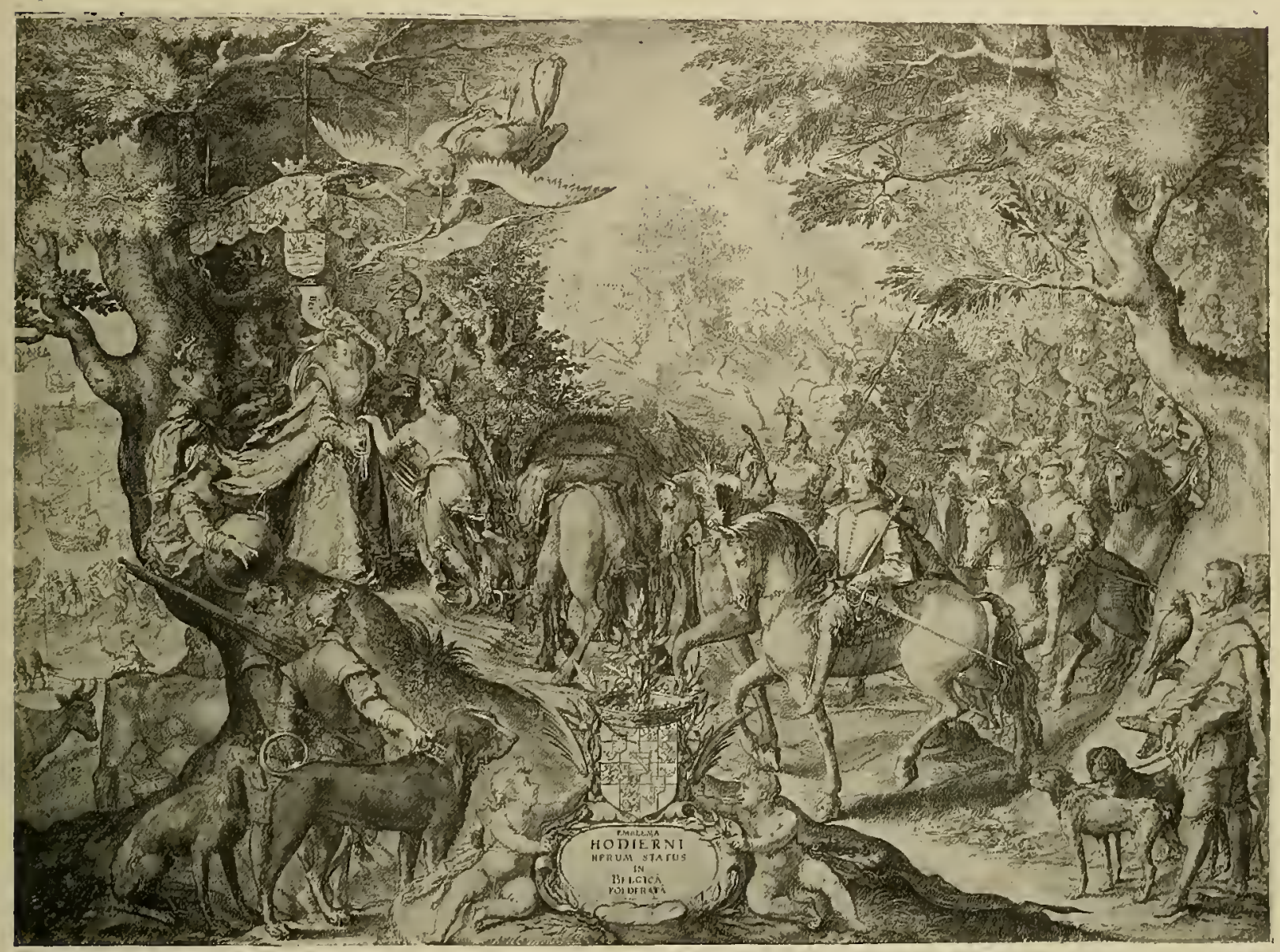

FIG, 107. ALLEGORICAL DESIGN BY IOANNES SAENREDAM, A PUPIL OF GOLTZIUS, AND SHOWING LAT'TER'S INFLUENCE. PUBLISHED IN AMSTERDAM IN 1602. See Page 170

To be precise it must be mentioned that there exist two copies or rather two editions of the Jacht Buch, for the pictures in the two sets one knows of are not identical. The older set, consisting of twenty-one gouache designs, is undated and it was unquestionably drawn during the last years of the Duke's life, i.e. before 1633 . The title-page contains one picture of him in hunting dress as a youngish man of about forty, and another representing him as a white-haired old sportsman well up in the sixties. These twenty-one drawings were accidentally discovered a generation ago in Vienna by Count Wilczek, the great Austrian sportsman, and were given by him and some friends to the father of their present 


\section{SPORT IX ART}

owner, the Duchess Marie of Ratibor. Those of our readers who visited the great International Hunting Exhibition of 1910 in Vienna will, no doubt, remember the extraordinarily interesting originals which formed for many visitors one of the great attractions of the exposition.

The second set, of about the same size, i.e. 20 by 9 inches, was completed, as the inscription on its somewhat different title-page informs us, in 1639; it consists of thirty-nine drawings executed also in gouache. The scenes represented in the older set are all repeated but with slight differences, while the other eighteen pictures depict wild-fowling of various kinds, badger-drawing and wild-boar battues, all of which are omitted in the older series. This newer set is preserved in the Veste or Fortress at Coburg, where there is a most interesting collection of ancient trophies, arms, and appurtenances of the chase to which we shall have occasion to refer repeatedly. Though not equal to the Vienna Imperial Museum and the royal collection in Dresden in respect to hunting arms or armour, the Coburg Sammlung possesses some ancient appliances that are unrepresented in any other collection known to the writer.

Our reproductions are taken from the older series, and were it not for lack of space we should have liked to publish the whole twenty-one pictures instead of selecting only six.*

A brief historical digression with the view of making the reader better acquainted with the personality of a typical German royal sportsman of the sixteenth century and the autocratic manner in which he conducted his sport, may not be out of place. Born in the year 1564 , the youth of Duke John Casimir was an eventful one, for as the elder of two sons he shared, when still a child, the prison in which his dethroned father was kept captive. The latter, a staunch Protestant, had rashly dared to give shelter to a miuror noble upon whom the Emperor had pronounced the ban of the empire and the Pope the excommunion of the Church. For harbouring this dangerous guest, this proscription was extended also to the host. To the Elector Augustus of Saxony, who, though descended from the same ancient Wettin stock, was a fervent Roman Catholic, the Emperor of Germany delegated the duty of punishing his kinsman of Coburg. His capital, Gotha, was besieged and taken, and the real cause of the trouble as well as the Duke's principal minister were quartered alive, while the sovereign himself with hundreds of his subjects were sentenced to be decapitated. This sentence, however, was at the last moment in the latter's case changed into lifelong imprisonment in an Austrian castle, his faithful wife voluntarily accompanying him. Both died there after many years

\footnotetext{
* One might almost say that there exists a third copy of this chronicle, for many of the pictures in it are reproduced in wood inlay in the panelling of an octagonal room in the Veste at Coburg known as the Antler Chamber. It is a probably unique piece of intarsia work, various coloured woods, some of the rarest foreign kinds which it must have been very difficult to obtain in those far off-days, being used.
} 


\section{COBURG HUXTIXY CHROXICLE}

within a brief span of each other. Their children, young John Casimir and his brother, were at an early age taken charge of by the Elector of Saxony and were educated at the gay court of Dresden. There the former married before he came

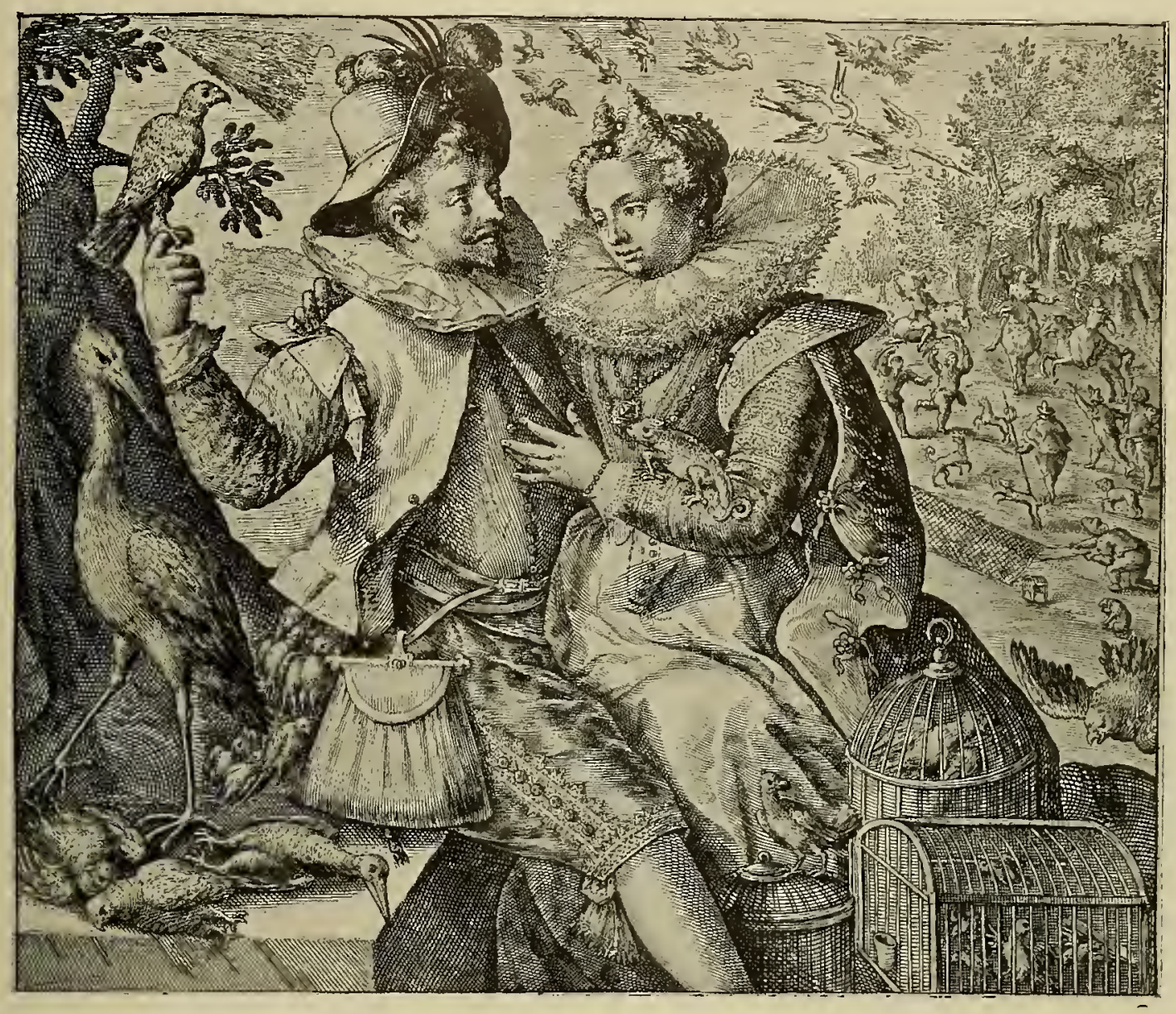

FIG. IO8. “THE SPORTS OF THE AIR.” PAINTED BY MARTIN DE VOSS ; ENGRAVED BY CRISPIN DE PASSE THE ELDER, END OF SIXTEENTH CENTURY. See Page I70

of age Princess Anne, the Elector's daughter. When this occurred he was reinstated as ruler of his father's Duchy of Coburg, and he soon seems to have given unbridled rein to his passion for the chase, sadly neglecting his pretty wife who, as her correspondence shows, found Coburg a very dull residence after all the frivolous gaieties of the Dresden court. Then ensued a romantic tragedy, Knight Ulrich von Lichtenstein, one of the nobles attached to the court, having taken advantage of the Duke's constant absences hunting, lifelong imprisonment of the Duchess and her lover, lasting in the one case over forty years, followed. Upon the 


\section{SPORT IX ART}

wronged husband the event had the effect of increasing his unbending sternness and his devotion to the chase, which alone afforded him distraction.

Next to his pack of great boar-and bearhounds which, we are told, were of the size of yearling steers, Duke John Casimir loved his dwarf jesters of whom he had five at his court, his favourite being the famous Claus whose reputation for caustic wit had spread all over Europe. The very first picture of our hunting chronicle, after the elaborate title, shows us the famous Claus. The scene represents Duke John Casimir receiving his Master of Game's report and propositions in respect to the day's sport. White-haired, but erect, garbed in the peculiar costume to which he seems to have stuck throughout his long sporting career, if we can judge by Master Pirknes' pictures, the Duke is standing, staff in hand, at a table in a room decorated with stags' antlers. The three hunt officials, probably portraits, are standing in front of him. At the Duke's side we see the famous Claus. The latter bears a parrot on his left fist as were it a falcon, and if the artist kept to the truth, which there is no reason to doubt, Master Claus was not as tall as the Duke's great boarhound which we see sniffing the Master of Game's coat-tails. The scene represented in our first reproduction, Fig. I I I, shows us the preparations for a drive, or what was called an Eingestelltes fagen, which we might translate to mean a battue within enclosures. We see the old Duke personally superintending the erection of canvas screens, by which the deer, boar or bear roaming the forest were surrounded by impenetrable panels of the stoutest canvas eight and, in some cases, ten feet high, stretching in circular shape for many miles through the forest. For the erection of these temporary enclosures every man, woman and young person of the peasant class in the neighbourhood was impressed for weeks at a time, generally just at harvest season, when their presence was most needed on their own fields. For, unfortunately for these wretched serfs, the Feistzeit, or "grease-time" as it was called in England, when the stags are fattest and instinctively seek the thickest coverts, occurred at this very season, the consequence being that crops had to be left to rot on the ground where, more than ever, they were at the mercy of vast herds of deer and wild boar.

Our next picture, Fig. I12, shows us the Duke in the act of shooting (on the left-hand side), but, of course, the lack of space and absence of perspective in the picture give a wrong impression regarding the distance between the two enclosures. In reality these were much further apart - a thousand paces is the distance which one author says was the usual one. The Duke's loaders must have had a busy time, and the eight terribly unwieldy rifles that are being handled by them must have often got hot, for the quantity of game slain on such occasions was prodigious. The third picture, Fig. I 13 , has more perspective about it, and illustrates one of the principal ceremonies connected with the chase, $i$ e. the "weighing in " of the stags. The greatest possible importance was attached to the weight of stagsonly those from ten points upwards were weighed-and if these princes were 176 


\section{COBURG HUXTIXG CHROXICLE}

capable of wielding a pen, which was by no means always the case, their diaries and correspondence almost always contained more or less minute notes as to the weight of the great stags they had brought down. It was ascertained in those

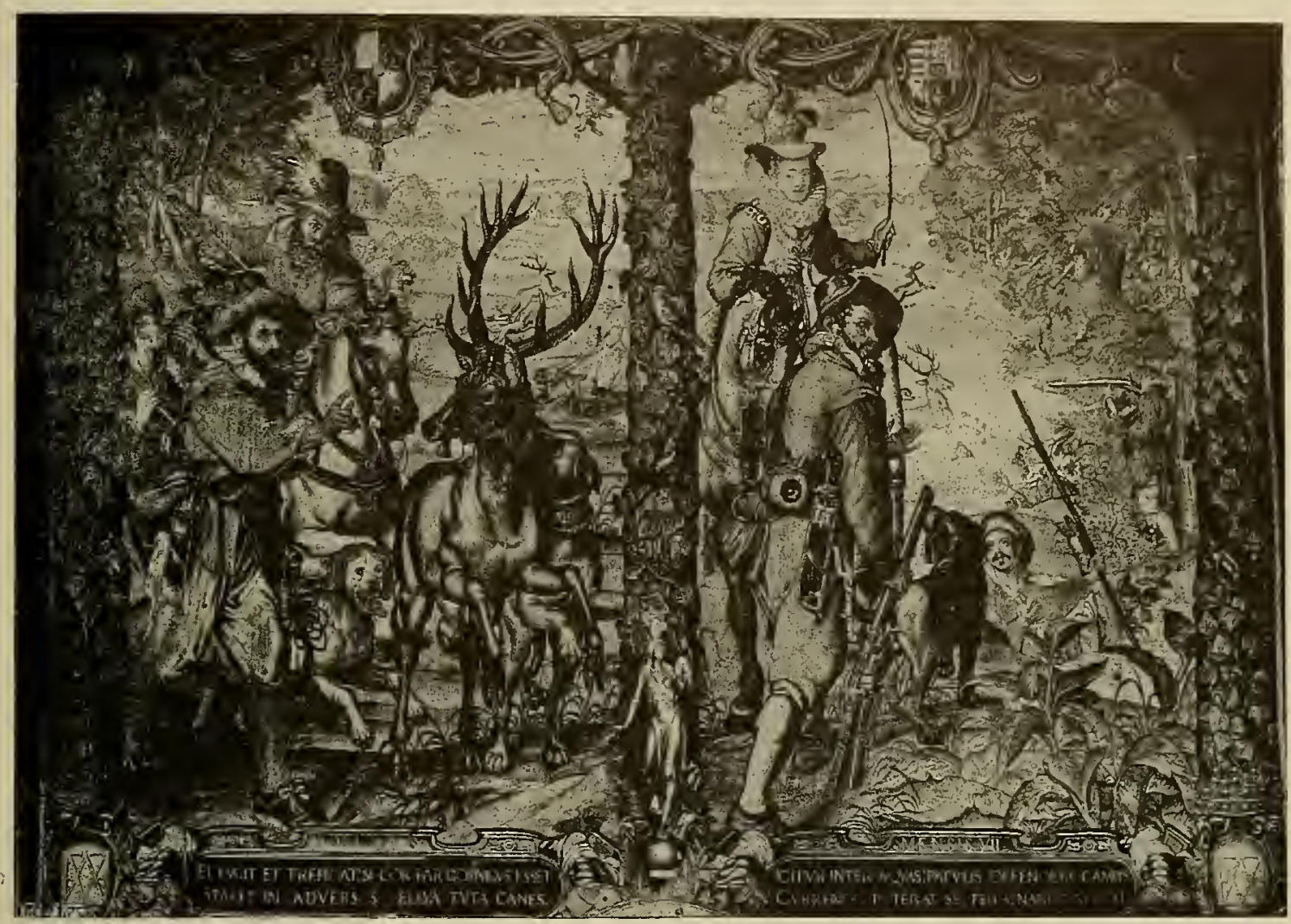

FIG. IOg. TAPESTRY DEPICTING THE ELECTOR AND ELECTRESS OF BAVARIA GOING OUT HUNTING. THE PANEL REPRESENTS THE SPORT OBTAINABLE IN THE MONTH OF JULY. WOVEN AFTER THE CARTOON OF PIETER DE WITTE OR CANDITO BY HANS VAN DER BIEST IN MUNICH BETWEEN I603 AND I609. IN THE NATIONAL MUSEUM IN MUNICH. See Figs. I 4 I, I $4^{2}$, and Pages I 7 I, 223

days without first breaking up or gralloching the beasts, which were put on the scales as they fell, the necessary appliances, as we see here, forming part of the vast paraphernalia that was taken into the woods. "In the background we see eight keepers blowing a horn signal, probably the "mort," as a sign that the

* Also in Scotland stags used to be weighed as thev fell, and no doubt it is the fairest method, and the one least liable to "doctoring." The modern "clean" weight is by far less accurate, not only because sportsmen are by no means agreed as to what should be removed at the gralloch, but also because of the varying loss of blood. The difficulty of weighing a deer on the spot is the principal reason against it. 


\section{SPORT IX ART}

master weight of the day was being ascertained, the Duke himself reading off the tally. Behind him, where the three stags are lying, is being enacted one of those amusing, if coarse, scenes incidental to sport in those days. It was called "blading," or "giving the blade" to a culprit who, in the course of the day's sport, had contravened any one of the numerous rules of venery, or had failed to use the correct terms of venery in his speech. As a punishment he was laid across the body of a dead stag with his face downwards, and the softest part of his body was spanked three times with the flat part of a "waidblatt" or huntingknife, the Duke himself applying the blade if the culprit was of sufficiently high rank. Each blow was accompanied by a rhyme, which, roughly translated, ran about thus :

\section{Jo, Jo, ha, ho! this is for the King, princes and lords! \\ Jo, ha, ho! this for the knights, huntsmen and servingmen! \\ Jo, ha, ho! and this by the noble law of venery.}

Upon which the culprit could rise, and had to thank the Duke for his mercy in not punishing him more severely. Three of the five Court dwarfs are in the picture, probably enjoying the scene, the one nearest the Duke being almost certainly the precious Claus. "Precious" can be used advisedly in connection with this diminutive specimen of humanity, for a contemporary writer informs us that after the Duke's death, when his possessions came to be divided among his heirs, so highly was Claus valued, that he was rated to be worth eighty thousand thalers, a sum the ordinary purchasing power of which to-day would be something like one hundred thousand pounds.

The fourth picture, Fig. I i 4, shows us the return of the vast hunting train to what was probably intended to represent Coburg. Its characteristic details show us how the peasant women were employed in leading the lesser canine quality; the great bear-and boarhounds, that head the file, being led singly by men. The quaintly-shaped coach drawn by six horses at the head of the file contains, we may presume, the Duke. The springless cart and the vile roads of those days must have made this manner of conveyance a very doubtful pleasure.

Our next picture, Fig. I I 5, a very curious one, depicts another detail of ancient venery, to which the greatest attention was paid at a period when its laws were a regular science, and nobles broke any other canons rather than those of venery. The drawing shows us in a series of twenty-one groups how stags were undone. We see here to what use the heavy hunting-knife of peculiar shape, which the Duke wears slung on a belt from his shoulder in Fig. I I6, was put, viz., as a sort of chopper, the single-edged blade being very heavy, so as to enable the hand wielding it to give heavy blows sufficient to unjoint the bones of even these giant deer. They were very massive tools, the blade, which had no point, weighing, with sheath and small knives at the side of the big blade, as much as a modern small-bore rifle. The hounds that we observe being led about on leash are lymers, 178 


\section{COBURG HUXTIXG CHROXICLE}

or track-hounds, the most valued adjunct of the mediæval sportsman as we have already heard. When the carcass was finally undone in the workmanlike manner we see depicted, the antlers were "presented" to the lymer that had tracked him, and he was allowed to lick them, while the more tangible "reward" consisted of

\section{Of the Bifon.}

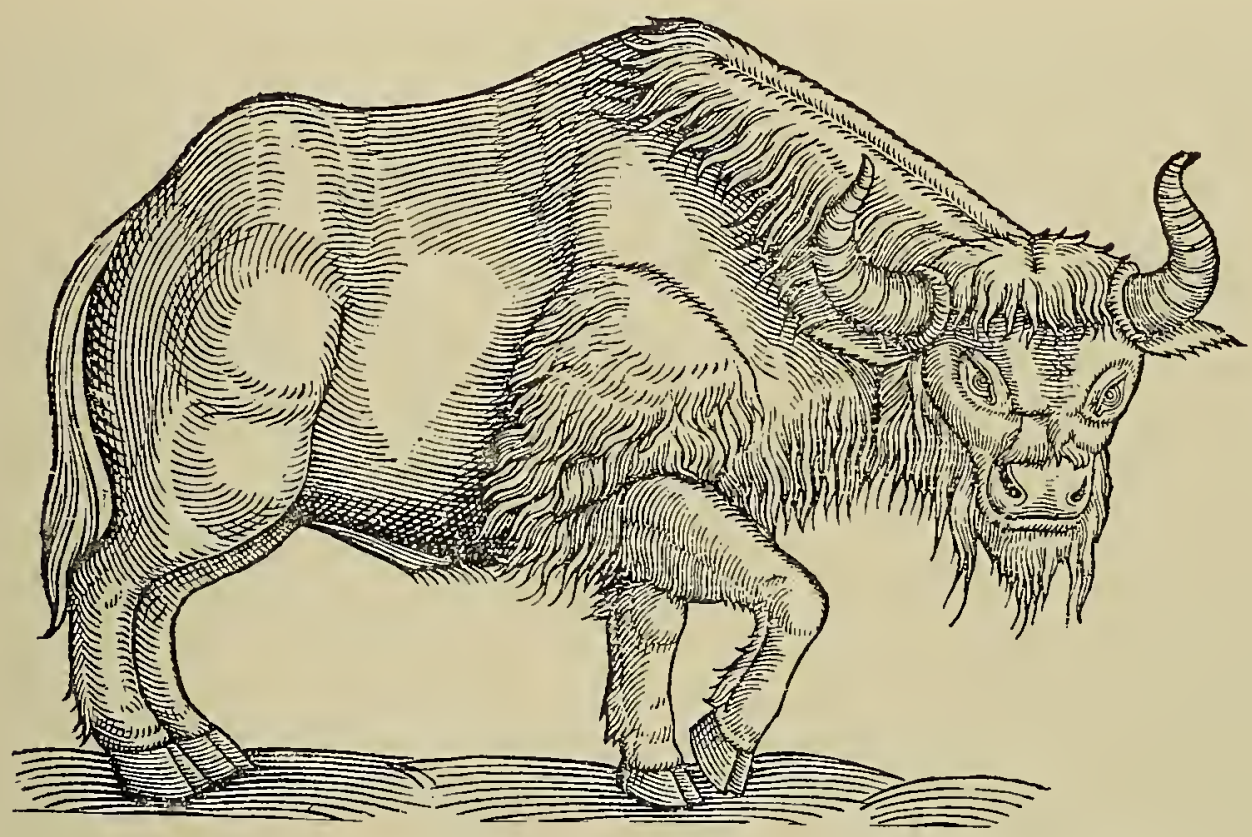

FIG. I IO. BISON IN TOPSELL'S “HISTORIE OF FOURE-FOOTED BEASTES,” I607. COPIED FROM HIRSCHVOGEL'S WOODCUT IN HERBERSTEIN'S WORK ON HIS RUSSIAN TRAVELS IN THE FIRST HALF OF THE SIXTEENTH CENTURY. See Figs.

20, 46, 47, 79, 88, 99, 102, 151, 210, 225, 227 ; and Pages 37-51, 86-90, 149

certain carefully selected tit-bits of the deer. Fig. I 6 depicts the curée, or the rewarding of the ordinary packs used in the hunt. It was a ceremony of the first importance, various measures being blown on the short hunting-horn of the time by the hunt officials under the personal lead of the Duke, every detail being as carefully attended to as if it were a state ceremony of the first importance. The deer's "pryse," as our own author, Turbervile, calls it, with the recheats that belonged to it, was the measure usually trumpeted, though, of course, each country had its own particular hunting notes. Not even from this hunting scene is our friend Master Claus absent, for we see him tootling away gaily just in front and a little to the right of his Royal master. Let us hope his little lungs did not produce a squeaky discord amid the melodious fanfares with which those great hunts found their conclusion. 


\section{SPORT IX ART}

The two last-described ceremonies took place only when stags had been stalked singly or had been hunted on horseback, for in the case of battues the quantity of slain game was far too great; on these occasions the strecke, or laying out of the dead game, was the concluding scene. This consisted in placing the slain in long rows, each kind by itself, the heaviest stags lying in the place of honour at the

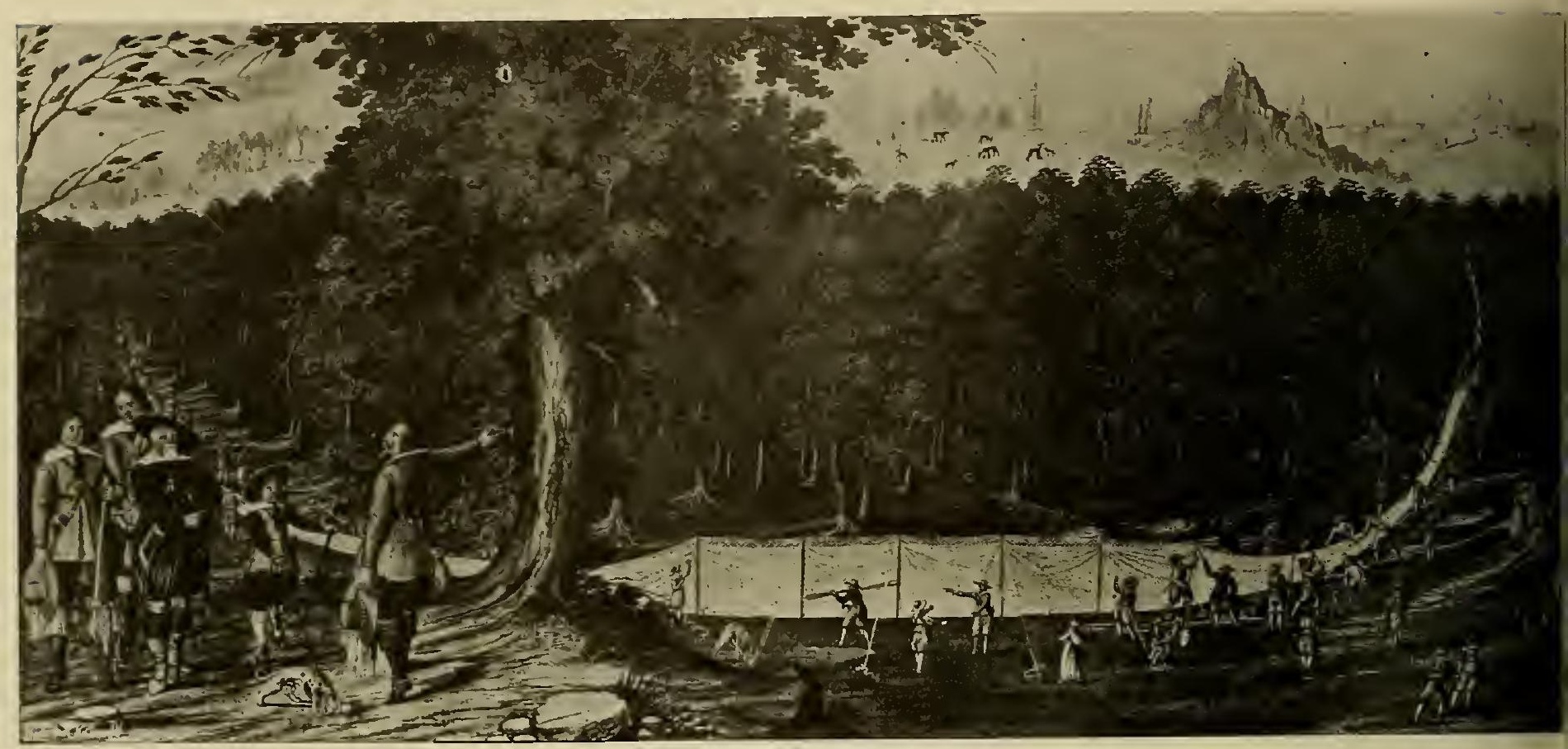

FIG. III. THE COBURG CHRONICLE. DUKE JOHN CASIMIR $(1564-1633)$ ORDERING THE SETTING UP OF SCREENS IN PREPARATION FOR A DEER BATTUE. See Pages $172-18+$

head of the deer line. Thus arranged the Duke would walk down the rows holding a last review of his victims. Earlier in the day they had passed him while he stood ensconced $i n$ his stand, flying in serried ranks for their lives along those fatal canvas screens; now it was they, reposing in long rows on the greensward, that remained in repose, while he passed along commenting to his hunt officials or guests upon any unusual feature that caught his eye.

Among the fifteen drawings in the Coburg Chronicle for which we cannot make space, there are pictures of a bear-hunt showing to what use those huge hounds were put; then of a wolf-hunt, a roe drive, and several drawings relating to battues of the kind depicted in our reproductions. Of the Strecke as conducted under varying surroundings there are also several pictures, so that we can form fairly correct ideas of the sport enjoyed by John Casimir of Coburg. We lack only the 180 


\section{SPORT IX ART}

near the districts ruled by these two game-slayers. This was the Thirty Years War that lasted from 1618 to 1648 .

The position of the lower classes in the German Empire was a pitiable one even in time of peace. For centuries they had remained helpless victims of their rulers' passions, for the little episode at Rumnymede was unrepresented in their own

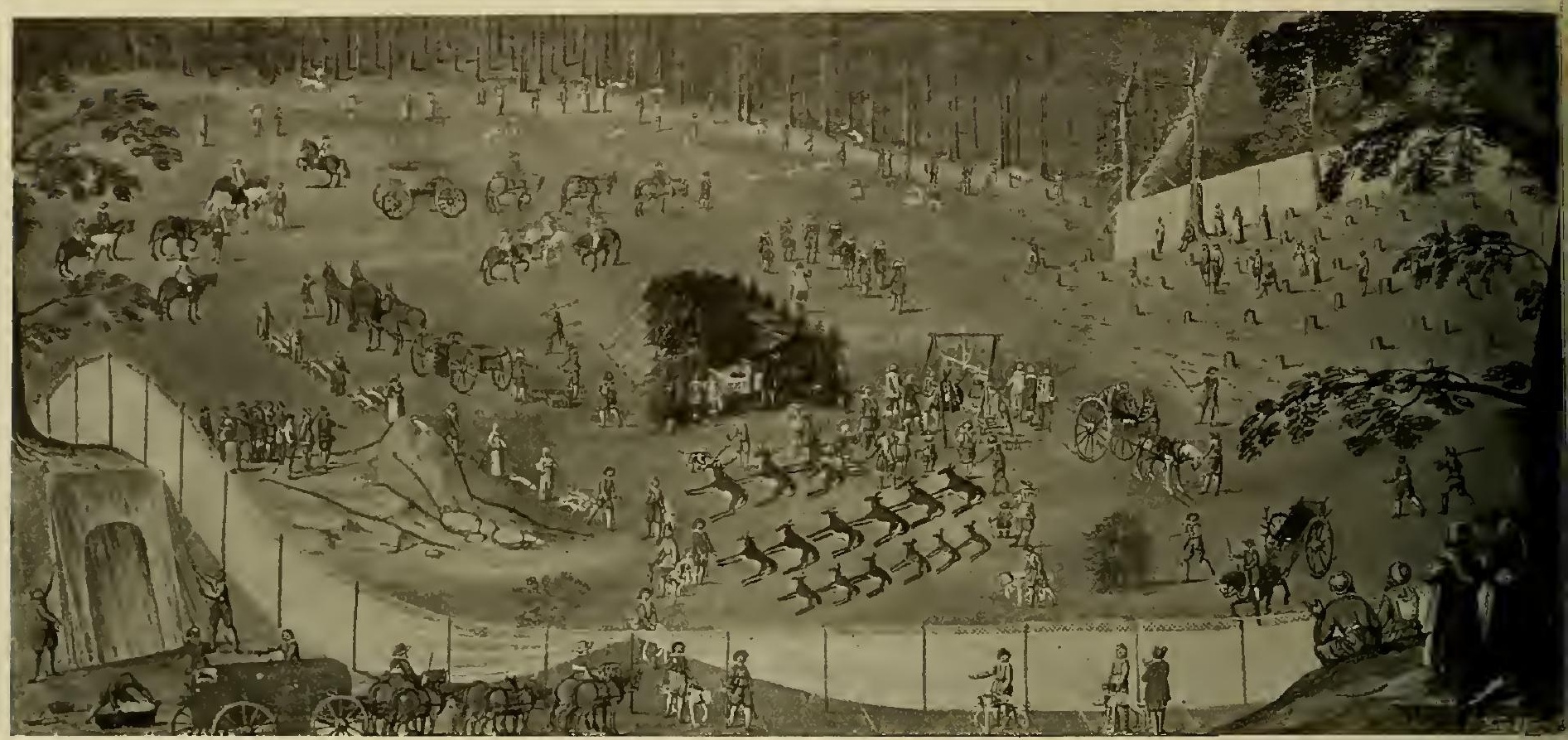

FIG. 113. THE COBURG CHRONICLE. HOW STAGS WERE WEIGHED AND HOW THE CEREMONY OF "BLADING" CULPRITS WHO HAD CONTRAVENED RULES OF VENERY WAS PERFORMED. See Pages $172-184$

history, and the ferocious game-laws from which that June day of 1215 had for ever freed us, remained in force there quite five hundred years longer than in Britain. In the eyes of the score or two of German potentates the tiller of the soil, the artisan and the craftsman existed but to minister to their pleasure. The farmer grew his crops for the great herds of deer and boar to feast on. Neither fence nor ditch could be constructed to prevent their unwelcome visitations, and to put up a trap or snare was literally a matter of life and death. For weeks at a time every adult villager had to turn out to beat the woods and drive together deer and boar, endless chains of watch-fires having to be kept up at night-time, so as to get together as much game as possible for the great court hunts when thousands were slaughtered. The artisan had to give his labour gratuitously to construct and keep in repair the enormous bunting equipage, the hundreds of carts I 82 


\section{SERUICES OF THE CH.ASE}

and waggons for its transportation, while during the off season male and female had to manufacture and make up the miles upon miles of canvas screens from six to ten feet in height, the use of which our Chronicle so graphically illustrates, or they had to share with the Jews the equally onerous duty of providing the Lappen or sewells that were used to surround huge districts as a further aid in keeping game

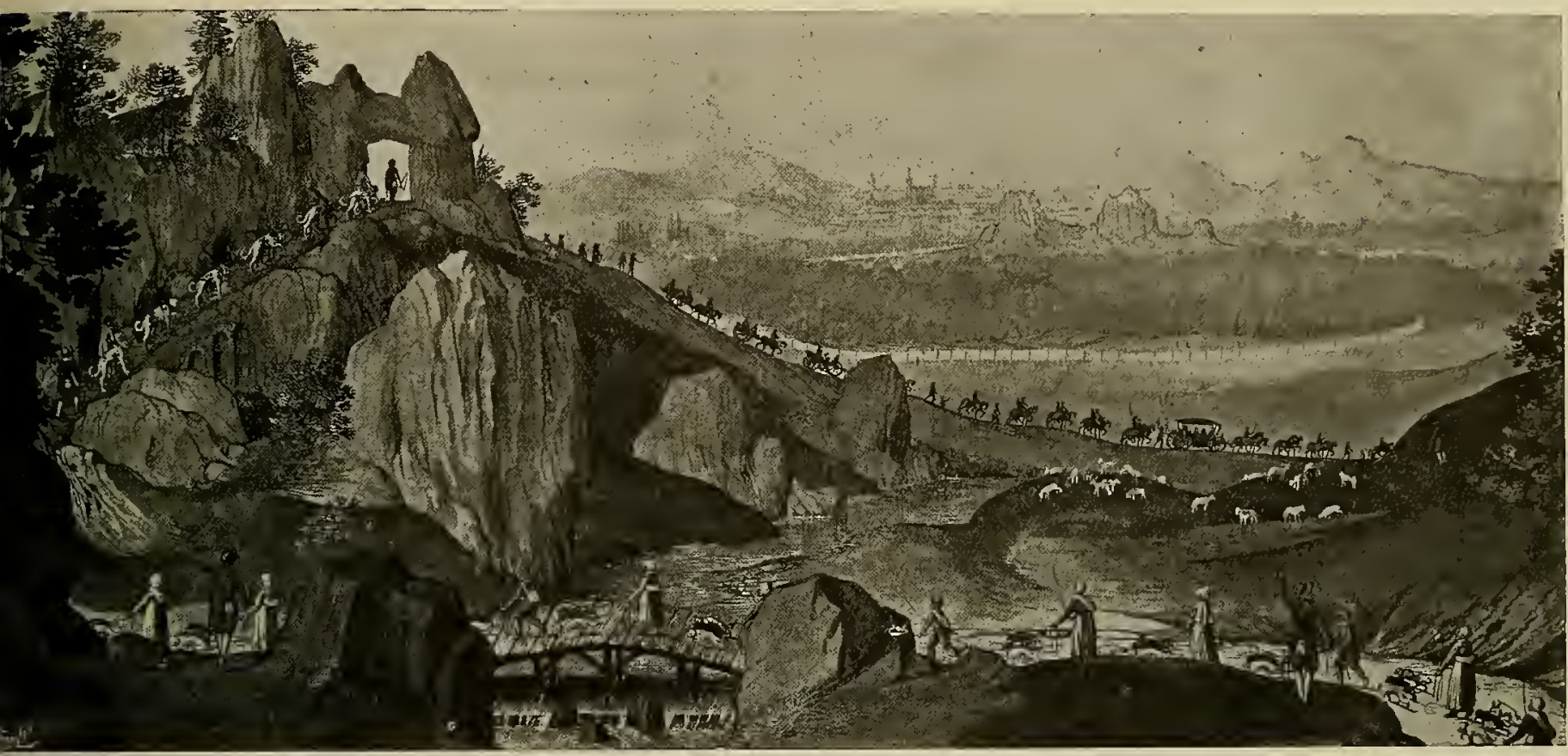

FIG. II4. THE COBURG CHRONICLE. DUKE JOHN CASIMIR RETURNING FROM THE CHASE. MEN LEADING THE BEAR-HOUNDS SINGLY; MINOR HOUNDS BEING LED IN THREES BY WOMEN. See Pnges I $72-184$

together for the pleasure of the sovereign. Well into the eighteenth century did this unspeakably oppressive servitude of the chase continue. An instance culled from documents of the time will illustrate this. In his report to his superiors the district commissioner of Storkow, near Berlin, writing in 1720 , declares that in consequence of orders received from the King's groom-of-the-chase, he commanded the whole population of his district again to meet at the Par force Park to clear it of stones, and for this purpose to provide themselves with bread for three days. "But, Mighty Lords," writes the distracted commissioner, "most of these miserable subjects had not bread for more than one day in their hovels, and not a few absolutely none at all, so what was I to do?" How, indeed, could this unfortunate official turn away the wrath of the lords of the Green Cloth ? To set starving wretches to pick up stones so that the King's cavalcade pursuing the 


\section{SPORT IX ART}

lordly stag, should not trip up over stray pebbles, seemed even to this Prussian official just a trifle hard, for he concludes his report by suggesting a slight remission of these services of the chase, of which, as he says, "they have had more than their share."

While the country groaned under enormous taxation, the people's substance was

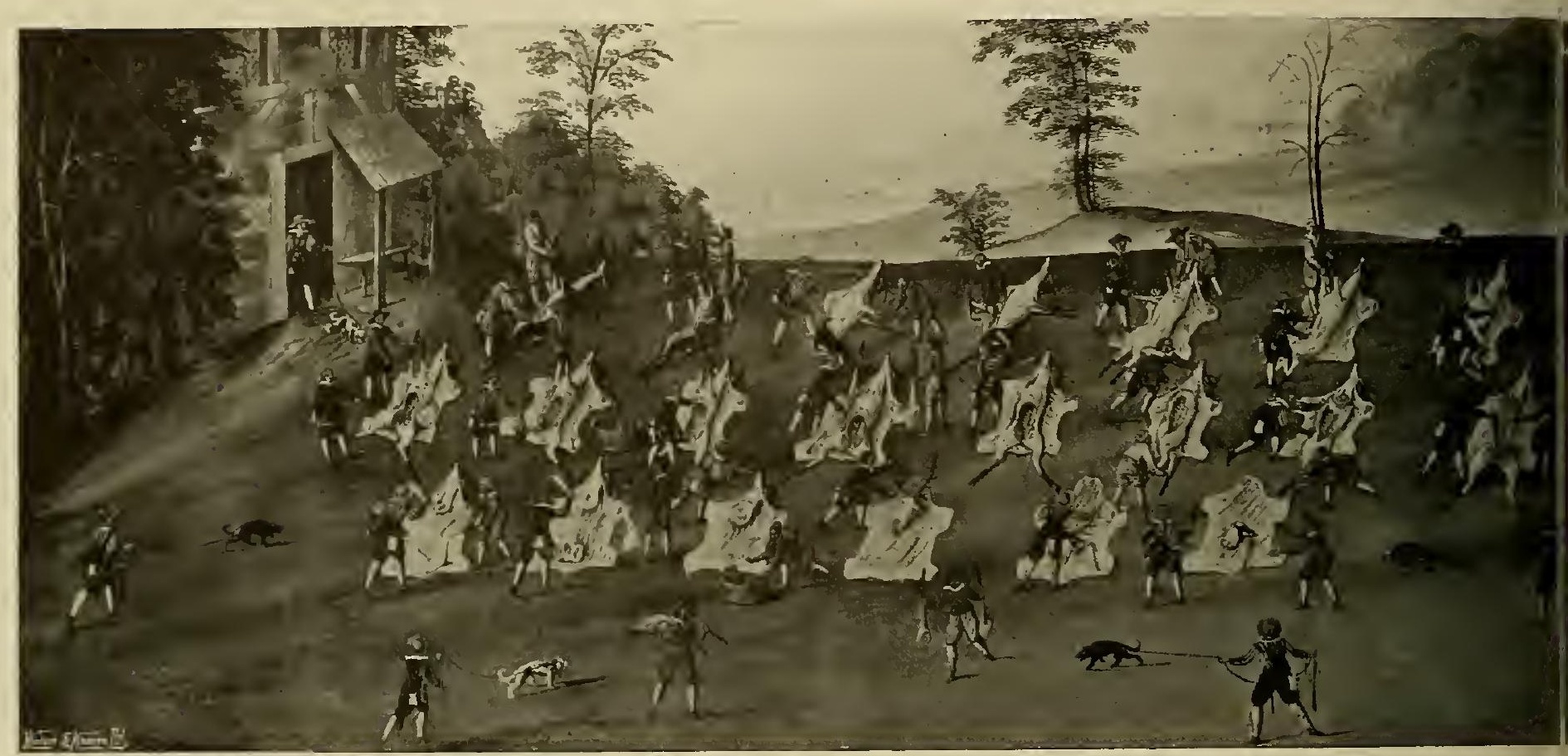

FIG. II. THE COBURG CHRONICLE. HOW STAGS IVERE UNDONE. THE TWENTY-ONE SCENES DEPICT THE WHOLE PROCESS. See Pages I $72-1 S_{+}$

dissipated in wild drinking bouts or licentious debauches, or wasted in costly expeditions to distant countries to collect rare beasts such as lions, tigers, rhinos and bison, some of which were transported for months in litters borne by men, and, when they did finally reach their destination, were used for baiting matches. The chief occupation of ambassadors at foreign courts seems to have been to present or to receive selected specimens of hunting dogs, falcons, horses or trophies of the chase; while the latter, such as antlers of great size or abnormal growth, were eagerly purchased for incredible sums.

Another form of oppressive service of the chase enforced by sport-loving rulers was the billeting of thousands of hounds upon the peasantry, who had to keep them in good condition, and thus had often to deprive themselves of food badly needed for their own families. Monasteries and even the quiet retreats of nuns 184 


\section{THE ABUSES OF THE PEASAXTRT}

were not spared when homes were to be found for hungry packs, which were mostly mongrels used for wild-boar hunts where scores lost their lives; the choicer breeds and the track-hounds being, of course, kept in kennels in or near the palaces.

Three little books* of the period we are discussing give some startling details of the awful abuses under which the peasantry of Germany had to suffer. The

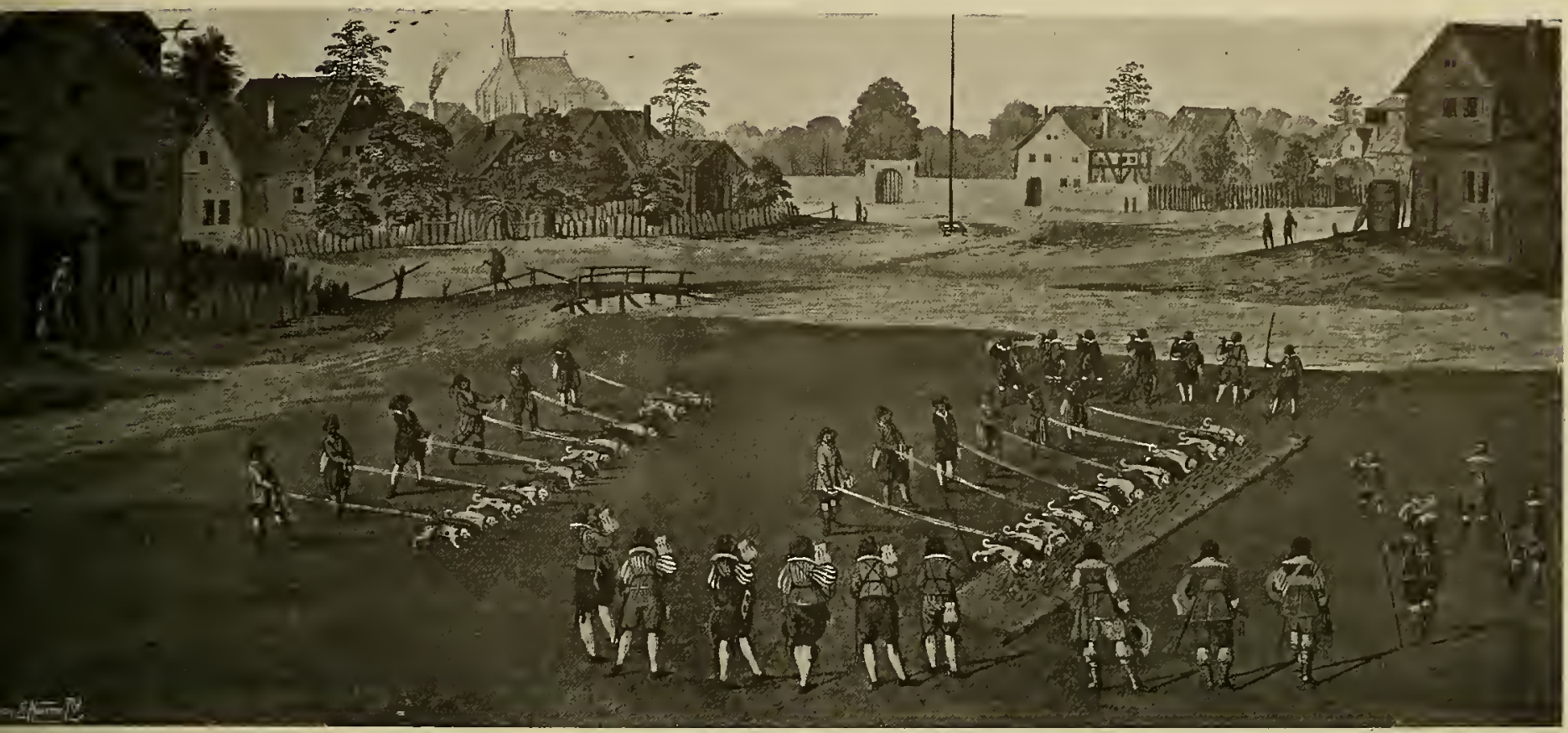

FIG. II6. THE COBURG CHRONICLE. THE CURÉE, OR HOW PACKS OF HOUNDS WERE REWARDED IN THE PRESENCE OF THE DUKE AND HIS HUNT OFFICIALS. Pages $172-184$

instances of ferocious punishments awarded to poachers cited in these treatises seem hardly credible. What shall we say of Archbishop Michael of Salzburg, who in 1537 ordered a peasant discovered in the possession of a dead stag (which he declared he had found in that condition in his own field) to be sewn up in the skin, and, placing it in the market-place, set his whole pack on it, he himself blowing the Morte while the ravenous brutes were tearing the unfortunate peasant to pieces? "If my good hounds do not finish him off he shall have another chance of "finding' dead stags in his fields," mockingly said the Church lord. Duke Ulricus of Württenberg must also have been a pleasant overlord. By an "unfortunate accident" in the hunting-field this potentate rid himself (by a shot

* Spangenberg's Der Fagdteuffel (Chase Devil), I560; Rebhans' Esau Venator, or Sixteen Christian Sermons of the Chase, Wittenberg, I62I ; and Colerus' Hausbuch, 1627.

$2 \mathrm{~A}$ 


\section{SPORT IX ART}

from his cross-bow) of Knight Hans von Hutten, the husband of a lady with whom the Duke desired to carry on an intrigue. The Duke made the law, and enforced it without mercy, that anyone found in his woods with a fire-arm, crossbow, or other weapon should have his eyes picked out, whether he had killed anything or not. When his minister Breuning dared to remonstrate with him about his severity he caused his clothes to be drenched with spirits and then set fire to them himself. A peasant found with a hare under his coat had it forced down his throat, and was of course suffocated.

The obsession for the chase revealed by some of the German potentates seemed to know no limits, and while at some courts it was not driven to the same extremes as at others, the chief offenders were the rulers of the last-named Duchy of Württenberg, the lords of the two Hesse principalities, the Electors of Saxony, and the Dukes of Coburg. In these five countries everything had to give way to the chase, the most important considerations of State, Church, Court, Domestic arrangements-all were secondary matters when stags commenced their rut, or when they entered their Feistzeit " grease-time," to use the English term), when wild boar came into season in December, when capercaillie and black-cock mated in April, or the spring and autumn flighting-time of woodcock and wild fowl lured the lords into the woods.

In certain accounts left to us by some of these royal slaughterers, carefully kept diaries recount the lord's daily achievements with gun or hounds, and copies of these game-books were sent by special couriers to friendly sovereigns, who returned the compliment in like manner.

The greatest possible importance was attached by these record-hunting old sportsmen to weights and heads that were out of the common. The news of an unusually large pair of antlers having been bagged or of a stag having been grassed, who scaled more than record figures, was immediately sent to all the other royal sportsmen with whom the fortunate nimrod had personal acquaintance, and from their courts the news spread over the continent of Europe as were it the most important affair of state.

In the Imperial archives in Vienna and in those of Dresden,. Stuttgart, and Munich the student can find piles of such ancient hunting documents that have lain there undisturbed for three hundred years, the sand with which the writers strewed the ink to prevent blotting still sticking to the cramped handwriting. They are difficult to decipher, and of more than quaint spelling, as the two specimens in Fig. 117 and 162 will show. The former is reproduced from a page in Elector John George I's diary, in which with his own hand he noted the particulars of four stags he stalked on September i 8th, I6I9, mentioning the place, exact weignt, and size of the head. Fig. 162 is a reproduction of a portion of Emperor Charles VI's diary in which, in his illegible handwriting, he relates the details first of a stag and then of a chamois hunt held in September 1732, in the I 86 


\section{HUXTIX్G DIARIES}

Salzkammergut, in mountains with which the writer of these lines happens to have been familiar in his boyhood, as they formed part of his father's estate.

One of the most interesting correspondences in this respect is the letters sent by the writer of Fig. I I 7, the Elector John George I, to Emperor Ferdinand, which

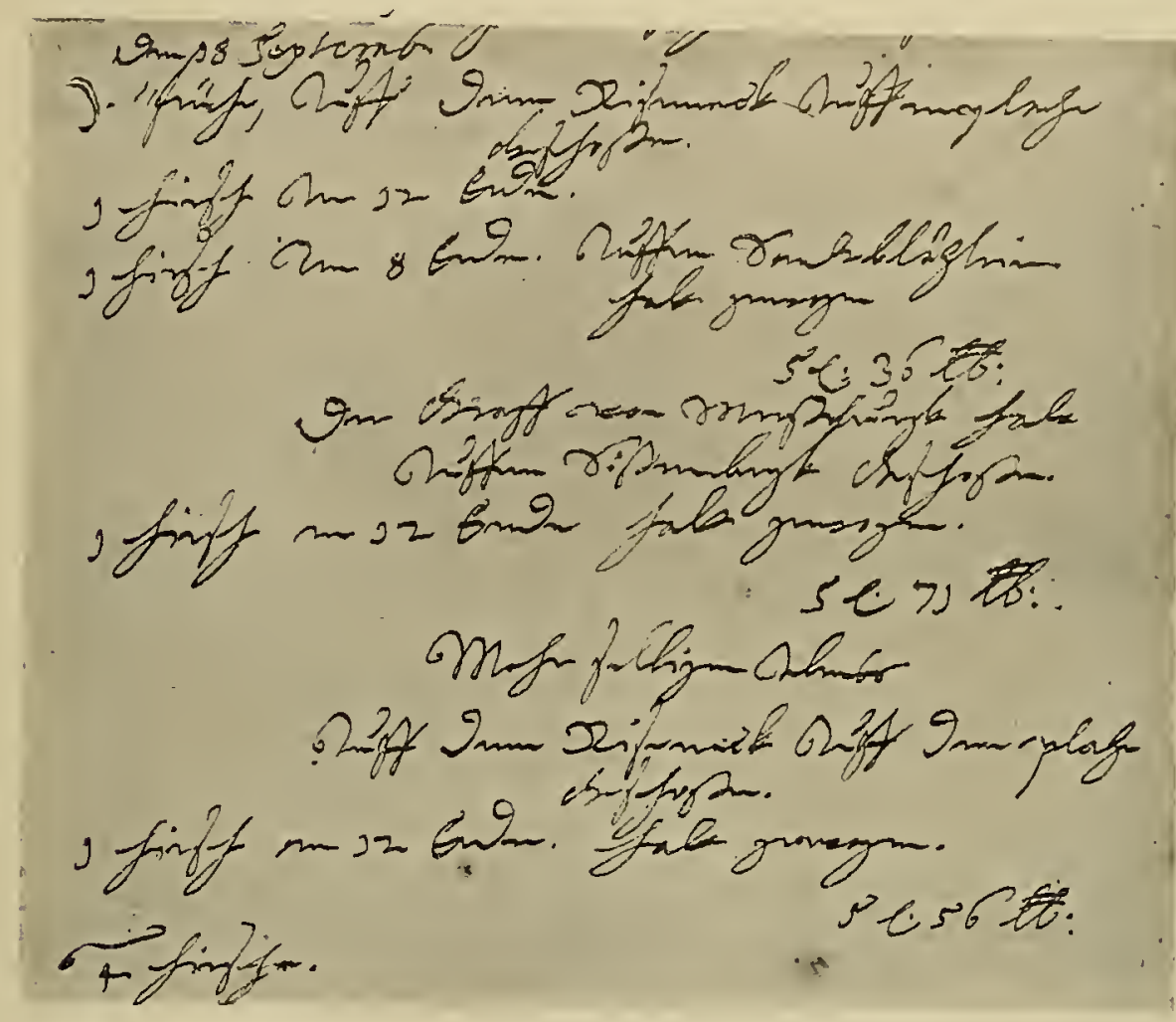

FIG. II7. PORTION OF ELECTOR JOHN GEORGE I'S HUNTING DIARY, GIVING PARTICULARS OF FOUR STAGS HE STALKED ON SEPT. 18 1619. See Fig. 162 and Page 186

are preserved in the family archives of the Habsburgs at Vienna. They deal exclusively with the chase and give even more minute details relating to stags than his diary contains. Thus in many instances the Elector draws, on the margin of the paper, lines indicating the thickness of the layer of fat on the brisket and on the stag's haunches which he ascertained with his own august hands.* The following two lines are accurately copied by the writer from one of

* In Scotland it was also customary to measure the thickness of the fat on the stag's haunches, as we know from the instance mentioned by Scrope, who tells us of an exceptionally heavy stag killed by the Duke of Atholl in the woods of Dunkeld that weighed as he fell $30 \mathrm{st}$. $6 \mathrm{lb}$., his antiers 13 lb. 2 oz., while the fat on his haunches was $4 \frac{7}{8}$ inches thick. To-day, alas! a film of fat a tenth of that in thickness is already deemed satisfactory. 


\section{SPORT IX ART}

the original letters. They relate to a stag he grassed on August I 2th, 1622, weighing $605 \mathrm{lb}$.

thickness of fat on brisket.

thickness of fat on haunch.

A much heavier stag was the one the same sportsman killed on July 3 I, I 626 , which scaled $743 \mathrm{lb}$. or 6 I stone I I lb. avoirdupois. The longest "line of pride" the writer came across in the Elector's communications to his imperial friend refers to a royal which he killed in the same month and year but a fortnight earlier (July I7, 1626). It measures :

or just four and a

half inches of fat on his haunches! His weight was however less by some $98 \mathrm{lb}$. than that of the foregoing beast.

In conclusion we are tempted to repeat some condensed statistics showing the totals of different species of game bagged by the two Electors, although the writer gave space to them many years ago in his "Sport in the Alps." In illustration of the enormous decrease in the quantity and quality of stags that has occurred in two hundred years, the bag made by a descendant of these nimrods who was one of the keenest sportsmen of the nineteenth century has been added.

\begin{tabular}{|c|c|c|c|c|c|c|}
\hline & & & & $\begin{array}{l}\text { or John George I } \\
\text { Saxony, reigned } \\
1611-1656\end{array}$ & $\begin{array}{c}\text { Elector John George II } \\
\text { of Saxony, reigned } \\
\text { I } 656-1680\end{array}$ & 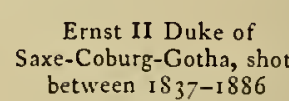 \\
\hline Red deer & . & $\ldots$ & $\ldots$ & $35,+21$ & 43,649 & 3,283 \\
\hline Fallow, & ... & $\ldots$ & $\ldots$ & $I, 045$ & 2,062 & - \\
\hline Roe ", & .. & $\ldots$ & $\ldots$ & 11,489 & 16,864 & - \\
\hline Wild boar & .. & $\ldots$ & $\ldots$ & 31,902 & 22,298 & - \\
\hline Bear $\ldots$ & $\ldots$ & $\ldots$ & $\ldots$ & 238 & 239 & - \\
\hline Wolves... & $\ldots$ & $\ldots$ & $\ldots$ & $3,8 \div 2$ & 2,195 & - \\
\hline Lynx ... & ... & $\ldots$ & $\ldots$ & 217 & I 91 & - \\
\hline Hares ... & $\ldots$ & $\ldots$ & $\ldots$ & I 2,047 & 16,966 & - \\
\hline Foxes $\ldots$ & $\ldots$ & $\ldots$ & $\ldots$ & 19,015 & $2,74^{\circ}$ & - \\
\hline Beavers... & $\ldots$ & $\ldots$ & $\ldots$ & 37 & 597 & - \\
\hline Badgers & & $\ldots$ & $\ldots$ & 930 & $.1,045$ & - \\
\hline Otters ... & $\ldots$ & $\ldots$ & $\ldots$ & $8 \mathrm{I}$ & 180 & - \\
\hline Wild cats & ... & $\cdots$ & $\ldots$ & 149 & 292 & - \\
\hline Stags' heads & of 30 & oints & $\ldots$ & I & - & _- \\
\hline$"$ & 28 & $"$ & $\ldots$ & I & - & - \\
\hline$"$ & 26 & $"$ & $\ldots$ & I & - & - \\
\hline$"$ & 24 & $"$ & $\ldots$ & 3 & - & I \\
\hline$"$ & 22 & $"$ & $\ldots$ & 9 & 6 & 2 \\
\hline$"$ & 20 & $"$ & $\ldots$ & 25 & 26 & 4 \\
\hline ", & 18 & $"$ & $\ldots$ & 133 & 54 & 8 \\
\hline$"$ & I6 & $"$ & $\ldots$ & 374 & 295 & $3^{8}$ \\
\hline$"$ & $I_{4}$ & $"$ & $\ldots$ & $\mathrm{I}, 202$ & 985 & I 28 \\
\hline$"$ & 12 & $"$ & $\ldots$ & $3,1+7$ & 2,108 & $?$ \\
\hline
\end{tabular}

The Eingestellte "fagen to which Casimir of Coburg was so partial remained popular throughout the seventeenth century, and even such a famous artist as I 88 


\section{THE ART OF SHOOTIX FL FIX}

Velasquez deigned to follow the example of Wolff Pirkner and leave us a large canvas depicting a boar-hunt within an enclosure at the court of Philip IV of Spain. It hangs, as is perhaps unnecessary to state, in the National Gallery. The hunt it depicts probably took place in the preserves at the Prado which commenced within a short distance from Madrid. There was one peculiarity about them that deserves notice. The gentlemen participating on these occasions had to be expert horsemen, and the chief end of their sport was to exhibit good horsemanship. In their hands they hold the horquilla, a long pole with fork-like short spikes at the end with which the sportsman warded off the onslaughts of the wild boar and wolves, the intention being not so much to kill as to show off strength of arm and skill in handling their mounts. Another reason for not killing vast numbers being that Spain never harboured such prodigious numbers of wild boars and wolves as did the vast German woods with adjacent fields where they could seek rich provender without hindrance. In shape these horquillas appear to have resembled the German Wolfsgabeln of which we shall have to speak in the next chapter.

Philip IV, who like most of his countrymen was but a moderately keen sportsman, held annually three great court hunts in the Prado preserves which lasted eight days and cost 80,000 Escudos. But, unlike all other countries, drunkenness was unknown there, for the Spaniard was then as sober as he is now. No wonder that all the German and Flemish officials and soldiers detested the Madrid court as were it worse than a prison.

We now propose to turn to another branch of sport, namely, the art of shooting flying. There is a good deal of uncertainty at what period and in what country the art of shooting wild fowl on the wing was first practised. To arrive at any conclusions we have to turn to pictorial material, this being one of those instances when the artist's graver has left us more valuable evidence than the pen, for with the exception of a few stray notes there is absolutely no very early literature on the subject. Bonfaldini's ra Caccia dell' arcobugio: con la practica del tirare in volo, in aere, ed a borita, published in or about I640 at Bologna, is the earliest treatise mentioning the subject in definite form. It is followed by Martinez de Espinar's Arte de Ballesteria y Monteria, published in 1644 , and ten years later by Tamariz de la Escalera's Tratado de la Caza del buelo, instructing the sportsmen how to shoot on the wing. As to the period when it came to be first practised in England, the following will show that this most probably occurred between the years I674 and I686. In the former year Nicholas Cox published "The Gentleman's Recreation," treating amongst other kinds of sport also fowling, but it contains not a word in respect to shooting on the wing. * Twelve years later

* In the third edition of Cox's book which appeared in I686, a rough woodcut of a stalking-horse is added. It depicts a "stalker" hiding behind the horse, firing his gun at some fowl swimming close by. The cut, which bears the initials W.D.F., is nothing like as good as Blome's print, Fig. 130. 


\section{SPORT IX ART}

Blome published his fine folio under the same title, and there for the first time we meet with instructions concerning "shooting flying," which, he says, "is now the Mode." (See Figs. 139 and 140.)

Although one well-known writer expresses the opinion that the Italians knew the art in 1590 , because in a book published in 1669 it is said that the method had been known in Rome about eighty years, we think that shooting flying was not practised until the end of the first decade of the seventeenth century. For not only is this reliance on an unknown person's memory in itself hardly very convincing, but there is an entire absence of all reference to it in the numerous sporting pictures of earlier dates. Stradanus, who died in 1605 , his contemporary Hans Bol, Vincboons, who issued his series in $16 \mathrm{I} 2$, and finally that very prolific producer of sporting scenes, Tempesta, who is said to have worked right up to the dily of his death in 1630 , all still seemed ignorant of it. In one of the last works designed by Tempesta, his Aucupationis Multifariae Effigies, he depicts a duck-hunt where several sportsmen indulge in the usual pot-shots at ducks on the water, just as Stradanus and Hans Bol drew them half a century earlier. And as Italy, it must be remembered, was supposed to have been the home of the art of shooting on the wing, it seems unlikely that the artists we have named should not have heard of the practice had it been in general use in their time.

The oldest picture of sportsmen shooting at flying game known to the writer is reproduced in Fig. I 8 , depicting Venetian noblemen bringing down flying wild geese and wild duck by the boat-load, though one of the sportsmen is still using a bow and arrow. The latter shows that the picture was drawn at a period of transition when both arms were used. The Venetians were the very persons who would first hear of and practise the new art, for their world-wide commerce, their wealth, as well as the presence of myriads of wild fowl on their lagoons, would assuredly combine to make them earlier votaries of the new "invention" than persons in the inland of Europe or other parts where wild fowl were far less plentiful or civilisation in a less advanced state.

And now to the question, when was this picture designed? It is one of several prints illustrating a little-known folio work on Venetian life and customs, published about the year I626 by Giacomo Franco, who also signed our engraving.* Of course this does not preclude the possibility of the engraving having been produced some years earlier; but in this instance this is not likely to have occurred, as the book was evidently the work of a professional man who

* Giacomo Franco was born in Venice in 1566, the year of his death being unknown. The book is exceedingly rare; the first edition was published in 1609 , the second in 1610 . The title is Habiti d'momeni it donne Penetiane. The only copy of the forner we have been able to examine is the one in the Royal Library at Munich, and it does not contain our print. It is probable, therefore, that if this lack is not an accidental one, our shooting picture was added in the subsequent edition, which would confirm the impression we have expressed. See Appendix : Franco. 


\section{SHOOTIX్XG WILD FOWL FLYIX్G}

would not postpone longer than he could help the sale of his prints. For these reasons it would seem to us that of I 590 is too early by almost a generation.

There is other evidence supporting the belief that it was only in the fourth decade of the seventeenth century that sportsmen began to shoot at flying game, which abroad was called Luftschiessen (air-shooting). Thus the experienced sportsman and author Baron Hohberg, in his Georgica Curiosa published I 682, declares that it was in 1638 , during the Thirty Years War, while he was quartered at Bremen that he first witnessed this "noble and pretty sport" by Marshal Prince Mathias Medici. This sportsman not only shot with the Fusil, i.e. shot-gun, partridges, quail and snipe, but was also such an adept with the Balester (stonebow) that he could hit a ball thrown into the air by his page, so that the two bullets (made of baked clay) would be shivered to pieces in the air.

Louis XIII of France is generally believed to have been the first monarch who shot at flying game : but Magné de Marolles declares that as this Prince was born only in 1601 , he could not have been the inventor of the art, but may have been the first to introduce it

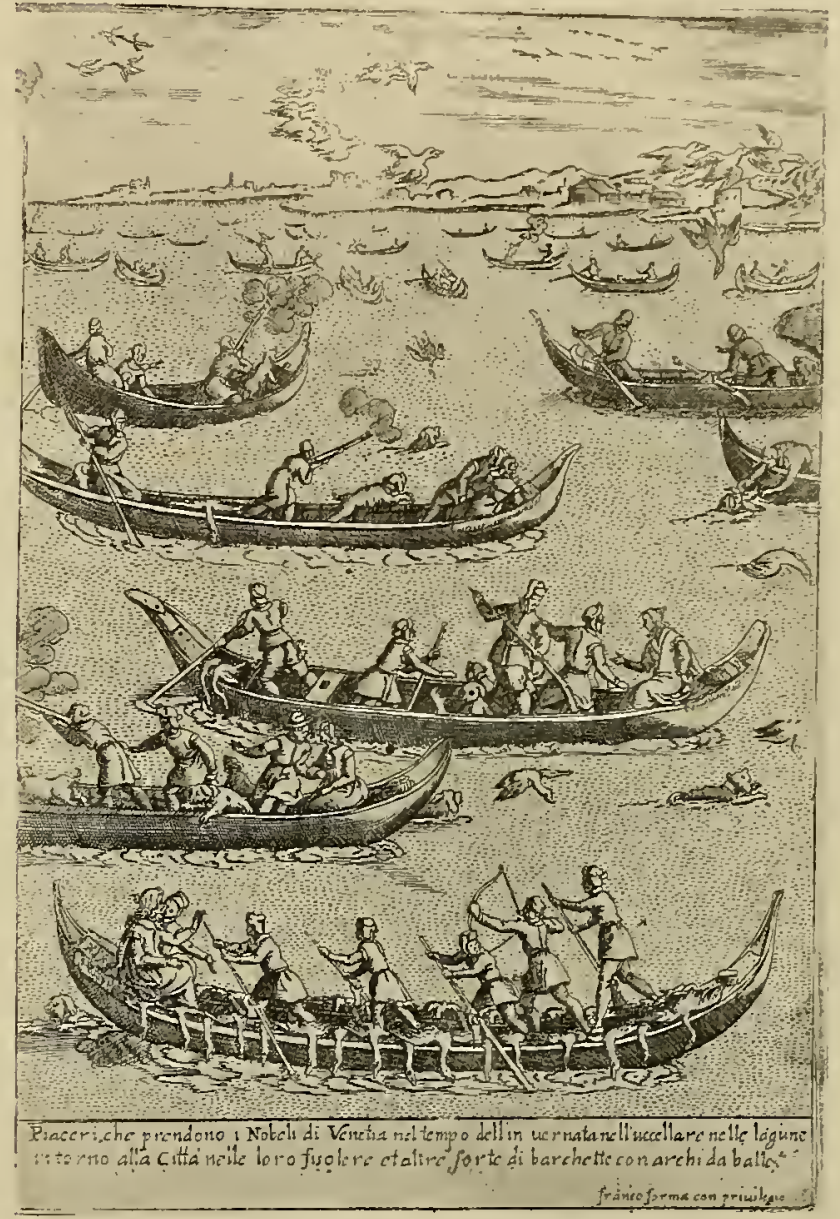

FIG. II8. VENETIAN NOBLEMEN SHOOTING WILD FOWL ON THEIR LAGOONS. THIS IS BELIEVED TO BE THE EARLIEST PICTURE ILLUSTRATING THE ART OF SHOOTING ON THE WING. DESIGNED BY G. FRANCO. IN 1609 . See Figs. 139 and 172, Pages 199-193, and App. into France. Still it does not support the theory that it was invented in the year 1590 . Nor does Martinez de Espinar's remark, that "partridges are shot with an arquebus flying," help to confirm it, for it was made in I644. The same may be said of d'Arcussia's recommendation to falconers, tendered in I 605 , to shoot birds "over the setting-dog with arquebuses" when their falcons were in moult and therefore could not be used. For this did not 


\section{SPORT IX ART}

necessarily mean shooting on the wing. Stradanus and his contemporaries have left us ample evidence that the arquebus in their day was used only for pot-shots.

Emperor Joseph I (1678-r7II) was one of the first German rulers who took up shooting on the wing. His biographer Rink cannot say enough in praise of the Emperor's skill, which he acquired under the tuition of the Italian professional Marc Antonio, who when exhibiting his wonderful skill before the Turks at Belgrad was suspected of witchcraft in consequence of his being able to hit one Hying swallow after another. Rink says that the Emperor shot as well as, if not better than, Master Marc, but that coming from a courtier's lips will bear probably some discounting.

Baron Hohberg repeats some sensible instructions which he says that he received from Baron Pernau in respect to shooting on the wing: when shooting at a suipe (possibly he refers to woodcock), pheasant or quail, stand firm and move only your body and let your left hand govern the gun. Always shoot after a bird has passed you, never as it is flying towards you. Do not aim in front of the bird, but swing in time with your body slightly bent forward. You can shoot as far as one hundred paces (about seventy yards) and even further, but you must take twice as much shot as powder, not by weight, but by eye measure (volume). As the "gas-pipes" with which they did this shooting at a hundred paces were of tremendous length, quick shooting on the wing could have been learnt only by dint of constant practice.

One of the causes which retarded the practice of shooting on the wing from coming into general use, at least in France and in other parts of the Continent, was the belief that setting-dogs were most destructive to partridges, quails, \&c. Henry III and IV of France were both rabid believers in the theory that the disappearance of these game birds was solely caused by the use of these dogs. They and their successors Louis XIII and XlV passed numerous and mostly very stringent edicts prohibiting the use of the setting-dog for sporting purposes, this being called by them chasse cuisiniere, or pot-hunting. By this ferocious legislation, for it was nothing less, the threatened punishment being in the case of repeated offences banishment for life, the practice of shooting on the wing.was naturally also disconraged. Mr. Arkwright in his classic on the pointer gives a number of instructive instances of these edicts.

Pepys' well-known but not very clear allusion, in $166_{5}$, to Louis XIV's bag of partridges: "Sir Robert Long [Charles II's secretary during his exile] told us of the plenty of partridges in France, where he says the King of France and his company killed with their guns, in the plain de Versailles, 300 and odd partridges at one bout," throws little light upon the question, except to show that in that year it was still a noteworthy event to kill partridges with a gun, and, presumably, Hying.

Frenchmen, according to the evidence of Markland, the author of Pteryplegia 192 


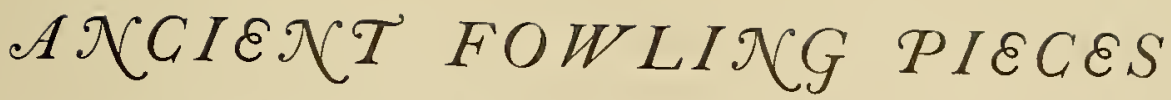

published in 1727 , were then of all men the most expert wild-fowlers. "It's as rare for a professed marksman of that nation to miss a bird, as for one of our's to kill," he declares. This inferiority ceased to exist half a century later in consequence of the extinction of game in France by the Revolution; but that it did prevail two centuries ago proves that shooting on the wing was practised at an earlier period and more extensively abroad than with us. This view is supported by the fact

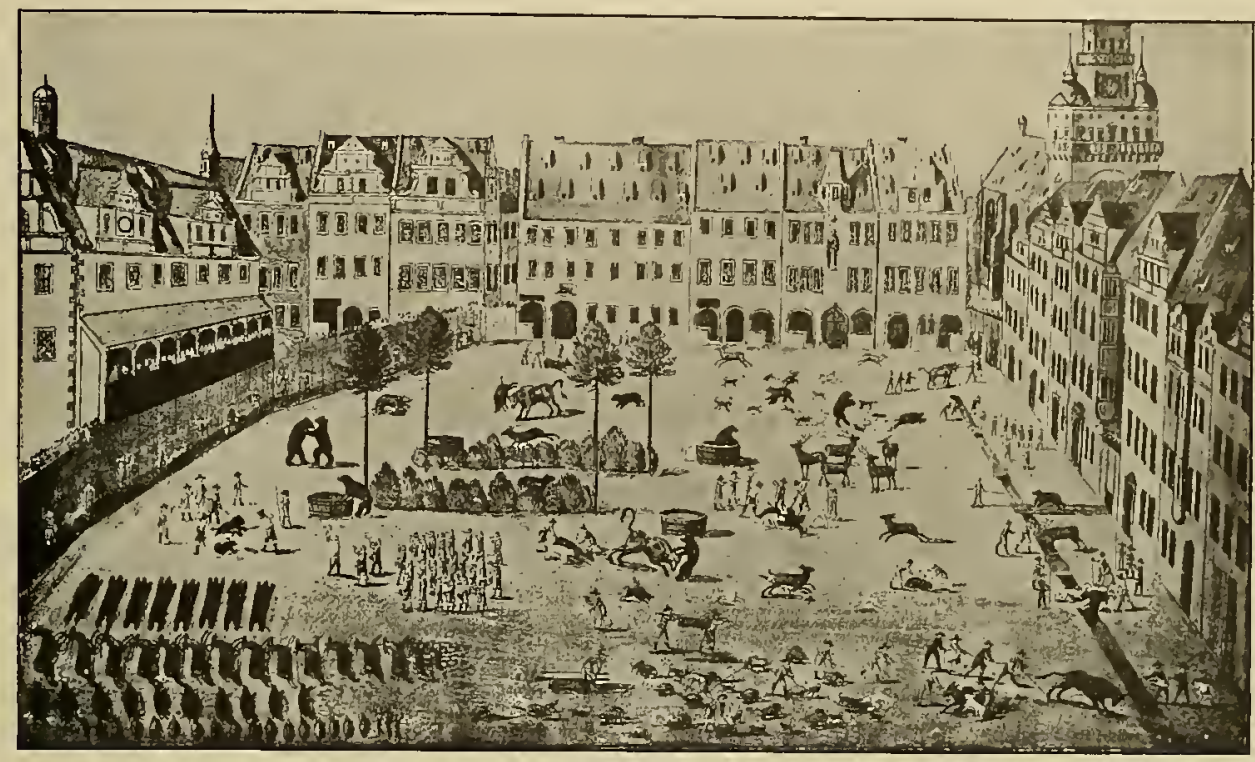

FIG. II9. COMBATS OF WILD ANIMALS, HELD IN DRESDEN IN 16 I7. AFTER A PICTURE BY DANIEL BRETSCHNEIDER (1578-1640). See Pages 193-5

that Continental writers gave instructions in the art at an earlier date than did ours. Blome, who was the first English author to write about it, evidently considered that the longer the barrel of the gun the nearer the bird. He says that "the gun most proper for this sport should be about four foot and a half long in the Barrel, and of a pretty wide Bore ... you should have your gun always Cock't, in readiness with your Thumb over the Cock, for fear of its going off contrary to your intention.... Some are of Opinion that you must shoot something before the Fowl, otherwise it will be past before the Shot can come to it, but that is a vulgar Error; for no game can fly so quick, but that the Shot will meet it, for the Shot flyeth as wide as about the compass of a Bushel, if rightly ordered in the Charging."

One of the strange phases of sport, if it indeed deserves to be so called, which was at one time prevalent at most European courts, was the combats between 


\section{SPORT IX ART}

fierce animals, or the baiting of them by dogs. They were an echo of the scenes in the Roman arenas, and in England they took the form of bull and bear-baiting, the last remnants of which diversion survived until recent times in the shape of dog-fights and the cock-pit. An enthusiastic patron of this sport was the ruler of Saxony in the first half of the seventeenth century, John George I, of whose record-breaking performances in a more legitimate species of sport we have already spoken. David Bretschneider (1578-1640), a Leipzig painter of modest attainments, seems to have chiefly occupied himself with depicting court and civic festivities, and has left us several pictures of such combats. The performances depicted by him usually took place on the Old Market in Dresden, a locality familiar to all visitors. A particularly magnificent show was held there in $6^{6} 7$ in honour of Emperor Matthew's visit to the Elector John George. All imaginable sorts of combats were arranged; bison, then often called aurochs, brought thither from Polish forests at enormous expense, were matched against bears, and wild boars against wolves and stags. A favourite diversion was to let a grumpy old bear be harried by mongrels until he at last took refuge in a big open tub filled with water, such as we see in Fig. I I9. The bear would retreat into it and sit down in it, defending himself by dealing out blows to the yelping mob. This afforded great amusement, so much so that on this occasion when the invalid Emperor had to be carried on a chair to the stand from whence he witnessed the show, we are told he laughed so heartily that he was almost cured from his ailment. John George was probably the most enthusiastic patron that arena combats ever had since Roman days. He received presents of wild beasts from all parts of the world: bears in great number from the Duke of Holstein and Prince Radziwill, white bears which the Elector of Prussia presented to him, and reindeer came from Gustavus Adolphus. Maurice of Orange sent him a lion and a tiger. Bison were sent him by the Polish court, and when Prince Christian of Denmark desired to make overtures for the hand of his handsome daughter, the suitor began the negotiations by a like present for "the Elector's particular pleasure and entertainment." White roebucks, black foxes, chamois, bison, wild sheep from Barbary, dromedaries from the East, wild cats and strange birds from India, as well as several kinds of rare pheasants were received by this ducal nimrod from various other potentates. Most of these beasts arrived in litters and in great cages, in some cases carried by men, in which they had been transported from the remotest parts of Europe. In fact, any animal that showed fight was put to the test in these combats. Immense prices were paid for window-room to witness these fights, which generally lasted several days, as many as nine and ten bears and thrice that number of great wild boars being killed on one day.

A poet named Pezold composed a song belauding the show that amused Emperor Matthew so much, and he tells us that the Elector himself, then a young man, personally took part in the combat, killing bears in the arena with his spear. 194 


\section{PICTURES BY GREAT MASTERS}

His example was not followed by his contemporary Philip IV of Spain, for we are told that when on one occasion at Madrid a particularly fierce and brave bull remained victor against several bears and a lion, leaving them disembowelled on the sands of the arena, Philip ended the courageous animal's career by a shot from his rifle fired from the royal box.

Of another great show at Dresden with which a wonderfully elaborate " Nimrod's 'Triumphal Procession" was combined. J. Drentwed designed and Sigmund Gabriel Hipschmann engraved a huge plate, 136 by $79 \mathrm{~cm}$. in size. It depicts some curious details. Gigantic triumphal cars containing monster allegorical groups of the various gods and goddesses connected with venery were the principal feature. Some of these groups towered so high that they could not get through the city gates, and the road had to be dug down so as to enable them to pass. We refrain from reproducing the plate on account of its enormous size, for the details would have to be so much reduced as to be almost invisible. Another very large plate which it is also impossible to reproduce for the same reason, is an etching made in 1724 by Michael Rentz (170I-58), a Nürnberg painter and etcher, who was called by Count Spork to his huge domain in Bohemia, where was situated a famous watering-place called Kukuk's Bad, or the Cuckoo's Bath. The plate in question $(82 \mathrm{~cm}$. by $68 \mathrm{~cm}$.) gives a bird's-eye view of the whole country-side, various sporting incidents filling in a most skilful manner the foreground, sport being evidently the principai end of the count's vast establishment here so cleverly depicted.

As promised in the Preface, and as the reader has had full opportunity of observing, it has been our object to illustrate the evolution of the chase by drawings and prints in private collections, rather than by reproductions of the more or less wellknown works of great masters in the public gaileries of Europe. Indeed, if we come to look in to the matter more closely, we soon discover that the great masters left us comparatively very little of instructive value. There is nothing very illuminative in the vast canvases of Rubens' various wild-boar, lion, and tiger hunts distributed all over Europe's principal galleries, in Titian's Diana and Adonis in the Corsini, or in that depicting Diana's adventure with Actæon, that Peeping Tom of mythology whom we never want to see again, or in Dominichino's Chase of Diana in the Borghese, or in Carracci's Diana in the Lichtenstein, or Bordone's in the Dresden gallery. It might be interesting to follow the wanderings of certain hunting canvases, such as Rubens' boar-hunt now hanging in the Dresden collection. In this picture Snyders painted the animals, and the master intended the picture to adorn the large hall in "the Roman style" in his own house in Antwerp. Subsequently it formed part of the collection which the Duke of Buckingham acquired in 1627 for the then vast sum of 100,000 florins, to pass by and by into the hands of another keen collector, the Archduke Leopold of Austria, who gave 


\section{SPORT IX ART}

it to the gallery at Prague. From that gallery the Dresden court finally bought it for 800 florins: but with these alluring details, we repeat, we cannot deal in this place.

A curious and most interesting Hunting Calendar and scoring appliance, engraved

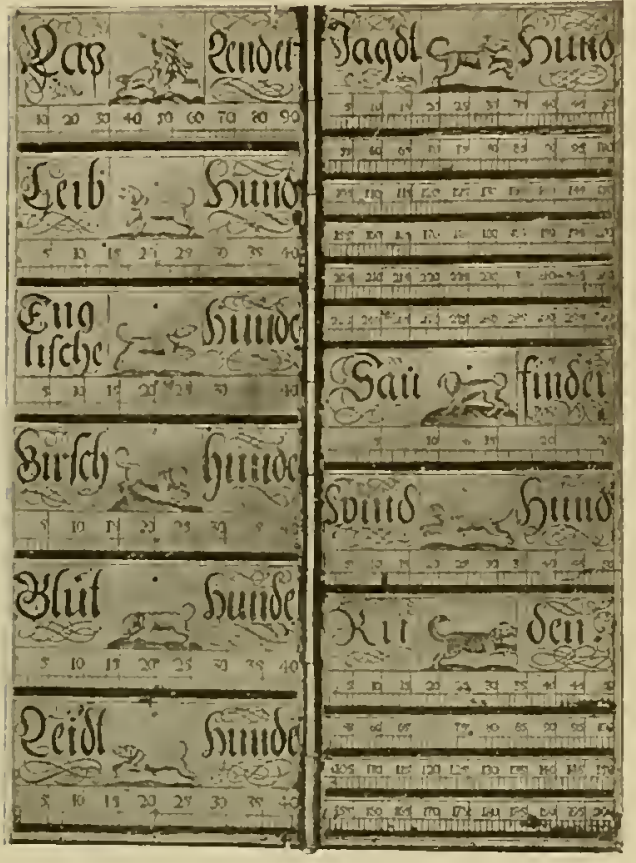

FIG. IIQA. TWO OF THE EIGHT TAB. LETS OF A SCORING APPLIANCE OF THE ROTHSCHILD BEQUEST IN THE BRITISH MUSEUM. See Page 196 on eight tablets of gilt brass, dating from the first quarter of the seventeenth century, is to be seen among the treasures of the Waddesdon Bequest in the British Museum (Fig. I 19A). The tablets are hinged together and are engraved on both sides. On one side each of the tablets bears, at various distances from each other, horizontal furrows about $\frac{1}{10}$ th of an inch wide. These are filled with red wax intended to be marked with a scratch. Above these wax furrows are numerals, and above each set of numbers are engraved the names and the diminutive representations of various animals. First comes the stag, then the hind, then the fox, \&c., with the idea evidently of marking the score or bag by a scratch in the wax below the corresponding number. On the fifth leaf or tablet the hunting appliances are named: Hohe Tücher, Mittel Tiicher, Lange Tuicher (meaning the high, middle, and long screens of canvas used for drives); then come the bundles of Hirsch Lappen, Feder Lappen (meaning sewells made of pieces of plain or coloured canvas or of feathers, such as we see in Fig. 201), and Saw Netze, or wild-boar nets. The seventh and eighth tablets have the names of the various hounds used for the chase. There is the Lap Lender or Lapland dog, of which there were 90 ; the Liib hunde or body dogs; the Englische hunde or English hounds (40); Hirsch hunde (40); Blut hunde (40); Leidt hunde (40); Sau finder (30); Rüden (200); and finally the fagdt hunde or ordinary running hounds. Of these hounds the score could be marked up to 300 . Total 865 hounds.

We have never seen nor heard of any like Calendar or scoring arrangement, and among those who have puzzled over it was the late King Edward, who examined it for more than a quarter of an hour. Unfortunately the donor, the late Baron Ferdinand Rothschild, declined also in this case to disclose from where he obtained it, so there is absolutely no history to it. A suggestion the writer ventures to make to Sir Hercules Read is that these curious tablets be placed a little higher in the case at the Museum, and so that the back could also be seen. 196 


\section{CHAPTER IX: BARLOW, BLOME AND OTHER ARTISTS OF THE SECOND HALF OF THE SEVENTEENTH CENTURY}

$\mathrm{U}$

NQUESTIONABLY the most interesting English hunting-prints of the seventeenth century are those comprised in the set entitled Severall Wayes of Hunting, Hawking and Fishing according to the English Manner, invented by Francis Barlow, etched by $W$. Hollar, which was published in London in I67I. It consists of twelve plates beside the title-plate, their size being 9 inches in width and not quite 7 inches high. Underneath the title is the following quaint quatrain :

\footnotetext{
If Hunting, Hawking, Fishing, pleasure yeald

How much may Art exceede as if in Feild

You vewd each sport, by figure so exprest

The Severall wayes they take Fowle Fish and Beast.
}

Being an interesting and scarce set it will not come amiss if we rectify a mistake in the title, in order that one of our most talented native artists should not be shorn of his dues. For it is giving Hollar more than his due to attribute to him the etching of the whole of this very charming little set. Parthey, to whom the collector instinctively turns for the most authoritative information concerning the works of that wonderfully productive Anglo-Bohemian artist, declares that only the first six plates (counting the title-page as one) were etched by Hollar, the other seven being the work of an unknown artist. As to five of the plates, viz. the titlepage, which we do not propose to reproduce, Hare Hunting, River Fishing, Salmon Fishing, and Angling, being etched by Hollar there can be no doubt, for they are all signed by him; but it would be interesting to know why Parthey attributed also the Cony Catching print, Fig. 1 21, to Hollar's graver, as it does not bear his signature, and, besides, the technique resembles much more that of the remaining seven cuts by the "unknown" master. Our curiosity is also aroused by Parthey's silence in respect to the striking resemblance existing between the above seven prints with the widely-known illustrations that adorn "Esop's Fables," which Barlow not only designed but also etched. In other words, it seems to be almost certain that our talented Lincolnshire artist, and not Hollar, engraved as well as designed the seven "unknown" prints.

Following the sequence given by Parthey to these prints, 2028-2040, which, it is to be presumed, is the order designed by Barlow, we are at once struck, in Fig. I 20 , by the circumstance that our artist still adheres to the ancient rule of giving hare-hunting the premier place, following in this respect the example set to conservative English sportsmen by their forbears who rode with the Plantagenets. We have already explained why England's oldest writer on hunting 


\section{SPORT IX ART}

in his "Master of Game," gave precedence to the smallest and most timid beast that was chased, and it is another and telling proof of the stability of English customs that this otherwise unnotified habit should have persisted for so many centuries. However, Barlow was the last one to recognise the old order, for Blome, compiling but fifteen years later his "Gentleman's Recreation," places

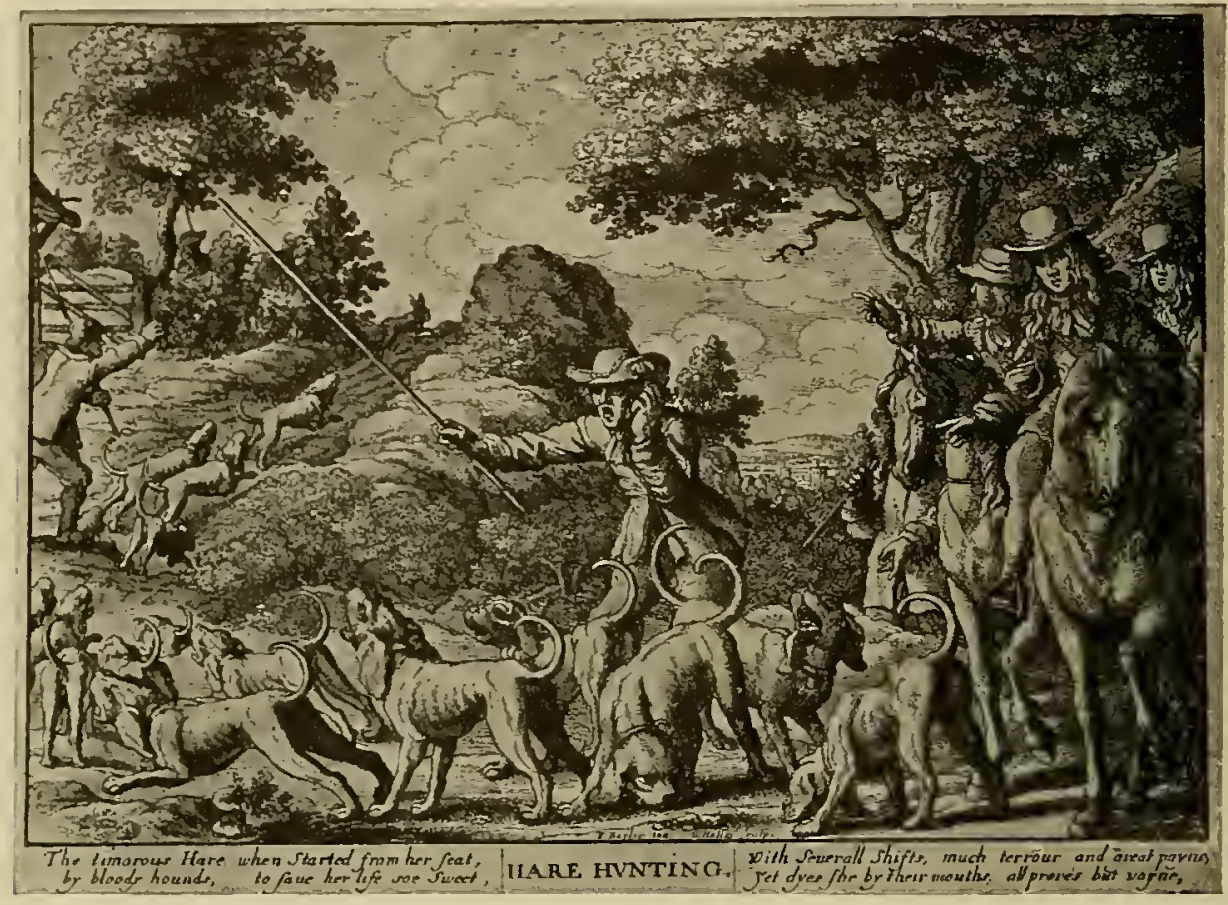

FIG. I 20. DESIGNED BY FRANCIS BARLOW, ENGRAVED BY W. HOLLAR, AND PUBLISHED IN LONDON 1671. See Page 197

stag-hunting first, relegating hare-hunting to quite a minor position. As a contemporary of Barlow-the latter designed the picture of otter-hunting in Blome's handsome folio-his notes are not without interest when bearing upon Barlow's set. The tone of enthusiasm respecting hare-hunting has almost disappeared: "Men of a lower rank may sometimes divert themselves with the hare," he tells us, though he acknowledges that it "affords delight and recreation to many." According to Blome's description, Barlow's hounds, as here depicted, were probably the "deep-mouthed" or "Southern-mouthed hounds," which are "heavy and slow and fit for woodlands and hilly countreys.. . and are most proper for suct, as delight to follow them on foot, as stop-hunting, as some call it, but by most it is termed "Hunting under the Pole." "When the alpenstock-like implement, reminding one of the Venabulum of classic times, was flourished, the hounds came to a dead stop, even if they were on the hottest scent. 198 


\section{BARLOW'S HUXTIX PRIXTS}

Our next picture, Fig. I21, is the reproduction of the Cony Catching print to which we have already alluded. The descriptive quatrain has this time a distinctly commercial ring about it, and there is little about the scene this picture depicts to indicate that it took place nearly 250 years ago, the businesslike spirit that underlies the verse only adding to its apparent modernity.

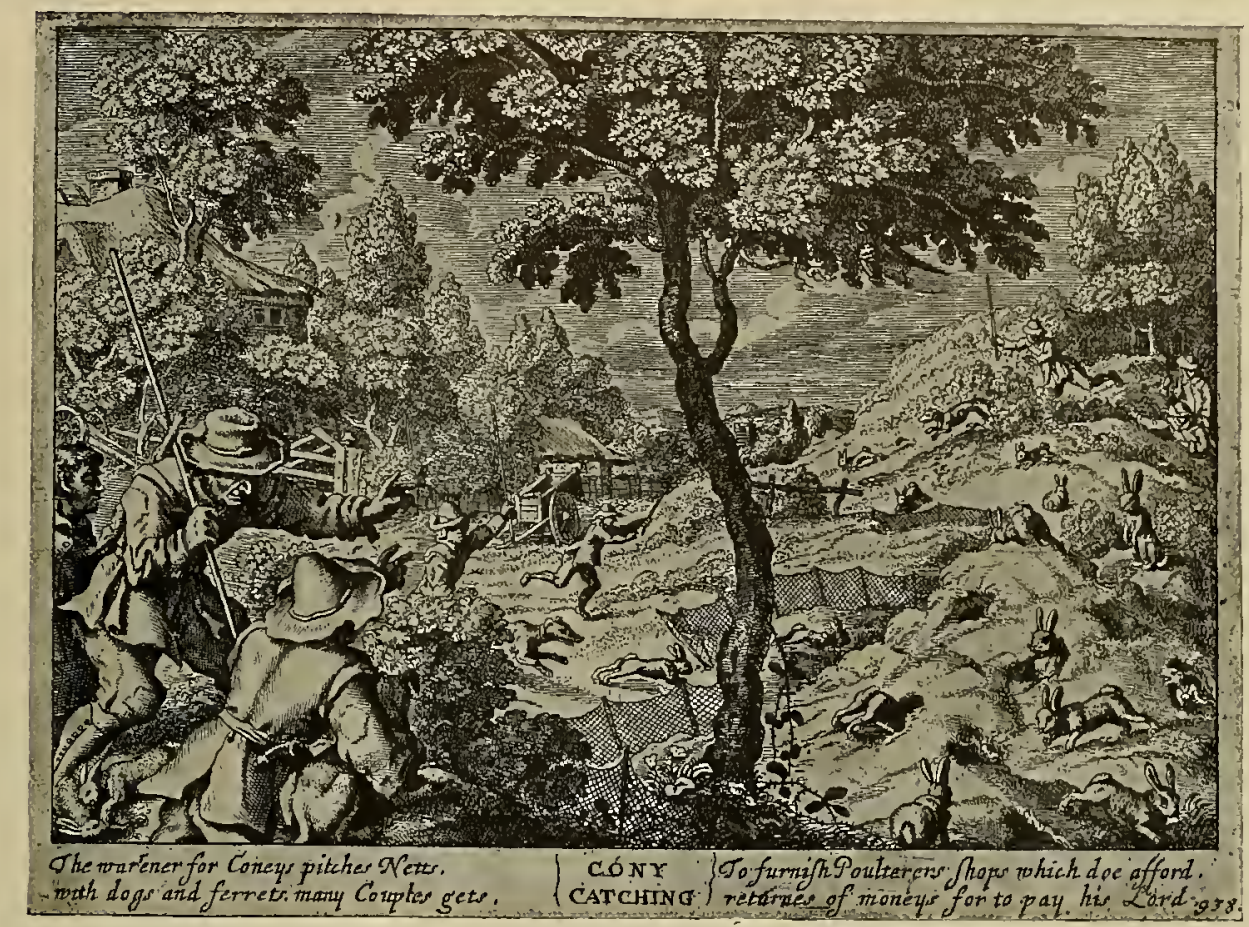

FIG. I2I. DESIGNED BY F. BARLOW AND PROBABLY ALSO ENGRAVED BY HIM. See Page 199

The next three plates, Figs. 122, 123, 124, occupy themselves with the gentle art, as it was then understood, the first being "River Fishing." The poles, of which the quatrain speaks, were evidently large, for the holes that could harbour so many and such a diversity of fish were deep. Of a similar type is the next plate dealing with "Salmon Fishing."

Let us here turn again to Barlow's plagiarising contemporary, Blome. To judge by the scanty space devoted by him to the king of fishes, "sniggling and bobbing for eels," "snapping and huxing and trowling for pike" and various other forms of "poaching" were in his day considered more delectable pastimes than salmonfishing ! Were he right about what he says of some of the salmon's habits, what hotly-waged piscatorial controversies would have been spared to the world of fishermen! Thus " the salmon," he says, "casts his spawn in August, making 


\section{SPORT IX ART}

a hole in some safe gravelly place in the river, and therein hide their spawn, covering it over with stones and gravel and so leaves it; and both the melter and the spawner betake themselves to the sea before winter, and if they meet with any obstruction by floodgates or wears, or become lost in the fresh waters, then those so left do by degrees become sick, lean, unseasonable, pineing away and dye in

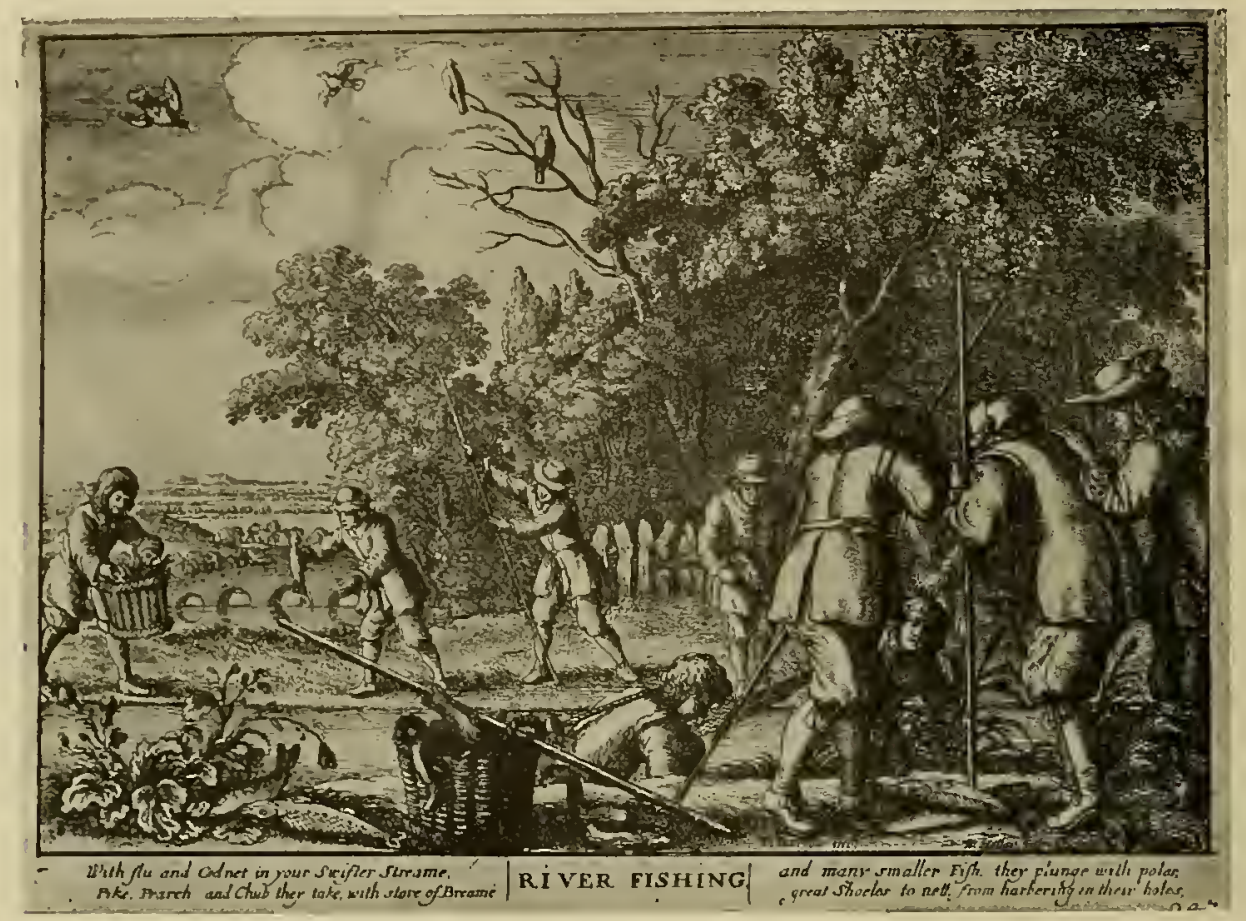

FIG. 122. DESIGNED BY F. BARLOW AND ENGRAVED BY W. HOLLAR; PUBLISHED 1671. See Page 199

about two years; notwithstanding which they delight most in fresh waters, nor will they be so fat and good in salt water as in the fresh; and 'tis observed that those little salmons called skeggers are bred by such sick salmons."

Netting seems to have been the favourite way of salmon-fishing, but Blome gives us also some amusing instructions concerning salmon-angling. "The baits proper for the Salmon, juice of Ivy-berries, or Oyl of Polypody of the oak mixt with Turpentine, it is an excellent Attractive."

"Angling," Fig. 124, is the next print on the line, and it is among the best, both in design and in execution, and one only regrets that it immortalises no higher form of sport.

According to Blome the usual length of rods then in use was fourteen feet, and they had two joints ; the lines were either "all silk or all hair, or mixt with both." 200 


\section{BARLOW'S SPORTIX్X PICTURES}

The creel, of a shape more or less as we know it to-day, does not figure in any of Barlow's etchings; but fifteen years later we find one represented in a picture in Blome's chapters on angling. The common market-basket portrayed in the print before us points almost to the conclusion that the creel, of the shape known to us, had not been invented when Barlow designed this picture.

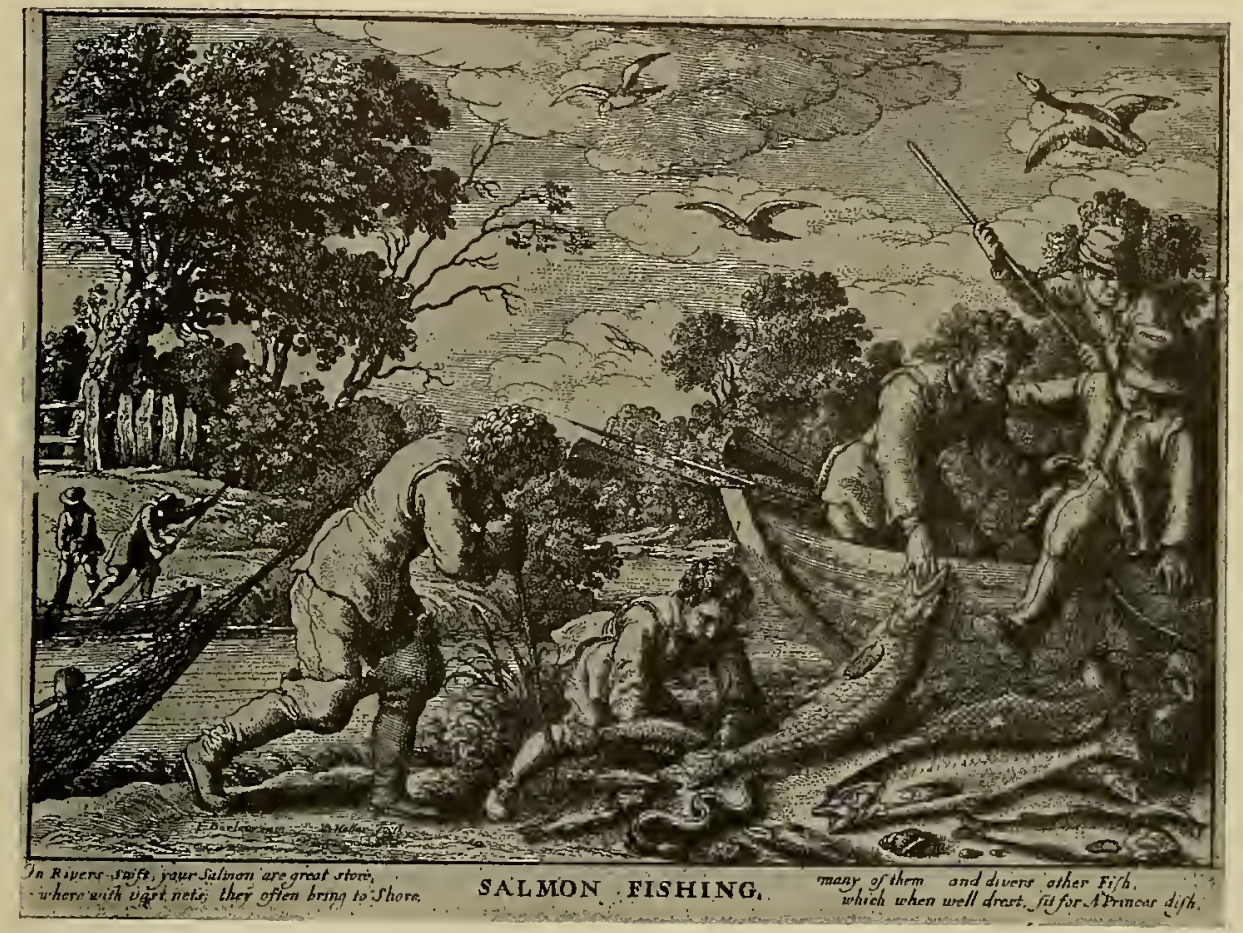

FIG. 123. DESIGNED BY F. BARLOW AND ENGRAVED BY W. HOLLAR; PUBLISHED 1671. See Page 199

Fig. 125 introduces us to a very different form of sport, 2.e. hawking. It deals with "Hern" or heron hawking, as the usual verses inform us. It is only when we peruse the wonderfully-detailed instructions about this most princely sport in books of the period that we realise what immense pains had to be taken in training the hawks to these exciting "struggles in the blue," and how brief, at best, was the period when this sport could be enjoyed, for heron-hawking could be followed at its full only when these migratory birds were on passage, some time in March. In this respect our picture, showing trees in full leaf, is somewhat misleading, if it is intended to show the sport at its best. Staunch spaniels were essential for it, and their training, so as to assist the capture of the heron without frightening off the hawk, could have been attained only by very close attention and constant practice. Here we have another instance of an artist famed for his 


\section{SPORT IX ART}

truthfulness depicting an occurrence which was based on imagination without any substratum of truth, viz. the fabled use of the heron's sharp beak to impale the pursuing hawk when the latter made his fatal stoop.

"Feasunt Hawking" Fig. I 26 , is the next plate according to the sequence established by Parthey. It shows us to what uses the spaniel was put in Charles II's reign,

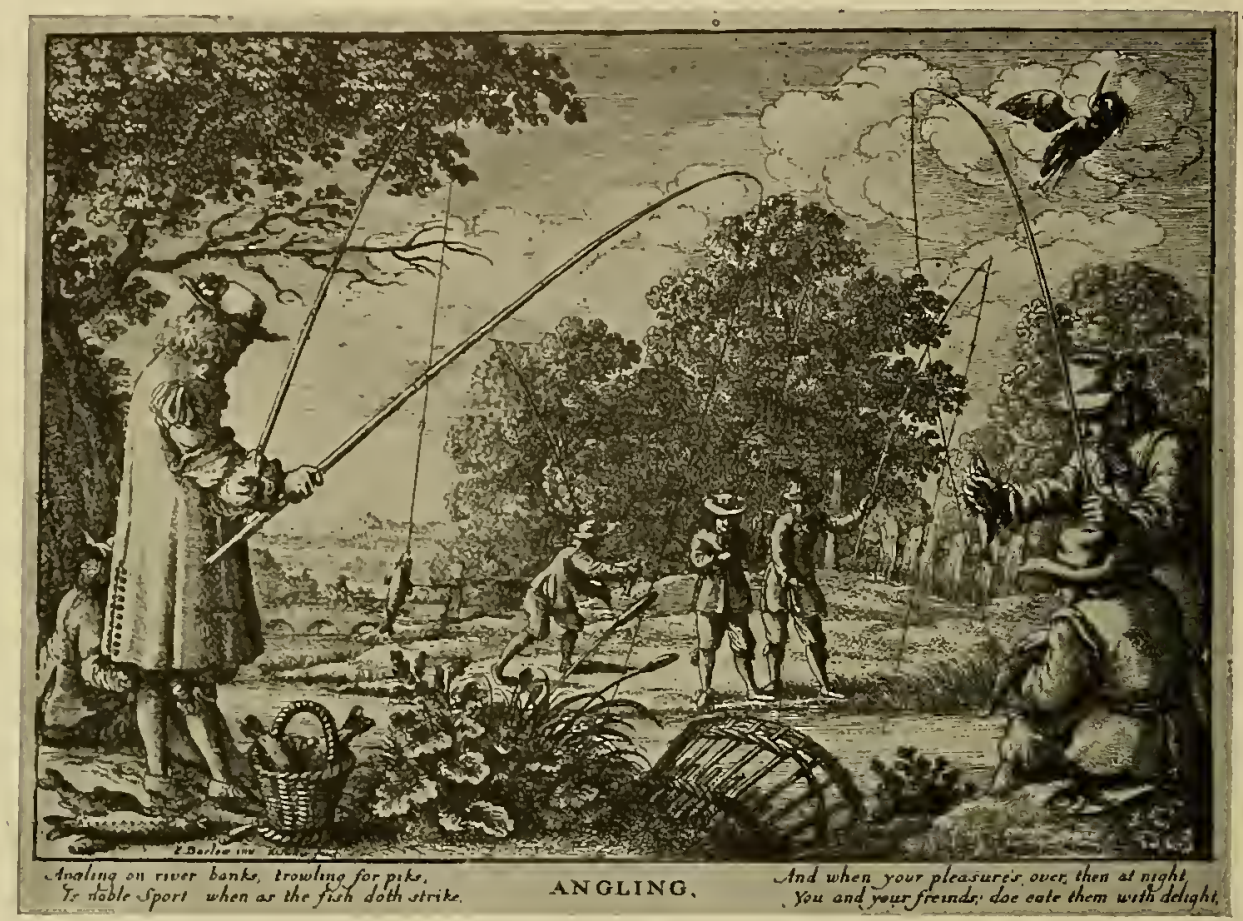

FIG. 124. DESIGNED BY F. BARLOW AND ENGRAVED BY W. HOLLAR ; PUBLISHED 167 I. See Page 200

and this is confirmed by the quaint quatrain, where the term "pearch" is used. Pearch meant, of course, to perch, which gave the name to a particular type of sport with the gun, about which Blome gives us an amusing account and illustration, Fig. 137, to which we shall allude presently.

Pheasant-hawking in the wooded landscape represented in our picture must have been a short-lived sport, for, of course, no sane pheasant would willingly leave covert under the circumstances. As a fact, pheasant-hawking was almost invariably indulged in during the months of November, December, and January, when the trees were not in leaf, and even then, as Blome says, "you must make good choice of time, place, and dogs." For this reason Barlow's picture, in which the trees are in full leaf, is not as true to facts as is the cut in Blome's folio (by Arthur Solis), who, though a much inferior artist, depicts a winter's scene without a leaf on 202 


\section{B.ARLOW'S PRIXTS}

the trees. It is to be feared that Barlow's proverbial fondness for foliage caused him to err more than once in this respect.

"Partridge Hawking," Fig. I27, is fitly the next print, and, if true to life, quite a pack of spaniels were required on these occasions.

Blome declares that "this game affords great diversion and recreation, and is

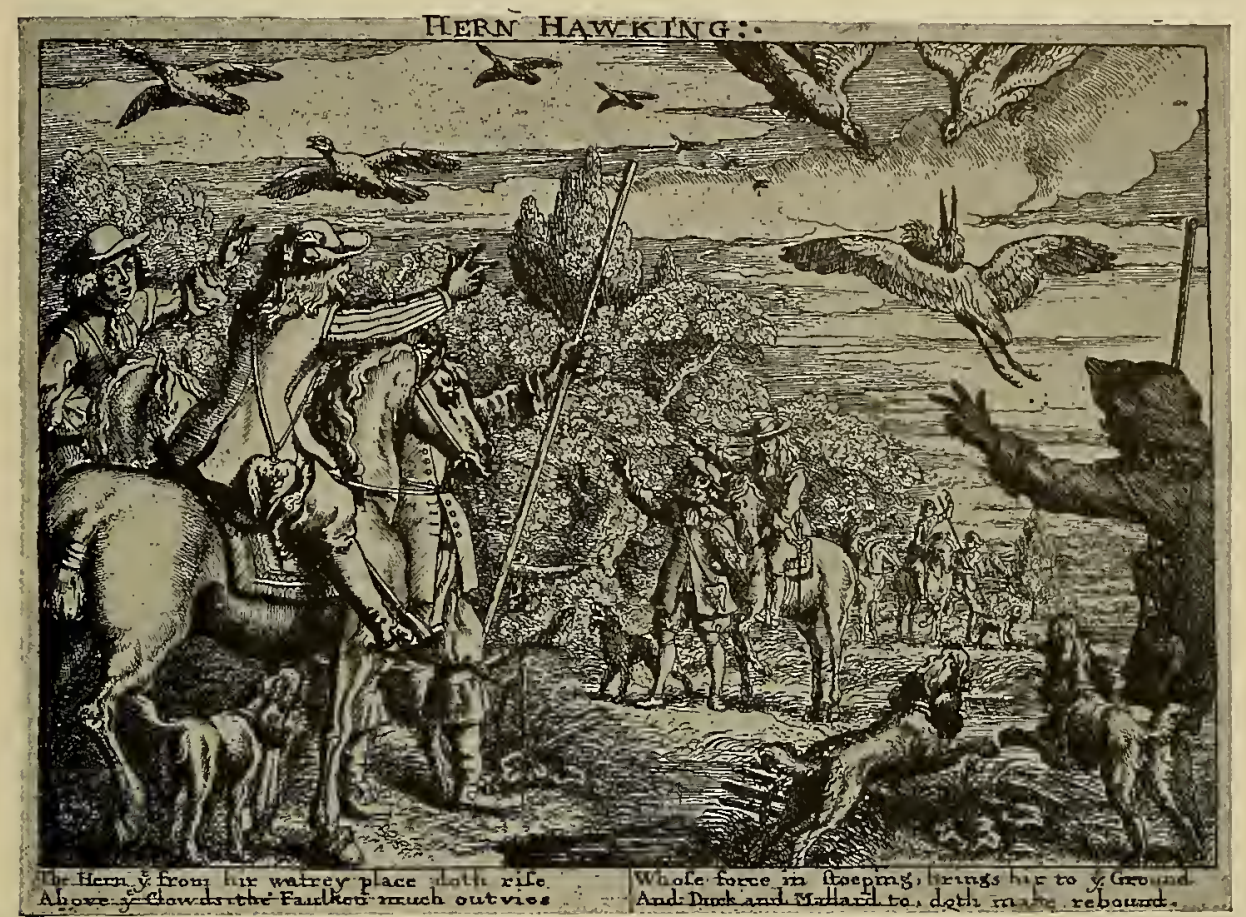

FIG. 125. DESIGNED BY F. BARLOW AND PROBABLY ALSO ENGRAVED BY HIM ; PUBLISHED i67i. See Page zor

attended with no small profit; for I have been credibly informed by a worthy gentleman and an expert falconer, Sir Ralph Dutton, that he hath killed in a season with one Goshawk an hundred brace of Partridges." He proceeds to say that "it is now the mode to go into the Field with a cast or two of hawks, and about six or seven couple of good ranging spaniels, and when a covey is sprung, to cast them all off at a time (sic) which affords good diversion to the spectators." $\mathrm{He}$ adds, however, the saving clause: "but in the opinion of some, this way is not approved of, as being designed rather to go out to kill what they can, than only for the sport."

The next print, Fig. I 28 , makes us familiar with otter-hunting, and though one might wish that Barlow had drawn the quarry more lifelike, the pleasing details of the landscape condone to some extent the otter's malformed headpiece and his 


$$
\text { SPORT IX ART }
$$

prodigious size, which is rather more like that of a British Columbian giant, the weight of which occasionally approaches seventy pounds (the writer once trapped one weighing sixty-six pounds, with a length of something over that same number of inches), than that of the British representative of the species, the weight of which

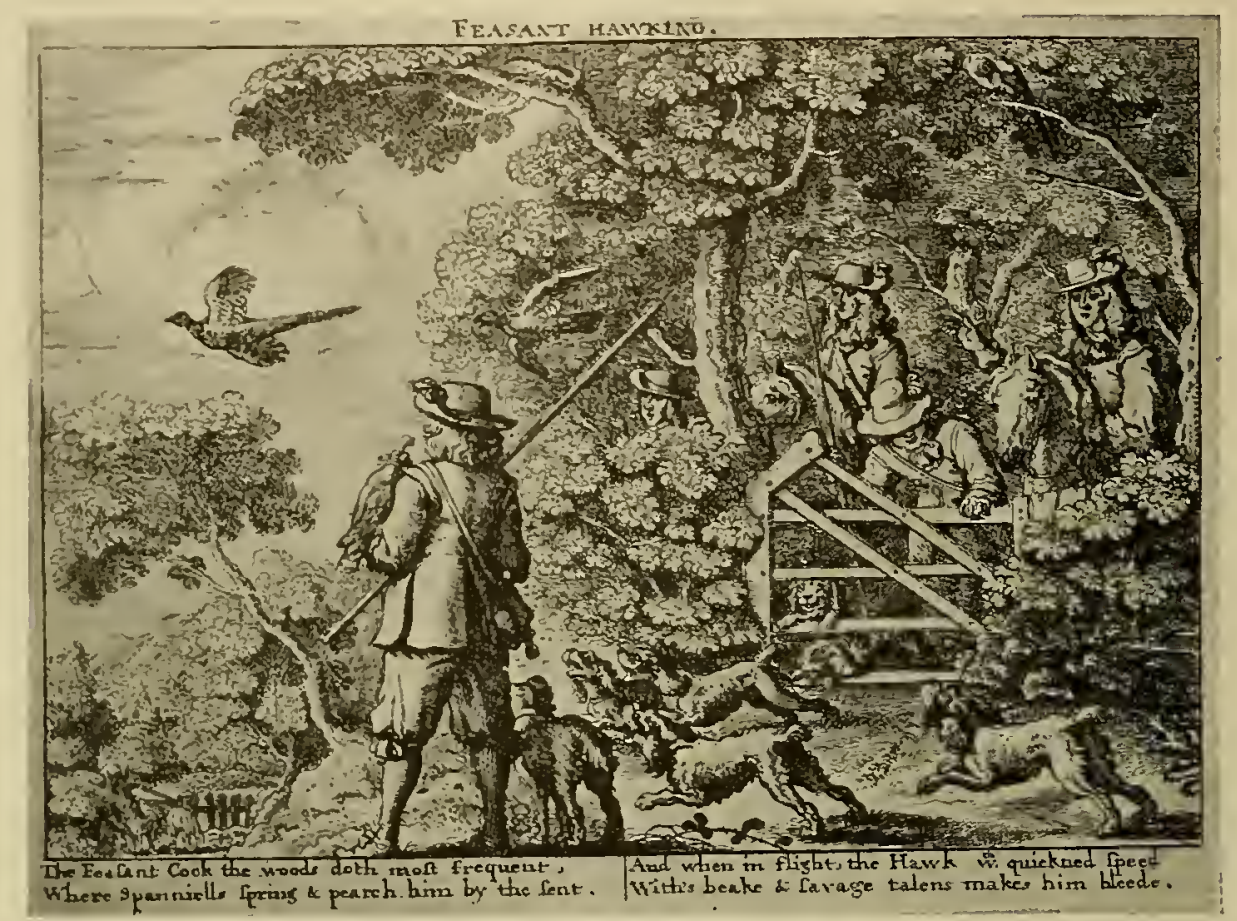

FIG. 126 DESIGNED BY F. BARLOW AND PROBABLY ALSO ENGRAVED BY HIM ; PUBLISHED $16 \%$. See Page 202

seldom exceeds thirty-eight or forty pounds, though possibly British waters may have harboured heavier beasts two or three centuries ago.

Curiously enough, Barlow seems to have become convinced of this mistake, for in the picture of otter-hunting (see Fig. 138 ) which he drew a few years later for Blome's volume the size of the beast is much reduced and the drawing quite lifelike. In medixval days the otter, the wild cat and the badger formed a class by themselves, being neither beasts of venery nor of the chase. As Edward Il's huntsman, William Twici, quaintly expressed this in his verses:

And three other bestis ben of gret disport,

That ben neyther of venery ne chace;

In hunting ofte thei do gret comfort.

As aftir ye shal here in other place,

The grey is one therof with hyse slepy pace, 


\section{BARLOW'S PRIXTS}

In the Norman and Plantagenet days the Kings of England employed otter-hunters - "Valets of our Otter hounds" - -with a permanent staff, consisting in the days of Henry II of three hunters, i.e. Roger Follo, Ralph and Godfrey, who were sent to Somerset with two men and two horses and twelve otter-hounds to capture

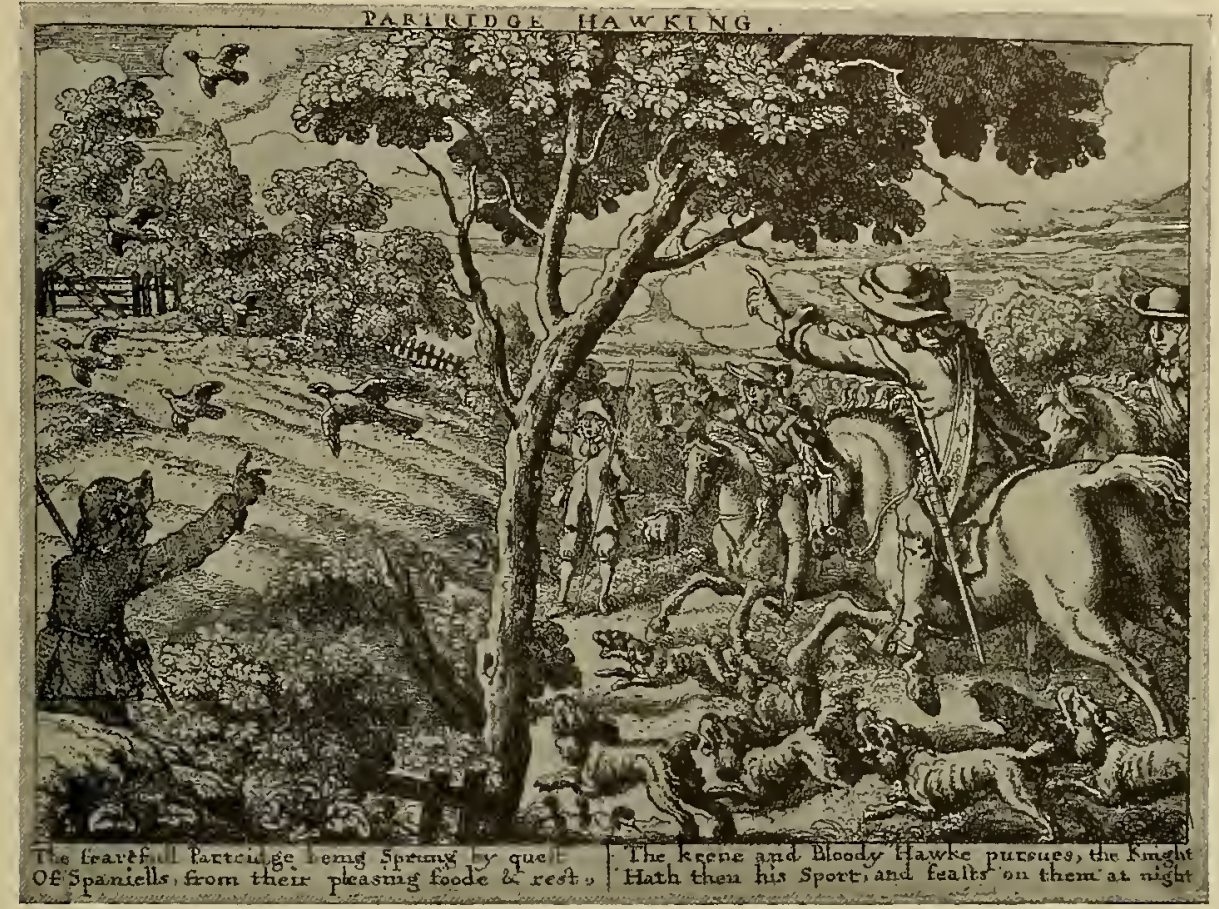

FIG. 1 27. DESIGNED BY F. BARLOW AND PROBABLY ALSO ENGRAVED BY HIM ; PUBLISHED 167 I. See Page 203

otters for the sake of their pelt. The strength of the otter-hound kennel seems to have remained very much the same for close upon three centuries (1212-1485).

Slight changes only appear to have occurred in the manner of hunting, as also in the shape of the spear. In Gaston Phobus, written in 1387 , we observe threepronged tridents, and a yet earlier writer, the author of Roy Modus, orders that every hunter should have a fork to put on to the haft of his pole when occupied in the chase of the otter. Barlow, in the picture before us, seems to have forgotten to put spears in the hands of the hunters, while in the picture he designed for Blome's folio he arms all the otter-hunters with these weapons of the twopronged type.

Our next illustration, Fig. I 29, "Coursing Fallow Deer" affords another instance that Barlow's reputation as a truthful delineator of Nature did not always rest on a sound foundation, for the antlers of the deer depicted by him are those of red 


\section{SPORT IX ART}

deer and not of fallow deer. There were two kinds of deer-coursing then in use - "the one," Blome instructs us, "is coursing from Wood to Wood, and the other upon the Lawns by the Keepers Lodg." "If you course from Wood to Wood," which is evidently the type here depicted, "first throw some young hounds into the Wood to bring out the deer, and if any deer come out that is not

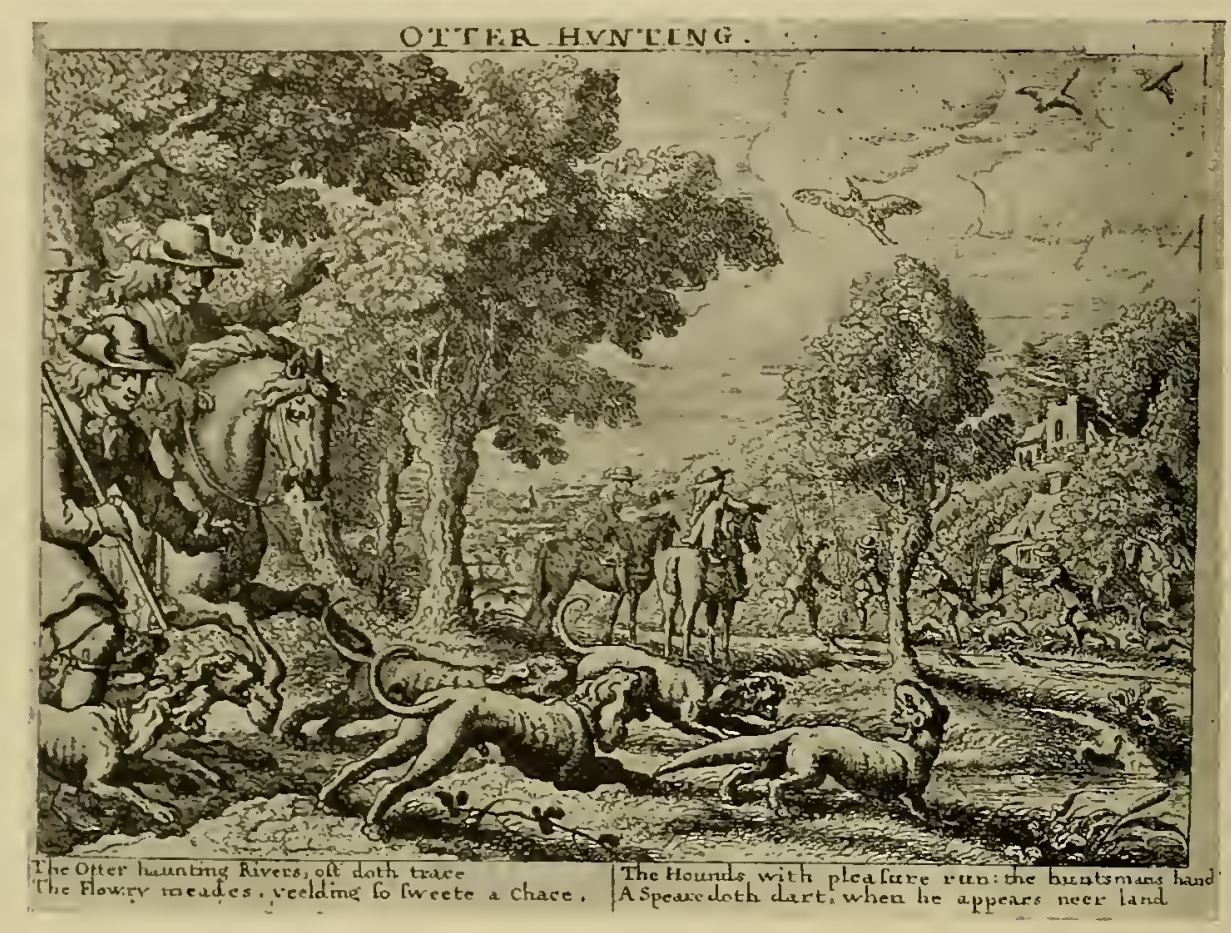

FIG. I28. DESIGNED BY F. BARLOW AND PROBABLY ALSO ENGRAVED BY HIM ; PUBLISHED 1671 . See Page 203

weighty, or a deer of Antlier, which is Buck, Sore or Sorell, then do not slip your greyhounds that are held at the end of the wood where the deer is expected to come forth, which the keepers have good judgment to know. And if you mistrust that your greyhounds will not kill him, then you may way-lay him with a brace of fresh greyhounds. For the coursing upon the Lawn, when you have given the keeper notice, he will lodge a deer fit for your course; then by coming under the wind you may come near enough to slip your greybounds for a fair course."

"Stagg Hunting," Fig. I 30 , hardly does justice to what was still the premier as well as stateliest sport or Britain, for most of the ancient ceremonies of the chase, the lusty hunting calls, the strenuous blowing of horns, the shape of which had not yet undergone any great changes since the days when the quaint woodcuts in 206 


\section{BARLOW'S ST AG-HUXTIX}

The Noble Arte of Venerie immortalised Queen Bess' hunting equipage, were still in vogue.

But Blome's nearly contemporary account gives us such a good description of the scene here depicted that it would be a pity to omit it. After describing how the hart is to be brought to bay, he proceeds to instruct his readers how he is to be

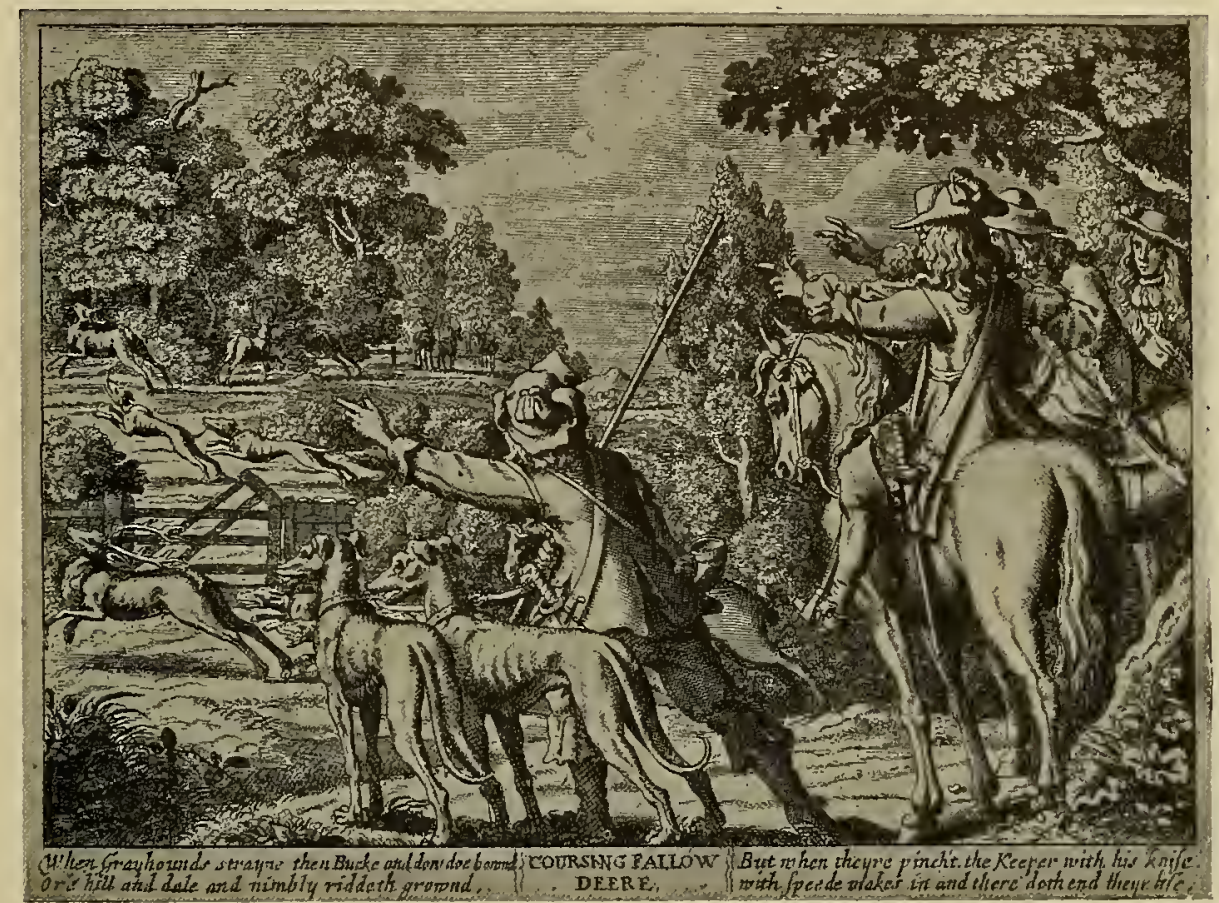

FIG. I 29. DESIGNED BY F. BARLOW AND PROBABLY ALSO ENGRAVED BY HIM ; PUBLISHED 167 r. See Page 205

despatched. This is about to happen in the engraving before us, as is indicated by the bared hunting knife-one is almost tempted to call it a cutlass-in the hands of the man warily approaching the victim.

There were two kinds of bays - the water bay, to which the stag takes when he takes soil, and the land bay. "As to the land bay, if the hart be frayed, and burnished, then the place is well to be considered, for if it be in a hedge side, or thicket, then whilst he is staring on the hounds, you may come covertly amongst the bushes behind him, and so kill him; but if you miss, and he turn his head upon you, it is convenient to take refuge behind some tree, or when he is at bay, couple up your hounds, and when you see him turn head to fly, gallop in roundly and kill him with your sword or gun, before he can have time to turn head upon you; but if he be at bay in a plain and open place, where there is no wood, tree 


\section{SPORT IX ART}

nor covert, 'tis dangerous and difficult to come to him. He that gives the falling blow, ought of right to sound the recheat, to assemble together the rest of the company, as also the dogs (sic). Also at the death of a stag, there are several ceremonies that should be observed. When the huntsmen come in to the death of the hart, they should cry Ware Haunch, that the hounds may not break into

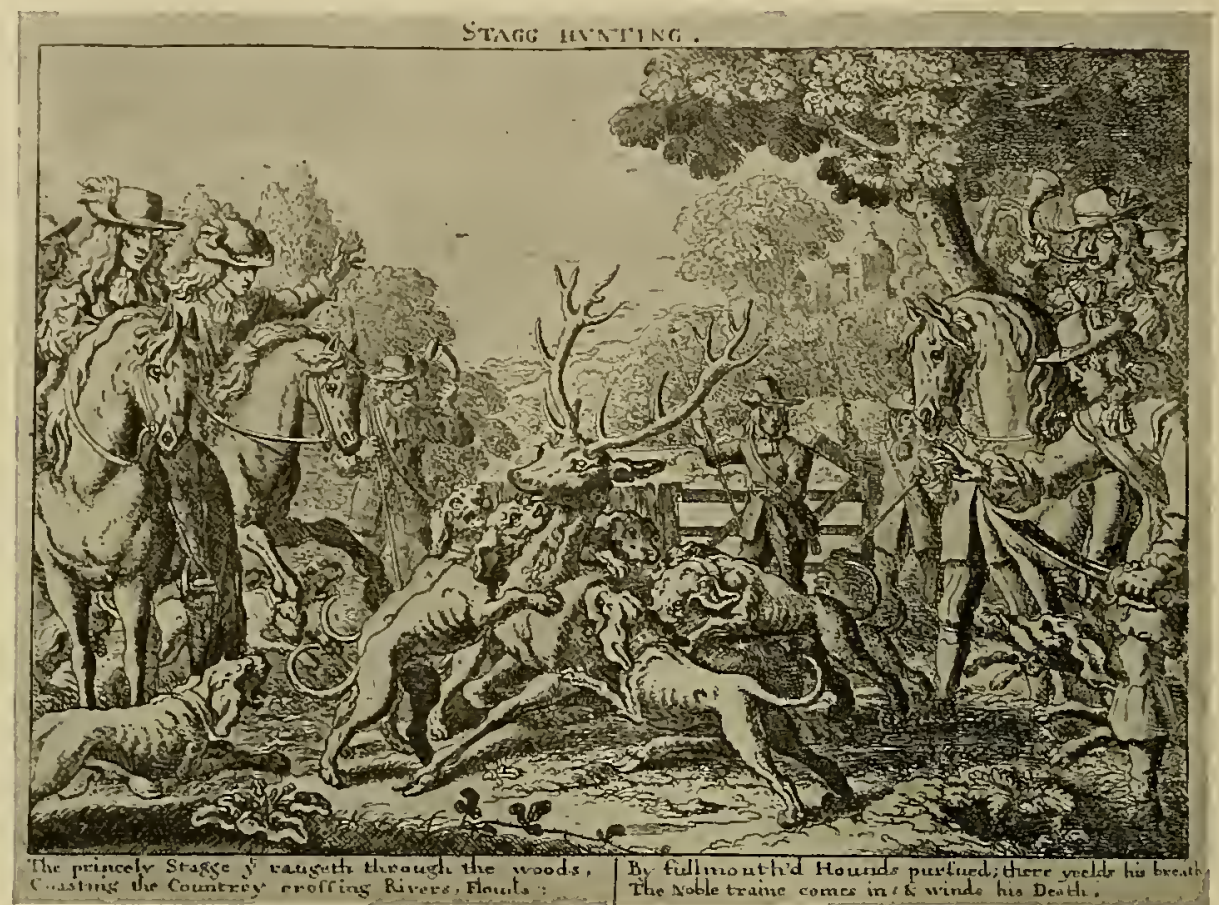

FIG. I30. DESIGNED BY F. BARLOW AND PROBABLY ALSO ENGRAVED BY HIM ; PUBLISHED 167r. See Page 206

the deer, which being secured, the next business is to cut his throat and to reward the young hounds with the blood, to make them in love with a deer, and learn to keep at the throat; then having sounded the Mot or Morts, he that is to break him up (that is, to take say), first slits the skin from the cutting of the throat downwards, making the arber so that the ordure may not break forth; then he is to be paunched, and the hounds to be rewarded therewith. Another ceremony is the huntsman presents the person that took the Essay with a drawn hanger, to have a chop at his head, and after him, every one hath a chop if it is not cut off; and generally the huntsman, or keeper is provided with such a hanger that is not over sharp, that there may be the more chops for the gaining more fees; every one giving him a shilling at least: which done, the huntsman takes up the head and shews it to the hounds for their 208 


\section{BARLOW'S FOX-HUX⿻弋 TIX}

encouragement, rewarding the young ones with the blood. And the concluding Ceremony is to blow a treble Mot by one, and then a whole recheat in consort by all that have horns, bare-headed, with a general Ho-up. Upon which they depart
home."

To the student of ancient venery this old English custom of "chopping" at the

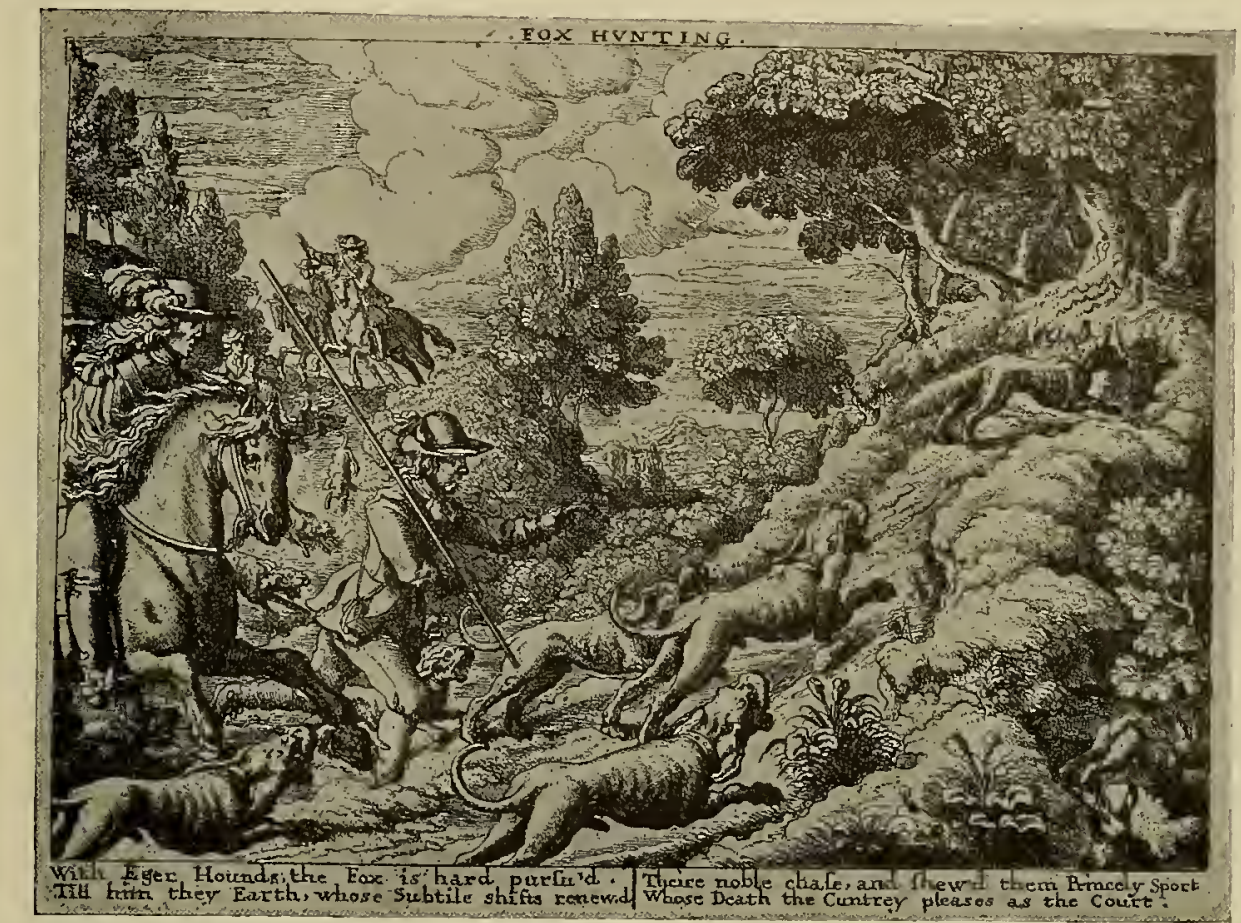

FIG. I3I. DESIGNED BY F, BARLOW AND PROBABLY ALSO ENGRAVED BY HIM ; PUBLISHED 167 . See Page 209

stag's head presents puzzling features, for it was unknown in any other country, more particularly in France, from which practically most of the ancient hunting ceremonies in use in Britain originally came. When, where and why it originated are all questions that remain to be solved.

The last of Barlow's Severall Wayes of Hunting, Hawking and Fishing is of special interest to the modern hunting-man, for it deals with "Fox Hunting," Fig. I 3 I. It tells its tale so plainly that one hardly need do more than quote the quatrain with its feeble spelling :

With eger hounds the fox is hard pursu'd Theire noble chase, and shew'd them princely sport

Till him they earth, whose subtile shifts renew'd Whose death the cuntrey pleases as the court.

"Chopping a fox in covert, where after a fast run, thoroughly beaten, he crawled to ground," would be our modern way of describing the scene. 


\section{SPORT IX ART}

The fox-hunting depicted in our print was then still distinguished from a more ancient form of fox-hunting by adding "above ground," the alternative method being to net them as well as to dig them out of their earths as if they were badgers.

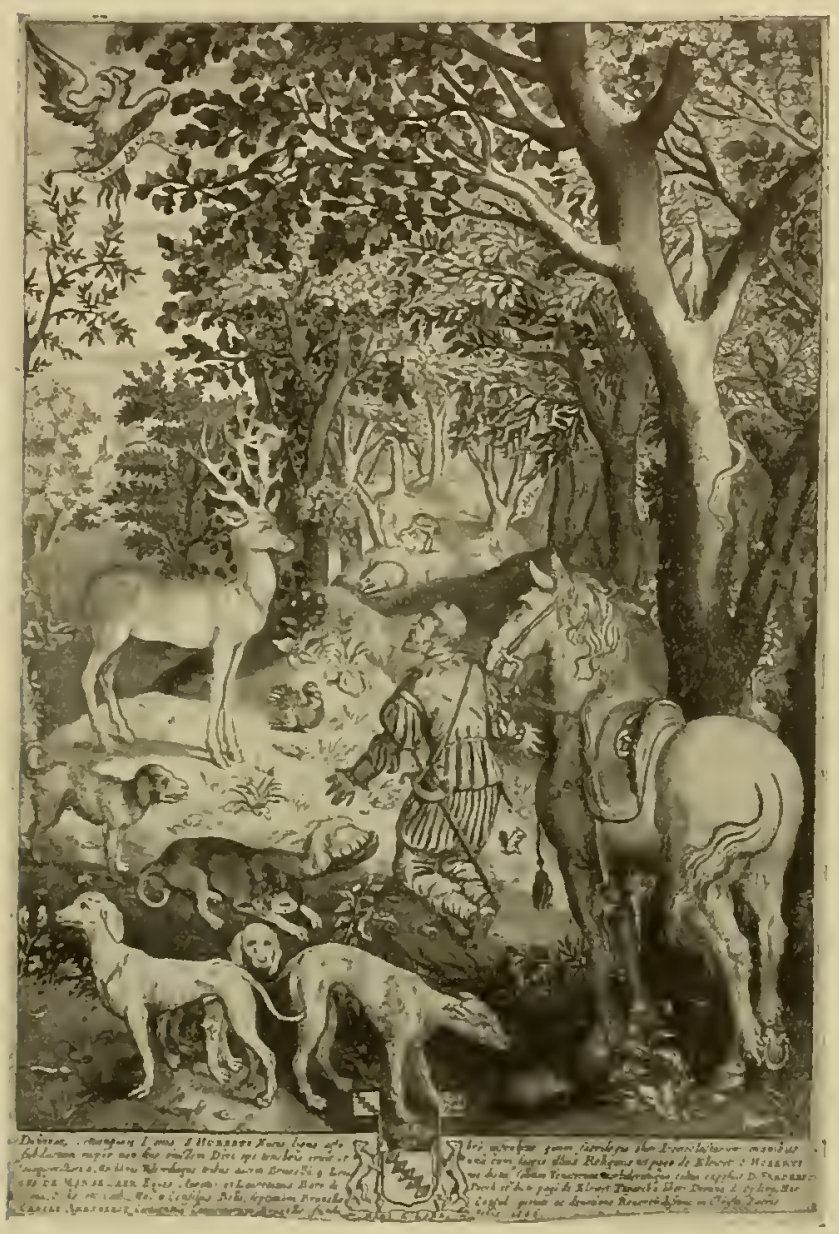

FIG. 132. THE LEGEND OF ST. HUBERT. FNGRAVED 1666. BY AN UNKNOWN BELGIAN ARTIST. See Figs. $+5,100$, and Page 85
In a little book published by Nicholas Cox in 1674 , three years subsequently to the origin of our picture, and also called "The Gentleman's Recreation," the author still uses the term "above ground" when describing the sport our picture depicts, while Blome, in his much more voluminous great folio, published in 1686 , no longer uses this differentiating term, the reason for waging a war of destruction against the robber of hen-roosts and of rabbit-warrens having in the meanwhile more or less disappeared. This is what Blome has to say about it: "Amongst the divertisements used by the Gentry of this Kingdom, Fox-hunting is of no small esteem : what has been wrote on this subject, and what has likewise gone by tradition, was that which was practised when the land was much more woody, and when they abounded so much to be a general nuisance, as wolves were (especialiy in the mountainous parts) beofre they were destroyed, and Wales was freed from them hy an imposition of skins to be paid to the Crown of England, which at large is taken notice of in our

British History. And the ways by them then used (by what I can understand) was by a great company of people, with dogs of all kinds, assembled together, to go to such woods and coverts where they thought they were, and so to beset the place, whilst others went in to beat and force them out with some of the dogs, and to be either coursed by the rest of the dogs, or taken in nets or hays, set on the out-sides for that purpose. But of late years (by experience, the 210 


\section{BARLOW AS ARTIST}

Mother of Invention) the knowledge of this (as indeed all other chases) is arrived to far greater perfection being now become a very healthful recreation to such that delight therein."

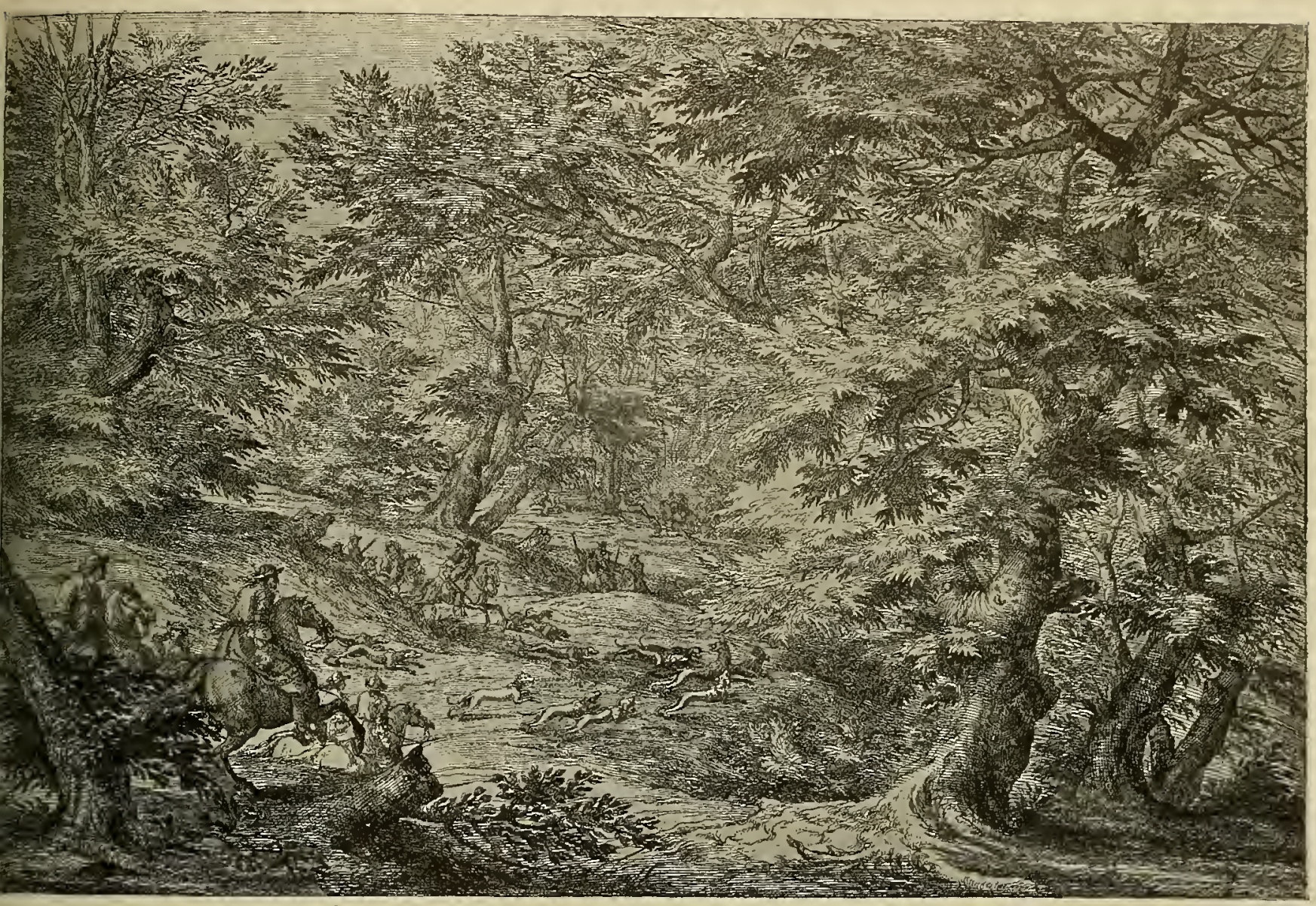

FIG. 133. THE WOLF-HUNT. ENGRAVED AFTER A. VAN DER MEULEN (1634-1690). Page 223

For the rest of Blome's description of his modern account of "tox-hunting" the reader must turn to the tall volume, for we have still to say a few words about Barlow.

Strangely little is known about this artist, neither the date of his birth ( 1626 ?) nor that of his death ( 1702 ?) being positively ascertained. Of his works no complete detailed list has ever been published, and most of the writers who mention him have copied their information from one or two early standard works, to which much might be added as the result of later research. Thus, in the "Dictionary of National Biography" the statement is made that the series here described 


$$
\text { SPORT IX ART }
$$

consists of fourteen plates instead of thirteen, an assertion which Sir Walter Gilbey repeats. Now it would be interesting to ascertain if this be really the case, for none of the great print collections in England and on the Continent examined by

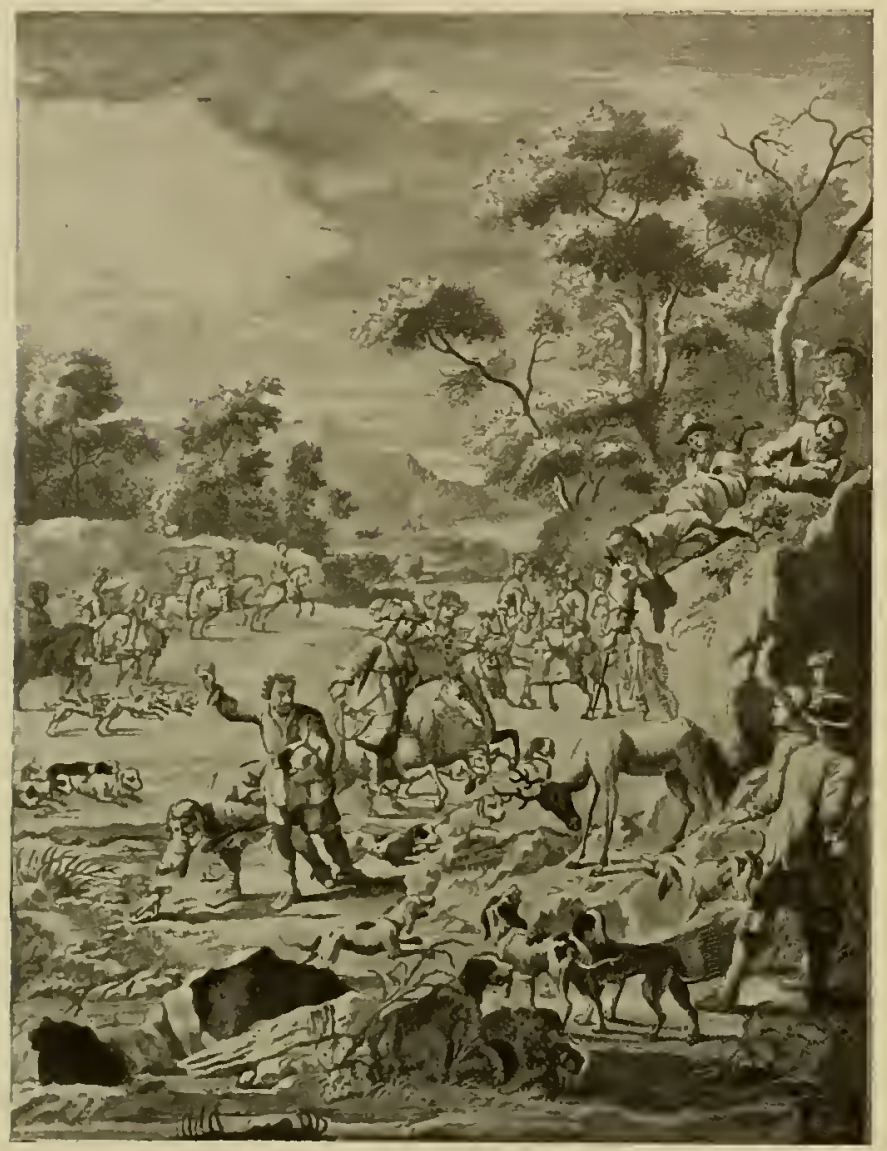

FIG. I34. STONING A STAG AT BAY. OUT OF CASTELLAMONTE'S “LA VENARIA REALE." PAINTED BY J. MIELLE, DESIGNED BY G. B. BRANBIL, ENGRAVED BY G. TASNIERE. TURIN 1674. See Page 219 the writer, including the Dresden cabinet, which is one of the richest in respect to sporting subjects, possesses a series containing more than the thirteen we have described. Should these lines meet the eye of any collector possessing this fourteenth plate, he would confer a great favour were he to announce the fact. A concluding word must be added concerning Barlow's best-known work, the now very scarce work " Æsop's Fables," of which almost the entire stock perished in the great fire in 1666 , in which year it was published. One or two of its fine etchings are of interest to us. Thus Fable 19 is illustrated with a picture of a beaver biting off the receptacle in which the male was believed to carry the much-prized castorium. Underneath is printed:

Beavers by eager Hunters oft persu'd Cause Nature with castorium had Indu'd Their pregnant Testacles, they by instinct Knowing to what cause their persuit is linckt Byte of ye Bagg which does ye drug comprize And baile their lives by that rich sacrifice.

Fable 94 is illustrated with an etching representing a heavily armoured sportsman or knight on horseback pursuing a very harmless looking stag.

Though belonging to the next generation, we still may briefly revert here to the only other British animal painter of the seventeenth century, viz. Luke Cradock who lived from 1657 to 1717 . So far as we know he confined his artistic contributions-his real trade was house-painting - to birds and animals not connected with sport, the only exceptions being a small set of four plates engraved by 


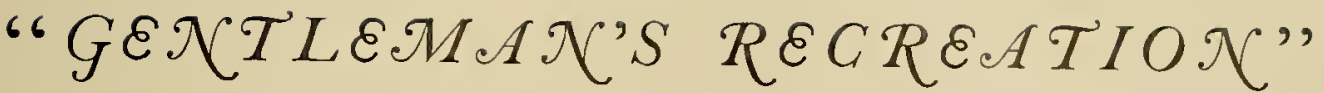

Sympson between I 740 and I743, on two of which a hawk stooping at fowl and a hawk carrying off a chicken, are represented.

Irrespective of these two, Barlow and Cradock, the third-rate designers and

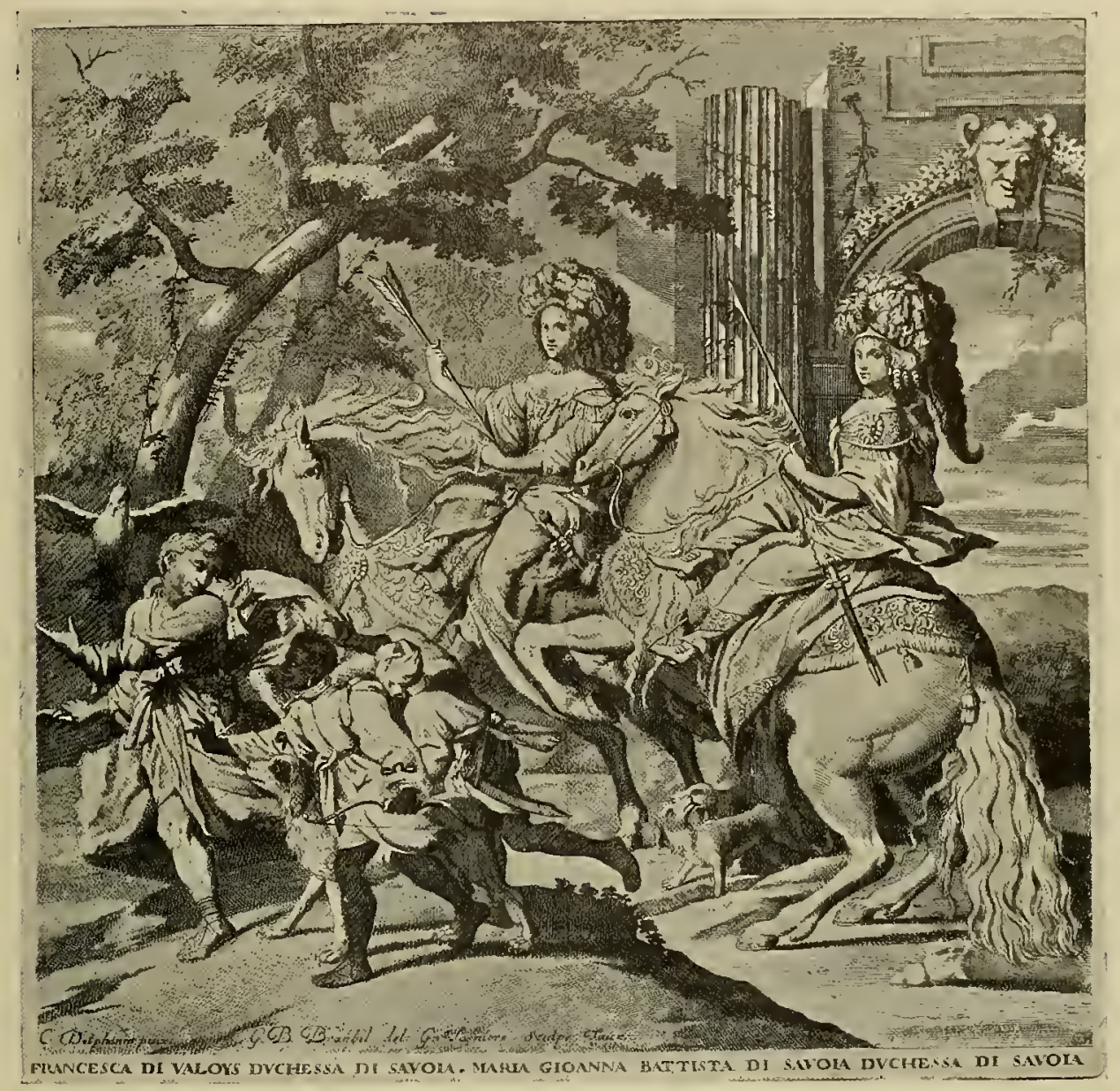

FIG. I35. OUT OF COUNT CASTELLAMONTE'S “LA VENARIA REALE." PUBLISHED TURIN I6 $\tau_{4}$. BY G. B. BRANBIL, AFTER A PAINTING BY C. DELPHINUS; ENGRAVED BY G. TASNIERE: See Page 2 I 9

engravers employed by Blome on his "Gentleman's Recreation," and the yet poorer draughtsmen who did their best to disguise Nature in their plates for Nicholas Cox's book hardly deserve to have even their names mentioned.

The stately and profusely illustrated folio "The Gentleman's Recreation," " printed for the Undertaker Richard Blome, A.D. I 686, treating of Horsemanship, Hawking, Hunting, Fowling, Fishing and Agriculture which are collected from the most 


$$
\text { SPORT IX ART }
$$

Authentick Authors, and the many gross Errors therein corrected," is such a wellknown and oft-quoted work that we need not devote much space to it.

The illustrations are of very unequal artistic merit, the three designed by F. Barlow

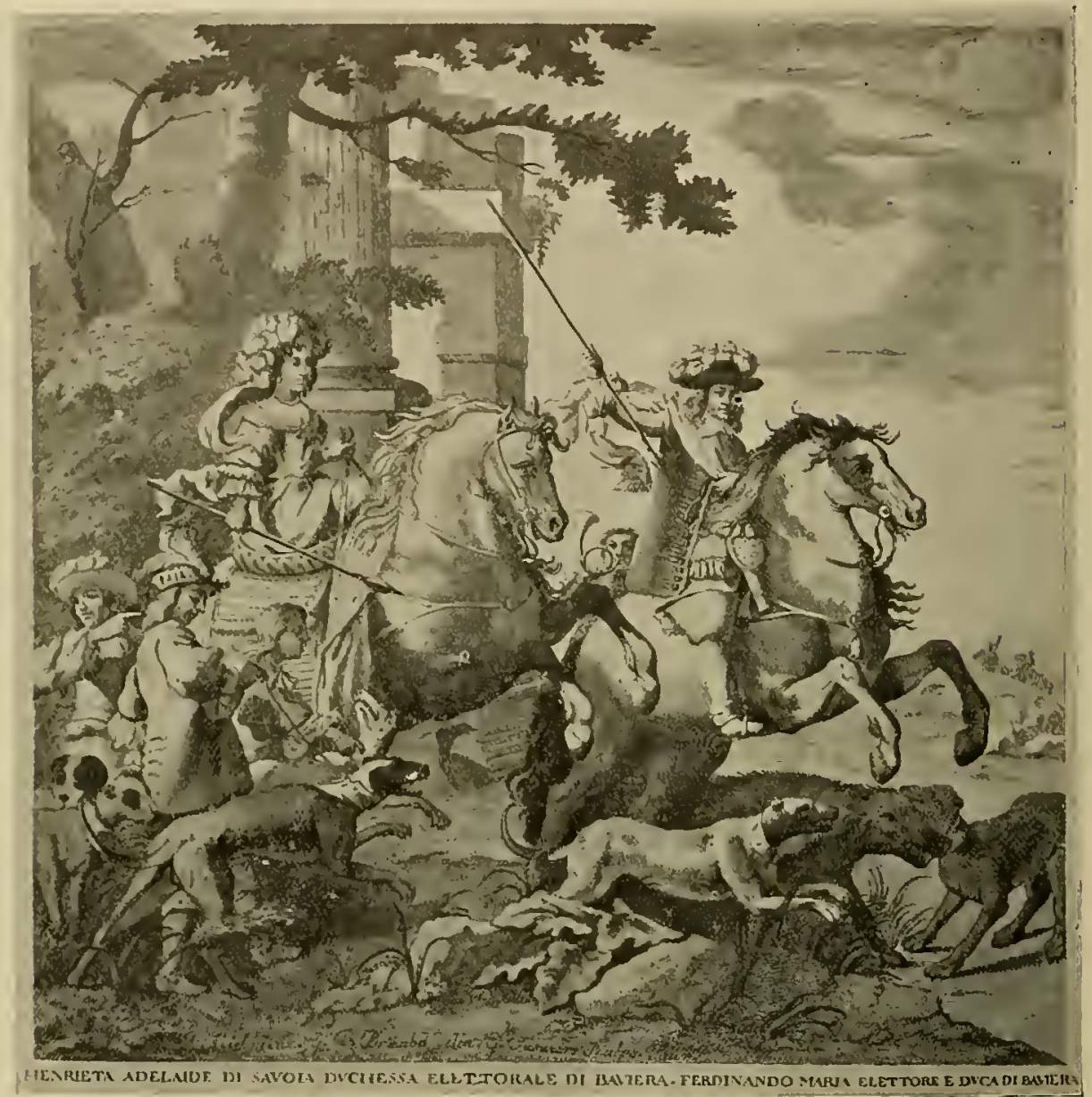

FIG. I 36. OUT OF COUNT CASTELLAMONTE'S “LA VENARIA REALE.” BY G. B. BRANBIL, AFTER A PAINTING BY J. MIEL (MIELLE ?). ENGRAIED BY G. TASNIERE; PUBLISHED $167+$ IN TURIN. See Page 219

(two of them being signed, the third, the Setting Dogg, unquestionably his also) are infinitely superior to the rest, many of which are evidently by 'prentice hand and unsigned. Besides Arthur Soly, Ni. Yeates and S. Gribelin, James Collins and Wyke (Wyk ?) seem to have been principally engaged upon Blome's plates.

One of the illustrations we reproduce in Fig. I 37 deals with a form of poacher's sport to which, as we have heard already, Barlow in the verses of one of his 2 I 4 


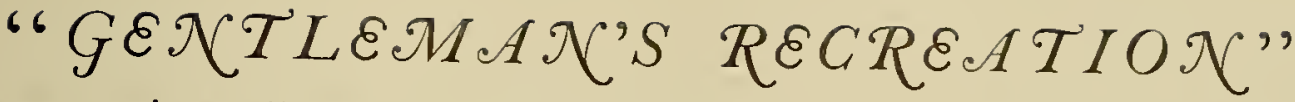

twelve engravings alluded, viz. Pearching Pheasants. The picture of a bewigged sportsman intent upon a pot-shot sneaking up to a tree on which a long-tail is perched leaves little to imagination. To make it quite clear the text furnishes us

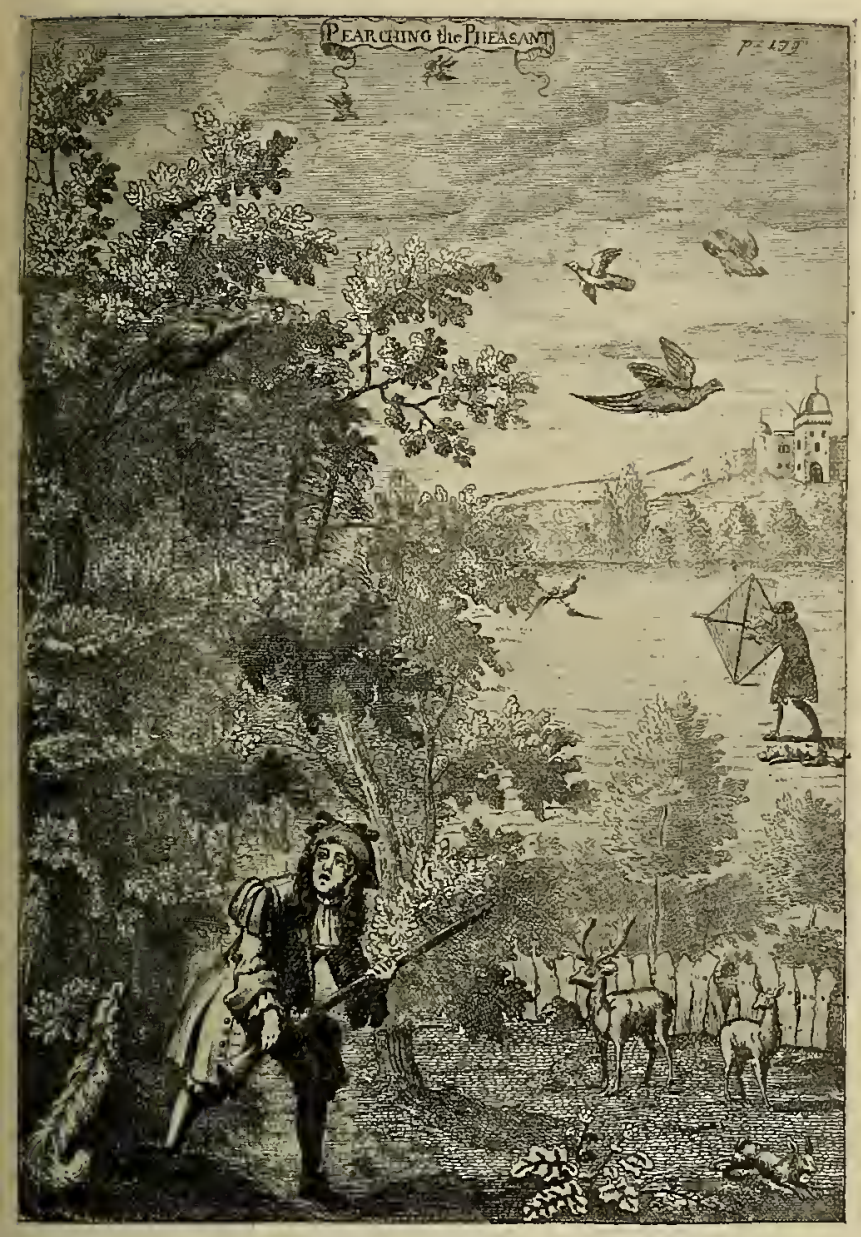

FIG. I37. FROM BLOME'S “GENTLEMAN'S RECREATION" (I686) BY ARTHUR SOLY. "PEARCHING PHEASANTS." See Page 213

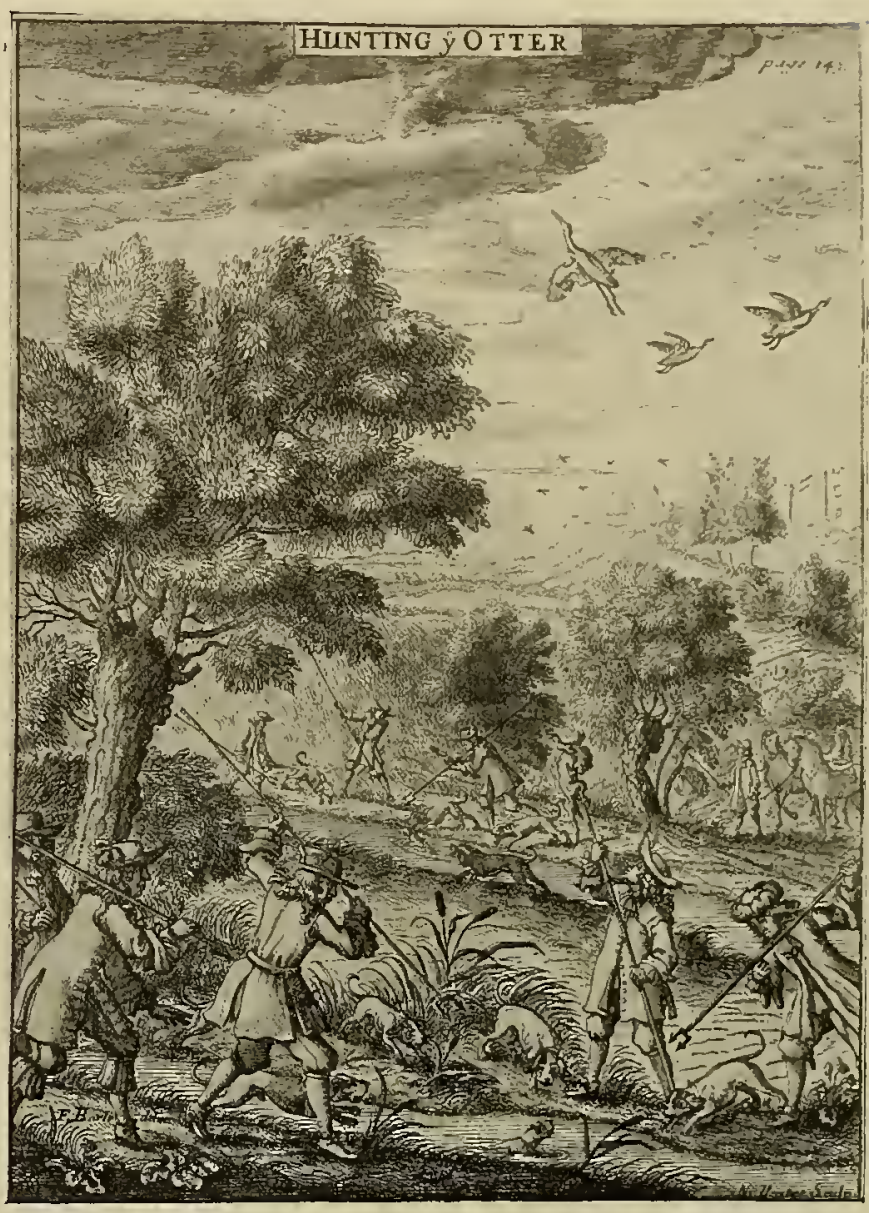

FIG. 138. FROM BLOME'S “GENTLEMAN'S RECREATION" (1686). DESIGNED BY F. BARLOW; ENGRAVED BY NI. YEATES. See Page 213

with the following explanation: "For pearching pheasants you must be provided with a good spaniel that will range well about, and when he hath pearched the pheasant, to bay soundly, which will cause them to keep the Pearch the better ; then hearing whereabouts he is, make up to him as privately as possible, and having espied him (being at a reasonable distance) make your shot, and for your dog's encouragement let him bring it to you, and make much of him." 


\section{SPORT IX ART}

Blome, upon whose literary methods modern authors have heaped sharp rebuke, calling him the arch cribber of his time, hardly deserves such adverse criticism, for in his Preface he makes it plain that his book is of an encyclopædical character,

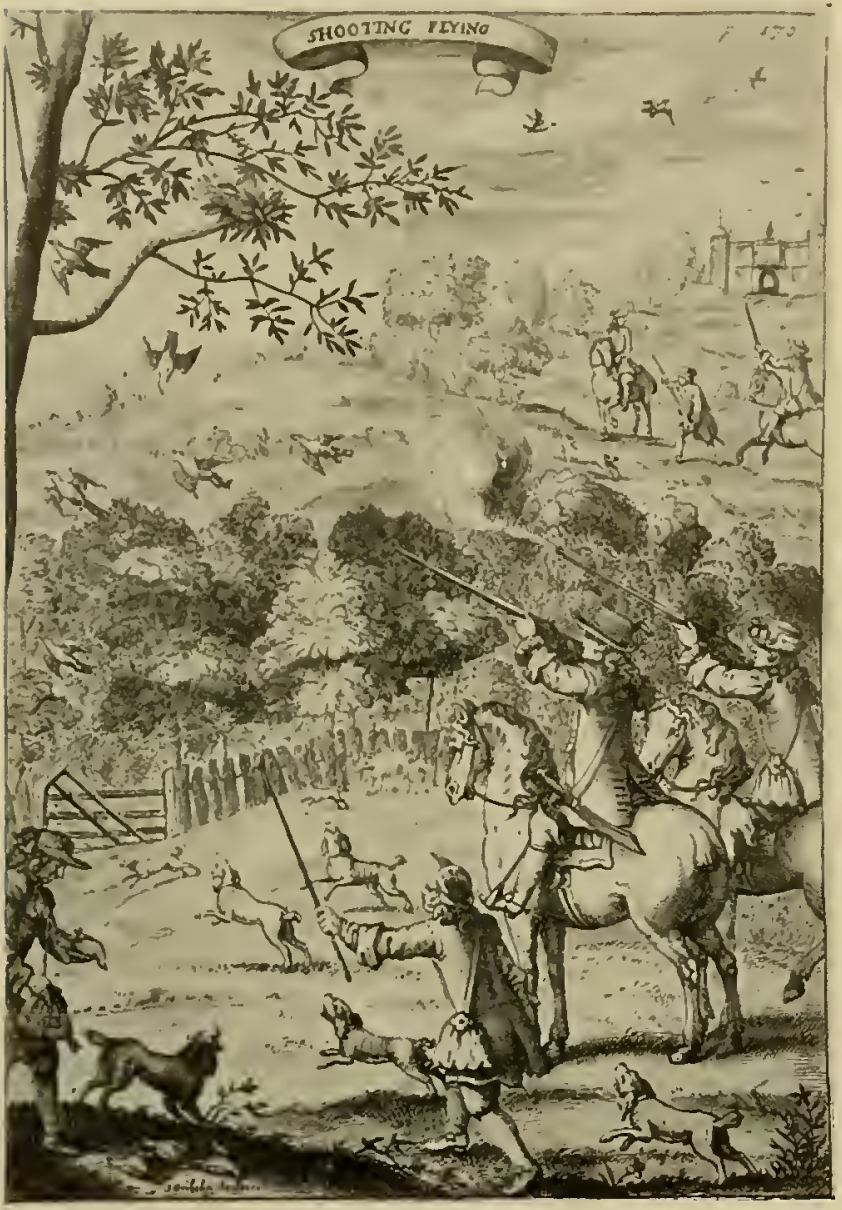

FIG. 139. FROM BLOME'S “GENTLEMAN'S RECREATION" (I686). ENGRAVED BY S. GRIBELIN. Set Figs. 11 $8,140,172$, and Page 213

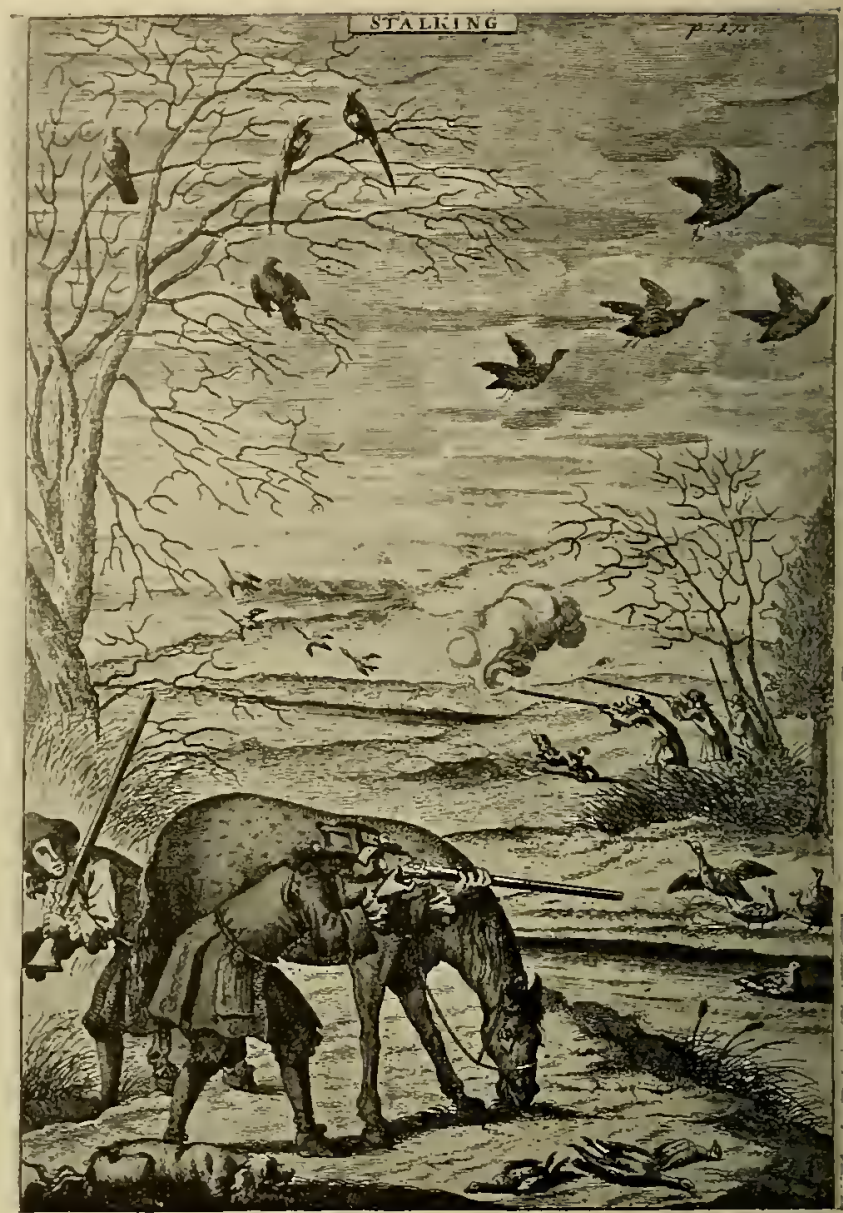

FIG. I 4 . FROM BLOME'S “GENTLEMAN'S RECREATION" (I686). FIRST ENGLISH PRINT OF SHOOTING ON THE WING. "ARTHUR SOLY

FECIT 1683." See Figs. 118, 139, 172, and Page 213

a "Methodical Digest of humerous writings." He openly acknowledges that the foundation of it consists of a translation of Le Ruises Innocent (sic), of Turbervile, Markham and others "although," as he adds, they are "stuft up with more Errors than Truths." These extracts he had "supervised and rectified by such Sports-Men as were approved Excellent which took me up above four years," and 2 I 6 


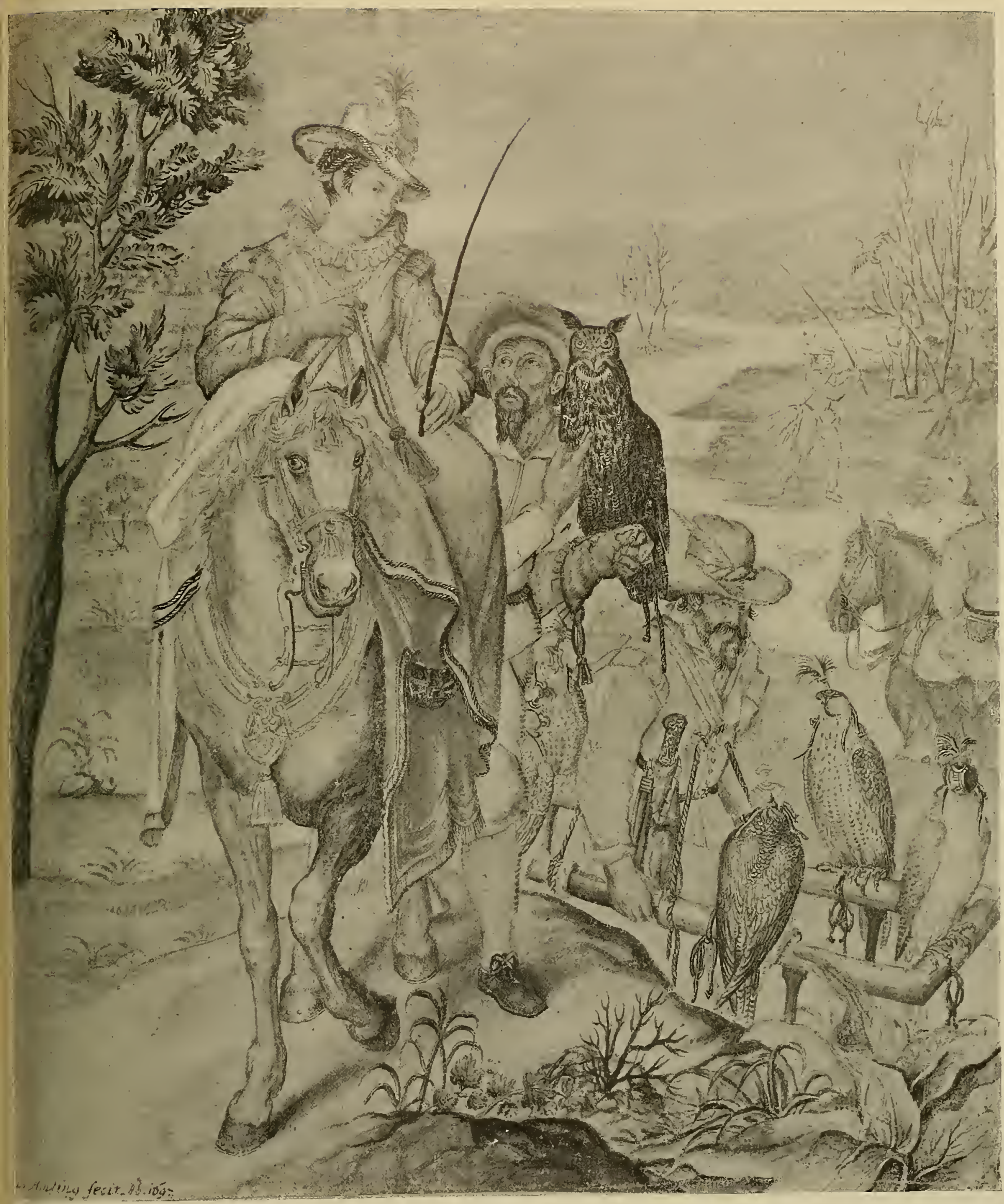

IIG, III THE ELECTRESS OF BAVARIA GOING HAWKING, DESIGNED BY C. G. AMLING IN I697 FOR TAPESTRY. $T$ SHOWS DETAILS TAKEN FROM CARTOONS DESIGNED BY PIETER DE WITTE, OR CANDITO OR CANDID, ILMOST A CENTURY EARLIER. SIGNED AND DATED. See Fig. 109, and Page 223 



\section{CASTELLAMOXTE'S VEX CARIA REALE}

finally, after consulting many such experts he "presumed in Modesty to say that it was a work worthy of the acceptance of any Gentleman, thus observing the humour of our Age which is for multum in parvo."

In his chapter on Hunting, Blome brings a full-page illustration of hunting music under the title The Antient Hunting Notes of England, and as these are often referred to by writers, it may perhaps prove of interest to give a few particulars of two other similar, slightly later broadsheets. The one, of which Fig. 152 is a reproduction, was published in the first years of George I's reign; it consists of a large sheet, 16 inches wide and 20 inches high, while the second is 20 inches wide and I $5 \frac{1}{2}$ inches high. The latter's title runs: "Forest Harmony or the Musick of the English and French Horns as it is now performed in Field, Park, Forest, or Chase with the proper Notes, Terms and Characters made use of in Field Hunting." Eight animals frame in the music, and the artist whose pencil designed them did well not to immortalise his name, for they are about as bad as they can be. In the second sheet, which has on top in lieu of one picture two designs, and was published by quite another firm, use is again made of these wretched specimens of animal caricatures as framework, but in this case they occupy reversed positions, i.e. the stag, hind, \&c., which in Fig. 152 look away from the notes are now made to look towards them. To this end they were redrawn, showing what an extraordinary dearth of good designs from which to copy must have prevailed in England at that period. Curiously enough both these rare musical broadsides were picked up by the writer in Paris.

No illustrated book conveys in a more concrete form the debased ideas regarding sport prevailing in Italy in the seventeenth century than does Castellamonte's La Venaria Reale. Count Amadeo di Castellamonte in a fulsomely obsequious dedication, dated 1672 , inscribes this curious volume to his royal mistress, Maria Giovanna, Duchess of Savoy, of whom he gives us a portrait drawn by Sacchetti. She is represented in the guise of Diana with an arrow or spear in her hand, a hound leaping up her side, while a wreath of oak leaves frames in the portrait. Of Dutch embonpoint and no longer in the flush of first youth, she looks a very matronly Diana, but possibly her performances in her youth may have merited the distinction conferred on her by her servile Amadeo.

On the principal title-page 1672 is given as the year in which La Venaria was published, but on the second caligraphic title-page we are told that Bartolomeo Zapata in Turin issued it two years later, i.e. in 1674 . Though it professes to deal with the chases of the stag, bear, boar, fox and hare, the information we gain from its text is decidedly meagre, and the same must be said of the illustrations. With a few exceptions the sixty-six plates* are portraits of the royal princes of the house of Savoy, views of palaces, plans and architectural features of royal

* It should contain this number of plates, but complete copies are exceedingly scarce. The calligraphic title, to which we have alluded, is to be counted as a plate. 


\section{SPORT IX ART}

dwellings, allegorical designs in which the various goddesses connected with venery largely figure. Only ten plates relate to the chase proper. It is to be hoped for the sake of Italy's reputation that some of these do not represent actuality, but are imaginary scenes. Thus the picture, Fig. 134, of a stag at bay being done to death by a crowd of cowards who are actually stoning him, while one bold veneur is attempting to kill the wretched beast with his sword, but is doing this by lying on his stomach on a rock above the stag and prodding down at him, hardly redounds to the lonour of Italy. The other plates which we reproduce, Figs. I 35 and 136 , show the monstrous get-up of the great ladies and royal sportsmen. We see the Duchess of Valois and her sister the Duchess Maria Gioanna of Savoy proceeding to the lounting-field, while the other plate introduces us to a pair of royal visitors at the Italian court, i.e. the Elector and Electress of Bavaria hunting wild boar. Other portraits of the same highly uninteresting type present to us Christine of France and her spouse Charles Emanuel of Savoy; Marie of Savoy and Francis of Valois; Margarite of Savoy and the Countess of Villafaletto; Elisabeth of Savoy, Queen of Portugal; Christine de Fleury and Emanuel, Prince of Carigan; Louis Marie de Savoy and Henriette of Savoy, Electress of Hesse. Besides Jan Mielle, or Miel as he occasionally spells his name, Delphinus, Branbil, Mombasilio, and Carausglia perpetrated some of these dreadful royal portraits ; the first-named, however, who was a native of Antwerp, has the majority of them on his conscience. Of the other artists very little is known, a circumstance that need not surprise us. Until lately many of these royal portraits were to be seen in the royal hunting-box, La Venerie, near Turin. Fate evinced a deplorable lack of discrimination in sparing:these impossible pictures and destroying, as it lately did, some perfectly irreplaceable treasures in the same city. Students of sporting literature would not have mourned long had the remaining copies of the Venaria Reale been also overtaken by the flames!

Turning to another Continental court between which and the Italian royalties there existed many ties of relationship, namely, that of Vienna, it is worth noticing that the latter never went in for great show-hunts to anything like the same extent as marked other less important German courts. One of the few exceptions of which artists have left us a record was the formal Chasse held A.D. 1666 in the Prater near Vienna to celebrate the marriage between Emperor Leopold I and Margaret of Spain. Six plates engraved by Melchior Küsel, an Augsburg artist and pupil of Merian, give one a capital idea what these "ceremonious slaughtering matches" were like. As we shall again encounter these hunts when dealing with Fleming in the next chapter, there is no need to give further details at present.

Wouverman, it is probably needless to point out, painted his Le Conseil des Chassems, Petite Chasse a loyseau, Le Boufon des Chasseurs, and other sporting subjects not as a sportsman but as a landscape painter, with an eye to effective 220 

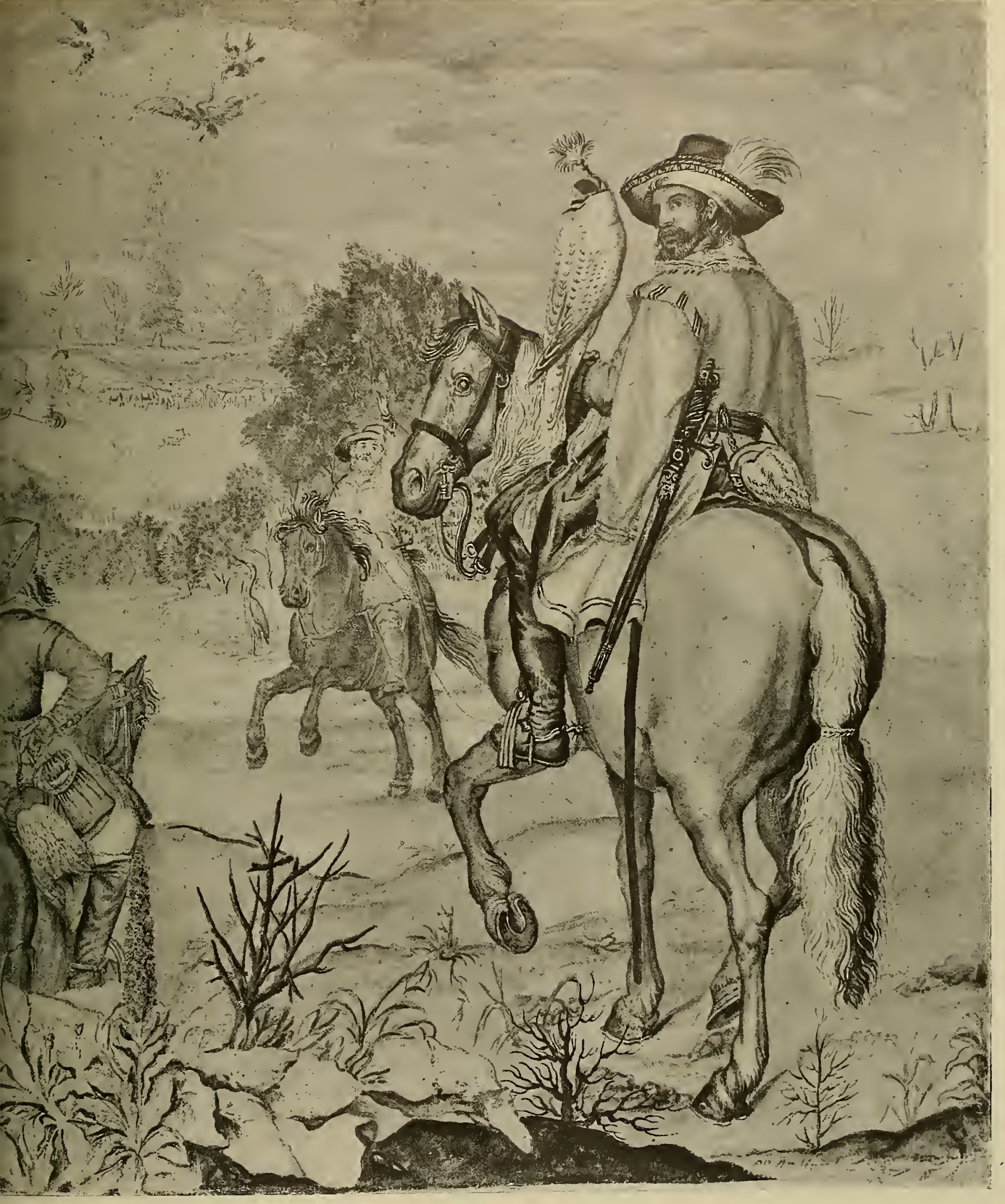

i. 142. THE ELECTOR OF BAVARIA GOING HAWKING. DESIGNED BY C. G. AMLING (1697) AS PENDANT FIG. 14. BOTH DRAWINGS IN THE AUTHOR'S COLLECTION. See Fig. 109 and Page 223 



\section{AMLIX్X'S DRAWIX $\mathcal{X} S$}

rendering of distances, to delicate cloud effects, to gracious grouping of trees, and to other picturesque details dear to the delineator of beauteous scenery. As there is little to learn concerning venery from any of his plates we omit examples. The diligent graver of Jean Moyreau reproduced almost a hundred of Wouverman's pictures, some with more success than others.

Van der Meulen (1634-90) had a distinguished career at Louis XIV's court in that long-lived monarch's belligerent days. He was more of a battle painter than a delineator of sport, but he left us a series of hunting pictures of which Fig. I 33 is a reproduction of a wolf-hunt. None of them are of marked interest or merit.

The two next reproductions from a pair of interesting drawings in the writer's collection, Figs. I $4 \mathrm{I}$ and $\mathrm{I} 42$, stand in striking contrast to the designs with which we have been dealing. Amling ( $6_{5}$ I-I $_{702}$ ), who drew them in the year I 697, was a German artist who worked during the last years of his life in Munich. Clever and graceful as was his execution he seems to have lacked inventive genius, for most of his designs are taken from the works of others, chiefly from those of Candito (Candid), the Pieter de Witte of whom we have already spoken at some length when considering the tapestry reproduced in Fig. Io9. Amling must have been a great admirer of this versatile artist as he copied details in his pictures and cartoons with hardly any alteration at all. This, where costumes are concerned, is apt to cause some confusion and incorrect ascriptions, for the two men were separated by a century. An instance of this occurs in the cadge-bearer in Fig. I 41, which is a facsimile copy, only reversed, of the same figure in an oil painting probably by Candito himself or at any rate by his school, preserved in the fine collection of $\mathrm{Mr}$. Schwerdt of Alresford in Hants, a collector who is making the chase his speciality.* Many other like instances could be cited.

For those interested in this little-known artist's drawings we may mention that at the National Museum in Munich are preserved Amling's drawings after which he engraved the well-known series of prints illustrating the history of the famous progenitor of the reigning house of Wittelsbach, the knightly Otto.

* Mr. Schwerdt thinks that his picture is by Stradanus, but with this opinion we cannot agree. 


\section{CHAPTER X:DESPORTES, FLEMING,OUDRY AND OTHER ARTISTS OF THE FIRST HALF OF THE EIGHTEENTH CENTURY}

HE great popularity enjoyed to-day by the French school of the eightecnth century tempts us to begin this chapter with some typical examples. We do this with two charming pendants produced by the two most important masters of the period who devoted their talents to sporting subjects. The first is the portrait of Madame de Vermenton, Fig. I 43, painted by VVatteau and engraved by Bénoît Audran, the most talented member of that famous family of engravers. Retour de Chasse is considered by many to be his best plate, and it is certainly a most decorative engraving, in which Watteau's touch finds full expression. It is regrettable that on account of the premature death of both masters there exist so few of these delightful plates.

Our next reproduction, Fig. 144, is the selt portrait by the celebrated François Desportes of whom François Joullain, the engraver of it, speaks as a worthy hunter gifted with sublime genius. Desportes, who painted this picture in the year I699, gained access to the Academy thanks to it ; but it was probably one of the last portraits he executed, for after his return to Paris from King Sobieski's court a year or two before, he began to devote himself almost exclusively to hunting and animal subjects, Louis XIV having made him his painter of the chase. As he accompanied the King on his hunts he had, of course, quite unusual opportunities to study wild animal life.

Joullain engraved this portrait thirty-four years after it was painted, and in his panegyric beneath the picture he claims that Desportes' genins gave new life to the game which his shot had brought down; and in this he was not saying too much, for the victims of that long-barrelled fowling-piece are certainly depicted with rare skill. The fact that the portrait was painted as early as 1699 accounts also for the formidable length of Desportes' fisil, for in the intervening generation fowling-pieces had become much shorter. This change is shown also in Figs. 146 and 147 .

Fig. I 45 shows us one of Desportes' numerous hunting pictures engraved by the same faithful henchman. Most readers will know Desportes' canvases from the examples that hang in the Louvre and in Versailles. They remained general favourites for a long period.

Of the two portraits, Figs. 146 and 147 , we have just spoken. They represent two historical French sportsmen, father and son, of royal rank. The former is the Dauphin Louis, only son of $R$ oi Soleil. He is represented in his hunting dress, and the picture must have been painted about i 699 or 1700 . In the 224 


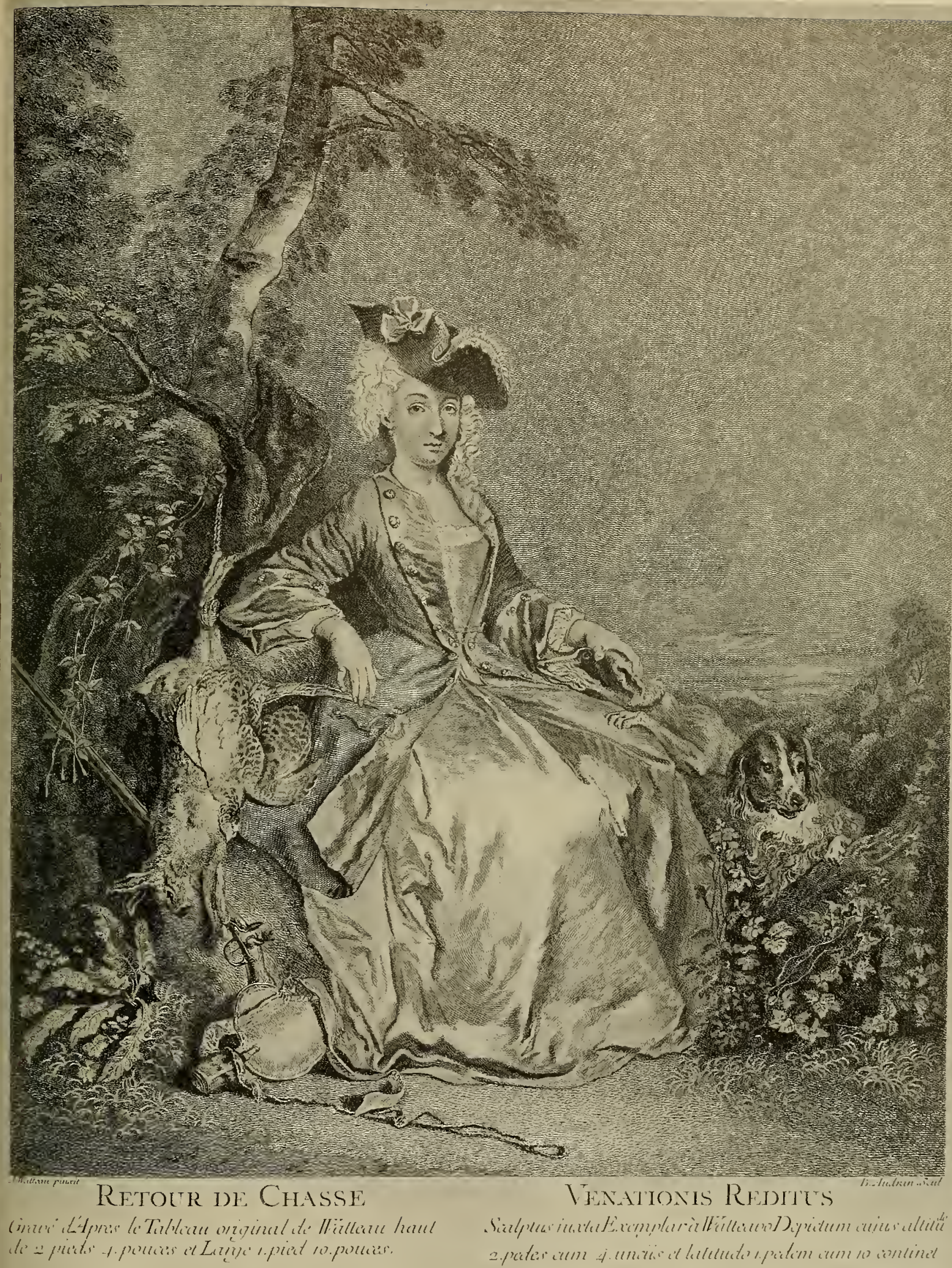

FIG. I43. WATTEAU'S “RETURN FROM THE CHASE." BELIEVED TO BE A PORTRAIT OF MADAME DE: VERMENTON. ENGRAVED BY BENOÎT AUDRAN (1661-1721). See Page 224 



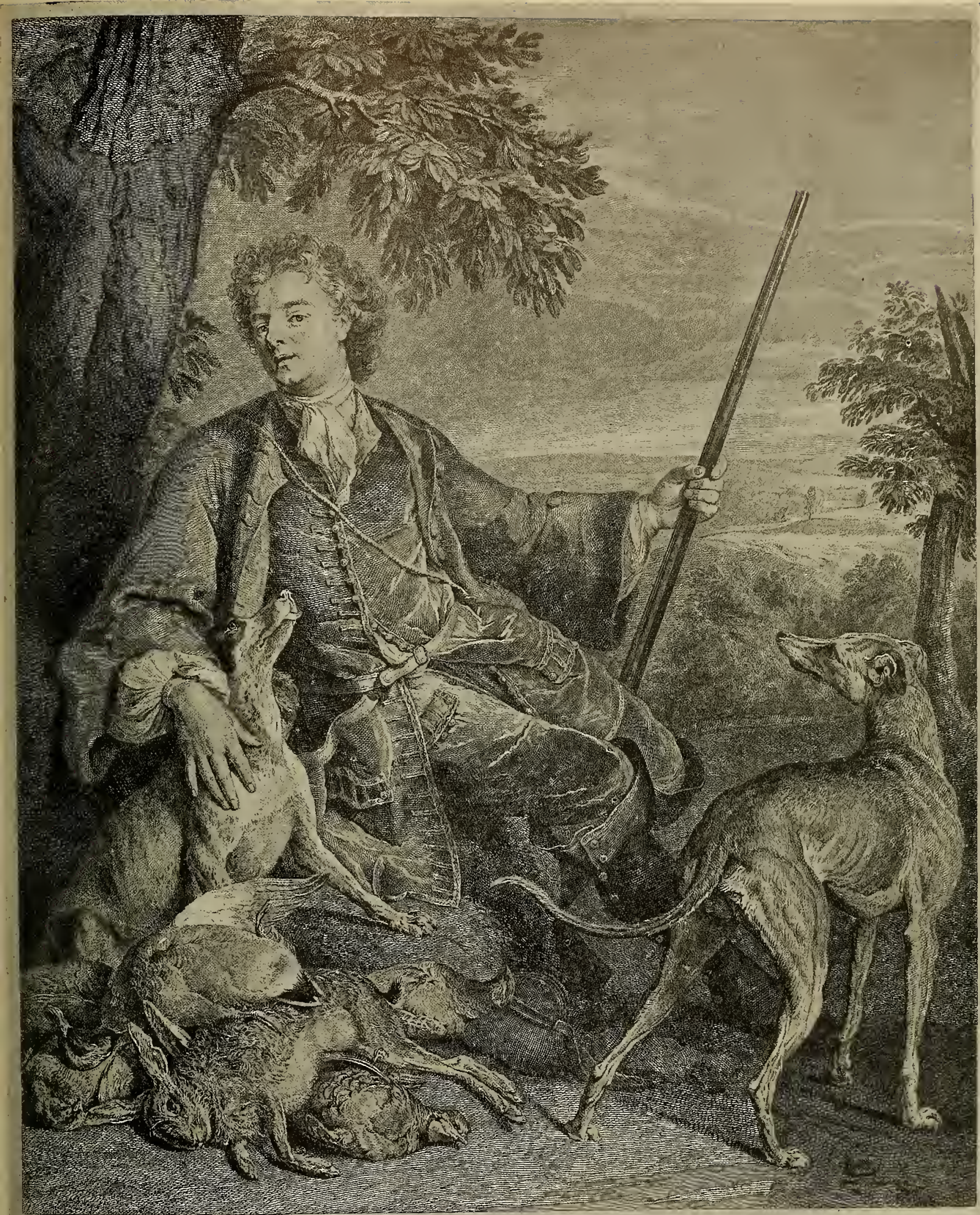

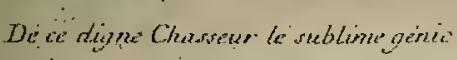

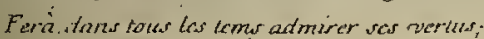

Il sait aux Animaur sons ses cuups abutus

Deminerivpris.leur mat' une nourdle vir:

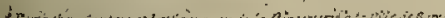

FRANCOIS DESPORTES,

Pein tre ordiuaire du RoY, Cou friller en fon

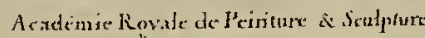

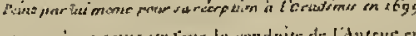

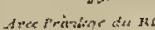

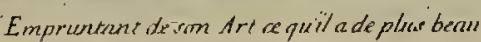

Il sest rendu parlant tians sn propre peinuerc;

Et dans tous ses Tablicaure rival de la Masure,

Arec eur il a sit s'afranchir dii tombecan.

FIG. 144. FRANÇOIS DESPORTES (I66I-I743), LOUIS XIV'S GAME PAINTER. PAINTED BY HIMSELF IN I699, AND ENGRAVED IN I733 BY FRANÇOIS JOULLAIN. See Page 224 



\section{THOMAAX'S MEZZOTIXTS}

background we perceive the castle and donjon of Vincennes, and in the grounds surrounding it some kind of chase is going on. Fig. I 47 is the portrait of his son, Louis of France, born I 682, in like costume. This must have been designed

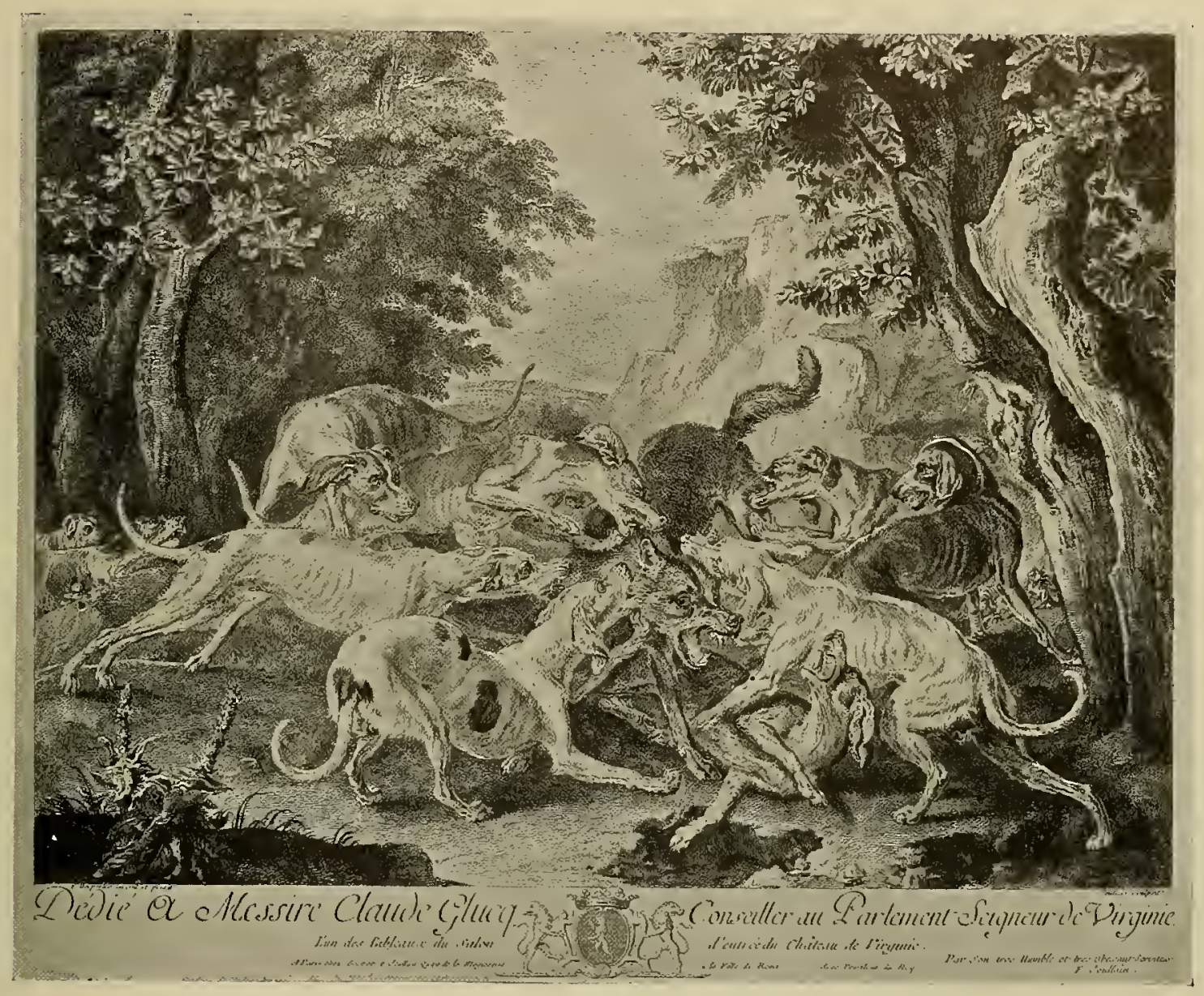

FIG. 145. THE WOLF - HUNT. PAINTED BY FRANÇOIS DESPORTES (I661-1743), AND ENGRAVED, BY F. JOULLAIN. See Page 224

shortly before his death in I7I2, and the abbreviated barrel of his fusil and lightening of its whole construction marks the change sporting fire-arms are known to have undergone in the first decade of the eighteenth century.

Two mezzotints, Figs. I 48 and I49, introduce to the reader the works of a couple of little-known Augsburg artists, Ernst Philip Thoman and his son Tobias Henry. These are among the earliest mezzotints dealing with sport. There exist sixteen of these curious plates, particulars of which will be found elsewhere. 


\section{SPORT IX ART}

They remind one of the extraordinary duration of Stradanus' influence upon art, for a number of them are merely enlarged replicas of the Florentine's pictures, even the descriptive verses being in some cases copied verbatim. Quite different

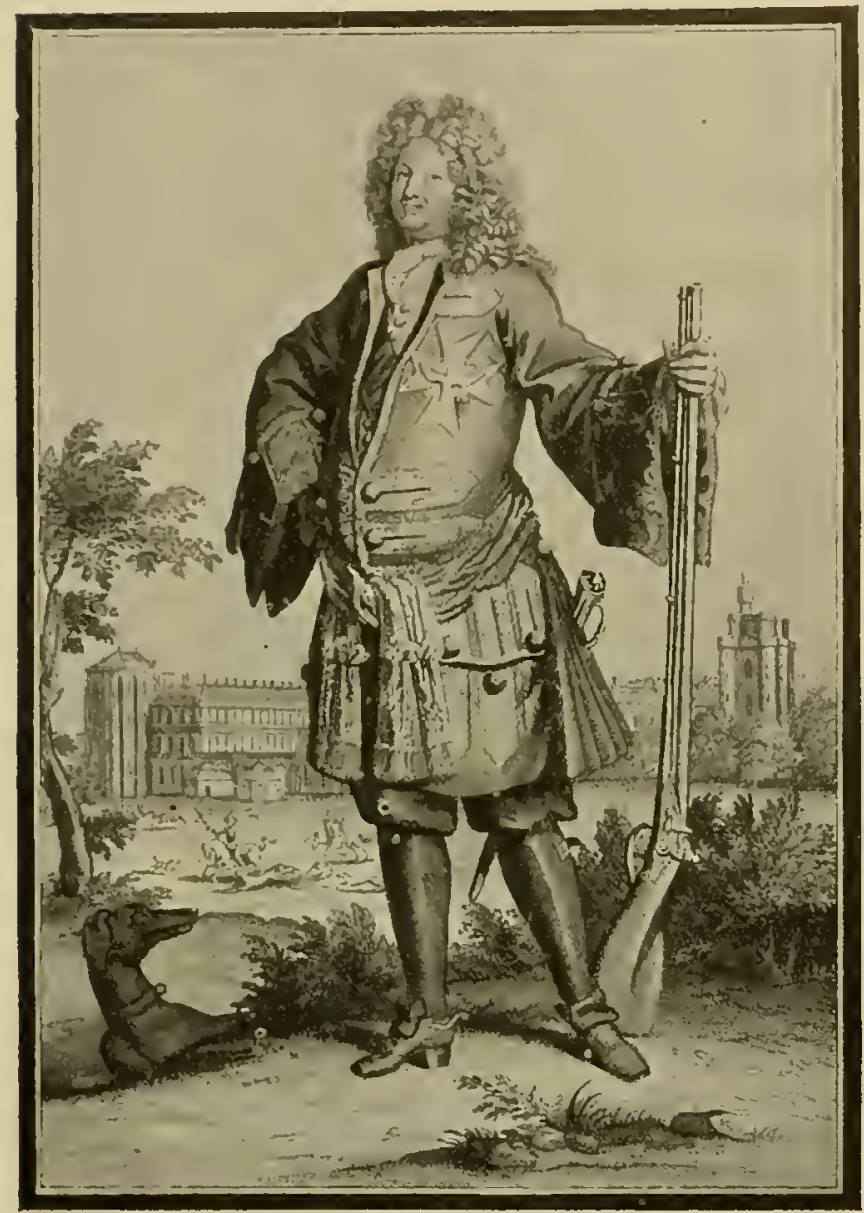

FIG. 146. THE DAUPHIN LOUIS, ONLY SON OF LOUIS XIV. BY BERNARD PICARD. IN THE BACKGROUND VINCENNES. See Page 24

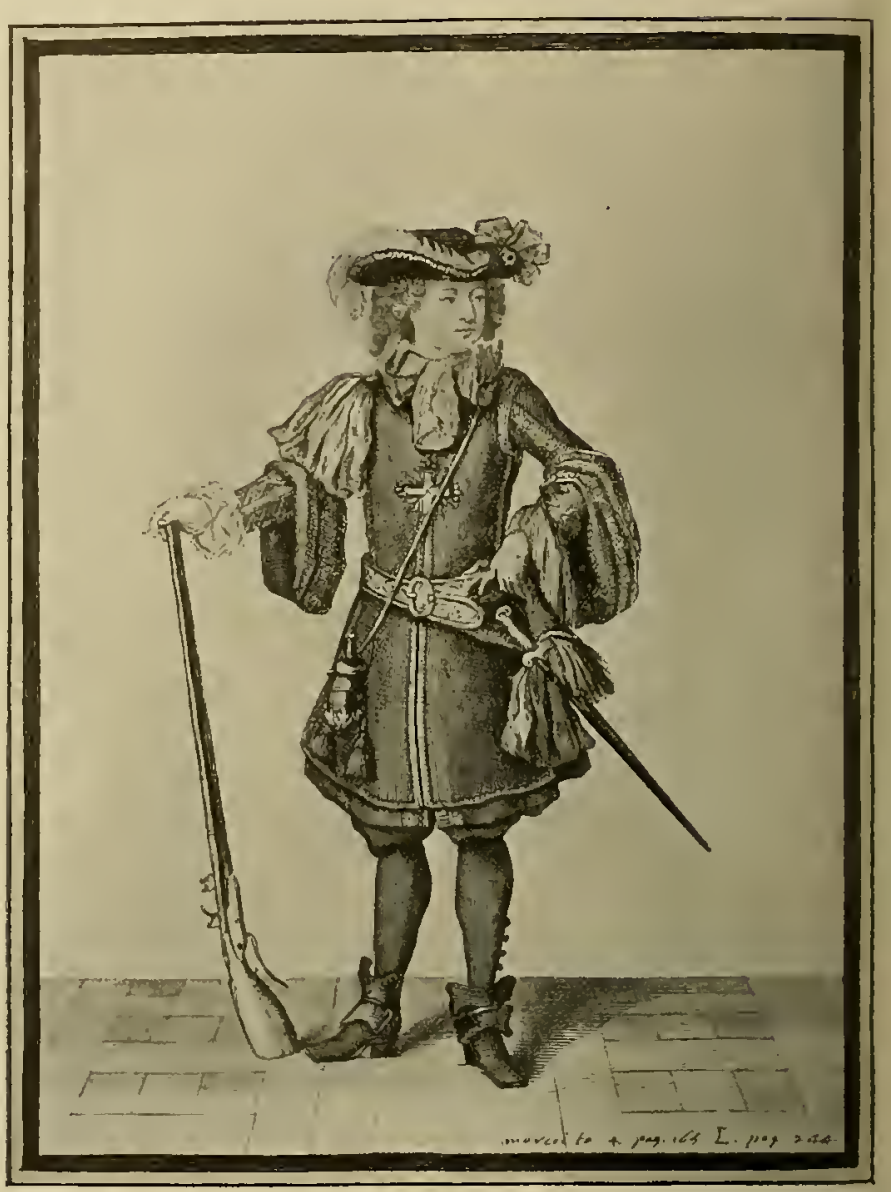

FIG. 147. LOUIS DE FRANCE, DUKE OF BOURGOGNE, GRANDSON OF LOUIS XIV AND FATHER OF LOUIS XV. DESIGNED BY N. ARNOULT. See Page 224

in style from these mezzotints is a set of four engravings designed by the younger Thoman. They depict the four seasons, Fig. I $5^{\circ}$ being a reproduction of "Spring," with the emblematic scene of heron-hawking.

About this time came into fashion satirical prints on sport. The vogue started about two hundred years ago by prints which generally were of a very scurrilous nature, poking unbridled fun at various follies of mankind, the latter being 230 


\section{SATIRIGAL SPORTIX్ PRIXTS}

generally represented by dwarfs. The earliest of such series was probably the Italian set called Il Callotto resuscitato. A subsequent series by the hand of a French artist was Le Monde plein de Fols or Le Théatre des Nains. Both are well

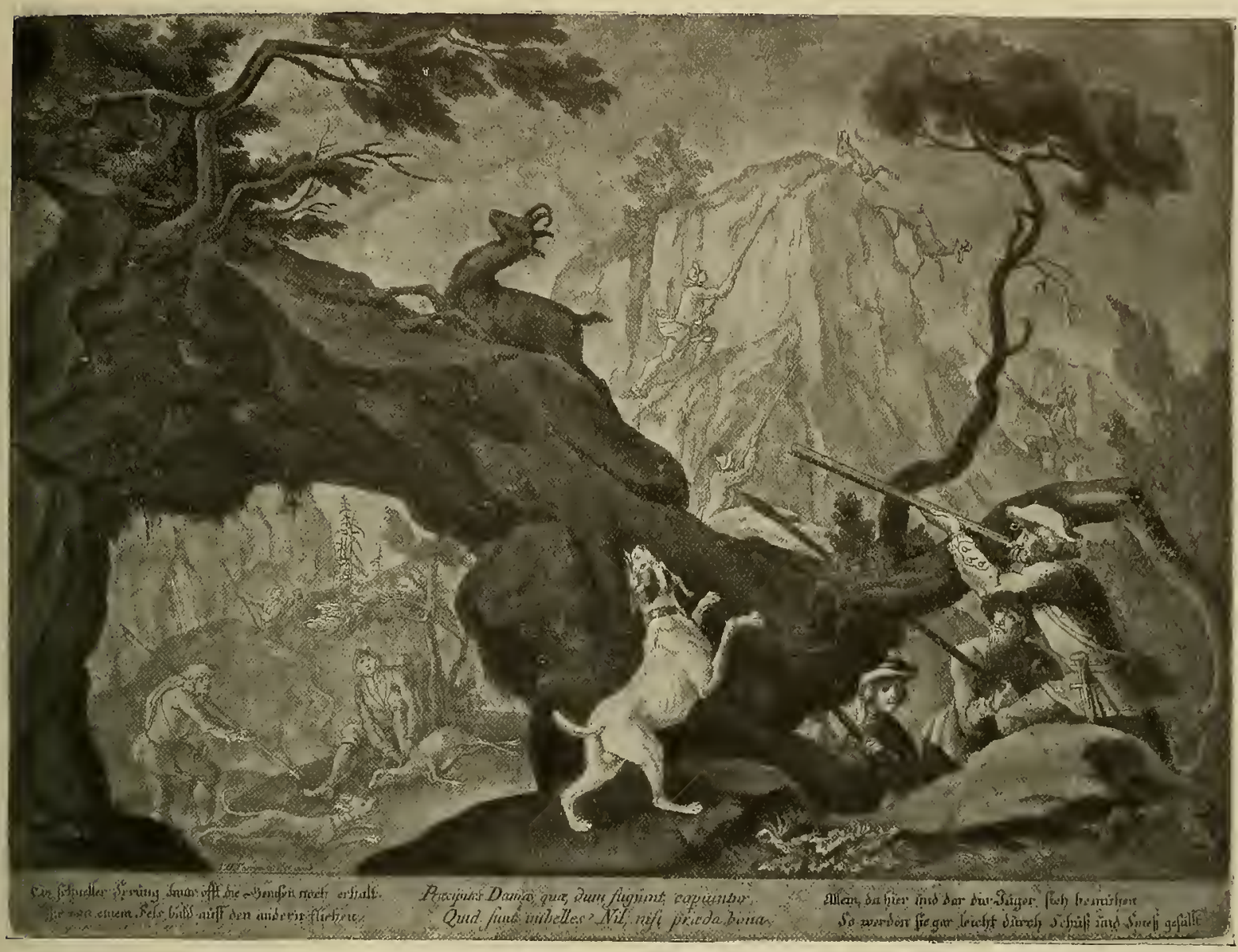

FIG. 148. CHAMOIS-HUNTING. MEZZOTINT BY T. H. THOMAN. FIRST HALF OF THE EIGHTEENTH CENTURY. See Page 229

known to collectors, but as they treat more of dress and fashions than of sport, neither concerns us as much as the following. It is an excessively rare set, there being only one other known, but also incomplete copy, which is preserved in the Van Stolk collection in Rotterdam.* Unluckily both want the title-page, so we lack

* Mr. Moes, head of the Prentenkabinet of the Amsterdam Rijksmuseum, to whom Sir Sidney Colvin was good enough to send the writer's prints for identification, was also unable to give other information about them than what we have quoted, his own museum not possessing any of them. According to him Le Théâtre des Nains was also published with a Dutch text in 17r6, and probably our prints are of that period. They measure $20 \frac{1}{4} \times 17 \frac{1}{2} \mathrm{~cm}$. The Rotterdam copy lacks PIs. 5, 6, I 2, I 5, and 16. 


\section{SPORT IX ART}

the usual means of identifying rare prints, and none of the authorities of the English and Continental print collections to whom the writer has submitted the fifteen plates numbered 2 to 16 of which his copy consists, were able to solve

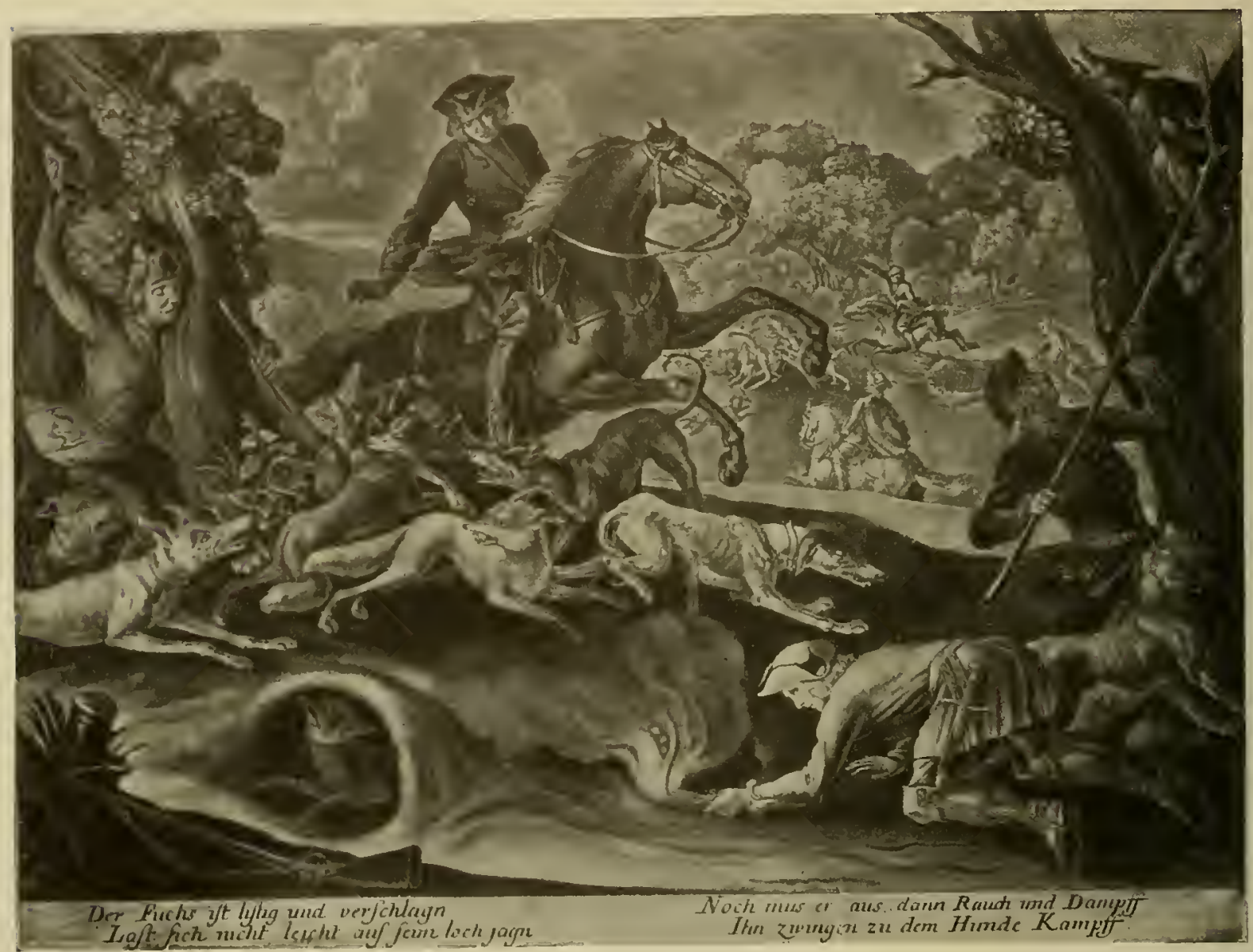

FIG. 149. FOXES BEING SMOKED OUT OF THEIR EARTHS. MEZZOTINT BY T. H. THOMAN. FIBST HALF OF EIGHTEENTH CENTURY. Sce Page 229

the riddle of their origin. As a complete set with the title-page intact may, of course, still be discovered, any information on above points would be much appreciated.

In Fig. I 53, the first of the two we select for reproduction, the artist uses his caustic pencil to travesty the then fashionable sport of fox-tossing, of which we. give an account when describing Fleming's illustrations, see Fig. 159. An unhappy fox, held by a courtier by the teeth, is undergoing a tossing; a wild boar with a hat over his eyes is lying close at hand, but whether the animal is supposed 232 


\section{DUTCH S.ATIRE}

to be simulating sleep or has succumbed to the fate of the tossed, we must leave to the reader to guess, for, unfortunately, the twelve lines of Dutch underneath each print leave us in the dark. The prince, with his buxom duchess of unmistakably Flemish cast of features and figure at his side, is watching the tossing through a magnifying glass. In front of him is a nondescript kind of dog holding what is probably meant to be a dead heron in his mouth.

Fig. I 54 lampoons heron-hawking. The wonderfully got-up royal lady, mounted on a steed with blinkers, with a monkey seated on its hind quarters and holding a buge umbrella over the lady's head is a funny enough sight. In front of ber is the dwarf cadge-bearer, who is busily handing his mistress parrots instead of falcons. They are not only unhooded but without jesses or bells. $\mathrm{He}$ is smoking a long clay pipe, possibly because this would be about the last thing the bearer of the cadge should do when on duty. In the background we see a man climbing up an unsupported ladder into the air, holding a heron by its neck which he is about to cast loose, and at which the parrots are to stoop.

The other prints poke fun at various incidents. In one we see

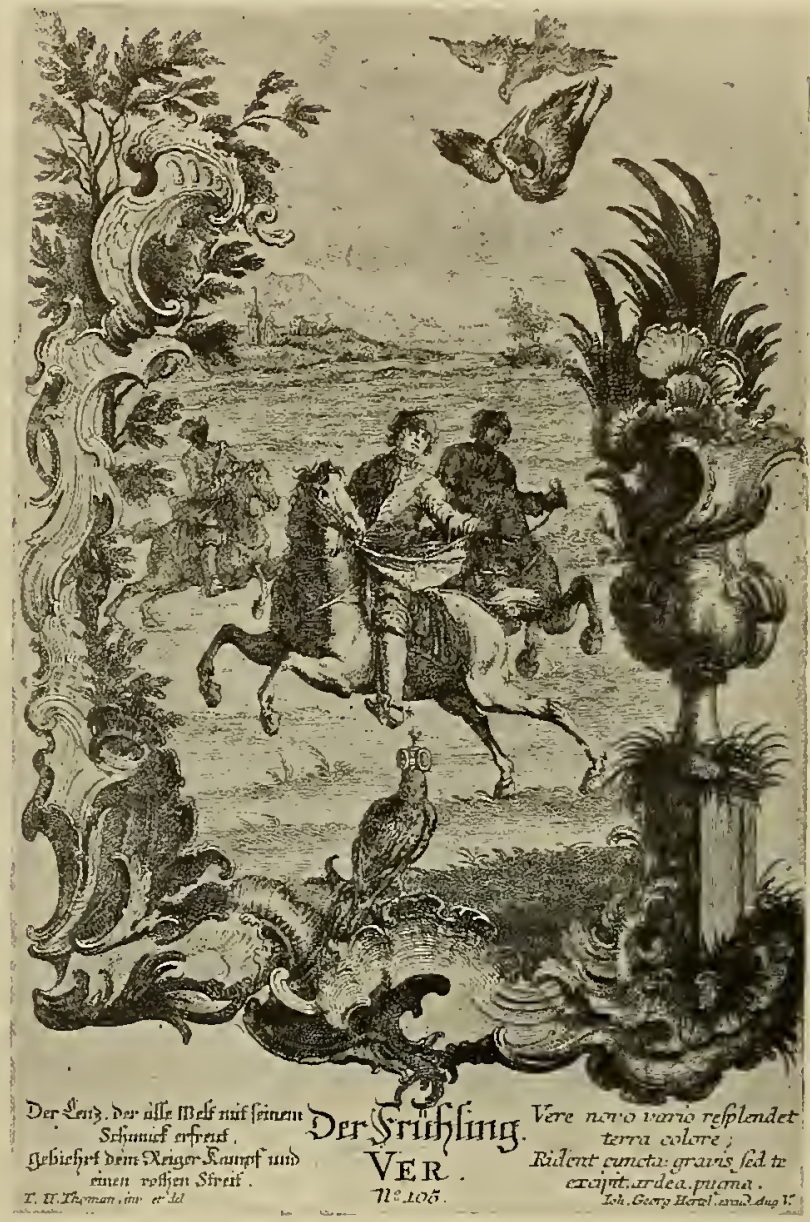

FIG. I 50. HERON-HAWKING. BY T. H. THOMAN FIRST HALF OF EIGHTEENTH CENTURY. P. 230 amazons of Dutch buxomness out stag-hunting. A dwarf with his wig tumbling off has been tossed by a stag of diminutive proportions that has floored another pursuer, while a third hunter who is belabouring the animal's quarters with a hay-rake is in evident danger of being gored by the stag's antlers. A fourth sportsman, behind him, is running even greater risks of having "daylight let through him" by the sword of his companion. To increase his jeopardy the benignly smiling amazon in front of him is deliberately aiming her flint-lock at his person. A turbanned 


\section{SPORT IX ART}

negro is holding with one hand her horse and, with the other, a hound in leash, which is probably a hit at the then prevalent, much-resented fashion of great ladies having negro pages as personal attendants.

Another picture satirizes hare-bunting. A hunter has taken off his jack-boot, evidently with the fell intention of slaying with it poor puss that is being held by a man lying on the ground. This is probably meant to ridicule the poor chances of the hare to escape its pursuers.

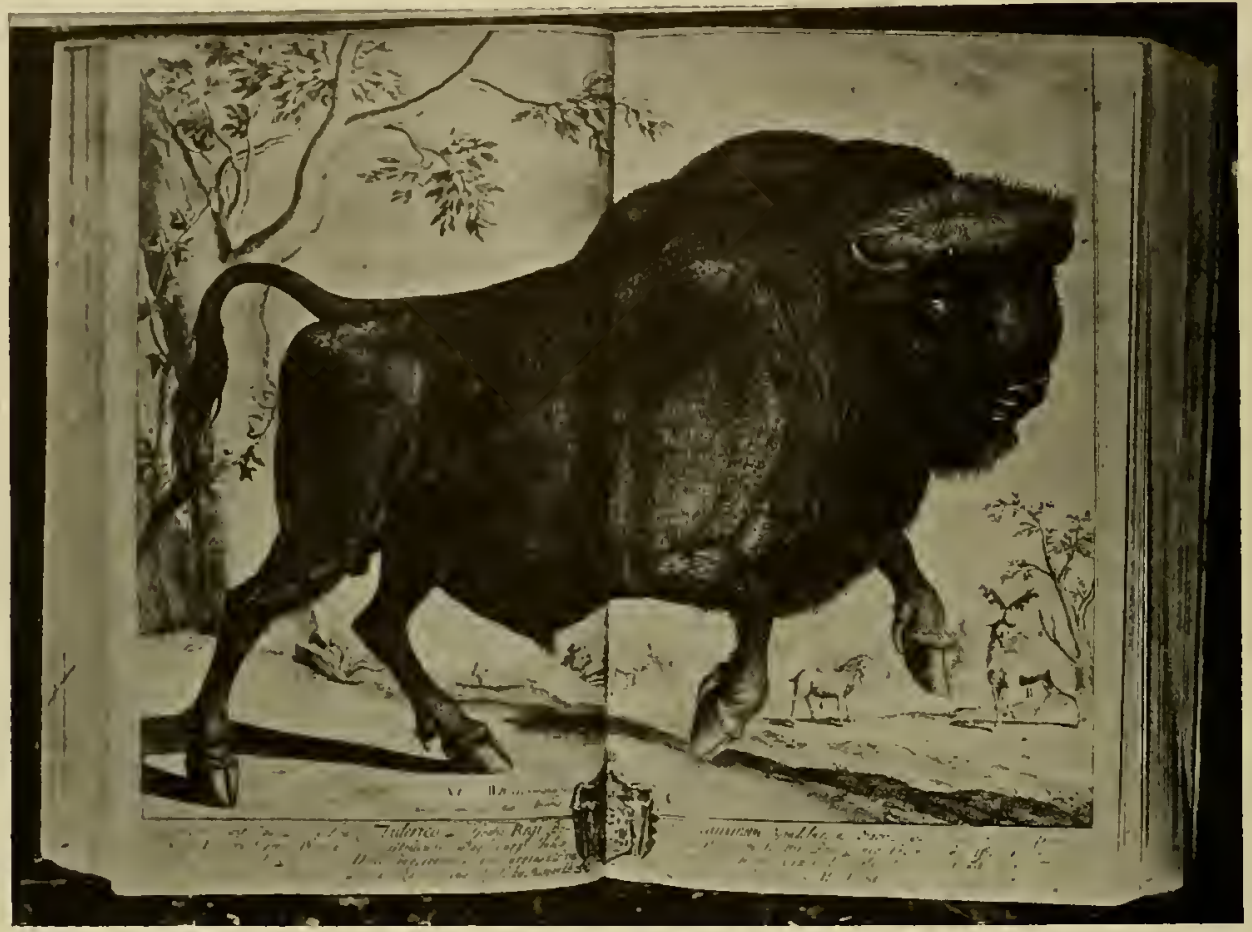

FIG. 151. THE URUS OR AUROCHS. FROM SAMUEL CLARKE'S “JULIUS CASAR," 1712. See Figs. 20, 46, 47, 79, 88, 99, 102, 110, $210,225,227$, and Prge 50

Another makes fun of tilting at the quintain or ring, then a fashionable amusement. The instrument with which a rider is spanking his horse appears rather out of keeping, for it is nothing less than a kitchen skimmer, though one might also take it to be a warming-pan! Dutch humour, never of a very spirituel type, is often coarse, and some of the fifteen prints make no exception to this rule.

The most interesting of the German books on the chase of the eighteenth century is unquestionably Fleming's Der vollkommene teutsche Jäger, which appeared in two handsome and profusely illustrated folio volumes A.D. 17 Ig. The six illustrations we reproduce will give the reader some idea of the eccentric length to which scores of German potentates and the great nobles of the Holy 234 


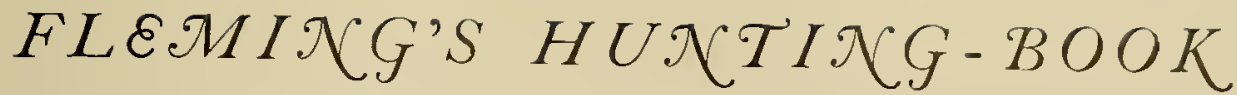

Roman Empire went in the pursuit of sport. Slaughter of the grossest kind, achieved with the least possible trouble, fatigue, or danger to the sportsman, seemed to be the principal object aimed at. As we turn Fleming's leaves, and examine in detail the elaborate machinery of sport he pictures, we ask ourselves whether a couple of centuries hence the representations of our own fashionable sport of to-day will not evoke similar criticism? Whether our own achievements, say at deer and grouse drives, will not seem as ridiculous and as objectionable as appear to us the feats of Fleming's Jäger? Incongruous as were their bright - coloured, gold - bespangled coats, lace frills and three-cornered hats in the hunting-field, we must not forget that they unquestionably knew more about the habitat of the game they ruthlessly slaughtered, and that they possessed a more intimate knowledge of woodcraft than we do, man for man.

And how handicapped were the shots of those days by the incredibly unwieldy fire-arms! The fearsomely stocked, tremendously heavy Schrottbüchse, foreweighted, ill-balanced, with archaically slow ignition, inferior powder, irregular-sized, hand-made shot, and gas-pipe barrel, was a tool the clumsiness of which it is nowadays difficult to realize. And yet, if we can believe eye-witnesses, men used to bring down flying swallows at

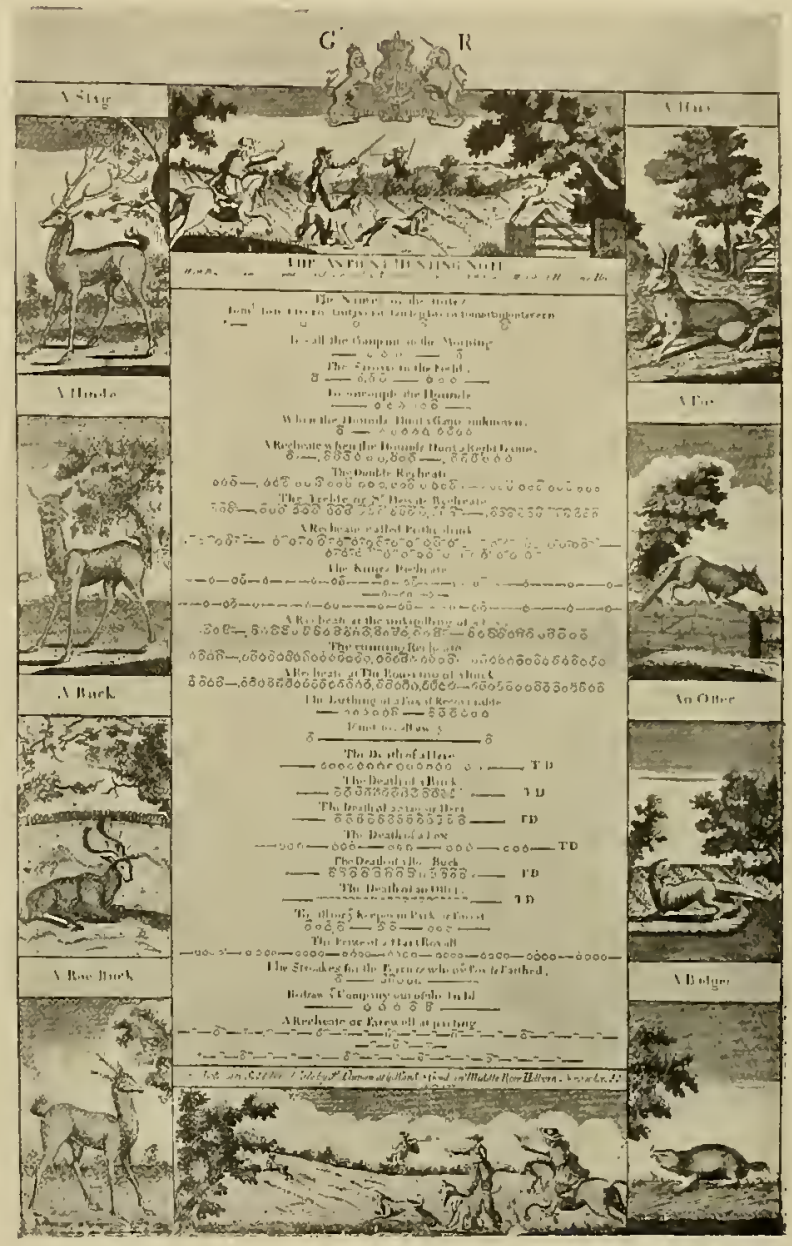

FIG. 152. BROADSIDE ENTITLED “THE ANTIENT HUNTING NOTES WITH BEDFORD'S LATE FIRST AND SECOND NEW ADDITIONS." ABOUT I7I5. See Page 219 "almost every shot," and "would rarely miss snipe or quail on the wing." George I had in his Windsor library a finely bound copy of Fleming's volumes, and probably turned their pages oft enough to recall the days spent after the long-tails in his beloved Herrenhausen Phasanerie. What a pity that the belated camera failed to secure pictures of George I's performances, such as photography has garnered for us of the feats of the Fifth of the name, the matador of our own day! 


$$
\text { SPORT IX ART }
$$

But it is high time that we begin our review of Fleming's prints. Figs. I 55 and 156 depict show-hunts where roofed-in stands were erected in the forest from which the ladies of the court could watch the proceedings, while the populace

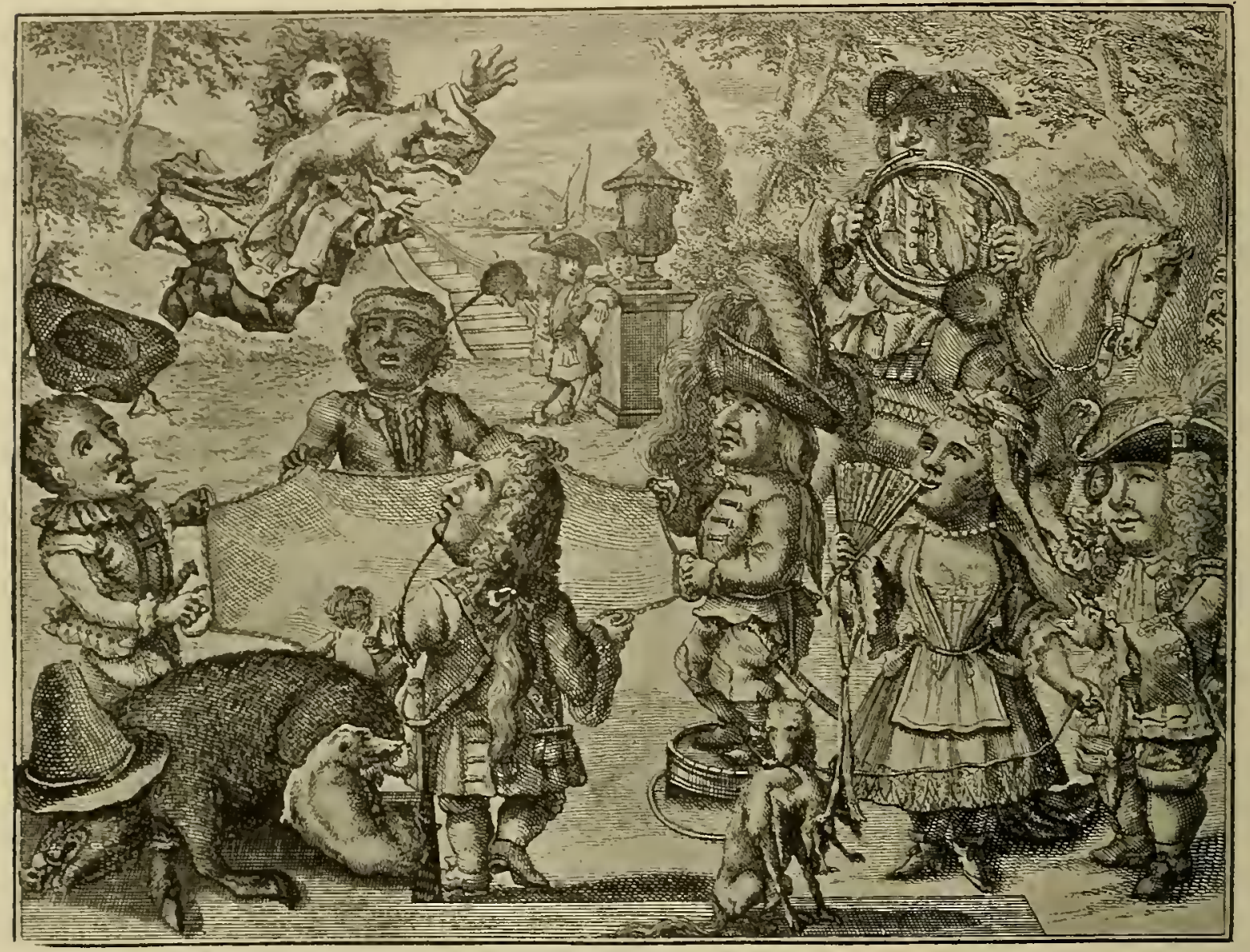

FIG. 153. DUTCH SKIT ON THE THEN FASHIONABLESPORT OF FOX-TOSSING. DESIGNER AND ENGRAVER UNKNOWN. PUBLISHED ABOU'T 17ז6. ONLY TWO SETS, BOTH INCOMPLETE, ARE KNOWN. Sec Fig. I59, and Pages $23 c-23+$

occupied improvised erections behind the canvas screens, which were 8 to ro feet high. What is probably the most extraordinary thing about the scenes we see depicted is that so few accidents seem to have occurred from stray bullets. The inner nets we observe in Fig. I $5 ;$ had evidently to serve a twofold purpose : to prevent the frightened beasts from dashing through the screens, and to enable the officials to escape. In the background we see an individual perched on one of the stays which holds up the net, seeking safety from an onrushing infuriated boar. 236 


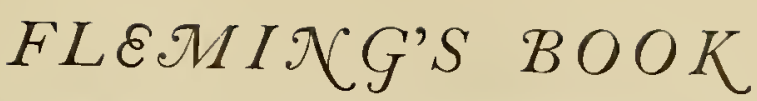

The wolf-hunting picture, Fig. 157 , is of interest chiefly because it shows us two instruments used for this sport, i.e. the wolf fork and the wolf tongs, which latter were probably the same as the badger tongs. It goes without saying that

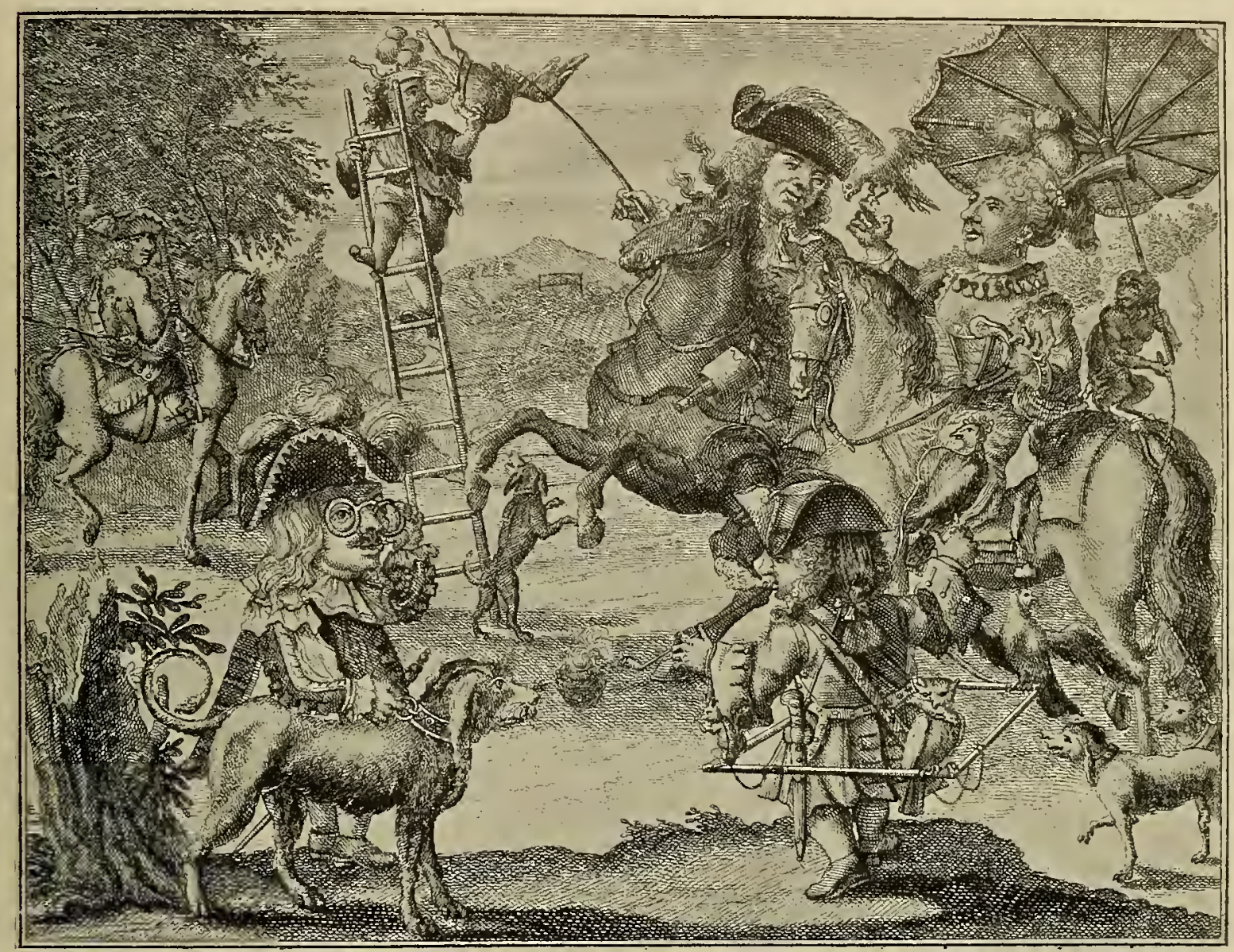

FIG. 154. DUTCH SKIT ON FALCONRY. DESIGNER AND ENGRAVER ARE UNKNOWN. PUBLISHED ABOUT I716. ONLY TWO SETS, BOTH INCOMPLETE, ARE KNOWN: ONE IN THE VAN STOLK COLLECTION IN ROTTERDAM, THE OTHER IN THAT OF THE WRITER. See Pages 230-234

the wolves turned loose on such occasions were captive beasts that had been caught in pitfalls or snares. In the background we see a wolf in the act of tumbling into one of these pitfalls. Another aberration of the sportsmen's mind of Fleming's time was the water-hunt, when deer were forced to cross ponds or streams on which were boats where the sportsmen hid behind screens made of green boughs, as is depicted in Fig. 158 . A still worse instance of decadent sport which was greatly 


\section{SPORT IX⿻ART}

enjoyed by the courtiers, and in fact by all classes, we see depicted in Fig. I 59, which gives us the detail of fox-tossing matches such as were then fashionable at most German courts. These entertainments were either held in woods in

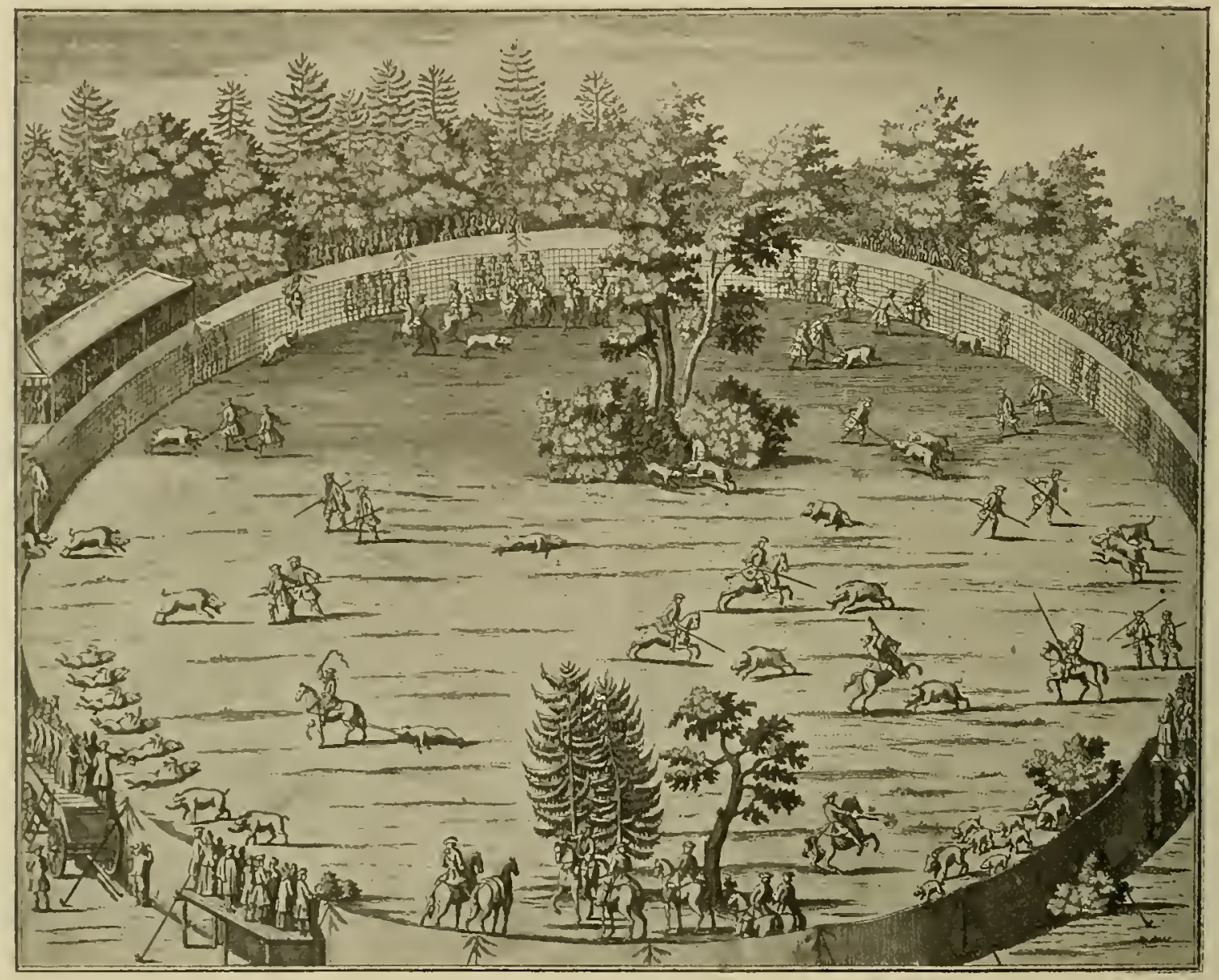

FIG. 155. A SHOW-HUNT AT A GERMAN COURT. WILD BOAR BEING KILLED IN AN ARENA. FROM FLEMING'S “TEUTSCHE JÄGER.” PUBLISHED i 19. See Pages $234^{-2}+3$

enclosures formed by canvas screens, or in the large courtyards of palaces where their Serene Highnesses could witness the "gay scene" from their windows. Not only foxes were tossed, but also hares and badgers and sometimes wild cats. The beasts were turned out en masse and careered about the enclosure in a state of abject fright. 'The tossing was done by two persons standing about twenty or twenty-five feet apart holding the ends of tossing slings made of webbing or cordwork about twenty-five feet in length. As the terrified animals were running about leaping over 238 


\section{FOX - TOSSIX $\mathcal{X}$}

the tossing slings, the centre of which lay slack on the ground, it behoved the tossers to jerk the animals into the air as forcibly as their strength permitted. Skilled male tossers could toss a fox twenty-four feet high. To prolong the sport

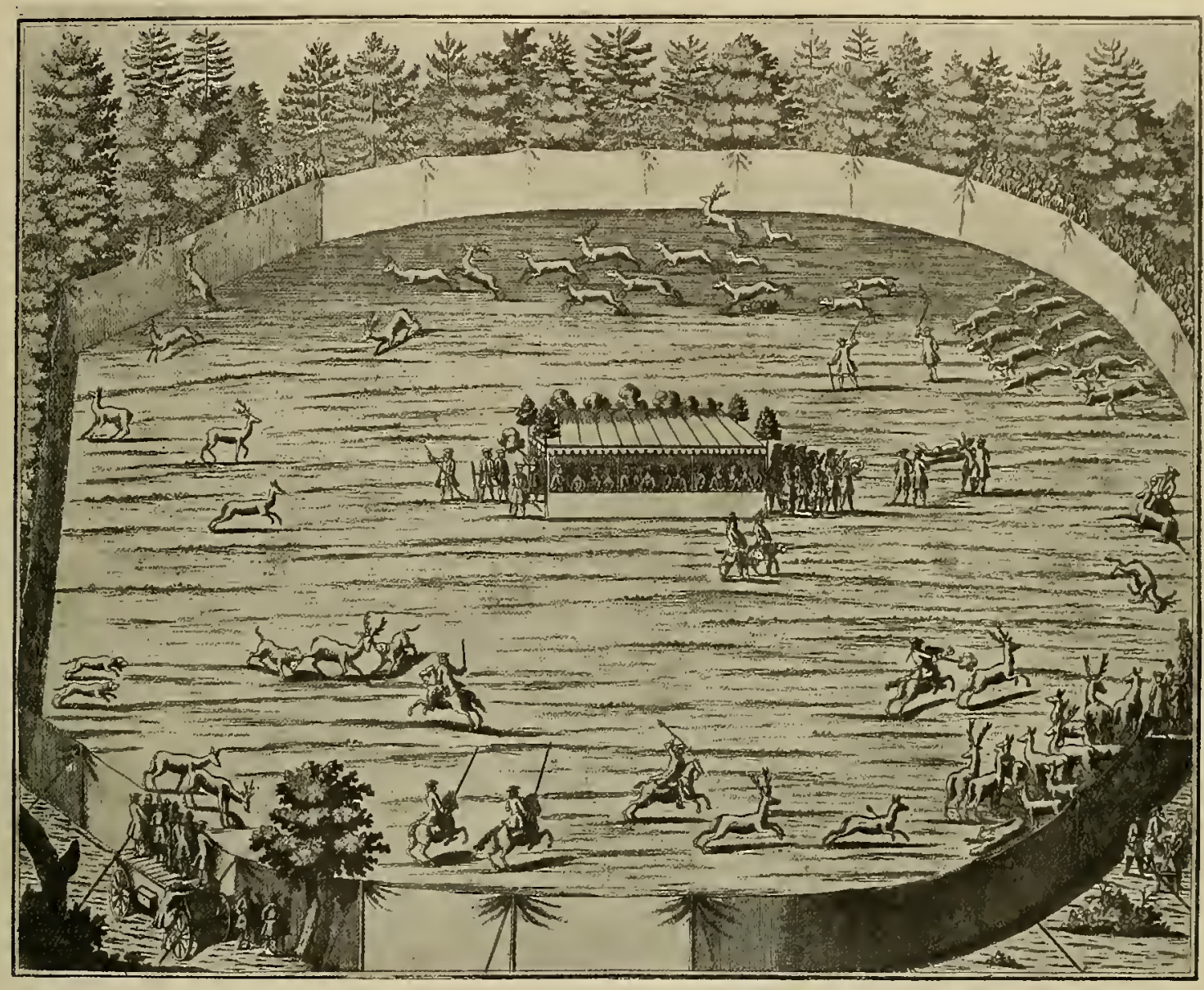

FIG. 156. A SHOW-HUNT AT A GERMAN COURT. DEER BEING KILLED IN AN ENCLOSURE FORMED OF CANVAS SCREENS TEN FEET HIGH. FROM FLEMING'S

“TEUTSCHE JäGER." PUBLISHED I 7 I 9 . Se Pages $234^{-243}$

the ground was covered with a thick layer of sand or sawdust, so as not to kill the wretched animal at the first toss. A great number of couples-generally a lady and gentleman were partners-could participate at the same time, and the quantity of game thus slaughtered on great occasions was something almost beyond belief, the rivalry between the separate couples giving additional zest to the cruel amusement. At the Saxon court, which was then the most pleasure-loving one 


\section{SPORT IX ART}

in Germany, Elector Frederick Augustus, who subsequently became King of Poland, and is perhaps better known as Augustus the Strong, was the first to introduce this amusement. This monarch, while mentally one of the most

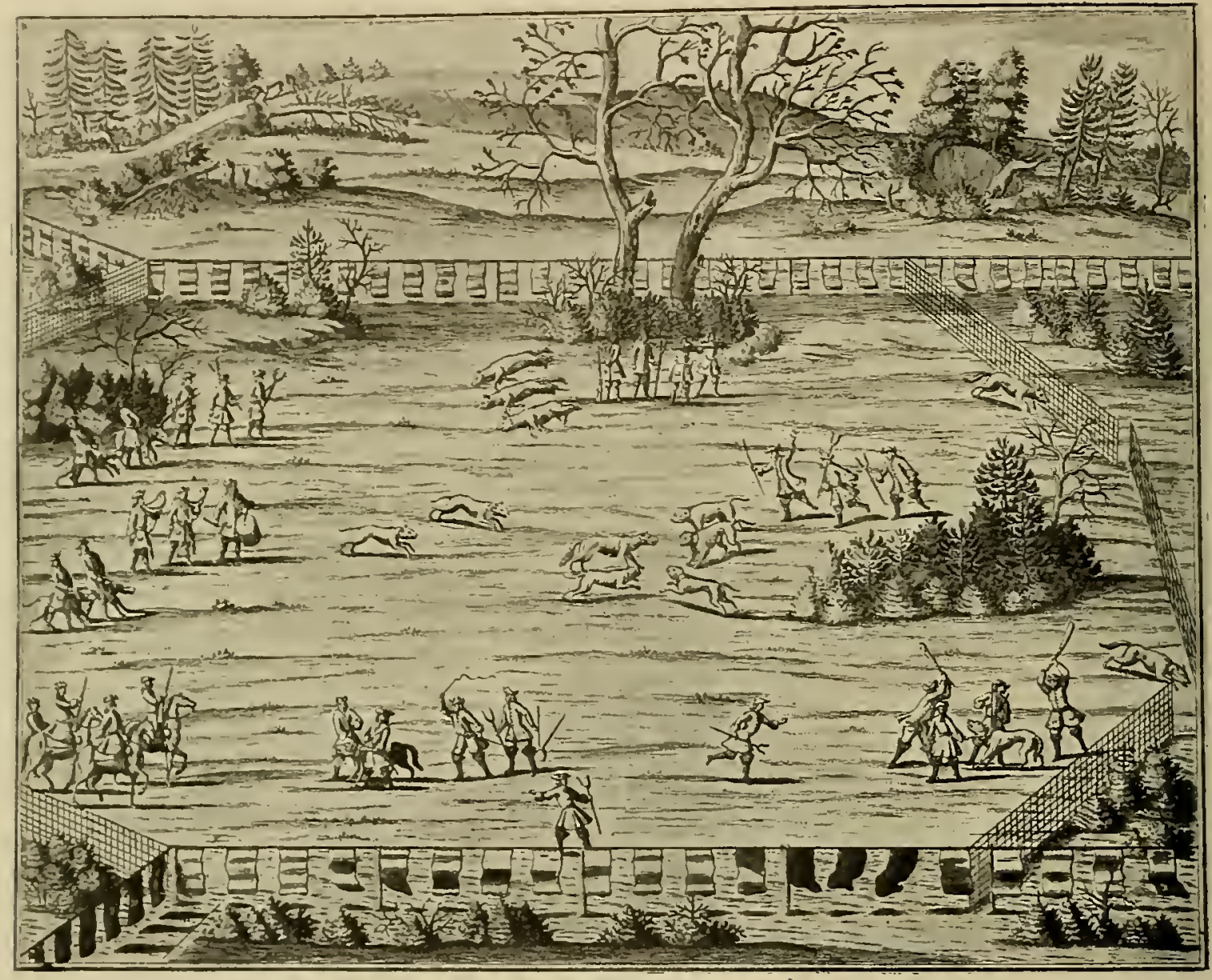

FIG. 15;. WOLF-BAITING : WOLVES CAPTURED IN PITFALLS WERE TURNED OUT IN ENCLOSURES AND HUNTED DOWN BY LARGE MASTIFFS. WOLF FORKS AND WOLF TONGS ARE BEING USED. FROM FLEMING'S “TEUTSCHE JÄGER." See Pages $234^{-2}+3$

vacillating of rulers, was physically one of the strongest men of any age. Considering that he could hold standing on the palm of his outstretched hand a fullyequipped cavalryman, it can hardly surprise one to hear that when he engaged in fox-tossing he would hold his end of the tossing-sling with one finger, and notwithstanding that the two men who held the other end were the strongest to be found, they were no match for him. It was he, also, who introduced heavier 240 


\section{FLEMIX్G'S COURT HUXTS}

animals, such as two-year-old wild boars and even wolves. At a famous fox-tossing in Dresden there were tossed 687 foxes, 533 hares, 34 badgers, 2 I wild cats, and at the end 34 young wild boars and 3 wolves were turned into the enclosure, "tc

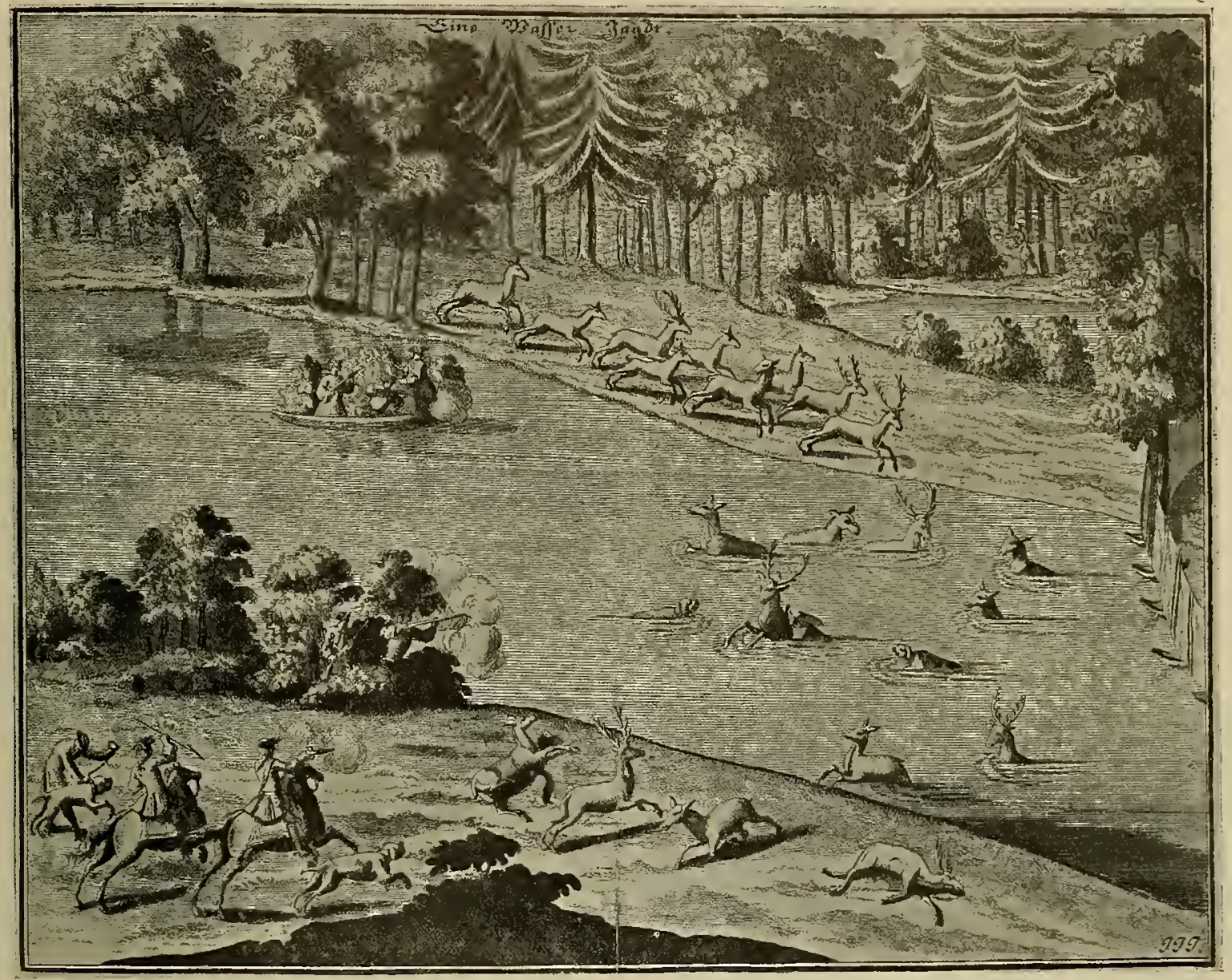

FIG. I 58. A WATER HUNT : THESE WERE FASHIONABLE AT GERMAN COURTS IN THE EIGHTEENTH CENTURY. THE BOAT ON THE WATER CONTAINS SPORTSMEN HIDDEN BEHIND GREEN BOUGHS. FROM FLEMING'S “TEUTSCHE J̈̈GER.” See Pages $234^{-2} 43$

the great delectation of the cavaliers, but to the terror ot the noble ladies, among whose hoop-skirts the wild boars committed great havoc, to the endless mirth of the assembled illustrious company." That injuries on such occasions were not infrequent need hardly be mentioned, and more than one tosser was marked for life by the claws of a wild cat or the tusks of a young boar. The former animals, as one writer remarks, "do not give a pleasing kind of sport, for if they cannot 


\section{SPORT IX ART}

bury their claws and teeth in the faces or legs of the tossers, they cling to the tossing-slings for dear life, and it is next to impossible to give one of these animals a skilful toss."

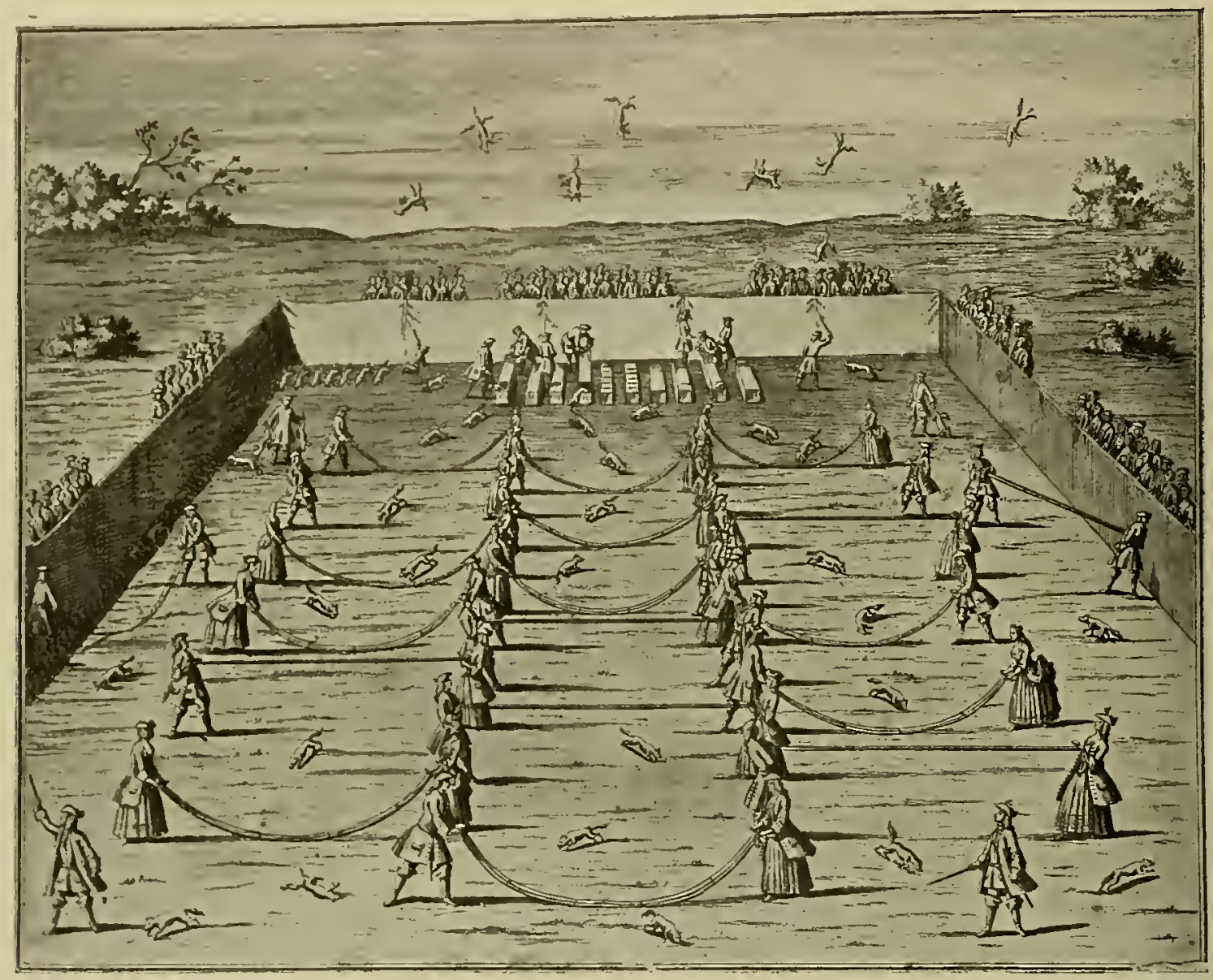

FIG. 159. FOX-TOSSING, FASHIONABLE AT GERMAN COURTS IN THE EIGHTEENTH CENTURY. FROM FLEMING'S “TEUTSCHE JAG̈ER.” PUBLISHED 17ig. See Pages $234^{-2}+3$

At some of the minor German courts fox-tossing remained long in favour. Landgravine Emily of Hesse, an ancestress of the present grand-ducal house of HesseCassel, was a great patroness of the sport; but it was left to Duke Louis of Brunswick to add a further element of grotesque absurdity to this amusement by inventing masked fox-tossings. Not only did the players put on bizarre costumes, dressing themselves up as Dianas, sprites of the wood, nymphs, hobgoblins, centaurs, sphinxes, and other creatures of mythology, but these master-buffoons did the same thing to the animals they tossed. By means of cardboard, bits of 242 


\section{FOX-TOSSIX్XG AT GERMAX COURTS}

gaudy cloth, and tinsel, the wretched foxes and hares-these latter being the favourites for this purpose-were dressed up in the most fantastic manner imaginable, unpopular personages or political foes being represented in as lifelike a manner

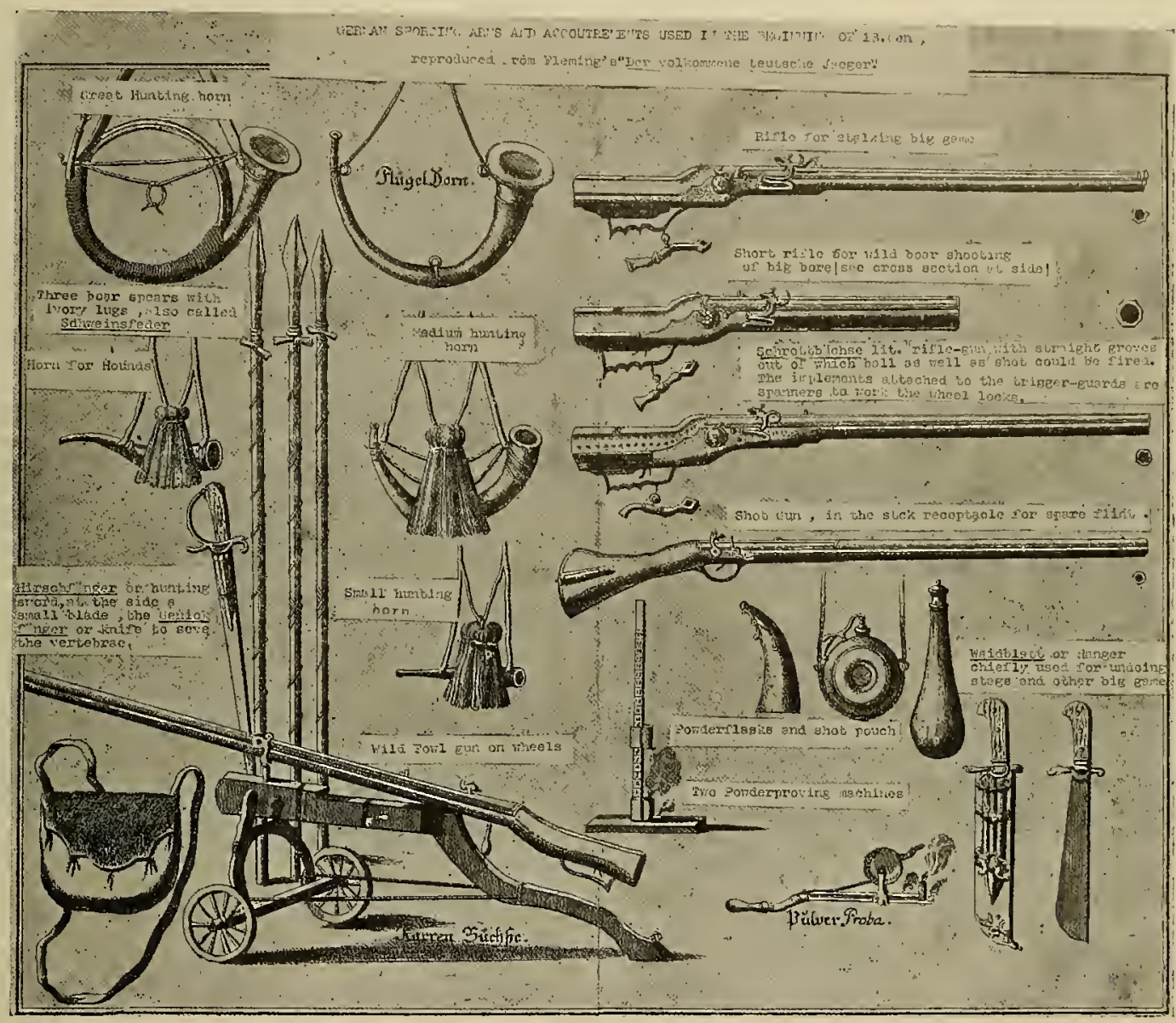

FIG. I60. SPORTING ARMS AND ACCOUTREMENTS USED IN GERMANY 200 YEARS AGO. FROM FLEMING'S “TEUTSCHE JÄGER.” PUBLISHED 1719. See Pages $234-243$

as possible. At the end of this farcical buffoonery, when the layer of sand in the great courtyard was sodden with the blood of the wretched hares and foxes, the whole company of courtiers, cavaliers, and noble ladies finished off the day's "sport" by a torchlight masquerade through the rambling park of the château; or they took part in some bombastic stage-play, where they represented themselves as gods and goddesses, or personified the great warriors of history or heroes of mythology. It was indeed a periodmeriting the name baroque in sport, as well as in art, manners, and customs. 


\section{SPORT IX ART}

Our last illustration from Fleming, Fig. I60, needs no further description, for we have appended English translations of the names of the various accoutrements and arms which the German writer massed together on one of his double plates.

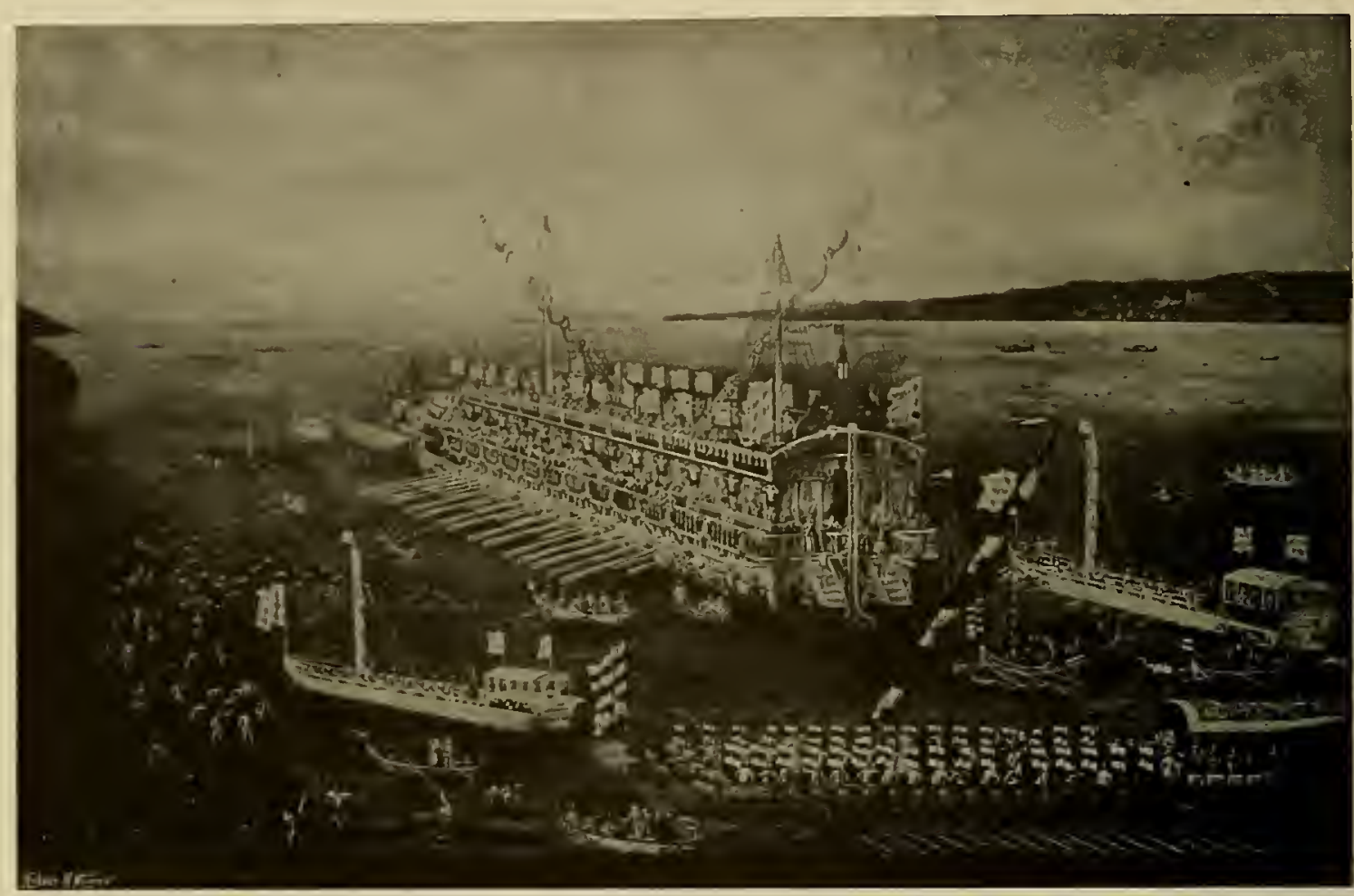

FIG. 161. A STAG-HUNT AT THE BAVARIAN COURT ABOUT 1730. THE SCENE IS THE STARENBERG LAKE NEAR MUNICH, AND THE GREAT BARGE WAS AN EXACT COPY OF THE “BUCENTAUR” OF VENICE. Sec Page $24+$

We trust the writing will be found legible, notwithstanding the unavoidable reduction in size. Even worse, if that be possible, than the sport depicted by Fleming, is the "hunting" shown in Fig. $16 \mathrm{I}$, representing one of those fantastic coups de théatre replete with the monstrous extravagances then en vogue. The royal stag-hunt we see in this picture took place in the first half of the eighteenth century on the shores of the Staremberg Lake, not far from Munich. A stag of fourteen-in the large painting one can easily distinguish the tines-hotly pursued by the enormous pack, then the fashion at the Bavarian court, was forced to soil, or to take to the lake near the spot where the great state barge, which was an exact copy of the famous Bucentaur of Venice, propelled by one hundred and ten oarmen, was lying. The royal company on it was evidently awaiting the event depicted in the picture. In the rowing boat, which is heading off the 244 


\section{JEAX BAPTISTE OUTRY}

swimming stag, is the Duke, who either killed the deer there and then, or what was occasionally done, the exhausted animal was dragged on board the Bucentaur and killed at the feet of the Duchess; after which the right fore-leg, cut off at

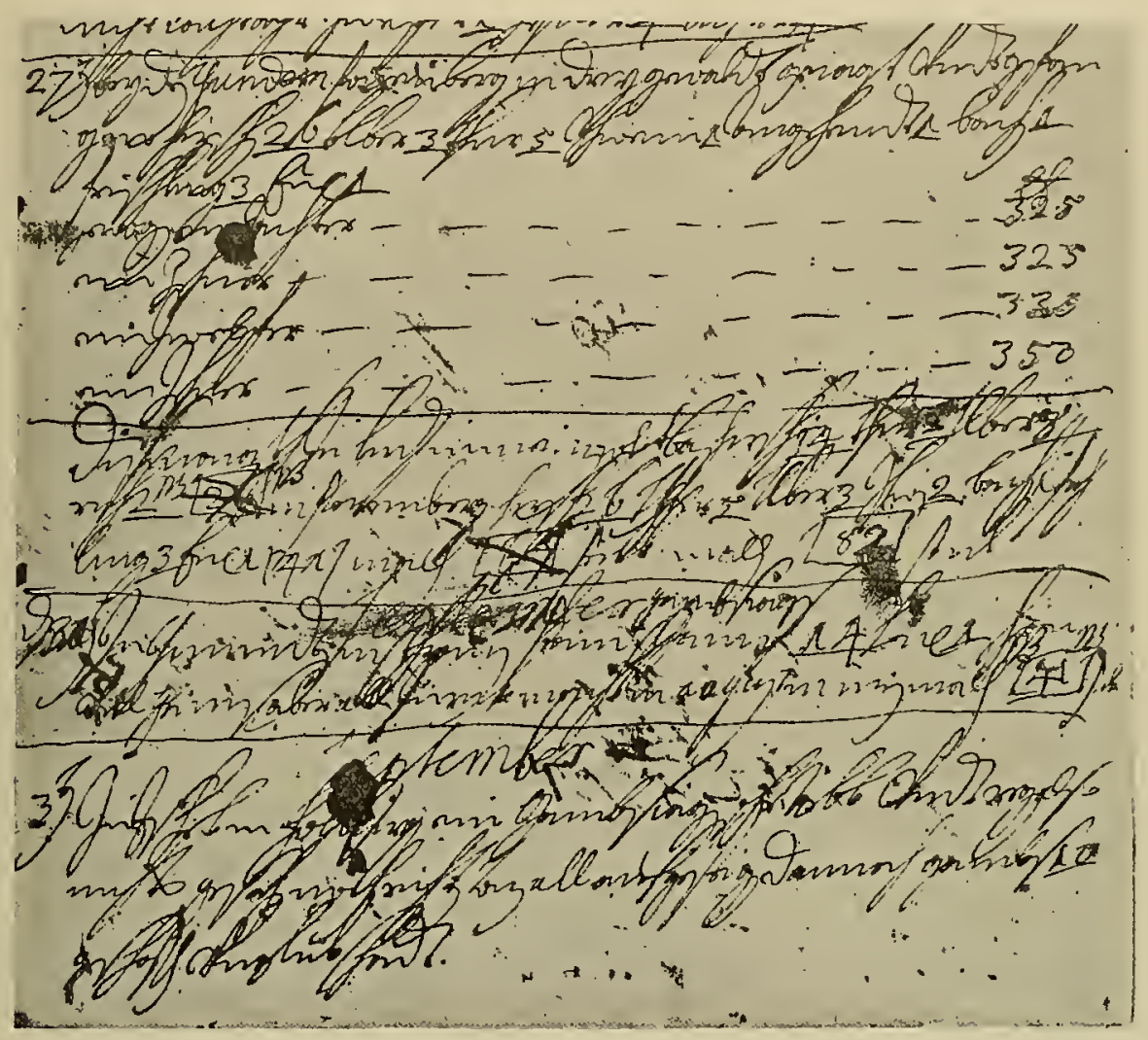

FIG. I62. A PAGE OUT OF EMPEROR CHARLES VI'S DIARY, GIVING DETAILS OF STAGS AND CHAMOIS KILLED BY HIM IN UPPER AUSTRIA IN SEPTEMBER 1732 . See Fig. 117 , and Page 186

the knee-joint, was presented to the august lady. As a cannon is being fired from the bows of the barge, and trumpeters, drawn up on its gaily-beflagged roof, are blowing a fanfare, it is likely that the stag came to his end in the former manner.

With a sigh of relief we turn from these pictures of decadent sport to the stately Grande Vénerie of the French court depicted by Jean Baptiste Oudry (I686-I755). Our Figs. 163 and 164 are reproductions of the celebrated Les Chasses de Louis $X V$, of which seven were woven between I733 and 1738 at the Gobelins manufactory after Oudry's designs and under his guidance. Two sets exist, one adorning Fontainebleau, another, and much finer one, 


$$
\text { SPORT IX ART }
$$

being preserved in the National Museum at Florence. 'These hangings, from which our reproductions are made, are said to be the finest tapestries ever made for harmony, vigour of colours, and magnificent design. They are one of the

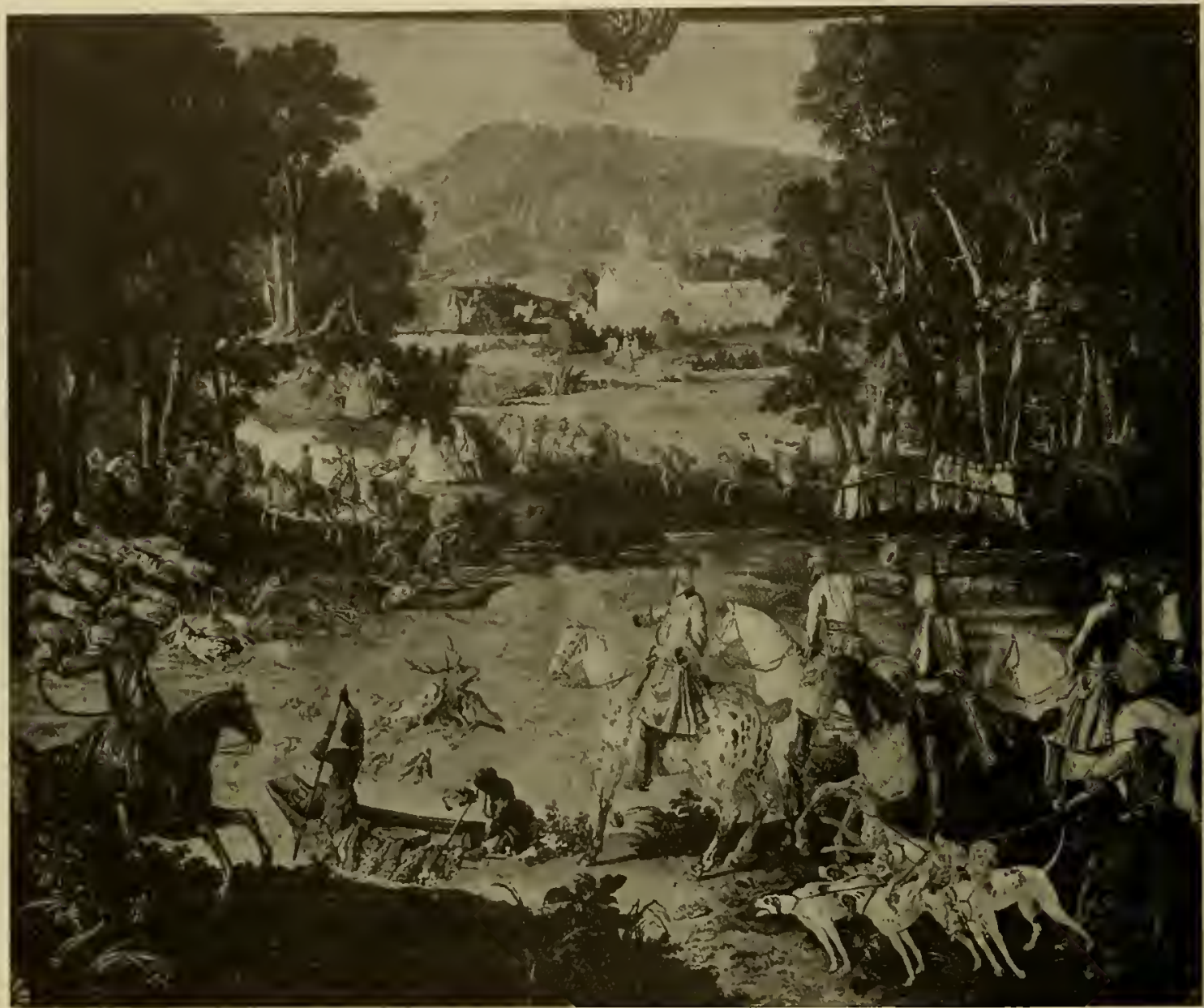

FIG. 163. "CHASSE LOUIS XV" TAPESTRY AFTER JEAN BAPTISTE OUDRY, WOVEN BETWEEN 1733 AND 1738 AT GOBELINS. See Page 245

few instances where the tapissiers have shaped something superior to the designs after which they worked, and one can imagine with what mixed feelings of satisfaction and humiliation the designer saw these marvellous hangings gradually take shape under his directing hand. The truth is that Oudry's work with the brush was very unequal; those who have seen the Florentine tapestries and know his wolf-hunt and wild-boar chase in the Louvre, whose hard and un246 


\section{SPORT IX ART}

forthwith made most favourable overtures to the artist to accompany him back to. St. Petersburg. These the patriotic Frenchman dared to refuse, and in order to escape the autocrat's pressing solicitations he secreted himself in Paris and remained "lost" until the Czar had departed. This coming to the ears of Louis XV caused him to interest himself in the painter's future, with the result that Oudry was received into the efcademie des Beaux-eArts and was made court painter. Hitherto he had confined himself to portraiture and historical subjects, but after executing an order from the Duke of Antin to paint some hunting scenes for his château, he took to sporting subjects. In this he was strengthened by the favourable reception of a painting of his depicting the King surrounded by twelve courtiers in the hunting-field.* Encouraged in every way by his royal patron he eventually became a second Desportes, and in respect to designs for gobelins his fame became even greater. In 1734 he was made superintendent of the Beauvais works, and his success there caused him to be appointed director of the Gobelin establishment. When he died he was head of both these unrivalled manufactories of the basse lisse and haute lisse warp.

Of the many striking scenes which Desportes might have depicted he has left us few records. How interesting, for instance, would a picture of that stirring and memorable scene in the Park of Rambouillet have been, of which La Vallee in his La Chasse à Courre tells us? It was on St. Hubert's Day (November 3) when three stags hunted by three different famous packs, viz., of the King, of Prince Conti and of Prince d'Ombre, took simultaneously to the l'étang de Hollande on the shores of which were presumably enacted the final ceremonies incidental to the death of the hart.

Although the well-known family of Van Loo played an important part in artistic circles of the eighteenth century, only one of the five members contributed to our subject. What peripatetic folk artists were in those restless days is illustrated by the family birth register, according to which Amsterdam, Aix, Nice, Toulon and Turin each scored a Van Loo. Carlo van Loo, the one born in Nice, left us a spirited bear-hunt, Fig. I65, engraved by J. J. Flipart, the well-known Paris artist. Carlo reached high honours, for he was not only made First Painter to the King of France, but also Director of the Academy of Art. There is a pendant to this fine print depicting a leopard-hunt, painted by Boucher, the contemporary of Carlo, both being good examples of Flipart's very effective style, which rendered Boucher's as well as Lancret's and Watteau's works so exceedingly popular. The two bears, spiritedly drawn, are having a hard struggle. Why the third beast in the background is not taking a hand in the fight is not quite clear, but possibly it was meant for a cub.

Among the host of Netherland artists who came over to England about this time were the two brothers Joseph and Alexander Van Haecken, to whom we are 


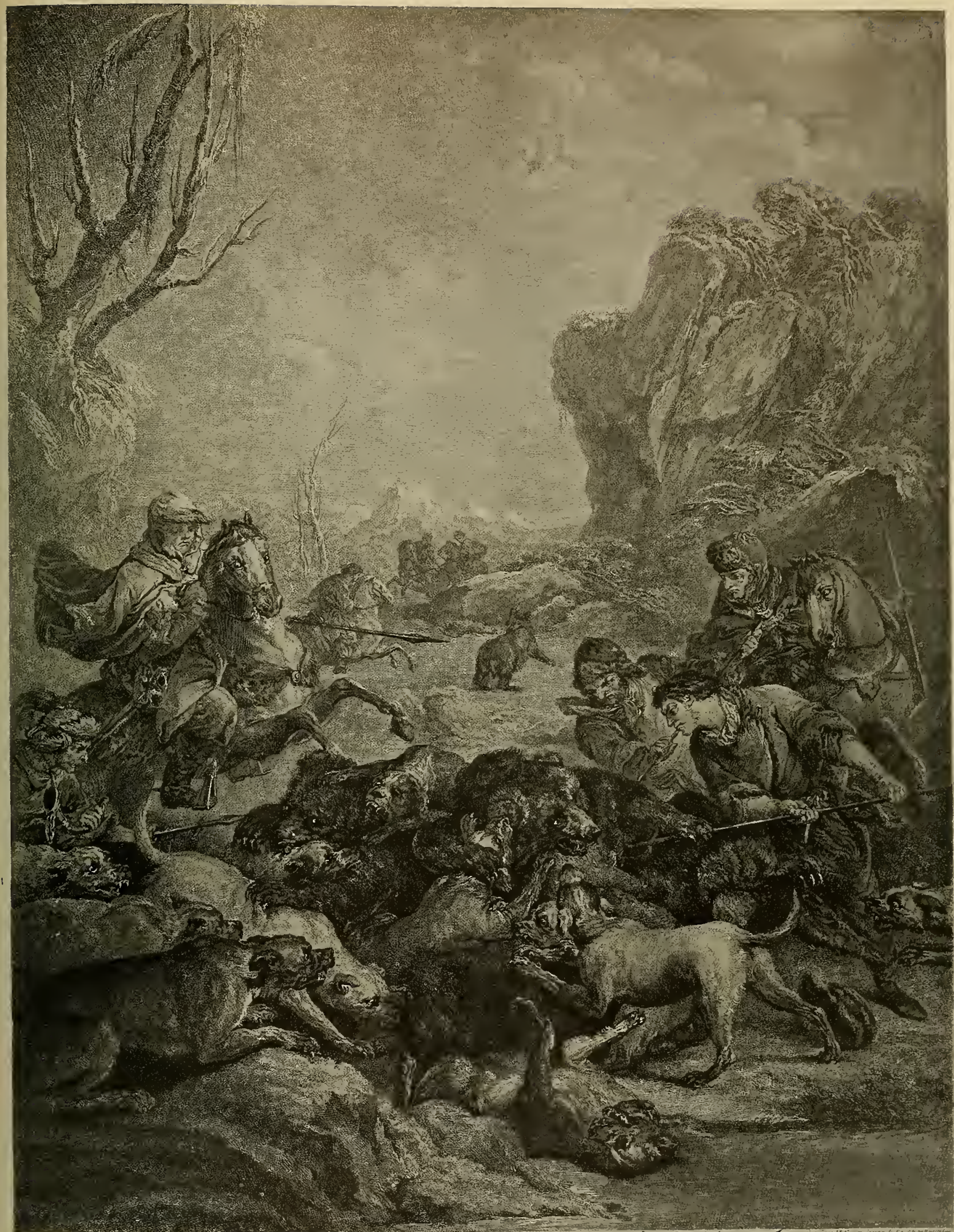

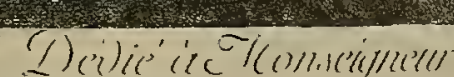

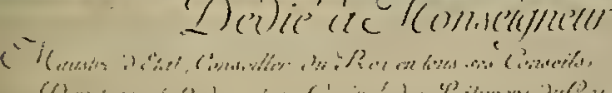

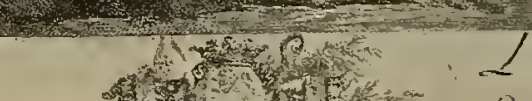

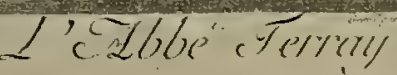

(1)

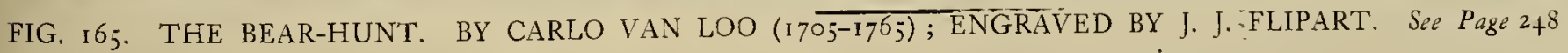





\section{EX⿱X LISH HUXTIXG PORTRAITS}

indebted for the two interesting portraits, Figs. 166 and 167 , of what according to Smith (III, pp. I 4 I 4-5) are in ail probability Mr. and Mrs. Davenport, of Davenport, Co. Salop, a couple of some fame in the hunting-field. The man's portrait

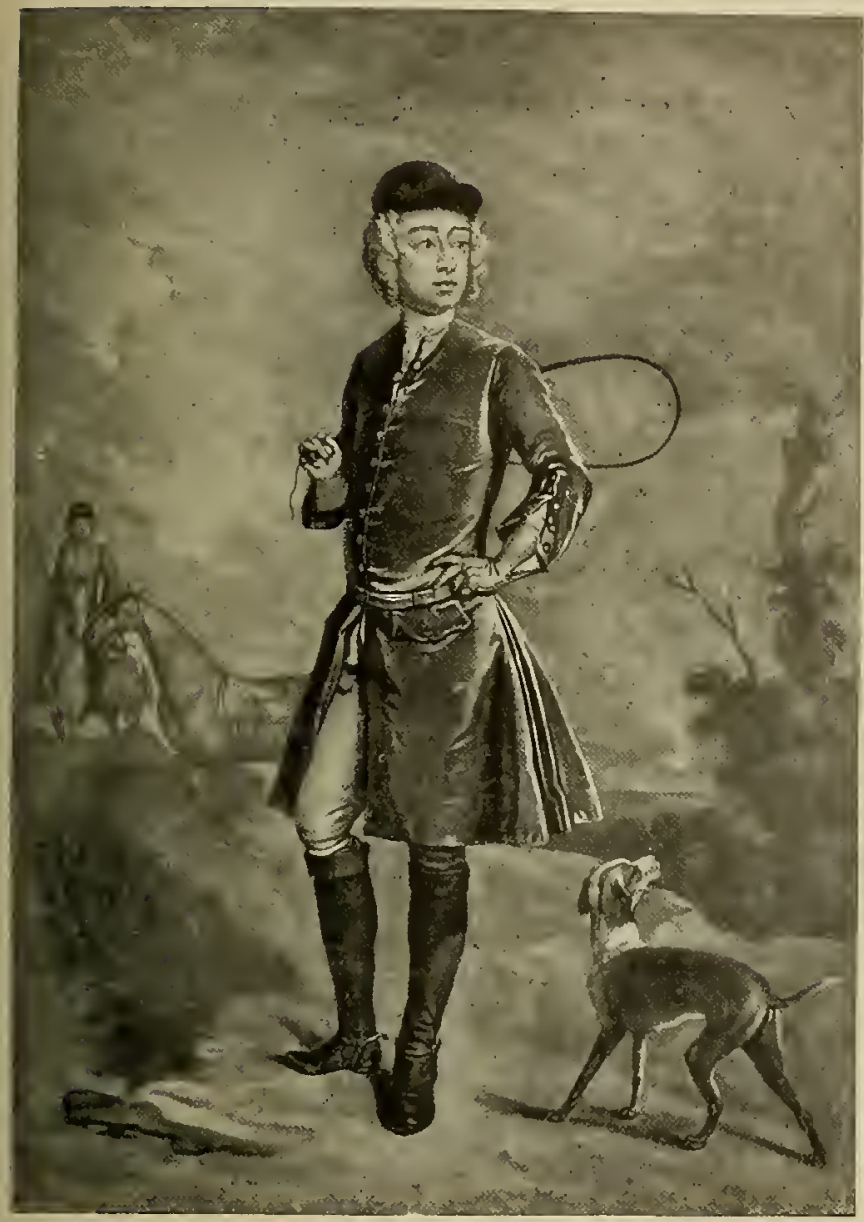

FIG. 166. MR. SHARINGTON DAVENPORT, OF DEVONPORT, SALOP. P PORTRAIT BY JOSEPH VAN HAECKEN. ENGRAVED BY ALEX. VAN HAECKEN, ABOUT 1740. STATE I. See Page 25 I

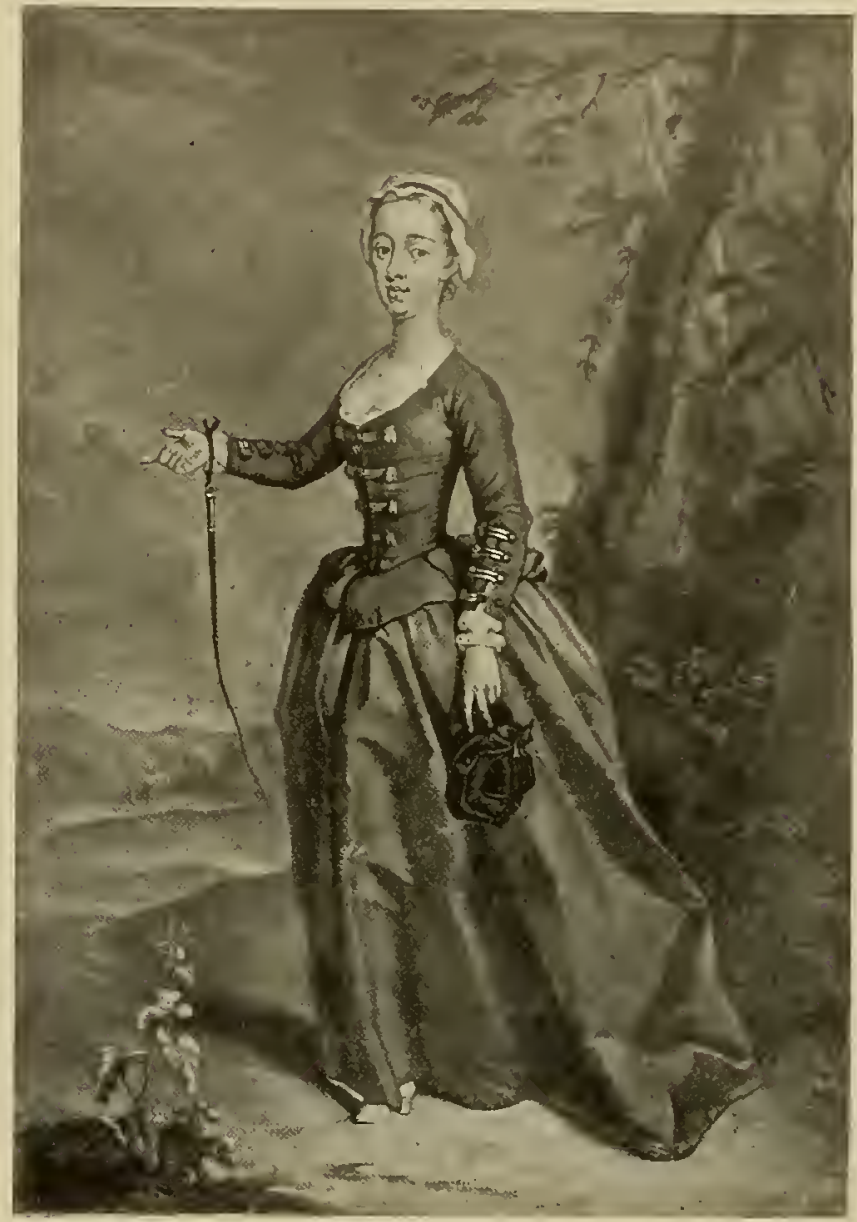

FIG. 167. MRS. DAVENPORT (GRATIANA RODD). PORTRAIT BY JOSEPH VAN HAECKEN. ENGRAVED BY ALEX. I'AN HAECKEN, ABOUT 1740. STA'TE I. See Page 251

is in the rare first state, and the print bears the same address as the lady's : "Sold by A. Vanhaecken, the corner of Queen Street, Holborn," which-it does not in the second state. Very little is known of the two artists, but Alexander probably worked in England berween 1735 and 1740 , and he appears to have lived with his brother Joseph. 


$$
\text { SPORT IX ART }
$$

The poetic effusion beneath $\mathrm{Mr}$. Davenport's portrait will bear repetition :

In a fair Chace a shady Mountain stood

Well stor'd with Game and mark'd with Trails of Blood,

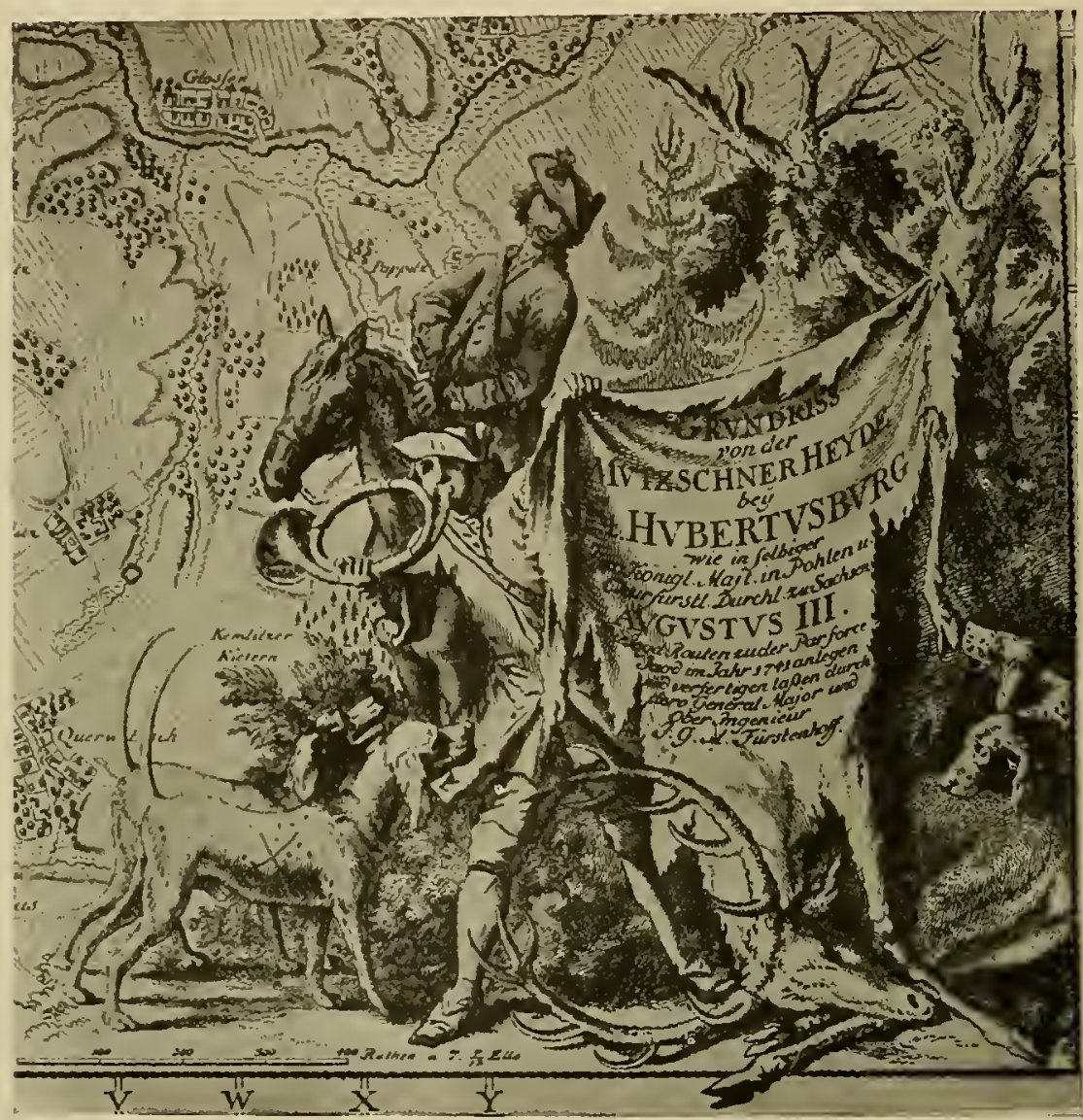

FIG. I68. AN ENGRAVING $(17+1)$ SHOWING HOW HOUNDS WERE BRANDED IN SAXONY, THE "CROSSED SWORDS" MARK BEING THE SAME AS USED FOR THE MEISSNER PORCELAIN. See Page 253

Here did the Huntsmen, till the heat of day Pursue the Stag, \& load themselves with Prey;

The Sun was high advanc'd \& downward shed

His Burning Beams directly on their Heads,

Then hy Consent abstain from further spoils,

Call of the dogs and gather up the Toils

And ere to-morrow's Sun begins his Race

Take the cool Morning to renew the Chace.

The inscription underneath the lady's picture is merely in praise; of her personal charms which are declared to be equal to those of Venus and the Graces. 252 


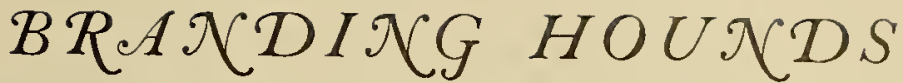

From about this period dates a large map of the vast Hubertusburg estate in Saxony where Augustus III of Poland and Elector of Saxony used to hunt the stag par force. In one corner of this map is the picture reproduced in Fig. 168 ,

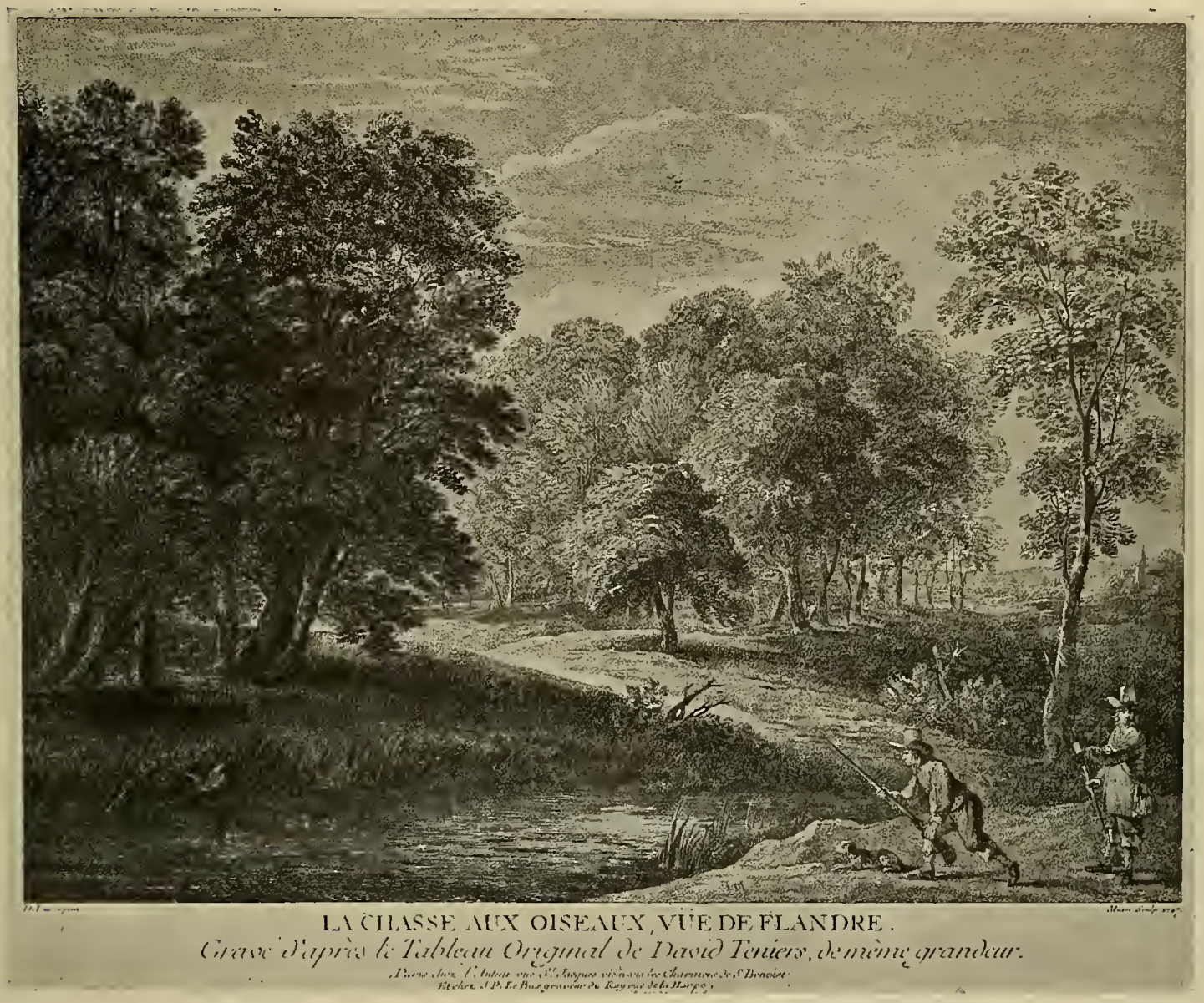

FIG. I69. WILD-FOWLING. AFTER D. TENIERS. ENGRAVED BY THOMAS MAJOR, 1747. See Page 255

drawn about the year 1741 . It is probably the oldest picture proving the existence of the strange custom of branding hounds, and as it subsequently spread to England is worth noticing.

The hound here depicted shows on his ribs the mark of the crossed swords, which was also used for the Meissner porcelain, as it is perhaps needless to point out. On the death of this monarch in the year 1763 , the custom seems to have died out, for we have not come across any later use abroad of such marks for hounds. In England it seems to have prevailed until well into the last century, and the 


\section{SPORT IX ART}

following three prints of English hounds show this. The first, so far as rareness is concerned, is one depicting the Raby Pack after a painting by $\mathrm{H}$. B. Chalon, engraved (mezzotint) by IVilliam IVard (1765-1826). Among the dozen or so

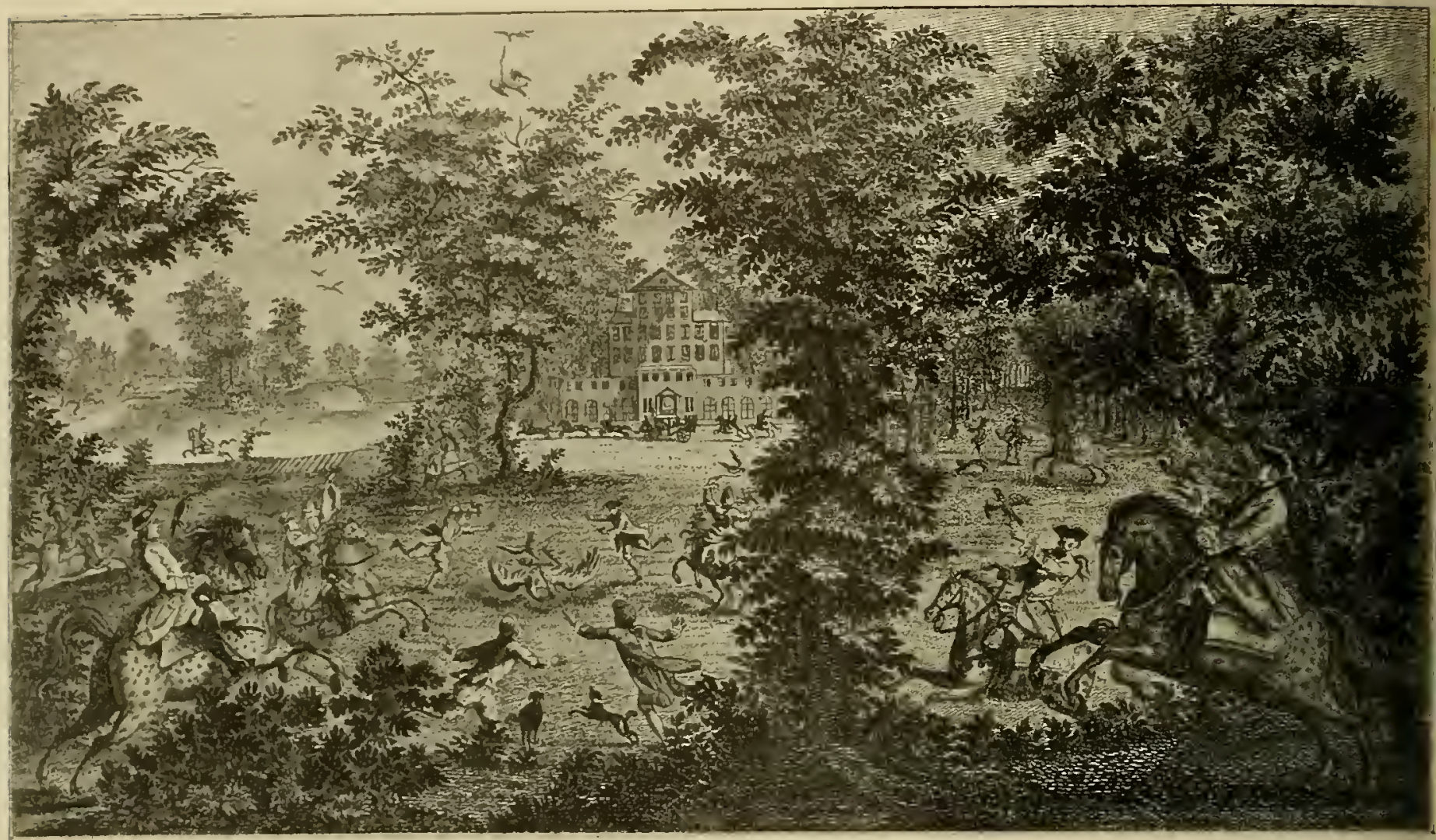

FIG. I7\%. HERON-HAWKING IN GERMANY. DESIGNED AND ENGRAVED BY MARTIN B. WACHSMUTH, MIDDLE OF EIGHTEENTH CENTURY. See Page $2 ; 6$

of hourds, the names of ten of which are given in the margin, there are two bearing a large brand roughly resembling a small "d." The print is dated April 20,1814 , and it exists also in a coloured state, being one of the rarest of its kind. The second instance is a similar print, also after Chalon, representing a pack some of which bear the brand "S." It is dedicated to Sir Mark Masterman Sykes, Bart., and was published in York by J. Wolstenholme. The third shows hounds branded "B." It is entitled Philip Payne, huntsman to the Duke of Beaufort, and is dedicated by Th. R. Davis, "Student of the Royal Academy, London," after a picture by his own hand. It is engraved by Charles Turner $\left(1773^{-1857)}\right.$. It would be interesting to discover whether any earlier instances are 254 


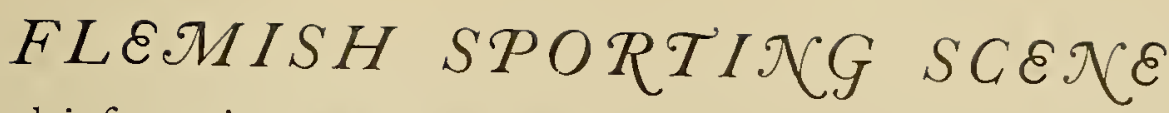

known, and information regarding this point would be much appreciated by the writer.

Neither of the Teniers contributed anything important relating to sport, but we

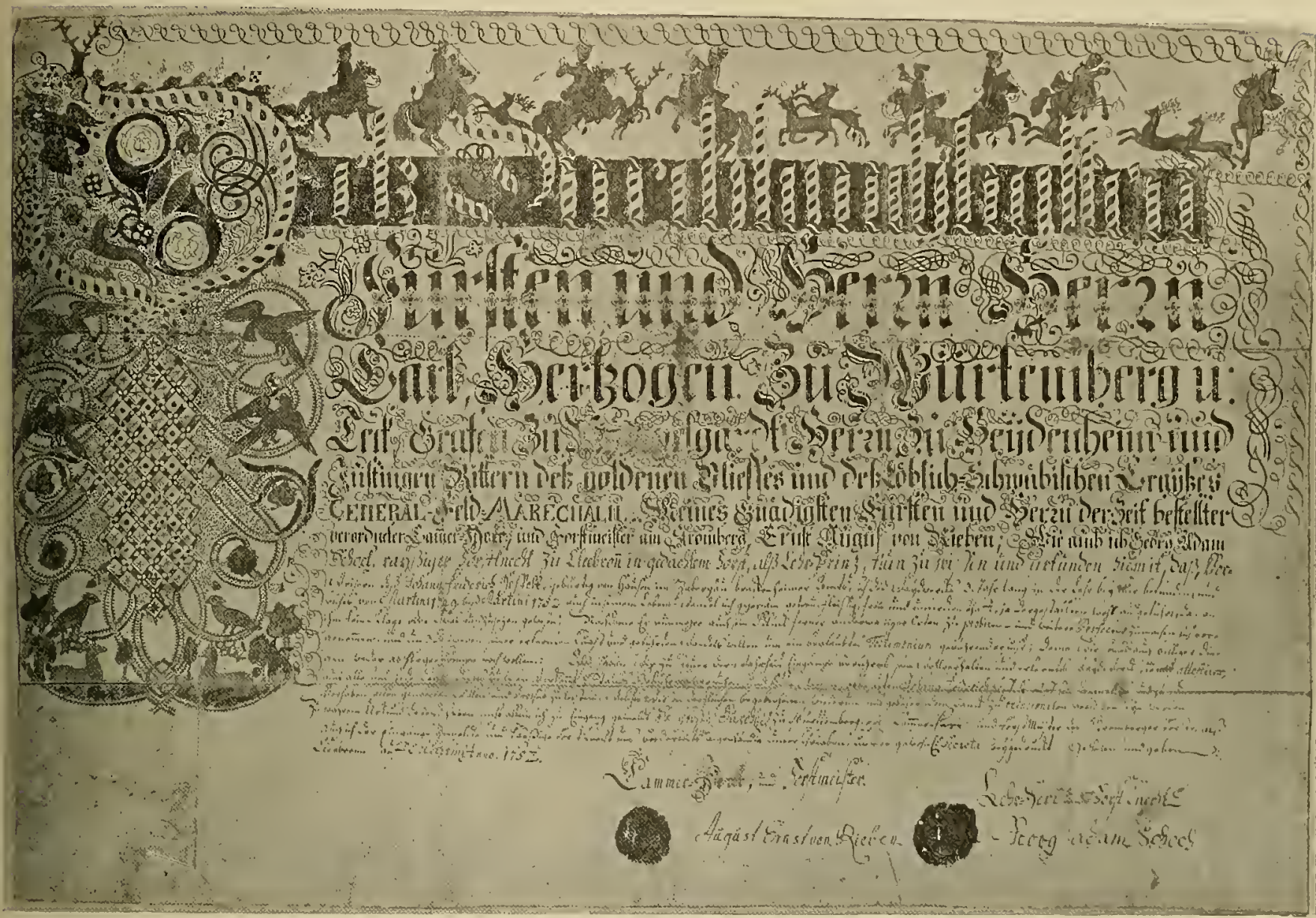

FIG. 17I. INDENTURE GIVING AN HUNTING APPRENTICE THE FREEDOM OF HIS CRAFT, ISSUED 1752 BY THE DUKE OF WÜRTTENBERG'S MASTER OF THE FOREST. PARCHMENT $52 \times 35$ CM. See Page 256

are tempted to reproduce in Fig. I69 a Flemish sporting scene by David the Younger, because it was engraved by one of our best renderers of landscape, Thomas Major (? I7 I 5-I799), who probably saw the original during one of his repeated visits to Paris. Here we have again one of those instances when, owing to a long interval between the origin of a picture and its reproduction on copper, one might easily be misled in regard to details. Major dates his engraving I747, 


\section{SPORT IX ART}

but the costumes of the two sportsmen as well as the shape of the fowling-pieces belong to the previous century, the younger of the Teniers having been born in 1610 .

Speaking of eminent renderers of landscapes, the works of William Woollett, who was the first to work that effective combination of etching (dry point) and engraving, must not be forgotten, for he has left us a few sporting plates of most effective workmanship, the Spanish Pointer after Stubbs (published 1768) being probably the best known to sportsmen. His plates found a ready sale in Paris, and some of his engravings after Jean Pillement, the court painter of Poland's last king, were furnished with French titles and published in Paris. Of these La Chasse au Sanglier is one of the most effective woodland scenes imaginable, although the sporting details are in some respects a trifle faulty. In the foreground a boar, of decidedly diminutive size, is being attacked by three men on foot with spears of somewhat incorrect shape, four hounds, and a lady and gentleman on horseback. The former is firing a small pocket pistol, the latter a gun or rifle at close quarters at the victim. It is to be hoped that the boar did not turn and give its pursuers a taste of its tusks.

Of the artist Martin B. Wachsmuth, evidently an Augsburg engraver, who produced Fig. I 70 , which is one of a set of three, very little is known. To judge by the frequency of prancing horses in his prints, he deserves to be called the Master of the Bounding Steed!

Our last picture, Fig. 171, reproduces one of those curious parchment Discharges, as were called the indentures by which an apprentice obtained at the conclusion of three lehrjahre the freedom of his craft, which in this case was venery. There existed two quite distinct classes of hunting apprentices, one being the sons of nobles, the others those of plebeian birth. The duties of the former, who ranked as court officials, were, needless to say, much lighter than those of the latter, and they brought them more into contact with the person of the lord or duke. Youths of non-aristocratic birth, such as was the Johann Friderich Gestell in whose favour our indenture was made out, were the real workers. Our document signifies that the said Gestell had been apprenticed for three years, from Martinmas 1749 to Martinmas I752, with George Adam Schock, keeper for the Forest of Stromberg in the realm of the Duke of Württenberg and Teck, and had proved himself to be obedient, trustworthy, pious, and capable, and was now leaving the ducal service to try his luck elsewhere so as to perfect himself in his art. 


\section{CHÁPTER XI: FOHANN ELIASS RIDINGER'S ENGRAVINGS ( I 698-I 767)}

AT Landseer accomplished for the sportsmen of the nineteenth century, what Van Orley, Stradanus and Hans Bol did for the sixteenth, and Tempesta, Barlow and Snyders for the seventeenth, that Ridinger performed for the sportsmen of the eighteenth century.

Indeed, in prolificness, so far as sport is concerned, he outstripped them all, for it is no exaggeration to say that Ridinger left us more sporting pictures, either designed or engraved by him, than did all the above-named artists collectively.

He produced in about forty-five years some 1500 engravings or designs for engravings, of which quite 1000 deal with sport, principally deer and other animals of the chase, dogs and horses, or of scenes connected with hunting: a record not easily beaten.

Until the appearance of Thienemann's biography, and indeed in some instances much later, one finds Ridinger's name spelt in different ways and the year of his birth incorrectly given. Thus Nagler, Waagen and others, who copied from them, state that he was born in 1695 instead of 1698 , and they spell his name Riedinger, while others, amongst them Goethe and Probst, write Rüdinger and one French publisher spells it Rhidinger. It is perhaps hardly necessary to say that it should be pronounced as if it were spelt Readinger.

He was born in the year 1698 , scarcely three months after his famous contemporary William Hogarth, and one is struck by the similarity which exists between the early lives of these two representative artists of England and Germany. Both were born in poverty-stricken surroundings, for the dark little alley in the mediæval fortress of Ulm, in which the former came into the world, was, we may well suppose, as sun-starved and as lost to artistic influences as was the squalid London street in which the latter, as the son of a lowly artisan and erst unsuccessful schoolmaster, first saw the gloom of a November day.

The great harts roaming through ducal forests, the gay scenes of princely sport in sylvan glades, the curvetting steeds mounted by great lords or fair dames, subjects which a quarter of a century later Ridinger's hand had learnt to depict with rare skill and faithfulness, must have seemed as infinitely remote from the German youth's dingy home surroundings as were the scenes of aristocratic follies and fashionable vice from those of young Hogarth. The low regard in which art was then still held obliged the rising genius to depend for his daily bread upon artisan work, such as designing signs for tradesmen and inns, the painting of hatchments, coats of arms and even of domestic furniture, or the adornment of Gretchen's bridal chest with fantastic tracing from which entwined hearts were never absent.

Ridinger, like Hogarth, was apprenticed at an early age-he was not yet fourteen 


\section{SPORT IX ART}

- to a worthy master painter of his native city. An amusing account of Ridinger's life in the house of the worthy Meister Resch is given in the biography published by Ridinger's sons. Mistress Resch, for she ruled the roost, was a good housewife of the ancient type to whom books were objects of abhorrence. When her spouse on one occasion was tempted to invest his hardwon guilders in the much-belauded architectural work by Sandrart, the great folio volumes had to be smuggled into the house without her knowledge. This was achieved by the young apprentice, and he was rewarded by his grateful master by receiving the permission to study the coveted pages every morning from 5 A.M. till 7 A.M. when work in the shop begun, and he had to return to his daily drudgery or rubbing colours, washing brushes, pointing pencils and charcoal, and other apprentice's duties of a similar menial nature. It does not surprise us to hear that the perusal of Sandrart's enthusiastic descriptions of the beautiful pictures and buildings in Italy inflamed the ardent youth's mind, and that he resolved to fly from dull Ulm to seek the scenes of which he daily dreamt. His escapade ivas not destined, however, to succeed, for hard cash was scarce, and though sorely tempted to break open his savings-box, he withstood the temptation, and made his escape with hardly enough money in his purse to pay for his first night's quarters. The result was easy to foretell, and a hungry and very dejected youth could have been seen slinking back to his native city, just managing to reach the fortress gates before they were closed for the night.

The parting between master and pupil when, some time afterwards, the five years' apprenticeship had expired, and the young painter, who could now sport a sword at his side, was about to leave his native town, was marked by an unpleasant scene. For the ambitious young artist had the moral courage to express his conviction that his master might have taught him more and made use of him less as a mere menial drudge. The former retorted angrily that he was now welcome to go where he could learn more. And this young Ridinger did, turning towards Augsburg, where the arts and crafts had ever been fostered by its rich and artloving inhabitants. There, amongst others, he had for master the famous battle painter Rugendas, whose style left its impression on some of Ridinger's earlier work. A three years' stay at Ratisbon, working for the splendour-loving Count Metternich, gave him the first opportunity to study deer, hounds, and horses, a choice of subject to which, fortunately for us, he stuck when he returned to Augsburg to settle down as master-craftsman and son-in-law of the portrait painter Seiter.

We must quarrel with the time and not with the man for making quantity and not quality of his work his chief aim, for the emoluments that rewarded genius were of a very humble nature, and Hollar's wage of twopence an hour was probably more than Ridinger earned at the beginning of his career. To be quite just we must not fail to recognise that the peculiar taste of the period in relation to sport opened a 2,8 


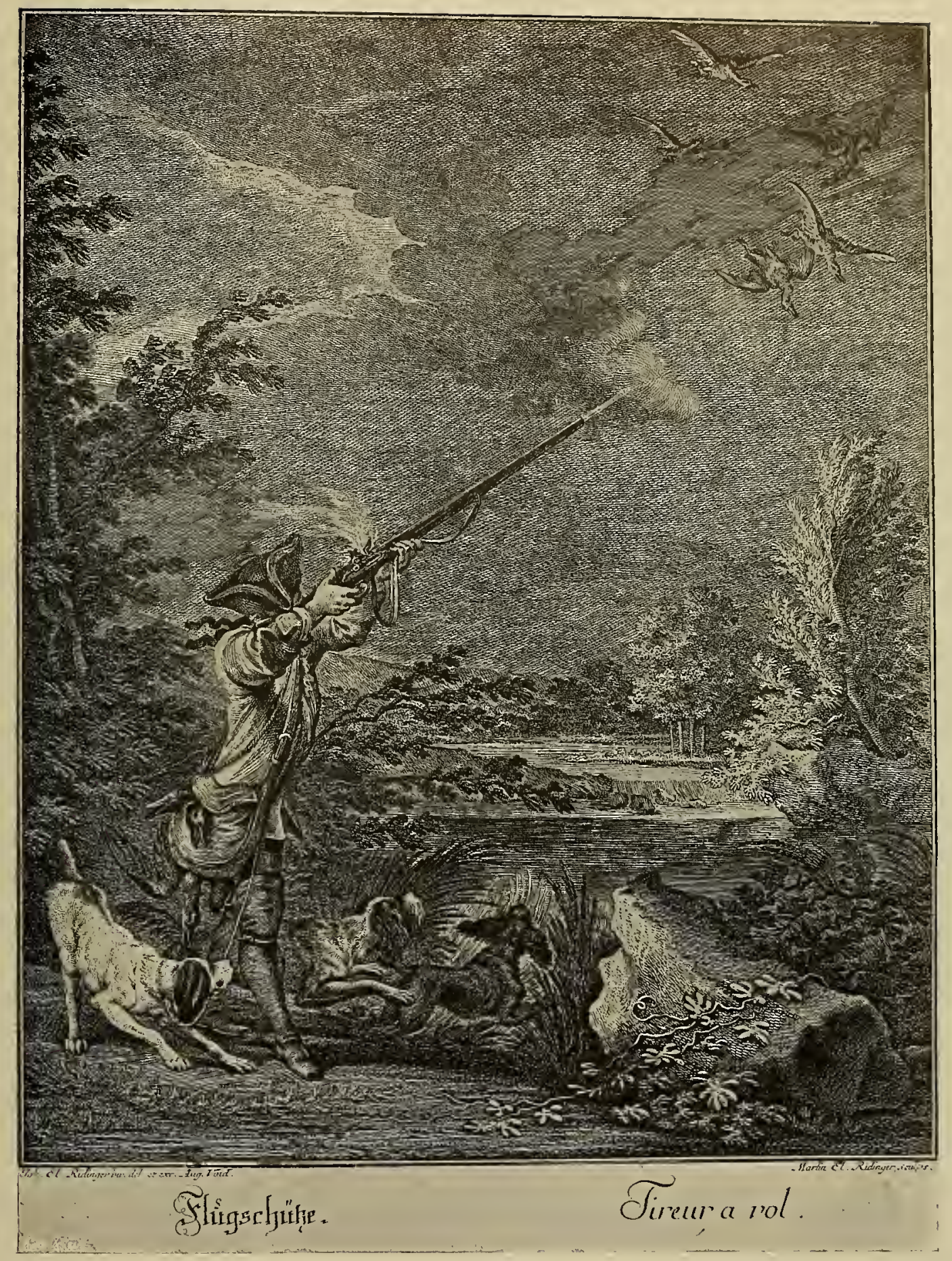

FIG. 172. SHOOTING WILD DUCK. BY RIDINGER (TH. I61). See Figs. 118, 139, and Pages 189-193, App. 



\section{RIDIX్RE'S PRODUCTIUEX}

wide field for Ridinger's talent, for which it seemed expressly fitted. Had there been no demand for his pictures, showing the various manners in which the great lords of Germany hunted the stag and the boar, depicting the hounds they used, the horses they rode, and the falcons they flew, Ridinger would probably have left us scores of insipid still-life scenes, wearisome allegorical or tiresome religious plates, or "portraits" of worthies he had never seen.

The statement that Ridinger produced some I 500 works needs some slight qualification, for quite a number of engravings known as Ridinger's were not drawn or engraved by his hand. His two sons, notably Martin, engraved many of his drawings, with results hardly as satisfactory as might be expected. Other artists, too, of which we shall have more to say anon, engraved "after" Ridinger.

Many of the original copperplates of Ridinger are still in existence, and inferior impressions are made to this day, but the principal demand is confined to old impressions, which find a ready sale all over Germany, in France, and

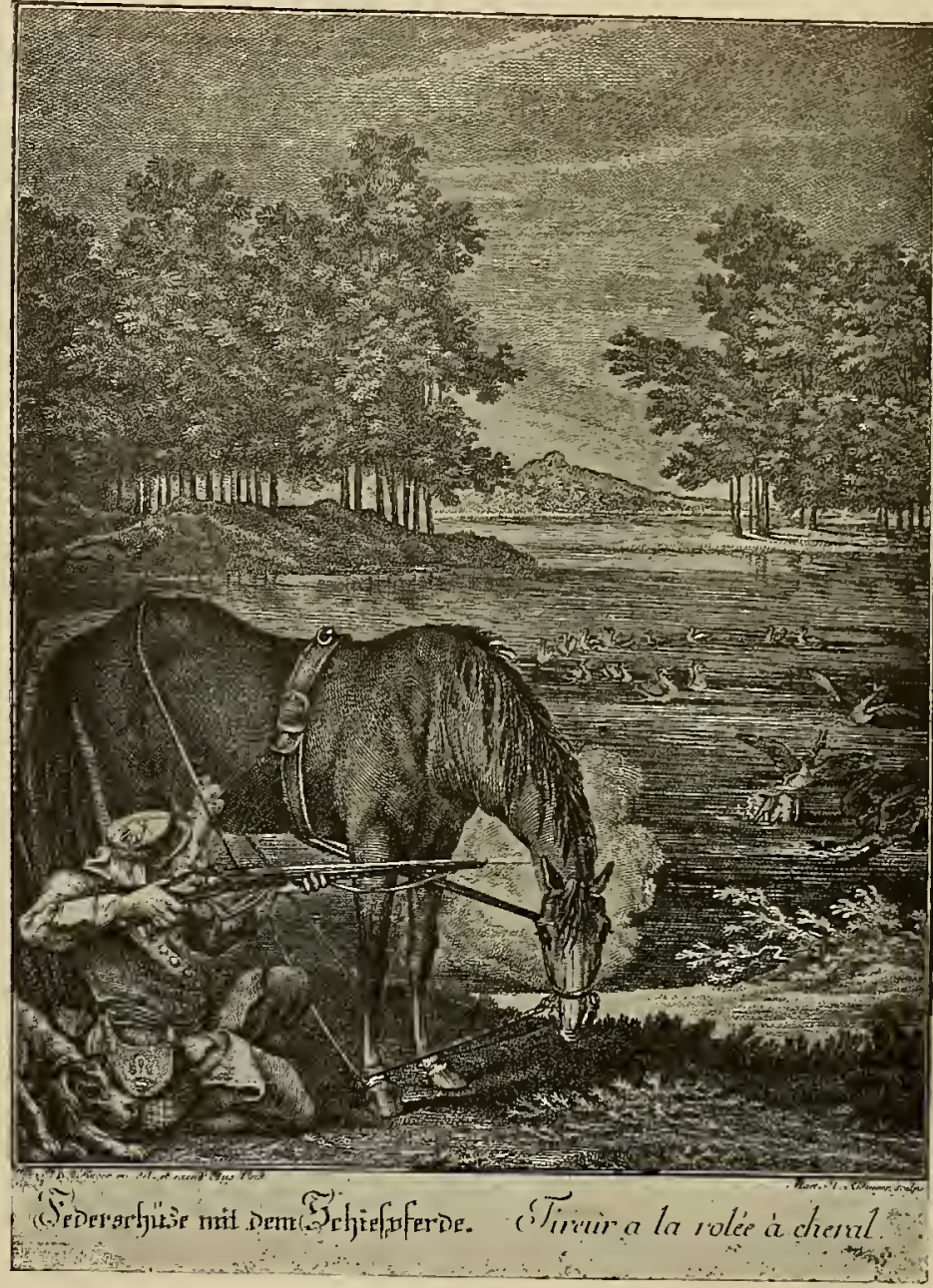

FIG. 173. USE OF THE STALKING-HORSE FOR WILD FOWL. BY RIDINGER (TH. I33). See Page 267 in Austria. Few chateaux or country mansions in Germany are without a row of his spirited hunting scenes to adorn corridors, gun-rooms, or halls. To the historian, sportsman, and naturalist Ridinger's prints afford an endless field for study. The accuracy with which the methodical artist worked, and the habit he had of giving all interesting or unusual details in the legends underneath the pictures, which occasionally extend to several hundred words in length, supply us with interesting 


\section{SPORT IX ART}

material. His deer and other forest animals are generally very life-like, particularly when in motion. In no detail can Ridinger's accuracy be better observed than in his antlers of deer. Their complex form few artists succeed in drawing correctly,

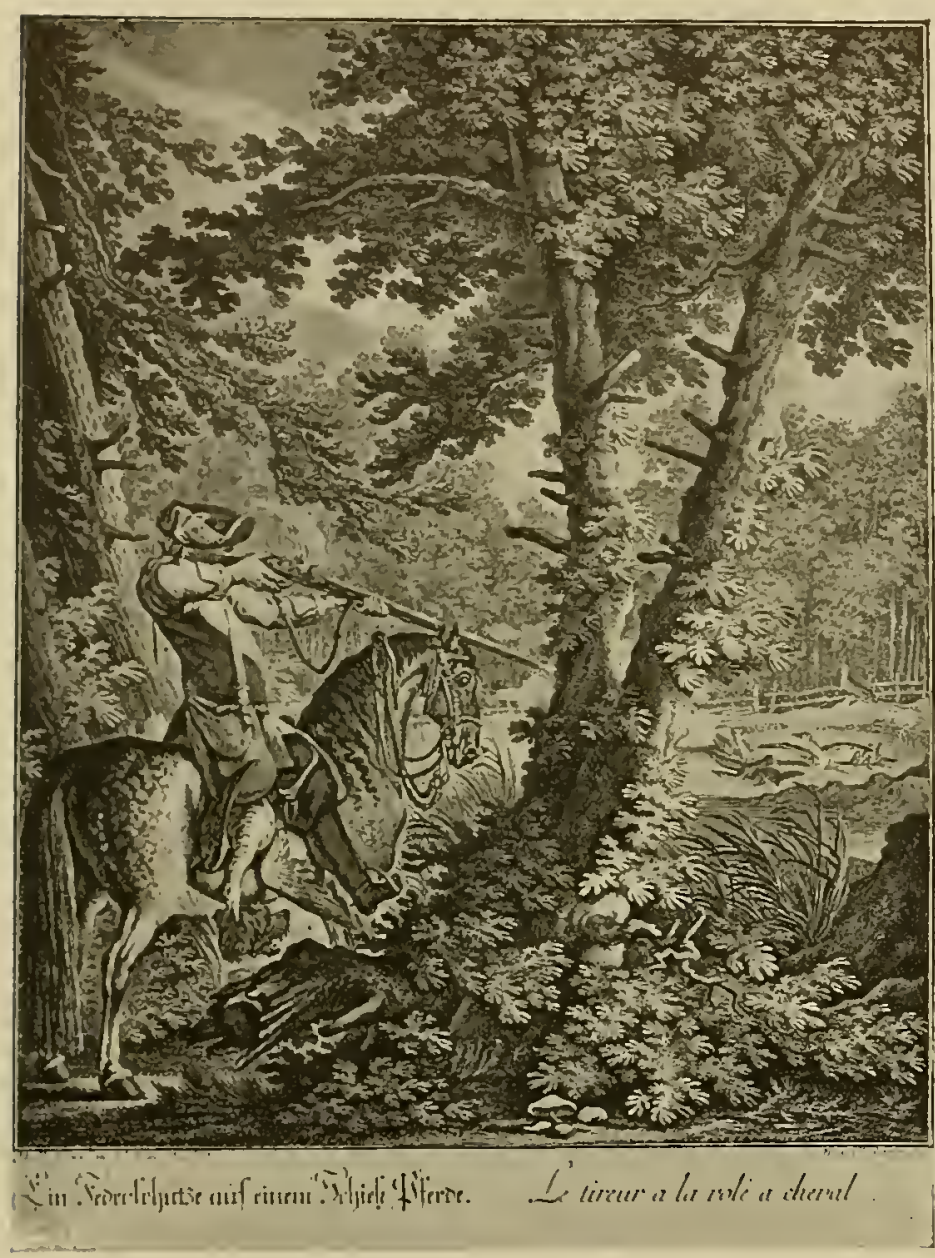

FIG. $17+$. SHOOTING WILD FOWL FROM HORSEBACK. BY RIDINGER. (TH. I 28 ). Sec Page 267

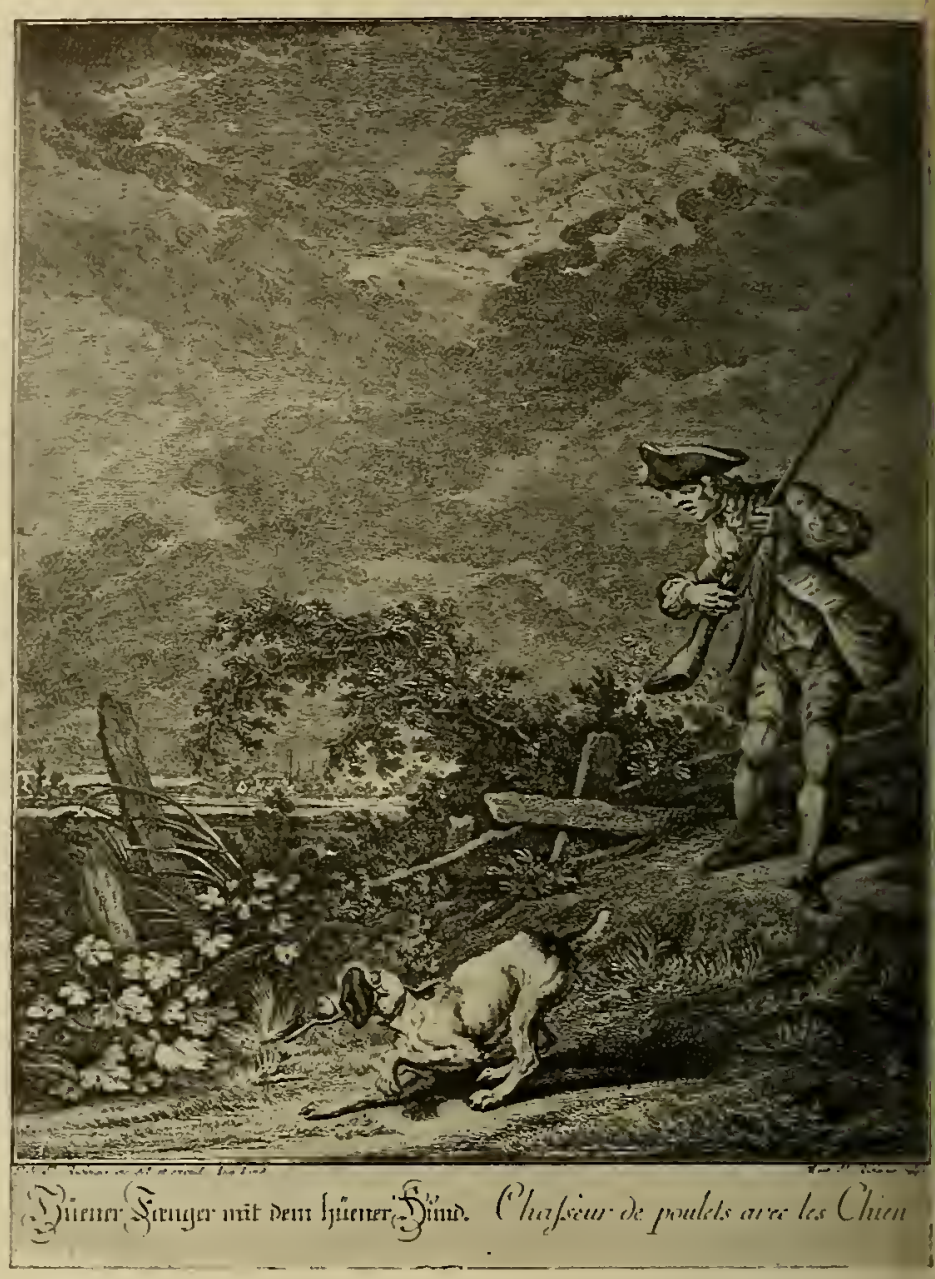

FIG. 175. USE OF THE POINTER FOR PHEASANT SHOOTING; THE DOG IS BEING TRAINED WITH THE MUZZLE-PEG. BY RIDINGER (TH. 122). See Page 26-

a bit of criticism from which we cannot even exempt Landseer, whose Highland deer are almost invariably the bearers of trophies of an exaggerated size, such as never graced the muckle harts of that region, where long inbreeding, poor food, and scant shelter have reduced both the body and the antlers of the native red deer.

* Landseer was a great admirer of Ridinger, whose work, he said, "left little or no room for others to improve."

262 


\section{RIDIXGER'S SPORTIXG PRIXTS}

Considering Ridinger's hapless youth in the dingy Ulm workshop, and remembering that he had never passed through the practical schooling of woodcraft, a curriculum which every forester and fäger was compelled to absolve, his powers of

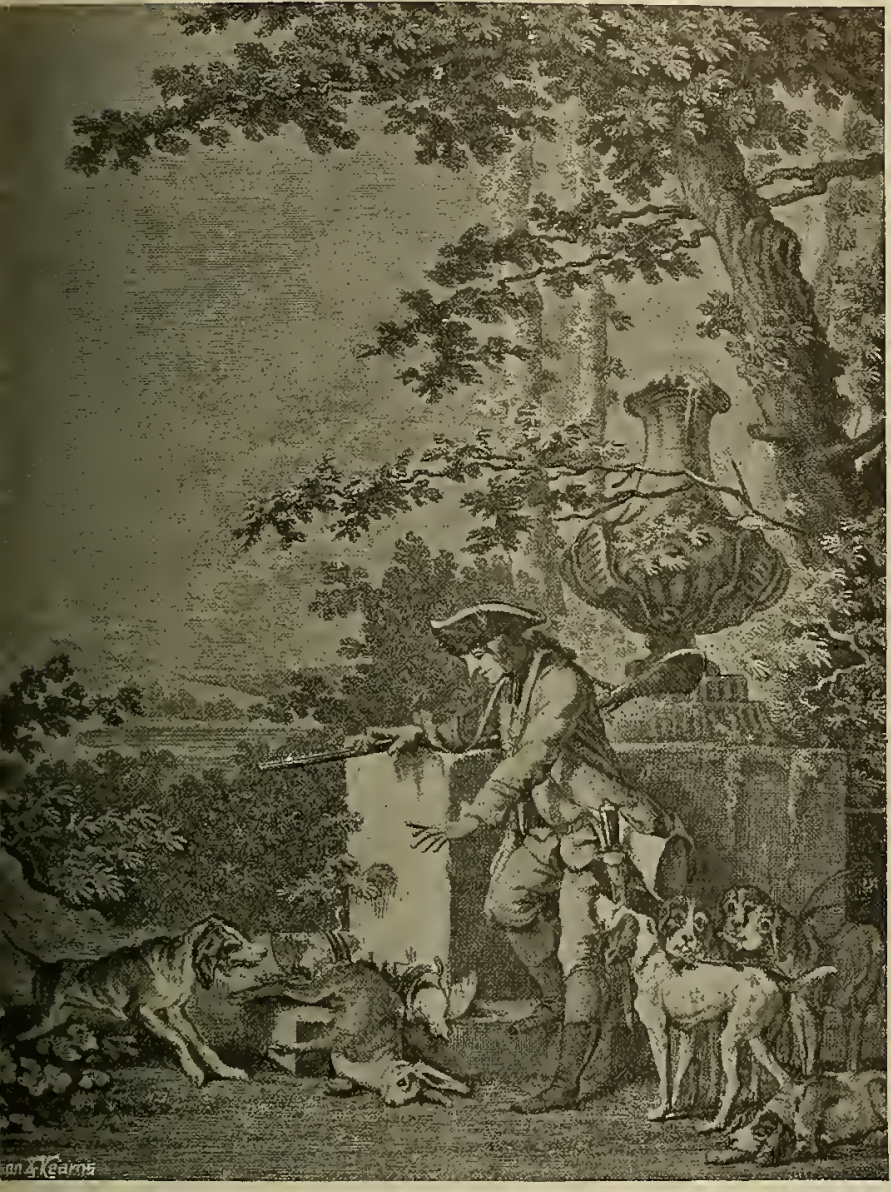

3. 176. THE TRAVELLING PROFESSIONAL GUNNER IISE JÄGER). BY RIDINGER (TH. I 25). See Page 267

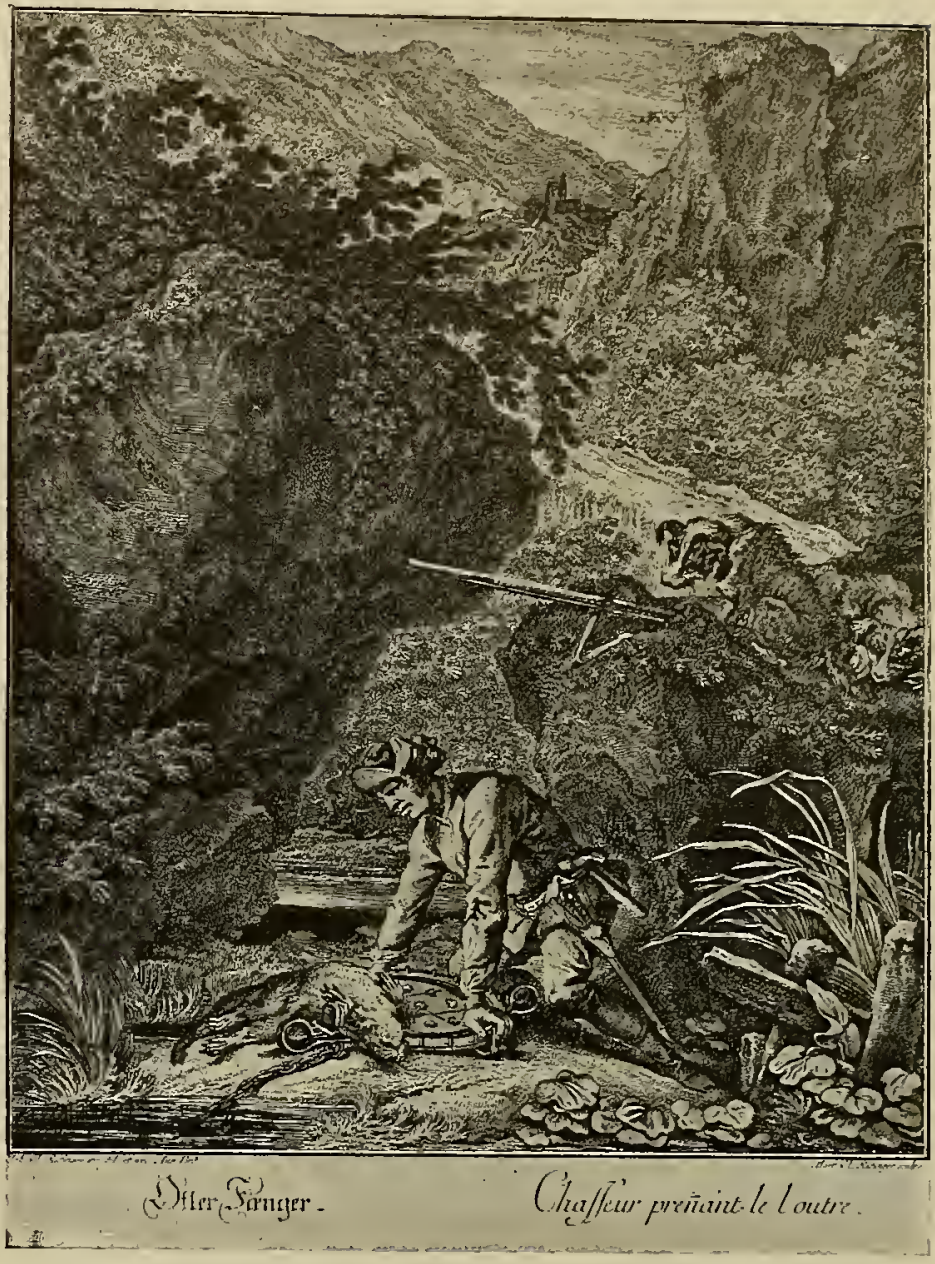

FIG. I77. THE OTTER TRAPPER. RIDINGER (TH. I 27). P. 268

observation were considerable, such as rarely distinguish persons born and reared in towns. *

Considering the important part played by Ridinger in the field covered by the present volume, it is necessary to give particulars of his various series, which, to avoid details that would be most wearisome to the non-collector, we relegate to

* In Bryan's revised "Dictionary of Painters," the statement that Ridinger "had been brought up a huntsman" is repeated. This is an entirely incorrect assertion, as a glance at his life by his sons and by Thienemann will show. 


\section{SPORT IX ART}

the Appendix, and shall proceed here to describe engravings which we have selected as being the most typical and interesting for our purpose.

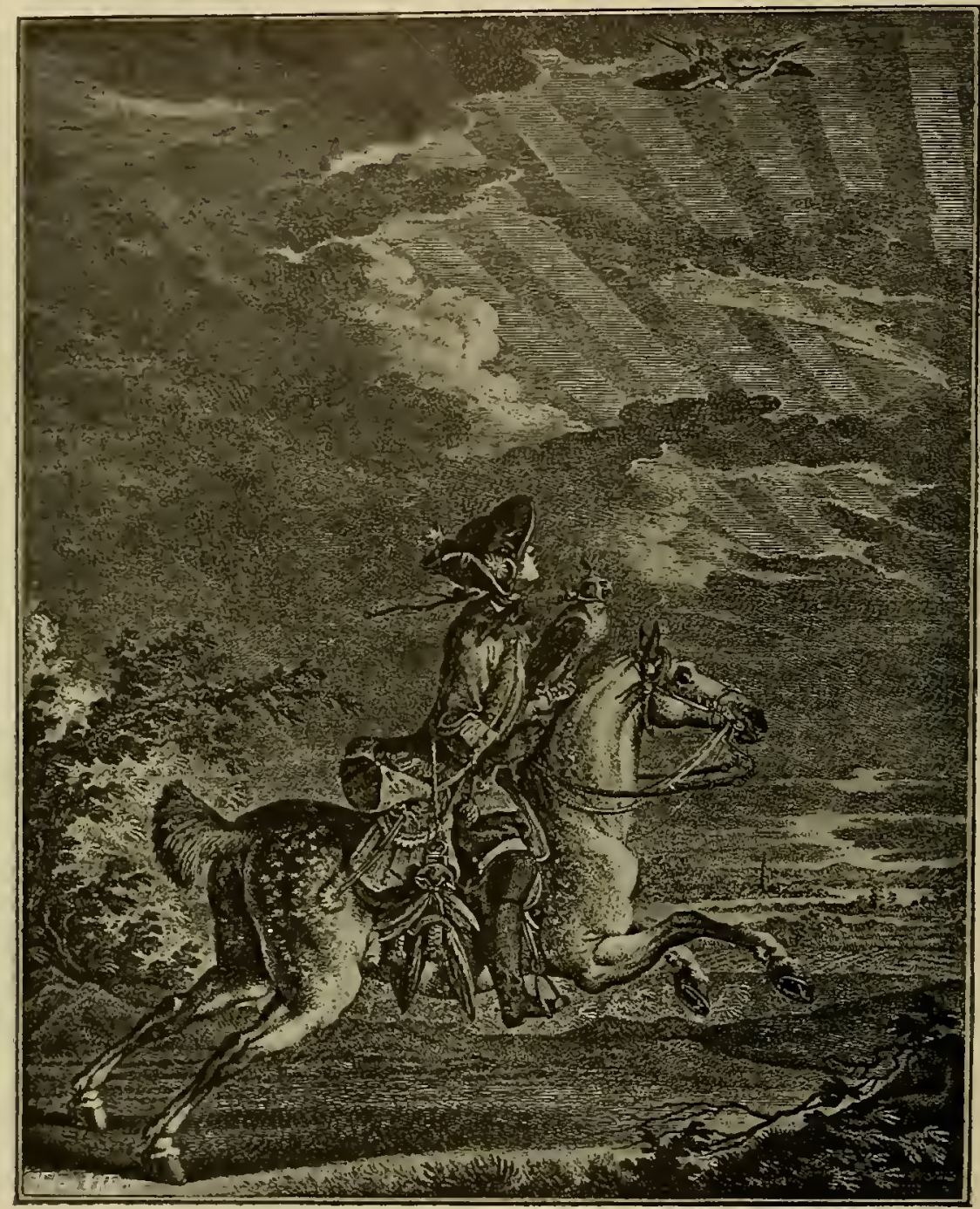

FIG. 178 . THE FALCONER, WITH HOODED HERON-HAWK, SIGHTING THE HERON. BY RIDINGER (TH. 117). See Page 268

One of the most pleasing sets is the one the German title of which we might translate by "Gunners and Hawkers." It consists of a title-print and twenty-five plates, but there exists considerable doubt respecting the former and, like Thienemann, the writer has never seen a set of these prints provided with a title. 264 


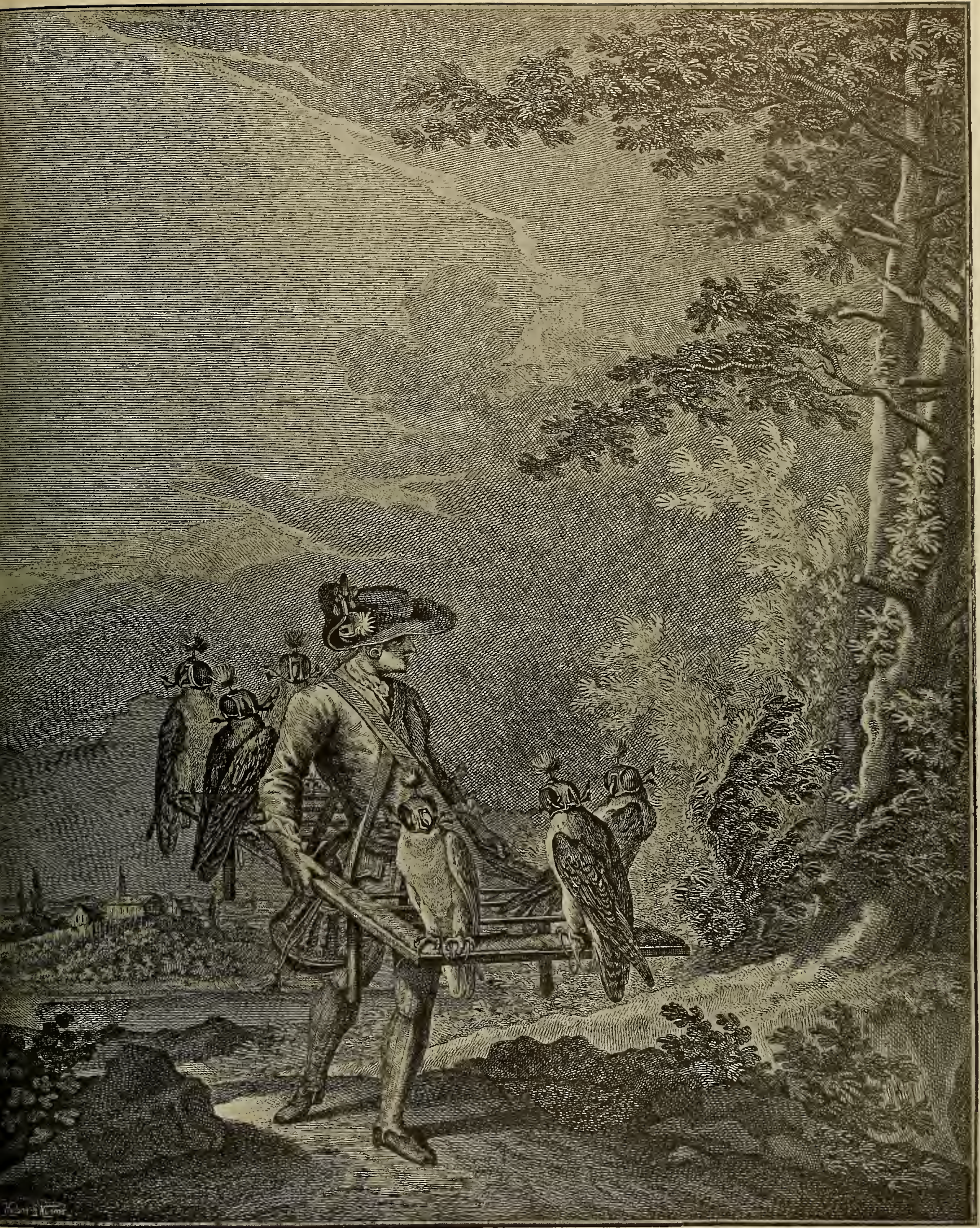

FIG. 179. THE CADGE-BEARER. BY RIDINGER (TH. II9). See Page 268 



\section{RIDIX $\mathcal{X}$ ER'S MUZZLE-PEG}

The sportsman in Fig. I 72 , who is in the act of bringing down a brace of mallards has a pointer on the line, evidently to show that he was out for some mixed shooting, and three ducks in his game-bag indicate that his blunderbuss had not been let off in vain on previous occasions. It would be interesting to know what allowance the sportsmen of old were wont to make in case of "winging fowl "; for even the flint-lock, great as was the advance upon the wheel-lock of previous generations, must have obliged them to hold yards in front of even a slowflying bird, the interval between the pull of the trigger and the charge leaving the muzzle being an infinitely greater one than with a modern central-fire gun.

Figs. 173 and 174 need but a brief explanation. The use of the stalking-horse for wild-fowling, which these plates depict, is chiefly interesting because it shows us how the "harness" of the horse was worked, so as to make the horse look as if it were feeding, and thus beguile the wild duck and geese, methods described also by Blome. The latter's description of the gun, part of which we have already quoted, appears applicable also to the German sportsman's arm: "The gun most proper for this sport should be about four Foot and a half long in the Barrel ... you should have your gun always Cock't, in readiness with your Thumb over the Cock, for fear of its going off contrary to your intentions; so that when you meet with any Game, you must be quick, and having got an aim to your mind, let fly with all Expedition." The slain goose hanging fron the saddle shows that a previous pot-shot has been successful.

Fig. I75 shows the use of the muzzle-peg in training pointers to prevent them from acquiring the bad habit of raking or snuffling about on the ground. It is, as is hardly necessary to add, not an unknown instrument to the modern dog trainer. Mr. Arkwright, in his "Pointer," reproduces a yet older picture of a dog with the muzzle-peg in one of Lonicer's engravings published in I 582 , in an illustrated sporting series, called Venatus et efucupium. But I cannot quite agree with the author when he declares that the muzzle-peg "was thrust between the poor brute's jaws." The picture in question is on such a small scale that it is impossible to say for certain how the peg was fastened on, but in the original of our illustration it is plainly visible. In shape like a spur made of wood, it encompassed the dog's mouth as if it were the heel of a boot, the two ends being fastened to a leather collar, a strap over the dog's nose and another under his jaws preventing it from slipping up or down.

Fig. 176 introduces to us an occupation no longer known to the world of sport, that of the professional or journeyman gunner (Reise Jäger). Accompanied by his sporting dogs, he travelled from place to place to pick up what game he could, or, what was as often the case, to teach others his art, or to trade in dogs, his roving life giving him ample opportunities to train them. His sporting gossip in days when newspapers were practically still unknown secured to him a ready welcome at most country mansions, and the fact that he could teach young nobles 


\section{SPORT IX ART}

how to shoot on the wing, and knew a thing or two about pointers and setters, created many favourable opportunities to turu an honest penny.

Fig. 177 has really little to do with the gun, for it is evident that the man engaged in taking a dead otter out of a Tellereisen, or trap, by pressing down the formidable jaws, had not used the long-barrelled blunderbuss lying on the bank above him. It is closely guarded by two dogs, which possibly are meant to be otter-hounds. The pool in the background and the whole mise en sceme show the master's keen eye to the natural surroundings peculiar to the various animals he depicts. The fact that the sportsman has a hammer stuck in his girdle next to his Hirschfïnger or Coutean de Chasse, is probably meant to indicate that the man is making a round of his traps, and is prepared to take up or drive in the stakes to which the traps are chained.

About half of the series "Gunners and Hawkers" relates to falconry, a sport which was then still quite popular and about which Ridinger seems to have informed himself very accurately. Mr. J. E. Harting, in his model bibliography of ancient and modern works on falconry - a work the extreme accuracy of which might well be followed by other English critical writers-calls it a rare set, of which he knows only two others in England; but this is no longer the case, for I know of a number of others, and there are many much scarcer Ridingers than these.

Fig. $17^{8}$ shows us a mounted falconer engaged in heron-hawking, carrying a hooded falcon on his fist and following a heron which, to judge by the whole action, another havk is presumably pursuing. The lure is hanging from the sportsman's right arm ready for use after the stoop, should the hawk fail to take the quarry.

Fig. 179 shows us how the hooded falcons were carried on a cadge, which is the technical English term for the German Chatche or Katche and the French cage or brancard, still in use. Thus the birds were taken from their mews to the scene of operations.

Fig. 180 represents a mounted falconer carrying an eagle-owl on his fist. This bird, as Mr. Harting explains, was used as a live lure to attract a soaring kite when it was intended to have a flight at the latter with jerfalcons. The kite would be espied soaring at too great a height to be flown at with any chance of success. At sight of the hawk it would at once commence soaring still higher, and by keeping above its pursuer would contrive to avoid the fatal stoop. Before any sport could be shown, therefore, it was necessary, by some artifice, to bring down the kite to a reasonable height from the ground. To effect this they resorted to the following curious device. A tame eagle-owl, called by the French falconers le grand duc, and by the Germans uhu or buhu (from its note), was liberated, with a fox's brush tied to its jesses. It flapped along slowly in the glare of day with this appendage dangling below it, and the observant kite deceived into the belief that it was carrying prey, after the manner of its kind, at once descended to 268 


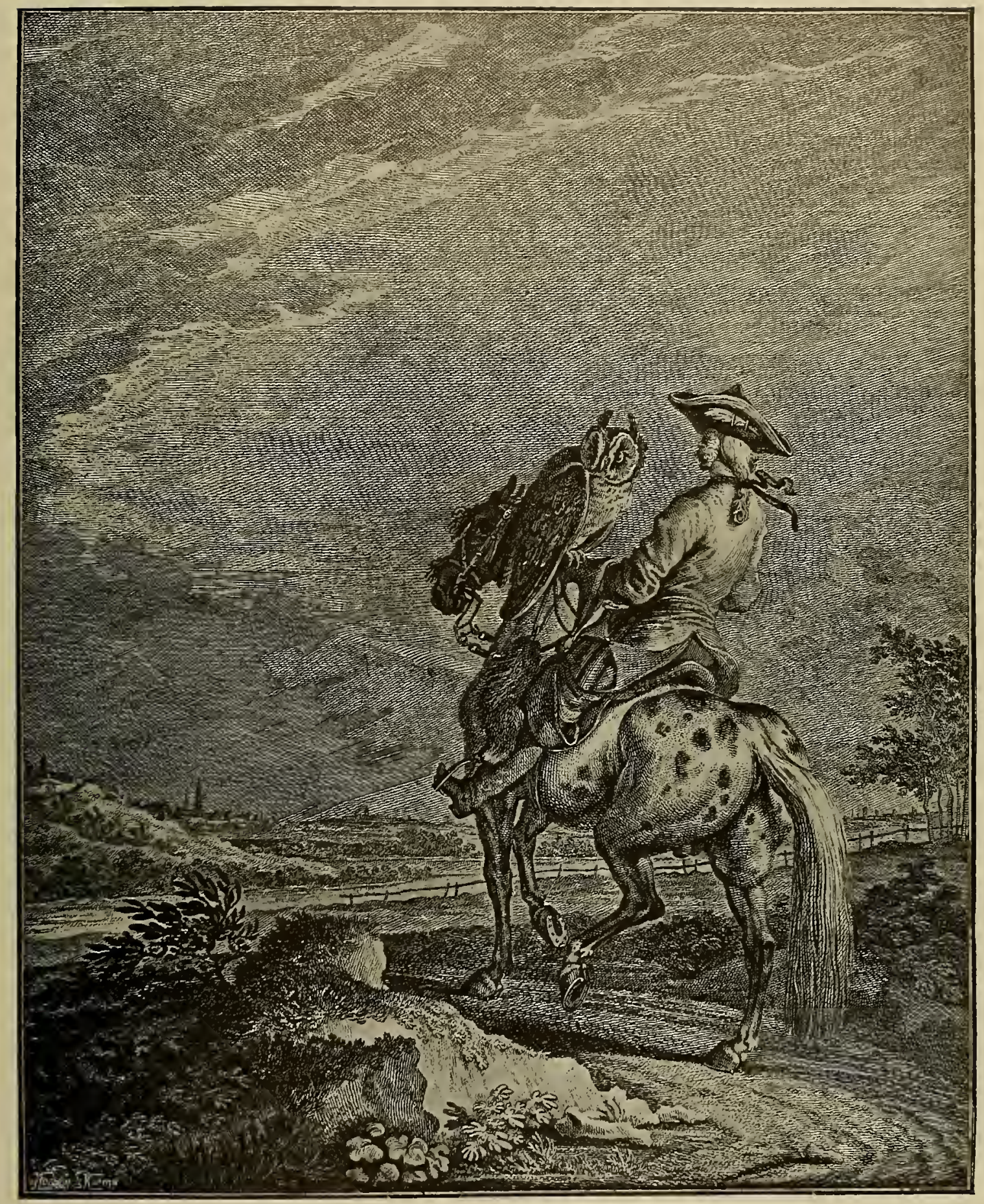

FIG. 180. THE FALCONER WITH THE “GRAND DUC" OR EAGLE-OWL. BY RIDINGER (TH. I 20). See Page 268 



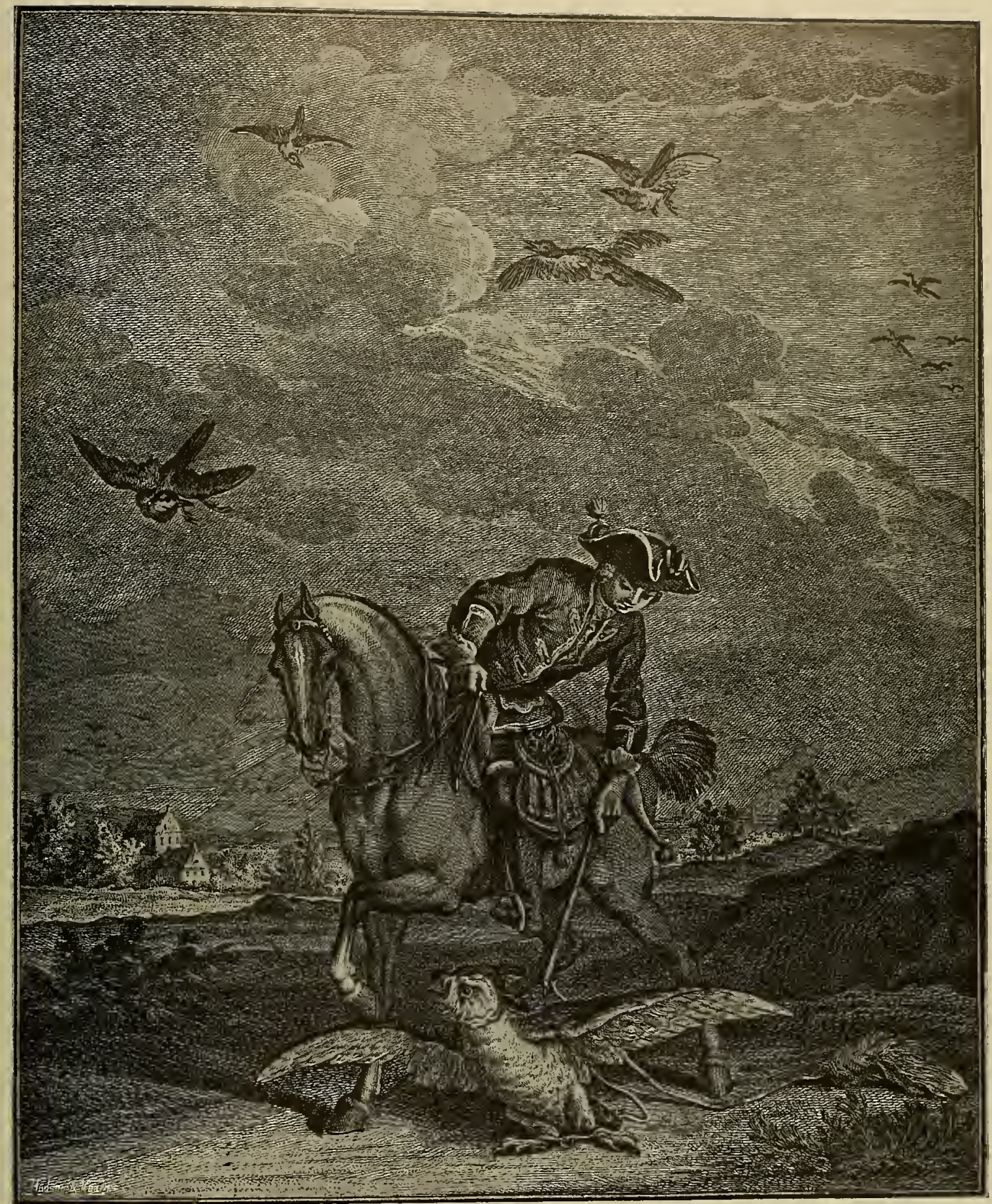

FIG. I8I. FALCONER PICKING UP THE “GRAND DUC.” BY RIDINGER (TH. I 2 I). See Page 268 



\section{USE OF THE JERF:ALCOX IX RUSSIA}

play the part of robber. As soon as it had come within a reasonable distance of the hawking party, a jerfalcon was unhooded and cast off, and the real spcrt commenced.

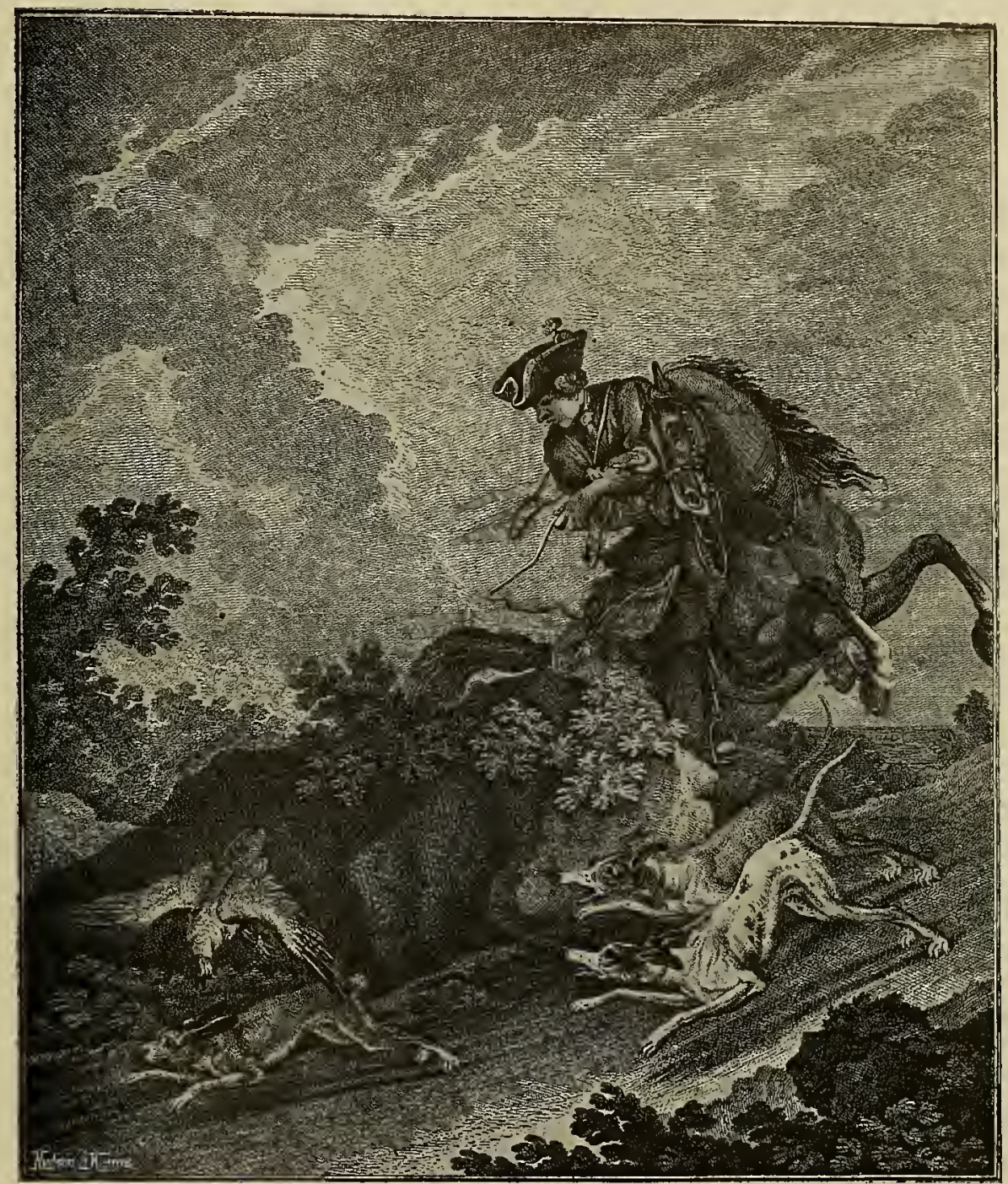

FIG. r 82. GOSHAWK STOOPING AT A HARE. RIDINGER (TH. I 29). P. 277

An amusing account is given in the "Art of Venerie" of the use the Czar of Muscovy made of the jerfalcon. It appears that this highly-prized hawk was flown at ravens, whose "monstrous strong flight" and tricky manœuvres make them very difficult to capture. "But in the end the hawk prevails, and the raven is forced to 'take the stand,' i.e. to perch in a tree. But that shift little $2 \mathrm{M}$ 


\section{SPORT IX ART}

prevails, for no sooner is she perched than the Emperor commands each Muscovite to draw his hatchet from his back (without which they never travel in that country) and to bestow his force to the felling of the tree, which is lightly done

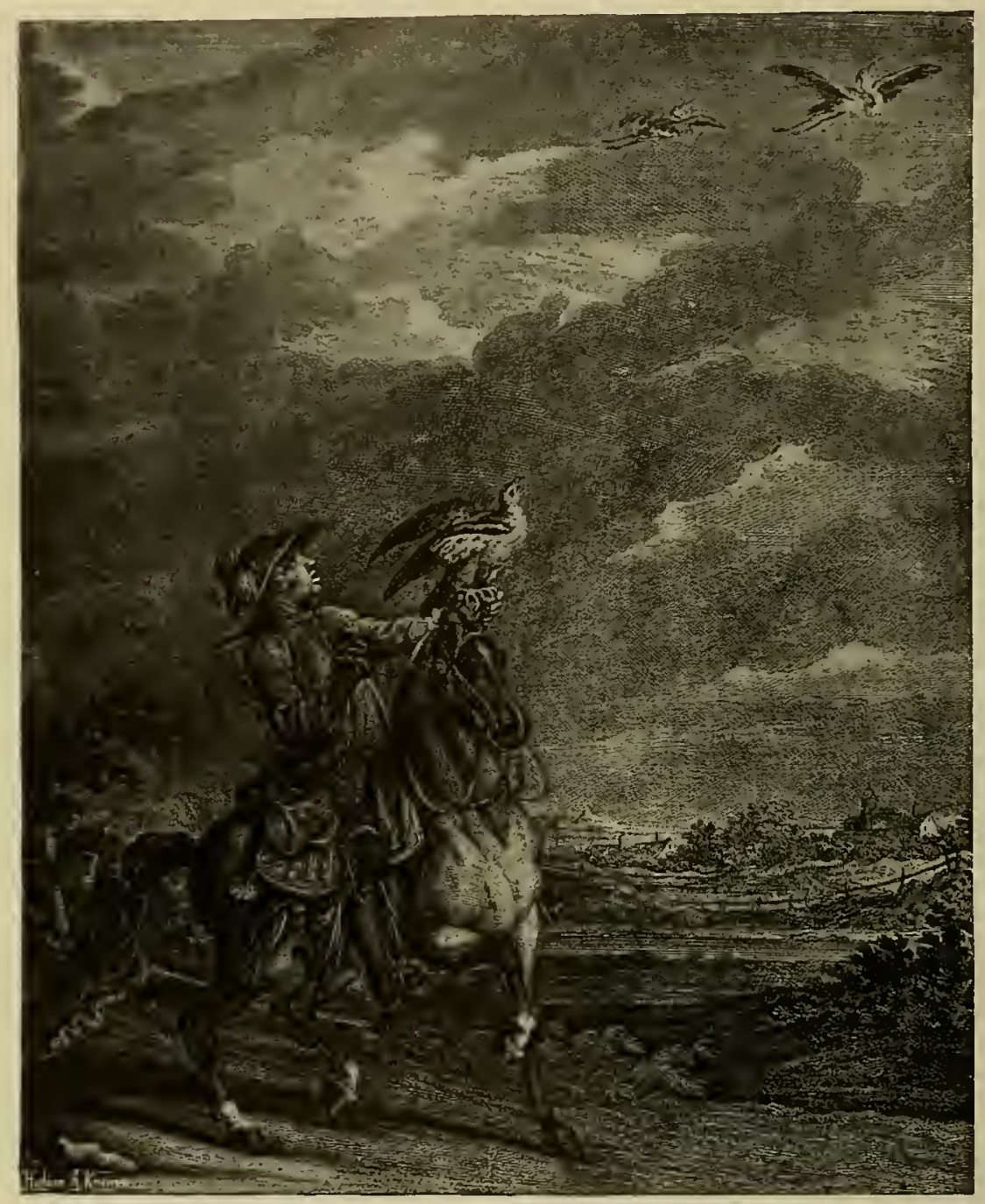

FIG. 183. THE FALCONER CASTING OFF HIS HERON-HAWK. BY RIDINGER (TH. 11s). See Page 277

by means of many hands, the hawkes all the while lying upon their wings looking for their game, who finding the tree to fail her, at the fall is driven to trust to her wings again, and so by a fresh flight and new encounter doth yield exceeding pleasure to His Majesty." 


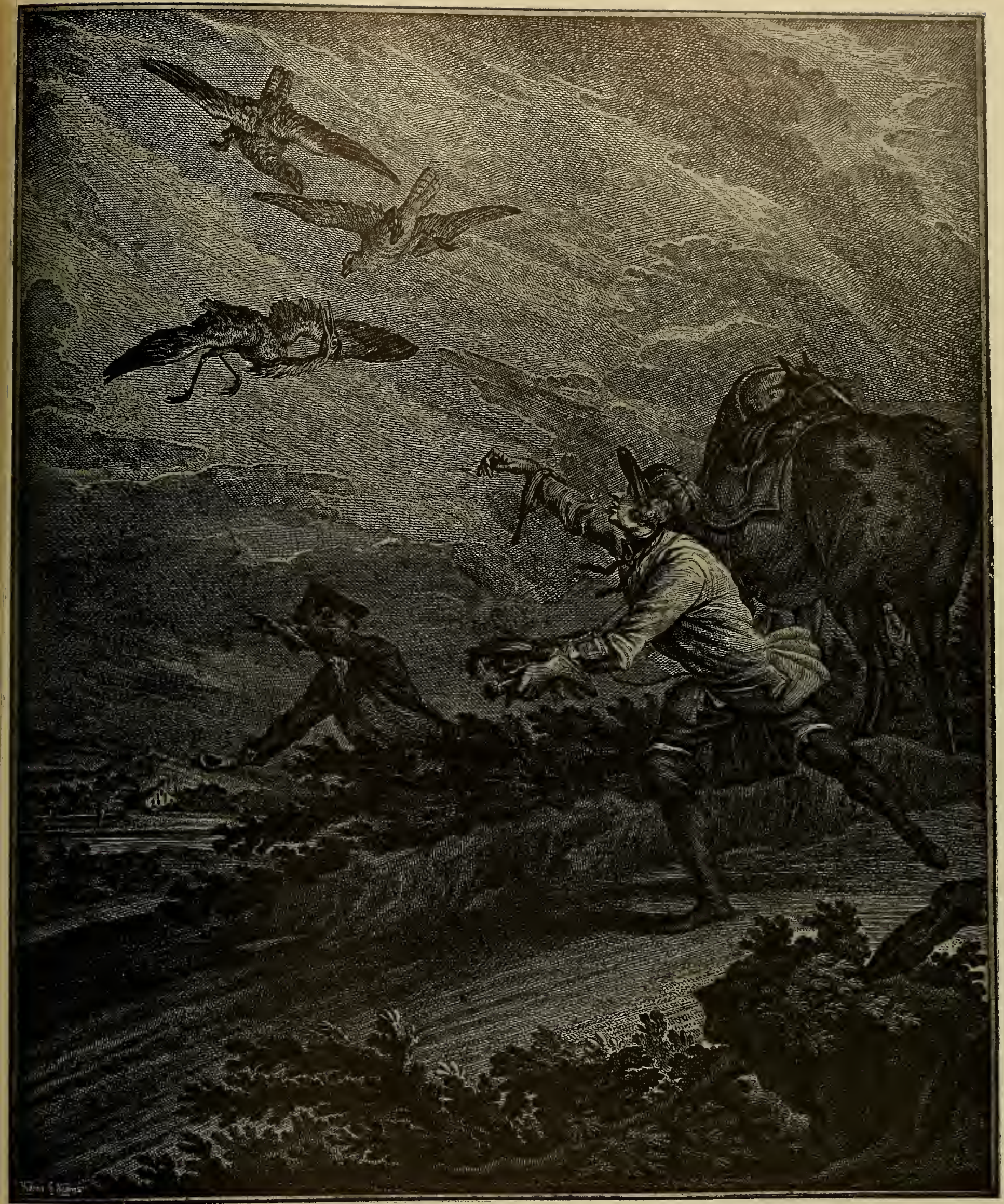

FIG. I 84. THE STOOP. BY RIDINGER (TH. I 36). See Page 277 



\section{RIDIX్RE'S HAWKIX్XG PICTURES}

Fig. I 8 I illustrates how the owl was picked up by the mounted falconer by means of a stick with a hook at the end. The horse on which the sportsman is mounted is an Engländer, according to Thienemann, who is probably right in his diagnosis, for Ridinger drew literally hundreds of horses from various countries, and in many instances the points peculiar to foreigners have been hit off with a great deal of spirit as well as truth.

The next picture (Fig. I 82) illustrates the capture of a hare by a goshawk, but, as Mr. Harting has pointed out to the writer, it is not so correct in one detail as are many of his other hawking pictures, for it represents the hawk as being about to seize the hare with its beak, whereas all hawks always grasp their quarry with their feet. Indeed, according to the old rule, it was the distinctive quality of the goshawk, sparrow-hawk, and tiercel to "have their chief force in their feet," as Turbervile expresses it.

The pictures of heron-hawking (Figs. 183,184 , and 185 ) show us what was the most popular of all hawking: the Sport of Kings as it was called. Turbervile has a picture of Elizabeth watching "How to Flee a Hearon," which the author pronounces "the most noblest and stately flight that is." But he tells us, too, that "there is not such art or industry therein as in other flights, for the hawk Heeth the hearon moved by Nature as against her proper foe, but to the river she fleeth, as taught by industry and diligence of the falconer." What this industry and diligence really meant we perceive if we peruse the multitudinous instructions and follow the minute details showered down upon the apprentice in old manuals. The art has its own language, of which Mr. Harting gives us more than 600 technical terms in the seven principal languages.

The literature of falconry originated, as did the sport itself, in the East, and both date back to the very earliest times, for no other sport had so many books devoted to it in bygone centuries, there being no fewer than 378 printed works known to the collector. Though France stands, with eighty-four printed books, at the head of the list, both quantitatively as well as qualitatively, England's eighty-two books run them very close, at least numerically ; but British authors "lifted "very much more from their contemporaries across the water than the latter did from our literature, a circumstance explained, no doubt, by the older civilisation of France. About no other sport have so many illustrious personages put their pen to paper, and about no other subject could a work written more than 600 years ago be still considered a standard work, and one of the best which exists. This is the Emperor Frederick II's De eArte Venandi cum eAvibus, written in the first half of the thirteenth century on his return from his Eastern travels, from which he brought back the great traditions of a sport which he considered the most worthy of all the arts.

Fig. I 86 introduces us to the sport of flying the hawk at wild fowl, a sport which combined the useful with the pleasant. The picture shows us the spaniel at work. 


\section{SPORT IX ART}

One of the earliest accounts we possess of "bird dogs" being used by falconers is given by Albertus Magnus, the famous Bishop of Regensburg (Ratisbon), who wrote that part of the Historic afmimalium containing the description of the chien d'oisel. This he must have written before 1250 , for Vincensius de Beauvais quotes him previous to that year. Whether this dog was the same kind about which Gaston Pharbus gives us such an interesting chapter in his La Chasse translated into English by Edward Duke of York, cannot now be decided, for Albertus .Magnus's remarks about this dog's appearance are rather general, but it is certain that the spaniel came originally from Spain. They possess, as Gaston Pherbus says, many good qualities and many evil ones, as do the people from the country from which they hail. The evil qualities, i.e. jangling and rioting, according to the "Master of Game," preponderated, though it is only fair to say that both these great medixval nimrods wrote more as eeneurs than as partisans of falconry. "Unless I had a goshawk or a falcon, or a hawk for the river, or sparrow-hawk, or nets, I would never have spaniels there where I would hunt," writes Edward of York. In his work on the pointer, Mr. Arkwright deals also with the spaniel, and we find in it much that is interesting to the fowler.

A still more ancient German church-lord, Boniface of Mayence, who died in 755 , left to us, in a letter addressed to him by King Ethelbert, an interesting proof that falconry was actively pursued by our Saxon ancestors. The King asks the Archbishop to send him two falcons that would fly to the crane, for, said he, "there are very few birds of use for that flight in this country," i.e. in Kent. Asser, as Mr. Harting, in his Bibliotheca efccipitrariu, tells us, refers in his life of Alfred the Great to that King's love of hawking; while WVilliam of Malmesbury records much the same of Athelstan, who procured his hawks from Wales. Edward the Confessor's partiality for this sport is also spoken of by this historian.

Of the apocryphal sport of flying at the stag with the eagle, of which Somervile tells us in his poem ( 742 ), Ridinger gives us fortunately no pictorial account, for it is very doubtful whether this sport had really ever an existence outside of certain poets' imaginations. Readers who possess Blome's fine folio and have glanced at our Barlow pictures will observe at a glance that the sport was conducted in the two countries on very much the same lines.

Fig. 187 deals also with an everyday event in falconry. The curiously-shaped object made of a bird's wings, swung at the end of a cord by the horsemen, is, of course, the "lure," which is brought into operation if the hawk has failed in taking his quarry, and has to be enticed back to his master's gloved fist.

We now reach the last two plates of the "Gunner and Hawker" set. Figs. I $8 S$ and I 99 , which illustrate what can no longer be termed a sport, but rather an occupation, viz. that of the bird-snarer. This man, with his pipes, lures, snares, traps, nets, and decoy birds, waged a deadly warfare against the feathery tribe. In the first picture we see this grotesquely-garbed figure travelling along a high road in quest $27^{S}$ 


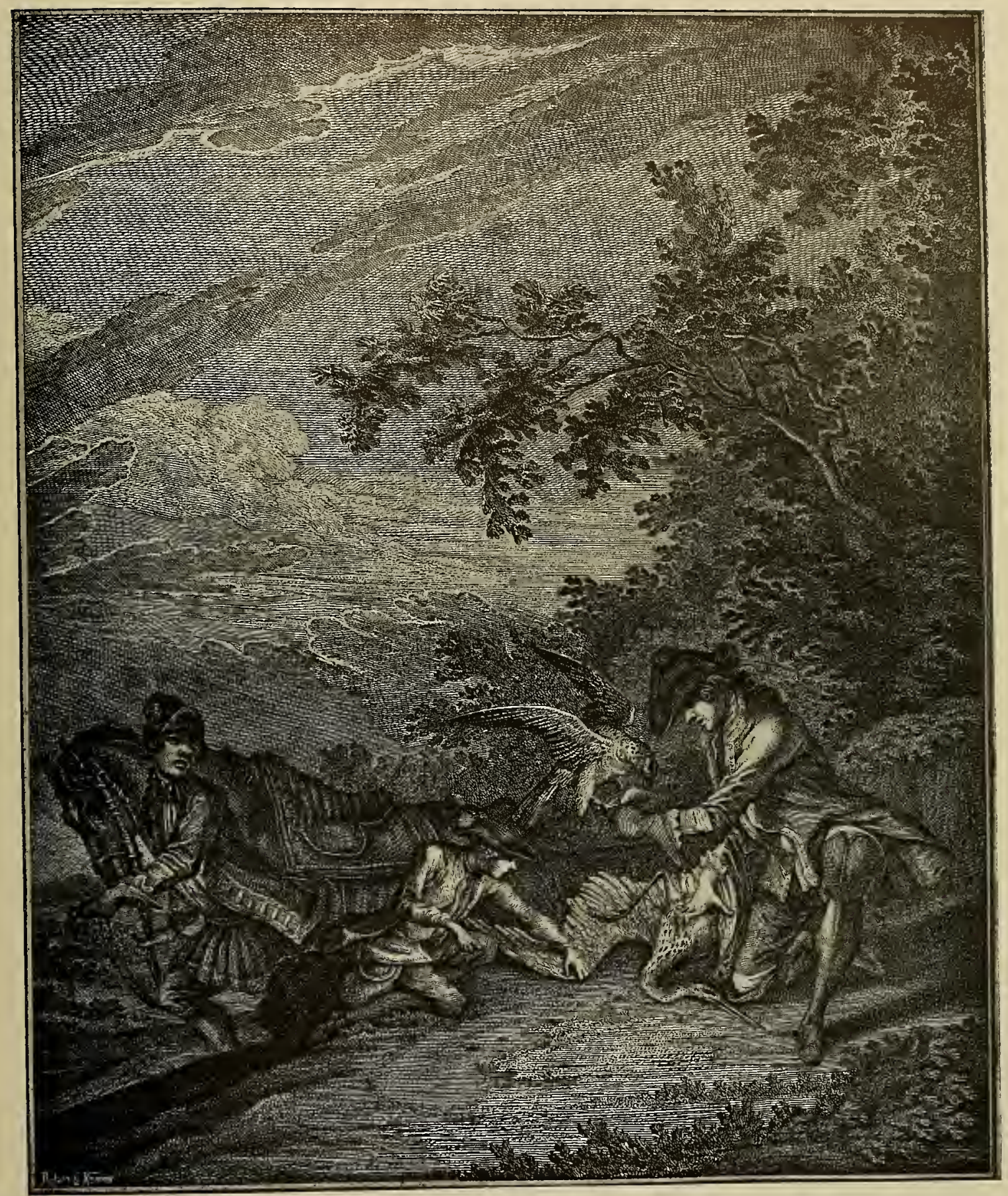

FIG 1 85. REWARDING THE HAWK WITH THE HERON'S LIVER. RIDINGER (TH. I 35) P. 277 



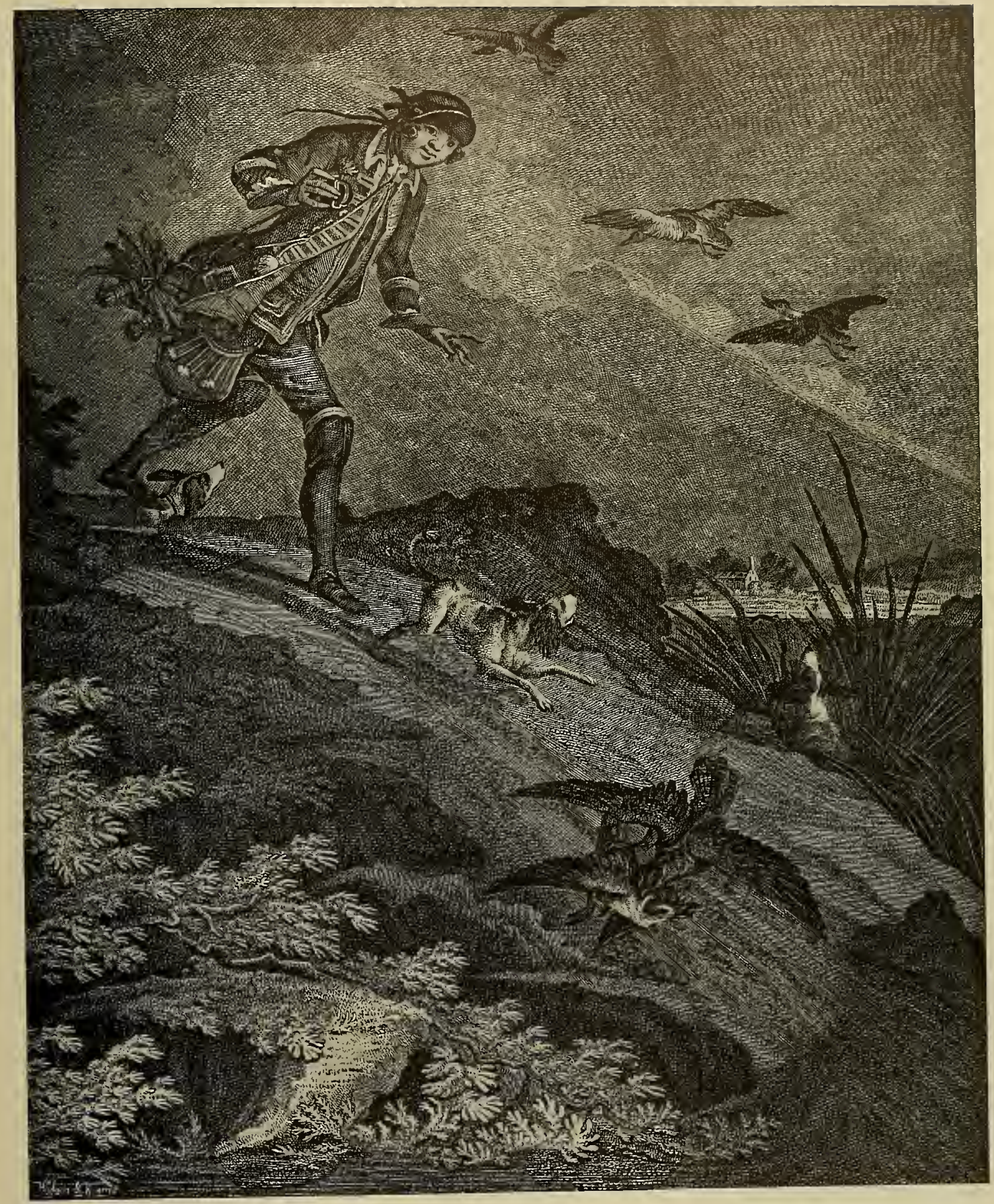

FIG. 186. THE USE OF THE GOSHAWK FOR WILD FOWL. RIDINGER (TH. I 38 ). P. 277

$2 \mathrm{~N}$ 



\section{BOOKS OX HAWKIX}

of new fields for his operations. Without shoes to his feet, with a fox's brush in his hat, he is leading his patient sumpter-horse, upon which is packed a strange medley of trapping contrivances of all sorts. In his hands he carries the "platform pole," upon which, when ready for operations in some quiet field, he placed the Grand Duc or the Moyen Duc, as were called the eagle-owl and the long-eared owl. In the background we notice the Vogelheerd, or snaring-ground, towards which he is making his way. This snaring and trapping of small birds was ever a favourite amusement of the Italians, much more so than of the Germans or English, and we need but scan the very numerous pictures of it by Stradanus, Bol, and others who knew Italian "sport" in the sixteenth century, to become acquainted with some of the "engines" employed by the bird-catcher."

There were, however, also English pictures and books that dealt with the subject. A few of these may be mentioned while upon the subject of fowling. One of the best known is a compilation by the freely-travelling pen of Gervase Markham, called "Hunger's Prevention, or the Whole Arte of Fowling by Water and Land," that taught readers in I62I how to capture birds, the "pourtrays" of which he figures. They show a somewhat primitive conception of art.

A far rarer book of that period was "A Jewell for Gentrie," published in I 614 by one who hid his identity under the initials "T. S." According to Mr. Harting, it was almost certainly Thomas Snodham who wrote it. It now ranks amongst the scarcest sporting books, and deals with its subject as "an exact dictionary or true method to make any man understand all the art, secrets, and worthy knowledge belonging to hawking, hunting, fowling, and fishing." The author's remarks upon the nature and properties of "fowles in the ayre" are quaint and interesting.

An almost equally rare but less original work of that time is William Gryndal's book published in I 596, the various editions of Symon Latham's works coming next in chronological order; but about all these bibliographical details the reader should consult Mr. Harting's books on the subject.

There were numerous occasions when the lure was not used; thus, when a hawk from one cause or another refused to stoop at the quarry he was flown at. Falconers used to call it "turning tail to tail," as Turbervile informs us in a quaint passage worth quoting: "It hapneth oftentimes that when you have let your Goshawk flee at a Partridge she wil neyther kill it nor flee it to mark, but turneth tayle to tayle, as Falconers term it, that is, when she hath flown it a bowshot or more, she giveth it over and takes a tree. Then shall you call in your

* Fleming names some of the contrivances used by the bird-snarers-the Roccolo, the Stangada, the Panthera, and the Tesa-which were already known to Olına, for he mentions them in his Uccelliera. By the second, which seems to have been particularly deadly, Fleming declares, often 10,000 quails were caught in one morning on the Roman Campagna not far from the sea, where the flights landed after their long journey from Barbary. 


\section{SPORT IX ART}

Spaniel, to the retryfe that way that your hawke flew the Partridge. And the Falconer drawing himselfe that way, may cast her out a quicke Partridge which he shall carry for such purposes in his Hawking-bagge, in such sort as the Hawke may see it, and thinke that it is the same which she flew. And so crying when you cast it out ' Ware Hawke, ware,' make her seaze it and feede her upon it that she may be encouraged thereby to flee out with a partridge."

One of the longest series of Ridinger's engravings is the one called "The Most Wonderful Stags" (Wundersamste Hirsche), consisting of just one hundred plates. It is a series which appeals specially to the antler-collecting sportsman, for it shows us some of the finest trophies garnered in foreign forests in days when this noble beast still flourished and waxed great. Antler lore has always had great attractions to sportsmen, perhaps more for men of the old school than for those of the twentieth century, for now quantity rather than quality seems to be the chief end, and the two cannot go together. As we have some of Ridinger's best work before us in this series, we propose to reproduce a number of the "Most Wonderful Stags," trusting that the reader will not weary of these portraits of defunct deer.

Fig. I 90 is a picture of the stag which carried the trophy about which, of all others, the most has been written-and fabled. It is a famous sixty-six pointer, grassed more than two centuries ago (September i 8, I 696) by the flint-lock of the first King of Prussia, when he was still Elector of Brandenburg. As Ridinger was not born till two years after the stag's death, we know that the artist could have had only the antlers to draw from. These are fairly accurately copied, for one can easily compare the drawing with the original, which hangs in the lofty Presence Chamber of Moritzburg, the ancient hunting castle of the rulers of Saxony. How the head got there is told in the well-known story of one of the most curious barters ever made. The successor of the lucky slayer of this huge stag, the second King of Prussia, cared less for his ancestor's trophy than for tall grenadiers, as those familiar with their Carlyle will remember. His contemporary, the Elector Frederick of Saxony, on the other hand, was a great collector of antlers. Hence it came to pass, so the story hath it, that in the year 1727 a company of the tallest grenadiers to be found in the fair realm of Saxony marched Brandenburg way, while the much-desired sixty-six-tined antlers were sent with three other fine stags' heads under suitable convoy to the Saxon capital, near which, as already mentioned, they can be inspected to this day by the student of antler lore. The marble monument which was erected by the delighted sportsman where the great stag ended his days was visible until lately, but, like most similar mementoes of lucky shots, which it was the fashion to erect, it has now disappeared.

To the critical eye of the modern sportsman-naturalist this head is disappointing, for, unlike other trophies preserved in what to-day is undoubtedly the most interesting collection of antlers in the world, it is an undersized, not to say 284 


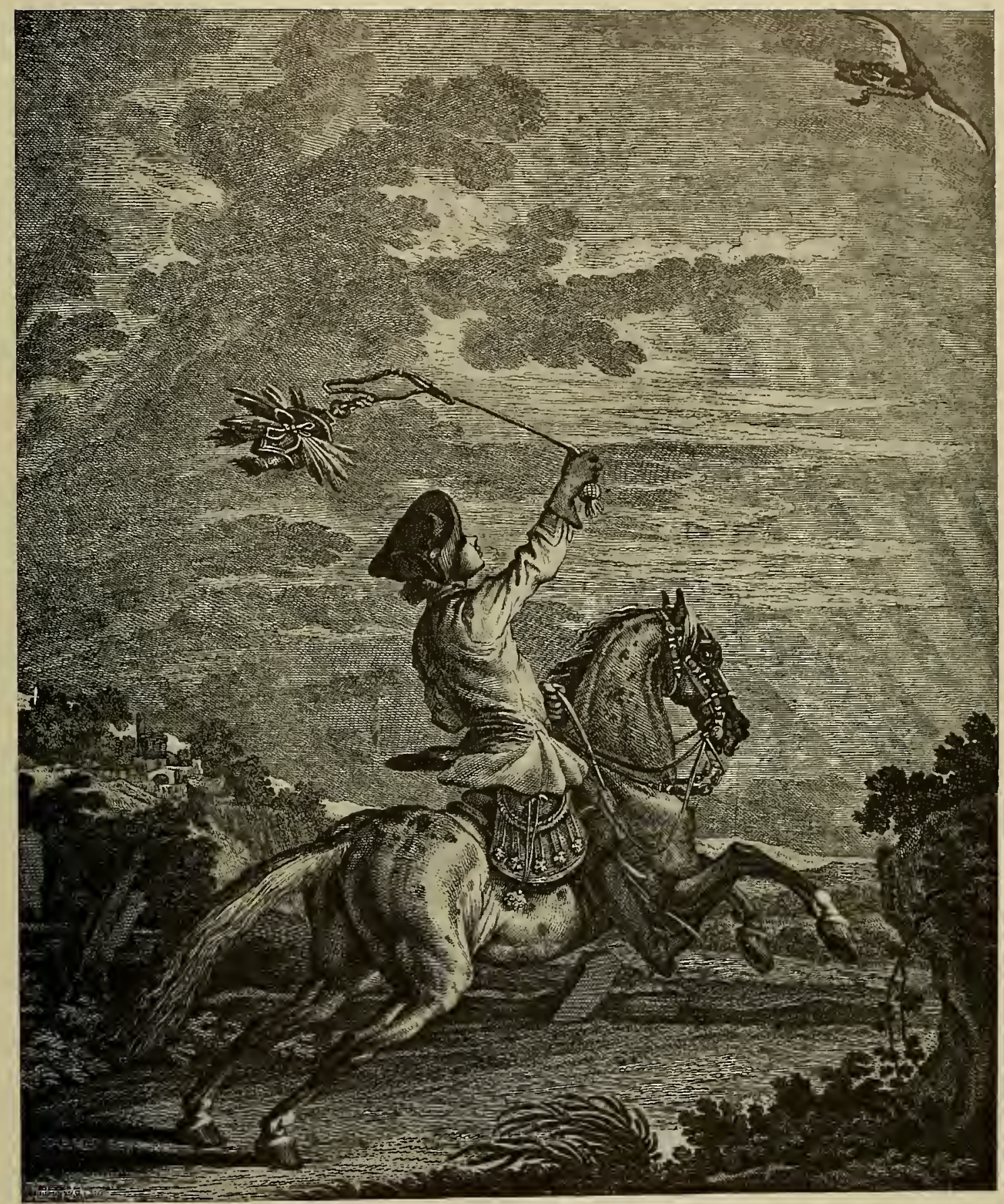

FIG. 187 . LURING THE JERFALCON. BY RIDINGER (TH. 130). See Page 278 



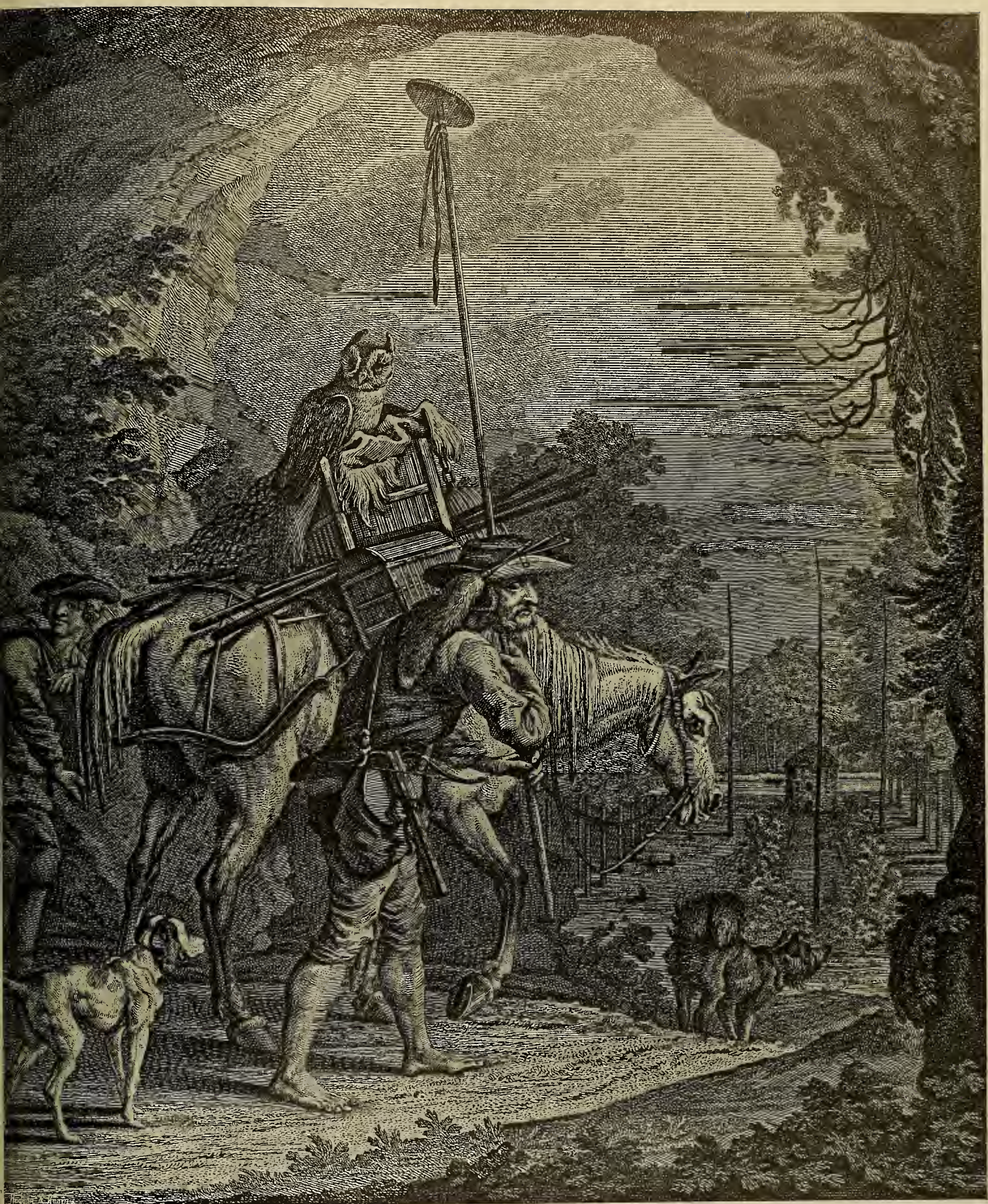

FIG, 188. THE BIRD-SNARER WITH HIS TRAPS AND “GRAND DUC." BY RIDINGER (TH. 131). See Fage 278 



\section{THE GERMAX EMPEROR'S TROPHY}

stunted trophy, on which the tines are by no means well developed or of fine proportions. But there it hangs, a trophy more curious than beautiful.

Between it and the pair of antlers bagged in 1898 by a descendant of the first King of Prussia, the present Emperor William, in his Rominten forest, there is, curiously enough, considerable resemblance, for the tines on this trophy are likewise "bunched" on top, forming a cluster of spikes, rather than the branching forest of well-developed "offers" one expects to see. In body the Emperor's stag could not compare with the giant his ancestor killed, for the latter weighed more than twice as much, viz. 59 stone $9 \mathrm{lb}$. against 29 stone $2 \mathrm{lb}$. as the animals fell. Whether the Emperor, who, as we know, does not allow the world to forget the old greatness of the Brandenburgers, has followed his forbear's example, and raised a monument in glorification of the death of his forty-four pointer, we cannot say. Anyhow, the marble monument erected by the first of the Prussian Kings was still standing within the memory of living persons.

Fig. I9 I is the portrait of another famous trophy secured by one of the sovereign lords whose realms made up that great patchwork known as the Holy Roman Empire. In this case the artist probably had the whole animal before him, for the Tübinger Forest, where the stag was shot during the rut, in 1724 , by Eberhard Duke of Württenberg, was not far from Augsburg, where Ridinger had settled down some years before. The antlers of this stag show a remarkable abnormal formation, for a third beam, which again shows a bifurcation on top, made it a highly-esteemed lusus nature of a kind which the collectors of the last two centuries loved to display in their galleries and halls.

Fig. 192 is a representation of two stags, killed by the same ardent ducal sportsman of Württenbery who grassed the hart shown in the last plate. These deer have both remarkable malformations. They were killed in different years and different regions, the one to the left coming to grief by the duke's flint-lock in I I IO, the other eleven or twelve years later. The head depicted on Fig. I93 reminds one again of the sixty-six pointer, for an ambitious sportsman could, by counting every little spike, get together a forty or fifty pointer. In this instance no such close counting has been attempted, for Ridinger mentions no number, and we suppose Duke Charles of Württenberg, who grassed this hart on August 22, I735, probably entertained reasonable views anent the mania for counting every little knob as a tine.

Judging by the date on which this hart was killed, it is safe to presume that he fell viction to one of those huge drives which were held in the month preceding the commencement of the rut. On these occasions the slaughter of the game was as enormous as were the burdens which these laboriously-conducted chasses imposed upon the rural population of the whole district.

Though the student of feudal institutions becomes accustomed to read of the gross suppression of personal liberty and rights, the dreaded service of the chase to 


\section{SPORT IX ART}

which the serf-like inhabitants were subjected, can but increase one's indignation. No field nor garden could be fenced higher than a deer could leap, or so substantially that a boar could not uproot it; hence fences were altogether abandoned, and the peasants' wheat and roots became the prey of the duke's game. Thousands of deer, and literally tens of thousands of boar, waxed fat, and a deaf ear was turned to all appeals. Venison-either fresh, smoked, or salted down in barrels- was in those days the chief article of food at the courts of these hunting lords; but so large was the quantity of game secured at the great battues, when 500 deer and 1000 wild boar were sometimes slaughtered in one day, that the authorities had to resort to other means to speedily dispose of the hundreds of tons of venison. Injury was added to insult on such occasions, for a lucrative way out of the difficulty was discovered. It was to send to each burgher in the nearest town a boar, with the order to buy it at a fixed price. The cruellyoppressed Jews, who then still formed separate communities in many of the German towns, were on such occasions the victims most to be pitied, for, of course, their religion forbade them to eat of the meat of wild boar, and in an already much overstocked market they found it impossible to sell their enforced purchases.

In these circumstances the Continental forests were then much more than they are now, the genuine article, i.e. densely-timbered woods in which game, be it even the lordly hart, could not be seen, much less stalked under conditions familiar to the Scotch stalker. Only during the rutting season was it possible to approach deer, for then the wary old stags cast aside their cunning, and betray their presence by their "roar" on coming forth from their retreats in impenetrable nooks of the tangled woods to do battle and to make love. Dawn and dusk found the hunter on the spot, for in daytime the stag rarely roars. Thus it came that many of these old nimrods lived in their little Brunft-hütten-plain little huts, erected in the wildest spots-and in these retreats they remained for the three weeks of the rut. In the background we notice a fence of the kind then in use, leaving gaps for the game. Why, in the circumstances we have spoken of, fences should have been used at all, it is difficult to say, except that under rulers not so devotedly attached to sport greater leniency was shown, and under their less cruelly selfish rule the peasants were permitted to protect their crops against the inroads of boar and deer.

But not only duchesses and princesses were passionately devoted to sport of the kind with which we are dealing; yet another class of devotee has to be added, namely the high dignitaries of the Church. Among popes, cardinals, and sovereign bishops were to be found keen nimrods. Julius II, Leo X, and their predecessor the famous Æneas Silvius (Pope Pius II) were renowned veneurs: equally so some of the Prince Bishops of Salzburg and of Constance. Fig. 194 commemorates one of the latter's feats. It represents a hart of eighteen points 290 



\section{AXTLER WORSHIP}

shot during the rut by Cardinal von Rodt, Prince Bishop of Constance. His principality comprised some of the choicest deer forests in Southern Germany, and numerous bunting-seats, including the picturesquely-situated hunting castle of Meersburg, overlooking Lake Leman from a precipitous height, though now in a state of sad decay, was once filled with a great collection of antlers; and the vast size and fine architecture even yet betokens the regal style in which these hunting lords of the Church lived their lives and slew their stags.

These antlers are fine specimens of the trophies carried by the South German race of stags. They are preserved in the museum at Constance, one of the few remnants of the famous collection, which, as a result of the Vienna Congress (by which these ecclesiasts were deprived of their sovereign power), was dispersed all over Europe. Unlike the preceding hart, this one was shot in what was known as a Gesperrte fagen, i.e. locked drive, that is, one from which escape was practically impossible, the whole ground being surrounded by huge screens, ro feet or 12 feet high, made out of stout canvas firmly lashed to supports strong enough to withstand the rush of the biggest stag, as we see it in the background of the illustration. These screens were drawn for many miles, as old accounts and pictures plainly show.

A word remains to be said concerning the artistic merit of the two last prints. Ridinger, the elder, was an old man in 1765 , when they were executed ; though the second illustration is signed J. E. Ridinger, fecit et sculpsit, the drawing does not come up to the master's standard. The whole pose of the stag, and somewhat faulty execution, betray the less skilled touch of Martin, the eldest son of Ridinger, who, though he followed in his parent's particular line, was a far less gifted artist. The last print no longer sails under false colours, for it bears Martin's signature. Many of the sovereign sportsmen, whose doings Ridinger so faithfully chronicled, were passionately fond of experimenting with their beloved deer to test the effect of food and of a tranquil existence in some vast park. The almost invariable object was to discover the best means of improving the antlers, with a view of extending the experiment to deer living in a wild state, for large heads were the principal consideration to that antler-worshipping class. Fig. I 95 is the portrait of a remarkable stag bearing a grand head of no fewer than thirty-two tines, which was caught alive in the year 1762 in the Battenberg country, in the Duchy of Hesse-Darmstadt.

The Landgrave, who occupied a throne upon which to-day his descendant, a giandson of our late Queen, is seated, was a keen sportsman. He ordered the stag, which then had a head of twenty points, to be transported to his favourite hunting castle, Cranichstein. There in the Feasanderie, as Ridinger describes the pheasant coverts round the famous old ducal seat, the stag was turned out. The following year he set up antlers with twenty-two, then twenty-four, and in I 76 I he actually grew a thirty-two-tined head. This feat he repeated in the following year, when his portrait as we see it was painted. That, however, was 


\section{SPORT IX ART}

the climax, for in the following year he began to "set back," his head showing but twenty-six tines.

The Hesse-Darmstadt Landgraves were, as a rule, keen sportsmen, though the reputation of the country for heavy stags and large antlers was not as great as that of Saxony, Württenberg, and Bavaria. For one peculiarity, however, it became widely known, i.e. for its famous white stags, with a specimen of which Fig. 196 makes us acquainted. It is an interesting picture by John Elias Ridinger, though it is impossible to convey by pencil and graver the weird effect produced by a white stag flitting like a ghost through the green thickets of Hessian forests. In the distance we see one of the prince's hunting establishments in the Jägerthal. White stags have been seen occasionally in Hessian woods since the sixteenth century, the first one of which written record has come down to us being a stag which poachers killed in 1564 . One hundred and twenty years later a white-red deer calf was caught alive on the Schleusingen estate; but though it was a wellknown fact that quite a number of white deer frequented certain forests, all efforts to trap them had proved ineffectual. Landgrave Louis Frederic II paid particular attention to white deer, and several of his great deer parks, for which his duchy was famous, were stocked with quite a number of them. After the death of this Landgrave the deer parks fell into decay, and Landau tells us that in 1806 only four head of white deer were ieft in the principal park at Aue, a vast enclosure where the late prince was wont to hunt his white favourites with hounds.

It has generally been supposed that this abnormal colouration is inherited from the stag only, and many an author on venery devoted pages upon pages to theories connected with this circumstance. But the author I have already quoted gives an instance which tends to disprove this belief. In 1807 a white stag had escaped from the deer park at Darmstadt, and became the father of a white female calf out of a hind of the ordinary colour. In 18 Io this offspring became the mother of a calf of the usual colour, but from I 8 I I onwards for six consecutive years she produced annually a white calf, that of the year I 8 I I being finally shot in 1820 as a stag of fourteen points.

One reason why it was found so difficult to propagate the white breed of deer was that they fell far more easily victims to poachers than did the normal ones, for they could easily be seen at night; while the far greater value of white skins, as objects of curiosity, held out a further inducement to poaching, notwithstanding the cruel punishments-loss of a hand or branding with red-hot ironswhich we know were frequently inflicted upon incorrigible poachers.

August II of Saxony kept twelve white stags in a park just outside the walls of Dresden, but they injured so many people, finally killing two persons, that they had all to be shot in 1793 , their last appearance in public being at a carnival

* This is a curious confirmation of the ancient belief that stags never set up more than thirty-two regular tines, already voiced by 'Twici (1320).

294 


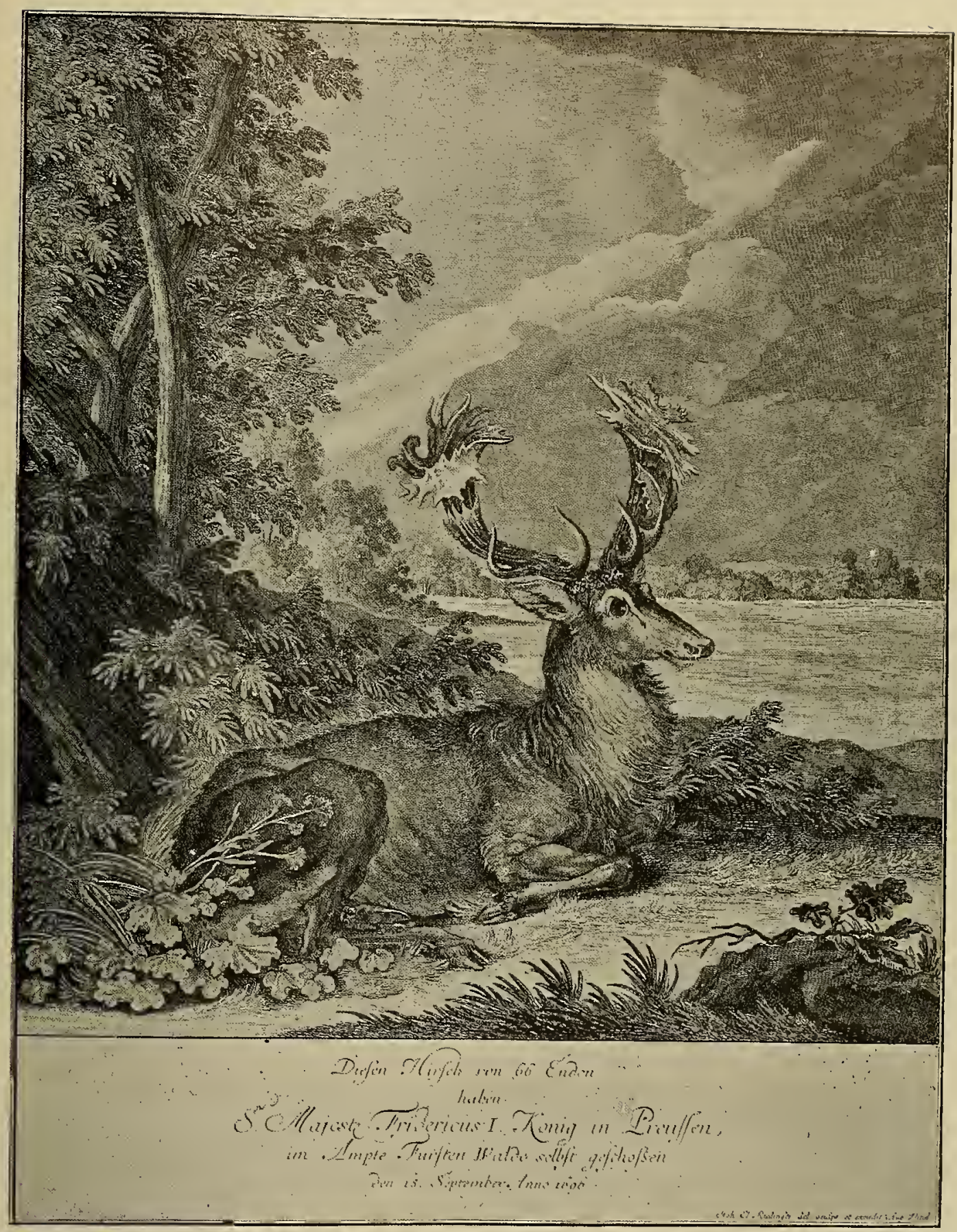

FIG. I 90. THE CELEBRATED “SIXTY-SIX POINTER,” SHOT IN I696 BY THE FIRST KING OF PRUSSIA. FOR THESE ANTLERS A COMPANY OF TALL GRENADIERS WAS OBTAINED IN EXCHANGE. BY RIDINGER (TH. 247). See Page 284 



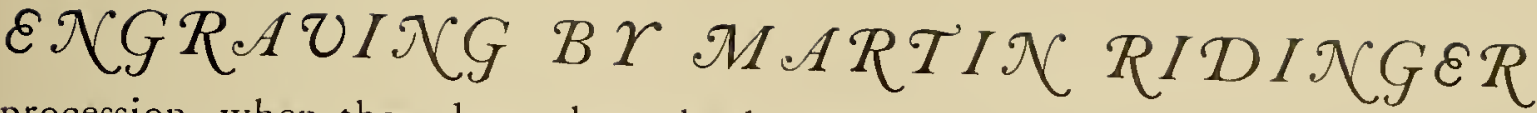

procession, when they drew through the streets of Dresden a triumphal car on which was seated a princess dressed as Diana.

Fig. I 97 is one of Martin Ridinger's engravings. In design rather stiff and out of

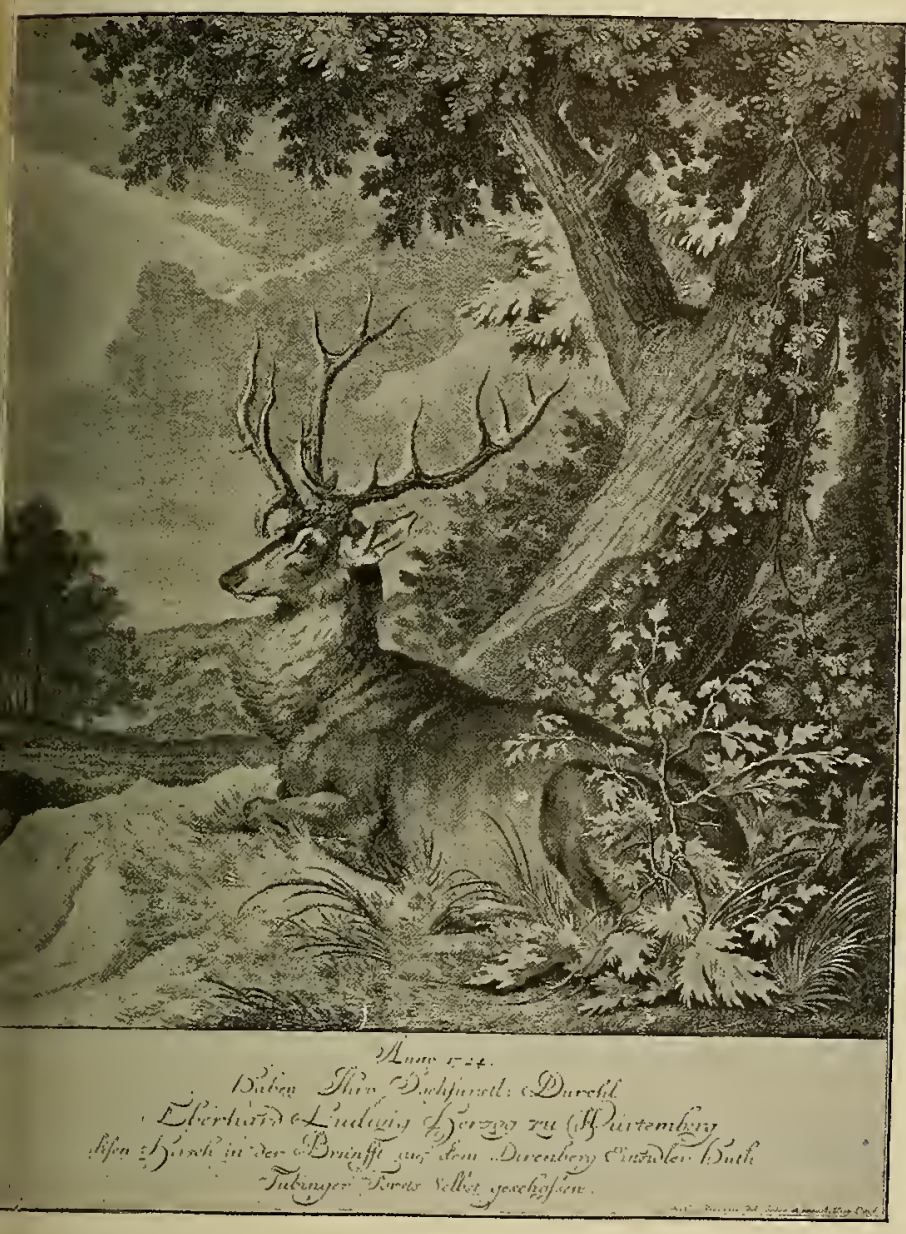

G. 191. STAG WITH THREE ANTLERS, SHOT IN $172+$ EBERHARD DUKE OF WÜRTTENBERG. BY RIDINGER H. 243). See Page 289

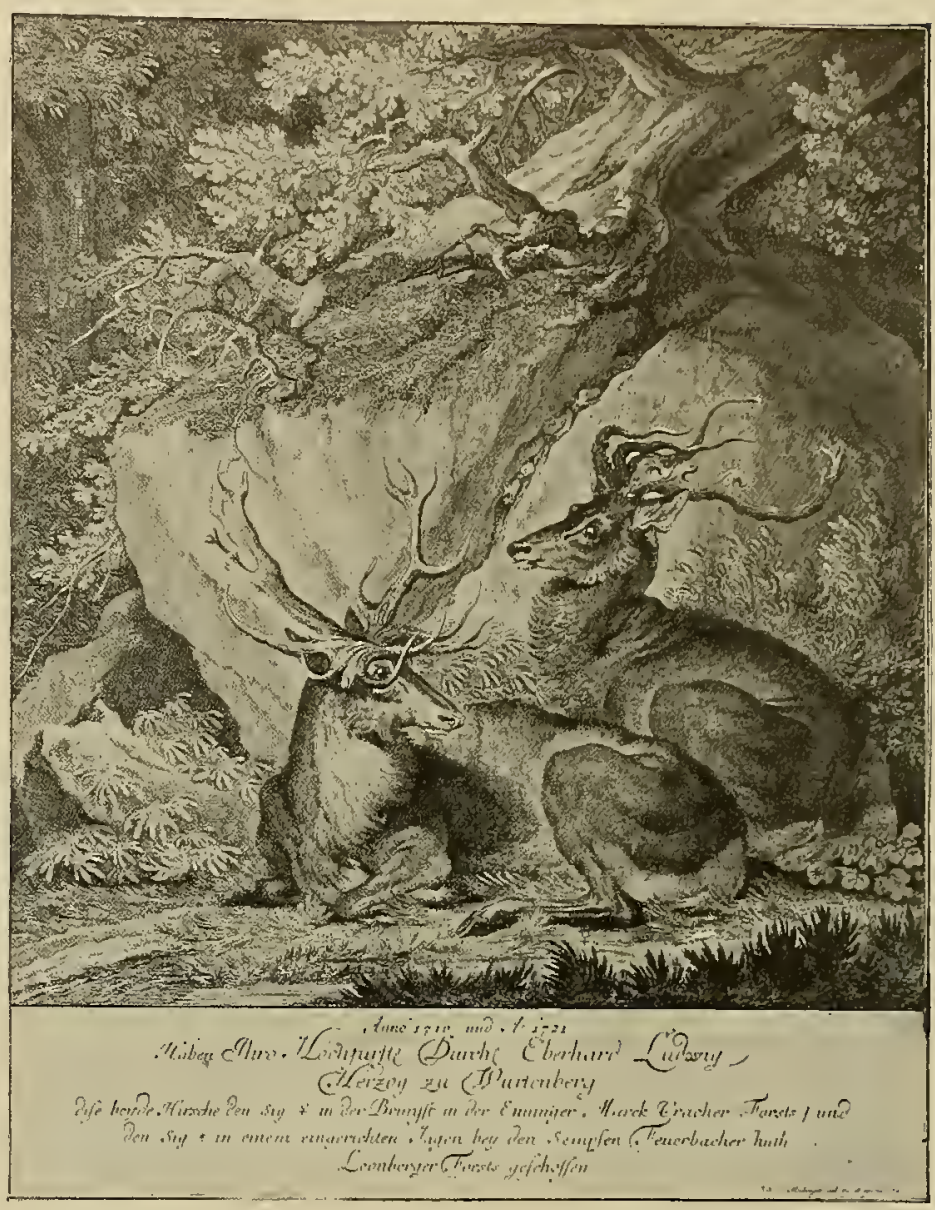

FIG. 192. TWO STAGS WITH CURIOUS MALFORMED ANTLERS SHOT IN 1710 AND 1721 BY EBERHARD, DUKE OF WÜR'TtenberG. BY RIDINGER (TH. 263). See Page 289

drawing, it represents another historical trophy of the chase. It is a head with three antlers, two springing from one and the same burr. In the background another hunting seat of the Landgrave of Hesse is seen. In the legend below the picture Ridinger tells us that this stag when hunted par force, i.e. with relays of hounds, by Louis VIII of Hesse, in the "Great Pheasant-coverts" of Cranichstein, jumped the park wall, which was twelve feet high, and thus escaped. The rutting 


\section{SPORT:IX ART}

season, however, sounded his death-knell, as it did for so many other monsters of his species. He was shot where Hesse and Erbach marched in the autumn of the same year. Few such leaps are recorded in an authoritative manner, and

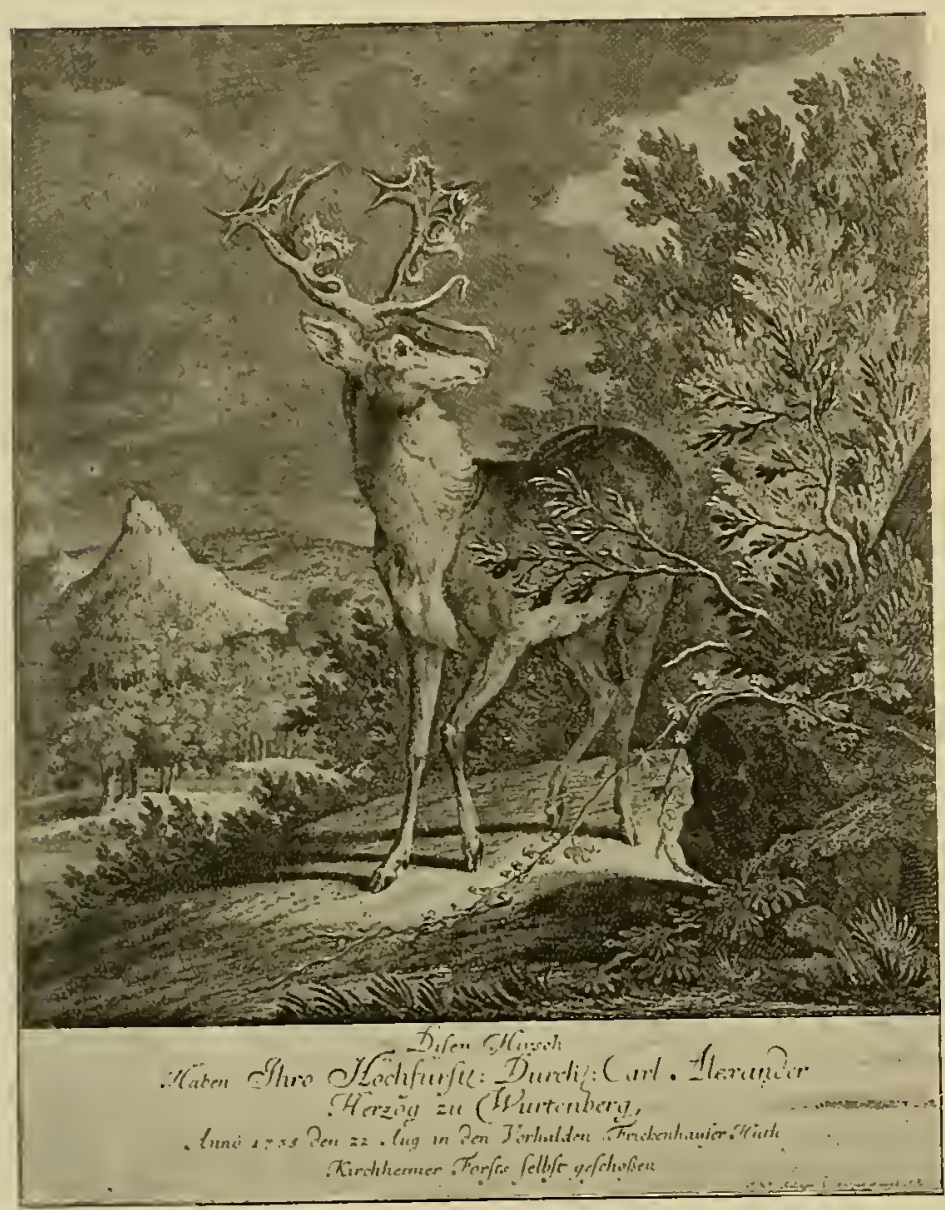

FIG. 103. STAG WITH CURIOUS MALFORMED ANTLERS, SHOT IN 1735 BY CHARLES ALEX. DUKE OF WÜRTTENBERG. BY RIDINGER (TH. 255). See Page 289

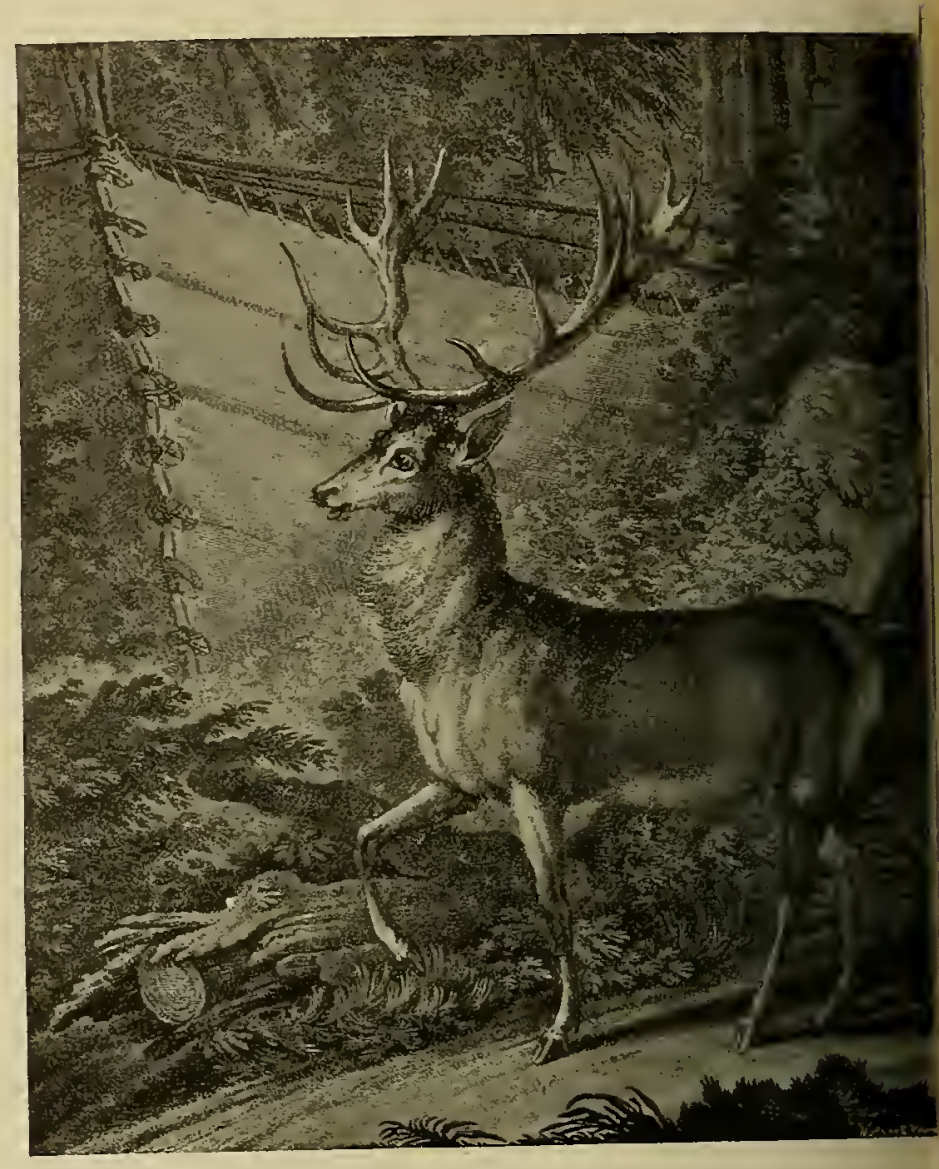

FIG. 194. FINE EIGHTEEN POINTER, SHOT IN $1 ; 63$ B THE REIGNING DUKE OF WÜRTTENBERG. IN THI BACKGROUND SCREENS OF CANVAS TEN FEET HIGH USED FOR DEER DRIVES. DESIGNED BY WOCHER ENGRAVED BY M. RIDINGER (TH. 326). See Page 290

though it seems almost incredible that an animal should be able to top a wall almost three times his own height at the shoulder, we cannot in this instance doubt the evidence before us.

As one walks through the great castle halls and long corridors of some of the old hunting seats, the walls of which are closely hung with great trophies such as we have described, feasting the eye on rows upon rows of antlers, the product of a time when greater store was set upon the life of a stag than upon that of 298 


\section{SPORT IX ART}

concerned; while Count Arco-Zinneberg's in Munich, consisting of over 4000 trophies, represents more modern times. The visitor who knew the Moritzburg collection, say twenty years ago, will, if he re-visits it to-day, miss a remarkable picture which once occupied almost the whole side of one of the 200 rooms of that castle. The writer often saw it there, and when re-visiting the old Schloss, not very long ago, at once missed the huge canvas from its wonted place. Enquiries elicited the following story.

The picture in question represented the supposed life-size facsimile of a gigantic pair of antlers, almost ten feet in height. Painted apparently a couple of centuries ago, a Latin inscription informed one that the stag which carried this monster head was killed in the reign of Louis XII of France in the Ardennes. Doubts about the authenticity of this impossible-looking pair of antlers were yet further allayed by the information that the original of this picture, the veritable antlers themselves, were preserved in the castle of Amboise, in France. During the Franco-German war, some German officers came to be quartered in this castle, and one of them, being a keen sportsman, set about to examine more closely the huge antlers, which he at once recognised as the original of the Moritzburg painting. They were hung high up on the walls of the principal hall, but ladders were forthcoming, and the head was taken down. Lo and behold! their true character speedily became apparent. They were cleverly worked imitation antlers of wood! So these ten foot antlers had to go the way of so many frauds which modern investigation has uncovered, and as a consequence the King ordered that the old painting should be removed from the walls of his hunting-seat.

A very remarkable head is reproduced in Fig. I98. It is a very forest of long tines, twenty-four in number. To the connoisseur the forked bay is a feature of special interest, this being very rare indeed. One of the Brandenburg Markgraves bagged it in 1719 , in the course of what one might call a drive of harboured quarry, to translate as literally as possible the German Bestätigtes Fagen. These drives had for their object not so much the slaying of a large quantity of game, as the bagging of special stags that had previously been marked down or harboured, and then driven up to the guns.

The reader, after glancing at the remarkable antlers we have reproduced from Ridinger's engravings, will have observed what superb heads were still to be found in the Continental woods I 50 years ago. And considering that no trouble or expense were spared in acquiring fresh blood, or in trying various kinds of food with a view of finding out which had the best results upon the growth of antlers, one cannot be surprised at the results. Everything was sacrificed to the production of fine antlers; no axe touched the favourite haunts of the stags, no stranger's foot trespassed upon the sacred soil lest the deer might be disturbed at the critical period, and, as we have already narrated, the peasants existed but to grow and tend crops for the delectation of the antlered sybarites. 


$$
\text { GREAT AXTLERS }
$$

We have yet another great head, bagged by the same hand that secured the one last portrayed, to show to the reader. Fig. 199 is the picture of a hart that had evidently escaped his doom on many a previous occasion, for Ridinger tells us that

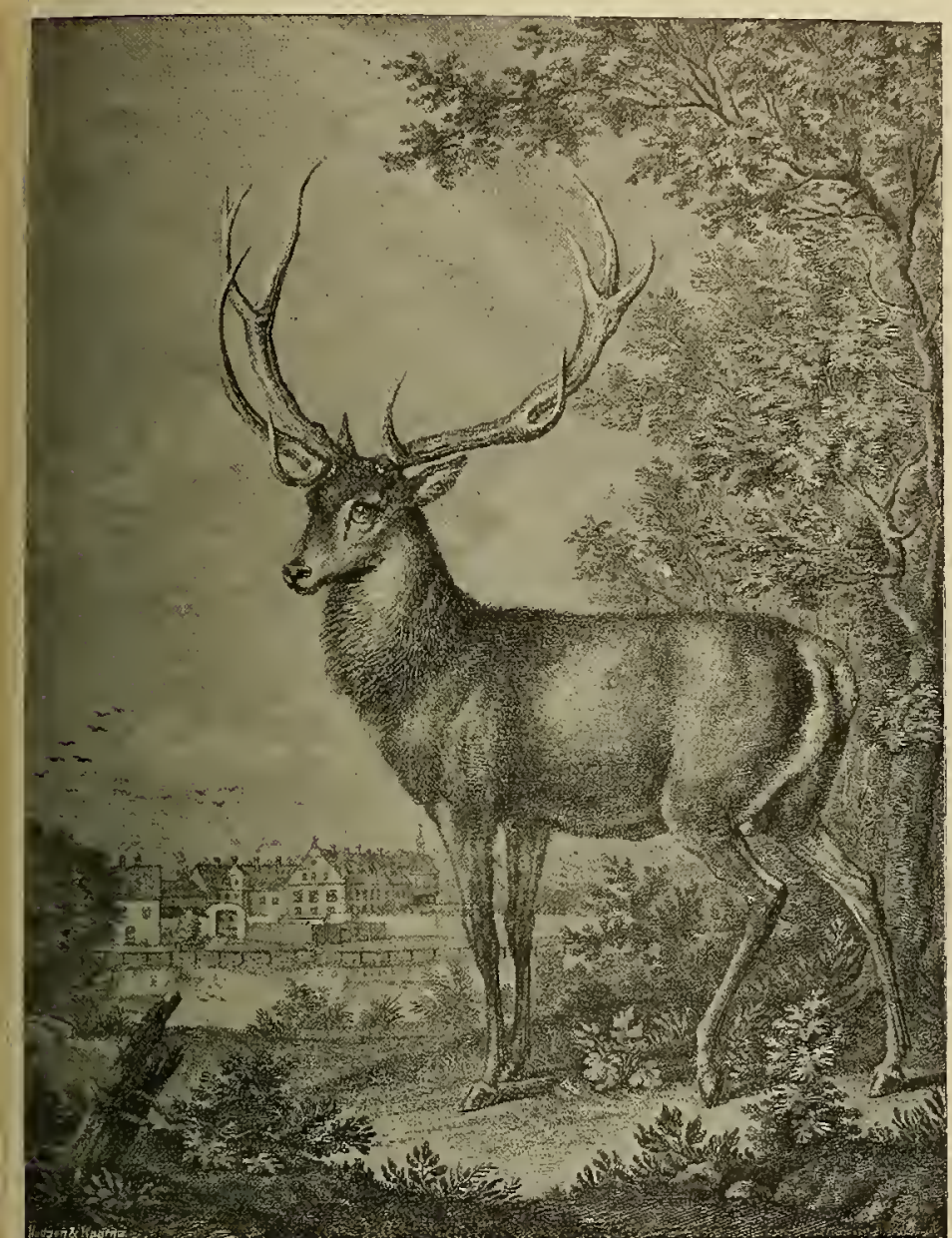

FIG. 197. STAG WITH THREE ANTLERS WHICH ESCAPED FROM THE LANDGRAVE OF HESSE'S PARK BY LEAPING A WALL TWELVE FEET HIGH. BY G. A. EGER; ENGRAVED BY MARTIN RIDINGER (TH. 339). Page 297

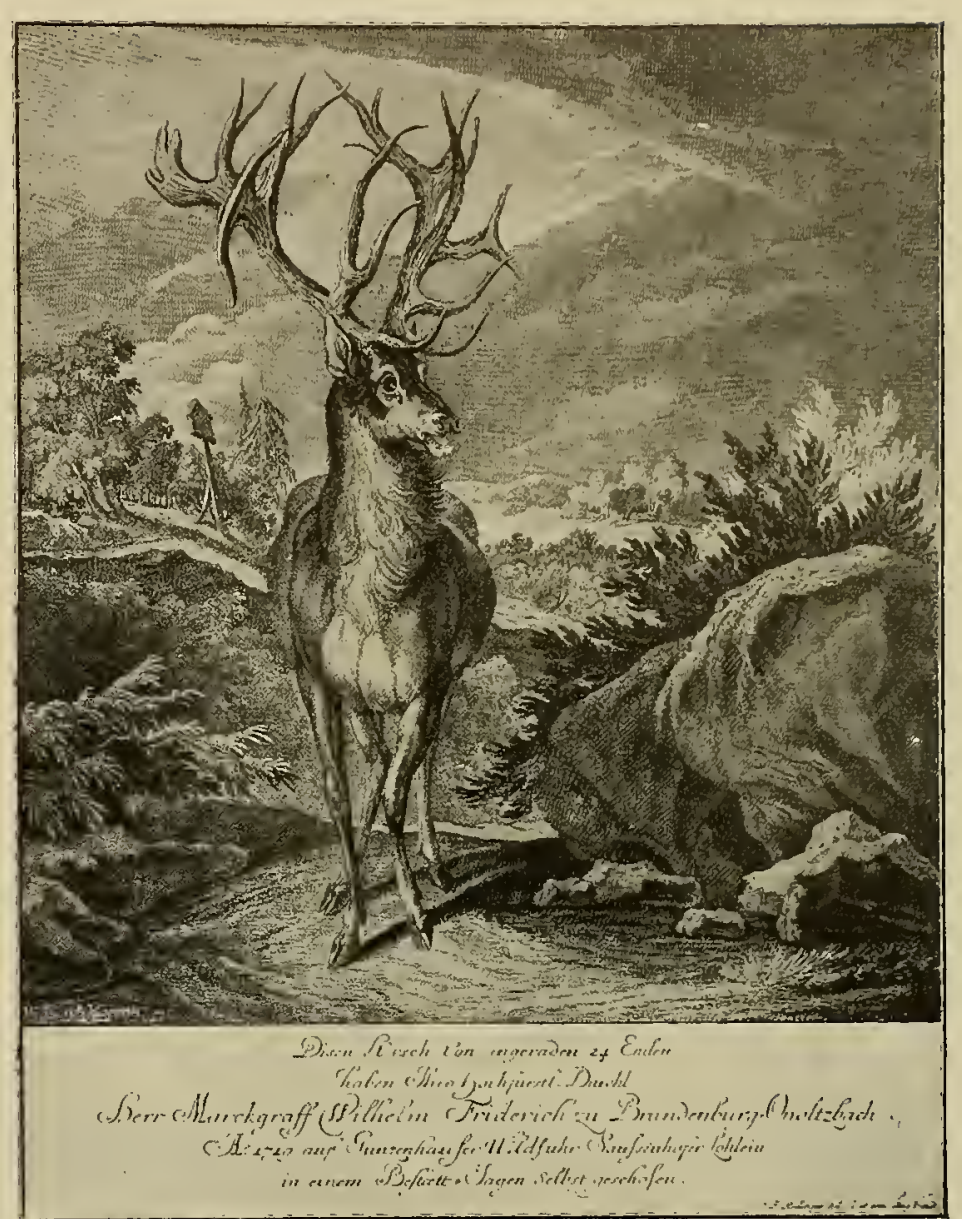

FIG. 198. 'THIS “TWENTY-FOUR POINTER” WAS SHOT IN 1719 BY THE MARKGRAVE OF BRANDENBURG. BY RIDINGER (TH. 24 S). Sce Page 300

the Markgrave shot him in a Bestätıgtes Yagen expressly arranged in order to bring this trophy to book. What enormous preparations, what thorough knowledge of the quarry's dodges and wiles, were entailed in the feat of bringing up a certain stag to the master's stand, only those can realise who are acquainted with the uncertainties of sport in a densely-timbered country. Correspondingly great must have been the rejoicings of the anxious foresters, with their enormous train 


\section{SPORT IX ART}

of underlings, when at last the much-sought-for hart lay stretched out at the feet of the sovereign, and the branching antlers did not belie the tales of their vast size that had caused the lord to order out hundreds of peasants to assist

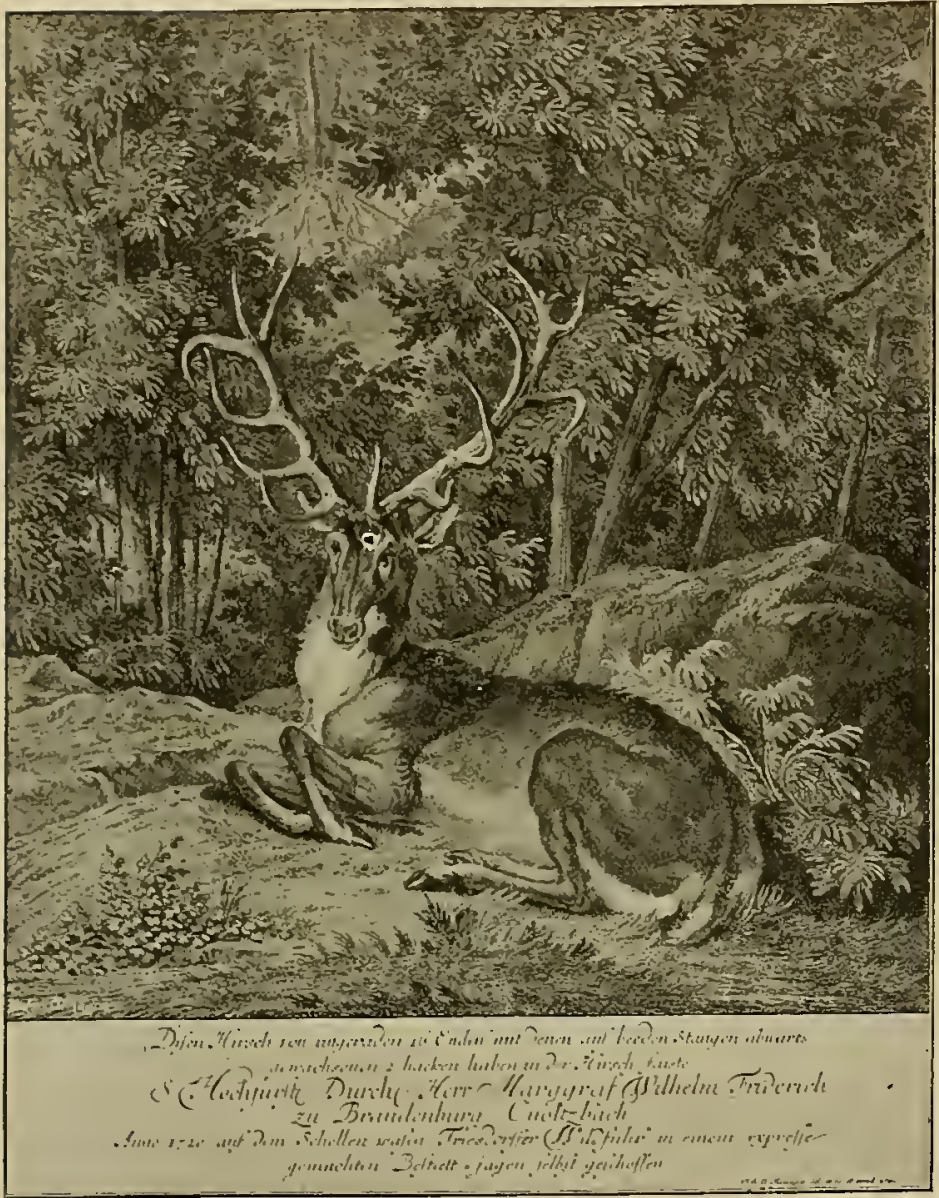

FIG. 199. STAG WITH ABNORMALLY FORMED ANTLERS, SHOT IN 1720 BY THE MARKGRAVE OF BRANDENBURG. BY RIDINGER (TH. 264). See Page 301

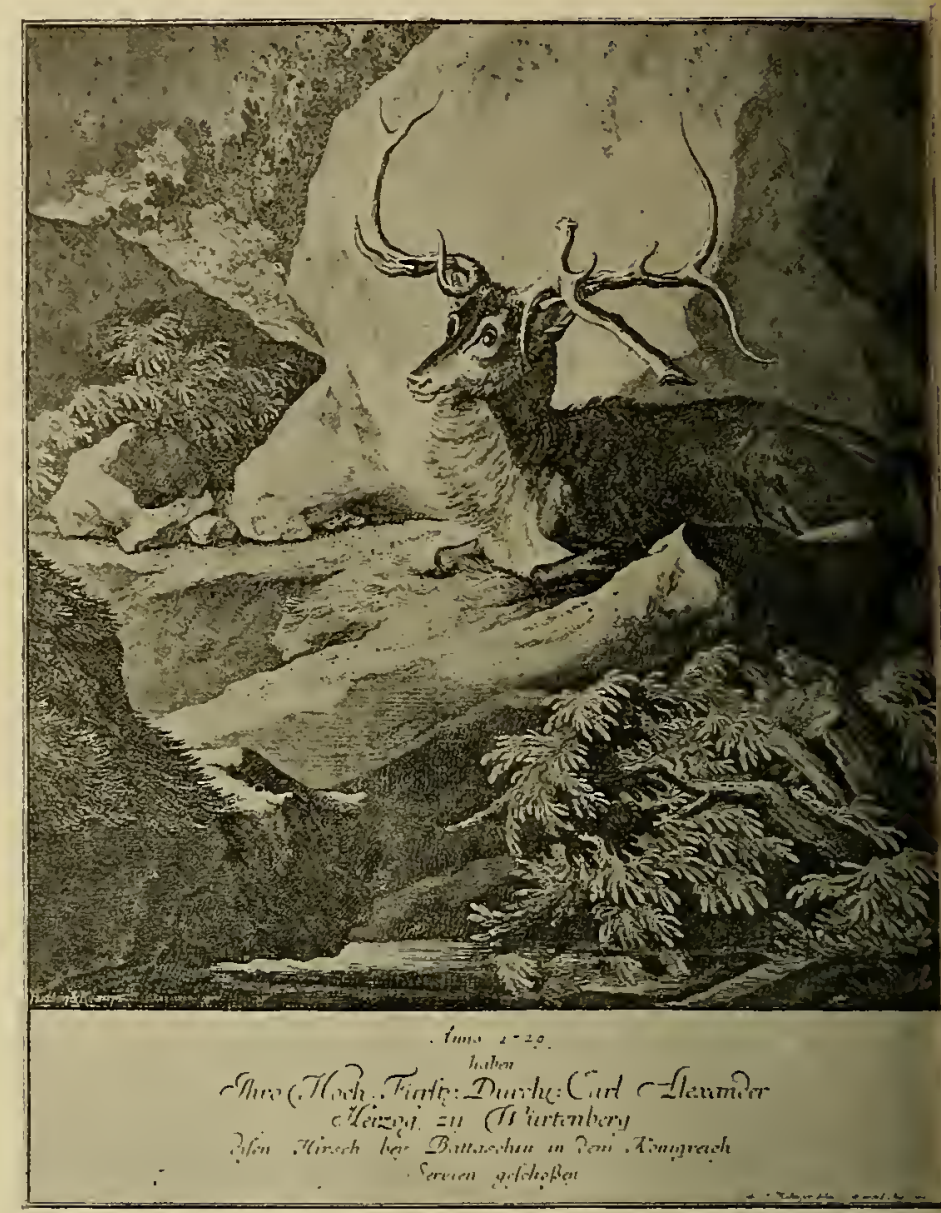

FIG. 200. STAG WITH ABNORMAL ANTLERS, SHOT BY CHARLES ALEX. DUKE OF WÜRTTENBERG IN BATTAS CHIN IN SERVIA, 1729. BY RIDINGER (TH. 253). Page 303

in erecting and guarding for many miles the enclosing screens, and other hundreds to beat the woods.

Two centuries ago shooting expeditions to distant countries, such as we now undertake at a moment's notice, stepping from a sleeping car or from a comfortable steamer in close vicinity to the scene of sport, were very different undertakings, resembling crusades rather than pleasure trips. There are not many instances known of such expeditions, one of the few exceptions being the hunting 302 


\section{SPORT IX ART}

to one authority (Wildungen), this was a speciality to be only found in that duchy. Duke Charles caused them to be separated from the other deer, and to be confined in a park by themselves. Our illustration (Fig. 20I) gives a picture of

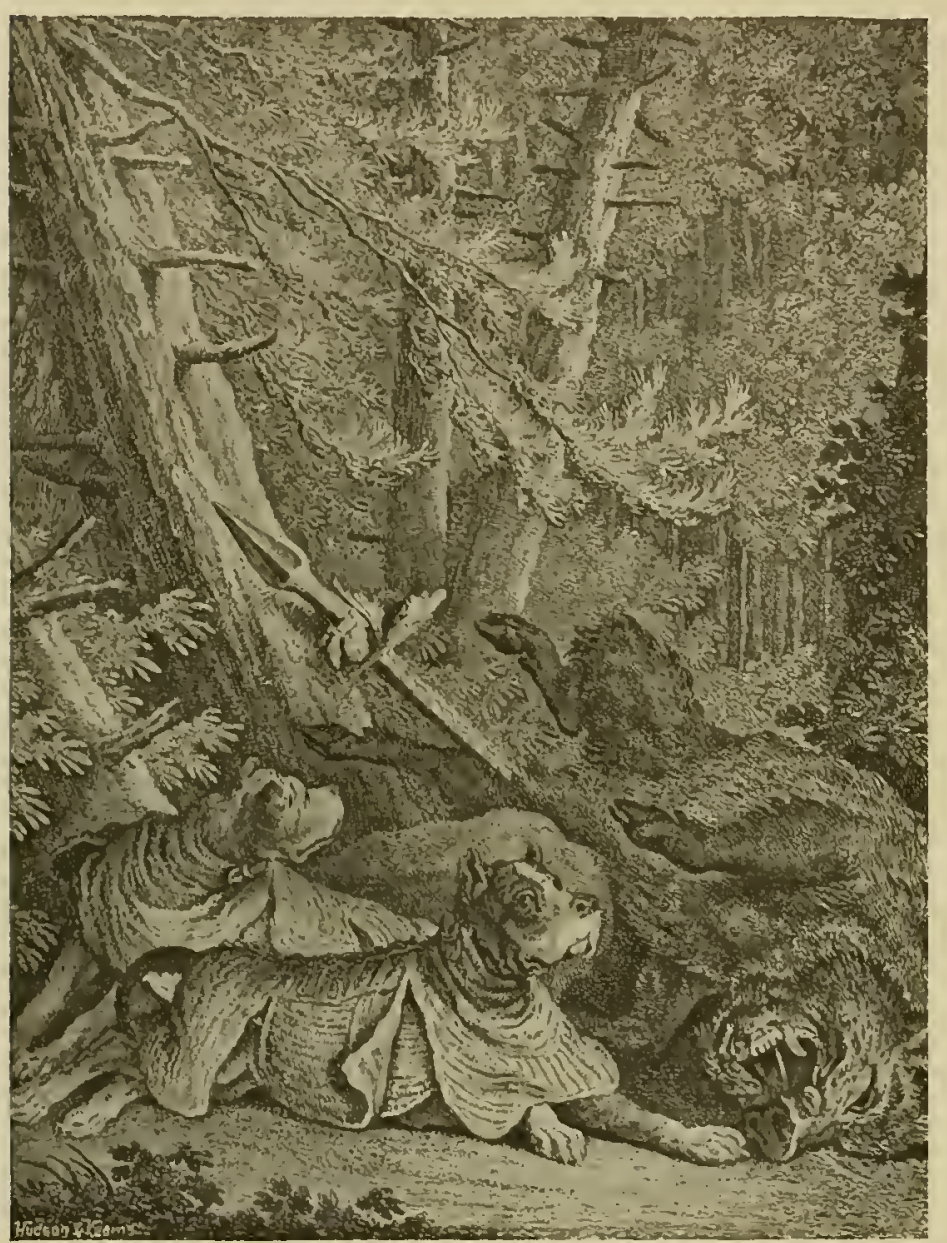

FIG, 203. HOUNDS USED FOR WILD-BOAR HUNTING IN IYHLIR COATS OF MAIL, MADE OF QUILTED CANVAS OR LIAI'FILR. BY RIDINGliR (TH. 309). See Page 30 j one shot in I7I 5 in the course of a drive. There is an additional interest attached to this engraving, for we see how the two kinds of "Lappen" were used. The one consisted or pieces of coloured cloth attached to cords and hung up in such a manner that they would flutter in the breeze and scare back the game, and thus keep it in the drive. The other and more familiar kind were made of bunches of feathers, such as we know were already used by the Romans, who called then formido. In many parts of Germany the manufacture of these latter was a duty imposed upon the persecuted Jews, and woebetide him who failed to turn out the 1000 bunches per annum which each Jew had to furnish to the keepers of his lord. On the cloth "Lappen" it was usual to blazen the coat of arms or the ducal initials. In the picture before us the frightened stag made a clean leap over both lines, for to judge by the inconsiderable height of the "Lappen," the drive was a roe-deer drive and not a Hirsch 'Jagd.

Fig. 202 is a spirited plate executed at what was Ridinger's best period, i.e. about the year 1742 . The stag in question after being pursued by three hounds took a prodigious leap down a sheer cliff into the Danube. Two of the hounds 304 


\section{FOX GAUGHT BY A PIKE}

stuck so pluckily to their quarry that the hart was caught alive when leaving the river.**

Fig. 203 pictures the bygone custom of protecting the hounds employed in hunting the ferocious boar with "coats of mail," if we may so term coverings made of leather, or strong canvas, wire and hempen cord. They were used for several centuries, in fact until the nineteenth century, and of course the life of many a valuable boar-hound must have been saved thereby from cruel tusks. When hunting with the late Duke Ernst II of Coburg in Thuringian forest in the seventies, the writer was shown some sets of these curious " coats of mail" preserved in one of the old sporting armouries near Gotha.

Fig. 204 tells its own tale, but the particulars which the careful Ridinger gives us in the lengthy inscription engraved under the picture are worth repeating. $\uparrow$ It appears that on the occasion of some ponds being laid dry to get at the fish, the captured "bag" was carried home in a wooden trough. While being thus conveyed overland by two

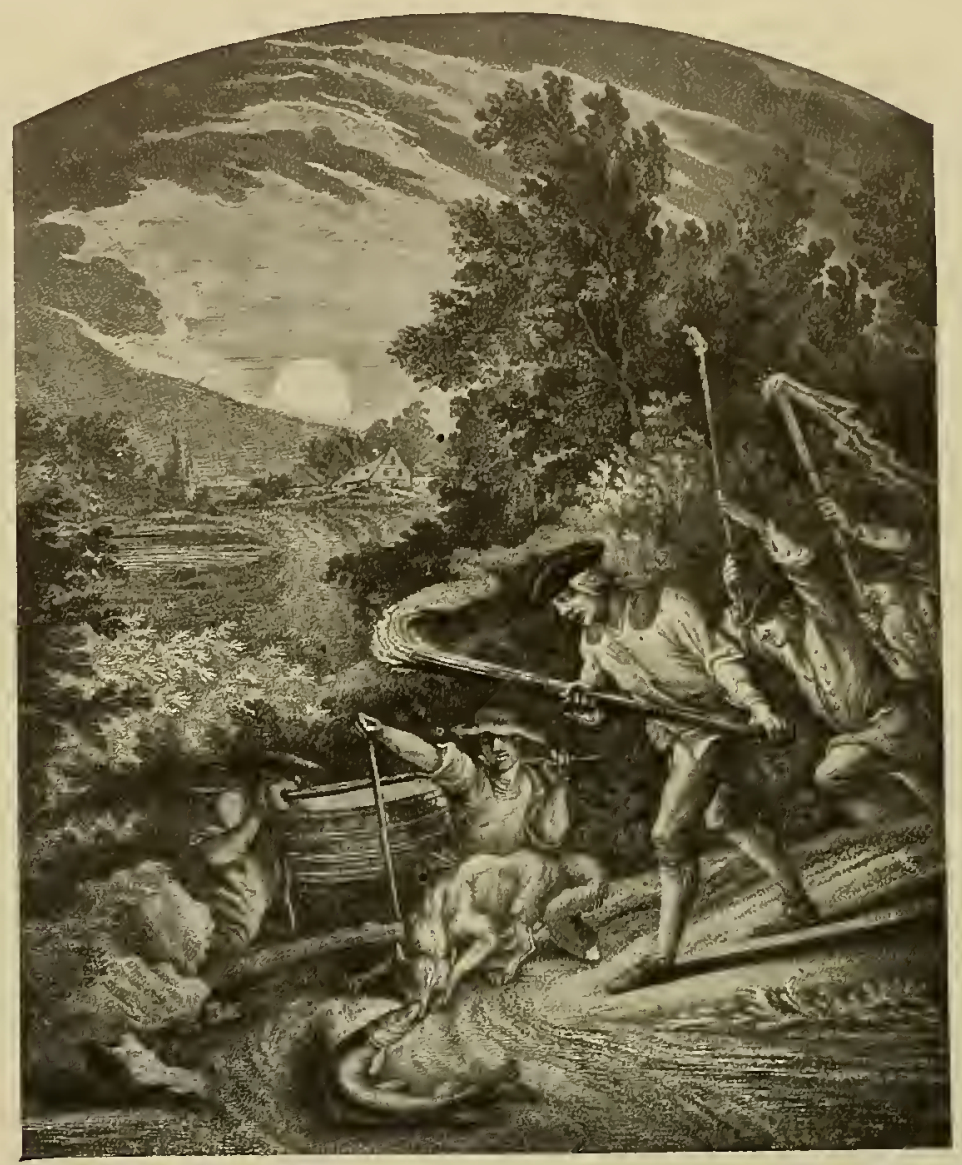

FIG. 204. CURIOUS INCIDENT OF A LIVE FOX BEING CAUGHT BY A LARGE PIKE WHICH HAD ESCAPED FROM A FISH TROUGH WHILE BEING CARRIED OVERLAND. IT OCCURRED IN THE YEAR I723 IN PYRBAUM IN THE COUNTSHIP OF WALDSTEIN. THE PIKE WEIGHED 15 LB. BY RIDINGER (TH. 317). See Page 305 men, a large pike escaped, and three men with torches were sent back when the loss was discovered. They found the lost fish, but in a somewhat peculiar position! A prowling fox had discovered the pike, and approaching it carelessly the pike had caught his muzzle in his wide maw, retaining him a prisoner. It is a good and probably true story.

* The original drawing of this plate is in the Albertina in Vienna.

$\uparrow$ The original drawing is in the Albertina in Vienna. 


\section{CHAPTER XII : RIDINGER AND LATER ARTISTS OF THE XVIII CENTURY}

URNING now to another interesting series of Ridinger's engravings, we reach the one called "Curious Events," if we may freely translate the German Besondere Ereignisse. It consists of forty-eight plates, counting the title-plate, and the subjects it depicts do not belie the title, for some of the events it illustrates are quite remarkable. The three reproductions we have selected will suffice to show this, though, as a matter of fact, it would have been far more fit to classify the last print we spoke of among the "Curious Events" rather than among the "Most Wonderful Stags."

Figs. 205 and 206 are pendants; the first shows very faulty drawing, for, in the first place, no European ibex horns possess the twist Ridinger has given them; and, secondly, the flowing beard with which Ridinger has adorned the animal is a creation of his imagination not corresponding with reality, though its existence was universally believed up to comparatively quite modern times. That lynx frequented the region inhabited by ibex is rather nearer truth, as is also the manner in which the ibex punished his sneaking foe. Curiously enough when out shooting in the Rockies, the writer came across an instance of a big-horn having crushed to death a specimen of the same dangerous vermin. Though he did not see the struggle itself, and only came upon the dead body of the lynx some hours afterwards, the tracks in the ground left no doubt of the identity of the beast that had killed it.

The other picture out of this set (Fig. 207) is to an equal extent an emanation or Ridinger's imagination, for, needless to say, our master never crossed the ocean, and could not possibly have witnessed a fight between an American bison and three bears!

A fourth series, "The Manner of Capturing Wild Animals," illustrates in thirty plates the various methods of shooting, trapping, snaring, and netting various animals, such as the different deer species, the chamois, bear, fox, wolr, boar, badger, otter, and, lastly, wild fowl, such as the capercaillie, black-cock, and partridges. The latter were captured by "tirassing" with a net in the manner similar to that we have already noticed in the prints of Stradanus and Hans Bol; though in their time there was rather more excuse for using these poaching devices in view of the primitive nature of fire-arms.

Fig. 208 is an amusing picture of a sportsman's dress as worn when stalking stags in dense woods. His cocked hat hardly assimilates itself to his bare feet, his boots being fastened behind to his belt.

Although we know that Ridinger frequently visited the Black Forest and the foothills of the Alps, it is doubtful whether he ever got among the higher 306 


\section{RIDIX్R'S MOUXTAIX GAME}

mountain regions of Switzerland or Tyrol, and probably the task of depicting a mountain sportsman must have puzzled the Augsburg painter. As an instance may be cited his print of three sportsmen, ensconced behind bushes, shooting at a band

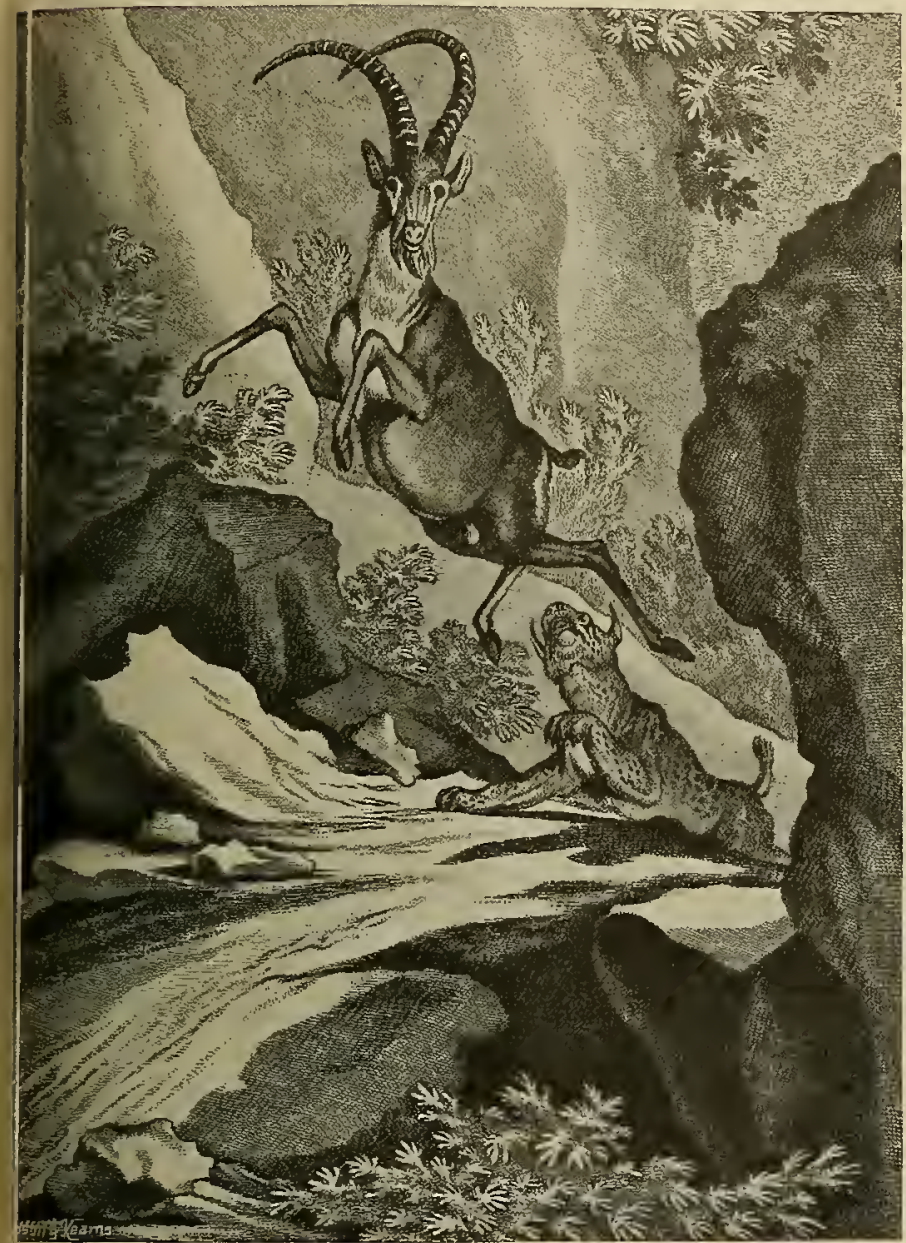

13. 205. IBEX ESCAPING FROM A LYNX. PROBABLY I' MARTIN RIDINGER (TH. 363). See Page 306

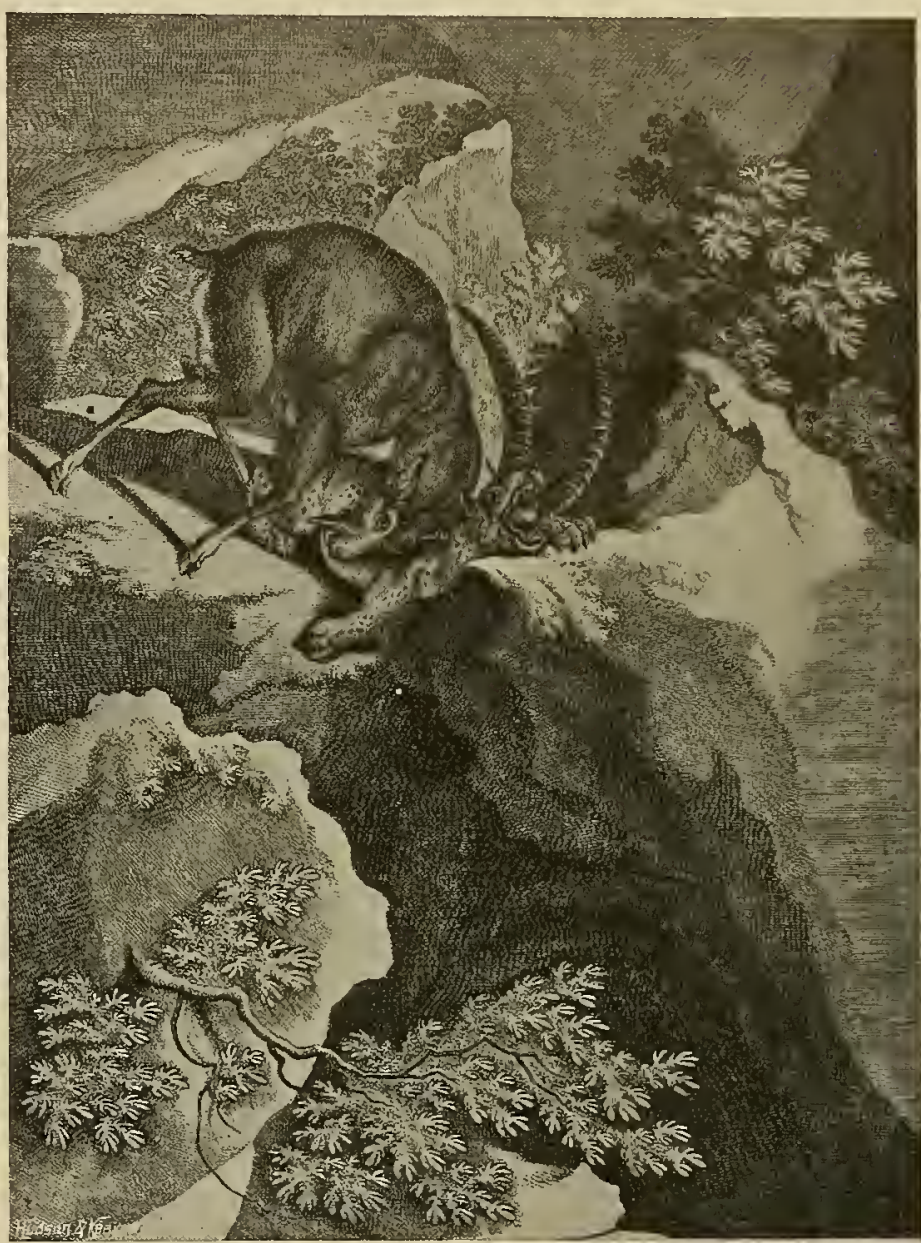

FIG. 206. IBEX CRUSHING TO DEATH A LYNX. PROBABLY BY MARTIN RIDINGER (TH. 364). See Page 305

of five chamois running at very close range past the men's hiding-place. The bold chamois-hunters wear three-cornered hats, and broad white bandoliers cross their chests in a manner that must have made these hunters very conspicuous objects. No wonder chamois increased and throve in days when their pursuers wore pig-tails and powder, with big three-cornered hats to top off the fancy costume! Ridinger evidently knew more about his stags, wild boar, and roebucks with 


\section{SPORT IX ART}

monstrous heads, than he did of chamois and ibex. But that, after all, was the fault of the time in which he lived, and of the popular ignorance, which firmly believed that the higher regions of the Alps were inaccessible, monster-inhabited wilds, which to invade spelt death in one form or another.

It will probably suffice to give of each of four other series a single print. The set called "Sporting Animals with their Tracks" consists of twenty-four plates,

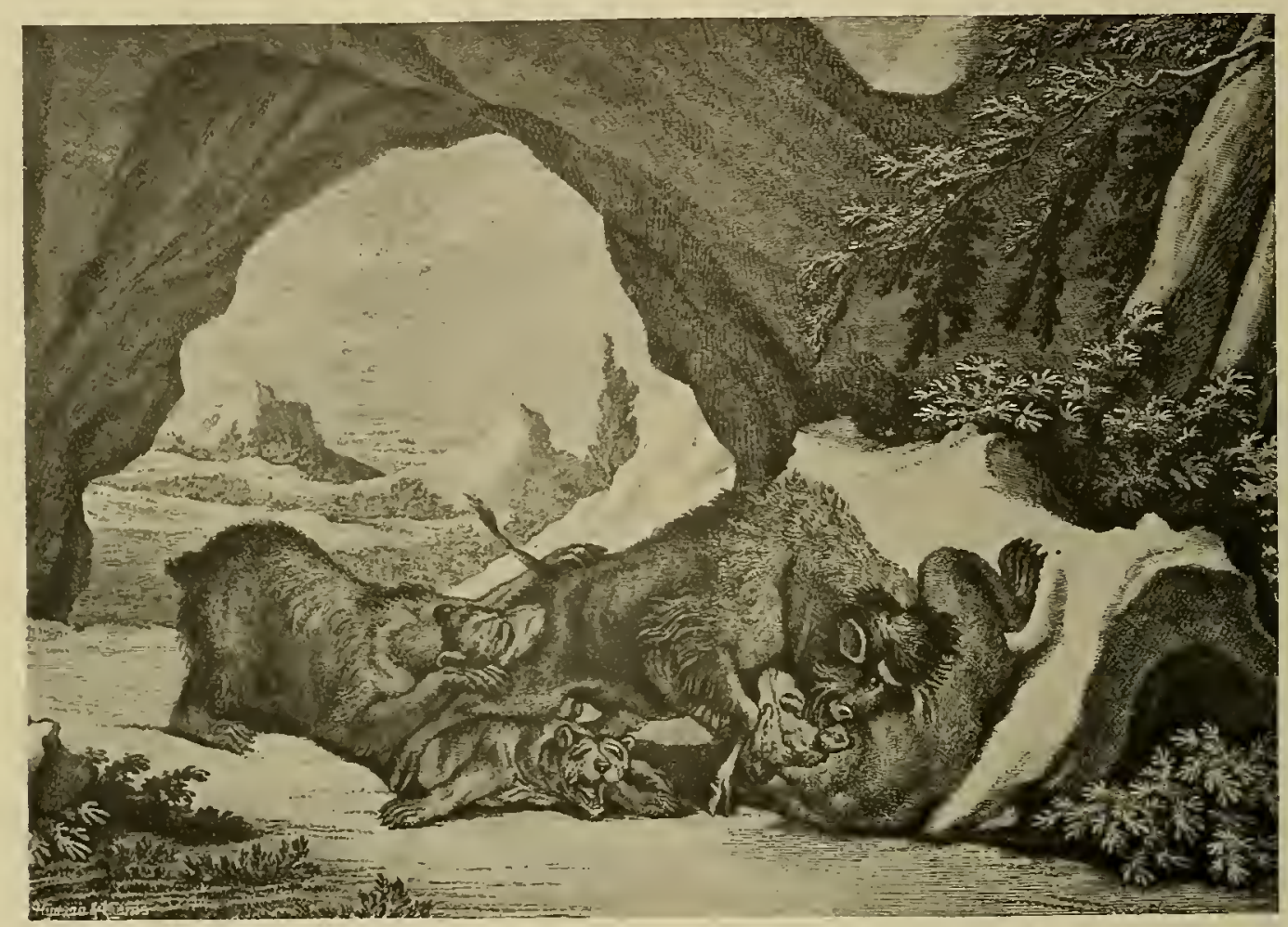

FIG. 20\%. AMERICAN BISON FIGHTING BEARS. BY RIDINGER (TH. 362). Page 306

counting title-plate, and, as Fig. 209 shows a large size picture of each animal's track underneath that of the animal, carries out the idea indicated by the title. In this, as in most others of this set, Ridinger gives the spoor when the animal is walking quietly and also when in flight, a distinction as useful to the practical sportsman as it is interesting to the amateur veneur. In this instance the ibex is drawn fairly correctly, the "beard" being of natural proportions.

The second series, "The Fights of Wild Animals," is more curious than interesting. Consisting of eight plates it represents fights between a horse and a lion ; a combat between a she-bear defending her cubs against a lioness; a fight between a leopard and a donkey; a camel and a jaguar; an elephant and a rhinoceros; 308 


\section{RIDIX్XGE'S WILD A A I MALS}

a buffalo and a crocodile; a hippopotamus and a lion; and, finally, a fight between an "aur-ochs" and a tiger, of which Fig. 2 ro is a reproduction on a much reduced scale.

We must not forget another long series, "Contemplation of Wild Animals," consisting of forty-one plates, including the title-plate. Unlike some other series it is the exclusive work of Ridinger, every plate being drawn and engraved by him.

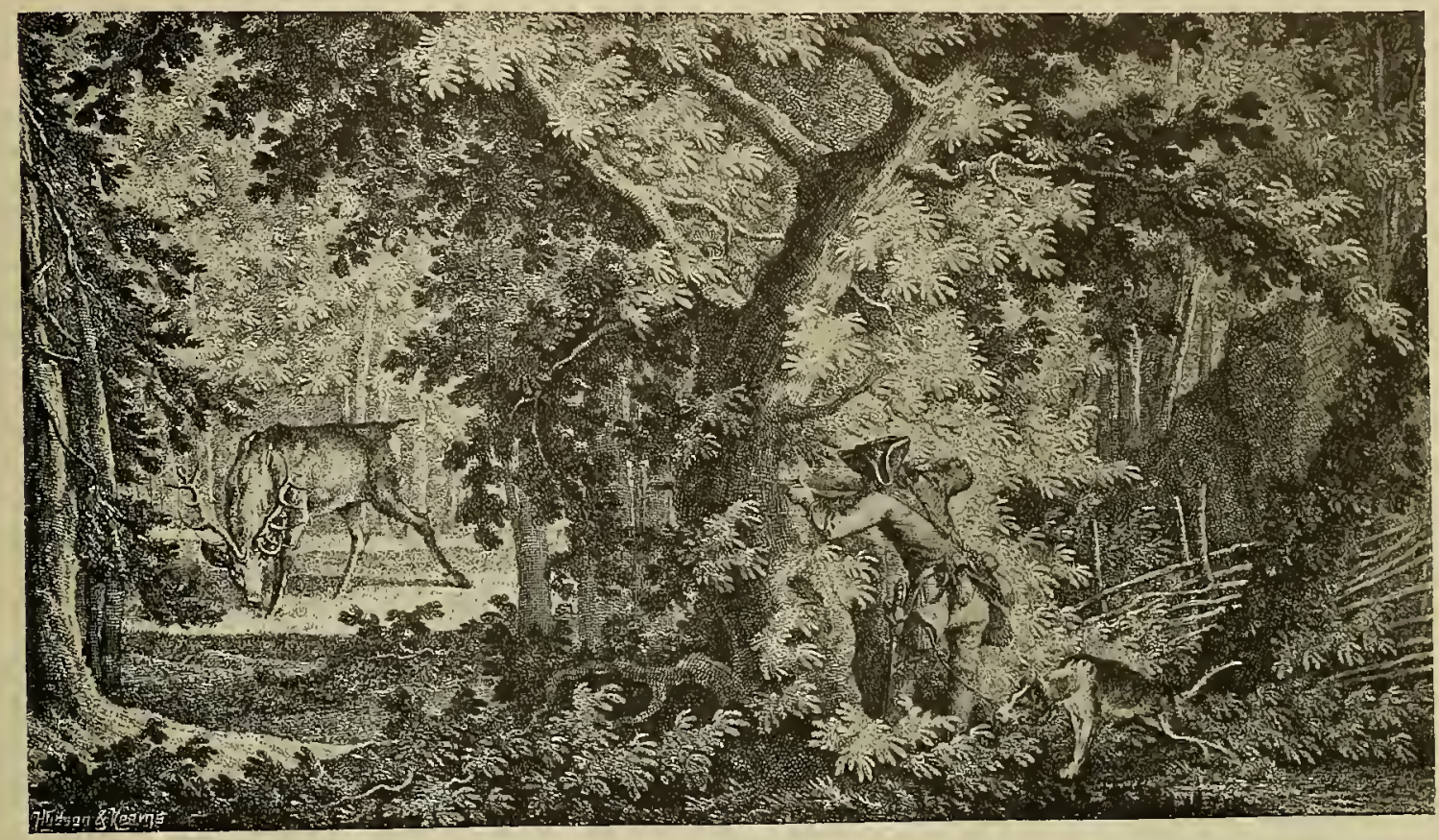

FIG. 208. STALKER IN COCKED HAT AND BARE FEET APPROACHING STAG IN DENSE WOOD. BY RIDINGER (TH. 7r). See Page 306

On the title-page we are told that the "very considerate reader's humble servant, Joh. El. Ridinger, designed, drew and engraved these forty-one plates in the year 1736 at Augsburg." German and Latin verses, which the artist describes as "excellent poesy by the exceedingly celebrated Herrn Berthold H. Brockes," adorn each plate ; and to make the meaning of his designs even more plain to his foreign readers there is a French inscription added to the German and Latin titles. The animals depicted in this set comprise practically all the game animals then known to the sportsman-the last of the set, a wild horse, showing that he had come to the end of his tether. Master Brockes' rhyme, informing the reader that this is the last of the lot, says: "for I cannot follow you any longer, Ridinger, or you'll have to draw all alone."

Of horses Ridinger has left a great number of pictures. There is a combined set 


\section{SPORT IX ART}

of thirty-six purporting to show us the animal according to nationality. We

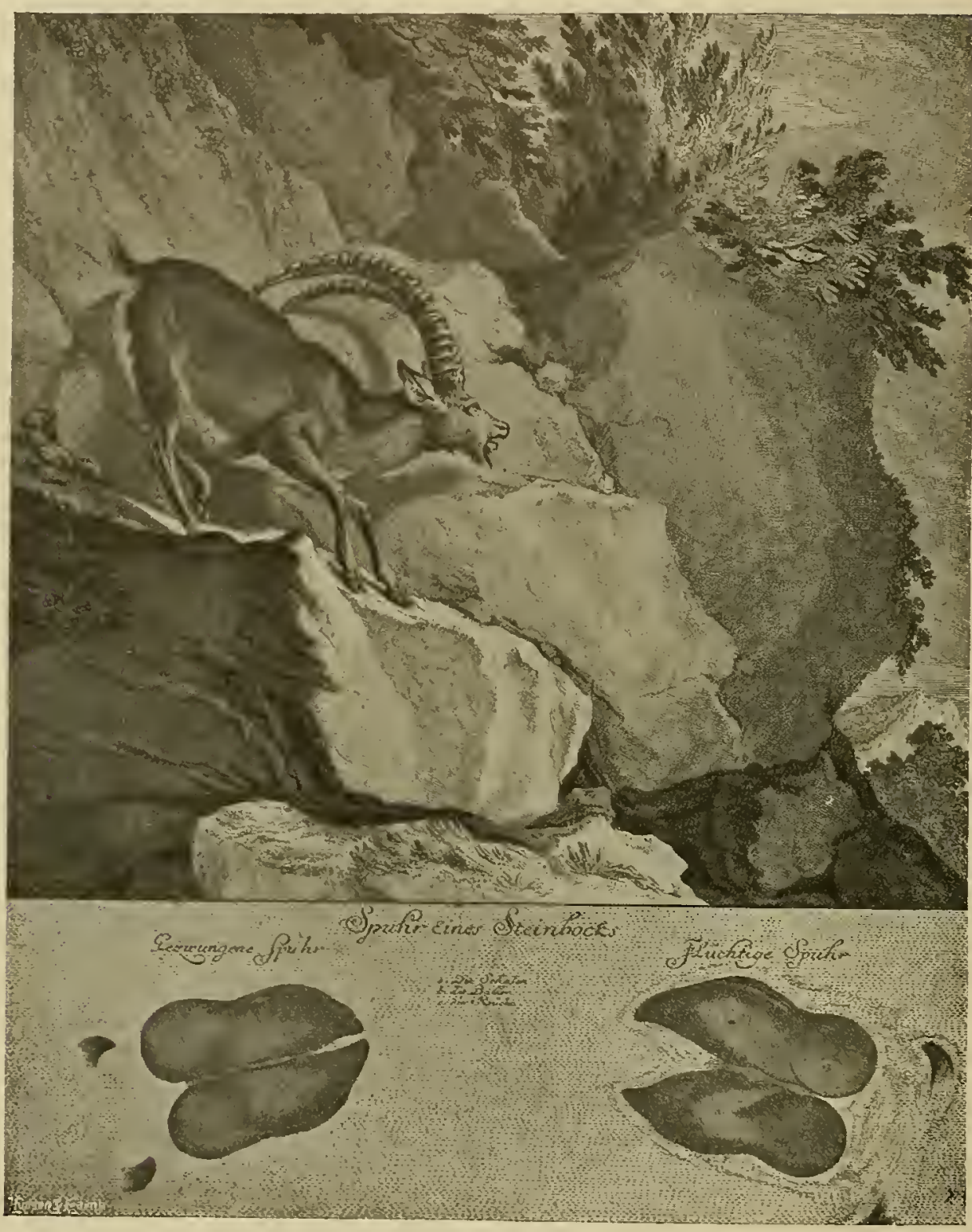

FIG. 209. ALPINE IBEX, AND HIS TRACKS WALKING AND RUNNING. BY RIDINGER (TH. 173). Sce Page 308

have the Arab, the Persian, the Barb, the Turkish, the Wallachian, or Seraskier, as Ridinger calls this species, the Tartar, the Spanish, the Spanish Genet, the Engellaender (which might be any of the other types), the German horse, the 310 


\section{RIDIX్RE'S PRIXT'S OF HORSES}

Russian, the Bohemian, the Holstein, the Mecklenbourg, the Oldenburg, the Frieslander, the Dutch, the French horse from Limosin, the Norman, the Neapolitan, the Dane, the Swede, the Polish, the Hungarian, the Transylvanian, the Croatian, the Muscovite, \&c. Then there is a set of six plates showing the various operations upon horses, by farriers and vets., some of which are depicted with great realism.

A far pleasanter subject is the art of riding depicted in several series of prints. The earliest, consisting of twentytwo plates, dates from the year 1722 and is called the New Art of Riding. It was evidently a set which Ridinger completed on commission, Jeremias Wolff, art dealer in Augsburg, being the publisher. They are a somewhat tame lot, engraved not by Ridinger, hut by J. B. Probst, the publisher's sonin-law. The pictures have German and French titles: thus Das Trottiren or Le Trot, with a verse in French. Many of the plates illustrate

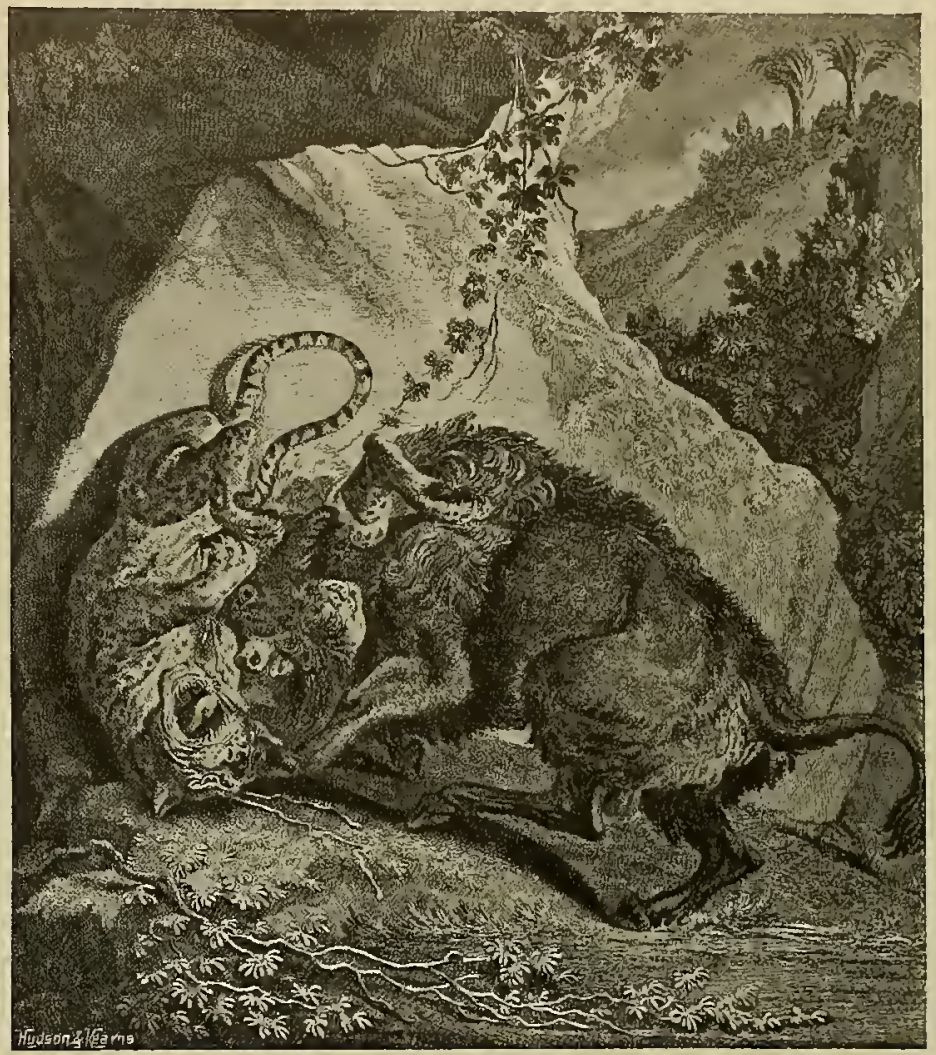

FIG. 210. “AUR-OCHS" AND TIGER. BY RIDINGER. (TH.717). See Figs. 20, 46, 47, 79, 88, 99, 102, 110, 151, 225, 227, and Prges37-5I, 86-90

the curious rather than useful training which horses received in Ridinger's time. Another set, "The New Riding School," comprises eighteen plates, and is but another version of the same subject. Then there is a set called "Description of the School and Campaign Horses" which embraces no fewer than forty-six plates, while another, the "The Carousel," with fifteen plates, deals again with ridingschool performances. A really fine and interesting set is "The Large Riding School," which, drawn by Ridinger, was engraved after his death by his son Martin. It is the latter's best work. These six plates, and two additional ones that may be included, are fine large pictures which give a capital idea of the real character of this riding-school horsemanship. A brief explanation may not be out of place. 


\section{SPORT IX ART}

The term art would not have been applied by the horseman of the old school to that kind of riding which enables a man to stick on in some fashion or other, while his horse carries him across country after, or too often on to, the hounds, nor to being perched monkey-like on the withers of the horse, by which some modern jockeys bring their mounts first past the winning-post. About the middle of the eighteenth century, when Ridinger limned these pictures, the art of riding meant that knowledge which enabled both horse and rider to show themselves off to hest advantage, in all the dignity and ceremony befitting the position of a courtly cavalier and a stately steed. In his time the Manege, i.e. the training and riding of the great horse, as the war-horse was called, and the "stirrer," or pleasurehorse, was still considered one of the essentials of a gentleman's education. A remnant of this training of horses may occasionally still be seen at circus performances, but the staid "comeliness" and "decency," indispensable to the riding school of the ancient régime, have disappeared from our midst, whether for good or for bad the reader can best decide.

From the time of Elizabeth to the pericd represented by our illustrations this art, and the training of horses for the haute école, was the subject of a great number of books, pamphlets, and prints. One of the earlier English works of this kind was penned by one Maister Blundevill in I 597. He laments the lack of knowledge on the part of Englishmen, "as is best seen at a muster when the Queenes Maiesty hath need of horses and horsemen, where oftentimes ye shall see some that sit on their horses like wind-shaken reeds, handling their hands and legs like weavers; or if the horsemen be good, then the horse for his part shall be so broken, as when he is spurred to go forward he will go backward, and when his rider will have him turne on the right he will turne clean contrarie, and when he should stop he will arm him selfe and run awaie, or else stop sooner than his rider would have him, or use such-like toys."

In Fig. 2 I I we observe the elementary lessons for a young horse and young rider. The horse we see in the left-hand corner of the foreground is being led in blinkers till he gets accustomed to the sights of the school. In the background on the right we see one of the young ones being lunged. In the right-hand corner is the mounting-block, and the rider is learning to mount. In the centre he is seated in the correct position upright, his stirrups " neither too long nor too short, his elbows close in to his sides, his reins in his left hand close to the pommel of the saddle, and his 'rodde' borne low by the rider's thighe, but not upon his thighe, with the point upward, and before you come to the place of turning you may let it fall to the right side of his (the horse's) head." This is all being explained to the rider by the riding-master standing in the centre group of the picture. In the background a man is trotting his horse along a wall, considered an excellent manner of teaching a horse to keep a straight line, or, as our ancient authors say, to keep a "forthright path." 


\section{SPORT IX ART}

accustomed to the drum and waving banners on parade or on the field of battle. The lessons of the school intended to teach a horse first to pace, then to trot, then to gallop round the ring, first taking, as Blundevill says, "two tornes to the right and then two tornes to the left," so that they might be handy turning on both hands. In the background a horse is being taught to back, "which will

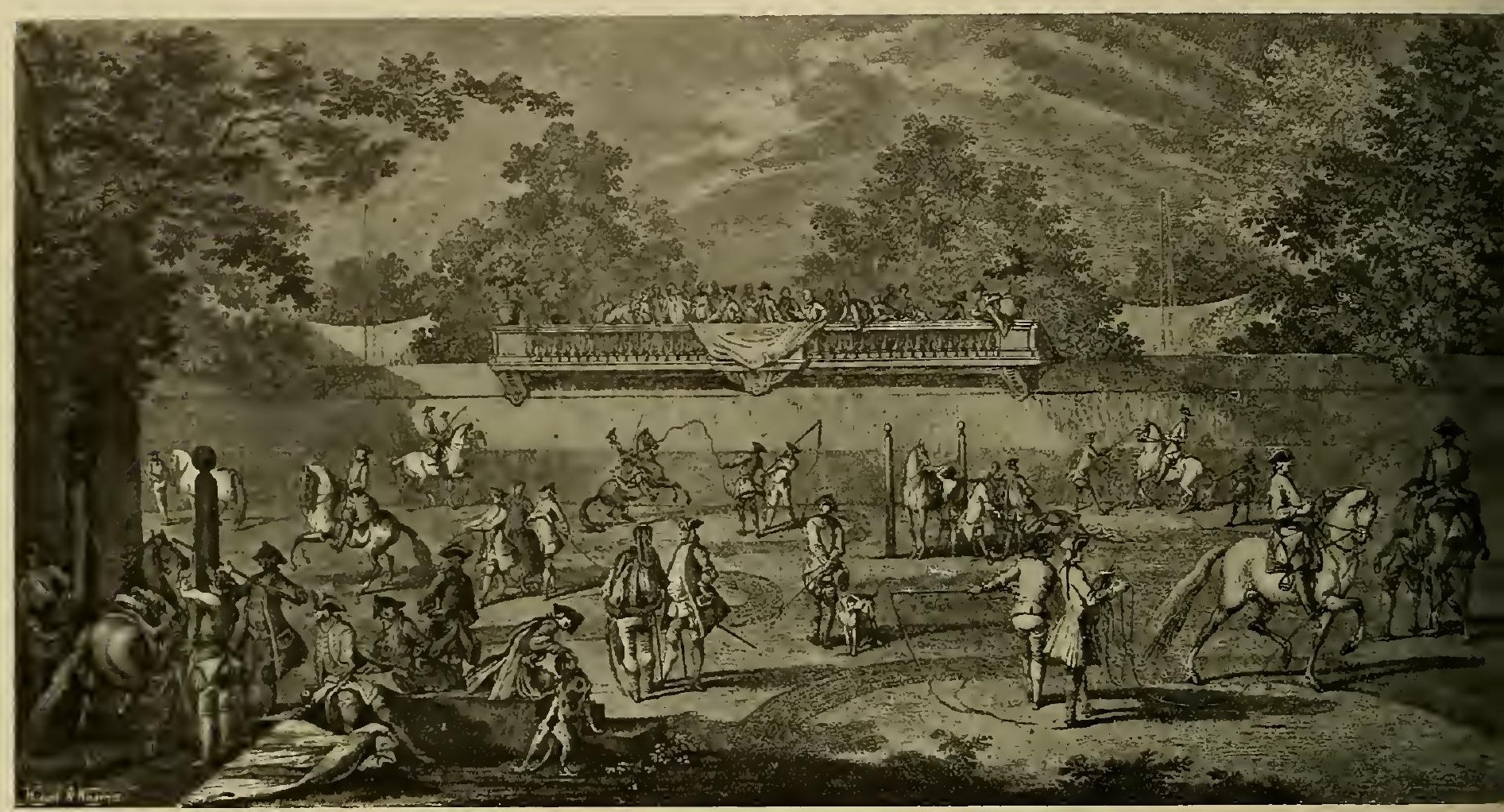

FIG. 212. TEACHING HORSES VARIOUS EVOLUTIONS. BY RIDINGER (TH. 709). See Page $3{ }^{\mathrm{I}} 3$

not onely staie his mouth, and make him light of head, but also to lift his legs and to be the more apt to advance before."

Fig. 2 I 3 shows us a riding school, in the centre of which horses are being trained "to turne readily on both hands." There were "half turnes, whole turnes, and double turnes: the half turne is when a horse turneth on the one side, setting his head that way where his taile before stood, but if he doubleth the same and setteth his head that waie it stood at first, then it is called a whole turne, and two such turnes do make a double turne." We see two horses being taught to go sidelong, one with his hind quarters against a pillar, and the other with his head towards the pillar, and going round it. In the background against the wall 3 I 4 


\section{RIDIXG SCHOOL TRIGKS}

is another horse being taught to go "sidelong both with his foreparts and hinder parts in equal motions," as it was " of great use in the warres, and of so much delight in the place of pleasure." The rider on the right near the wall in this picture is doing the terra terra, which one author describes as "how to train your horse to turn upon the ground." This especial feat was that the horse turned on

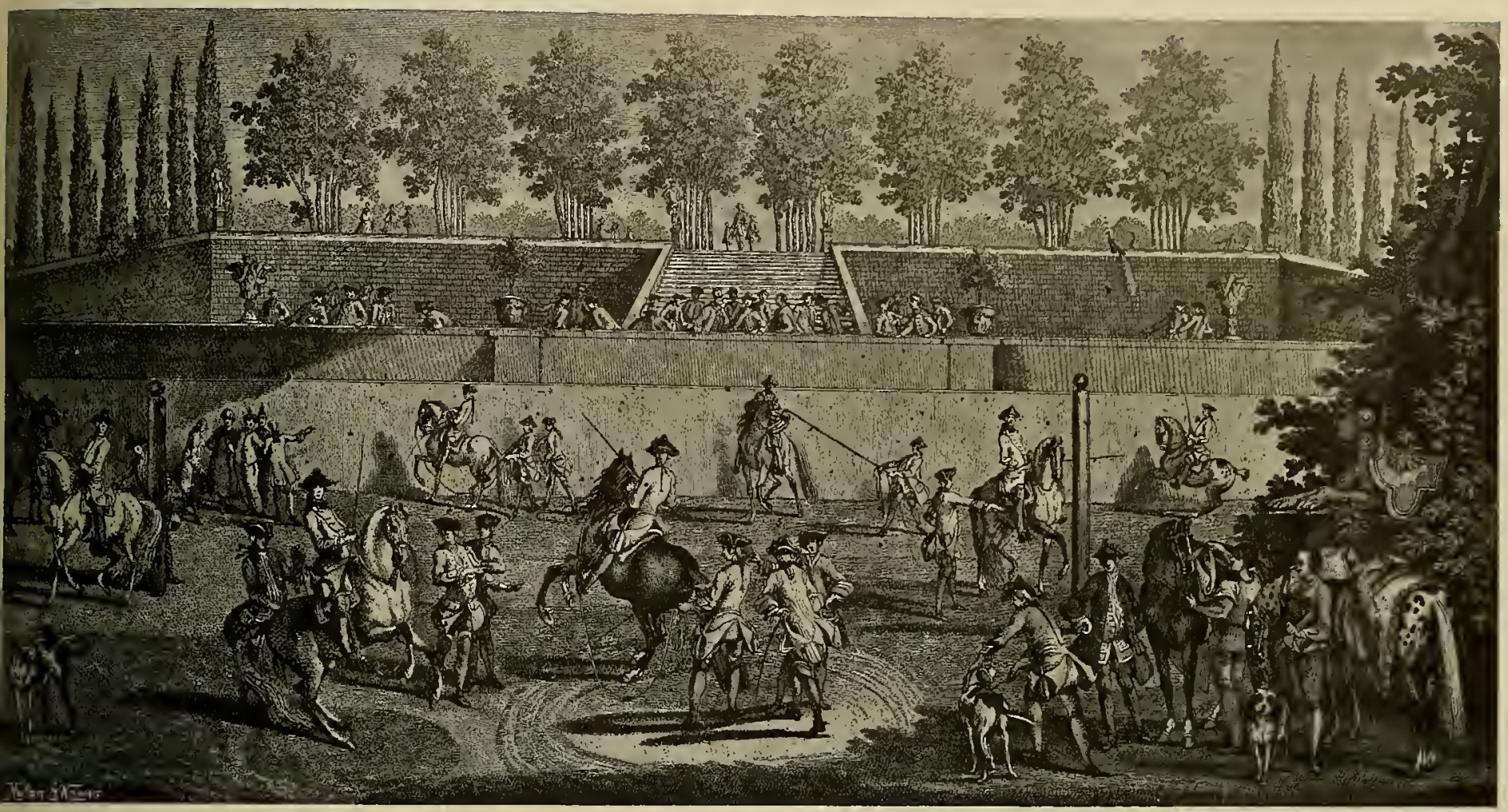

FIG. 213. HOW HORSES WERE TAUGHT THE TRICKS OF THE RIDING SCHOOL. BY RIDINGER (TH. 710). See Page 314

his haunches, only lifting his fore-feet a little above the ground, and not with a bound in the air, which was a trick they were also taught, and was called "turning aloft." Fig. 2 I 4 shows us horses doing the double-turn, curvetting and pirouetting.

In Fig. 2 I 5 the performances are more advanced. We have the pesate, or, as Blundevill calls it, "the advancing before," when "the horse at the stop lifteth both his fore-feet even together, and somewhat above the ground, and letteth them fall again twice or thrice together." Then came the lesson to teach the horse to yarke behind, i.e. " to gather up his rumpe and cast out both his heels even togithere," which action, combined with the pesate, became the capriole, or 


\section{SPORT IX ART}

"goat's leap." In the last picture (Fig. 216) a great noise is being made in the right-hand corner. They are drumming, waving a banner, and letting off "harquebusses," to accustom the horses to the din. One horseman in the background has reined in his horse and is standing at parade, having finished showing his horse's feats, and along the wall behind him a borse is passing his

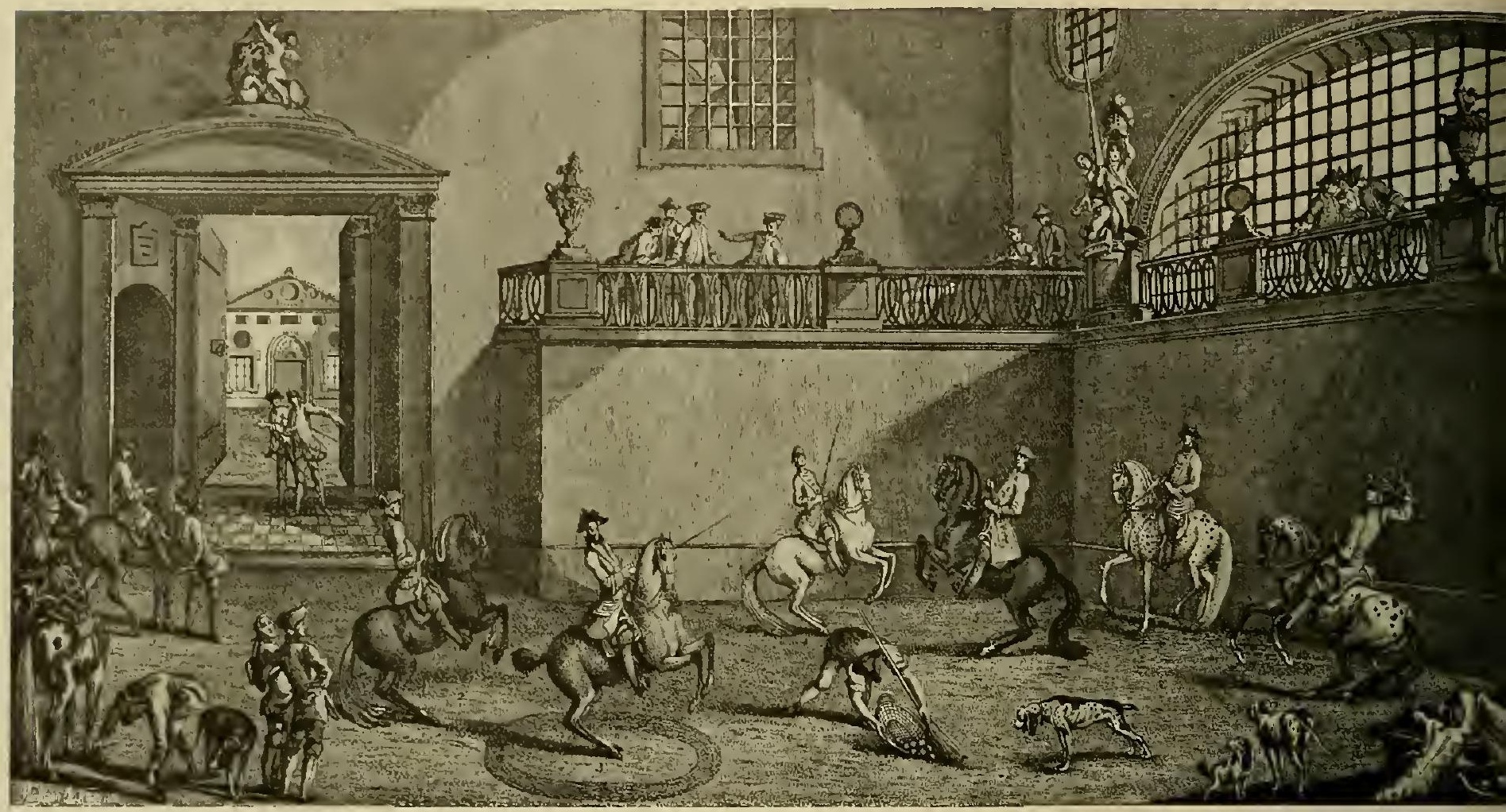

FIG. 214 . LEARNING THE DOUBLE TURN, CURVETTING AND PIROUETTING. BY RIDINGER (TH. 711). Sic Page 315

cariere. The cariere was a short course of some four score and ten paces, along which a horse galloped at full speed, stopped, did the pesate, or turned terra terra, or with a single turn, and again galloped or passed the cariere, being forced " to rum so swiftlie and so roundlie as he possibly can, even to the ende to the intent that he may stop on his buttocks." And for a proper finish to every feat of horsemanship our good Master says : "If upon every stop and conclusion (as the last of all labour) you make your horse bound and yarke out withall, it is most comely."

One of Ridinger's largest-sized series is the so-called "Paradise" set, consisting of twelve plates measuring $5^{\mathrm{I}}$ by $36 \mathrm{~cm}$. It is a work upon which Ridinger 3 I 6 


\section{RIDIXGER'S SPORTIX్ DOGS}

devoted probably more pains and time than upon any other. Weigel possessed a big portfolio, so Thienemann mentions, full of studies for this set; and this we can well believe if we examine the wealth of detail in these plates. As their subject, the creation and fall of man, does not come within the scope of our treatise, we cannot spare space for an example.

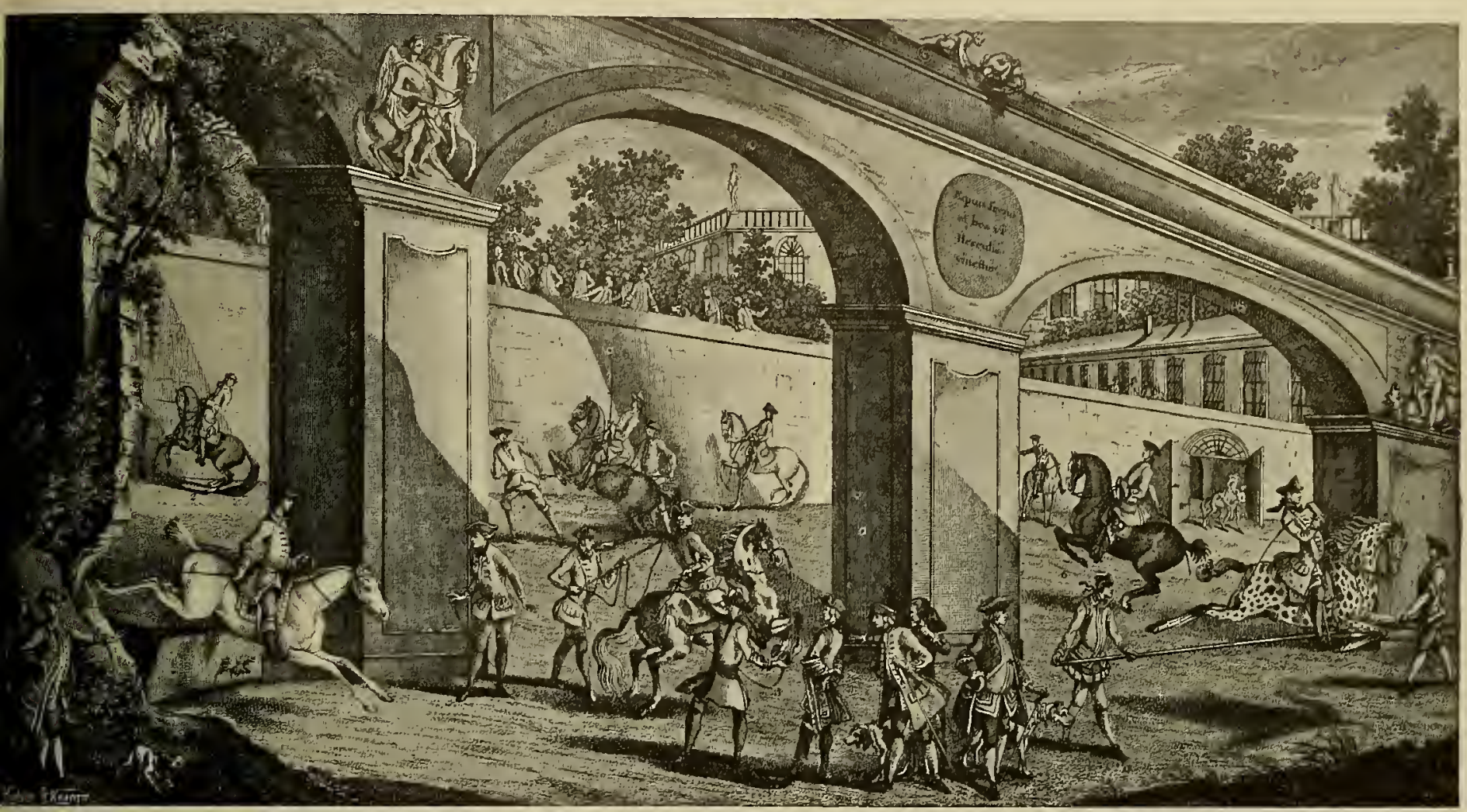

FIG. 2 I5. BEING TAUGHT THE “PESATE” AND TO “YARKE BEHIND." BY RIDINGER (TH. 7 12). See Page 315

The same conscientious attention which Ridinger devoted to horses, he extended also to hounds. We have the set called the "Four Seasons of Hounds," to which Ridinger added some French verses that hardly bear close examination respecting grammar or scanning. Then there is a much more attractive series, called "Pointing Partridge-setters," a title which does not quite correspond to the drawings. For the first (Fig. 217) shows a "setter" pointing a hare, the second a pheasant, the third two partridges, and the fourth a couple of quail. As the writer was fortunate enough many years ago to secure the original drawing by Ridinger of the first print, this is a good opportunity of showing the reader one of the master's drawings (Fig. 218) after which Fig. 2 I 7 was engraved. 


\section{SPORT IX ART}

Another set that deserves special mention is called "The Sport of Princes," consisting of 36 engravings depicting various kinds of sport enjoyed by sportsmen of princely rank. These plates are artistically of very unequal merit, and as Ridinger, in a long-winded and somewhat servile introduction in German and French, engraved on the title-plate, carefully mentions, it was not a spontaneous creation, but was produced gradually according to the demand for the first six prints, which were issued as a trial in the year 1729 .

And now to Ridinger's chef-d'aure, for so most collectors consider his set of sixteen prints called the Par force fagd, i.e. the French manner of hunting the stag. How it came that a Teuton painter who so far as we know never visited France, produced the best existing pictures of hunting in the French style the following pages will endeavour to explain.

The first halt of the eighteenth century was a period when Louis XIV's epochmaking conquests caused everything that was French to be admired and slavishly imitated by the Germans. French terms were dragged into German sentences, often in a very ludicrous way, French manners, customs and costume were affected, French was the fashionable language of German courts and of the aristocracy, and French amusements and sports were imported. By the time Ridinger had completed his apprenticeship the chase of the wild stag after the French manner was introduced at some thirteen or fourteen German courts. French and also English packs and horses were brought over, as well as piqueurs and English grooms, the latter being particularly favoured at the courts of HesseDarmstadt and Hanover, where as many as eighteen couples of hounds and half a dozen hunters were imported from England at a time. But the popularity of Par Force hunting was a short-lived one in Germany, for according to Fleming and Döbel, the two most dependable German authors on hunting of the eighteenth century, "it was a fearsome and riskful manner of hunting, ill adapted to suit the bodily ease of our lords and ladies." Its expense was another factor against it, for all the petty courts vied with each other and practically ruined themselves in the upkeep of hunting establishments hitherto unknown in Germany and quite out of keeping with the country's finances. Hence after a short life of a decade or two these unfortunate attempts at imitating French hunting were given up. Par Force hunting disappeared, leaving posterity, besides Ridinger's prints, a few chapters in German sporting books full of bad French phrases, and a vast accumulation of debts under which these small countries continued to groan for many years.

In France its history was very different; from the simplest beginnings, in the early days of the Capetian kings, it grew in favour, the kennels and stables increased, and it is not too much to say that not only every century but almost every monarch saw an increase of the persomnel of the hunting establishments and an augmentation of the expense of its upkeep. 318 


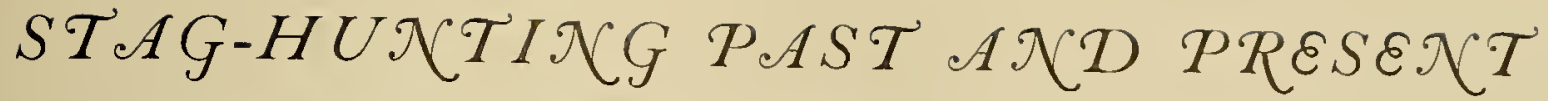

Much of the interesting matter to be gleaned from the works of the French authors belongs to true stag-hunting, that is to say, when the object was to hunt a great hart in its wild state with hounds in a non-enclosed country. What they tell us about the signs by which a warrantable stag is to be recognised, of the various cognisances of slot, gait, fewmets, feedings and fraying-stocks, \&c., how

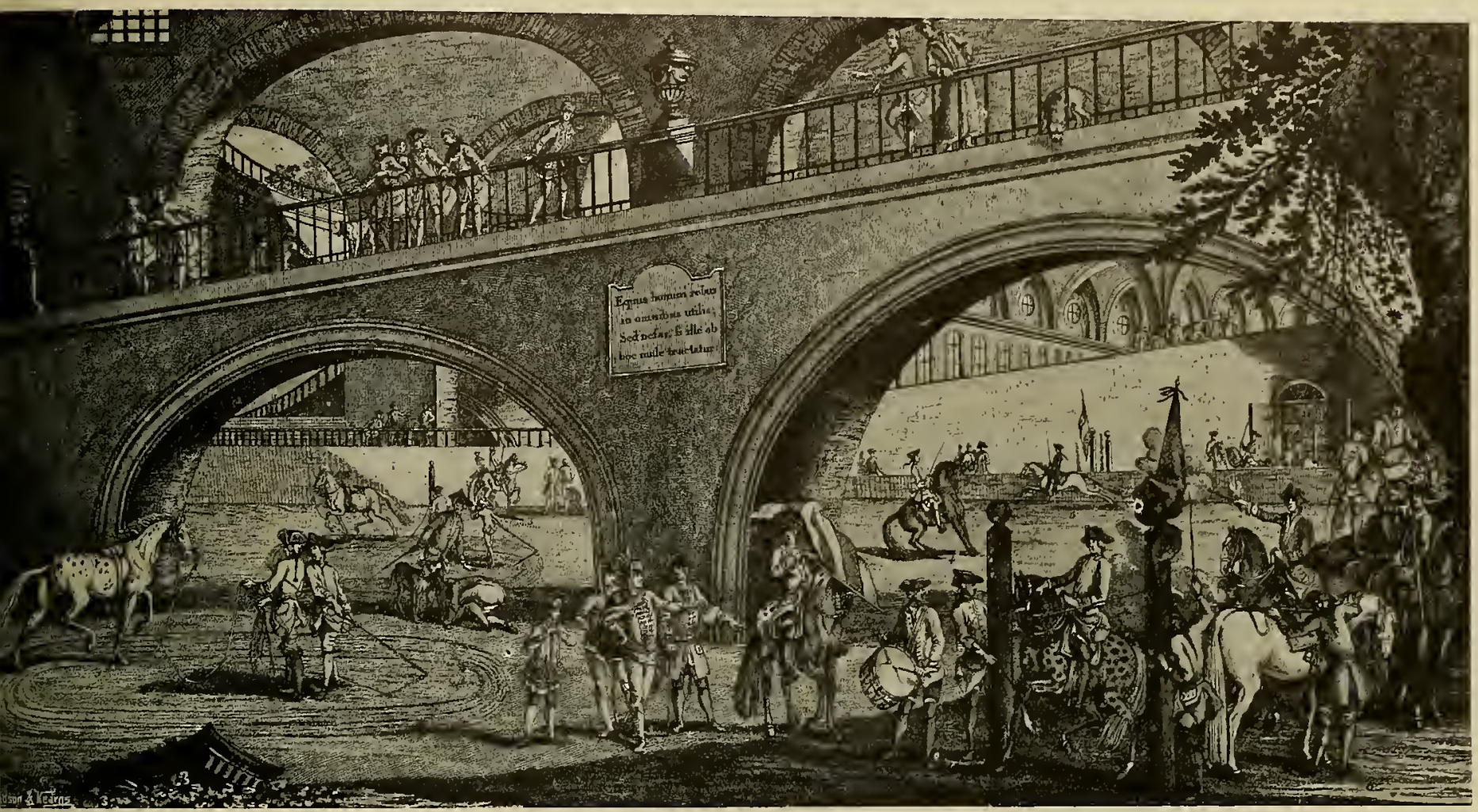

FIG. 216. ACCUSTOMING HORSES TO MARTIAL NOISES AND FIRING. BY RIDINGER (TH. 713). See Page 316

to harbour him, to hunt him in woodlands or across an open country, how to cast for him along the water's edge, or up or down stream, is much what a modern M.S.H. pens to-day when moved to write on this subject. There is, however, a good deal in the old French hunting that does not obtain to-day in the chase of the wild stag on Exmoor or in the hunting of "the carted calf" in other parts of England. If we could go back two or three centuries and join a French hunting party, probably the proceedings would seem to us extremely slow, the runs long and dragging; there would be less pleasure in riding, as there was more forest-land than open country; and less jumping, for the cultivated land was not divided off into small fields such as is customary in England. 


\section{SPORT IX ART}

Also we know more about speed, and require the maximum of motion for the gratification of our senses. Lacking steam-engines, motor-cars or even bicycles by which to gauge the pace of their steeds, the sportsmen in the olden days seem

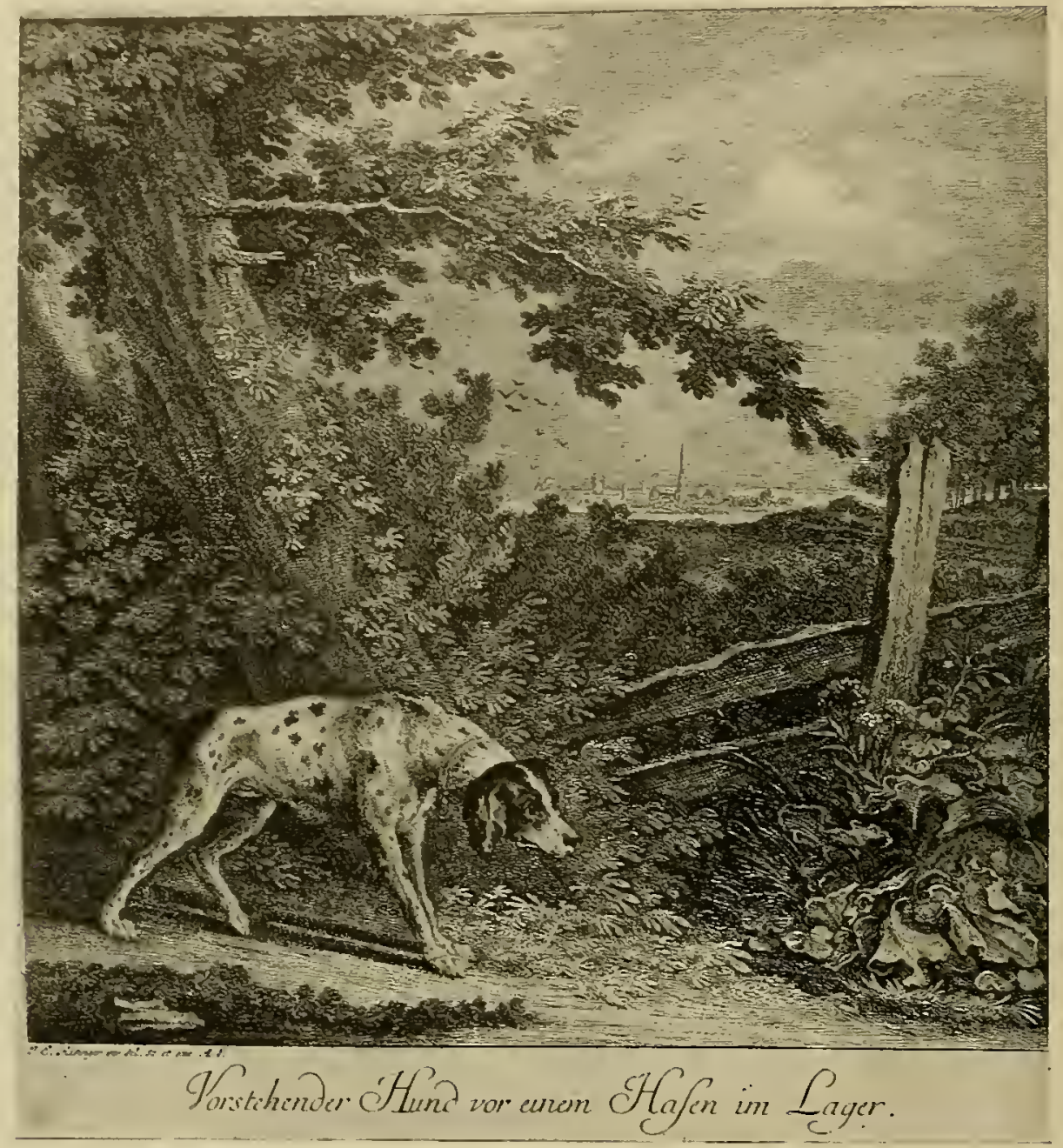

FIG. $21 \%$ POINTING A HARE. ENGRAVED BY RIDINGER (TH. 10I). $P .317$

to have been quite content with their slow-paced "chaceors" and "courtaults." Gaston de Foix, writing of his horses, says: "They were never blown because in good condition, and not fat from long intervals of idleness like those of inerchants." Evidently they were quite able to carry him "close to the tail of his hounds," which he tells us is the place for all bons veneurs, and what more could anyone wish for? We should have to be content to let them make the 320 


\section{RIDIXTGR'S "PAR FORGE" SET}

pace, and to see the proceedings of the hunt carried out with much ceremonial and in a leisurely manner, and to appreciate the patience shown by both huntsmen and hounds when "unravelling a change" or hunting a ringing deer in

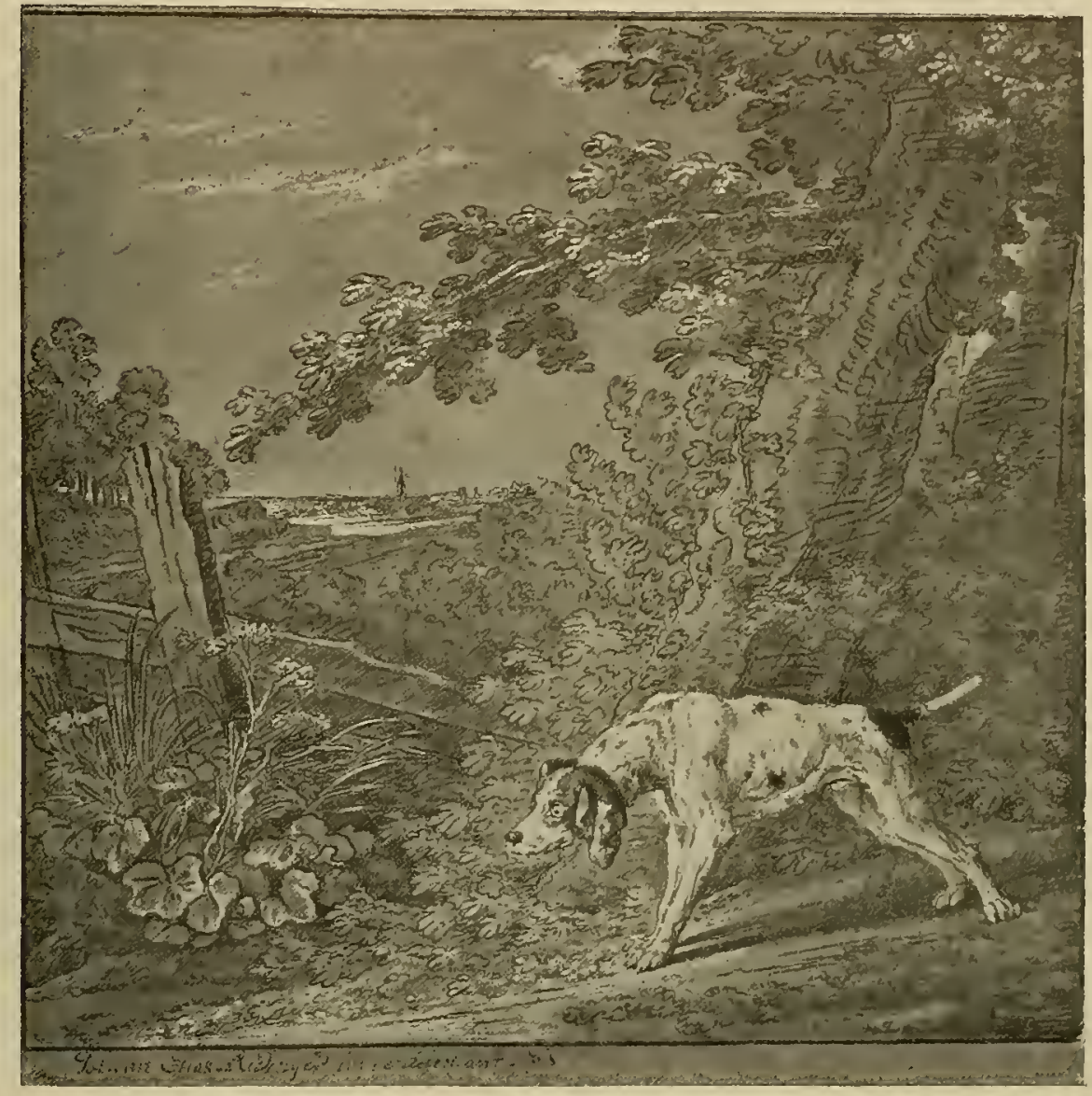

FIG. 2 I8. ORIGINAL DRAWING BY RIDINGER, SIGNED AND DATED 1758, AFTER WHICH FIG. 2 I 7 WAS ENGRAVED. See Page 317

a forest, although we should sadly miss the dash and go enjoyed by the present generation.

As we can spare space only for a few of Ridinger's Par Force series, we shall briefly describe the proceedings to which these sixteen plates are devoted. The first picture shows us the harbourers with their hounds on the "lyam "questing for the largest warrantable stag in their respective precincts. One harbourer was not considered sufficient in those days, so several would start out at dawn, each taking a different part of the forest. As everything connected with the royal hunts became more and more precisely regulated, the forests were all divided into 


\section{SPORT IX ART}

districts, and the huntsmen came overnight to the Commander of the Venery, and received the names of their quêtes, as these divisions were called, written on a slip of paper. Each huntsman being eager to harbour the biggest stag, many tricks were played by the less honourable upon each other. If one saw the slot of a large stag entering his neighbour's quête, all signs of it would be carefully effaced;

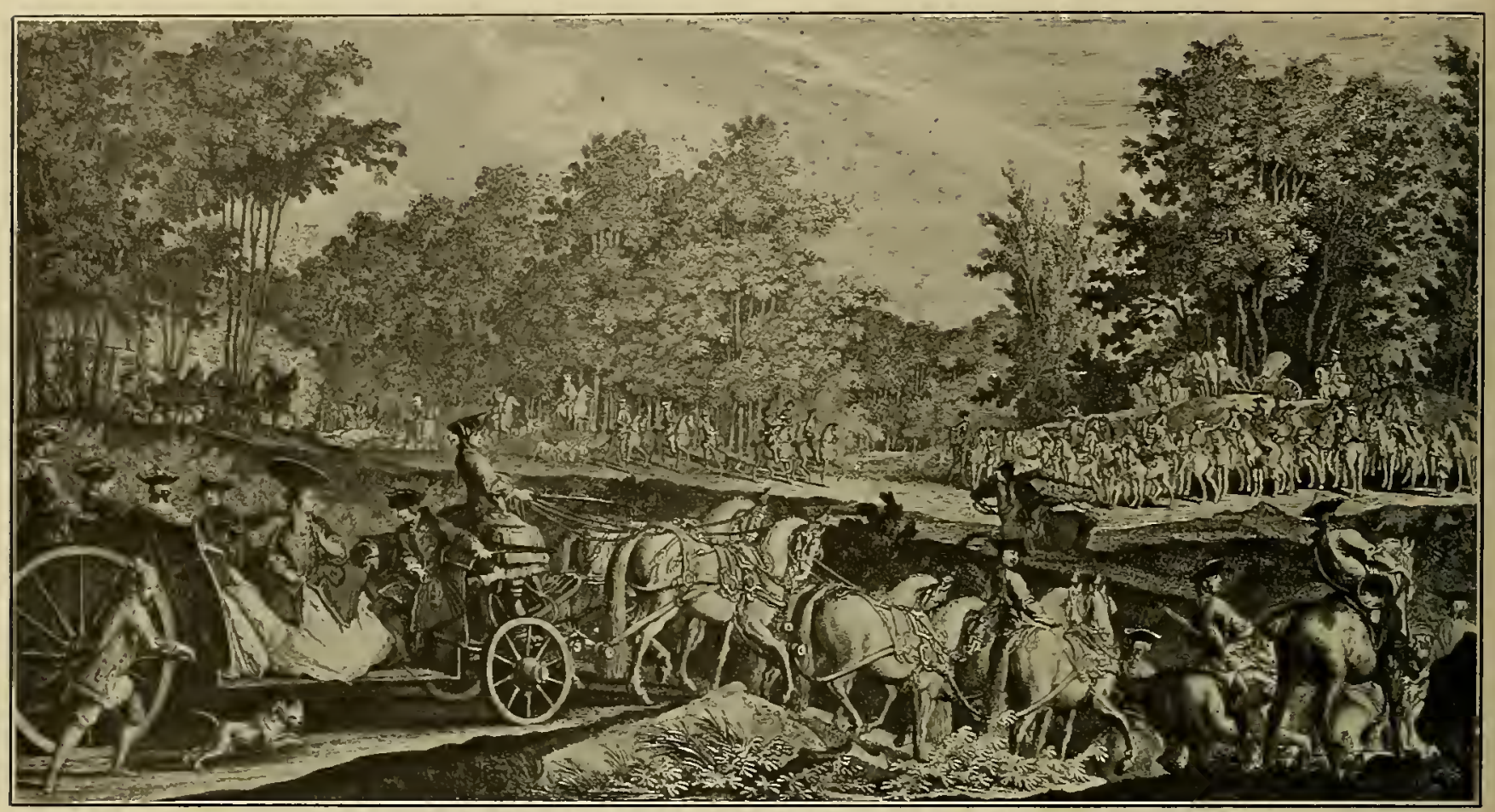

FIG. 219. ROYALTY DRIVING TO THE MEET. BY RIDINGER (TH. 54). See Page $32-$

or, knowing that his companion, more successful than himself, had already gone off to the assembly to give news of his morning's work, it was easy enough for the jealous knave to go into his territory and drive the stag out. These gentry seem also to have manufactured imitation fraying-posts or saplings against which the stag had rubbed his antlers, for the sake of the reward. For in the old days the huntsman who brought the first fraying-post of the season to the King was presented with a horse if he were one of the gentlemen of the venery; were he a valet he received a new coat. In the time of Francis I this gift was altered to a tip, which was divided among all the hunt servants.

To return to the first plate, we see one harbourer holding his lymer between his legs, while he is occupied in sticking twigs into the ground; this was done to mark the place where a slot was first seen; a corresponding twig was broken on a $3^{22}$ 


\section{"PAR FORCE" HUXTIX}

branch above and left hanging. This was called faire ses brises hautes et basses. Did he fail to do this, and one of his companions noted the slot, although not in his quête, he could follow it up, and to him would be the honour of having harboured the stag. In the background of the picture we have a second huntsman

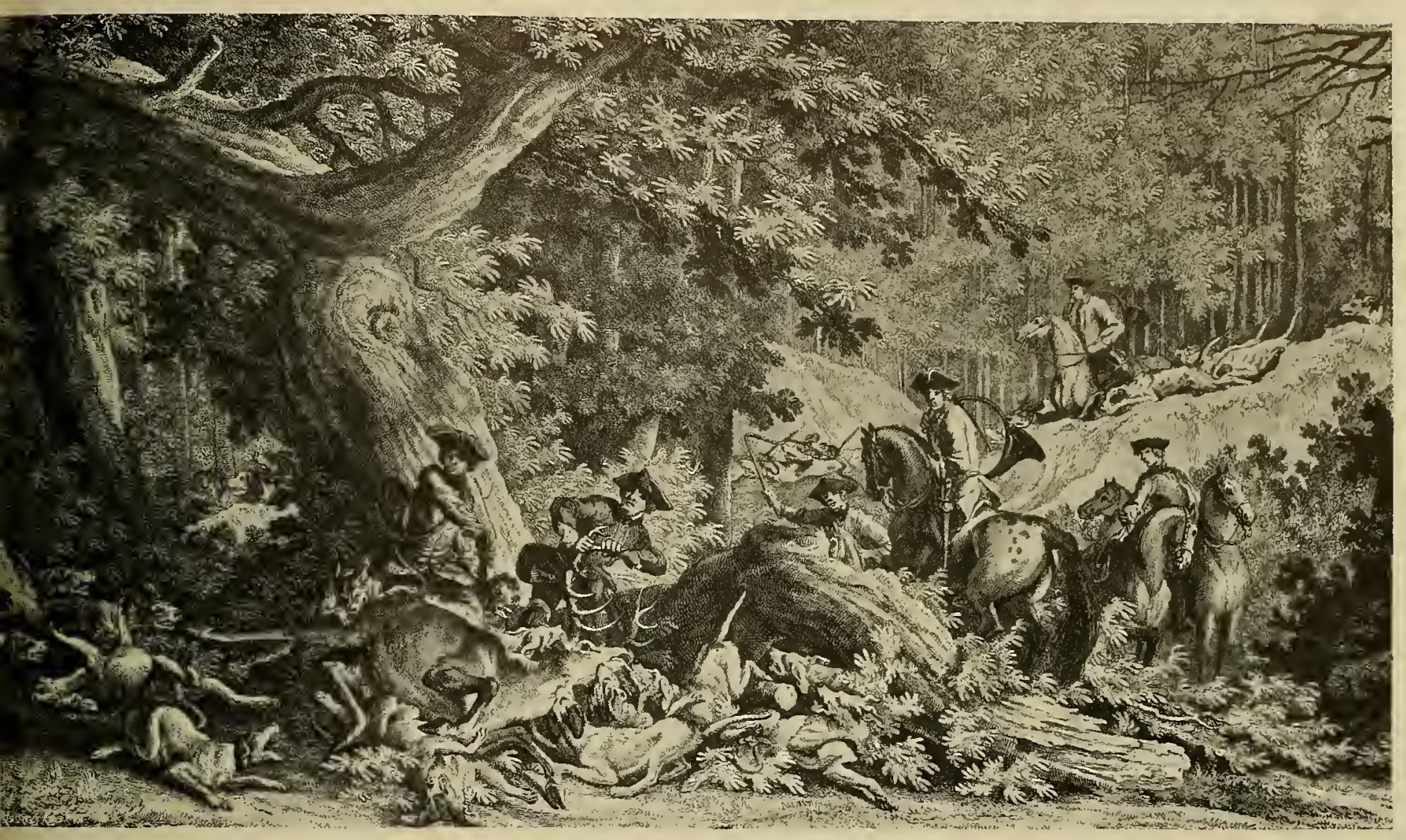

FIG. 220. GIVING THE “COUP DE GRÂCE.” BY RIDINGER (TH. 62). See Page 330

holding his hound in his arms, whilst another is stooping down to examine the slot. He appears to be measuring the width of it by placing his fingers in the depression, a veiy usual proceeding. A fourth is examining the gait, and marking how many fingers-breadth the print of the hind foot is behind that of the fore-foot -another sign by which the age, sex, and size of deer were recognised. We must not imagine that all the harbourers were at work in such close proximity to each other, but the artist has drawn them all to show us the way they went to work. The next proceeding after having barboured their stag was for them all to repair to the place of meeting and make their several reports to the Prince or Master of the 


\section{SPORT IX ART}

Venery. Arrived at the meet, or place of assembly as it was called, the huntsmen made their reports. In previous centuries it was the custom, as we have already heard, to present the fewmets (excrements) of the harboured stag, placed on fresh leaves, to the Master, so that he could see for himself that the animal he was about to hunt was of great size.

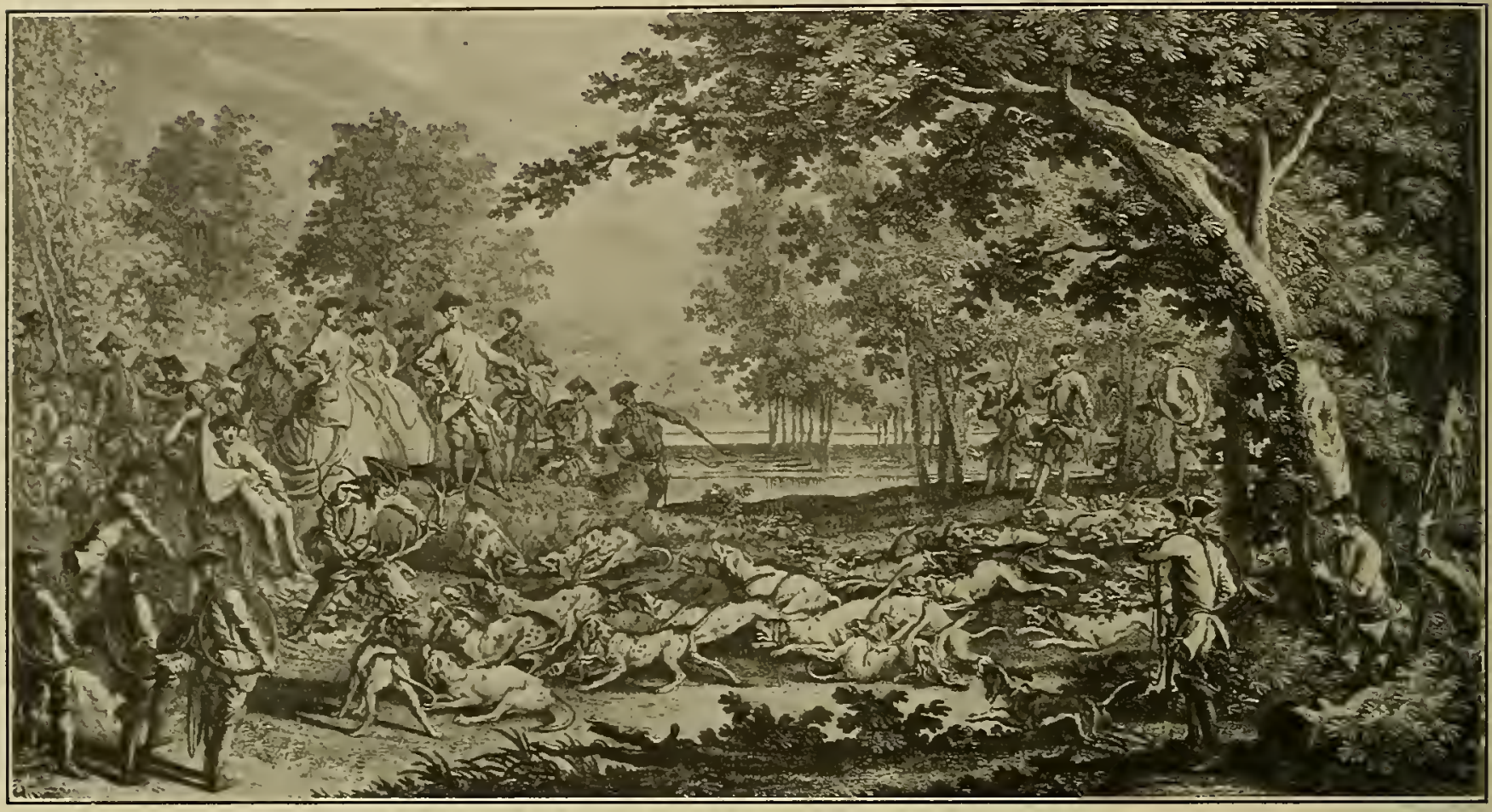

FIG. 221. THE "CURÉE," OR REIVARDING THE HOUNDS IN THE PRESENCE OF THE ASSEMBLED COURT. BY RIDINGER (TH. 64). See Page 332

Ridinger gives us in the series Par-force Fagd no picture of the hunt breakfast, partaken of by great lords beneath the shade of wide-spreading trees, but he has left us a plate of a sylvan breakfast scene where the hunt officials, prickers, and valets de chiens are refreshing themselves whilst waiting for the court to arrive. In Ridinger's time the lordly out-of-door feasts had been generally abandoned. Du Fouilloux's description of the "assembly" and of the good things that should be provided gives a capital idea of a hunt breakfast in the sixteenth century. After reading it, one can only think that perhaps it was just as well that in those days the hounds were more noted for staunchness and perseverance than for pace, for a sharp burst on a broiling summer day after such a feast could scarcely have been beneficial for the most hardened of sportsmen. Thus these feasts were 324 


\section{HOW THE PACKS WERE MAAXAGET)}

gradually abandoned, and breakfast was taken at some convenient inn, house, or castle nearest to the forests where it had been decided to hunt; or the hospitality of monks or nuns was requisitioned, if their monastery or convent was conveniently situated. By Ridinger's time all this had undergone changes, and those that came to the meet " to eat like fifty and talk for a hundred" were looked upon with contempt.

Another plate shows how the hounds were taken to the meet in hardes, * that is, several couples tied together by means of a thong slipped through their couplings. The number of hounds taken out generally varied with the strength of the pack. In the fourteenth century Gace de la Buigne mentions fifty hounds being uncoupled at once at a royal hunt. In the next century the famous huntsman Jacques de Brézé, in his description of a day's hunting, mentions all the hounds that were out by name; there were just eleven couples. Later on there were usually from fifteen to twenty couples out. There were

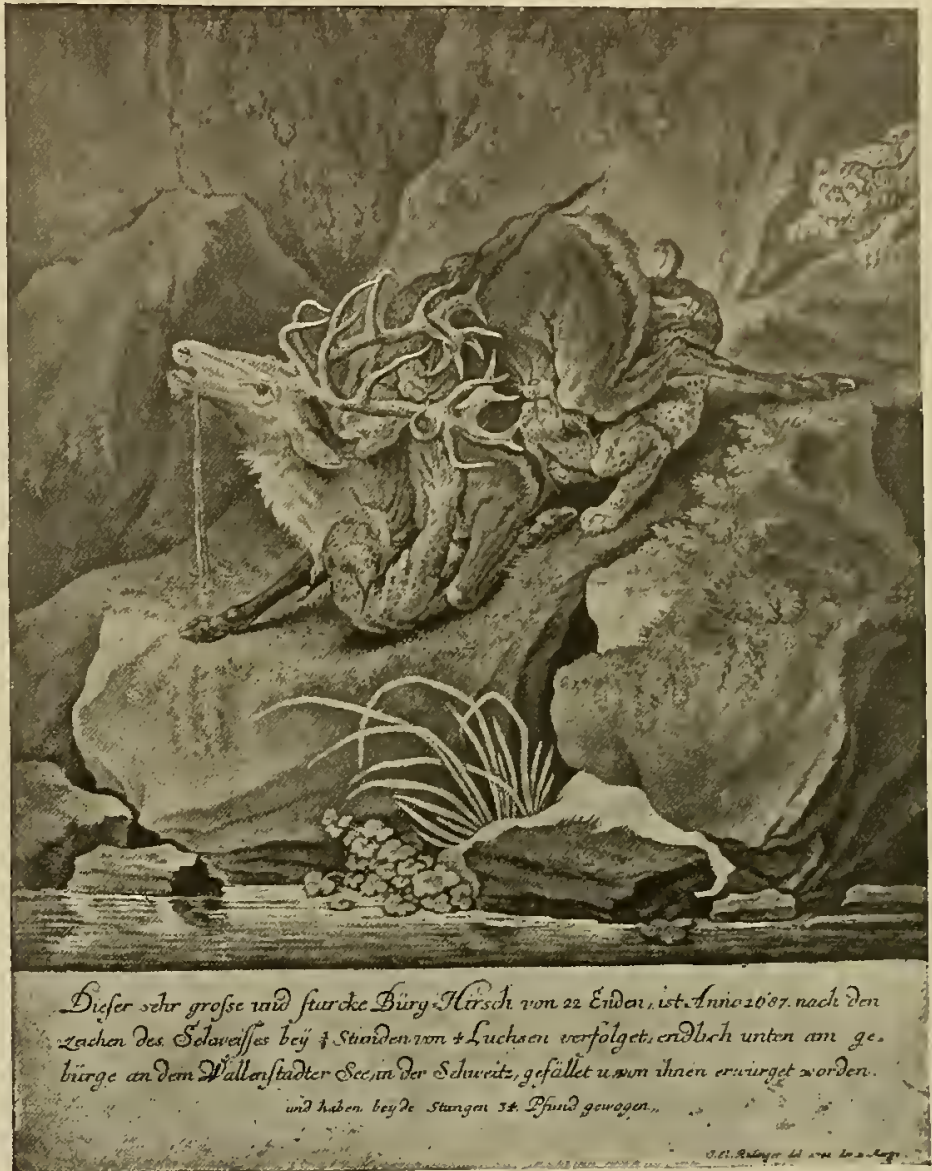

FIG. 222. A GREAT HART OF TWENTY-TWO BEING PULLED DOWN BY FOUR LYNX ON THE SHORE OF THE WALLENSTADT LAKE IN 1687. MEZZOTINT BY RIDINGER, WHO STATES THAT THE ANTLERS WEIGHED $3+$ LB. (TH. I I +5). See Page 332 never more than four couples led in each harde, and two hardes made a relay. At least this is what Louis XIII's Grand Veneur Salnove tells us; but the letterpress accompanying Ridinger's picture says that if the pack is a strong one as many as ten to

* When the hounds were taken to the meet in couples in the old days on Exmoor it was called "harling" them, probably from the French harder. See "Master of Game." 


\section{SPORT IX ART}

twelve couple should be placed in each relay, adding, however, that generally only two hardes are placed for each relay, and that about sixteen or twenty couples should remain at the assembly and form the main pack. In the print in question, while the prickers and huntsmen are refreshing themselves, we notice that they have separated the hounds ready to be placed as relays, leaving the younger and more vigorous ones for the mentt a'attaque.

In the next print we see the Grand Veneur, or his representative, sending the relays off to their posts. The hounds have been divided into four lots: the main pack or mentte d'attaque, and the three relays, the first called the vielle meutte, the next called the seconde vielle, or simply the seconde, and the third, or relais des six chiens. Occasionally there was an extra relay known as the relais volant, or flying relay, which was expected to be on the look-out, to take short cuts, and to be ready to be cast off when wanted, which was only in the case when the stag had not gone the way which had been anticipated, and had therefore missed the other relays. There were the same number of hounds in the relay known as that of six chiens. Why it was so called originated from its being probably composed of some of the hounds of St. Hubert, six of which had to be sent annually by the monastery of St. Hubert as an offering in fief to the royal kennels. They were reputed slow but staunch, and capital hunting hounds.

Salnove is the first author who gives us the exact number and names of the relays, but he asserts that they have been the same from time immemorial (de tout temps). Sometimes they were placed double, that is to say, one on each side of the route of the stag. It required a good knowledge of the country, judgment and experience to place them satisfactorily, and even then anything unexpectedly heading the stag must have rendered their use nugatory. One is therefore not surprised to read that, in spite of all preparations and precautions, the stag was sometimes taken by the main pack without the aid of the relays, de meutte a mort as it was called.

In the same illustration we see the departure of the quaint chariot in which the Master of Hounds has evidently driven to the meet, and the hounds being led off in various directions, accompanied by the second horsemen of the seigneurs. With each relay of hounds were also placed relays of horses for the sportsmen. Every relay was under the charge of two valets de chiens (which term, we suppose, may be freely translated by the old word "berner"), one on foot and the other on horseback. The latter was at the French court generally one of the gentlemen of the venery, under whom stood the kennelmen and grooms of the king.

In the eighteenth century attempts were made by some M.S.H. to do away with this system of relaying, but M. d'Yauville, Grand Veneur at the time, speaks sceptically of the assertion made to him by a Maitre d'Equipage, who told him that he took all his deer at all seasons in this manner. D'Yauville considered that with a good pack of hounds it might be possible in winter, but was certainly not feasible in summer. 326 


\section{THE HARBOURER AXD HIS LYMER}

The next plate, Fig. 2 I 9 , shows us the company proceeding to the covert side, the prince and princess and one of her court ladies in a chaise volante accompanied by a train of cavaliers. The harbourer and his lymer precede this procession, and

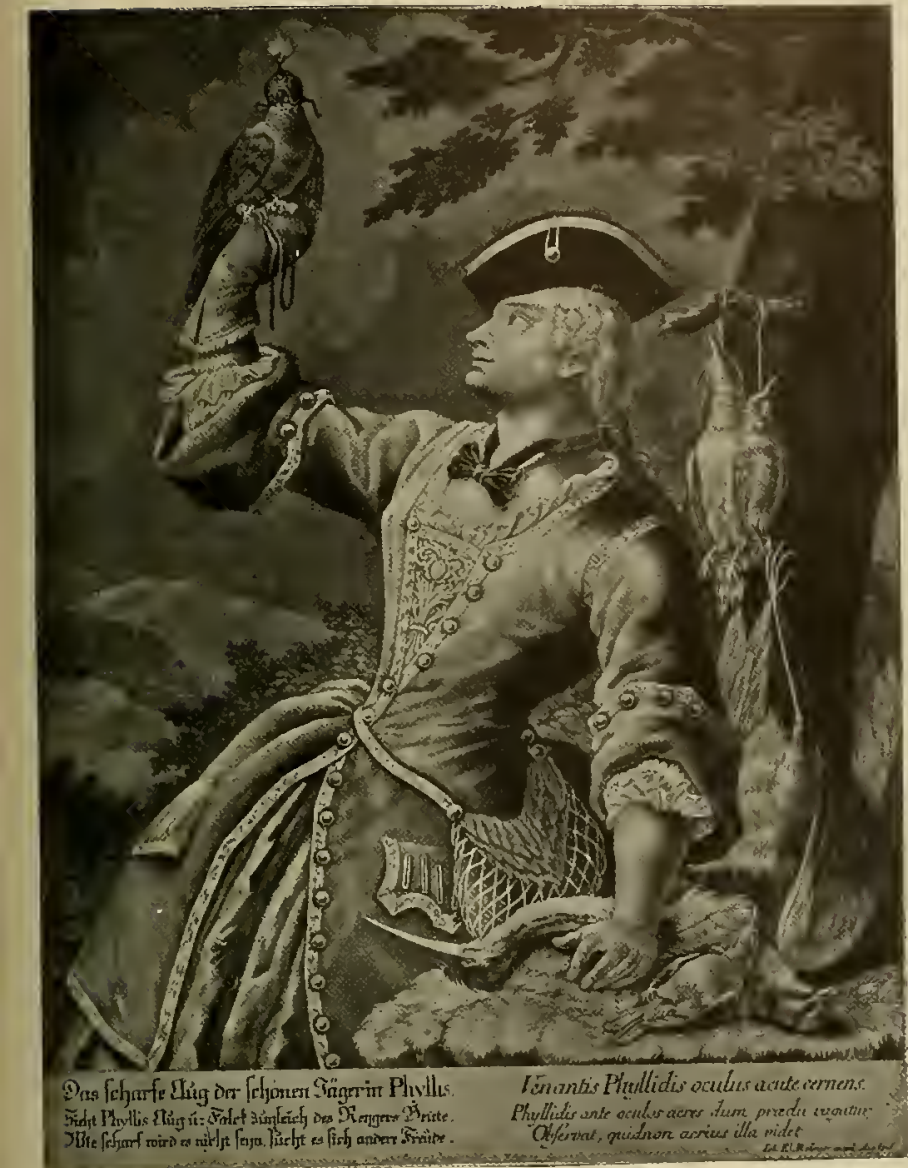

FIG. 223. MEZZOTINT PORTRAIT OF A LADY WITH HOODED FALCON. RIDINGER (TH. 1327). Page 332

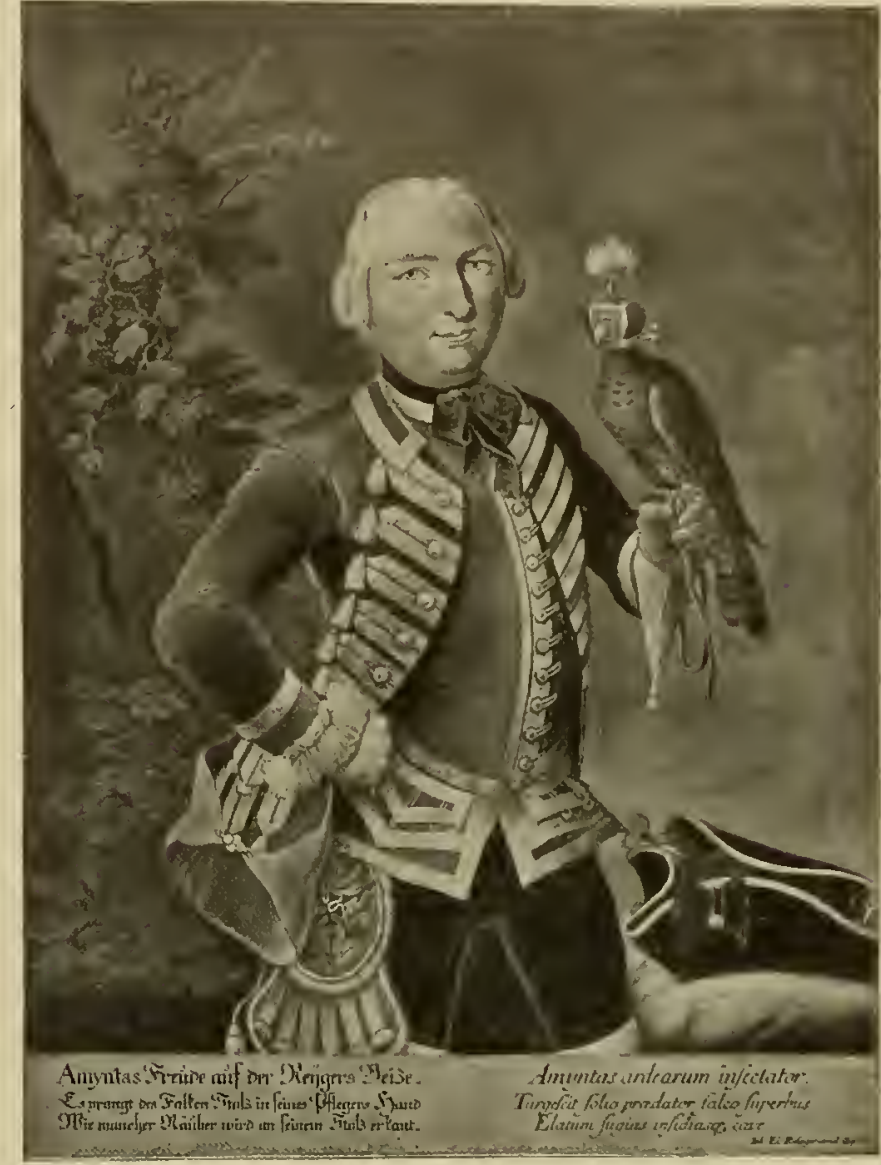

FIG. 224. MEZZOTINT PORTRAIT OF A GERMAN FALCONER. BY RIDINGER (TH. 1328). Page $33^{2}$

lead it to the place where he has marked the slot of the stag as it entered the covert some hours previously. Here again we have a huntsman trying the breadth and depth of the print with his fingers. The harbourer, holding his hound on a short lyam, follows the line of the stag into the thicket, and at his heels come the hounds of the main pack, still coupled, some sixty paces intervening, as the text informs us, so that they should not interfere with the work of the lymer.

In another plate the exciting moment is depicted. A stag of fifteen points, or as the French would call it of seize mal seme, has sprung from his lair ; the huntsman 


\section{SPORT IX ART}

is sounding his horn, and could the picture speak we should hear the cry of Tahou, Tayoo, Tielhaut, or Tahillaud. That talismanic cry, although spelt in endless variations, always had the same meaning, that the quarry was viewed and had broken

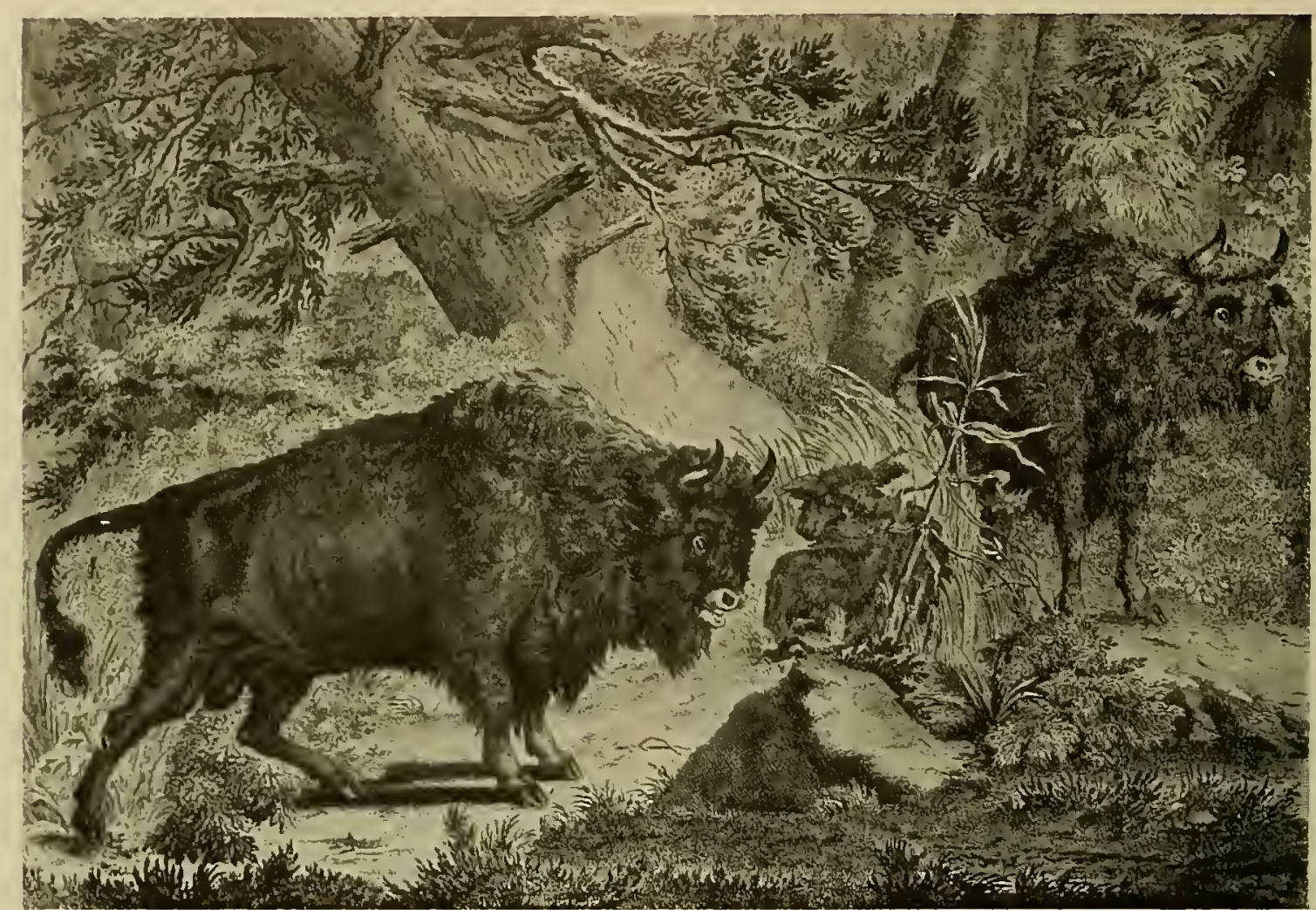

FIG, 225. THE AMERICAN BUFFALO. ENGRAVED BY J. S. MULLER OF LONDON IN 1748 , AFTER RIDINGER. Sec Page 334

covert. And now the harbourer can hand over his hound to his valet, and leave the rest to the straining pack, the first hardes of which are already uncoupled.

The idea of dispensing with the harbourer and his lymer for the purpose of rousing the stag, was not carried out till the eighteenth century, when $M$. d'Yauville, under Louis XV, started the system of tufting which now obtains on Exmoor. There they draw the covert with a few of the older hounds, recoupling them as soon as the stag is well on foot, and then lay on the other hounds. It would be interesting to know whether this was an original idea of the Grand Veneur, or if English custom had anticipated him in the introduction of tufters. We have followed the stag-hunt up to the time of the laisser conre, the dislodging of the stag by the harbourer and his lymer. The next plate shows 328 


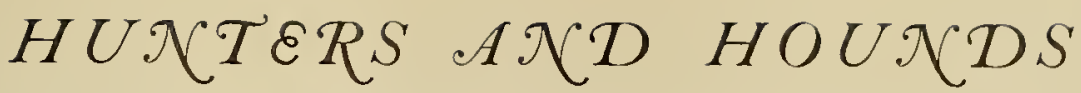

us how the pack was uncoupled, and how they hunt the stag in the forest, while in the following picture the quarry seems to be making for more open country, the hounds being in full cry.

It is curious that d'Yauville in the eighteenth century is the first author who mentions the art of riding as the first thing necessary for a would-be huntsman to acquire; the older writers have left this accomplishment out of their list altogether. He speaks of the hacquenees d'Espagne, hobins d'Irlande, and courtauits, the latter appellation applying to any horse that had his tail docked! From the sixteenth century onwards the most prized hunters came from England. Louis $X V$ rode courtaults from Suffolk, and the most useful hunters at that time were considered those imported from Yorkshire.* But they always seem to have been a secondary consideration, and Salnove was the mouthpiece of his countrymen when he said of the hounds, "se sont enx qui font

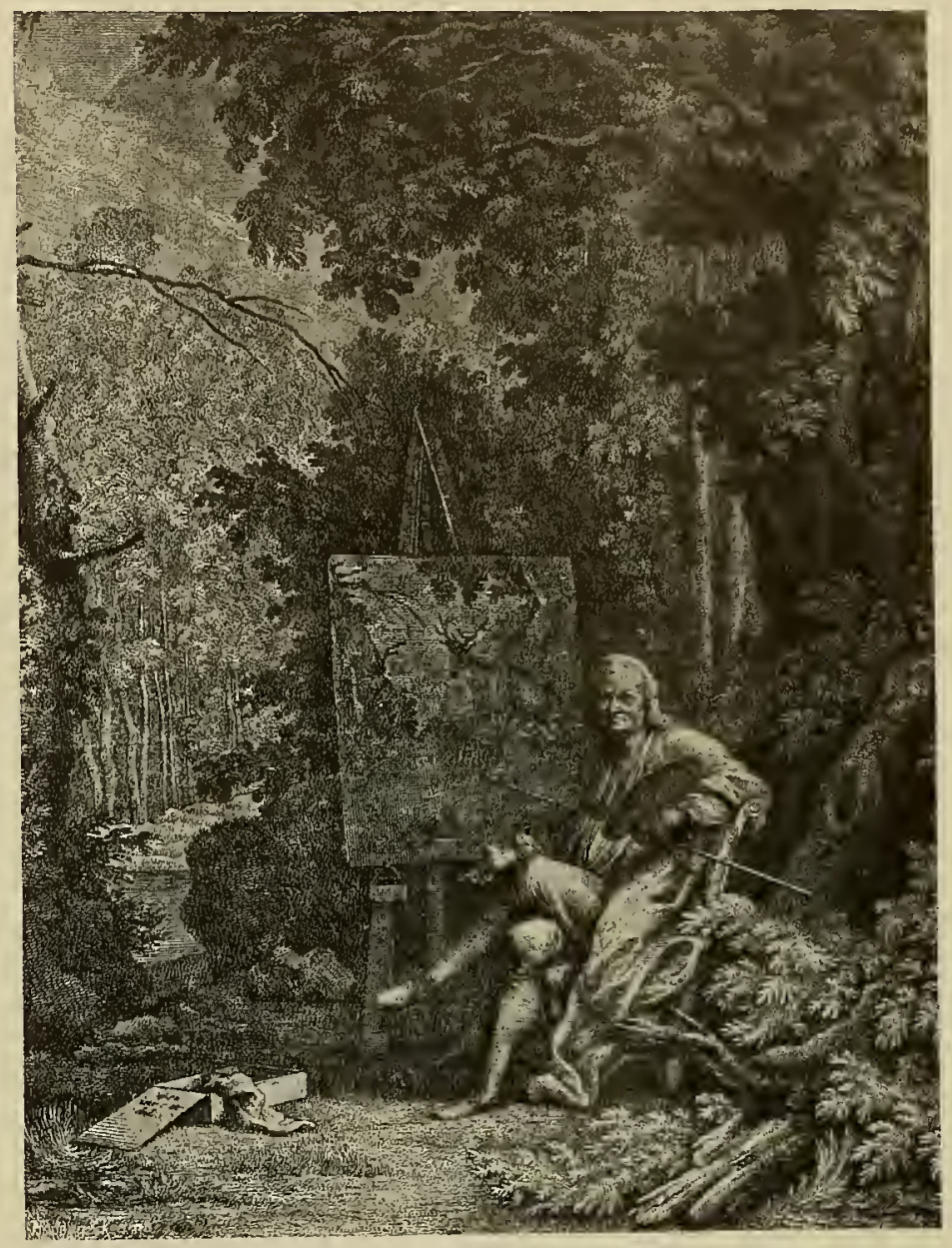

FIG. 226. PORTRAIT OF RIDINGER. ENGRAVED BY HIS SON TOWARDS THE END OF HIS LIFE. See Page 335. la principe de la chasse."

In the next picture the hounds are being checked, the stag has put up "a substitute," and they have been hunting the change. Now all the knowledge of the huntsmen has to be called into requisition to find out the line of the right stag and once more to get the hounds on it. In the early days and up to the first half of the sixteenth century, it was customary in such a case for the harbourer

* As an early instance of hunters and hounds being imported into France from England, may be cited the present of twenty couples and six hobins d'Irlande sent as a present to Louis XIII by Anne, Queen of "the Wisest Fool of Europe," in the year 1618. 


\section{SPORT IX ART}

to come up with his lymer and unravel the line. After having dislodged the stag he mounted his traquenart or ambling horse and, keeping below the wind, skirted the course of the hunt, so as to be at hand when wanted. These harbourers, we are told by Charles IX in his book on hunting, written in the second half of the sixteenth century, had to be connoisseurs. There used to be two sorts of huntsmen: those that ranked highest were the connoisseurs who harboured and dislodged the stag, and the others were prickers who rode always at the tail of the hounds. If the stag "brought the hounds to change," if they overshot the line, or were, in fact, in any difficulty, the prickers were obliged to check the hounds and wait the coming of the connoisseur with his lymer, for says the royal author, "l'art le voulait." However, he tells us that this timerobbing proceeding had been given up in his days, and that to be a good huntsman one must combine the qualities of pricker and connoisseur-that is to say, "never to lose sight of the hounds when they are hunting, and to be well versed in the knowledge of a stag by the signs and judgements thereof." But to dispense with the services of the harbourer and his lymer on such occasions must have been quite a recent innovation, as Du Fouilloux (who wrote his book just before Charles ascended the throne) gives detailed instructions that he is to be at hand in case the hounds come to fault, when his services will be required.

In Ridinger's drawings the oak trees seem to be in full foliage, and he was not wrong in thus drawing them, for the stag was hunted all through the summer. In fact, till the reign of Francis I the chase of the stag was only pursued from May 3 rd till September.

The one thing one has to be thankful for nowadays is that a horn is not an essential part of the accoutrement of the would-be sportsman. In the old days every one carried one, and was supposed to know the proper lengths and number of mots or notes to be sounded on every occasion. One can imagine how this system was abused even in the early days of venery!

The hunting-crops as drawn by Ridinger, which appear to differ little from those now in use, were another innovation in his time. For from the days of Charlemagne till the beginning of the eighteenth century it had been the custom to present the King and all guests present with switches of hazelwood before they started off to the laisser courre. These switches, called destortoires or estortpoires, were about $2 \frac{1}{2}$ feet long, and it was the custom to peel the bark off them if the stag had finished fraying, but the bark was left on as long as the head was in velvet. They were held before one's face to save it from blows of branches when riding through a thick covert ; and when hunting "one slaps it on one's big boot to encourage the hounds, or one can employ it for one's varlet or for one's hound."

In the next picture, Fig. 220 , we see the stag brought to bay, and a huntsman in the act of hamstringing him, while another is preparing to despatch him with his hanger. In mediæval day's, as we have already remarked, it was considered 330 


\section{GIUIX్ THE FOURTH RELAT}

unsportsmanlike to kill the stag with anything but cold steel wielded by the master or principal guest. This, according to Ridinger's picture, seems still to have been the ideal manner of despatching the stag in the first half of the eighteenth century, but we doubt whether it was often carried out by royalty,

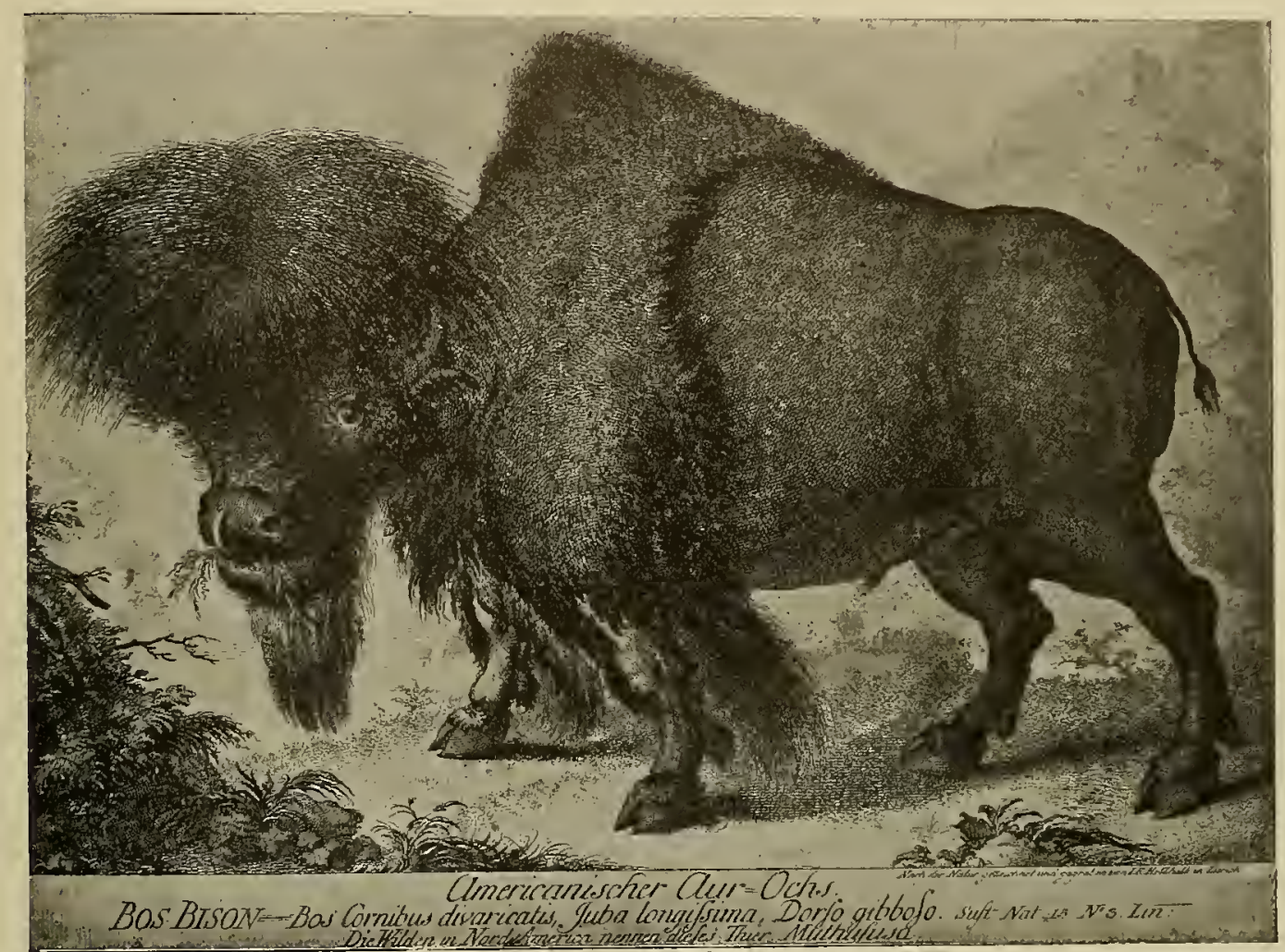

FIG. 227. THE “AMERICAN AUROCHS" (BISON). BY J. I. HOLZHALB OF ZÜRICH, 1768. See Page 336

who no longer evinced an irrepressible desire to encounter danger in the pursuit of any type of sport. In France the safer method of using an arquebus was at that period approved of ; the old-fashioned way, we read, being "dangerous for men and hounds, and a mere act of bravado." Since that time "giving the fourth relay," as despatching the quarry at bay with a shot was called, became the usual method in France. In a picture belonging to another set we see the ceremony of cutting off the right foot of the stag, and presenting it to the Prince, or, by his order, to the most honoured guest. This ancient custom is said to have owed its origin to the old feudal right known as main morte, by which a seigneur had the right hand of any of his serfs who died brought to him as an indisputable proof that the serf in 


\section{SPORT IX ART}

question was in all truth defunct, and had not feigned death and fled in the hopes of obtaining his freedom.

Last of all came the curée (see Fig. 22 I), the undoing and breaking up of the stag, and giving the hounds their fees. The huntsmen sounded the mort on their horns, and amid the cries of Hallihi, Hallili, first the lymers then the other hounds were rewarded. In the right-hand corner of the picture we see some tit-bits put on a large wooden fork. These were delivered to the hounds last of all. This was called forhuer, or giving the hounds their forhu. According to the illustration these obsequies seem to have taken place at the scene of the stag's last struggle for life. The neighbouring piece of water suggests that it had been his last refuge. So that this was a curée chande. The same ceremonies, when the dead stag was taken home, and the reward was given to the hounds in the courtyard of the palace, was called the curée froide.

So far we have spoken only of engravings by Ridinger; it is now time to say a few words about his mezzotints. Of those relating to the chase there are only a few of any particular interest for us. The one principally deserving our attention is reproduced in Fig. 222, of which the original drawing is to be seen in the British Museum Print Room, it being one of the few originals by Ridinger secured by our principal institution. Thienemann calls our print a fine and rare example of the master's mezzotint work, but as the writer has come across quite a number of copies, it cannot be quite as rare as the biographer imagined. It depicts an extraordinary incident, viz., how a large stag of twenty-two points was attacked simultaneously by four lynx and after a desperate attempt to escape by a run, the length of which Ridinger describes as three-quarters of an hour, a trail of blood marking the route, made for Lucerne lake, into which he plunged. There he was finally killed by three of his relentless foes, the fourth probably having been in turn killed by the stag. Of what great size the stag must have been is indicated by the enormous weight of the antlers, which Ridinger mentions weighed no less than $34 \mathrm{lb}$. or $38 \mathrm{lb}$. avoirdupois. This is the weight of a very fine pair of wapiti antlers carried by a beast weighing at least 800 or $900 \mathrm{lb}$., or more than double what a stag of to-day scales! Curiously enough it is possible to convince ourselves of the likeness of old Ridinger's drawing, for the antlers are one of the prized treasures in the celebrated collection of Count Erbach-Erbach in Castle Erbach in the Rhine country where the writer saw them a few years ago. The whole curious incident which thus gave rise to one of Ridinger's most spirited plates, must have interested the old painter to an unusual extent, for he acquired the antlers which remained in his heirs' possession until 1830 , when the abovenamed famous collector purchased them.

Figs. 223 and 224 show us Ridinger as a portrait painter and his later mezzotint style. For us the pictures have the value of fashion plates, giving us a good idea 332 


\section{RIDIX $\mathcal{X}$ R REZZOTIXT PORTRAITS}

of the costumes worn by German nobles about the middle of the century when engaged in falconry. Unfortunately it is not known who these two pictures represent. It is of interest to compare these two essentially German sporting

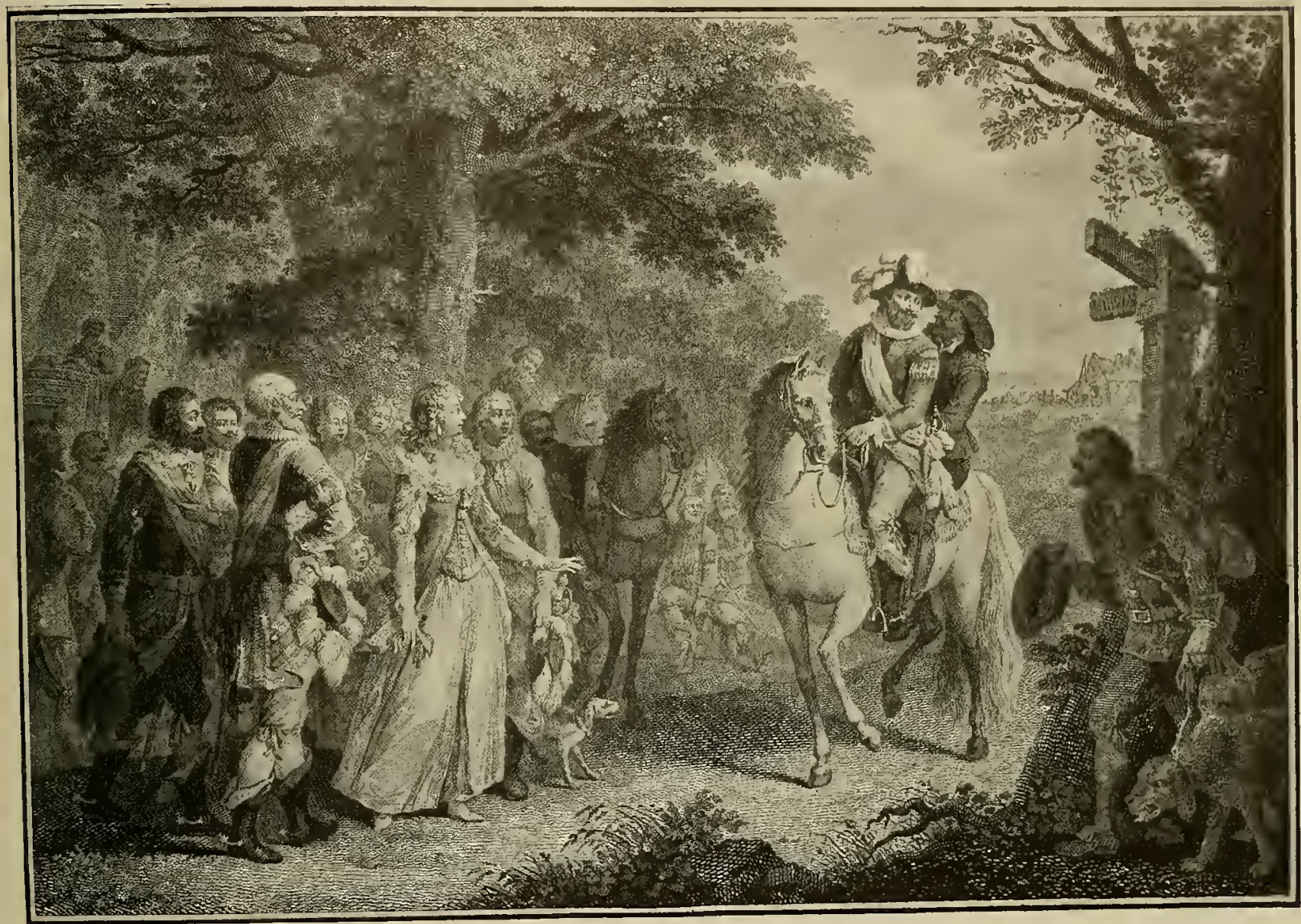

HENRY IV OF FRANCE'S ADVENTURE WITH THE CHARCOAL-BURNER DESIGNED BY ANT. BOREL, AND ENGRAVED BY HENRI GUTTENBERG ABOUT I770. Page 336.

portraits with the French ones (Figs. 143 and 144) and with the two English portraits (Figs. 166 and I67). The three pairs are very typical of their respective countries, and although the French portraits are about half a century earlier, their elegance and beautiful finish is in telling contrast to the somewhat graceless stiffness of the German in subject as well as in technique, while the unaffected simplicity and businesslike directness of the English pair have unquestionably attractions of their own. 


\section{SPORT IX ART}

It has already been said elsewhere that by far the largest number of Ridinger's drawings were engraved either by himself or by his two sons Martin Elias and John Jacob, or by his stepson John Seuter, none of whom, however, approached his skill. There were, moreover, some other artists, German, English, American and French, who engraved after him. Of these the most important were J. S. Miiller and Kirkall, and of these and of their productions the Appendix will be found to contain information that probably will be novel to most.

Fig. 225 is a reproduction of one of J. S. Müller's engravings after J. E. Ridinger, to which we already have had occasion to allude. It is a most life-like picture of the American buffalo; indeed, we have seen worse likenesses turned out by artists that are still among us. The English text underneath the engraving is also remarkably correct considering it was written in the year 1748 , and is perhaps worth quoting: "The Buffalo is a very strong, fierce Animal found in Livonia, but more particularly in those parts of America possess'd by the Spaniards. The Buffilo resides in Forests, \& lives on Vegitables. The Americans often kill them for the sake of their skins, which serve them for Beds. The Hair of the Male being longer than that of the females. The above people commonly eat only the tongue and throw away the Carcass. In some countries their flesh which is hard, is dried in smoak and us'd for victualing of ships that make long voyages. They often are yoked to the plough and delight to lye in water. The Male is of a dark lead colour, that of the Female somewhat lighter and the calf still more so. They are in their perfect state in their sixth year and able to copulate. Buffaloes commonly produce but one at a litter, and they suckle their young till they can provide for themselves. A very remarkable circumstance is, the Hair on the forehead of the Male emits a fragrant odour, whence ladies in Spain, Russia and Poland, wear that part of the Buffalo skin on their arms. They are often baited in Spain, or made to fight with other wild Beasts. They then are vastly courageous and active, goring and squeezing to the ground all that comes in their way. They are very long lived, and frequently engage in furious battles, when a female is to be covered. They are in Nature like to the domestic Bull, but infinitely fiercer. Buffaloes are commonly shot or allur'd to some Inclosure either by a tame female or a common cow." The print was published by "J. S. Müller at the Golden Head the corner of James Street Long Acre March 1 3, 1848 . Price I sh. 3 d." We might add that the frontal bunch of hair on two mounted bison heads in the writer's possession which were killed in the 'seventies certainly emits a peculiar though faint smell, which possibly may have been stronger soon after death, before they were treated by the taxidermist. Perhaps this has been noticed by others.

The opinions of art experts regarding Ridinger's productions vary a good deal. Hind, to quote one of the most unkind, says in his new "History of Engraving and Etching " that "their artistic value is a negligible quantity, so dull and lifeless 334 


\section{CRITICISMS OF RIDIX RGE}

is their draughtsmanship." Had this critic shown a little less nescience in other respects concerning Ridinger one would bow more readily to his verdict. In any case, be this as it may from a strict art point of view, our numerous reproduc-

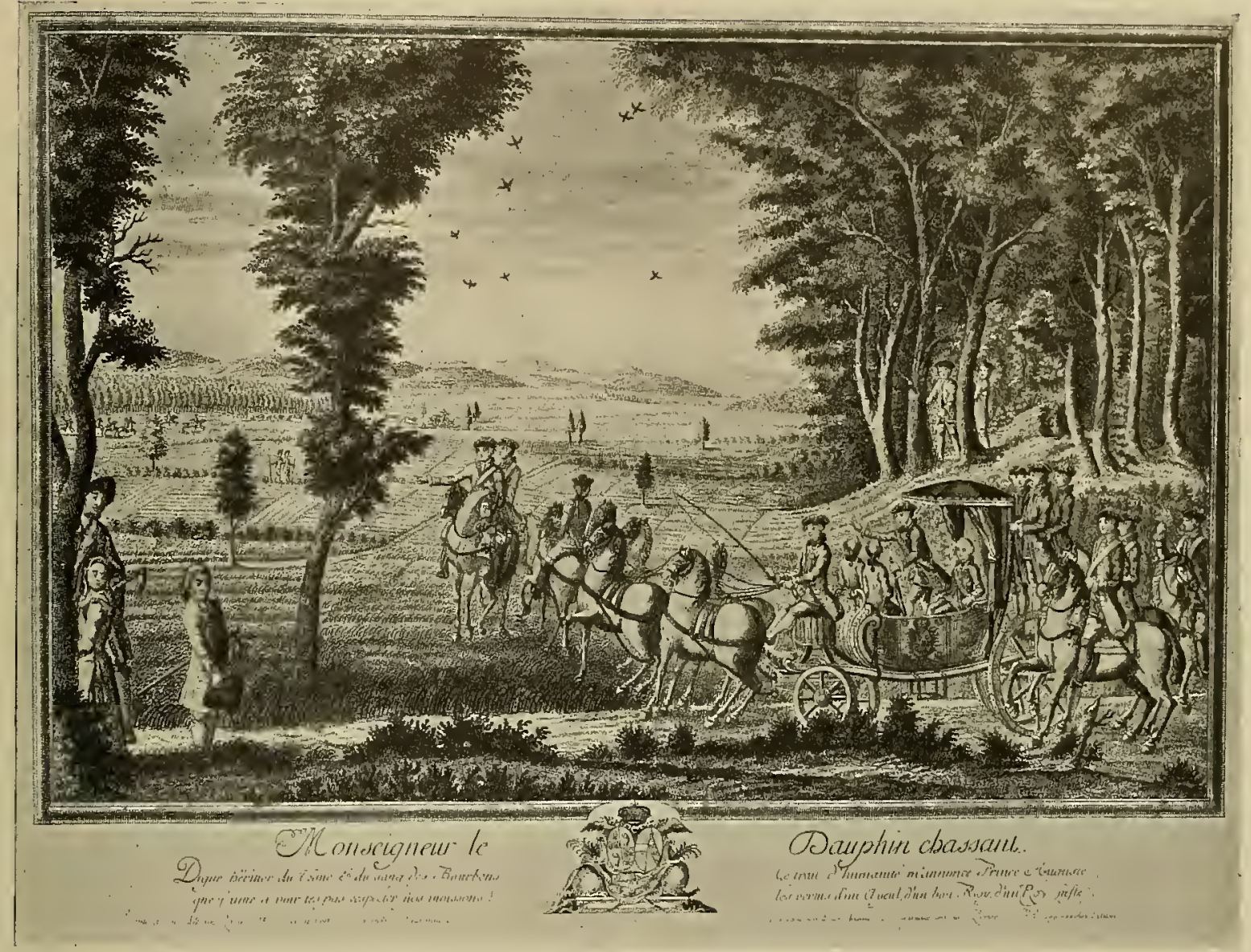

FIG. 229. LOUIS XVI, AS DAUPHIN OF FRANCE, DRIVING OUT TO SHOOT. BY PERRIER OF STRASSBURG. See Page 336

tions will enable the reader to form his own opinion. Of their importance as historical documents illustrating Continental sport and sporting customs in the eighteenth century there can be no two opinions.

In conclusion we feel tempted to publish one of the five existing portraits of the diligent old Augsburg artist, Fig. 226, which drawn by himself was engraved by his son Martin. It pictures him amid the sylvan surroundings he loved so dearly, engaged in depicting the animal foremost in his art as in venery. It is faulty in drawing and in no respect a masterpiece, but it will not fail to appeal to those 


\section{SPORT IX ART}

who have perused the foregoing inadequate account of an artist and lover of Nature who can rightly claim to have been the most productive designer of sporting pictures in the history of pictorial art.

IVe propose to conclude this chapter with three typical prints. Hardly credible does it seem that a contemporary artist of Ridinger-he outlived the latter by some years-could have drawn and, what is more, dared to thrust upon the market, such a bad dream of a picture as is Fig. 227. The perpetrator, one I. R. Holzhalb of Zürich, carefully dates his grotesque production as originating in the year 1768 , hence his late friend, good old Ridinger, was probably spared the sight of this abominable caricature of an animal he himself depicted so correctly. To those who once saw this lordly beast roaming in tens of thousands over the rolling plains of the West, Fig. 227 will possibly explain why it suffered itself to be exterminated.

Fig. 228 hangs at the other end of the line: it is one of those delightfully light and elegant French creations of the second half of the eighteenth century, that period of unmatched elegance and beauty in this branch of art. Its title, Rendezvous de Chasse d'Hemry $I V$, indicates its connection with our subject: an adventure which once befeli that gay French King in the Vendée forest of Vouvant. Getting separated from his courtiers in a dense thicket, he discovered he was lost in the woods. Meeting a lonely charcoal-burner he asked his way back to the place where he knew his attendants would be anxiously awaiting his return. The peasant, not recognising the King, offered to show him the way, and to do so the King invited him to mount his horse behind him as depicted in the picture. Asking the King, presently, whether it was true that his Majesty was hunting in the forest that day, and receiving an affirmative reply, he wanted to know how one could know the King if one met him. "By seeing that everybody stood uncovered in his presence," replied the amused sovereign. On getting to the meeting place, where stood about hat in hand many princes and nobles, King turning to the peasant behind him asked him laughingly whether he now knew who was the King? "Ma foi," replied the charcoal-burner, "if it isn't you who is the King, then it must be I!"

Our last picture, Fig. 229, is of pathetic interest, for it portrays the young Dauphin, future Louis XVI of unfortunate memory, going out shooting in the environs of Paris. To the painter, one Perrier of Strassburg, he was still Digne Héritier of the world's greatest throne, and of the sacred blood of the Bourbons. As the picture is dedicated to Marie Antoinette Dauphine de France, it must have been made between their marriage in 1770 and their accession to the throne four years later. As the monarch's carefully kept diary shows, he was an over-keen sportsman, who assuredly would have ended in a less dramatic manner had he

\footnotetext{
336

* The lady in the centre is Gatrielle d'Estrie;, who had but recently become the King's favourite.
} 


\section{SPORTSAAX DEVOURED BY HOUXDS}

vouchsafed as much thought to his peasants and merchants as he directed to his pheasants and partridges.

Speaking of tragic ends, a brother of the unfortunate Marie Antoinette, Emperor Joseph II, had to lament one of another kind in his family. For his father-inlaw, Don Philip of Parma, while hunting in the woods of Colorno, near Parma, in July 1765 , got separated from his companions, and was devoured by his own hounds. It is supposed that he fell from his horse, and that the hounds began by licking his blood, tearing him to pieces, probably, before he recovered consciousness. 


\section{CHAPTER XIII : THE PICTURES OF DE SAUSSURE'S ASCENT OF MONT BLANC}

$\mathrm{T}$

HE series with which we propose to conclude the present volume relates to a form of sport to which we have had no previous opportunity of referring, for mountaineering, as a pastime, has but recently celebrated its centenary. There exist, of course, hundreds of engravings and woodcuts of mountain scenery, mostly by Swiss and German artists of no great fame, that precede our prints, but none deal with mountain climbing. And inasmuch as Horace Benedict de Saussure's ascent of Mont Blanc, La Montagne Maudite of innumerable stories and legends, first drew attention to mountain exploration, a pastime, if so we may call it, which was destined to have extraordinarily important results for the Alpine regions of Europe, the story pictorially told of the adventurous expedition undertaken by the Genevan professor of geology, claims fuller attention than it has hitherto received. De Saussure won his race by a short head, for had his expedition been delayed but by a short week, an English climber* would have secured the undying fame that fell to the lot of the Genevan, and August 9, I 787 , instead of August 3, I 787 , would have been the red-letter date that witnessed the conquest of Europe's highest mountain by an amateur, by a gentilhommemontagmard, as Saint Beuve called de Saussure. His ascent, while not the first-for Jacques Balmat, the hero of Chamonix, had twice reached the top before him, first on August 8, 1786, with the village doctor of Chamonix, Michel Gabriel Paccard, $\uparrow$ and secondly on July 5, 1787 , accompanied by two other guides-drew the attention of the civilised world to the little hamlet that is now known so well to every lover of mountain-climbing, and alas! also to tens of thousands of makebelieves who have long ago robbed it of its pristine charms.

Of Balmat's two preceding ascents it is unnecessary to say much in this place, for unfortunately there exist no pictorial records of any kind in relation to them, and the question whether he or his companion, Dr. Paccard, was the first actually to reach the top, with the equally puzzling enigma concerning the fate of the book describing his ascent which the latter was known to have written, have quite lately been set at rest by the researches made by an enthusiastic mountaineer, Mr. Henry F. Montagnier. Paccard's book which had disappeared altogether from the ken of man, though written, had never been published.

Ve have said that the pictorial account of de Saussure's expedition has hardly received the attention it deserves, and this is borne out by the meagre information in the latest collective work on the history of mountain exploration, viz. M. John Grand-Carteret's La Montagne à travers les efges. Its thousand and odd

* Mr. (subsequently) Colonel Mark Beaufoy of the Tower Hamlets Militia.

$\dagger$ Also spelled Pacard, but as the doctor himself and de Saussure use the double "c," it is probably the correct spelling.

$33^{8}$ 


\section{SPORT IX ART}

German publication on mountaineering: Der clpinismus in Bildern, by Alfred Steinitzer (München, 19 I3). For this reason we venture to think that a succinct account of the various illustrations dealing with de Saussure's ascent will, as the first of its kind, be found acceptable.

It is perhaps hardly necessary to premise, that examined in the light of modern alpinism these pictures, as well as the accounts left us by these early mountaineers, appear essentially infantile, and one might say medixval, in the nescience they display of the simplest phenomena. It seems hardly credible that they were drawn or penned not much more than a century ago. Indeed, so remote from the ken of the world was everything connected with the present Playground of Europe, that even the highest peak remained nameless until the middle of the eighteenth century: The first time that the name Mont Blanc occurs is in Peter Martel's account of the "Glacieres" (he meant, of course, the "Mer de Glace"), of which the English translation was published in 1744. In the Duke of Rochefoucauld's account of his ascent of the Montanvert, which prodigious feat he achieved about that time, principally to show that the French were as courageous as the English, he writes: "To avoid tripping, which the stones along the path would have made dangerous, I was obliged to hang on to the tail of my frock-coat which one of the peasants carried slung over his shoulder." One could quote dozens of similar amusing instances out of the writings of early visitors to the Alps.

The prints which we propose to examine first, Figs. 230 and $23 \mathrm{I}$, which are the progenitors of a numerous offspring, are of fairly large size $(39 \times 50 \mathrm{~cm}$.) and are printed in outline on grey paper, which adds to their effectiveness. They are hand-coloured, at least we have never come across two quite identical in colouration. Of the lengthy French inscription below Fig. 230, the following is a translation: "Voyage of Mr. de Saussure to the top of Mont Blanc in the month of August, I787. This celebrated Genevan physician, accompanied by the intrepid Jacques Balmat, nicknamed 'Mont Blanc,' and by seventeen other guides, ascended this famous mountain, and after a difficult and dangerous march which lasted i 8 hours, he reached the top which has an elevation of about $245^{\circ}$ toises over the level of the sea. Published by Chr. de Mechel in 1790, and can be found at his address in Basle." Beneath the picture of the descent, Fig. $23 \mathrm{I}$, is much the same inscription with the additional remark, "after having made on the 3 August on the top of this famous mountain diverse interesting observations which can be found detailed in the third volume of his Voyages."

The two prints, to differentiate them from others, we propose to call the "published Mechel prints," for there exist a few proofs of two other plates commemorating the same event. These, there is reason to believe, de Saussure caused to be suppressed because the artist had represented him in a somewhat undignified attitude. Of the most interesting of these two suppressed plates Fig. 232 is a reproduction, and of it probably not more than three or four are in existence, so that it 340 


\section{DE SAUSSURE'S DESCEXTT}

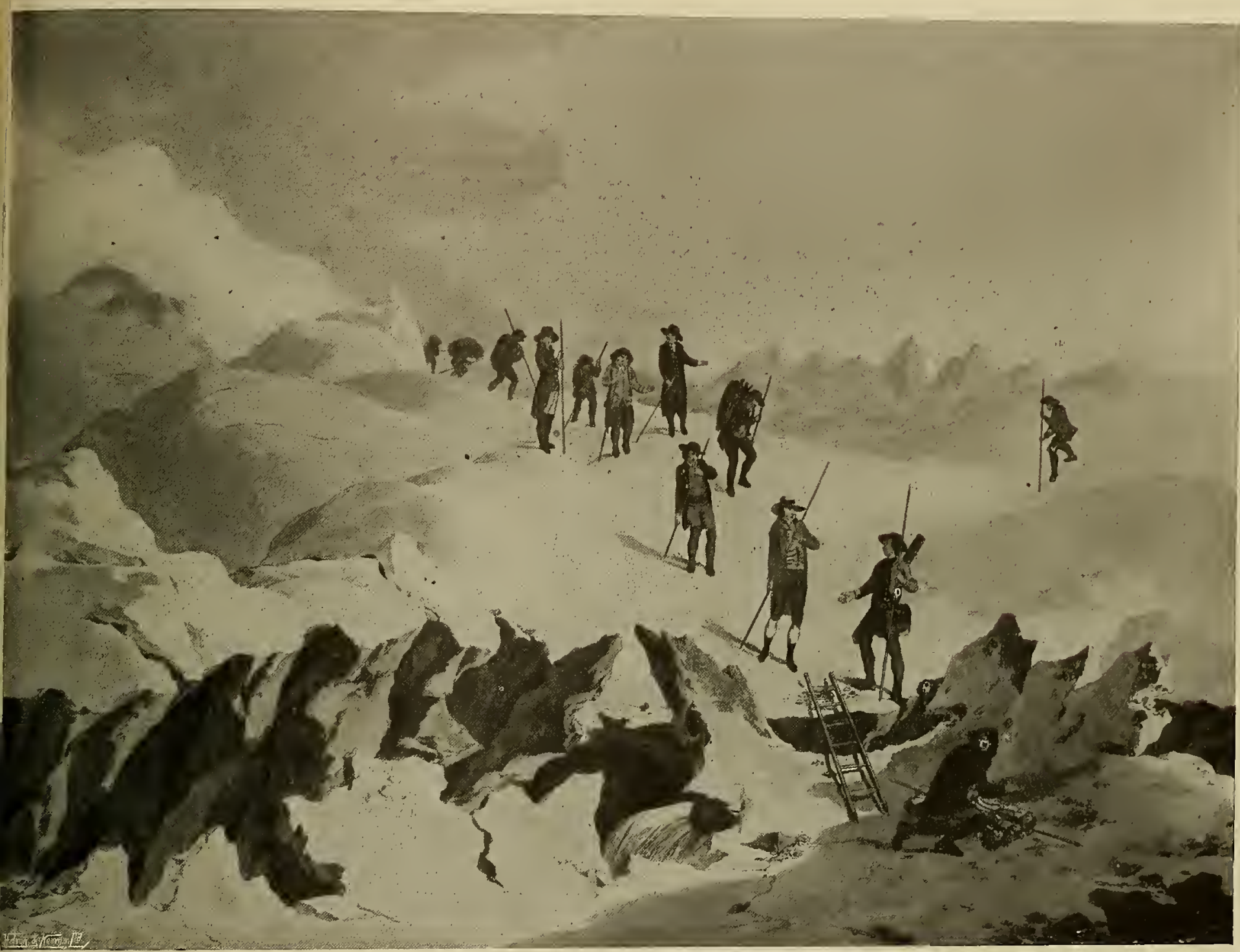

FIG. 23i. DE SAUSSURE'S DESCENT FROM MONT BLANC IN I787. BY AN UNKNOWN ARTIST. PUBLISHED IN COLOURS BY CH. DE MECHEL IN 1790 IN BASLE

is among the rarest of Alpine engravings. Whether de Saussure's undignified pose, sitting on the ice and being helped by two men with ropes over an absolutely dangerless cleft, was a truthful representation or an invention on the part of the artist, we can perfectly well understand that the great traveller objected to go down to posterity in such an inglorious position. The two proofs of this suppressed 


\section{SPORT IX ART}

plate with which we are acquainted are of a beautiful finish, particularly de Saussure's face, which is of exquisite fineness; his straw hat, rosy cheeks, and white hair could not be better.

Of the second suppressed plate we do not bring a reproduction, for it differs only triflingly from Fig. 230. De Saussure is represented as a much older and stouter man, and his pigtail is longer, while his scarlet coat comes right down to his boots. As there are fewer features about this picture to which de Saussure could reasonably object, it was probably the last described "descent" picture which caused the trouble, and condemned both to remain unpublished, the few existing proofs "before letters" being all that is left of them.

The not unimportant question who drew and engraved these plates is not easy to answer with any degree of certainty, for there are no fewer than five claimants for that honour. According to Mr. Godrrey Ellis, the owner of the best collection of Alpine prints in England, the published Mechel prints, Figs. 230 and 23I, are by Bacler d'Albe, who subsequently rose to be a Baron and Brigadier-General. He painted landscapes and classical pictures. But Mr. Ellis confesses that he has nothing positive to go on. Against this ascription the following must be considered. On one of the two existing proofs of Fig. 232 (the suppressed Mechel), which is in the hands of a collector in Geneva, is the signature "Marq. Wocher illum. 1789 ." This Marquard Wocher was a quite well-known painter of Swiss scenery who had studied in Paris and became an artist of repute. As there is a striking resemblance between this signed suppressed plate and the published ones (as we write we have them all before us for comparison), it would seem very likely that all four were designed by Wocher, were it not for two remarks of de Saussure himself, which again raise doubts. The one occurs where he describes the convenience and security of the barriere ambulante, which we see graphically illustrated in Fig. 230. It consists of " a light but strong bâton eight or ten feet long which is held by two guides, one before and the other behind, while you walk between them." "This," he adds good naturedly, " neither bores nor tires the guides in the least, and may afford support to themselves if one should happen to slip. It is in this attitude I have been represented by M. le Chevalier de Mechel in the large coloured plate that he has engraved of our caravan." The second reference is to be found in a very rare little octavo pamphlet of thirty-nine pages, which Mechel published in 1790 to accompany his two published prints of the ascent of Mont Blanc. A typewritten copy of this has been kindly sent me by Mr. Montagnier. It is called Relation abrégée d'un Voyage à la Cime du Mont-Blanc en clont 1787. Par M. H. B. de Saussure, Professeur émérite de Philosophie et Membre de diverses cAcadímies. Nouvelle Edition faite pour accompagner deux Estampes enluminées qui représentent cette expédition, Publiées Par Chrétien De Mechel, Graveur et Membre de diverses eAcadémies. eA Basle MDCCXC. There under the heading "efvis de l'eAuteur "we are informed by de Saussure that $34^{2}$ 


\section{THE SUPPRESSED PLAT E}

"these two plates which Mr. de Mechel has had engraved (vient de faire graver) to depict my voyage to Mont Blanc give a very good general idea of this expedition, of the views of this mountain, of the route, and of the attitudes of the travellers.'

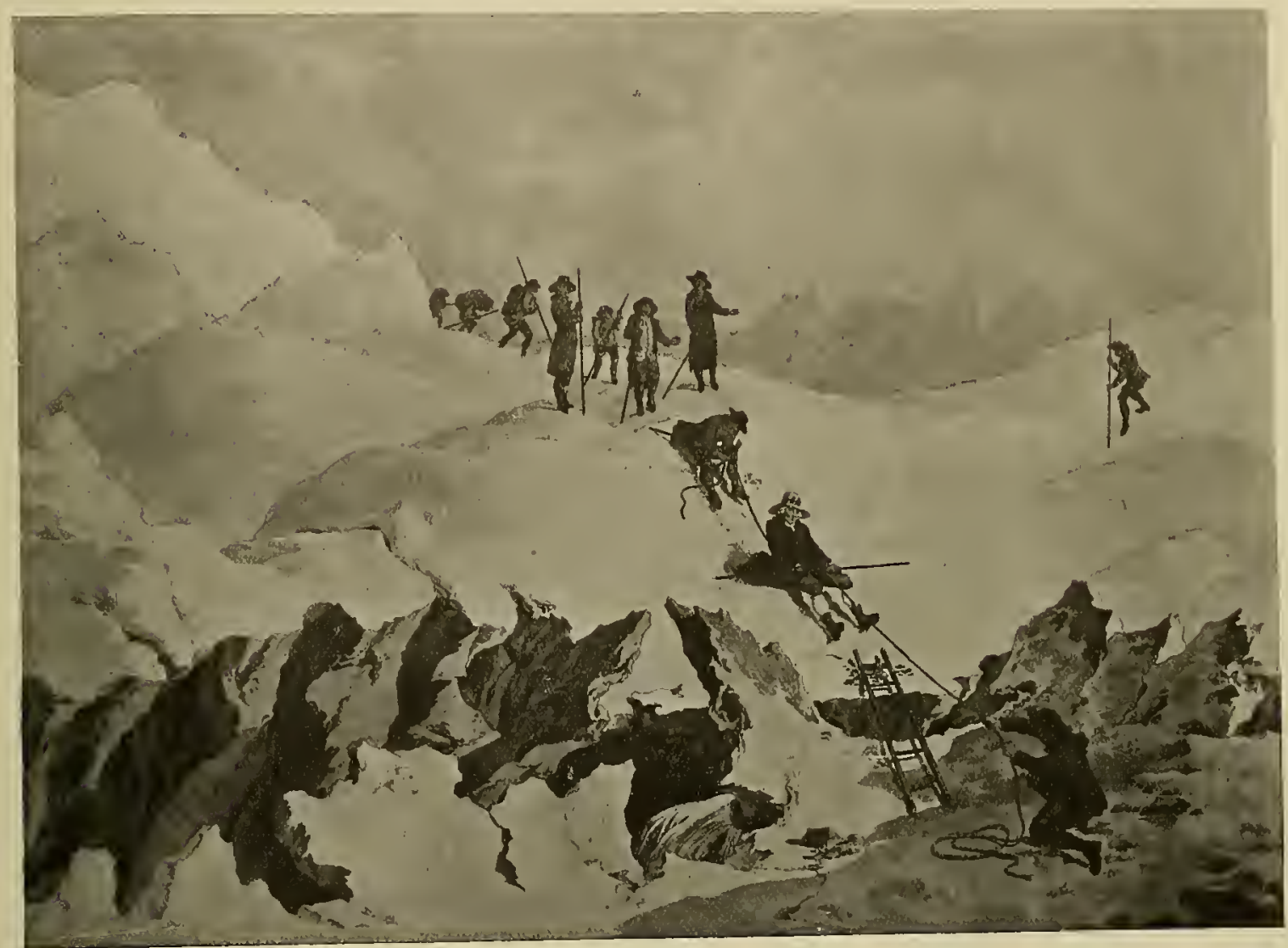

FIG. 232. THE SUPPRESSED PLATE OF DE SAUSSURE'S DESCENT FROM MONT BLANC IN 1787 , THE POSITION OF DE SAUSSURE BEING CONSIDERED DEROGATORY. A VERY RARE PRINT. SIGNED "MARQ. WOCHER ILLUM. 1789"

This vient de faire graver can, of course, be taken in both senses, and, besides, it is always possible, though unlikely, that as Mechel published these prints de Saussure believed that he had also engraved them. A possible, indeed likely, explanation of Wocher's signature on the proof of the suppressed plate has been suggested; it is that he did the colouring only, the designing and engraving being done by others.

A fourth claimant to the honour of having designed these important pictures is disclosed by some correspondence communicated by $M$. Etienne Charavay to M. Grand-Carteret (see his vol. i, p. 445-7). In a letter dated I790, the year 


\section{SPORT IX ART}

when the prints were published, Mechel writes from Bale to C. L. Zehender begging him "to complete as soon as ever possible his views of Mont Blanc so that he can have them at once engraved and impressions taken (pour qu'il puisse les mettre immédiatement en gravure et les faire tirer), for otherwise he cannot satisfy the demand which has arisen from every side." He also impresses upon Zehender to make "your glaciers white, very white, of a milky whiteness." Zehender was a talented Swiss artist who had studied in Paris, where he was made designer of the Duc de Chartres, but eventually returned to his mountains and became a well-known water-colour painter of Swiss scenery and historical events. It cannot be denied that from a technical point of view he might well be the designer of our set.

Of the fifth and last claimant, Henri L'Evêque, the designer of the next set of which we shall speak, we know that he accompanied de Saussure on one of his expeditions, at least such is said to be the case by the usually correct Biographical Dictionary of Swiss Artists. Mr. Montagnier, who contends that L'Evêque drew these published Mechel prints, has kindly given me the following information in support of his belief. It appears that he possesses a good water-colour copy of Mechel's published "Ascent" $(32 \times 23 \mathrm{~cm}$.), entitled "Beklimming van den GTont Blanc," which is signed " $W$. K. Mandemaker fec. naar de originele teckening van H. L'Evéque," showing that it was copied from L'Evêque's original drawing. It agrees, Mr. Montagnier tells me, with the Mechel print in every detail, a fact which certainly is evidence worth considering.

It is to be hoped that further research into the history of these important and now much sought for pictures will throw definite light upon the question whether Bacler d'Albe, or Wocher, or the Chevalier de Mechel, or Zehender, or L'Evêque drew them. The writer's efforts in this direction in the public and private collections in Switzerland, more particularly in the Library of the Zuirich Polythecnicum and the Bern Landes Bibliothek, the two principal sources for local information, failed altogether to unearth proofs. Neither of the last named possessed even the two published Mechel, or the two L'Evêque prints, nor had the custodians ever heard of them-a surprising avowal considering the wonderful results for Switzerland following de Saussure's Alpine exploration. Mons. Charles Bastard's collection in Geneva, said to be the best of its kind in the country, was not to be seen, "it being locked up in an Alcove from which it would be a very great and long labour to unearth any portion," as the owner obligingly informed one; and the information he gave about these prints did not go beyond what one already knew. So a wide field for enquiry into an interesting question is awaiting a de Saussure among bibliophiles. In the Appendix will be found all obtainable details concerning the artists that have been named.

We now have to speak of the L'Evêque set which deals with de Saussure's explorations of the Mont Blanc regions in the year following his ascent. Fig. 233 344 


\section{SPORT IX ART}

peeping invitingly from hampers, the only cooking implement being the same old coffee-mill we saw in the larger prints. De Saussure mentions in his book that his eldest son ardently desired to accompany him on his successful attempt to ascend Mont Blanc, but he feared that he was not sufficiently robust, and so he was left behind to make observations at Chamonix. But a year later the youth, who, if our artist gives us a true picture of him, was a lusty enough young man, probably better able to withstand the fatigues than was his father, who was fortyseven years of age when he topped Europe's highest mountain, was allowed to accompany his parent for the seventeen-day picnic on the Col du Géant. These " 1788 " prints were designed and also engraved by $\mathrm{H}$. L'Evêque, and are really mere outline sketches with the shading washed in with colour.

What a great stir de Saussure's exploit created is shown by the number of sets of coloured as well as of uncoloured prints which were published in quick succession to commemorate the conquest of Europe's highest mountain. A word or two must be said about these sets. Although they are with only one exception practically copies of the Mechel prints, certain "improvements" of sorts were introduced here and there with an amusing freedom. Two plates designed by Grundmann and published by J. P. Lamy of Basle, Lausanne, Geneva and Bern bear the inscription "Ascent of $M$. de Saussure to the top of Mont Blanc in the month of August 1785 " (sic); the second print dealing with the descent. Another pair by Volz, published by the same firm, perpetuates the above extraordinary mistake by which de Saussure's ascent is made to ante-date Balmat and Paccard's first successful assault of the virgin peak by a full year! Another smaller set ( I $\times 7 \frac{1}{2} \mathrm{~cm}$.) differs considerably from the much-copied Mechel originals, but inasmuch as the above 1785 mistake is repeated, Danzer who designed them and Sperli who was the engraver (they were published by Moehly and Schabelitz of Basle) cannot have known much at first hand about the scenes depicted by them. In the picture of the ascent a ladder bridges a narrow chasm, and a man, obviously intended to be de Saussure, is represented using it. In the picture of the descent a rope ladder hangs down a precipice, de Saussure is descending it, being held up by a rope which is tied round his shoulder. On the brink stands a basket from which peep six bottles.

The writer possesses an hitherto undescribed coloured plate of medium size $(32 \times 23 \mathrm{~cm}$.) representing the ascent differing in a few details from the Mechel plates. Unfortunately it is cut down to the margin so that there is no indication of its origin. A detail distinguishing it is that the last but one man in the file carries on his back a basket with seven bottles sticking out at the top. Whether this print has a pendant we have been unable to ascertain.

Another coloured variant in the writer's collection is a small coloured plate $(16 \times 12 \mathrm{~cm}$.), lithographed by Kellner at Geneva. It differs in unimportant details from the Mechel picture of the ascent, and being probably the latest of all, the 346 


\section{HOW MIST AKES ARE PERPETUATED}

bottles have increased to nine from the three in the original picture! In fact the later the copies were produced the more bottles were put into the basket! Had not the dreadful Hamel accident, by which three guides' lives were lost, occurred in 1820 , causing a number of new pictorial descriptions of the dangers attached to the ascent of the great peak to be placed on the market, it is probable that a second basket full of bottles would have before long appeared on the scene.

To speak finally of the uncoloured prints which appeared mostly as bcok illustrations it would lead too far to give a list of them, but almost all perpetuate the mistake of stating that the ascent occurred in the year 1785 . Indeed there are many more old prints about with the wrong date than with the right year, a condition of affairs which glaringly illustrates how easily one slip sets going an avalanche of errors. A few generations hence greater numbers and a far wider circulation enjoyed by the prints giving the wrong year will probably begin to tell, and the year 1785 may go down to posterity as the one that witnessed the conquest of the Alps.

It is now high time to say in conclusion a few words anent those of the details in our pictures that are of interest to the climber of to-day. Many of them will naturally bring a broad smile upon his face. In the hundred and twenty-five years that have since elapsed we have learnt all there is to know about climbing, or at least we think we have. But in Jacques Balmat's day the invasion of the regions above snow-line was deemed to be beset with appalling dangers, natural as well as supernatural. Though to the native the roar of the winter-avalanche was of course a familiar sound, he had not yet learned the risks arising from the SommerLavine, from crevasses hidden by snow, from stone-falls and ice-falls, from treacherous cornices, from physical exhaustion in high altitudes that invites sleep from which there is no awakening. To a man of Jacques Balmat's generation, mountain-bred though he might be, the climb to the Fardin or to some harmless $\mathrm{Col}$ was as riskful a proceeding as would prove to-day the crossing at the Mansion House to that dear old son of London, Mr. Pepys. This utter lack of experience is shown in every detail in the modus operandi of de Saussure's caravan. Contemporaneous writers tell us that the long-tailed scarlet coat worn by de Saussure was of silk and was profusely adorned by huge buttons. He wore knee-breeches and white thread stockings; and the light boots of flimsiest make, such as he might have worn promenading on the lake-terrace in his own Geneva, lack even the crampons such as we see the guides are wearing. And what with the pigtail, the ribbon-bedecked broad-brimmed straw hat and the parasol which, though the designer of these plates omitted it, we know he carried, good old de Saussure must have presented an unique sight as he stood victorious on the top of the great White Mountain. By the next season, if we can believe our artist L'Evêque, he had learnt his lesson, and in the 1788 pictures, Figs. 233 and 234 , we see crampons on his feet, gloves are hanging from the eAlpenstock that forms that farcical barriere ambulante, 


\section{SPORT IX ART}

a hat of felt and of more suitable proportions is on his head, and the pigtail as well as the scarlet coat have disappeared! The complete absence of ropes which is such a noticeable feature in the published prints, the presence of only one iceaxe and of a long ladder, which latter, we are told, was de Saussure's invention, the wholly unscientific manner in which the slpenstöcke are being handled, which would infallibly bring the bearer speedily to grief, the man staggering along under a stack of bedding large enough to render the passage of even the most harmless mawiais pas a matter of impossibility, the contrivance which looks uncommonly like a coffee-mill dangling from the Kracksen carried by the last man in the file, the obvious inadequacy of provisions in the one basket from which peep three forlorn bottles - a number which, by the way, does not seem to have been decreased in the course of the ascent and of two bivouacs, for in the second plate the same number peep out of the diminutive peripatetic larder-these and a number of other ludicrous details challenge our amused criticism. How it came that the idea of connecting the members of the expedition by ropes had not occurred to the leaders we cannot say. A brief reference to their use is made by de Saussure (chap. ii. of the iv. vol.), where he describes the lucky escape of one of his guides. He writes: "One of my guides went overnight with two others to reconnoitre. Fortunately they took the precaution to tie themselves together with rope; the snow gave way under him in the middle of a large and deep crevasse, and he remained suspended between his two comrades. We passed close to the hole which was made under him, and I shuddered at seeing the danger he had encountered." It seems hardly possible that in view of this warning the party should have continued to court disaster in the manner depicted by our artist. In the suppressed plate we do observe a rope, but in what an absolutely idiotic manner is it being employed! Poor de Saussure, who is evidently in difficulties, for he is squatting on the ice, would have been simply cut in two by the rope which he has round his waist, had the "rescue" taken place in the manner depicted, for while from the top one burly guide is heaving and tugging with all his might, the other stalwart Swiss is lugging as lustily in the opposite direction! The two men looking on in horror with uplifted arms from above are evidently expecting that the worst will happen, for is not a crevasse some eighteen inches wide yawning to engulf the bold Professor? We know that he escaped death on this occasion, and that not a single accident marred the great expedition. A transposition of the French proverb : "Fortune est nourrice de Folie "would justly describe the extent to which kind providence protected those nineteen men against the folly of inexperience.

Were it not for de Saussure's own remark, that these pictures give " a very good general idea of this expedition and of the attitudes of the travellers," serious doubts would arise in one's mind whether the artist who drew these pictures had really seen the scenes he depicted, and whether they can be taken seriously. One $34^{8}$ 


\section{SPORT IX ART}

There are some other pictures connected with Mont Blanc dating from the eighteenth century. F. Ch. Exchaquet made a relief of the Mont Blanc range, showing de Saussure's route, after which relief C. Mechel made an engraving more curious than correct. Another print in outline, coloured by hand, was engraved by Exchaquet after his relief in 1791. Marc-Theodore Bourit or Bourrit designed a similar one which A. Moitte engraved. A picture of the valley of Chamonix after Schmidt Anglois was engraved about the same time by G. S. Stouder or Studer ; and J. A. Link, a Genevan engraver of some renown, produced a coloured print of the Chapeau du Glacier des Bois very soon after de Saussure's expeditions, viz., in or about the year 1788. Very numerous engravings relating to Mont Blanc and other Swiss and Tyrolese peaks were issued after the Napoleonic wars; indeed, of the Gross Glockner there is a curious print in Hacquet's Travels which was published in Vienna in 1784 . Hence it really takes precedence of the Mont Blanc pictures. Another distinction the great Austrian peak can claim is that it was the first mountain the ascent of which was commemorated by a finely modelled medal which the Prince Bishop of Gurk had cast in memory of the first ascent achieved, not by himself, but by another priest of rank in the year I799.

And now to sum up with a few words what the pictorial story of de Saussure's expedition reveals to us : success in spite of gross inexperience! But let us be honest, and ask ourselves whether that disdainful curl of superior wisdom at the flagrant ignorance displayed in these pictures is quite in place on our own lips? Have not some of us, who are now old fogies, in our salad days, when our inexperience was stupendous but our hearts were light, committed quite as foolish breaches of the elementary rules, and outraged as idiotically the primary laws of mountain climbing? The writer, for one, must plead guilty of having courted disaster by conduct quite as imbecile as that at which we smile in reviewing our little gallery. When nigh upon forty years ago he and four companions as harebrained as himself, undertook to make the first winter ascent ever achieved of any high peak in the Eastern Alps, the rash party started out quite gaily armed only with a snow-shovel to attack the Matterhorn of Austria, an ice peak of the first order, without a single ice-axe between us five simpletons. And when on getting to the top of the lower of the lofty twin peaks, well known to us from summer ascents, we discovered instead of the sharp point, a safe-looking platform as large as a room; did we not rush to the edge, and for some minutes stand on a shallow snow-cornice that overhung an abyss of 4000 feet? A few pounds more of foolish humanity or a single step further out towards the treacherous brink, and the peaceful iittle cemetery of Heiligenblut nestling at the foot of the great peak would have had to house five gory objects sewn up in sacks, the manner in which the High Alps most generally lay to rest their annual toll. We five imbeciles on that 2 nd January 1875 escaped, as did de Saussure and his companions. But master-peaks do not forego their tithes so lightly; and the White Mountain $35^{\circ}$ 


\section{UICTIMS OF THE MOUXT}

gathered in his when Randall and Beans' entire party of eleven perished on its slopes, while the Gross Glockner, of sterner aspect, though lower altitude, insisted as inexorably on his tribute a short time after the writer's escape. The fate that overtook the poor young scion of a great house and his four guides at the very same spot that had so nearly become fatal for us and, so far as could be discovered in a case where all perished, as a result of carelessness similar to ours in foolishly trusting to a deceptive snow-shelf, was one of those lessons the ever-alluring Alps impress upon those that sit at their feet. 

A PPENDIX

$2 \mathrm{Y}$ 



\section{APPENDIX}

$\mathrm{T}$

HE following brief biographical notes regarding some of the lesser known artists who contributed to our subject have been carefully verified by the writer. A "?" signifies that some doubts exist. When dimensions are given they are the usual ones-of the plate-expressed in centimetres $(2.54=\mathrm{I}$ inch), width first, then height.

Of a few of the most interesting series of sporting prints about which little or no information has hitherto been published, we have given details that may assist collectors. Being in many instances the result of the writer's personal researches much of the information here given is original.

The writer must gratefully acknowledge the assistance extended to him by a near connection, the late Hugo von Tschudi, through whom sources of information were made available that otherwise remain closed to the amateur outsider.

AKEN, JAN VAN (I6I4?-I66r?), a Dutch designer and etcher about whom little definite information has come down to us. C. Walker published 42 facsimiles of etchings ascribed to him. One of the plates depicts a stag-hunt (B. II).

ALTDORFER, Albrecht (1480?-1538), a Ratisbon painter and designer. Formed himself after Dürer and painted mostly landscapes and devotional pictures. In one or two of his panels sporting animals are introduced, but otherwise his work does not concern us, except as a candidate for the honour of having helped in the completion of Emperor Maximilian's Prayer Book con1menced in 1515 by Albrecht Dürer (see p. 88).

AMBERGER, Christoph (I 500-1558), an Augsburg painter and designer of woodcuts. He chiefly painted portraits, the three most interesting, of Charles V, Sebastian Münster, and of the famous Landsknecht leader George v. Frundsberg, the hero of Pavia, being in the Kais. Friedrich Museun in Berlin. Of the first-named portrait it is said on reliable authority that the painter received for it not only the agreed price of Io Thaler $\left(£_{3} 3^{s}\right)$ but was rewarded with a gold chain. Sporting subjects he did not paint, but he probably contributed sporting designs for woodcuts.

A MLING,Carl Gustav (I 65 I-I 703 ?), also written Ambling, a talented Nürnberg artist. He was a pupil of the Parisian engraver N. de Poilly, and on his return to Bavaria was given employment by the Elector Maximilian II, who made him court engraver. He worked much in Munich, producing plates after Pieter de Witte, or as he is more commonly called, Candito (Candid). The Print Room at the Alle Pinacothek in Munich possesses the largest collection of his engravings, though one or two of the sets are incomplete. Two drawings there attributed to him are poor specimens in comparison to Figs. I 31 and 132 (signed) in the writer's collection.

AMMAN, Joвst (I539-I59I), also called Jost Amann, born in Zürich, was a versatile and most productive designer and wood engraver. It was generally supposed that he emigrated to Nürnberg as early as 1560 , according to researches published recently, but a sumptuously got up history by a descendant of Amman (for private circulation) it noould 


\section{SPORT IX ART}

appear that he did not settle down in Nürnberg until some fifteen years later, for the work in question quotes a resolution of the town council of Nürnberg of October I5, I 575, to the effect that Jobst Amman be granted the permission to live in this town for a year and to have his own smoke, i.e. hearth. (Dem Jobsten Amman von Zürich sei es vergunnen ein Jahr alhier zu sitzen und sein aigen rauch $\approx$ uhalten.) From that time on he seems to have resided permanently in this centre of German art, and to have developed an extraordinary diligence. Of his versatility the numerous books he illustrated tell an astonishing tale. Bibles galore, works on Natural History, the military sciences, philosophical works, treatises on costumes, on tournaments, and, last but not least, on our own topic, make Keller's report credible that a hay waggon could not draw away Amman's wood-blocks cut in the course of four years. Amman's first work on sport is an insignificant looking little quarto, now of considerable rarity, called Adeliche IV eydwerke, which he and W. Serlin published in $156 \mathrm{r}$ at Frankfurt, the town which subsequently becaine the headquarters of Feyerabend's great book-publishing establishment which issued most of the works illustrated by Amman (see Feyerabend.) Adeliche Weydwerke was doubtlessly inspired by Jacques du Fouilloux' Vénerie, and subsequently many of the woodcuts it contains were used in Amman's Neuw Fag und $W$ eydwerck Buch, a fine folio, also rare, which is divided into two parts with separate title-pages. The first deals with hounds, hunting-music, the chase of the stag and other beasts (taken mostly from du Fouilloux), while the second part treats of falconry and fishing. It was printed by Johann Feyerabend and published by the famous Sigmund of that ilk A.D. I 582 . Anıman's name does not appear in any shape or form in this volume, and yet almost all of the $\mathbf{1} 74$ woodcuts that adorn it are certainly designed and probably also engraved 356 by him. The suppression of the artist's name shows us to what an extent the masterful publisher had succeeded in silencing the individuality of the artists who worked for him. The following is therefore all the more curious. In the same year and same town, but by another publisher (Martin Lochler) was issued a quarto entitled Künstliche Volgerissene new figuren won allerlai fag und weidtwerck, durch den Kunstreichen Fost Amman Wonhafft zu Nurnberg... which is illustrated with impressions from blocks used in the last-named folio. This practically simultaneous publication of impressions from the same blocks by two rival publishers of the same town is one of the many puzzles presented by the publishing business of that period which has never been cleared up. Considering that the title-page of the folio bears, printed in red ink, the "Imperial Privilege" prohibiting the pirating of text or illustrations, and that it is also stated that the "beautiful prints have not been published before," it is difficult to suggest an explanation. If the quarto appeared after the folio such a direct infringement of Feyerabend's rights would have been a very riskful proceeding. One unlucky publisher of the same town who contravened a minor regulation was sent to Vienna (where sat the court having the requisite jurisdiction), chained to the open waggon on which he had to perform a weary journey of several weeks' duration in the depth of winter, during which he never left his exposed seat. Baudrillart, to add to the already existing confusion caused by the folio and the quarto of 1582 , mentions a second quarto of that year, published this time by Feyerabend and illustrated with forty cuts by Amman. This seems to have been a Latin edition embellished by some poems-we have never cone across a copy-and he gives its title as : Venatus et aucupium, iconibus ad vivum expressa et succinctis versibus illustrata, per Joannem Adamum Lonicerum : accedunt Herculis 


\section{APPEXDIX}

Strozza de Venatione carmen, et Adriani cardinalis de venatione aulica carmen; necnon Gratii, M. Aurel. Olymp. Nemesiani, et Joannis Darcii de V enatione et canibus carmina. Francof., Sigismundus Feyerabendius, 1582 , in $4^{\circ}$. Buddrillart himself does not seem to have known much about the matter, for he says "perhaps Amman's pictures are the same as those used by Feyerabend in his German translation of a French work on hunting." Other sporting pictures designed if not cut by Amman are to be found in the Thierbuch, containing 107 pictures of animals. Of it five editions were published-in I 569 , I 579, 1592, 1612, and 1617; then in Plinius' Natural History ( $1565, \& \mathrm{c}$.) then in Fagd und Forstrecht, I 576 ; but where they are not replicas of cuts that had already been used they are unimportant so far as sport is concerned. Amman's inventive skill showed itself in designing the elaborate title-pages then so much in vogue, and his ornate allegorical or architectural designs were copied far into the seventeenth century. Drawings by Amman are not common. There are a few in Dresden and Vienna. In a private collection in Munich there is a pen-andink drawing of a bear-hunt attributed to this master.

ANJOU, Rente of (I408-I480), King of Naples and Duke of Lorraine, a talented miniaturist, probably a pupil of the Van Eycks. Unfortunately this royal artist when depicting scenes of daily life in the delightful miniatures that have come down to us in unumerous Heures and devotional books neglected with one or two exceptions to depict sport. Had he dealt with the subject in anything like the manner in which he depicts the customs and incidents of the tournay in his tournament book which he completed in the year 1449 in the castle of Tarascon, we should have been the richer by a work second only to Gaston Phebus.
BaCLER D'AlBE, Louis Albert GuisLAIN (1761?-1824) was in his younger years an artist; he enlisted in the French army about I793, rose to the rank of BrigadierGeneral in I 803, was created a Baron of the

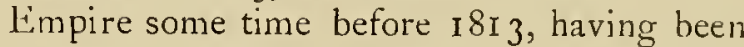
made by Napoleon director of his topographical cabinet. According to Mr. Henry F. Montagnier, Member of the Alpine Ciub, from whose excellent paper on Dr. Paccard's lost narrative of his ascent of Mont Blanc in the Alpine fournal for February I9I2 I take these details, Bacler d'Albe lived in Sallanche from I 786 to I793, which, of course, speaks in favour of his authorship of Figs. 230 and 231 . Authentic works of his consist of landscapes and a few battle scenes and some pictures on classical subjects, such as the death of Paris, OEdipus and Antigone, \&c.

BALDUNG, Hans, also called Grien (about I476-I 545) one of the celebrated early artists and engravers of Germany; born in Gmünd, in Suabia, and a follower as well as personal friend of Albrecht Dürer. The latter when starting on his second journey to the Netherlands took with him some of Baldung's pictures to sell on the way. None of his paintings relate to sport, but there exist drawings of his representing hunting scenes. In a private collection in Munich there is a sepia drawing attributed to him of a wooded landscape with stags and roedeer, some of which are fighting $\left(19 \times 30 \frac{1}{2} \mathrm{~cm}\right.$.). He engraved both on copper and on wood, his work on the latter medium being considered superior, the lights and shades being brought out most effectively. Amongst his woodcuts there are three prints of horses.

BARLOW, Francis (1626? - I702), a famous Lincolnshire designer and etcher, the first native British delineator of animal life worthy of comparison with the foreigners who up to then were undisputed leaders. 


\section{SPORT IX ART}

First a pupil of the portrait painter, William Sheppard, and then of the great Hollar, who subsequently engraved or etched many of Barlow's designs, he became associated with Place, Faithorne, Henry Hulsberg, Jean Simon, R. Greywood, E. Cooper, the Bowles Brothers, P. Tempest, Griffiere, and Dudley. With the last named and Hollar, Barlow's finest piece of work, i.e. the well-illustrated Esop's Fables, which contains some interesting pictures of wild animals, was produced. Most of the copies of this book were burnt in the great fire, and, as one often finds it stated that this book was published in 1665 , it is as well to say that it should read I666, for on the second title it is expressly stated that it was published in the latter year, which also explains how almost the entire stock perished.

A considerable number of small sets of wild and domestic animals designed by Barlow and engraved hy one or the other of the abovenamed artists was issued between the years I $65^{8}$ and his death, which is supposed to have occurred in 1702 . Some of these are first-class, better than anything so far produced in that line. Of these sets numerous reprints were published in the eighteenth century, and in the absence of a catalogue raisonné it is often difficult to know them apart. In a few of his pictures Barlow introduces interesting landscapes; thus in Plate 2 of the set dedicated to Lord Lauderdale, which F. Place engraved and P. Tempest published, there is a delightful picture of Bass Rock, showing the fortifications on it and a great variety of exceedingly well drawn aquatic birds in the foreground.

The rarest of Barlow's works is the etching representing "The last Horse Race run August 24 I 684 before Charles II of Blessed Memory by Dorsett Ferry near Windsor Castle." This inscription, as Mr. T. A. Cook in his "History of the British Turf" points out, is not quite correct, for it should read "run in that place," for there is ample $35^{8}$ evidence that although Charles died on February 6, 1685, he attended the New Market Races for nearly three weeks in October, I684. Many of the details in this print are exceedingly interesting, but one would like to know on what authority the author of theabove-mentioned work attributed the quaint verses below the picture to Barlow. As a rule, the publishers had these inscriptions composed and affixed without consulting the artists who did their hack-work for them. That publishers were a strangely careless lot many of Barlow's prints prove. Thus, on the title-page of one set of "Divers Species of Birds," it says they are "drawn after the life in their natural Altitudes"; then in various instances Barlow's name is spelt wrongly, either without the " $w$ " or with an " $e$ " at the end: then we read of Lapwinks, Pegions, Peacokes, Gease, Dockes, Woode Cockes, Patriges, Grate Tom Tit, Feasants, \&c., words which are spelt correctly in other instances.

Besides the edition of thirteen hunting and fishing scenes to which we have fullyalluded in the text, there exists another edition, which is undated, and bears the title " $A$ sett of Prints of Hunting, Hawking, and Fishing, designed by Francis Barlow," the name of Hollar being omitted altogether. On the title-page is engraved the following:

"The stag rouz'd before us, awav seems to Ay, And pants to ye Chorus of Hounds in full cry;

The day's Sport when over makes blood circle right

And gives ye brisk Lover fresh charms for ye nighr."

BARTSCH, ADAM von (I757-I82I), a famous Viennese engraver, and even more celebrated author of works on engravings. A few of the 500 plates he produced relate to animals of the chase, but most of his animal subjects are after Roos, Potter, and Rugendas, and are of no instructive value for cur purposes. 


\section{APPEX I IX}

BASSANO, Jacopo da Ponte (1 $510-1592$ ), a painter born in Bassano, but who worked chiefly in Venice, the works of Titian being closely studied by him. He has left us hardly any sporting pictures; a stag-hunt in a fantastically lit-up landscape being one of the few. In the latter part of his life he worked for Emperor Rudolph 11 at Prague. His four sons, Francesco, Leandro, Giovanni, and Girolamo, were his pupils and assisted him, the two first-named doing also some original work of merit.

BEAUVARLET, Jacques ( $731-1797$ ), a Paris engraver of considerable fame. Besides a sporting scene by Huet, he engraved a crocodile hunt, a fishing and a bird-catching scene by Boucher.

BECK, Leonhard, an Augsburg painter, designer, and wood-engraver, of whom little is known except that he worked with Burgkmair at the illustrations of Theuerdank and Weisskunig.

BEHAM，BARTHEL (I 5O2-I540), painter and engraver, born in Nürnberg, and pupil of Dürer. It is a pitythis talented master, as well as his brother, devoted themsel ves not more to our subject; their delightful friezes of gladiatorial combats and naked men in the style of Pollaiolo show how much they profited, and to what excellent use they put what they had learnt in their wide travels in Italy.

Sebald Hans (I 500-I 550), elder brother of the above. Both these men and a third artist, Georg Pencz, had in 1525 to leave their native city owing to their religious as well as socialistic opinions; but the old story that Sebald Beham after starting a disreputable house in Frankfurt, was put to death by drowning in accordance with the legal custom of the time, has been shown to be a fable. Both were patronised by the artloving Dukes William and Louis of Bavaria, and it was they who caused the two brothers to study in Italy.

Bella, Stefano della (ífio-i664), a Florentine etcher of some renown, of whom nearly I 500 plates are known. Amongst them there are a score or so of sporting scenes representing the usual boar-, stag-, and bear-hunts, but of no particular interest.

BERCHEM, Nicolas, often written Berghem (1622-I683), a Harlem painter and etcher of renown, who produced some works on our subject in which, however, the sylvan or idylic played generally a more pronounced part than the sporting. Pictures dealing with sport are at the Hague (Boar-hunt, 1659), Hermitage (Halt of Huntsmen), San Donato (Return from the Chase, 1655).

BEWICK, JoHn (I760-I795), born at Cherryburn, near Newcastle, apprenticed as wood-engraver to his brother, made the designs for Somerville's "Chase," but did not live to engrave them.

Thomas ( $7753-\mathbf{I} 828)$, elder brother of above. At fourteen years of age he was apprenticed to Ralph Beilby of Newcastle, a copperplate engraver. His Old Hound, illustrating one of Gay's Fables, obtained for him the Society of Arts Premium as the best specimen of woodengraving in the year 1775. His Chillingham Bull, engraved I 789 , is considered one of his best works. See Ridinger.

BOCKSPERGER, Hans, also Boxberger (I 540-?), a designer and woodcutter, born in Salzburg. He worked for S. Feyerabend, the Frankfurt publisher, contributing 122 


\section{SPORT IX ART}

illustrations for a bible and also the designs for the second Thierbuch, published I 592 . In the writer's collection there is a spiritedly drawn woodcut of a youth armed with a dirk, fighting a tiger or leopard.

BOL, HANs (I 534-1593). This talented, hitherto somewhat unappreciated painter and etcher was born in Malins, at the height of that city's art boom. He became a pupil of his uncles Jacob and Jan Bol, little known artists. When he had completed his apprenticeship he went to Heidelberg. There he worked for two years for the Elector. Returning to Malins, he became when twenty. six years of age master of his guild ( 1560 ), an early age as matters were then conducted by these exclusive corporations. Flying from Malins when it was sacked by the Spanish hordes ( 1572 ), he settled down temporarily in Antwerp, where be joined the local art guild in 1574. Until then he is said to have chiefly occupied himself with designing tapestry, but he was so disgusted with the fact that numbers of artists copied his designs surreptitiously that he took up work far better suited to his talent, viz. miniature landscape and still-life painting, producing examples which modern critics declare to be inimitable little masterpieces. They are mostly penand-ink drawings washed in water-colours. At first he appears to have drawn religious subjects; one of three biblical drawings of this kind in the writer's collection (signed) is dated 1575 , and represents Jerusalem. In the British Museum there are two drawings by Bol, one signed and dated I 568 , but most of his designs for his sporting plates have unfortunately disappeared.

His etchings also show fine work. J. Ph. van der Kellen in his Le Peintre-Graveur says that Bol's eaux fortes are among the finest of his time, and his drawings are, so to speak, unfindable. In the IVinckler Catalogue 284 works of $\mathrm{H}$. Bol are enumerated. Among 360 the engravers who worked after him were the Galle, A. Collaert, J. Goltzius, C. de Passe, P. à Merica, H. Cock, J. Sadeler, N. de Bruyn. Most of the plates after him do not bear the engraver's name. thus not a single one in the $V$ enationis set has a mark. Not many oils by his hand have come down to us. One of the few about which critics have raised no doubt is reported to be in the royal collection at Schleisheim, near Munich. It is said to represent a stag-hunt, but on inquiry the writer was informed that the picture was no longer there. Bol not only etched but also engraved. Almost all of his plates are quite small. There are, however, a few exceptions, one fine instance being mentioned by Riegel in his Beiträge zur Niederländ, Kunstgeschichte, where it is described as consisting of two plates measuring $39 \mathrm{I} \times$ $3^{8} 3$ and $398 \times 375 \mathrm{~mm}$. representing a staghunt where the huntsmen are armed both with rifles and cross-bows. It bears $\mathrm{H}$. Bol's name, and "H. Cock excudebat," and is preserved in the Copenhagen Cabinet d'estampes. Also a plate Chasses in folio, dated I 574 , with the address "Quatre Vents," both being after the designs of Stradanus.

Hans Bol is counted often among the miniaturists on the ground that he illuminated in I 582 the Duke of Brabant's "Book of Hours," which is now preserved in the Bib. Nat. in Paris (MSS. Lat. I0564). It contains charming miniatures of high merit.

In Berlin there are five works by him, one depicting a fishing scene.

Antwerp, where Bol had settled down, was hardly as peaceable a city as the artist could have desired : the troubles of the Inquisition, of the "Spanish Fury" in 1576, the "French Fury" of 1583 , and the long and terrible siege of I $58_{4}-5$, sent our artist awandering again. He went to Bergen-op-Zoom, Dordrecht, and finally to Amsterdam, where in I 59I he acquired the rights of citizenship, but was not destined to enjoy them for long, for he died there two years later. 


\section{$A \mathcal{P P E \mathcal { X }} \mathcal{D} I X$}

Jooris Hoefnagel and Savory were his pupils, and curiously enough both these artists became court painters of the art-loving Emperor Rudolf II.

For us Bol's delightful set of forty-eight little oblong prints, to which we have frequently referred, and which, to differentiate it from Stradanus' Venationes, we call Venationis, is of principal importance. There exist of it at least three editions, viz., the frst edition is the one in which the plates are still unnumbered. The title-page bears the date 1582 , and above it in the tablet we read :

Venationis, Piscationis, et Avcvpil typi loes Bol depingebat Philip. Galleus excud.

Below the richly adorned title-picture is the dedication: Clarissimo viro domino Paulo de Kempenare, Brabantiae ordinib. à secretis, omnis elegantioris picturae summo non tantum admiratori, sed et insigniter perito.

Whether the first edition consisted of $4^{8}$ plates inclusive of title-page it is difficult to determine, considering its rareness; thus the writer has never come across another copy but his own, which contains not 48 but only 38 unnumbered plates including title-page. Information upon this point would be most welcome. As we know that the earlier editions of Stradanus' Venationes, issued by the same publisher four years before, contained fewer plates than the later editions, the same may have occurred in this case.

Second edition: Same title-page, with the additional words below the dedication: Philippus Galleus Chalcog. dedicab. The plates following the title-page are all numbered in left-hand bottom corner, from I to 47.

Third edition: On the title-page the words within the tablet the same as in the previous editions, with the exception that in lieu of Philip Galleus, the Christian nanse shortened to Ioes is put, and instead of the date a small "putti" ornament has been substituted. In the dedicatory inscription below, the noble Paul Halmali, Senator of Antwerp, takes the place of the illustrious Paul de Kempenare. The 47 plates are numbered as those in the second edition, but on close comparison with the latter one discovers many trifling differences, showing that new plates were made or the old ones worked over. In what relationship this Johannes Galle stood to the Philip of the first edition has not been definitely ascertained. According to Wurzbach, who enumerates eleven Galle, the only Johannes he has come across was christened in the year 1600 , and died in 1676 . It is probably he whose name figures on the third edition. As Philip Galle died in 1612 (he was born 1537), we know that the third edition was issued after that date, and probably not before 1620 or 1625 , by which time Johannes had probably taken over the former's business. Even of the second and third editions it is very difficult to obtain complete sets. An incomplete series (it lacked the last plate) was priced $f_{42}$ in one of Magg's catalogues. We append translations of the title-page, and of the inscriptions below the 47 plates of Bol's Venationis. The engraver, who probably did not know Latin, made occasionally wild blunders, and in two cases the Latin is so corrupt that we can make guesses only. Thus on Plate 36 the word Alesus (in another edition it is spelt Alosus) must read Asellus, while the word Vinto, intended to designate a kind of fish, does not exist in low Latin; and the expert who kindly undertook to clear up this mistake was unable to find any like name in spite of a very thorough search. In Plate 25 not one but several mistakes have occurred, to which we have already alluded in the text when dealing with this particular engraving. Other mistakes occur in Plates 6 , I I, 3r, 32, and 45 .

The following are the translations of the title-page, and of the underlines of the 47 plates, and so as to identify the latter the edition with numbered plates is selected. 


\section{SPORT IX ART}

"Illustrations of hunting, fishing and fowling designed by Joannes Bol issued by Philip Galleus, dedicated to the illustrious gentleman M. Paul de Kempenare of Brabant, Privy Councillor, not only a great admirer, but also a consummate judge of all artistic imagery, by Philip Galleus, engraver."

Plate 1582 .

No.

I. Thus mighty elephants gather in a herd in hollows with a great noise, and are captured at the point of the spear.

2. Thus with darts, swords, and light arrows men everywhere drive the horned aurochs into pits.

3. Thus the lion, when his temper is aroused by many a spear, attacks the back of the laggard huntsman.

t. Thus the glad(?) huntsman strikes the bears armed with hooked claws, and lays them on the yellow sand.

5. Men capture tusked wild boars in the high mountains, either with bullets from fire-arms or with stout spears.

6. Men thus capture swift stags in wooded wastes, either with javelins or (hidden) under a sham wooden ox.

7. With a javelin, and by coursing, men wear down stigs in green meadows and pools that are wooded.

8. From the crown of the peak men with impetuous spears throw down timid chamois in the windings of rocky mountains.

9. Thus the wolf is captured, either tempted by a bait of blood, or in a net, or with a stout pike.

10. Men thus course timid hares with keenscented dogs, through fields and vales, and meadows covered with grass.

II. The rabbit that loves to dwell in mossy 362 holes is taken either with a bolt or with fire-arms.

I2. Men thus chase swift hares with gruff dogs, after disturbing their bushy homes with a stout pole.

13. Men thus hunt wild cats with light-footed dogs, and despatch them either with a club or with the sharp point of a spear.

14. The ape which imitates the human face is thus cunningly caught by slight and with arrows in woody places.

I5. The sly fox, whose hairy pelt keeps off the cold, is caught by applying fire to its hole.

16. Men thus drive strong-smelling foxes into deceptive nets, in green valleys and in coverts abounding in marshland.

17. The tapir is taken with bows and bloodstained darts; men cut up the entrails and cook them whilst still warm, upon spits.

I8. Thus, after that they have been caught in the roving chase, animals of divers forms are offered for sale in the markets.

I9. The Moors pursue the ostrich with sivift morossian dogs, and fasten its feathers on their helmets as tokens of honour.

20. Whilst the noble heron flies above the lofty clouds, smitten by the falcon, it falls thus with fluttering wings.

2I. The river duck is thus captured, either by gunshot, or by dogs, or by the farflying arrow.

22. Also by means of a dog swimning in the shady pools, the gentle duck is thus lured into winding nets.

23. The river duck is thus caught, by means of a dog, with fire-arms scattering its feathers in the stream, when it perishes stricken. 


\section{APPEX⿻ IX}

24. Thus the wild partridge is caught in snares, or with ample nets, in the woods bushy with shading branches.

25. Thus in the furrows of the cornland is taken the wily partridge, with her long train (or flock) of small young.

26. A mouse or a frog having been enclosed in a wickerwork snare, the hawk is thus caught with treacherous bird-lime, the fowler having turned himself away from view.

27. Thus birds are caught with deceitful birdlime, when they see the bird of night abroad after sunrise.

28. Hollow nets are thus spread over the tops of the ears of corn, while the foreign quail is caught with a piping sound.

29. When the threshing-floor has been made even, and presents a level bed, the gentle finch is caught in an outspread net.

30. The bees, greedy of honey, are thus by frequent crashes recalled to the sweet wax and the odour of the hives.

3I. Here fowl on every side, and all kinds of birds are for sale in the noisy market resounding with shrill voices.

32. Thus men hunt greedy otters in a hollow boat, and strike them with pointed tridents through flowing waves.

33. When whales raise their vast bodies (above the water), they are thus smitted with different kinds of weapons and missiles.

34. Thus the artful fisherman drives the large salmon from the open sea to the mouths of a river.

35. Tunnies are caught with nets, or with a stout fishing-spear, when they are lying at rest at night under the light of the moon.

36. The haddock files from the open sea at the sound of thunder and lightning; at the sound of bells ... falls into the white nets.

37. Thus the carp is caught on a line furnished with various hooks, or in baskets woven of flexible willow.

38. Men catch fish after they have fed, either with large nets or by running off the water of the fish-ponds.

39. The turbot is thus taken in enciosing nets on the open sea. The seal is caught on the shore when asleep.

40. Foolish cod are thus caught with various hooks, and ugly ray, which lie hidden in the deep.

4I. Under the burning sun in the tropics, the sea-turtle is caught for special uses; the natives eat the flesh slightly roasted in the sun; and their huts are covered by the enormous shell.

42. Nets having been spread under the light of the yellow moon, the anchovy to be cured with salt, is taken in the waves.

43. Scaly fish are thus caught with a hook, a waxed line attached to a quivering rod.

44. The Brazilians in a party thus hunt fish with a whistling arrow, swimming in the sea (to secure their quarry) after the manner of their ancestors.

45. Thus are conveyed in light boats to the spacious markets crawling crabs and shellfish with hard shells.

46. The pearl is thus gathered, near the shore of noble Ormus, by sailors who search the inmost secrets of the deep. 


\section{SPORT IX ART}

47. Here those scaly creatures, caught in the cold flood, fish are offered for sale in the market.

Bol designed another small set, consisting of twenty-four oblong pictures of somewhat varied subjects, sporting scenes, agricultural and religious topics being represented. They are distinguished from the Venationis set by the beautiful border surrounding the picture itself, and consisting of cleverly designed groups of flowers, trophies of the chase, fishes, \&c. The prints bear the address, Eduardus ab Hoeswinkel, Antuerp, exc. Ad Collaert fecit: hence must have been produced between the years 1572 and 1584 , when he lived and worked in Antwerp. This set is in the Munich print-room. Hans Bol's work is gradually receiving the appreciative attention it deserves; thus Wurzbach, the strictest of critics, says of his small landscapes that they are "unique of their kind, and beyond all imitation."

BOEL, Pieter ( $1625-1680$, according to Wurzbach 1622-1674), an Antwerp painter and etcher of considerable repute. According to some he was a pupil of Snyders and of his uncle Cornelis de Waal, and studied in Venice, Rome and Genoa. Is said to have become court painter in Paris, but Felibiens' assertion that he married Synders' widow is probably incorrect. His etchings of dogs and other animals and birds are considered very fine, his wild-boar hunt being a masterpiece. We do not reproduce it, as it has no feature of any interest.

BOLSWERT, Scheltius (1586-1660?), a Frisian designer and engraver, was constantly in Rubens' company engraving numerous plates after him. Only a few relate to the chase, the principal one being a lion-hunt after Rubens. His elder brother, Boetius Bolsvert, designed portraits and landscapes.

BOUCHER, Françols (I703-1770), a Paris painter, who occasionally also etched. $\mathrm{He}$ possessed extraordinary natural talents, for his studies ended after a three months' course in Le Moine's studio. Obtaining already in 1723 the first prize of the Academy, he visited Italy with Carle van Loo. After the death of the latter he became Director of the Academy and Court Painter of Louis XV. One of the few sporting pictures he left us depicts a tiger-hunt, in which three ferocious specimens in various "striking" attitudes occupy the foreground of what is an effective but also an affected canvas. Some 10,000 drawings of his are said to exist. He died whilst sitting before an unfinished picture of Venus at her toilet.

BREDAEL, Jan Pieter van, also known as Breda (I683-1735), an Antwerp painter, who frequently signed himself Bredal. Most of his pictures are military camp scenes and battles, but in the Vienna gallery there are two interesting paintings (one on copper) depicting a boar drive; a prince standing in a blue tent surrounded by ladies is shooting at wild boar. It is dated ( 1717$)$ and signed. In the Lichtenstein gallery there are eight paintings by him, amongst them a couple of sporting subjects signed J. P. van Breda 1715 .

BRETON, C., of whom very little seems to be known. He designed the nine plates which illustrate the Marquis de Dampierre's Recueil de Fanfares pour la Chasse, representing the rut of the stag, the limerer, death of the stag, the Curee, the boar-hunt, the "Royal Fanfare," the King's Fanfare, the Dauphin, the St. Hubert, \&c., which B. L. Henriquez engraved.

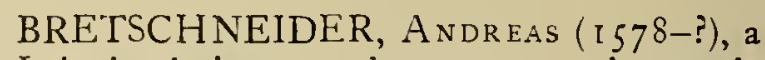
Leipzig designer and engraver, who made court shows, arena fights between wild 


\section{APPEX $\mathcal{X} I X$}

animals, and ceremonious functions of all sorts his speciality. See Fig. 119.

BREU, JÖro THE ELDER, died in Augsberg in 1547 (?). In the Munich Cabinet of Engravings there are two pen-and-ink drawings (round in shape) belonging to a series of four drawings illustrating the hunts of Emperor Maximilian I, depicting the Emperor shooting stags and hunting bear. The style of these drawings reminds one rather of the illustrations in Weisskunig and Theuerdank. Breu contributed to Maximilian's Prayer Book, but on the whole very little is known of him. Wurzbach says he flourished from 1512 to 1530 , and died at Augsburg in I 536 .

BrUeghel, Peeter the Elder, also Brueghel I (1525?-1569) the founder of a celebrated and very popular family of artists. He was born in the village from which he derived his name, near Breda. He was apprenticed to Peter Coecke in Antwerp, but he left him for Hieronymus Cock, the enterprising art publisher. In $\mathrm{x} 55^{\mathrm{I}}$ he became master of his guild and began his travels through France and Italy. In 1553 he was in Rome. Karel van Mander calls him a silent but able artist. In ${ }_{1563}$ he married the daughter of his erstwhile master, Mary Coecke, and settled in Brussels. His speciality was peasant scenes in which in a few instances our subject was touched upon. He was an admirer of Hieronymus Bosch's fantastic panels and gave free reins to his caustic wit. Thus in his will he specially left to his wife a picture depicting a jackdaw perched upon a gallows, in allusion to his conviction that busy tongues deserve to end that way.

Brueghel also engraved; there exists a fine plate by him depicting a sportsman armed with a cross-bow stalking some rabbits. A river is in the background and a castle on a towering crag, the whole a little masterpiece. To distinguish Peeter I from his offspring he is often called Peasant Brueghel.

Peter II (1564-1637 or 1638), son of the above, who from his predilection to paint scenes depicting the tortures inflicted upon sinners in the lower regions is generally known as Höllen Brueghel. His first tuition he received in miniature painting from his grandmother; then he went to Antwerp to Gillis van Conincxloo, with whom he remained until 1585 when he became a master and married. In one or two of his landscapes sport is introduced incidentally.

- JAN (1568-I625), also a son of Peeter 1. He is generally known as "Velvet" Brueghel.

Peter III (1589- ? ), son of lastnamed artist. He became a master in Antwerp in 1608 .

JAN II $(1601-1678)$, son of Jan I. $\mathrm{He}$ was friend of Van Dyck, and of his seven sons, five became artists. His style was so similar to that of his father that according to Wurzach it is impossible to distinguish undated work.

Abraham (1631-I690), also a son of Jan B. II. A well-known flower painter. Nagler says he painted flowers in the pictures of Luca Giordanos. Besides these there were Ambrosius, a brother of Jan B. II, and Ferdinand B., a son of Jan B. II ; then there was a Philipps B., son of Jan B. II, all painters but of lesser distinction who do not appear to have contributed anything on sport.

BRUYN, Abraham de (I $538-?$ ), an Antwerp painter and engraver, considered generally one of the Little Masters. Of his 


\section{SPORT IX ART}

paintings little is known, but he engraved several sporting plates in the manner of Wierx, as well as a set of rare book illustrations of costumes (I $57^{8}$ ). A large wildboar hunt, a hawking picture, and a set of small oblong hunting scenes $(1565)$ are the best known. He died in Cologne at an advanced age.

Niculaus (i $570-1656$ ?), engraver, horn in Antwerp, son and pupil of the above. He worked, however, in Amsterdam, where he also died. His plates show a rich imagination and a free action, rather in Lucas van Leyden's style. His St. Hubertus $\left(16 \mathbf{I}_{4}\right)$ is one of his best plates. He also engraved twelve plates of aninals, twelve of birds, and thirteen of fishes.

BRY, JAN DIRK DE (I56I-I623), son of Theodore de Bry, born in Liège, died in Frankfurt, where after his father's death he managed the great publishing business established by the latter. He was assisted by his brother

- Jan Israel, who appears to have died in $\mathrm{I} 6 \mathrm{I} \mathrm{I}$, and by his sister, wife of M. Merian the Elder, who took over the business at Jan Dirk's death. The mother seems also to have assisted in the completion of Theodore's great work.

-, Theodore (1528-1598), born in Liège, but banished from that town in the year 1570 on account of his openly acknowledging the Protestant religion. In consequence of this he settled in Frankfurt. He visited London at least twice, in 1587 and in I588. Both as engraver and publisher his fame was considerable, his principal work, the "Great Voyages," being entirely his creation, at least so far as go the important parts, of which six appeared during his life366 time (i.e. between 1590 and 1596 ), while the complete collection in twenty-five Latin and twenty-seven German parts, under the title Collectionesperegrinationum in Indiam Orientalem et Indiam Occidentalem, was not completed until I63+. During his stay in London he engraved the funeral of Sir Philip Sidney after designs by Thomas Lant, in thirty-four plates forming a frieze. In the Albertina in Vienna there are four very fine pen-andink drarvings of sporting subjects showing his excellent execution. He left two sons and one daughter, who married M. Merian the Elder.

BURGKMAIR, HANS (I473-I 53I), born in Augsburg, son of Thoman Burgkmair, and one of the most interesting of early German masters of the Augsburg school of designers. His plain mark, "H. B.," unadorned by any flourishes, is typical of the simple, direct and forceful style of this famous collaborator and intimate friend of the immortal Albrecht Dürer. For us his contributions to Emperor Maximilian's Theuerdank and Weisskunig are of principal interest, those for the Grosse Triumphzug and the Genealogie of lesser moment, as neither contains any sporting scenes, only some pictures of animals of the chase. Burgkmair in most cases only drew the designs, while others cut them, and amongst these diligent Formschneider the Antwerp artist Jost de Negker or Dienecker appears to have been the most skilled. A large number of the 700 or 800 designs by Burgkmair were cut by him. Burgkmair also painted, but his pictures are mostly portraits or devotional subjects. His sister became (the elder) Holbein's wife, and his two sons were also artists, but did not distinguish themselves.

BYE, Marcus DE (I6I2-1670), born at the Hague. He became a first-rate animal painter and etcher, Paul Potter's pictures 


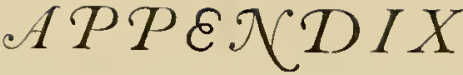

serving as originals of many of his fine etchings. A series of sixteen plates depicting bears, after Gerard, and eight plates with bears, lions and wolves, after P. Potter, together with a second series of eight pictures of lions, after the last-named painter, are his principal contributions to our subject.

CAMPAGNOLA, Giulro (born about I483), a Paduan engraver, who learnt to copy Mantegna and Bellini with surprising skill. His backgrounds he produced by aid of a punch, the opus mallei, which consisted of dots.

\section{CANDID or CANDITO, see P. DE WITTE}

COCK, Hieronymus (i $510-1570$ ), an Antwerp etcher, engraver, and art publisher, whose influence upon the local development of art was of the most far-reaching nature. His extensive travels, and the fact that he had worked a long time in Rome, and had there become acquainted with the principal artists and writers (Vasari made great use of information imparted to him by Cock respecting the Netherland school), was of much utility to him when in or before 1560 he established himself as art publisher in Antwerp. His Schilder-Camerwas situated near the Exchange, and Vredeman de Vries, in his Scenographia (published I560) gives a picture of it, with the master standing in the doorway and his wife behind him. He was a great admirer of Raphael, and etched almost all his paintings, and many of the elder Breughel, Floris, \&rc., as well as landscapes by his brother Matthys Cock. The trade-mark, Aux quatre Tents, which he placed on many of his later publications, see Fig. 80, he seems to have used only shortly before his death, the usual address being H. Cock exc., or Hierorymus Coquus excudebat.

COLlaERT, Adriaen the Elder, the founder of a celebrated family of engravers of Antwerp. According to Kristeller he was working there in 1520 already, and it is probable that many of his works have been ascribed to his son.

,Adriaen theYounger ( I 540?-I6i 8?), whose style resembled very closely his father's. He became a Master of the Guild in 1580 , and married one of the Galle daughters. It was he who engraved many plates after Stradanus and Hans Bol; also his brother,

$\longrightarrow$, JAN (HaNs) (I 545 ?-I622 ?). He became a member of the Guild in Antwerp in I580. He engraved a considerable number of Stradanus' drawings, but his work shows considerable inequality, Fig. 74 being one of his better plates. He also engraved in metals for armourers; a very beautifully finished hunting sword, the blade of which shows finely designed allegorical emblems incised in the steel and inlaid with gold, bearing the signature "Jan Collaert Antwerpen I580," from the Royal Arsenal at Berlin, was exhibited at the Vienna Sport Exhibition in I9Io.

CONINXLOO, Gllles van (I 544-?), an Antwerp landscape painter, probably the son of the Jan van Coninxloo, who in May I527, together with Bernard van Orley, was accused of heresy, and who is supposed to have escaped death at the stake by the intervention of van Orley's royal patroness, the Regent Archduchess Margaret. Coninxloo painted chiefly landscapes and still-life, following David Vincboin's style. One hawking scene of his is in the Lichtenstein Gallery in Vienna. $\mathrm{He}$ was alive in 1598 , for he came in conflict with the law in Amsterdam in that year, Abraham Diamant, the rich hat-maker, trying to recover a debt for 25 florins. As a compromise, cash being evidently somewhat scarce, Master Gilles painted him a picture worth 22 florins and paid 3 florins in coin (Floerke, p. 33). 


\section{SPORT IX ART}

CORT, Cornels (I530-I $57^{8}$ ), born at Honn in Holland; one of the best engravers of his time, was a pupil of $\mathrm{H}$. Cock, for whom he seems to have worked in later life, and thus had for consorts such talented artists as Rogier van der Weyden, Cocxie, Floris, and others, who made Cock's establishment one of the most famous of the time. Cort was the master of Carracci in his art, and Titian hinself conmissioned Cort to engrave some of his pictures. That he engraved some of Stradanus' sporting designs we have already mentioned elsewhere.

COSIMO, Piero di (I44I ?-1527), a painter of Florence, supposed by some to bave been born in I 462 . With the exception of his picture in the National Gallery, interesting to us on account of the four dogs he depicts, he painted nothing in our line, religious and allegorical subjects usually occupying his brush.

DELAUNE, Etienne, who signed himselt Stephanus (1519-1583), a Paris engraver. He produced a number of decorative plates of very effective execution in the style of Pollaiolo. A few relate to sport of somewhat fantastic nature. Fig. 52 is a typical instance, and one involuntarily asks who is hunting what, and which is killing which. He worked for sonte time in Strassburg and Augsburg.

DEMARTEAU, GilLES (I729-1776), born in Liege, but worked as an engraver all his life in Paris, where he also died. Louis XV gave him a pension, and in 1764 he became member of the Academy. He perfected the then fashionable crayon style of engraving, copying with happy results the drawings of French masters in that art. His nephew Gilles Antoine Demarteau, born about : 750, worked for his uncle and copied his style. 368
DESPORTES, Françors (I66I-I743), an eminent French animal and landscape painter. He learnt the groundwork of his art in the studio of the Flemish painter Nicasius, who lived in Paris, and at his early death in 1678 was left to his own devices. His means being limited he had to eke out a livelihood by assisting other painters in decorating houses, theatrical scenery, and by similar humble makeshifts. Under these circum: stances his manifest talents remained unrecognised until his emigration to the Polish King's court at Warsaw. There success almost immediately rewarded him, his portraits of Sobieski and his Queen securing him wide fame. After the death of Vienna's deliverer, Louis XIV, who had in the meanwhile heard of the young French artist's success, recalled him to France, and liking his pictures of animals made him his Court painter, and by letting him take part in all the royal hunts enabled him to study at first hand wild animal life. In 1712, when his reputation was at its highest, and Louis, on account of his old age, could no longer hunt, Desportes visited England, where he painted a number of pictures. On his return to France after the great King's death, Louis XV continued his predecessor's patronage.

- Nicolas (1718-1787), a nephew of the above. Only one sporting picture by him, that of a wild boar, which gained him the membership of the Academy, is known.

DUJARDIN, KaREL (I6I2-1678), an Amsterdam painter and etcher, pupil of Nic. Berchem, and as animal painter almost equal to Paul Potter. Typical sporting pictures he does not appear to have produced.

DÜrer, Albrecht (I 77 I-I 528). This immortal artist attained at an early age an astonishing degree of skill as painter, etcher, 


\section{APPEX I IX}

engraver, and carver. Born in Nürnberg, to which town he remained faithful for his whole life, in spite of most flattering offers from the authorities at Venice and Antwerp, who wanted him to settle there, he became at the age of fifteen a pupil of Nürnberg's then most famous master, Michael Wohlgemuth. He travelled twice to Italy and twice to the Netherlands, covering his expenses by the sale of his portraits and other pictures. His contributions to our subject are lamentably few. Besides those of which we bring reproductions or which we mention in the text, there are some fine drawings of birds in the Albertina, and in the Court Library in the same city is preserved his sketch of the lions at Ghent on a leaf of his sketch-book. Count Wilczek possesses a delightful pen-and-ink drawing of a kinight on horseback going hunting, with the usual background of a castle perched on a cliff. It was one of the numerous treasures which that eminent sportsman, collector, and antiquarian exhibited at the Exhibition in Vienna. Dürer was one of the few artists who could draw stags' antlers correctly. He collected rare specimens, and made sketches of unusual heads wherever he coùld. He must have possessed some fine specimens at his death, to judge by Pirkheimer's well-known letter anent the refusal of Dürer's widow to let him have some of them. Besides the two couchant stags after which Hollar engraved plates more than a hundred years later, there is a little known and now somewhat faded water-colour drawing of a dead stag's head in life size, which is a marvel of delicate handling, in the National Library in Paris. Another stag's head, which Thausing declares to be the study for the one in the copperplate Adam and Eve of 1507, which is in many ways superior to the one of 1504 , forms part of the Posonyi-Hullot collection.

Dürer had a passion for natural history curiosities and strange animals. No trouble was too great, no distance too formidable, if there was anything out of the way to be seen.
His comparatively early death is ascribed by some to the results of one of his quests. An unusually large whale had been thrown ashore by a great gale in Zeeland. Hearing of this unusual event on his arrival in Antwerp, he at once arranged to travel to the distant spot. After days of hardships he reached it just too late, another great gale having washed the huge carcass away a few hours earlier. In consequence of the inclement December weather and unaccustomed exposure Dürer is said to have contracted a bad form of fever which he never quite shook off.

DUVET, JEAN (1485-still living in 156r) born in Langres, also known as the Maître ì la Licorne (Master of the Unicorn), a gold. smith by profession, was among the first to engrave on copper in France. Though he did not reach the excellence of Mantegna, whose style he copied, or of Dürer's school, his engravings are much sought after, and rarer than most of those of the just-named masters.

His famous set of twenty-four representations of the Apocalypse, in Paris, and other series contain very numerous pictures of the legendary unicorn and of other animals. In his set illustrating the capture of the unicorn Duvet introduces some allegorical allusions to Henry Il's intrigue with Diane of Poitiers, but of genuine sporting subjects he does not seem to have left us any. His engravings can be recognised by their resemblance to Mantegna's style.

EYCK, JoHN van, probably born between I 380 and 1390 at Maesyck. Became a pupil of his elder brother Hubert (believed to have been born about I 366). John the Merciless, Bishop of Liège, a lover of the fine arts, made him his painter and varlet de chambre, and he seems to have remained in his service at the Hague until i424. The following year we find him at Bruges at the Court of Philip 


\section{SPORT IX ART}

the Good, with a similar official title. It was probably about that time that he painted his kinsman, Fig. 2I, who, we know, was a warlet des faulcons to that prince.

FABRICIUS, KILIAN, spelt also FABRITIUS, of whom very little is known except that he was from 1633 to 1680 court painter of the two Dukes John Georg of Saxony. He is known to have etched a large plate depicting a great court chasse held by the abovenamed Elector, John George II, on August 17 , 1677 , in honour of an imperial visitor. Of his brother George even less is known, but also he seems to have worked for the Electors.

FALENS, C. VAN (I683-I733), an Antwerp painter who worked and died in Paris, he painted, in the manner of Wouverman, a few somewhat sentimental sporting scenes. Two of them in the writer's collection depict the return from hawking, a cadge with three hooded falcons standing in the foreground and near it, seated on the sward, two fair huntresses who are being amused by a cavalier with a guitar. The other print shows a pile of dead partridges and hares in the foreground, and a cavalier with a fowlingpiece in his hand seated near a lady with a feather bonnet. They were engraved by J. P. Le Bas and published in I745. Van Falen's pictures were very popular in Louis XY's day, and however uncongenial to the modern eye are their conventional and sentimental details, they were prized for their decorative qualities.

FEYERABEND, SigMUND (I $527 !-$ I $585 \vdots$ ), one of the most famous publishers of his century, who himself was an artist of some skill. His establishnent at Frankfurt was for many years an important centre of the book trade. His brothers, cousins and father, known by 370 the initials: L.; V.; S. H.; M.; M. F. and Iohann, were all employed by him, but he managed to suppress their names, which he also did with other artists who worked for him, taking as much credit as possible for himself. Among the latter Jobst Amman was probably the most prolific; other wellknown engravers who were employed by him being Christian and Tobias Stimmer, Christian Maurer, and Hans Bocksperger.

FINIGUERRA, Maso (I426-I464), a Florentine goldsmith and designer, said to have been the inventor of taking impressions from niello plates, an ascription concerning which experts, however, still differ.

FLAMEN, Albert (I620-I664 ?): according to some authorities he was thus named because he was a native of Flanders, others declare he was born in Paris ; he was working in the latter place from I640 onwards. He owed his reputation to his etchings, less to his paintings. Of the former he executed over 600 plates, the most dealing with fishes, birds and still-life; only a few deal with sport, and those are of no special interest.

FLORIS, Frans, whose real name was Frans de Vriendt (I5I6?-I570), a very clever Antwerp painter, who during his studies in Italy acquired some of Michael Angelo's mannerisms. His portraits made him famous and reached high prices soon after his death, as we learn from an instance narrated by van den Branden (343). For when Frans Francken bought in I58 I from the town of Antwerp a house, he paid for it with a picture by Floris, which experts valued at 350 florins. In a large picture which Floris presented to the Lucas Guild of Antwerp he painted himself engaged in grinding colours. It is now in the Antwerp Museum, No. I I4. Sport was not his subject, but there exists a delightful 


\section{APPEX $\mathcal{X} I X$}

portrait of a falconer, whose identity is unfortunately not known, with a falcon on his fist, signed F. F. I 558, and the words ETATIS SVE XLVII. It is now in the Brunswick Gallery and probably represents one of his numerous patrons, amongst whom were the Prince of Orange, and the Counts Hoorn and Egmont. Mr. Harting has published a good reproduction of it in his Bibliotheca Accipitraria, p. 44. There is, according to the account kindly communicated by the Director of the Brunswick Gallery to the writer, quite an interesting history attached to this portrait illustrating how the fortunes of war even as late as the last century decided the fate of precious pictures. Floris, it seems, painted a pendant to this falconer, the likeness of a lady, which to-day hangs in the Museum at Caen. Both pictures were in the seventeenth century in the collection of Archduke Leopold William, and are mentioned in the Inventory of 1659 . After that they passed into the Imperial Gallery in Vienna, where they remained until the beginning of the nineteenth century, when the French took a liking to them. When after Waterloo a restitution of the booty made by Napoleon's troops took place, by the characteristic carelessness of the Viennese authorities only one of the portraits found its way back over the Rhine, and even that one did not reach its proper home, but somehow remained in Brunswick, while the other one never left France at all.

FRANCO, Giacomo (1 $566-\longrightarrow$ ?), born in Venice, where he worked most of his life. He was a pupil of Caracci, and book illustrations seem to have occupied him most. His Habiti d'huome niet donne Venetiane, to which we have referred in the text, is now a rare book and very hard to get, even the 2 nd and 3 rd editions being priced at 600 or 700 francs.

Since writing our remarks in the text respecting the curious fact that the early editions of
Franco's Habiti do not contain our Fig. 118 , we have had opportunities of examining other copies. The one in the Print Room of the British Museum, said to be the first edition of 1609 , does also not contain the picture, but the copy in the Reading Room and the one in the South Kensington Museum Library both have it. The former is unquestionably the first issue, the latter apparently a later one. It seems probable, therefore, that the picture in question was added at the last moment when some of the copies of the first edition had already been issued, and we can therefore take it as fairly certain that Franco drew it while his book was in the press, i.e. in 1609 . Each of the four early copies examined by us differs in important respects from the others, a circumstance which confirms the surmise that Franco or his publisher made alterations or added illustrations while the book was being issued. Brunet evidently had not seen a copy of the 1609 edition, for he declares the one of 16 ro to be the first. A reprint (100 copies) was issued in 1876 in Venice.

FRISIUS, Simon, also known as Simon de Vries (1580-1628?) born in Leuwarden in Friesland, was an etcher of talent whose works are however very scarce. He worked after Hondius the Elder, Goltzius and Vincboins. Wurzbach states Goltzius' picture of the boy with the dog, Fig. 105, represents the son of Simon Frisius; but in this he is wrong, for the inscription on the engraving leaves no doubt that it was Theodore Frisius. According to Müller and other authorities, Simon Frisius and Simon de Vries were not identical, though they appear to have been born in the same year.

FYT, JAN (161 ? ?-1700), an Antwerp painter, many of whose pictures of animals and game are masterpieces. He was born about I6I I ; at any rate he appears to have been baptised in that year. He became a pupil of Snyder, 


\section{SPORT IX ART}

and in 1630 member of the St. Luke's Guild, showing that his talent was developed at an carly age. His reputation in his particular line was so great that Rubens and lesser artists bespoke his assistance. His best canvas is supposed to be the one in the Augsburg gallery; Dresden and Tienna also possessing tine examples. In the latter gallery, of four pictures, two depict dead partridges with masterly skill. He also etched two series of eight plates each, the one dealing with hounds, the other depicting various animals. Master Jan Fyt's pictures came to be highly appreciated by his countrymen in his own lifetime, and Floerke tells us that at one of the famous Friday sales in Antwerp a picture of his of dead game was bought at the then very high price of 370 florins. Already in 1660 a syndicate of artist speculators declared at some professional enquiry that they would be willing to pay Master Jan as much as is florins per day if he would paint for them. Four years before one of the prominent picture dealers of Antwerp, Franz Diericx, got himself into trouble for attempting to sell a picture of a hare and fowl as by Jan Feyt. Hauled up before the Justices Diericx got off on the plea that the picture did not bear the painter's signature! (Van den Branden, I089).

GALLE. The members of this Antwerp family, of which no fewer than twelve distinguished themselves in art, chiefly as engravers, were among the first to make a commercial success of pictorial publications for the masses. In selecting the works of their countryman Stradanus, whose studio on the distant banks of the Arno turned out a constant stream of popular religious and sporting designs eminently suited for their reproductive activity, the energetic

- Philis, the Elder (I537-I6I2), the real founder of the family's fame, made a great hit. As we have already had occasion 372 to remark, their presses were kept busy for many years with this work. But not only Philip's sons, grandsons, sons-in-law (Karl de Malery and Adriaan Collaert had married two of his daughters), but a number of assistants, some of whom we have named in the text dealing with the painter, assisted in the Galle establishment in the manner so cleverly depicted in the Nova Reperta. As it would lead too far to differentiate between the works of the different Galles (as many as three different Galles figuring occasionally in one address), we append a list of their names and the periods of their activity.

\section{Philip the Younger (I560-I6I2).}

Theodore (I 570-I633), Philip's eldest son.

Cornelius the Elder (I 576-I650), Philip's second son, settled down in Rome and became an artist of considerable repute. He has the distinction of being the artist who engraved the first plate after Rubens.

- Cornelius II (I6I5)-(1678).

- Cornelius (III) (I642-I678).

, Hieronymus the Elder, born i625.

, Hieronymus the Younger (i656I713).

—, Joannes (1600-1676), eldest son of Theodore Galle.

Ambrosius (I 7I4-I/55), sculptor.

Antonius, became master of his guild in 1710 . 


\section{APPEX $\mathcal{X} I X$}

- Hubertus, in 1637 pupil of Abraham Sack in Antwerp.

GEERARDS, MARcus, also written Garrards, Gerards, Gerhard or Guerard (I 540 ?-I600?). According to Wauters there were two, father and son, both called Marcus. The one we are speaking of was the elder, a pupil of Martin de Vos, and a native of Bruges, who came over to England and in I 57 I obtained the title of painter to Queen Elizabeth. Besides painting a number of portraits and historical subjects, he designed cartoons for stained glass windows, illustrated manuscripts, and acquired a great reputation as an engraver. Of sporting subjects he produced little, a series of sixteen pictures of bears, which he designed in I 559, and which Marc de Bye engraved after him in 1564 , being all we are able to trace. His best work is said to be the series of 108 etchings illustrating " Æsop's Fables" which were published in I 567 under a Dutch title. Considering the eminence of some of his and of his son's work strangely little is known of them. According to Wauters his son succeeded him in his official dignity, and died in $\mathrm{I}_{35}$.

GHEYN, JACOB DE (I565-I6I5), an Antwerp artist, who engraved a few sporting subjects, amongst them a lion, which Jan Nic. $\mathrm{V}$ isscher published. He seems to have worked in Goltzius' studio.

GHURAERTS, Marcus (about I550), of whom very little is known. A stag-hunting scene said to have been engraved by him was published in the Badminton Magazine, August I 895 .

GLASER, Hans Wolfang (1565), a littleknown Nürnberg engraver. In the Badminton Magazine, August I 895, p. I04, there is a reproduction of a sporting scene (it is more like an etching) by this artist, dated 1550 , after a drawing by Virgil Solis. We have not come across any other sporting prints of this master.

GOZZOLI, Benozzo (I424-1485), botn in Florence. His father's name was Lese, hence the artist called himself occasionally Benozzo di Lese. A pupil of Fiesole, his talent came to be developed at an early age. Most of his work was of a devotional character, but some of his frescoes depict sporting incidents. His best-known works were the famous pictures in the Campo Santo in Pisa.

GUTTENBERG, HENRI, an engraver of the eighteenth century, born in Nürnberg, who worked for many years in Paris. He left at the outbreak of the Revolution. His name is sometimes written Guttenberger. According to Kristeller he worked for the Abbé de Saint Non (I727-I79I), who spent a large fortune on reproductions of Fragonard's paintings.

HACKAERT, Jan (I629?-I699?), a Dutch painter who worked in Amsterdam about the year I659. His landscapes were finely painted and lifelike. Indeed this was so much the case that when once painting an outdoor scene in Switzerland the peasants attacked him because in their opinion only sorcery could enable any man to paint nature so truly. Our National Gallery possesses a stag-hunt by him in which, however, the figures are painted by Nicolas Berchem.

HAECKEN, Alexander van, born I7OI, probably in Holland, painter and mezzotint engraver. He seems to have come over to London as a young man, and appears to have died in 1748 . The original of Fig. 166 is a rare mezzotint in the first state, with the address: Sold by A. Vanhacken, the corner of 


\section{SPORT IX ART}

Queen Street, Holborn. On the second state, of which the British Museum possesses also a copy, this address is erased, and in its stead: Sold by T. Feffreys in the Strand, and $W$. Herbert on London Bridge. On the original of Fig. I67, that representing Mrs. Davenport, a portrait which bears some resemblance to the one by Faber, the address is the same as on the first state of her husband's portrait. Whether a second state of it exists we were unable to find out. She died in I744, but these portraits were probably engraved some time before. See Smith III, I4I4-5; Wurzbach does not enumerate these two portraits.

Joseph, the elder brother of above. He appears to have joined his brother in London, and worked there between the years 1735 and I740, and probably assisted Alexander in his business as print dealer.

HAMILTON, ANTON IGNaZ (I696?$17 j 7$ ?) Born in Vienna, the son of John George Hamilton; learnt painting in his father's studio; his style, as well as choice of subjects, being very similar. He became Court painter of the Duke of Saxe-Weimar, and afterwards followed the call of Augustus III, King of Poland and Elector of Saxony.

—, Charles William (i668-I750 ?), born probably in Brussels, entered the personal services of the Prince Bishop of Augsburg, but afterwards devoted himself exclusively to art, and also went to Vienna to paint for Charles VI. He painted animals and plant-life, the thistle being a special favourite, hence his nickname "Thistle Hamilton."

JAMES (I640?-I720?), the founder of the celebrated family of painters. A Scotchman by birth and painter by profession, he emigrated in Cromwell's time to Brussels, 374 where he painted still-life scenes, which were rather popular. He died there at the age of eighty. All his three sons and a nephew became well-known painters.

John George (1672-I737), was born in Brussels and died in Munich. He was a distinguished animal painter, who worked for some time for the court of the first King of Prussia, but left Berlin to enter the service of the Elector of Bavaria. Later on he worked for Emperor Charles VI at Vienna; hence a good many of his pictures-none of which are of special interest for us-are to be found in the Munich and Vienna private and public galleries. His next brother :

- Philipp Ferdinand Von (i664I 750), best known as the painter of horses, in which he excelled. In the Emperor of Austria's palace at Schönbrunn a large room is filled with pictures by him while he was working in Vienna as Emperor Charles VI's court painter, the room being still called the "Chamber of Horses." In the Imperial gallery in Vienna there are some sixteen pictures by him, those dealing with what might be called the still-life of sport-i.e., dead game-being the least interesting. Whenever a chance presented itself he painted abnormities, such as white-spotted roedeer, white woodcock, fallow-buck with abnormal heads, \&c., the popular taste leaning that way. He spelt his name with two m's, a singularity not followed by his brothers, and was ennobled.

HENRIQUEZ, BENOIT LouIS (I732I 803 ?). A Paris engraver who worked for some time in St. Petersburg. On his return to Paris he became a member of the Academy (I 779). He engraved the nine sporting plates designed by Breton for the Marquis de Dampierre's Recueil de Fanfares. See Breton. 


\section{APPEX D I $X$}

HIRSCHVOGEL, Augustin, also spelt Hirsfogel (1503?-I 553 ?). An etcher, mapengraver and author born in Nürnberg, who, after studying art under his father, travelled extensively, and settled down in Vienna in I530. His maps, some of which illustrate Herberstein's works of travel, as well as his etchings of scenery, people, and his portraits of royalties that lend so much interest to that famous diplomat's and explorer's books, show great talent and diligence. For our purpose, his pictures of the aurochs and bison, both of which he appears to have drawn after sketches furnished by Herberstein, assisted by the skins and horns brought back by the explorer, possess great interest. With several of his blocks some juggling seems to have occurred; thus an interesting woodcut of a bear-hunt, which he dated I545, was subsequently altered to 1569 , but it was done so carelessly that the " 6 " appears reversed. A similar instance can be seen in his boar-hunt which is in the British Museum Print Room. In that repository can be seen two reproductions of drawings by him, representing fighting stags and a man shooting with a cross-bow at a sitting hare. The Dresden Gallery has also a drawing representing a group of stags and hinds, which has been reproduced by Braun of Paris (No. 398). Two interesting drawings of wild boar- and hare-hunting scenes were exhibited by Count Wilczek at the International Exhibition in Vienna in igro. Hirschvogel had a brother, Veit $(+1553)$, who had a son $\left(+I_{5} 89\right)$, both of whom were skilful engravers.

HOGENBERG, Johann, a Cologne engraver who flourished at the end of the sixteenth century, of whom very little is known. He issued a small series of sporting scenes of no importance, and another set of twelve with birds and animals. Two namesakes of his, Franz and Remigius Hogenberg, went to England about 1560 and engraved portraits, and then returned to Cologne, where they were employed upon battle scenes.

HOLLAR, Wenceslaus (I607-1677). Born in Prague of noble parentage, he passed the greater part of his life in London, being acknowledged by modern critics to be one of the most industrious and skilled etchers of any age. More than $275^{\circ}$ plates, many perfect little masterpieces, emanated from his hand. Political and religious upheavals in his own country caused him to leave Prague in 1627 , and to turn to Frankfurt-on-the Main, where he became the pupil of the elder Matthew Merian, from whom he imbued the solid foundations of his art. Visiting Strassburg and Cologne, he came in the latter city under the notice of the Earl of Arundel, then returning to England from a mission on which Charles I had sent him. Recognising his talent the Earl induced him (1637) to accompany him to England. where Hollar married Mary Tracy, the Countess's maid. Besides working for Arundel-his fine etching depicting London as seen from the top of Arundel House being one of the numerous plates-Hollar worked for several London publishers at incredibly low rates of remuneration (for one of his masterpieces, the view of Greenwich, he received but thirty shillings, while as a rule he received but twopence for the working hour). At the outbreak of the Civil War Hollar somehow got drawn into the trouble, and he fought at the side of Inigo Jones and Faithorne holding Basing House for the royal cause against Parliament. As a result he seems to have been imprisoned, and the next move appears to have been a sojourn in Antwerp, where he again for a short time joined Arundel. But on the latter's departure for the south, he was left to his own resources in that much disturbed city. Returning to England, his lot does not seem to have become a brighter one until in consequence of the great fire in 


\section{SPORT IX ART}

I 666 more remunerative work seems to have been thrown in his way, his only son having died of the plague in 1665 . Three years later the King sent him to Tangier to depict the fortress and town, about which there was then a good deal of excitement in the political world. But as he only received f. Ioo for a year's work, and escaped capture and death at the hands of Algerian pirates (his ship proved victorious against seven pirates), he returned to London no richer than he left it. For nine or ten years more he continued his miserably paid artist's career, and finally died in abject poverty at IVestminster, the bailiffs-more merciful than usual-leaving him his bed until he should close his eyes. As Mr. Luke Taylor very truly says, Hollar's day has not yet arrivedat least in England. When that time does arrive we shall find him standing alone, towering above his contemporaries, a "complete etcher." Parthey's work on Hollar and his list of Hollar's engravings is too well known to need description. Hollar etched a number of sporting plates, the more important of which are mentioned in the text.

HOLZHALB, J. R. Members of this ancient Zürich family figure among the goldsmiths of that town famed for their skill as far back as the fifteenth century, Brun mentioning no fewer than fifteen of that name. There is, however, no J. R. among them, so the perpetrator of the "American Aurochs" cannot have reached any degree of eminence. We hear, however, indirectly of him, as we are told that a nephew of Chrét. de Mechel learnt engraving in J. R. Holzhalb's shop in Zïrich.

HONDEKOETER, MELChIOR DE (I636I695), born in Utrecht, was taught by his tather and his uncle Weenix. He painted principally birds and dead game and attained remarkable skill, so that he was called the 376
Bird Raphael. He is said to have trained a cock to stand as model and to crow at a certain signal. In consequence of his unhappy married life he ended his life by debauch.

HONDIUS, ABraham (1638-i69i), born in Rotterdan, became a painter and etcher of renown. He appears to bave come over to England at an early age, and his sporting scenes, generally bear- and wild-boar hunts, gained him celebrity, his dog fair being perhaps the best. His animal pictures are truthful, and the lightness of his touch and boldness of design caused him to be compared to Rubens and Snyders. His etchings show considerable talent, but some of his plates he produced in conjunction with others. A large etching $(51 \times 40 \mathrm{~cm}$.$) entitled Chasse$ a L'ours has the address: "J. E. Rehn acquaforti, Chenu perficit." It depicts eight large hounds attacking a huge bear, who has already put four of them hors de combat. He died in London. There were four other artists of his name :

HENDRIK, THE ElDER, born in Duffel in Brabant I580? an engraver, pupil of $J$. Wierix ;

Hendrik, the Younger, born in London about I5So, noted for some good portraits ; then

Jodocus, a Flemish engraver who fled to England in consequence of political troubles, where he engraved Drake's Voyages, but eventually returned to Amsterdam where he died in I6ı ; and finally

WiLlem, born at the Hague I60o (?), who worked in Van Dyck's studio. None of the Hondius except the first named occupied themselves with sporting subjects. 


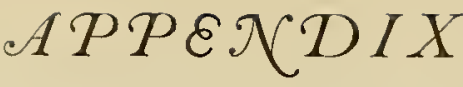

HUET, Christophe ( + I759), a painter of unknown origin, was professor at the Paris Academy in $175^{\circ}$. His genre pictures, surrounded by the elaborate framework of the period, show no special merit. A picture of two spaniels watching a dead hare and partridges near which a gun is leaning, called Le gardien fidelle, is the only one we have come across relating to our subject. Jaques Beauvarlet engraved it.

HUFNAGEL, Joris, also Haefnagel (I 54I?r600), who usually signed himself $G$. or Georgius, born at Antwerp; son of a rich diamond merchant, who would not hear of his becoming an artist. One day the Ambassador of Savoy discovered the boy trying to make a picture of his left hand, and it was at his instigation that the father at last allowed his son to follow his inclination and to study art. He visited many parts of Germany, Tyrol, Italy, and Spain. On his return home he became a pupil of Hans Bol, and when his father died he continued his business until the sack of his native city by the Spaniards ( 1576 ), an event which ruined him as well as his former master, Hans Bol. Turning with redoubled ardour to his art, he again set out travelling. In Augsburg he worked for the Elector of Bavaria; from there he went to Rome; in Venice he executed some commissions for Cardinal Farnese, and from there he went to Innsbruck, where he remained eight years ( $1582-1590)$, most of the time in the service of Archduke Ferdinand, the founder of the world-famous Ambraser Sammlung. Amongst other miniature paintings he executed for the Archduke was the voluminous Missale Romanum, for which contemporaries reported he was paid the enormous sum of 5000 ducats. It now forms part of the private Imperial Library in Vienna. From Innsbruck the restless artist went to Prague, Emperor Rudolph proving himself as usual a munificent patron, however parsi- monious he was in other matters. Amongst other work Hufnagel filled four stout volumes with pictures of rare animals, one being the dodo drawn from life. This probably was the last picture ad vivum of a species which became extinct soon afterwards. The final scene of Hufnagel's activity was Vienna, where he also died.

JACOBSEN, JUR1AEN (I610?-I664?). He is said to have been born in Hamburg, and became a pupil of Snyders at Antwerp. In the Dresden Gallery there hangs a picture depicting a wild boar being pulled down by five hounds, by this little-known painter.

JANSSENS, Cornelis (r590-r668), an Amsterdam painter, also known as J. Van Ceulen, who went to England in 1618 , where he remained for a quarter of a century, leaving it when his fame as portrait painter paled by the advent of Van Dyck. At one period he signed himself Johnson and Jonson. With the exception of one still-life displaying dead game and a painting of Venus and Adonis with the usual sporting attributes, in the Vienna Gallery, he does not seen to have executed anything in our line.

JOULLAIN, Françols ( I 697-I 779), a clever Paris engraver, who worked much for Desportes; both our reproductions, Figs. I 44 and 145 , being engraved by him. They show taste and feeling.

JUNE, Jонn, who lived in the middle of the eighteenth century, but of whom very little is known. He executed a large engraving, preserved in the British Museum Print Room, depicting a hunting scene-death of the fox -interesting on account of the costumes. It was reproduced in the Badminton Magazine, July 1897 . 


\section{SPORT IX ART}

KIESER, EBERHARn, born in the last quarter of the sixteenth century in Frankfurt-onMain, engraved the pictures for the Diarium of Emperor Matthew's coronation which appeared in $16 \mathbf{r}_{2}$, and for a few other similar works. About the year $16_{32}$ he engraved ten interesting pictures of hawks which seem to have remained unknown to most writers on this subject. He named them: Sacre mui ; Faulcon Passagier pris apprès la seconde miie; Alphanet muí, excellent pour la perdrix; Le même Alphanet tournant les espanlles; Lanier de dix mucss; Faulcon corse très bon; Autour Passagier muc; Faulcon montaignart de huiet muës; Gerfaut muè-dutour mais non mù.

KIRKALL, Elisha (1682?-1742?). An English engraver of whom surprisingly little is known, considering the quantity of work he produced. By some he is believed to have been born in 1695 and to have died in $175 \mathrm{I}$. There also exists considerable confusion in respect to his Christian name. Beginning with a mistake made by the otherwise so reliable Dr. Nagler, it was believed that there were two or even three Kirkalls, one called Elisha, the other Edward, and a third with a name commencing with "L." Bryan considers there was no Elisha, and other writers mix un Edward with the latter. Probably the explanation is that there was only the one: Elisha Kirkall. In the South Kensington Print Room is preserved a carefully engraved wedding announcement, evidently by his own hand:

$$
\left.\begin{array}{l}
\text { "Mr. Elisha } \\
\text { and } \\
\text { Mrs. Elizabeth }
\end{array}\right\} \text { Kirkall }
$$

"August 3I, I707. Printed at His Majest. Printing Office in Black Fryers." In the left-hand corner of the card there is a medallion of "Guttenburgh," and in the right-hand corner one showing "W. Caxton." Kirkall even as late as 1722 does not seem $37^{8}$ to have been overburdened with work, for in the same Museum there are preserved some curious engraved receipts which are of interest not only because they show the rate of remuneration he received, but also Kirkall's connection with Sloane. One runs : "London -r722. Received of Sr Hans Sloane one Guinea being the first payment for I 2 Prints in Claro Obscuro which I promise to deliver when finished on the payment of one Guinea more. Witness my Hand." His signature in ink being at foot, the whole being surrounded by an elaborate engraved framework in which the Goddesses of Love, Arts, \&c., figure conspicuously.

The second receipt shows an even more modest rate of pay. It runs: "London172-. Received of - one Guinea, being the first payment for I 6 Prints of Shipping in Chiaro Oscuro [sic] which I promise to deliver when finished on Payment of one Guinea more. Witness my hand.

In this case the receipt is framed by allegorical designs, in which Neptune is not torgotten. Kirkall is interesting in another respect, for it was he who invented the chiaro-scuro process-Kirkall was evidently uncertain how the word should be spelledwhich was a blend of etching and mezzotint, steel plates as well as wood blocks being used in the production of a picture. Kirkall produced a number of plates that concern us; three of them are after Ridinger's fine hunting series (Th. 2, 3, and 4) representing stag-, bear-, and wild-boar hunts; then there is a mezzotint with dead game, dogs and sportsmen. Another chiaro-scuro, also after Ridinger, pictures a hunting party, some of the sportsmen being on horseback, some on foot, starting out for their sport. "Going out [hunting] in the Morning" is its title. The huge hounds held by keepers are particularly fierce-looking brutes, with heads that are distinct misfits, being about two sizes too large for their bodies. And finally Kirkall 


\section{APPEX $\mathcal{X} I X$}

engraved eight plates of horses that had won races, their names, as well as those of their owners, being mentioned below each. These he executed after Pieter Tillemans, the Flemish painter, who came over to London in I708. Some of Kirkall's plates are worked in blue and green tones, which do not enhance their appearance. Amongst the non-sporting engravings by Kirkall there are some etchings he contributed to a "Collection of Prints of his Majesties Royal Navy, after designs by T. Baston." These are probably the prints of shipping to which the second receipt refers.

KLAUBER, JoHANN BAPTist (I7I2-I774). Brother of Joseph Sebastian, and also born in Augsburg, where they lived.

Joseph Sebastian (i7ic-i768). Engraver, born in Augsburg. He studied art with Anton Birkhard in Prague. Most of his plates were joint work with his brother.

KÖLDERER, Jörg (?-1540), a Tyrolese painter, designer and architect, who was probably a native of the quaint old posting town of Sterzing on the Brenner Pass. The researches of Privy Councillor F. von Wieser, the indefatigable delver into the art history of Tyrol, and of F. Fischnaler, the late Custodian of the Ferdinandeum in Innsbruck, have thrown much light upon the career of this hitherto little known artist. 'The former's investigation has shown that Kölderer's hand painted the once so famous frescoes on the Wappenthurm, the delightful old city gate tower of Innsbruck, which, alas! has shared the usual fate of mediæval structures and has disappeared. To judge by existing drawings it must have been of most decorative effect, reminding one of Holbein's designs on the Whitehall gateway. These Wappenthurm designs, which, needless to say, were the idea of Maximilian, were carried out in 1496, and probably the town had to pay for it, that being Maximilian's policy. In the following year we come upon the first traces of Kolderer's direct employment by Maximilian in the shape of an order to the Exchequer to pay Kölderer the sum of Ioo florins. Very soon after that Maximilian entrusted to Kölderer the adornment of his two sporting books with which our text deals in detail. In 1507 he received the appointment of court painter, with a salary of 3 florins per week, and I florin per week for each of his journeymen and the same sum for two apprentices. Kolderer in later years seems to have turned from art and have occupied himself more with architecture and designing plans for monumental structures, such as Maximilian's Xenotaph, the Ehrenpforte and other ambitious undertakings that sprung in sheer endless profusion from the fertile imperial brain. In 15 I $8 \mathrm{Kölderer}$ received the formal appointment of architect-in-chief (Baumeister) for Tyrol, a post which does not seem to have turned the artist's brain, for we find him employed in such lowly work as painting a sledge in oil colours! He also designed many of the illustrations that adorn Maximilian's books on artillery ("Zeugbücher"); in fact he seems to have acted as handy craftsman, whose pencil and brush were ever at the disposal of his versatile master.

KÜSEL, Melchior (i622-I683). An Augsburg designer and etcher, a pupil of Merian's at Frankfurt. His most important work for us is the set of six prints, designed and etched by him, depicting the great court hunts held in the Prater near Vienna in celebration of Emperor Leopold l's marriage with Margaret of Spain, on December 16 , I666. This set is rare; it depicts sport in the style of Fleming. Amongst the six prints there is one of Fox-tossing, but it is not as well designed as Fleming's representation (Fig. I 59). 


\section{SPORT IX ART}

LAMY, JOH. PETER. Nothing is known about his youth. He seems to have come about the year I79I to Berne, where he founded an engraving business, and, being successful, he established branches in Basle, Lausanne, and Geneva.

I.E BAS, J AcQues PHHLPpe (I TO7-I $\left.7 \delta_{3}\right)$, a prolific and once much admired Paris etcher and engraver, whose method of finishing his etched plates with the graver gave them character and strength. He was a pupil of Herisset and Tardieu, but formed his style after the Netherland masters Teniers and Wouverman, and produced a great number of fine plates after the former (over a hundred), Watteau's attractive paintings being also not neglected by him. Of less well-known masters he executed two very decorative plates after C. Van Falens $(42 \times 57 \mathrm{~cm}$.), which we described already on p. 370 , the titles of which, Le Chasseur Fortune and Rendes-l'ous de Chasse, sufficiently indicate the soft sentimental style in which it was then fashionable to depict sporting scenes among Watteau's and Boucher's contemporaries. Curiously enough Le Bas dedicated them both to Count Brühl, the famous Minister of the Saxon-Polish Court.

L'EVÊQUE, Henri $\left(1769-18_{32}\right)$, born at Geneva. It is known that he accompanied de Saussure on at least one of his Mont Blanc expeditions, viz. the exploration of the Tacul glacier, which is depicted in two of our illustrations. He seems to have sent these views to an exhibition held in I 789 , but we do not know where this exposition was held. L'Evêque travelled a good deal. He visited Spain and Portugal, and also England, where he appears to have married. He returned to Geneva in 1823.

LIMBOURG, PoL or PAUL DE, with his two brothers Jean and Armand were employed by 380 the Duc de Berri in the first decades of the fifteenth century. Their real name was almost certainly Manuel, a payment of 20 sols daily to the two enlumineurs Pollequin and Jeannequin Manuel as payment for their work upon a bible during four years being registered among the Duke's disbursements in the year I 402. The Très riches Heures is one of the very finest miniature works that has come down to us, and Pol's share is said to be superior in quality as well as quantity to his brother's contributions. It was not quite finished by them, for it was only in 1485 that Jean Colombe completed the book for Charles I of Savoy. Comte Paul Durrieu published a reproduction of its inimitable miniatures, and there are interesting references to it in the Burlington Magazine of I904, p. 297 , and of 1905 , p. 435, by Mr. R. E. Fry.

LOO, Carle ANdre van (I705-I765), born in Nice, whither his father had to fly from Paris in consequence of a duel. He was apprenticed to his father, Louis Van Loo, a native of Amsterdam, but who came to Paris at an early age, receiving in yet youthful years the first prize of the Academy. Carle studied carving under Le Gros, and consequently his modelling is exceptionally fine. With his elder brother he went to Rome to study art, and subsequently visited it again, when the Pope knighted him at the early age of $3 \mathrm{I}$. Returning to Paris, in spite of many attempts to retain him in Italy, he became a menber of the Academy and a professor at the School of Art, and then director of it. Raised to the rank of first painter to the King, he was endowed by Louis XIV with an annuity of 6000 livres, and was given rooms in the Louvre, and two years before his death he became director of the Academy, the greatest honour obtainable by an artist. $\mathrm{He}$ had a brother, Jean Baptiste, born in I684, who had two sons, Louis Michel and Charles Amédée, both distinguished artists. Fig. I65 


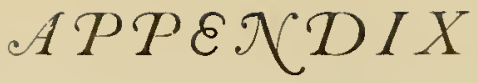

is a typical specimen of his somewhat fantastical style but fine touch, to which the eminent engraver J. J. Flipart did full justice. Carle Van Loo, the "painter of elegant frivolities" as he has been called, gave rise to the French term vanlootiser.

LOUTHERBOURG, Philippe Jacrues (I740-I8I2), also written Lutherburg, painter and etcher, born in Strassburg. Already as a young man of 23 he became a member of the Paris Academy, and soon afterivards attained his ambition of becoming the King's painter. In 177 I he went to England, where he painted historical scenes and some Cumberland landscapes. He died at Haversmith in I 812. He painted a few quite unimportant sporting scenes.

MAJOR, Thomas (I 7 I 5-?'), a clever English engraver, who worked chiefly in London and Paris. His plate La Mort du Cerf, after Wouverman, is among the best of his work. He also engraved many pictures by Rubens, Teniers, and Lauri.

MALLERY, KAREL VAN I 576 (?-after I63I). This Antwerp designer, engraver and art publisher was in 1585 a pupil of Philip Galle, and in 1597 master in the guild. The following year he married Catharine Galle, his old master's daughter. He engraved many of Stradanus' designs, notably his series on the silkworm.

-_ Philip de (born i 600 ?), probably son of the last-named. Did not reach fame.

MANDER, Karel V an, the Elder (I 548I606), draughtsman, painter, art critic and author. Though his contributions to our subject were of the meagrest sort and more or less mere genre pictures, his well-known work,
Het Schilder Boeck (Anisterdam, I6I8), in which he deals with the lives and works of Netherland, German, and Italian artists, contains much information about the less known artists who but for him would have vanished from man's ken. In his roamings through Europe he met with many adventures characteristic of those troublous days, when the invasion of the Turks, the plague, constant wars, shipwreck and pillage made journeys to foreign parts riskful undertakings.

MAURER， ChRistoph (I558-I6I4), a Zürich painter and engraver, who also devoted himself to enamel work on glass, of which he produced some very fine examples. He was a pupil of Tobias Stimmer, and subsequently the two did much work together, mostly for Feyerabend's publications, such as du Fouilloux and Clamorgan. These woodcuts are known by a mark combining their joint initials.

MECHEL, Chretien DE (I737-I 8 I 8 ), born at Basle. An engraver and dealer in engravings who made a great reputation for himself. Learning the art of engraving at Heumann and the Preisslers in Nürnberg, and with Kilian and Prinz in Augsburg, he went to Paris in I757, where he first worked for Wille and then established a business of his own. But he gave this up after a year's trial and went to Italy, and at Florence becanie a member of the Academy. In Rome he came across Winkelmann and other leading lights. Returning to Basle the following year, he founded a very flourishing business, and inaugurated exhibitions of pictures, \&c., which were visited by prominent persons, such as Emperor Joseph II and Goethe, who honoured his establishment on more than one occasion. So pleased was the former with what he saw that he ordered Mechel to arrange the celebrated Vienna picture gallery at the Belvedere, for which he received signal 


\section{SPORT IX ART}

honours, which were followed by others from different courts and learned societies. He employed a number of apprentices and minor artists whose works appeared under his name (Auvray, Romanet, Hübner, Zingg, Dunker, Gukenberg, Proll, \&c.). Subsequently he settled down in Berlin, where his active nind found fuller scope. The difficult ascription of the numberless works that appeared under his name has so far not been attenupted, and until more exhaustive studies have been made it is impossible to say what share he had in the production of the Mont Blanc set.

MEMLING, Hans, also MEMLinc (1435?If94 ?). Probably a Gernuan by birth. Known first as Hans the Painter : according to Weale, he assumed the name of Memling after obtaining the citizenship of Bruges. In 1467 he settled there as master painter, though bis name is not in the books of the guild. Soon afterwards many followers of the House of York came to Bruges in the suite of Margaret, sister of Edward IV of England, who married Charles the Bold (1468). Others believe he was one of the retainers of Louis de Gruuthuuse when he went on his mission to England in I 466. After the battle of Nancy $(1+77)$ he appears to have been treated at the hospital at Bruges. Less dubious is the circumstance that he painted an altar picture for this. institute in the year 1479 . He excelled also in miniatures, with which he adorned the Prayer Book of Philip the Good (grey in grey), and possibly also some of the pictures in the Grimani "Book of Hours," of which Fig. 25 shows the style. The snall travelling altar of Charles $V$ (Madrid Museum) is considered one of his best works.

MERIAN, Matthäus, the Elder (I 593I 560). A very prolific etcher, born in Basle. Learnt his art at Zürich in Dietrich Meyer's studio; worked in Nancy and Paris, where he came under the influence of Callot. Before 382 he could carry out his plan of going to Italy, he met Theodore de Bry's beautiful daughter and married her; as a consequence he settled down in Frankfurt. After the deaths of his famous father-in-law and his son, he carried on their publishing business, and on his own death left it to his two sons, Matthäus the Younger and Jacob. He illustrated a great number of important works, not the least being the bulky Topographie, which he and Zeiler issued in 1640, and which, in its final shape, consisted of thirty folio volumes, with more than 2000 pictures, maps and plans of towns, nost of which were made by him. We have already mentioned him among the artists who executed many of Tempesta's sporting designs. There are several little series, of which perhaps the best is a set of six $(2 \mathrm{I} \times 10 \mathrm{~cm}$.) depicting the never-failing stag, bare, wild boar, and bear-hunting scenes of which people never seem to have grown weary. The Strassburg engraver, P. Aubry, published it.

- - Matthäus, the Younger (I62II687), painter, engraver and art-publisher; born in Basle. He learnt his art in the studio of the celebrated Joachim Sandrart in Frankfurt, and accompanied his master to the Netherlands when still a youth. There he got to know Rubens and Jordaens. Proceeding before he had reached the age of 20 to England, he made friends with Van Dyck, whose style he assiduously studied. Then he went to Paris and Italy, where he came into contact with many famous painters. Returning to Frankfurt on account of his father's death, he just came in time to witness the great fêtes held in commemoration of the Peace of Westphalia. These afforded hin many opportunities to paint court ceremonies, hunts, and portraits of the royalties present. The same occurred when Emperor Leopold came to be crowned there eight years later. 


\section{$A P P E \mathcal{X} D I X$}

MEULEN, ADAM Frans VAN DER (1632 ? -1690), a native of Brussels, who came at an early age to Paris after passing through the studio of Pieter Snayers in Brussels. Called to Paris by Colbert, he was given employment at the Gobelin works, where he came under the observant eyes of Louis XIV, whom later on he was privileged to accompany on almost all of his campaigns as battle painter ; his accuracy of detail and his portraits, of which some of his pictures contain scores, make him one of the best battle painters. In 1773 he became a member of the Academy, reaching higher honours later on. He seems to have taken to sporting scenes in the intervals when no campaigns were occupying the armies of France. A series of four large plates $(46 \times 32 \mathrm{~cm}$.) depicting incidents of wolf-hunting in forests are spiritedly drawn, as our reproduction Fig. I 33 shows. They were etched by his pupil and countryman Anthony Franç. Bauduin (I640-I700), who had settled down in Paris. A fifth plate of the same size representing Louis XIV driving out to a hunt in a six-horsed coach in the forest of Vincennes is considered a masterpiece of etching. The plates of these five pictures have been preserved, for of late one meets with quite modern impressions. In the National Gallery there is a painting by him of Lous XIV starting in his coach on a hunting expedition (I662).

MOLYN, Pieter (1637 ?-r701). Born in Haarlem. Little is known of his youth; his landscapes are in the style of Goyen, and he painted some hunting scenes in the manner of Snyders, but soon took to marine scenes, more particularly storms at sea. On account of his preference for these he received the nickname Tempesta. The latter part of his career was a stormy one : falling desperately in love with a Genoese woman he caused his wife to be assassinated by bandits. During his ensuing sixteen years' imprisonment he was allowed to paint, acquiring quite a different style, and as he took the name of Muller or Mulieribus after his escape from prison (during the bombardment by the French in 1684), it is often difficult to identify his works.

MONFOORT, ANTONis VAN (called also van Blokland) (1532? -1583 ). Unimportant Netherland painter; only sporting picture known to us is the Diana and Actæon in the Dresden Gallery painted in 1573 .

MOUCHERON, FREdERIK (I633-1686). Born in Edam, but worked most of his life as an engraver in Antwerp. He studied under Jan Asselijn in Amsterdam and also in Paris. A stag-hunt by him is in the Städel Museum in Frankfurt.

MOURIK, B. (second half of eighteenth century), a little-known Dutch engraver and designer. Mr. Harting reproduces a hawking picture by him in his "Bib. Accip.," p. 48, depicting Prince William heron-hawking at the Loo in 1767.

MOYREAU, JEAN (I690-I762), an Orleans engraver whose work shows unequal merit, as can best be seen in his 89 plates after Wouverman some of which are carelessly executed. Amongst these are several sporting scenes.

MULLER, HERMAN or Harman, an engraver who lived between the years I $55^{\circ}$ and I 596. He worked for Hieronymus Cock in Antwerp.

MÜLLER, John Sebastian (I 720 ?-I 78 I ?े), born in Nürnberg between 1715 and 1720 , and came over tu England with his brother in 1744. Verv little is known about him, but it $3^{8} 3$ 


\section{SPORT IX ART}

seems certain that after the year I750 he adopted the spelling of Miller. He signed himself at first J. S. Miller, and then J. Miller, by which name he is generally known. Plates published in 1750 and 1755 support above surmise, while the illustrations to the large folio "Marmora Oxoniensia," published in $176_{3}$, already bear the last of the three signatures. He copied old masters with masterly skill, and Nagler says of him that he acknowledged to have forged in three cases the signatures of famous painters, a Murillo amongst others, and to have succeeded in taking in London connoisseurs.

He worked for the publisher J. Boydell, of Cheapside, mostly still-life, biblical, and some anatomical subjects. None of the English print rooms or collections seem to possess any of the following sporting prints by this engraver. Hence we propose to give the essential details about the sets in the writer's collection. The most important one is the series we have referred to in the text, consisting of nine plates $\left(\mathrm{t}^{\mathrm{I}} \times 3+\mathrm{cm}\right.$.), having for subjects the beaver, the marten and weasel, the squirrel and badger, the wild boar, the wolf, the bear, the lynx, the tiger, and lastly the buffalo, of which our Fig. 225 is a reproduction. The writer's very interesting and little known set was originally in the Royal Cabinet of Prints in Dresden, where they had two copies of the serjes.

To judge by the following circumstances it would appear that J. S. Müller must have published another rather similar series of animals after Ridinger. For the writer possesses besides these nine prints one other print in size and style very like the nine, but dealing with an animal not represented $i n$ the other series, i.e. "the Stagg or Red Deer," with "J. E. Ridinger advi et delin" in the rightband bottom corner. In the right-hand top corner there is a "5," showing that it was the fifth of a series which differed from the other one by the much greater length of the legend. On none of the nine does the legend exceed $3^{84}$ twelve or fourteen lines, while in the stag print there are twenty-eight lines of text or about 400 words. If this should meet the eye of any collector possessing any other of this "Stagg" set, the writer would be infinitely obliged for particulars.

When not working for Boydell, Müller appears to have been employed by H. Overton at the " IVhite Horse" without Newgate, and by R. Sayer at the "Golden Buck," opposite Fetter Lane, Fleet Street, for, with the collection of nine, the writer secured another series of four rather smaller and less wel] executed engravings which were drawn by Müller for the two last-named publishers. Their size is $33 \times 24 \frac{1}{3} \mathrm{~cm}$, and their subjects are: (I) "A Stag, a setting (sic) dog, a woodcock and thrushes"; (2) "A Hare, a Pheasant and Partridges"; (3) "A Wild Boar, a Dog and Fawne"; and (4) "A Doe, a Pointer, a Heath-Cock, a Phelfare (sic) and Partridges." In right-hand corner, "J. S. Müller Invt. et Sculps."

MUZiano, Girolamo (i530-I 592), a Brescian painter who studied under Romarino, following the lead of Titian as to colours, and of Michael Angelo as to form and movement. In Rome, where he died, he was also known as il Giovane de' Paesi. None of his pictures except the one reproduced, Fig. IOO, deal with our subject.

ORLEY, BERNARD VAN (I492?-I542), a Brussels painter known also as Bernard van Brussels, whose name was spelt in various mamers. Of his birth little is known, but he was almost certainly the son of Valentin, an illegitimate offspring of a noble Luxemburg family of the same name. Wurzbach and Weale consider that he must have been born at least seven years earlier on account of his being a master of his guild in 1515 , this honour, they assert, being at that time not bestowed before the thirtieth year. Conse- 


\section{APPEX(P) IX}

quently he must have been born in or before I 485. In opposition to this stands the fact that his parents' marriage took place on May I3, I490, and that he was the second son. Be this as it may, he went to Rome at an early age, where $i t$ is said he became a pupil of Raphael, and returned in I5I4 to Brussels. His first work was the celebrated portrait of young Charles, Maximilian's grandson and future Emperor, as a youth of 15 a charming picture, one of the treasures of the Magniac collection. This seems to have gained him the good-will of the Prince's aunt, the Regent Margaret, who made him her court painter in $15 \mathrm{I} 8$, with the result that a great number of portraits of the various royalties of the Habsburg dynasty were painted by Van Orley, and, which is also interesting, we know from the household accounts of the court the exact payments Master Bernard received. The Regent Margaret, his protectress, he seems to liave painted at least five times, but curiously enough not a single portrait of her is known to exist. No doubt a number of his pictures perished in the disastrous fire which destroyed in I74I Charles V's palace in Brussels, filled with what was one of the most wonderful accumulations of art treasures the world had ever seen.

One of the circumstances that probably contributed more than any other to the rapid rise of Van Orley was his being selected by Pope Leo $\mathrm{X}$ to superintend the weaving of the Acts of the Apostles, after Raphael's ten cartoons, with which the pontiff had entrusted Pieter van Aelst's looms in Brussels. 'This mark of distinction was shown Van Orley probably on account of his being personally known to the great master. When in less than four years, at a cost of $£ 30,000$, the wonderful panels were completed, they met with such general praise that some of the glory was no doubt reflected upon Van Orley. Anyhow, two years later, in I52I (not I520, as some put it), when Dürer visited Brussels, he was already a famous man whose portrait the German master painted twice-once in charcoal, now in the Grand Duke of SaxeWeimar's collection; the second time in oils, which is preserved in the Dresden gallery, where it hung for a long time unrecognised until Ephrusi "discovered" it. Dürer's curious complaint that he had painted six persons in Brussels who had forgotten to pay him for his work, which obliged him to borrow money for his return journey from a countryman of his, can hardly have been meant to include Master van Orley, for Dürer mentions with evident pride in his diary that Orley had entertained him at a sumptuous feast which must have cost him at the very least ten florins-a sum for which then three fat oxen could be purchased. As Dürer received for his portraits often not more than one-tenth of that sum, it is not likely that our Brussels master was one of the six sinners. In striking contrast to the two-shilling fee received by Dürer stands the sum of nearly $£ 20,000$ recently paid by Berlin for his portrait of Holzschuher.

Comparatively few works by Van Orley have come down to us, and with the exception of his cartoons of Maximilian's Hunts - a charm. ing drawing depicting sportsmen roasting a wild boar in a forest-preserved in the Albertina in Vienna, we know of no larger pictures of his on our subject. And, unfortunately, no engraver did for him what a score of artists hastened to do for lesser lights thirty or forty years later-viz., engrave his drawings-and for this reason Les Belles Chasses have remained little known.

Twenty-three drawings by Van Orley are preserved in the Louvre-i.e., the twelve cartoons of hunting scenes and eleven representing military subjects.

OSSENBECK, JAN or Josse (1627-I678), a Rotterdam painter and etcher, has left us a ferv unimportant etchings of sporting scenes. $3 \mathrm{C}$ 


\section{SPORT}

Having seen a good deal of the world, and being honoured by a call to Viemna as Court painter, he does not seem to have made the most of his opportunities.

OUDRY, JEAN BAPTISTE (I 686-1755), born in Paris; studied at first under his father, who was but an indifferent artist. He perfected himself in the studios of Serre and Largilliere, and became a member of his Mairrise in 1708 . He devoted himself at first to historical subjects and portraits, his picture of Peter the Great (I 7 I 7), to which we have referred in the text, making him famous. Subsequently he becanse one of the best animal painters of his century, and a great favourite of Louis XV, who assigned an apartment to him in the Louvre, and had him constantly at his court.

Most of the great public collections and private galleries possess specimens by Oudry. Of drawings the British Museum has three" hound tied up to a post, signed Oudri, I 754 ; a swan and dog, not signed; and a sleeping dog, signed $7 . B$. Oudry, I 750 , show that he spelt his name differently at different periods. In the Albertina there are also three fine drawings of pointers, partridges, \&rc.

Anong his large canvases of single animals none is better than the picture of a fine Mouflon ram which he painted from life, viz., from a good specimen in the King's Menagerie. The abnornally long hoofs are strong evidence of the beast's protracted captivity. A fine plate $\left(39 \times 32 \frac{1}{2} \mathrm{~cm}\right.$.) of this picture was engraved by $F$. Basan (I723I 797). Other still-life scenes with dead game and hounds, \&x., were engraved by $\mathcal{F}$. $G$. Huquier ( 1695-I 772), Gilles Demarteau (I 7291776), Nic. Charles Silvestre (1700-1767), and I. Doullé; while a book, Recueil de divers animoux de Chasse, designed by Oudry, was etched by J. E. Ren, and finished with the burin by I. P. Le Bas. A similar issue, called 1 Book of Beasts, P. Garon engraved and published at 53, Fleet Street, London. 386

\section{$I \mathcal{X} \cdot A R T$}

Oudry was also an engraver, though his name is omitted in some of the handbooks on that art. There is a set of four prints $\left(28 \frac{1}{2} \times 36 \frac{1}{2} \mathrm{~cm}\right.$. $)$ depicting dead game of various sorts and falcons, with the address: Peint et gravé par 7 . B. Oudry, Peintre du Roy, I725. But his graver failed to produce such good work as his brush has left us.

PASSE, DE, a Netherland family of which at least five male and one female member distinguished themselves as engravers. Their contributions on sport were unimportant, and mostly small book illustrations Considerable confusion still exists concerning the works produced by the individual members, their respective styles being singularly alike. Members of this family had the bad habit of altering plates to meet the popular demand of the moment, using the same figure with a different head. Even masterpieces were thus treated. Thus the Duke of Buckingham on horseback was altered after B.'s miurder to represent the King's later favourite, the Marquis of Hamilton. In anotier case Prince Henry of Wales' head was changed into that of his brother Charles. This, as we know, was also done by painters, Pierre Lombart inserting in Van Dyck's portrait of Charles I, which is in the National Gallery, the head of Cromwell.

—, Crispin, the Elder (I560? -I637), born in Armuyden, according to Kristeller and Wurzbach about I565; he travelled considerably in his youth, visiting Utrecht, Cologne, Ansterdam, Paris and finally Loindon, where he seems to have worked from I 615 to 1622 . He engraved his own designs and portraits of celebrities.

Crispin, the Younger (I585-i629?), born in Utrecht, son of the former ; worked also in England; he made the engravings for 


\section{APPEX $\mathcal{X}$ IX}

Pluvinel's "Art of Riding" which his father published. Is said to have died in or soon after 1629 .

Simon (I 59I-I637?), born in Utrecht; worked also in England, probably at about the same time that his brother Crispin was there. Afterwards went to Copenhagen, where the King made him his court engraver.

-, Willem (I 590 ? - - 660 ?), born at Utrecht, brother of the last-named, and pupil of his father. He also worked in England, his engravings being probably the most highly esteemed by collectors.

- Magdalena ( 1583 ?-——?), born at Utrecht, daughter of the first-named Crispin de Passe the Elder. It is not quite certain whether she also worked in England, though there exist portraits of English celebrities by her. Her execution was neat and showed considerable talent, though her style was rather laboured, resembling that of Count Hend. Gondt, the talented Utrecht amateur engraver who became insane through a love philtre administered by a young townswoman who had fallen in love with him.

CRIsPIN, grandson of the founder of the family, who was also a clever engraver.

PETERS, Grlles, also written Peeters (I6I2I653 ?), born in Antwerp, an engraver of animal pictures who never attained the reputation of his younger brother Bonaventura, the painter of marine scenes. Gilles etched some pictures of bears, one of them being marked Esloignement d'Altdorf en Suisse, so he probably worked in that country at one period of his short career.

PIRKNER, WoLfF, was born in Bayreuth, and alive in I639. Very little is known about this artist. In some of the pictures of the older (Vienna) set he has depicted himself in the act of drawing shooting scenes. In the "Antier Room" in the Coburg Veste, where the Chronicle of 1639 is kept, the walls consist of extremely fine intarsia-work reproductions of many of the scenes in the Chronicle. This inlay work, which is of a truly marvellous fineness, was made six or seven years before the completion of the 1639 Chronicle.

POLLAIOLO, Antonio (I429-I 498), a Florentine goldsmith, painter and designer, whose importance as a leading artist recent researches have established. It was he who set the fashion for pictures of naked men engaged in fights, or in combats with animals or monsters, delineations which disclose a masterly conception of anatomy; the plate Hercules slaying the Hydra (Duduit 338) being probably one of his first attempts in that line. Works of his relating more closely to sport have not come down to us.

POTTER, Paul (I625-I654), painter and etcher. Holland's most famous animal painter. He occupied himself in his unfortunately short career chiefly with pastoral scenes; his cows and oxen are drawn and engraved in most masterly style. Had he had opportunities to study wild animal life, such as deer, he would have given us probably very fine pictures.

RABEL, JEAN. A Beauvais engraver who flourished at the end of the sixteenth century. His style is not unlike that of de Passe and of Wierix. His son Jean seems to have been a pupil of Tempesta, or, at least, did work for him. A set of four sporting prints in the writer's collection bear the signature "Rabel," and were issued by F. L. D. Ciartres, of Paris. Probably they are the work of the son David. They measure $30 \times \mathrm{I}_{4} \mathrm{~cm}$., and are of no special interest. 


\section{SPORT IX ART}

REGENSPURGER, I. L. A little-known Augsburg artist of the second half of the eighteenth century. In the writer's collection there is a little set of eight etchings of big game, of which seven were engraved by the artist we are considering, while the eighth is the work of Elias Baeck, an equally littleknown artist. Regenspurger's third plate is a facsimile of Dürer's famous woodcut made in 1515 of the fantastic Asiatic rhino of which we have already spoken. Poor beast and poor naturalists! Not satisfied with its long reign of two hundred and fifty years, that impossible armour-plated bad dream with a horn growing out of its withers had again to trot out into the fierce light of publicity! One would like to know whether the publisher of this set-one Jeremias Wolff, of Augsburg-found it a profitable publication.

RIDINGER, JOHANN Elas (1698-I767), born in Uln!, where he also passed his apprenticeship. After a sojourn of three years in Ratisbon, he finally settled down in Augsburg, where he also died. Before saying more respecting the various sets produced by Ridinger, we must refer to his biographer, Georg A. IV. Thienemann, a man of considerible scientific attainments, who in the vear I 856 published the best existing account of Ridinger's life, and a caralogue raisonné of his engravings. In it he gives a specific number to every engraving known to him, i.e. I3 I3, as well as an unnumbered list of some hundreds of drawings by Ridinger, contained in twelve portfolios purchased in the year I830 from Ridinger's heirs by the well-known German bookman, J. A. G. Weigel. To this hoard the latter's son, R. Weigel, continued to add, so that at the time of Thienemann's publication this was by far the best existing collection of Ridinger's mezzotints, engravings, and drawings. The book was welcomed by an appreciative public, and some years later Thienemann made some $3^{88}$ additions; and in 1868 and 1876 another great admirer and collector of Ridinger, Count Henry Stillfried, published two further lists of hitherto uncatalogued prints, which brought the number up to 1435 . These additional lists are generally found bound with Thienemann's book. Since then other collectors, impressed by Ridinger's genius, have discovered more works, so that if one counts what for present purposes one might call "English Ridingers"-i.e. prints produced after Ridinger by artists working in England, of whom J. S. Müller, Kirkall, and Roberts are the best known-it is safe to say that there are more than fifteen hundred, without counting the numerous variations, differentiated from each other by changes in the numbers made by Ridinger in the plates, or by new titles or altered inscriptions, or by some other change on the plate.

The numbers given to Ridinger's prints by Thienemann, and which are invariably followed by collectors and dealers, afford a very convenient medium of designating any particular print. In Ridinger's case this is particularly useful on account of the immense number of his works, and of the fact that he often depicted one special animal in different poses, or amid surroundings varying only very slightly. Without these numbers it would be practically impossible to designate a particular print without reproducing it. Hence a study of Thienemann's pages is the first thing the would-be collector of this master's work must undertake.

Ridinger issued many of his engravings, at least those relating to sport, in series consisting of from two to one hundred and twenty-seven piates; but Thienemann, when cataloguing those that obviously did not belong together, failed to observe a chronological order, nor did he segregate those sets which Ridinger engraved as well as drew, from those which he only designed, but which were engraved by other hands. For this reason it takes a close study of his book to 


\section{APPEXP IX}

arrive at definite conclusions as to the number of each type. As to the prints themselves, a little practice will soon enable the amateur to tell them apart, for Ridinger's graver turned out very characteristic as well as much more uniform work than did most artists.

It would be going a trifle too far in praise of Thienemann's laborious and certainly most useful compilation were we to say that a modern catalnguer would in every case follow that writer's methods. In some cases Thienemann massed together into one series engravings which had no business to be thus assembled. The worst instance of such an inappropriate arrangement is that of the "One hundred most wonderful Stags," which is a flagrant example of mismanaged cataloguing, quite out of keeping with most of the other serialisation. Not only do some forty of the roo plates relate to other beasts, such as Bear, Wild-boar, Eagles, Swans, Foxes, Hares, Pelikans and Badgers, but some of these are of much smaller size and later date, in every way quite out of place under the heading given to them by Thienemann. How he came to make such a mistake is a puzzle that wants a lot of explaining.

The principal private collections of Ridingers are those of the Duke of Cumberland in Gmunden, Count Wilczek in Viemna, of Prince Hohenlohe-Waldenburg, Baron Dalberg, and Ritter Rudolf von Gutmann in Vienna, who lately issued a beautifully got-up catalogue of his very complete collection of Ridingers for private circulation.

As neither Thienemann nor Stillfried give much information about the present whereabouts of Ridinger's original drawings we are tempted to give the following particulars. The Albertina in Vienna possesses twentytwo drawings, amongst them the stag which, when pursued by several hounds, threw itself from a rock into the Danube, reproduced in Fig. 202 (Th. 266). Then the original of the curious engraving of the fox caught by a pike, of which Fig. $20+$ is a reproduction (Th. 317), as well as a number of interesting proofs before letters and plates in different states, notably of Th. 65, 99, 603, 604, and 605 .

In the Munich print room is preserved the drawing of a great boar, dated $174 \mathrm{I}$. Then there is one showing an artificially prepared rutting-place for stags dated $\mathbf{1 7 5 0}$, and an early study of a hound's head from the year I 725 , and finally a remarkable pen-and-ink drawing of a great court drive for stags and wild boar (Nr. 1 2,3 I6), which Ridinger never engraved-at least, so far as we know, no print exists of it. According to Waagen the gallery at Cassel contains a picture in oil of a stag, while the Dresden print room is particularly rich in fine early prints of his works. In the British Museum print room there are five Ridinger drawings dealing with sport, i.e. one of a wolf being caught in a trap, one of a fox-trap, both being dated $\mathbf{I} 748$, and the original of the mezzotint reproduced in our Fig. 222, to which we have already alluded, representing the killing of a twenty-two pointer stag by four lynx. This drawing is dated May I I, I74I.

Then there is the original of the large wild boar shot A.D. I 735 by Duke Charles Alexander of Württemberg (Th. 254), a beast which was remarkable on account of its malformed tusks, the points of which grew into the animal's snout. The date of this drawing is July 19, 1739. And lastly there is the drawing of a fine stag distinguished by an abnormal right antler, killed in the year 1737 by the Duchess Maria Augusta of Württenberg (Th. 262). It is dated April I7, I 739 .

There used to be many fine collections of Ridinger's prints in England, also some of his drawings, the former consisting almost always of really good old impressions with wide margins and in perfect condition. These prints were bought by rich English travellers doing the Continental tour in the leisurely 


\section{SPORT IX ART}

manner then happily still in vogue, and in the course of which so many art treasures from abroad were secured for English country mansions. For the last twenty or thirty years the supply has not only stopped but is flowing back to Gernany at a great pace, and these picked examples of fine engravings have in most cases returned to their native land, where hundreds of collectors eagerly vie for good impressions of their favourite master. As a rule English collectors had their Ridingers bound in volumes, and it is in the shape of stately tomes of great size that they have been turning up at Sotheby's and at Christie's during the last quarter of a century. Continental collectors, on the other hand, prefer to keep their prints loose in portfolios, one reason being that their treasures are thus spared the attentions of the bookbinder's knife.

In America Ridingers have, curiously enough, not yet "caught on," but the educational value of many of these quaint illustrations of ancient sport illustrating the customs of the ruling classes of Germany will assuredly one day be recognised by Americans. The writer had once occasion to show some Ridingers to a Western man who knew something of art, and who evinced the greatest possible interest in the subjects. When he had seen them all be exclaimed, "Why, if our libraries knew of these prints every one would insist on having full sets, and they would have to put them under glass, or they'd be thumbed to bits in one generation." "And perhaps he was not wrong.

Not uninteresting is the circumstance that in r775 Bewick, then only 22 years of age, received the "Premium" of the Society of Arts in London for his engraving called Hunsman and Hound after Ridinger, as is mentioned in Köhler's "The Works of American Etchers." In this useful book is also mentioned the fact that Alexander Anderson (born 1775) reproduced by a method favoured by Bewick, i.e. by using white line instead of black line, one of Ridinger's 390
Four Seasons which Anderson calls Returning from the Boar Hunl. It may be quite true, as Anderson remarks, that "no more vigorous piece of pure white line work has been done outside of Bewick's circle," but we fail to discover much reason to admire it.

And now let us briefly revert to the material used by Thienemann to write Ridinger's life story, the reason for our mentioning this detail being the circumstance that inaccurate statements regarding his birth, education, and occupation are constantly met with, even in the most recent art handbooks and biographical dictionaries. Thienemann when he wrote his Leben und Wirken had before him three biographies, one in writing, two printed. The former, written by a friend and pupil of the artist, was completed in 1764 , three years before Ridinger's death, and it was given Ridinger to read and correct. The MS., of which a contemporary copy is extant, shows some notes by the hand of the artist, who passed it as correct. The second biography is a printed one incorporated in a scientific publication of the time. It appeared in 1766 , hence could have been corrected by the artist had it contained any mistakes. The third is by his two surviving sons Martin Elias and Johann Jacob, who had lived with and assisted their father up to the end. In view of this unusually copious and also, one would think, peculiarly authoritative material, it is very singular that such totally incorrect assertions respecting Ridinger should so often disfigure art literature.

ROBERTS, H., an English engraver of the eighteenth century, about whom very little is known. He engraved several small plates after Ridinger which $\mathrm{J}$. Boydell published in the year I767. The work is poor, and the carelessness manifested in the titles does not increase the collector's regard for them. Thus one print depicts a stag standing quietly in front of a tree, and underneath is engraved "Stag Prancing." 


\section{APPEXPIX}

ROMANo, Giulro, also called Giulio Pippi and Dei Giannuzzi (I492--1546), the most celebrated of Raphael's pupils. Born in Rome, he settled in Mantua where he became a citizen and also was ennobled. The few paintings by him relating to sport are of allegorical character, and are topically of no interest. His best is probably Diana's Chase in the old palace at Mantua, where there is also an inferior wild-boar hunting scene by him.

ROSEX, also known as Nicoletto DA Modena (1470-in or after 1512 ), by profession a goldsmith of Modena, developed into an engraver whose plates vary a good deal in quality. Only a few sporting scenes are by his graver, one depicting a horseman in the act of spearing a hare being perhaps the most noteworthy.

RUGENDAS, Georg Philip (i666-I743), born Augsburg, a celebrated painter of battle pieces and an engraver who worked all his life in Augsburg. During the siege of that town in 1704 he made many studies, exposing himself to manifold dangers. In later life he took to mezzotint work, but his productions lack life and have all the faults of the German school at that period. He produced also some hunting scenes in mezzotint, some of which he printed in the blue tints much favoured by the Augsburg school. While not exactly copies of the works by his former pupil, J. E. Ridinger, his sporting scenes were unquestionably inspired by them. He followed Ridinger's example of inscribing descriptive verses in German and Latin under his engravings. So that there should be no mistake in regard to their origin his addresses were unusually explicit-G. P. Rugendas inv. delin. sculps. et excud. Aug. Find. His three sons, the eldest of whom had the same initials as his father, were also artists, who worked in mezzotint but with even less success.
SADELER. This was another celebrated Dutch family of engravers, painters, and art publishers, of whom at least six members reached distinction. By repeating Christian names and not sticking to one and the same mark, it is often practically as impossible to distinguish their productions as it is to recognize the relationship existing between them. But the following recapitulation of what we do know about them may assist.

, Egrdius (Gilles), the Elder, or E. S. I (born about 1550). This Antwerp painter, engraver and art publisher was a member of the Antwerp guild in 1580 .

, Egidius, the Younger, or E. S. II, born about 1569 , died in Prague in 1629 , probably the son of the former. In I 589 he was already a member of the Antwerp guild. He appears to have accompanied two relatives, Hans and Raphael Sadeler, on the usual journey to ever-alluring Italy, for we hear of them in Rome in 1593 . Two years later he was in Munich, where he engraved some of Candito's work with such success that the Emperor Rudolph II called him in I600 to Prague, where he remained until the Emperor's death, working almost exclusively for this consummate connoisseur. After Emperor Rudolph's death Sadeler entered the service of his successors Emperors Matthias and Ferdinand II. Sadeler's work is among the finest of the time, and he well merits the title " Phœnix of Engravers." Of the 2000 plates produced by this family those by Egidius II are generally considered to be the best, closely rivalled by the delicate work of

Raphael, the Elder or R. S. I ( 56 I1628). This Antwerp engraver was a member of the guild in 1582 , but later on we find him in Munich and in Venice. Like his namesake, Candito's canvases proved of absorbing 


\section{SPORT IX ART}

attractiveness to him, though Stradanus did not fail to charm this clever engraver, as we have already heard when dealing with Fig. SI.

RaphaEl, the Younger or R. S. II was born in Antwerp in 1590, and was probably a son of the last-mamed artist.

Besides these four Sadelers there were Hans I and I1, Josse, Justus, Marcus, Otto and Philip, but sone of them reached the distinction of the first entimerated members, and they produced little or nothing on sport.

SANDRART, JOACHIM (I606-I688). Born in Frankfurt, his parents being from the Low Lands. At the age of fifteen he went to Prague to study engraving in G. Sadeler's studio, but on being so advised by this artist he turned to painting, and became an apprentice of Honthorst, in Utrecht, who took him with him to England. Then he visited Venice and Rome. In the latter city he was honoured by being nominated as one of the twelve master painters who had to execute a picture for the King of Spain. Extending his travels to various Italian art centres, and even to Malta, he finally settled down in Amsterdam, where he married the rich Johanna von Milkau, with whom he obtained a castle near Ingolstadt, called Stockaw, which was, however, in a ruinous condition. In order to rebuild it he sold pictures he had collected for what was then a huge sum, i.e. 40,000 florins. He subsequently settled down in Augsburg, where he wrote $(1675-9)$ his wellknown work on architecture and painting, which made a great stir and made him famous. His paintings were chiefly portraits and stilllife. He issued many illustrated works, and in one of them, where the occupations for the twelve months are depicted, he strayed into our fold. We see a successful sportsman returning from the chase homewards. The 392 latter is a castle with moat and towers, above which its name, "Stockaw," indicates that the picture is probably a self-portrait. Over his shoulder, slung on a pole, he carries a hare, some partridges and quail, and in the distance a boar-hunt is going on. In his heavily-gloved hand he holds on leash two greybounds. Regner Persyn, an Amsterdam artist, engraved the pleasing plate.

SAVERY, JACOB, THE Elder ( i-I602). Probably born in Courtray; a pupil of Hans Bol. According to some, he was the father, and not the elder brother, of -

Roeland (1576-1639); but probably Van Mander was correct, and this is the former's younger brother. His talent was discovered when still quite a young man by Emperor Rudolph 1I, no mean connoisseur, who engaged him after seeing but one picture of his. He sent him to Tyrol, where he seems to have remained for two years. After his return to Prague he painted a number of Tyrolese landscapes for the Imperial gallery, many of which Giles (Egidius) Sadeler, the brother of Raphael S., engraved while also residing at that busy art centre in the capital of Bohemia. His sporting subjects are but few in number, and of no importance.

There appear to have been another Jacob S., called the Younger (I592-I627?), and a Jacob S. III (I6I7-I666), as well as a Jacob S. IV, a painter of flowers; but little is known about them.

SCHÄUFFELEIN, Hans Lenhard (I485?-1545?). Painter and engraver, born in Nürnberg; pupil of Dürer: his woodcuts were often taken for the latter's. His best-known work he did for Maximilian's Theuerdank, in which his well-known "H.S." with a spade mark a number of the quaint 


\section{APPEX $\mathcal{X} I X$}

illustrations. More than 240 woodcuts of his are known, exclusive of those by his son,

- $\mathrm{H}_{\text {ANS }}(?-1582$ ?) - many of which were at one time thought to be his.

SCHIEBLING, Christian, is said to have been court painter of the two Electors of Saxony, John George I and II, about the middle of the seventeenth century, but whether as painter, etcher or engraver is not known.

SCHMidT, Albrecht. An Augsburg engraver of the late seventeenth century. His engravings are all small and delicately finished, resembling rather the style of the de Passe. The writer's collection contains a set of ten of these diminutive little prints dealing w.th various sports, the one illustrating foxtossing being one of the earliest we have of that horrible pastime.

SEGHERS, Gerard (159I-I65I), also written Zeghers. An Antwerp painter. He studied in Rome and Madrid ; on his return to Antwerp called himself Gerardo. He contributed very little to our subject. In the Vienna Gallery there is a Diana in the Forest, depicting the goddess sleeping nude on a red cloth surrounded by such a profusion of dead game that one is not surprised at her exhausted condition.

SEISSENEGGER. A Tyrolese artist of the sixteenth century, who painted some of the great trophies and abnormities in the collection of Archduke Ferdinand of Tyrol, the founder of the famous Ambras collection.

SERWOUT, Pieter van, also Serwouters (1586-I657), an Antwerp engraver. Wurz- bach gives him the credit of having engraved' all the ten plates of the Has Venationis set (p. 150 ), but in this he is wrong, for as already mentioned three were executed by Nic. Visscher. Two other plates of bear and lion. hunts are known to have been engraved by Serwout.

SIBMACHER, JoHANN (?-I6II), an engraver born in Nürnberg, whose chief work consisted of two publications issued in 1605 on armorial bearings. Of these he engraved no fewer than 3300 specimens! For us ten small but spiritedly designed and well-engraved oblong prints $\left(17 \times 3 \frac{1}{2} \mathrm{~cm}\right.$.) on hunting are of greater interest. They deal with hunting the aurochs, stag, wild boar, partridge, wild ducks, monkey, hare, bear, then one on fishing, and concluding with a foxhunt. They are not numbered, but usually bound in above order. Of the three editions the first was published by Hier. Bang in Nürnberg in 1596 , the second by Paul Fürst, the third without either address. According to Andresen, in the Catalog Sternberg-Manderscheid (Nr. I 326), another like series is encountered. Frenzel does not consider them genuine, but copies after Sibmacher by an unknown artist. In the writer's collection there is a set of ten rather similar but a trifle larger frieze-shaped prints, date $16 \mathrm{II}\left(\mathrm{I} 7 \times 4 \frac{1}{2} \mathrm{~cm}\right.$.) signed $\mathcal{B}$. Rec. and $Z u$ finten bei Davit Funcken in Nürnberg. They are poor prints and of no special interest beyond their rareness, no other copy having ever come to the writer's knowledge. They may be by Sibmacher.

SNAYERS, Pieter (I593-I662 ?), a native of Antwerp, who became a painter of some eminence, both Rubens and Van Dyck praising his style, the latter painting also his portrait. He became court painter to Archduke Albrecht of Austria and to the Infanta of Spain. He painted principally battles, but 


\section{SPORT IX ART}

occasionally also hunting scenes. In the Prado at Madrid there are three of the latter, but they are of no instructive value.

SNYDERS, Fraxs (1579-1657). Born at Antwerp, friend of Rubens, whose brush, it is said, was often employed in adding details, such as human figures, or even outlining Snyders' designs, services which Snyders returned by painting in the lions, tigers and other aninals in Rubens' pictures. He has left a great number of very large pictures depicting game animals and hounds, generally in a lifelike but extremely conventional manner. Besides still-life scenes he also did some etchings. His animals are generally depicted in highly agitated poses of combat or chase. The most of his sporting canvases are in Madrid, where there are no fewer than twenty-three, and in the Ermitage there are sixteen. In the Louvre there is a couple of fine stag- and boar-hunts; at Munich two lions pursuing a roebuck; at Vienna a boar attacked by nine hounds, a fox-hunt, roedeer being pursued by hounds, two fish-market scenes, \&c. There is a sameness and artificiality about Snyders' canvases, a lack of human detail, that soon tires those searching for incidents illustrative of the methods of hunting. Snyders also etched, and, of course, scores of artists engraved after hin. Adam von Bartsch is among them with a Chasse au Sanglier.

SOLIS, NiclaAs, engraver of the sixteenth century, probably the brother or possibly the son of Virgil Solis (see below). He engraved principally court pageants, such as the fine series of fifteen plates depicting the marriage festivities of Duke William V of Bavaria in I 568 .

, VIRGIL (I I I4?-I568?) is said to have been born in Nürnberg, but it is more probable that, like his contemporaries and col- laborators, Jost Amman, Christian Maurer and Tobias Stimmer, he was a Swiss by birth though he worked most of his life in Nürnberg. His earliest woodcuts adorn a bible published by Froschauer of Zürich in I $53 \mathrm{I}$. Some 700 etchings and wood engravings are ascribed to him, most of them book illustrations. His best and most characteristic work is to be seen in the elaborately adorned titlepages of bibles and illustrated books issued by Nürnberg and Frankfort publishers. His sporting scenes are drawn with great freedom, and are of finer execution than Jost Amman's, whose style his woodcuts otherwise resemble. It is said that he had his eyes put out for engraving indecent scenes after Giulio Romano, but this lacks confirmation.

SPIELBERG, JohaNn (1619-1690), a painter, born in Düsseldorf ; became court painter of the Elector Wolfgang William of the Palatine, and besides numerous portraits he has left us a few spirited pictures of sporting character, of which a couple hang in the National Museum in Munich, one being a falconer (Der Falkonier). His daughter Adriana, born I646, at Amsterdam, was a pastel artist.

SPRINGINKLEE, HANs (first quarter of sixteenth century), a Nürnberg engraver, almost certainly a pupil of Dürer, who is said by some to have contributed to the Weisskunig, besides working for Koburger, Peypus, and other Nürnberg printers.

STEGE, ERwin von. According to Wurzbach's researches there can be little doubt that the Master E. S. and Maximilian's companion in his youthful days, Erwin von Stege, are identical. Considering that he was one of the leading masters of his time, very little is known respecting his activity. The few engravings of his that bear a date were 


\section{APPE $\mathcal{X}(\mathcal{D})$ IX}

issued in the year I466-7, but it is supposed that this was in the last part of his life. In the so-called Nümberger Hausbuch, which is ascribed to him, there is much interesting material, but little that concerns us here. In the University library at Erlangen is preserved a drawing in red crayon of a chamois hunt that must be mentioned, for it almost certainly relates to Maximilian, and reminds one of the Theuerdank woodcuts. In the centre of the drawing there is a tent with two armorial shields, one of which is the Austrian. Inside the tent we see two persons playing cards; in front of it a girl is petting a hound. To the left a knight and lady are riding off on horseback, and on the crags that form the background men are chasing chamois in the manner depicted in Theuerdank. A. Schulz reproduced this drawing in his Deutsches Leben, I892. Wurzbach mentions two other drawings, one of which depicts Maximilian hawking, two falcons stooping at a heron.

STIMMER, Christoph Hans (I549-?) worked for his brother Tobias.

—, Tobias ( I 534 - end of sixteenth century), born at Schaffhausen, a painter by profession who at first had to earn his livelihood by decorating the fronts of houses. His talent becoming recognised, the Markgrave of Baden employed him to paint portraits of his ancestors. Subsequently he took to wood-engraving, his free style being copied by Tempesta and others. He worked for Sigmund Feyerabend in Frankfurt, and produced a number of woodcuts in conjunction with $\mathrm{Ch}$. Maurer of Zürich.

In a private collection in Munich we lately saw a fine pen-and-ink drawing heightened in white, signed and dated $\mathbf{1 5 7 5}$, depicting a stag-hunt, a reproduction of which is to be found in Meder's Handzeichnungen alter Meister in der Albertina. On the back of the paper there is a less carefully drawn bear-hunt at night with torches.

STRADANUS, JoAnnes ( I $523-1605$ ), a talented and prolific designer, whose real name was Jan van der Straet; in Italy he was known as Giovanni della Strada. He was born in Bruges, and after receiving the first instructions in the paternal studio until the age of twelve, when his father died, he continued his studies under Maximilian Franc and under Peter Aertens, nicknamed Long Pete (Pierre Lungo). He appears to have become master in I 545. Then he began his travels, first working for six months in Cornéille de la Haye's studio in Lyons, from which place he went to Venice. But Titian and the newly arisen Tintoretto had less attractions for the young Dutch painter than Raphael, and particularly the divine Michael Angelo. So after a short stay in Venice he went on to Florence, where the great Cosimo de Medici was building up his undying fame as art patron. There S. evidently hoped to find lucrative employment. Exactly when S. reached the Tuscan capital we do not know, but he was there in 1553 . We also do not know what his first work consisted of, but it probably was in connection with the Arazzia Medicae, the tapestry manufactory which Cosimo had founded there in 1546 as a rival to the Ferrara establishment, re-created by Duke Hercules II some years previously on the lines of the Atelier de Vigevano in Milan. Duke Hercules had imported two famous Flemish master weavers, Nicolas and Jean Karcher or Carcher, and, as designers, Battista Dosso and Lucas Cornelisz. Under them some very fine sets of tapestry were turned out, which made such a stir as to cause the ruler of Florence to determine to out-do his Ferrarese rival. He set to work with characteristic energy, his first step being to induce the cleverer of the two brothers Karcher to migrate from Ferrara to the banks 


\section{SPORT IX ART}

of the Arno. With him he associated another Fleming, one Jean van Roost-also spelt Rost or Rostel-assigning to each of them the princely salary of 600 gold crowns, with the further privilege of being permitted to work for strangers. Karcher and Roost, on their part, undertook to establish twenty-four looms of which twelve had to be constantly kept at work, and to instruct apprentices gratuitously in their craft. The contract between Cosimo de Medici and these weavers is extant and furnishes much interesting information regarding trade customs, wages, \&c. Bronzino and then Salviati became designers of the establishment, which proved a very flourishing concern and, with brief intervals, remained so for just two centuries, until the Medicis became extinct.

Almost simultaneously with S.'s arrival in Florence there was recalled to that city Giorgio Vasari, the Tuscan painter and author of the famous "Lives of the Most Celebrated Architects, Painters and Sculptors," to whom the sovereign desired to entrust the embellishment of the Palazzo Vecchio and the building of the Uffizi. Vasari had worked in Rome for several Popes (during his life he painted for no less than five Pontiffs), and as he found in $\mathrm{S}$. as devoted an admirer of the immortal Michael Angelo as he was himself, a close friendship between Vasari and the Fleming was the result. In his enlarged edition of the above work, published in I 568, Vasari speaks with enthusiasm of S.'s work, as the following few extracts will show :

"The Fleming, Giovanni della Strada, is also one of our Academicians; and to good design, a rich fancy, and admirable power of invention, this artist adds an excellent method of colouring; he has worked much in fresco, in oil and in tempera during the last ten years. . . Giovanni may indeed declare himself the equal of any painter in the Duke's service. But his principal occupation just at present is to prepare Cartoons for arras. ... Giovanni has made very beautiful Cartoons for about 30 pieces 396 of arras, with others, also very tine, for the upper rooms occupied by the princess. . . . For the Palace of Poggio-a-Cajano, wherein 20 rooms are to be supplied with arras, now daily making progress, Giovanni has made Cartoons of Hunting pieces after the invention of the Duke; they exhibit all kinds of animals of the chase and portray the various modes of fowling and fishing with the most singular and beautiful fancies.. . have proved this Strada to be a truly able man, well skilled in the Italian manner."

For our present enquiry the words which we have put in italics open an important vista, but unfortunately there is absolutely nothing to show to what extent the great Cosimo helped S. in the "invention" of his sporting pictures. But as Vasari was likely to know better than any person the facts of the case, we may presume that S.'s designs portrayed sporting methods known also to the Duke, who in his wide travels had unquestionably more chances to witness such scenes than the artist. Vasari speaks of $\mathrm{S}$. as a fellow member of the Academy of Florence, that highly select body at the solemn sittings of which Cosimo himself presided. S.'s latest biographer, Orbaan, tells us that $S$. was already a member of it on October I $8, \mathrm{I}_{5} 6_{3}$. Borghini is another contemporary of S., who confirms his high position in art circles.

The frequent interchange of famous artists in the sixteenth century between Rome and Florence, as well as other art centres, affected also S.'s career, for the Pope invited him to adorn some halls in the palace at Reggio with the fresco work for which S. had become famous. In Rome, at the command of the Pontiff, he executed some frescoes in the Salle des Rois, work which had originally been entrusted to Francesco de Salviati, another well-known Florentine artist. While the two painters, between whom a friendship of old standing seems to have existed, were at this work. S. became involved in one of those characteristic artists' quarrels of which 


\section{APPEX I IX}

the literature of the day mentions many instances. A bitter feud between Salviati and the Roman artist Daniel de Volterra had sprung up, possibly in consequence of the nickname Braghettone, or Breechesmaker, with which Volterra had been dubbed owing to his carrying out Pope Paul IV's behest to put draperies on some of the nude figures in Michael Angelo's Last Fudgment in the Sistina. Stradanus took Salviati's part in the quarrel, of which the immediate cause was the "accidental" upsetting of Volterra's large canvas, fuel being added to the quarrel by some unflattering opinions they had mutually expressed. One upshot of this dispute was that $S$., when the frescoes in the Salle des Rois were completed, returned to Florence. His old patron, Cosimo de Medicis, received him with open arms, and at once gave him fresh work by commanding him to paint views of the principal I talian cities in the chambers of the Duchess, Eleanor of Toledo.

According to Orbaan, the first tapestries made after S.'s designs were completed in the year 1554, when a set called the "Towns" of Italy" are on record; then followed a number of other panels representing mostly mythological or religious subjects. The first panels representing sport were completed some time before the year I568. They were called Caccia de' daini, delle Chamozze, and though panels dealing with the Guerra di Siena and the Storia del Magnifico Lorenzo Medici seem to have followed in the years I569 and I570, S. had probably drawn their designs at an earlier period, the first-named war having occurred in I555. For it would seem that the new direction which he gave to his inventive genius met with such immediate success that with the exception of his stay in Naples in the following decade, whither Don John of Austria had called him in the summer of I 57 I to commemorate his victories, S. devoted himself for many years to the amazingly popular depicting of sporting scenes.
It is stated by some writers that Stradanus accompanied Don John to the Netherlands when the latter was made Governor-General by his half-brother Philip II of Spain. But this can hardly have been the case, for there is not the slightest trace of his being in Don John's train either in Spain, or in the latter's adventurous secret journey right across hostile France, or during the two years' sojourn in the Low Lands. Neither do any of the cor1temporary Flemish writers mention the presence of their distinguished countryman in their midst, as they assuredly would have done had he been there.

A similar absence of information is met in regard to S.'s contributions glorifying Don John's victory at Lepanto on Oct. 7, I 571 . Indeed, pictures of this naval battle, one of the greatest and most decisive historical victories, as Ranke declares it to have been, seem to have been pursued by an unkind fate: Titian, we know, refused to execute a commission to paint it; a picture of it which Montaigne saw in St. Peters, when visiting Rome in I580, has entirely disappeared; and the six large representations of the battle which Philip II commissioned Lucas Cambiaso to paint for the Escorial, being placed in an open gallery, became scarcely discernible, as Sir W. Stirling Maxwell tells us in his "Don John of Austria." There exists an engraving of the battle executed by $L$. Cornelis, and in the Vienna library a woodcut by the Nürnberg artist Christopher Krieger, or Christoforo Guerra as he subsequently called himself, but the original designs after which they were engraved have disappeared. The only one known to the writer is the sepia pen-and-ink drawing by $\mathrm{S}$. in his collection. It contains many interesting details of the famous battle at which, as Motley tells us, 600 war vessels were engaged, and some 35,000 or 40,000 men were killed or wounded. In the Memoires of the fair but frail Marguerite of Valois, Queen of Navarre, we come across a reference showing that there existed some tapestry 


\section{SPORT IX ART}

designs of the battle. For in the description of the gorgeously furnished sleeping apartment in the palace of Namur prepared for her by her gallant admirer Don John, it is mentioned that her bed-covering consisted of exquisitely worked pictures of the great seabattle won by Don John. Possibly these embroideries were made after S.'s designs, but as they, too, have perished, this remains a mere surmise.

What probably was one of S.'s last works is the set Schema, sev Speculum Principum, published in I 597 ; the exceedingly interesting set of twenty engravings after his design, known as the $\mathcal{X o v a}$ Reperta, which Theodore Galle and Joan Collaert engraved and Philip Galle published, preceding it probably by a few years. According to Fétis, S. took to oil painting in the last part of his life, executing two important pictures for Alexander de Medicis (Pope Leo XI); but with the exception of tivo small pictures on copper in Vienna there exist, so good judges state, no oils by him in any of the great European galleries. $\mathrm{S}$. signed many, if not most, of his drawings, some with "Joannes Stradanus," on others "Strada" or "Stradanus," and in one case only with " $S$ "; his real name, so far as the writer knows, never being used.

Nothing can give one a better idea of the extraordinary fertility as well as of the great popularity S. enjoyed among contemporary engravers than a perusal of the list of the names of those who translated his designs. The five Galle, viz., Philip, Cornelius, sen. and jun., Theodor and Joan ; the four Sadeler, viz., Aegidius (Giles), Jan, Marcus, and Rafael; the three Wierix, viz., Anton, Jan, and Jeronimus, then Adrien and Hans Collaert, his own pupil, Antonio Tempesta, Carl de Mallery, Lambert Cornelis, A. Scacciali, I. Callot, Cornelius Cort, B. Mazza, H. U]rich, M. Lochom, Crispin de Pass, Hieronymus Cock, Harman Müller, Henrick Goltzius, and probably also Virgil Solis. Besides these, many nameless artists, of whom the majority $39^{8}$ proved most indifferent engravers, tried their hands at reproductions of S.'s designs. Among the writers who deal with $S$. may be mentioned Hymans (C. v. Mander), II, I I ; Immerzell, III, I 18 ; Kramm, V, I58I ; Nagler, XVIII, 444; Michiels; Blanc; Liggern I, 153 ; Orbaan; Wauters; Muntz La Tapisserie Campori ; Fétis ; Baldinucci ; Borghiniand Vasari. S. died in Florence in 1605 , and lies buried in the church S. Maria Annunciata, where his son Scipio erected a monument to his memory, the inscription on which settles all doubts concerning the year of his birth. The latter is given sometimes in older works of reference as 1530 or 1535 .

Wurzbach's statement that $\mathrm{S}$. died at the age of eighty-four is disproved by his own words, for he asserts quite correctly that $\mathrm{S}$. was born in 1523 , and died on November 2, 1605. He therefore could not possibly have been more than eighty-two at his death. No fewer than five well-known artists left us portraits of S., i.e. H. Goltzius, Frisius, Hondius, J. Wiercx, and Vasari, whose design was engraved by $C$. Batta-Cecchi. On a large pewter platter in the writer's collection of mediæval pewter there is a sixth portrait with an inscription round it in the style made familiar by the above-named Flemish artists. It is of South German or Tyrolese origin and shows S.'s wide popularity.

Scipio S. followed his father's footsteps, but never reached fame. In 1596 he attained the rank of proveditore of the Academy.

We now have to examine S.'s work more in detail. His versatility led him, as we have already hinted, to tackle a great diversity of subjects. Of the 388 prints Nagler mentions as having been engraved after his designs, about a third deal with sport, another third with religious subjects, and the remainder with domestic and still-life scenes. For his religious pictures there manifested itself also a large demand, for the Jesuits and other proselytising religious orders found them of the greatest possible use, and thus these prints 


\section{APPEX $\mathcal{X} I X$}

came to be distributed all over the world from China to Mexico, probably over a wider field than fell to the lot of any pictorial publications since the invention of printing.
S's most important work, the Venationes set, he very naturally dedicated to his famous patron and collaborator, the Grand Duke Cosimo. The lengthy latin laudatory inscrip-

\section{COSIMO MEDICI GRAND DUKE OF TUSCANY}

After he had most magnificently adorned the city and his own palace with the noblest artistic works of every kind, having resolved also to decorate the royal seat at Villa Cajana with appropriate ornaments of his own, engaged me as a painter to prepare patterns for the most noble tapestries with which the walls of those residences were to be hung; in which tapestries should be contained every kind of hunting, hawking, and fishing. This work $I$ executed with the greatest diligence and artistic ability that I could command; and when I learned that it had been fully approved in the tapestry form, I endeavoured also to reproduce the same with all its ornamentation in a smaller shape, and to have it engraved on copper-plates, that I might gratify the wishes and eyes of men of taste. This was a difficult and laborious task, as all will easily understand who have reflected upon the varieties and natures of wild beasts, birds, and fish, and the devices and arts which men have used to capure them. Farewell.

7 OHANNES STRADENSIS OF FLANDERS DESISNED

$$
P \text { hilippus Galle engraved and frinted }
$$$$
\text { I } 578
$$

The writer has come across them in the most unexpected places. In Indian Mission chapels in the northern wilds of Alaska and British Columbia, in Californian adobe churches, in wooden shrines in the depth of Transylvania and Albania, and a set of the Tortures for Unbelievers was found plastered on the back of a Chinese altar in Victoria. tion occupies the centre cartouche, which is surrounded by an elaborate framework consisting of arms of the chase and various animals from an aurochs and elephant to a chamois and porcupine. The translation informs us that the engravings comprised in the series were made from drawings specially designed by him for this purpose 


\section{SPORT IX ART}

at a period subsequent to the completion of the cartoons after which the tapestries were wovell.

Below, running the whole width of the title page, we read: "To the Reader: Here reader behold numerous examples of the tapestries which adorn the palaces of my native Tuscany."

The I03 plates that follow the title-page are of fairly uniform size, varying from $26 \frac{1}{4}$ to $293 \mathrm{~cm}$. in width and from 19 to $21 \mathrm{~cm}$. in height. The dedication to Cosimo de Medici and the date distinguishes the first edition of the complete collection from the later ones. Earlier incomplete editions, consisting of from 36 to 102 prints seem to have been issued, but the smaller ones had no separate title-pages, at least we have never come across one. These earlier editions often had the numbers printed in latin numerals in the righthand botton corner, but in none of the sets we have examined (scores of Venationes have been examined by the writer) do these latin numerals go beyond XXXVI. In the complete edition, on the other hand, the numbers $1-103$ are invariably printed in arabic figures in the left-hand hottom corner, as can be noticed in our Figs. 63, 68, 69 and 70. Some complete sets of the 1578 edition have prints with both numbers, made up probably in the rush of business of earlier impressions that happened to be in stock to which later ones were added. But in these instances the arabic and latin numbers do not correspond beyond the first four pictures. Thus in one of the sets in the writer's possession there are prints with the respective numbers 60 and XVIII, 93 and XXVI, 8I and XXI, and so on. Later on, when the demand obliged the publisher to issue more editions, and for this purpose new plates were engraved, the latin numerals were omitted, or possibly they were erased in the original plates. When Philip Galle published the I 578 edition he evidently thought that the issue would suffice for all requirements, but the demand 400 that sprung up for this picture-book in the Netherlands alone soon showed him that Dutch editions would be needed.

A new and quite different title-page was designed in which the curious lacuna observable in the original title-page, viz. the want of a name or title, was remedied by Philip Galle, who also for the first Dutch edition figures as publisher. In the new title-page he calls the book $V$ enationes, and the dedication to the Grand Duke Cosimo, as well as the date, are omitted altogether. In lieu of them the centre cartouche is filled with a latin sub-title, which runs: Hunting of Wild Beasts, Birds, and Fish; Contests of Combatants with Beasts and of Beasts one with another, drawn by Joannes Stradanus; published by Philip Gallaeus; and ornamented with verse by Kilianus Dufflaeus. Below the cartouche, occupying the whole width of the page, we have a short latin dedication reading: "Dedicated to the high-born, wise, and most learned gentleman, D. Henricus of Osthorn and Sonnevelt, Licentiate in both canon and civil law, his relative, by Philip Gallaeus as a token of deserved respect."

Subsequently, probably after Philip Galle's death in I6I2, when the plates used for this first Dutch edition were worn down, and a new publisher, Nicolaus Visscher the engraver, had acquired the rights from the Galle heirs, a second Dutch edition, printed from new plates, was issued. For it, also, a new title-page was made, resembling in the main the old one, but instead of the dedication a second sub-title in Dutch occupies the bottom of the plate, Iachten van wilde Beesten, Vogelen en Visschen. Of this edition also a great number of impressions must have been issued, as is shown by the condition of later impressions. Some early ones were printed on special india paper, but though these are rare, and we have come across only one set besides the copy in the writer's collection, they can not, we think, be deemed proofs, as some writers have 


\section{$A P P E \mathcal{X} D I X$}

termed them. In the one set before us the last or I03rd print is omitted, but immediately following print No. IO2 is the Vermis Sericus series of six prints, in which versatile Stradanus depicts the silkworm industry. These "silk" pictures were evidently intended for a wide circulation, for below the latin inscriptions the publisher caused a French rendering to be engraved.

Nagler, whose invaluable work of reference is generally so extremely correct, says that one of the Venationes editions consists of I I 8 prints, but the writer has failed to find any trace of such an edition, nor of one containing more than $\mathrm{I}$ of pictures, counting the titlepage as one. A possible explanation of Nagler's assertion may be found in the circum. stance just alluded to, i.e. that many bound sets of the Venationes have at their end one or two of the other smaller, similar-sized series of Stradanus' works. In some Venationes the firm that issued them bound in besides the six Vermis Sericus prints the first eight pictures of the Nova Reperta set. This interesting series was first issued in that number, the remaining twelve prints being added at a subsequent period. Of these composite $V$ enationes volumes quite a number are about, which explains Nagler's edition of I 8 prints, but inasmuch as there are none, or at least we have never come across any, in which the numbering runs beyond $\mathrm{I}_{3}$, each of the small sets bearing separate numerals $I-6$ and $I-8$, we are fairly confident that this is the correct explanation. Had it been the intention to enlarge the great series by these smaller sets it would have been easy enough to alter the numerals.

Quite distinct from, and of earlier origin than the $V$ enationes set are several small seriesone of four and two of six prints-which were issued by S.'s first publisher, Hieronymus Cock of Antwerp. According to Orbaan the first of these Fachten (Hunts) were published in 1570 , probably just previous to Cock's death in the same year. This is probably the so-called
Tapestry set, for these engravings have elaborate borders of trophies of the chase, arms, \&c., such as framed-in all the tapestry hangings of that tine. None of these three series were provided with separate title-pages - at least we have never come across anybut each of the two "six" sets bears on the first print the date, in one case the date I 574 , in the other 1576 , and both are a trifle larger $(30 \times 22 \mathrm{~cm}$.) than the Venationes, and of superior workmanship, the twelve being probably by one hand. On one plate of the I 574 set we find Adri. Collaert excud., which, if the meaning in this instance is the usual one, would show that Adrian Collaert had taken over or was acting for Cock's establishment, the curious trade-mark of the latter, "Aux quatre Vents," being found on most. These sets are a good deal rarer than the $V$ enationes and one never meets with any later impressions. For this reason we may assume that all the plates engraved before or in 1576 perished in the savage "Spanish Fury" that overwhelmed Antwerp in the November of that year, when some Iooo houses, including the magnificent marble town-hall-one of the world's wonders-were destroyed by the Spanish troops and gooo citizens killed. In order to assist identification of single prints belonging to these six sets, we may add that the $157+4$ series have the numbers in the right-hand corner of the ruled-off space occupied by the four latin lines below the print, while the I 576 prints have the number in the left-hand bottom corner of the engraving itself.

Drawings by Stradanus are (or were) preserved in the following collections: In the Albertina in Vienna, nineteen designs of religious subjects (mostly unsigned). Edouard Fétis in his Monography on S. mentions: In a private collection in Amsterdam the twelve designs of the Twelve Months. The designs of Orpheus in the collection of the celebrated French amateur Sylvestre. A drawing of Enée aux Enfers in the collection of Archduke Charles in Vienna. In the 


\section{SPORT IX ART}

Paignon-Dijouval collection two draivings or wild-fowling scenes in pen and ink, washed with bistre and heightened with white lights, and three other religious subjects; also in Prince de Ligne's collection two religious subjects (described by Bartsch).

In the British Museum there are tour unquestionably genuine (two are signed) and one rather doubtful dirawings by $S$. Nagler states that J. A. von Silvestre possessed in I 800 a drawing depicting coral-fishing, which was probably the original of Pl. 92 of the Venationes.

Considering the terrible sieges and pillagings which most Netherland cities underwent it is not surprising that little survived, and that museums possess so few of S.'s originals. With the assistance of the extremely courteous Director, P. Haverkorn van Rysewik, of the Boymans Museum in Rotterdam, and of Dr. C. Hofstede de Groot, Director of the Amsterdam Museum, one was able to make interesting researches on the spot, but there is but little to investigate. Each of these important collections possesses twelve drawings by S. In the Rotterdam Museum only one is a sporting subject, viz. a wild-fowling scene, after which No. 68 of the Venationes series was engraved by Joan. Collaert.

In the writer's collection there are fiftysix original drawings by Stradanus' hand. They are mostly sepia or tinted drawings, heightened with white. Many are the originals after which Venationes prints were engraved. The rest, including what is unquestionably the most valuable of all, the original design of Vespucci's landfall, were reproduced in other non-sporting series of which there is no need to give particulars. Careful as Stradanus usually was in signing his drawings, he unfortunately failed to date them; only one in the writer's collection bears the date (1589). This failing, to which so many of his contemporaries were addicted, makes it almost impassible to give the chronological sequence in which the artist drew them.
One decidedly unsatisfactory bit of work Stradanus did turn out, i.e. his illustrations of Dante's Inferno, which are preserved in the Laurenzian Library in Florence. They date from about the year 1587, when he was at the height of his busy career. These illustrations are poor of execution and they lack all imaginative feeling; but because of this failure to grasp the inspired subject and intentions of the divine poet, the artist's reputation does not deserve to be overwhelmed by the vituperative criticism to which an English writer has given vent. We refer to Mr. John Addington Symonds' remarks in his preface to Dr. Guido Biagi's edition of Dante's "Opus Magnum." To expect a full appreciation or perfect realisation of the poet's heavenward flights of fancy from a phlegmatic, hard-working Fleming thriftily turning out pictures of everyday actuality, to quarrel with him because his prosaic brain, intent on the commonplaces of his craft, refused to soar, shows a lack of balance in criticism which could only be caused by failure on the part of the critic to understand the mercenary environment of art in Stradanus' day. 'To say that this "journeyman of an art," as he calls Stradanus, had sunk into self-complacent putrescence and could not grasp the meaning of Dante's pungent symbolism, his aristocratic disdain, and supreme pity, those rarities and delicacies of the mediæval spirit, that awful drama of damnation with its episodes of human tears and ever-enduring agonies, is fine writing, but hardly criticism springing from an intimate knowledge of the time or of the man, or of art as it was then practised.

TEMPESTA, Antonio De (I555-I630), a Florentine designer and etcher. Learning his art in Santi de Titi's and then in Stradanus' studios, he finally established himself in Rome, and there by his talent and industry achieved a high reputation. Pope Gregory XIII employed him to paint frescoes for the Loggias 


\section{APPEX D IX}

of the Vatican, and the Marchese de Giustiniani had him decorate his palace. By some his work is considered to have been equal if not superior to that of his Florentine master, and while this must remain a matter of opinion so far as freedom and lightness of touch is concerned, there can be no question that regarding inventive genius the master was far superior to the pupil. In fact it is not too much to say that there are few of Tempesta's sporting scenes which were not directly inspired by the works of the latter, even his faults, such as reversed chamois horns and ibex with long beards, being copied by Tempesta. Of the 1700 or $\mathrm{I} 800$ plates ascribed to Tempesta little more than a fifth relate to sport. Nagler and Bartsch give many particulars of these, but as the writer's collection embraces some that are not mentioned by either, it may prove useful to collectors to give in the briefest form possible the various Italian, Dutch, and German editions without entering into the many minor details which would be necessary were one to differentiate one edition from another by all the existing variations. Of these there are a great many, caused by the number of artists who worked after Tempesta.

\section{The Sets with Titles.}

I. Ucceliera, with 66 plates (according to Bartsch only 44), Rome, 1622 , another edition 1624 .

2. Venationes ferarum, avium, piscum, Romae, I605, 30 plates, obl. quarto.

3. Venationis Piscationis et Aucupii typi, no date or place, C. J. Visscher, 8 plates, obl. quarto.

4. Aucuptionis multifariae effigies, Amstelredami, I639, N. J. Visscher, I6 plates.

5. Facht boeck, C. J. Visscher, 1624,2 plates, obl. quarto.

6. Venationes ferarum, avium, piscum, Amsterdam Pieter Goos, no date, 40 plates. Subdivided in four sets of ten plates each, entitled respectively: Eerste Deel, numbers running from I-IO; Twede Deel, II-20; Derae Deel, 2I-30; while the Vierde Deel begins again $\mathrm{x}-\mathrm{IO}$. Margins left blank, except above numbering. In another edition the title-page bears date 1627 , and instead of Pieter Goos, Claes Janss Visscher figures as publisher. Other editions: Rome, 1602,1605 . 7. Title same as " 2 ," dated 1598 , and dedicated to the Duke of Ursino.

\section{SeTS without Title-Pages.}

A. Twelve etchings, numbered $I-I 2$, Ist plate: "A Tempest inuent. M. Merian fe," and underneath, "Peter Aubrey, excudit." Size 20 by $14 \mathrm{~cm}$.

B. Sixteen etchings numbered $\mathrm{I}-\mathrm{I} 6$, on one plate: "Ant. Tempest, inventor, C. J. Visscher, excud." These are subjects quite different from above " 4. "

C. Twelve etchings, no numbers, four latin lines underneath each place. Some of them bear address "M. Merian," the unsigned ones being evidently by the same characteristic graver.

D. Six etchings, no numbers; engraved by "M. Merian," published by P. Aubry.

$A, B$, and $D$ are probably proofs, as the same etchings exist with inscriptions.

All the above titled and untitled etchings depict sporting scenes, deer and wild boar hunts being Tempesta's favourite sport, to judge by their frequency.

Of single sporting plates by Tempesta, or after him, there are a considerable number, but they are, with one or two exceptions, of no importance, and one is glad to turn to less dull pictures.

THOMAN, Ernst Philip (1657-1726), was really a member of the noble family "von Hagelstein." He was an Augsburg painter and engraver of moderate skill, chiefly interesting on account of his early mezzotint work, of which he and his son, Tobias $\mathrm{H}$. Thoman, produced between them over one hundred plates, many of which deal with 


\section{SPORT IX ART}

sport. They are little known, and are nowhere catalogued. The following are in the writer's collection: Two sets of four large plates each, one being signed "Emst $P$. "Thoman del. fecit et excud.," the other without the "del." They consist of four large mezotints $\left(49 \times 36 \frac{1}{2} \mathrm{~cm}\right.$.), depicting (I) the chase of the ostrich, (2) crocodile, (3) monkey, and (4) tiger. The second set of same size, numbered $\mathrm{I}-4$, representing (1) a wolf attacking a tethered goat, (2) foxes being smoked out of their earths (see Fig. I 49), (3) hare-coursing, a mounted lady looking on and being handed a gun, and (t) hedgehogs and badgers being dug out. These prints, of which the design is original, have each four lines of German verses.

Tobias H., son of the latter. Of this Augsburg artist not even the years of his birth and death are known with any degree of certainty. There are five sets by him in the writer's collection. One a set of four large upright mezzotints ( $36 \frac{1}{2} x$ jo $\mathrm{cm}$.) representing a panther attacking a wild boar; a stag being attacked by a tiger, while a fox and lion are looking on; a fallow buck attacked by a lion, a bear and a fox looking on; a bison, erroneously called aurochs, being seized by a bear. Latin and German couplets describe the subject.

Then there is a set of four oblong mezzotints $\left(48 \times 36 \frac{1}{2} \mathrm{~cm}.\right)$, numbered: (1) fallow-buck shooting, (2) bear-hunting, (3) chamois-hunting (see Fig. I 4 ), (4) hunting wild cats with hounds. Three Latin and two German lines below the picture describe the subject. All four are signed "T. H. Thoman inve. et excud."

A third set of the same shape and nearly the same size represent the typical hunting methods prevailing in the four quarters of the world. They measure $49 \times 37 \frac{1}{2} \mathrm{~cm}$. The first, signed "T. H. Thoman excud. Aug. Vind.," represents European sport, a 404 young and immature stag being pursued by hounds and mounted men, a lady with threecornered hat and gun at her side sitting underneath a tree watching the chase and clapping her hands. The picture of American hunting represents a spotted leopard jumping up on the hindquarters of a horse which is kicking at it. Asiatic sport is depicted by a lion-hunt, African sport by an elephant-hunt, a number of natives shooting at a large beast with bows and arrows, making a sort of pincushion of it. None are numbered except the last mentioned, which bears the number " 22 " in the right-hand lower corner. Two Latin lines in the centre and on each side two German couplets describe the pictures.

Of another set of mezzotints, of similar shape and size, depicting par force hunting, the writer possesses only one numbered " 3 ." It represents the Curee, four men blowing French horns, the pack assembled in front of the dead stag, and is probably the last but one of a set of four. It is unsigned, but unquestionably the work of one or the other of the Thomans.

Lastly, a nice set of four engravings, issued in Augsburg, of which Fig. I50 is one signed "T. H. Thoman inv. et del.," and "Ioh. Georg Hertel exc. A.V." must be mentioned. Measuring only $20 \times 30 \mathrm{~cm}$. they represent the four seasons, spring being depicted by heron - hawking; summer by a sleeping shepherdess and partridye netting, autumn by wild-boar hunting, winter by wolf-shooting from an ambush, the prey being attracted to the spot by a bait. The elaborate scrollwork frame is typical of the time, and the execution shows far greater freedom, skill and taste than do the mezzotints by the same master. The four German lines on the lefthand side and the four Latin ones on the right side are also superior to the inscriptions we have noticed.

The British Museum possesses none of these early mezzotints or engravings, the artists being represented by a few portraits only. 


\section{$A P \mathcal{P} \mathcal{X} D I X$}

THULDEN, TheODORE VAN (1607?-1676?). Painter and etcher, born in Herzogenbusch. Pupil of Rubens, with whom he appears to have remained for a number of years. In I 626 he became master in Antwerp, and in 1632 we hear of him in Paris. He painted numerous allegorical, historical, and out-ofdoor scenes, but hardly anything relating to sport. In his picture of Orpheus taming the animals at Madrid, Snyders painted the latter. In Munich, in the hands of a dealer, we recently saw a coloured drawing of St. Hubert by him (signed).

TILlEMANS, Pieter (i680?-I734). Painter and etcher, born in Antwerp, son of a diamond-cutter. Came to England in 1708, where he found a ready market for his copies of Teniers and Bourguignon. Subsequently he took to original work, his landscapes and sporting scenes with horses becoming popular. The Duke of Devonshire became his patron, as well as Lord Byron, whom he instructed in drawing. To the former he dedicated the five plates of Newmarket races, etched by J. Sympson, while similar racing plates were dedicated by him to the Prince of Wales (etched by C. au Bosc), and to Lord Derby. Another set of twelve plates of horses was engraved by S. Ravenet, and another series of eight plates representing winners of races (the names of their owners being given too) tvas executed in mezzotint by E. Kirkall. Tillemans ultimately also took to etching, one of his best known as well as largest plates being dedicated to Lord Byron. It depicts sportsmen starting out hunting with their hounds, dated 1723 .

In 1733 it seems his health obliged him to give up work, and there exists a curious catalogue he issued of his art possessions, which were sold on April I9 and 20, I733, at "Mr. Cock's, in the Great Piazza, Covent Garden." In it numerous "Landskips" of his, and A Horse-race at New Market, are judiciously interspersed with cartoons alleged to be by Raphael, Van Dyck, Rembrandt, Teniers, and Poussin. Unfortunately, history does not relate what prices these treasures fetched.

TOPSELL, EDward, compiler of "The Historie of Fovre-Footed Beastes," published in London by William Iaggard in 1607 , was the Dean of Westminster's chaplain for "St. Buttolphe, Aldergate." The lengthy dedication which is addressed to the aforesaid Dean bristles with quaint homilies. It tells us of the "shamefastnesse of the adulterours lyonesse, the neatnesse and politure of the cat and peacock, the justice of the bee, the care of the nightingale, the chastity of the turtle," and other equally curious deductions. The 768 folio pages are illustrated with scores of woodcuts by unknown hands in the style of Fig. IIo. Bound in the same volume is usually "The Historie of Serpents," printed and issued by the same firm, but a year later, i.e. I608. It contains 324 pages, and it is not as profusely illustrated as the first part. It is not known by whose hand the prints are.

VASARI, Giorgio (I5II-I574), born in Arezzo, an ltalian architect and painter, but chiefly famous as the author of the "Lives of Celebrated Painters" (I 550 and I 568 ), which laid the foundation of art histories of Italy. For this great work his apprenticeship in the studios of Michael Angelo and Andre del Sarto fitted him excellently, while the favour he found in the eyes of the art-loving rulers of Rome and Tuscany (he worked for no fewer than five Popes and four Medici) brought him into contact with all the famous native as well as foreign artists who swarmed from all parts of Europe to these two art centres. As friend and biographer of Stradanus we cannot pass him over in entire silence, though he contributed nothing to our subject. 


\section{SPORT IX ART}

VELDE, ADRIAEN VAN DER (1639-16-2), an Amsterdam painter and etcher. Like his contemporaries, Paul Potter and Karel Dujardin, he became a famous animal painter at an early age. This we see by a series of twenty-one etchings of different animals which he commenced at the age of It. Like the above-named artists he seems to have lacked opportunities, and so failed to leave us sporting pictures.

VERHAAGT, Tов1AS, also V'erhaigt and Verhaecht (1566-I63I), born at Antwerp. Travelled in Italy, and painted for the Grand Duke of Tuscany. He was the first master of Rubens. Most of his pictures are landscapes, but according to the interesting instance cited by Dr. W. Martin in the Burlington Magazine (I906) he must have also painted sporting pictures. For the Antwerp dealer lieter Coenraets made a contract with him, according to which he ordered eighteen hunting scenes on canvas, for which Verhaagt was to receive 30 florins apiece.

VINCBOONS, DA VID, also written Vincboins and Vinckenboons (I578-1629), born in Malins, a painter and etcher of considerable repute, but inconsiderable productiveness. Studied art under his father who was a miniature painter. He travelled a good deal and settled down finally in Amsterdam. He also visited England, a picture of Richmond Palace by him being recorded by Nagler. In the Amsterdim Museum there is a fine hunting scene representing Prince Maurice and his retainers hunting. For us his most interesting work is the fine little series of ten oblong prints, of which the following are the principal details. The finely designed titlepage, marked "I," has in the centre a deerskin with stag's head above, as tablet, and bears the following inscription: I6I2 Has venationis, ancupii, et Piscationis formulas a DAITDE ITNCBOINS Pictore incentas et $+06$ delineatas. Nicolaus Piscator Chalcographus aeri incisas, in picturae amatorum et admiracoruin gratiam, hoc libello, spectatori benvolo Fruendas, dedicat. Then follow four lines of Dutch inscription and underneath : "Gedruckt $10 t$ Amsierdam bey Claes Ianss Visscher." On the title-page two men, one with hawk the other with fishing implements, and a great number of other sporting attributes, animals and dead game. Nagler says it contains twelve plates, but the writer has never seen more than ten.

This is probably the finest of all the small sets of sporting prints of the first quarter of the seventeenth century. Size $28 \times 10 \frac{1}{2} \mathrm{~cm}$. 2. Fox-hunting, marked left DVBoons Inuentor and P.S. 3. Bear-hunting, marked as last with additional P. Serwout sculpsit. 4. Wolf-hunting, marked as No. 2. 5. Wildhoar hunting, marked as Nos. 2 and 4 . 6. Rabbit-hunting, marked DVB. and below principal figure C. V. (for C. Visscher). 7. Stag-hunting, marked DVBoons and P. Serw. 8. Fishing, marked DVBoons and C. Visscher, fecit et excud; see Fig. 92. 9. Hawking, same as No. 2 ; see Fig. 93. Io. Hare-hunting, same as No. 2.

The three plates engraved by Visscher are inferior to those produced by $\mathrm{P}$. Serwout, of whom very little is known. Complete sets are scarce, the writer has come across only two; the last came up at Sotheby's, July I3, I 909, Quaritch buying it for $£ 20$.

Fig. 94 is a reproduction from a large proof plate $\left(48 \frac{1}{2} \times 35 \mathrm{~cm}\right.$. $)$ in the writer's collection, engraved by Ian. Londersel, representing various hunting scenes in the outskirts of a Flemish town. It is delightfully composed and full of charming details. Hind declares that his etchings of genre are exceedingly good.

VISSCHER, a family of famous engravers and publishers hailing from Amsterdam. They sometimes called themselves Piscator, and as in some cases father and son bore the same 


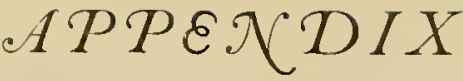

Christian names, it is in some instances almost impossible to differentiate them. Thus there were two Claes fansz, one lived from about I 550 to about I6I2, the other, his son, from I587-I660 (?). The Visscher firm of publishers was one of, if not the most, important in Antwerp in the first quarter of the seventeenth century, Nicolaes Visscher being probably the head when the second Dutch edition of the Venationes was issued, for it bears his name.

Cornelis, there were also two, the elder being known as "the old one," who lived from about I 520 to I 586, while another Cornelis (I1) lived from I 629 to I 662 (?), and became the most famous of his family. A pupil of Soutman, his technique with the needle by which he softened the lines of the graver was masterly, and he has been likened to Van Dyck in his skill for likenesses. A third Cornelis Visscher (1II) died in I7 IO. Dirk Visscher (1650-I707) flourished in Rome. Johannes Visscher ( I 636-i 692). LAMbert Visscher (I633? - after I690) died in Rome. Nicolas Visscher (16I81709).

VOS, Cornelis de (1585-165I), an Antwerp painter of considerable fame. Rubens used to send would-be customers to de Vos who, so he declared, "could do it as well as he could."

Cornelis, the Younger, probably a son of the latter, and brother of Paul and of Margaret who married Frans Snyders. Belonged to the Antwerp Guild in 1634 . Then there were a Jan and a Jan Janss de Voss, also a Jodocus de Vos of Brussels who copied Van Orley's Chasses de l'Empereur Maximilien Tapestry. There was also a Lambert de Vos who was an enrolled nember of the Antwerp guild in 1536 , and a Simon de Vos (1603-1678).
, Martin ( I53 I-I603 ?), a talented Antwerp painter of religious subjects. A few sporting subjects which the Sadelers and Collaert engraved after him are unimportant. He often drew in black chalk; a drawing by him in that medium is in the writer's collection.

It was Martii de Vos who prevented Queen Elizabeth's purchase, for the then enormous sum of 5000 rose-nobles, of the famous Burial of Christ by Quentin. Massis, when by a resolution of the owners, the Carpenter's Guild of Antwerp, the picture was offered for sale.

- PAulus, born in the beginning of the seventeenth century in Aelst in Flanders. He painted a few unimportant bear and stag hunts, his dogs being better than their prey. The Duke of Aershot and the King of Spain employed him a good deal. He died 1654.

-, Simon (1603-I678), born at Antwerp. From I6I5 to I620 he was a pupil of Cornelis de Vos. Like his namesakes he did a few hunting pictures, but they are unimportant, his chief work being portraiture and historical subjects. Van Dyck painted his portrait.

WACHSMUTH, Martin B, an Augsburg etcher, who worked about the middle of the eighteenth century, of whom very little is known. In the writer's collection there are three etchings on hunting and hawking, of which Fig. I 70 is one. They measure $30 \times 19 \mathrm{~cm}$., and probably were book illustrations. They bear the address "Joh. Georg Hertel, exc. Aug. V." Nagler mentions a Jeremias W., an engraver (1712-1779), who worked after Wouvermann and Teniers, but does not mention any artist with above initials.

WATTEAU, Antorne (I684-I72I), born in Valenciennes, painter and engraver, whose somewhat effeminate style hardly encourages 


\section{SPORT IX ART}

one to expect from his brush really interesting pictures of sporting scenes. He need not occupy us long. His short stay in England in $I 720$, which he had to cut short on account of the climate not agreeing with his weakly constitution, seems to have encouraged a manlier style; but his early death terminated only too soon any improvements in this direction. A picture by his brush, which is pleasing in itself, and which gives us a good idea of how sport was conducted in those powder-and-patch days, is Watteau's portrait of Madame de Vermenton, of which Bénoît Audran (I66I-I72I), one of a famous Lyons family of artists, engraved a fine large plate, of which Fig. I 43 is a reproduction. $\mathrm{He}$ calls it Retour de Chasse-I enationis Reditus. It is considered to be one of Audran's best plates.

WEENIX, JAN BAPTISTA (1621-I660), born in Amsterdam, according to Waagen in 1623 . He studied art in the studios of John Micker and Abraham Bloemaart, and finally with Nic. Moijaert, whose pictures he copied so well that the works of master and pupil could not be distinguished. Visiting Italy, Cardinal Pamfili and Pope Innocent employed him while in Rome. He excelled in depicting animals. Weenix, as Campo Weyerman tells us, used to take part in executing composite pictures, then very much in fashion. This was driven to excess by Antwerp artists, and pictures were produced in which the figures were painted by Eyckens, the fruit loy Gillemans, the flowers by Verbruggen, the stone vases by Balliuw, while the landscape and plants were put in by Rysbregts!

- JAN (164t-1719), an Amsterdam painter, son of the last, whose reputation rests chiefly on his pictures of dead game, which he usually painted in life-size, his speciality, as Waagen remarks, being dead hares, which are considered to be master works, almost a 408

match to Albrecht Dürer's chef d'auvre in the Albertina. One of if not the most important work of his is the huge canvas in the Munich Gallery (Alte Pinacothek), which measures some eleven by eighteen feet, and represents a dead stag, two hares, a wolf, and a wild boar lying dead in the foreground, while a boar-hunt is going on in the distance. Many of his important pictures went to England, but practically all the great Continental galleries contain pictures by hin. One of his principal patrons, Elector John William of the Palatinate, had three big halls in his château of Bendsberg, near Cologne, hung entirely with his game pictures.

WEYERMANNS, Jagues C. (1677 ?-I747), a Breda painter and author of dissolute character, who roamed through Europe bent upon amorous adventures, of which he had an extraordinary number. He died finally in prison, whither he had been condemned for life for attacking the Dutch East India Company! Of his sporting subjects, we have come across but two large prints. On the one a stag-hunt is depicted, where two sportsmen on horseback with drawn hangers in their hands are following a stag in the act of soiling. The other plate represents a hawking scene. Both are engraved by Jacob G. Thelot, whose name is occasionally spelt with two t's. Whether or not Weyermanns painted these pictures during his residence in England, whither he had fled with a widow he had abducted, and where he appears to have remained until he had spent her fortune, is not known.

WIERIX, Anton (1552?-1624), born in Amsterdan, the youngest of three brothers, well-known engravers in Antwerp. Between them, it is said, over 2000 engravings of various sorts were turned out, Dürer's style being carefully copied by them. Most of then are portraits or devotional subjects, 


\section{APPEX $\mathcal{X} I X$}

Stradanus' renderings of the latter type being special favourites, but a few unimportant hunting scenes were also produced by them.

Hieronymus (1553-16i3), brother of the above, whose work exhibits the same neatness of technique, attention to details, but lack of spirit, for which all the prints by the three brothers are remarkable. It was he who furnished the portraits of painters for van Mander's Levens der Schilders.

- JAN (1549-1615), the eldest of the three Wierix. His work resembles that of his two brothers.

WITTE, Pieter de, also Candid and Candito (I 548 ? -1628 ?), a Bruges painter and architect, who went to Florence and made friends with Vasari. In 1569 he was already designing tapestry cartoons. Vasari took him to Rome in 1564, and obtained employment for him there in the Vatican. He returned to Florence, where he was kept busy designing gobelins for the Grand Duke, and also assisted Vasari in adorning the great cupola of the Florence dome. In 1578 he went to Germany, and entered the service of Duke Albrecht $V$ of Bavaria, in whose bodyguard his brother was serving. When Albrecht died he continued with his successor William, and at his demise became a favourite with the next ruler, Duke Maximilian I, for whom he designed the new ducal palace, where he also painted several ceilings. $\mathrm{He}$ had a lasting influence on Bavarian art, and did for Munich what Vasari achieved for Florence. In the Pinacothek print room there are preserved many works of his. His "Deeds of Otto of Wittelsbach" C. G. Amling engraved in thirteen plates in the following century.

WOCHER, MARQUARD (I758-I825), designer and etcher, born in Seckingen, went to Paris, where he copied some of the Raphaels in the Louvre in miniature. On settling down in Basle he directed his attention to Swiss landscapes and costumes, etching many of Lory's and Aschmann's designs, but also executing original work. One of his best works, which earned him a good deal of fame, was a landscape of the entourage of Thun.

WOOLLETT, WiLLIA $(1735-1785)$, said to have been the first English engraver who worked his plates with a combination of point and graver, and who reached great perfection in landscapes. Though historical subjects and portraits seemed to have had greater attraction for hin than sporting scenes, he has left us some delightful plates after Stubbs.

WOOTTON, Jон ( 1690 ? -1765 ), a pupil of Jan Wyck, whose paintings of horse-races and hunting scenes secured him considerable renown, and high prices were paid for his work. His seven fox-hunting pictures, which Pierre Charles Canot (I7 Io-1777), a Parisian engraver, who came to England about the year 1740, reproduced, and which have lost none of their popularity, are his best-known works. A large canvas (6 ft. 8 in. $\times 8 \mathrm{ft} .5$ in.) called A Hunting Piece, which used to hang in the Hunting hall at Houghton, is interesting historically, for it contains portraits of Sir Robert Walpole and other celebrities. David Lerpinière, a London engraver, who worked there in the second half of the eighteenth century, engraved a handsome plate after it. The following possess well-known pictures by him: H.M. the King, A Stag Hunt; Duke of Devonshire, Nerwmarket; the Duke of Leeds, The Arabian; Mr. E. Tattersall, Flying Childers.

WOUTERS, Frans (I612 ?-1659), a Brabant painter, pupil of Rubens, court painter of Emperor Ferdinand II. In I637 he accompanied the latter's Ambassador to $3 \mathrm{~F}$ 


\section{SPORT IX ART}

London, where he got to know Van Dyck, and became attached to the Prince of Wales's court. He painted a number of landscapes and some mythological scenes dealing indirectly with sport. At the outbreak of the Revolution he returned to Antwerp, where he became Director of the Academy.

WOUVERMAN, Philips (1620-I668), was the cleverest as also the eldest of three brothers, natives of Haarlem, Pieter and Jan never approaching Philips. Of his 522 paintings the majority deal with out-of-door life, cleverly composed campscenes, cavalry fights, sylvan entertainments and sports of all sorts, pictures that are more noteworthy on account of their harmonious composition and pleasing effect than for any novel or striking features. Outside of Paris his picture of stag-hunting in Munich and of heron-hawking in Amsterdam are probably the most remarkable contributions on our subject. Jean Moyreau (I690I 762) engraved nearly ninety of Wouverman's canvases, of which twenty-eight relate to the chase, presenting scenes of "sporting still-life" of wearisome uniformity.

, Pieter (i626-i 683), has also left us some hunting pictures. They are well drawn and carefully painted, but lack his brother Philips' force and freedom. Some of his best hunting scenes are in the Ermitage, but we have not come across any engravings after this master. The third brother Jan painted only landscapes.

WYCK, JAN (1640?-I702), a Haarlem painter who lived many years in England and died at Mortlake. His principal subjects were battle scenes and also hunting episodes. $\mathrm{He}$ is said to have painted the horses in Kneller's equestrian pictures. Some of his paintings were reproduced by one of the earliest mezzotint masters of England, John Smith the Elder (I654-1719), the friend of Kneller. There is no special feature of interest in connection with them. Walpole states that he wrote a book on hunting and falconry, but we have been unable to discover a copy of it. There is a drawing of his in the Albertina of a stag-hunt, rather in the style of Wouverman. In the Ermitage there are studies of hounds which were attributed to Snyders, and which P. Earldom engraved many years later (I777). J. Smith and John Sympson engraved two stag-hunts after Jan Wyck, but we have not come across impressions. 
I N D E X 



\section{N D E X}

The artists dealt with in the Appendix, which is arranged alphabetically, are not mentioned in this Index

\author{
Abbey of St. Hubert, 2 I \\ Abbot horns, 35 \\ Achen See, 64,65 \\ Acts of the Apostles, 77, 80 \\ Adam and Eve of $1504,45,90,369$ \\ of 1507,369 \\ of 1509,45 \\ Adventure of Henry IV, 336 \\ Aelst, P. van, 77 \\ Eneas, Silvius, 290 \\ Asop's Fabies, I 97, 2 I 2 \\ African sport, 132 \\ Akbar, I 30 \\ Alardi, H., I 70 \\ Alaunts, 22, 32 \\ Albertina and other museums in \\ Vienna, 83,86, 92, 174, 305 \\ Albertus Magnus, 278 \\ Albrecht $V$, Duke of Bavaria, 98 \\ Alces malchis, 88 \\ Alfonso XI of Spain, 37 \\ Al fresco banquet, 66 \\ Alpenstock, 347
}

Alpine prints, best collection of, 342

Alresford Collection, 223

Altamira Cave, 2, 38

Ambassador's occupation, 184

Amboise, Castle of, 54, 300

Ambras, 6, 58, 64, 124

American anteater, 142

aurochs, 50, 336

bear, 306

bison, I 59, 306

buffalo, 334

fauna, 140

Amling, 223

Amman, Jobst, 96, I0I

Anjou, Charles of, 36

Marguerite of, 52

Anne, Queen of England, 1 Io of Bohemia, I64

Antient Hunting Notes, 2 I 9

Antin, Duke of, 248
Antler Chamber, 174

collections, 299, 369

Apocalypse, 80

Apollo, 3

Apprenticed to venery, 256

Arazzia Medica, I I 5

Arbalete, I 25

Archreological Journal, 94

Archduchess Margaret, 83

Mary, 83

Arco-Zinneberg, Count, 300

Arcussia, I9I

Ardennes, 3

Argote de Molina, 37

Arian, 2

Arkwright, I 92

"Pointer," 267

Arno, depicted by Stradanus, I 34

Arran, Earl of, 97

Arras tapessiers, 52

Art of shooting flying, 189

Arte de Ballesteria, 189

of Venerie, 103, 108, 128, 164, 273

Assembly, the, I 5, 324

Asser, 278

Athol, Duke of, I 87

Aubry, P., I67

Audran Bénoît, 224

Auerbach, Dr. M., 46

August II of Saxony, 294

Augustus, Elector, 174

of Poland, 46

III of Poland, 25 I

the Strong, $24^{\circ}$

Aurochs, $3,37,38$,

$$
\text { I } 63,309,336
$$

Ausfällen of chamois, 62

Austria, Duke of, 42

Author's bag of chamois, 72

bighorn, 306

escape, $35^{\circ}$
Author's otter, $20_{4}$

Aux quatre vents, 136

Aymar de Poitiers, 5

Bacler d'Albe, 342

Badger hunting, IOI, I 29

Baiting bear, 194

Balearic Islands, 127

Balen, van, I 69

Balester, 17

Balmat, Jacques, $33^{8}$

Baltic falcons, 42

Barker, Christopher, $\mathrm{I}_{0} 3$

Barlow, Francis, 197-209, 214,278

Baroque in sport, 243

Barriere ambulante, $3 t^{2}$

Bär Spiess, 68

Basse lisse, 248

Bastard, Charles, $3+4$

Bat fowling, I 26

Bâton fourchie, 26

Battle of Pavia, tapestry, 79

Baudre, $3 \circ$

Baumgärtner, T. W., 85

Bavarian Court, 244

Bayeux Tapestry, 7

Bear baiting, 194

hunters in armour, I I 8 , I 22

hunting, 32

Beasts of chase, 13

of venery, I 3

Beaufort, Duke of, 254

Beaufoy, Mark Colonel, 338

Beauvois, 109

Beaver, fable of the, 2 I 2

Beck, Leonhard, 57

Belles Chasses de Guise, 80 de L'Empereur'A Maximilien, 76-84

Belts of aurochs skins, 46

Benvenuto Cellini, 96

Bergen, Count of, 42

Bergstöcke, 6I

Bernard of Cles, 6 
Berner, 15

Berri, Due de, $;$;

Besançon Library, 86

'Bestiltigies Jagen, 300

Bestiaries, 3, +1, 119

d'Amour, 3

Dirin, 3

Becius, Caspar, 46

'Biobliothigue Nationale, 5, 99, 369

Bicst, van der, $1 ; 1$

Bighorn crushing lynx, 306

Bird-snarer, the, $2-8$

Bisct, 169

Bishop of Trent, 6

Bison, $37-51,149,159,163,309$, $33+, 336$

Blading culprits, 178

Blomc, 193, 198, 198-209, 210, Buckingham, Duke of, 195 213,278

Blundevillc, 312

Boitsfort, $8_{2}, \delta_{4}$

Bol, Hans, 49, 146,190

Bona, Qucen, +6

Bonaparte, Joscph, 94

Bonfaldini, 189

Bonifacc of Mayence, 278

Book of St. Albans, 132

Booke of Faulconite, $10+$

Borghini, 138

Bos Girmanus, 50

Boson, 26

Bottega, Tcmpesta's, 161

Bouc sauage, 28

ysarus, 28

Boucher, $2+8$

Boxberger, 101

Brabant, dukes of, 82

John $I V$ of, 5 :

Brandenburg, Elector of, 284

Markgraves, 300

Branding hounds, 251

Brantome, $16+$

Breadalbane, Lord, 93

Bretschneider, 195

Breuil dbbé, 38

Breuning, I 86

Brevarium Grimani, 55, 82

$4 I 4$
Brézć, Jacques de, 325

Jchan, 36

Louis, 6

Brimstone, izS

British Columbian otter, 204

Iuseum, 91, 155, 231, 332

Brittany, Mary of, 36

Brocke's veries, 309

Brooke, Sir Thomas, 86

Brue, Jörg, 87

Brueghel the Elder, 169

Brun, 9

Brunswick, Louis of, $2+2$

Brussels Gobelin manufactory, 78

Palace destroyed, 94

Bry, Theodore de, I I I, 153

Bucentaur, $24+$

Buffalo, see Bison

Buffon, 32

Burgkmair, Hans, 57,87

Burgundian Library, 58,82

Burgundy, Duke of, 35, $4^{2}$

Philip of, 5

Bynneman, Henry, IO4

Cabbaging the antlers, 107

Caccia de' daini, $13^{8}$

Cadge, use of, 268

Casar, 3, + I, I 28

Camera degli Sposi, 54

Campbell Dodgson, $8 z$

Candid, see P. de Witte, I7I, 223

Canterbury, Archbishop of, 98

Tales, I6+

Capitularies, 3

Captain Cook, 106

Capiuring aild animals, 306

Cardinal Adrian, 96

Gaetano, +8

von Rodt, 293

Cerigon, $141-3$

Carousel, the, 3 I I

Cartailhac, Emile, 38

Cartbende, van, 169

Castellamonte, Count, 165, 219

Castello di Carti, 54

\section{SPORT IX ART}

Castenado, I 60

Castle of Mererques, 37

Cave dwellers, 132

Caverne d Altamira, 2, 38

Caves of Ardiche, 2

Carezan, the, 312

Century Dictionary, 37

Cerr'us Virginianus, 156

Chaise volante, 327

Chalmers, Alexander, ro5

Chalon, H. B., 254

Chamberlain's letter, 110

Chamois hunting, 28, 58, 6r, 70, 72, $116,120,230,307$

rubbing their horns, 72

with reversed horns, 120

Chamonix, 338

Chantilly, 55, 80

Charavay, Etienne, 343

Charcoal-burner and king, 336

Charette de Chasse, 30, 101

Charlemont, Lurd, I 55

Charles the Good, II 5

the Gieat, 3, 38

$V$, Emperor, 76, 84, 92, 94

VI, I 86

I of England, so

II, $1+6,202$

VII of France, 5

IX, 100,330

Charlotte of France, 6

Chartres, Due de, 344

Chase Devil, the, 185

in boats, 96

Chasse à courre, $2+8$

cuisiniere, 192

Chaucer's Wife of Bath, $16_{4}$

Cheetah, r 30

Cheltenham MS., Io

Chopping a fox, 209

at the stag's head, 209

Christian of Denmark, 46, 194

Christie's, sale at, 94

Chronicle of Angilbert, 3

Churchmen as hunters, 290

Church organ-lofts, use of, 70

Clamorgan, Jean de, Ioo 
Clarence, Duke of, 37

Claus the dwarf, i 76

Clean weights of stags, 177

Coat of mail worn by hounds, 83,305

Coburg Hunting Chronicle, I 72

late Duke of, 305

Veste, 94

Cock, Hieronymus, I 6

Coggiola, Giulio, 55

Col du Géant, $34^{6}$

Collins, I., 2 I 4

Columbus, I70

Colvin, Sir Sidney, 23 I

Combat of Naked Men, 99

Combats of animals, 191

Combined arms, 94

Commercial exploitation of art, I 16

Commines, Philippe de, 54

Connétable de Bourbon, 6,96

Connoisseurs, 330

Conquest of Tunis, 80

Constance, Chronicle of, 39, 4 I

Contemplation of wild animals, 309

Conti, Prince, 248

Cony catching, 199

Cook, T. A., 358

Coques, 169

Cor d"Angleterre, 35

Coronado's expedition, 160

Corpus Christi, Cambridge, 35

Cort, Cornelius, 85

Corty, 160

Cosimo de Medici, I 15

Cosmographice Introductio, $1_{42}$

Cost of tapestry panels, 80

Costumes, fantastic, 220

Couderberg, Chapel of, 80

Coursing fallow deer, 205

Courtaults, 320

Court Jew, 66

Library, Vienna, 58

Cox, Nicholas, I 89

Cradock, Lucas, 2 I 2

Cranichstein, 293, 297, 299

Crayfishing, 68

Creel, shape of, 20 I

Crevasse, crossing a, $34^{8}$

\section{$I \mathcal{X} D \in X$}

Crispin de Passe, I 70

Cross-bow, 30

Csar of Muscovy, 273

Culverings, 97

Curée, 22, 107, 179

chaude, $33^{2}$

Curious Events, 306

"off-takes," I 56

Cuvier's Règne Animal, 50

Cynegeticus, 2

Dammkirsch of Goethe, 88

Dammthier, 40

Danube, stag in the, $3 \mathrm{O}_{+}$

Darmstadt, deer park, 294

Duuphin of France, 224, 336

Davenport, Mr. and Mrs., 251

David, Dr. Harry, 46, 88, 90

Davis, Th. R., 254

Dead hound's legacy, I IO

De Arte Venandi, 277

Death of Gaston de Foix, 6

of tracking hound, 72

stroke, giving the, 14

De Beaumont, I I 2

Delaune, 99

De Negkers, 86

Desportes, François, 224

Destortoires, 26,330

Devonshire, Duke of, tapestry, 47,52 Emanuel, King of Portugal, 9I

Diana, 3, 195

Diane de Poitiers, 6, 54, 369

Diarium, 42

Dictionary of Nat. Biography, 2 I I

Dienecker, Jost, 57

Döbel, 318

Dodgson, Campbell, 82

Doe at rest, 53

Dordogne caves, 2

Drau river in Tyrol, 68

Drawings by Stradanus, 19

Drentwed, 195

Dresden, 76, 175, 195, 212 combats at, 194

Dress worn by de Saussure, 345, 347

Droppings, presenting the, 19, 105 , 324
Dryden, Sir Henry, 113

Miss Alice, 113

Duck decoy's, 146

Dunkeld, woods of, 187

Dürer, Albrecht, 45, 57, 85, 91, 102, 1 I 4

visit to Brussels, 76

drawings in Brit. Mus., 45, 88, 90 prayer book, 86

Dürer, Hans, 87

Dutch artists, 169

Dutton, Sir Ralph, 203

Dwarf jesters, 175

EarLiest English fishing picture, 132

Eastwell Park, 30

Ebsdorp map, 42

Edward II of England, 204

Eingestelltes Jagen, 176

Elector John Frederick, 92, 98 of Bavaria, 220

Elephant hunting, 132

Elephas priniigenius, 1

Elizabeth, Queen of England, I03, I I $3,153,164,277$

Duchess, I 7 I

Elk by Dürer, 88

last, in Germany, 90

Ellis, Godfrey, $34^{2}$

Emperor William, $3^{\circ}$

England, King of, 42

Engländer, the, 277

English fowlers, 126

horses and grooms, 3 i 8

in France, 328

hunting, II

Epigrammata Selecta, $\mathbf{1}_{49}$

Erbach, Count, 298, 299, 332

Ernst II, Duke of Coburg, I 88, 305

Esau Venator, 185

Escalera, de la, I 89

Escurial, 92

Estortpoires, 26

Ethelbert, King, 278

Evelyn, 146

Exchaquet, F. Ch., $35^{\circ}$ 


\section{SPORT IX ART}

Exmoor, hunting on, $63,319,328$

Extinction of aurochs, +8

Eyck, Henry van, ; I

John van, +3, ;

Faire ses brises, 323

Faled Pompeian relic, 90

Falconry, Ridinger's, 268

Fall of Rome, ?

Fallow deer coursing, 205

Fees paid to painters, 96

Fistalit of stags, 1 86

Ferdinand, Archluke, 6, I1t

Emperor, 186

King, $+6,92$

the Carholic, 13

"Ferreter," 128

Fewmets, presenting, 19, 105, 32+

Fewterer's horns, 35

Feyerabend, 96, 101

Fifty sons, story of, 100

Figh's of wild animals. 308

Fire-arms, $6+, 96,123,12+, 235,24 t$

First plantation in America, $15+$

Fishing book of Maximilian, $; 7,68$

by Barlow, 199, 200

by Bol, 150

by Seradanus, 132

gloves, 64

Floschenthurm, $9+$

Fleet Sirect sale, 10

Fleming, $23+, 283,318$

Flipare, 248

Florence Muscum, $2+6$

Florentine Picture Chronicic, 53

Florida massacre, 154

Fontainebleau, 99

Forest of Sauveterre, 6

Forhucr, 332

Forked bolts of Shakespeare, 26

Formido, 304

Formschneider's craft, 86

Fortune est wourrice de Folic, $3+8$

Forty-four pointer, 289

Foucquet, Jean, 6

Foucquet, Jean, 6
Fouilloux, Jacques de, 32, 100, 101 Gestell, J. F., 2;6 $416^{324,330}$
Fournival's Bestiary

Fowling-pieces, 267

Fox caught by pike, 305

hunting, 26, 209

sinoked out, 230

cossing, 232, 238

Francis I of France, 6, 131, 322, 330

$$
\text { II, 97, } 99
$$

Joseph, Empcror, 58

Franco, Giacomo, 190 -German War, 300

Fraying-posts, 322

Frederick II, Emperor, 277

French antlers, 327

Par Force hunting, 70, 318-332

Fresco of V'espucci, $1++-5$

Frescoes in Tratzberg, 74

Frisian hound, 169

Frisius, Simon, 168

Theodore, I 69

Froissart, 9

Fúc, 126

Fumes or droppings, 19, 105, 324

Fusil, the long, $22+$

Gabrielle d'Estrées, 336

Gace de la Buigne, +2, 325

Galle, Cornelius, 135

Philip, 48,117 , I 46

Gallwey, Sir Ralph P., I 46

Game-books, 18 I

Game shot by Maximilian, 69

Gaston de Foix, 3, 5, 6, 34, 52, 83, $20,5,278$

Gathering, the, I5

Gaul, 2

Gejoid Buch, 57

Geldern, Count of, 42

Geneva, $3+7$

Gentleman's Recreation, 189

George I of England, I66, 235

Georgicn Curiosa, 191

German peasantry, 182

Gesner, Conrad, 9 I, I 3 I

Ghirlandajo, $14+-5$
Giehlow, Karl's reproduction, 86

Gilbey, Sir Walter, Pref., 212

Gironde caves, 2

Glacieres, 3 to

Goethe's Dammhirsch, 88

aurochs, 45

Golczius, H., 169

Gonzaga, Lodovico, 54

Goshawk, I 50, 203

Gotha, armoury, 305 siege of, 174

"Goths" or Gothians, 45

Gozzoli, 13 I

Grand-Carteret's book, 338

Duc, the, 268,283

Giant, 345

Gresse, 32

Vinerie, 82

Grande Chasseresse, $8_{3}$

Grate Posteritati, 46

Great antlers in Tratzberg, 75 pair of antlers, 332

Gregory XIII, Popc, I64

Grenadiers, company of, 204

Grenville, Sir R., I 53

Greyhounds, 32

Gribelin, S., 2 I $4_{4}$

Grimani's Book of Hours, 55, 82

Groenendael, 82

Gross Glockner, accident on, 350

first ascent, 70,350

Grünwald, battle of, 42

Gryndal, W., $28_{3}$

Gunners and Hawkers, 264

Gunnis, 97

Gurk, Bishop of, 350

Gustarus Adolphus, 90

Gutmann, R. von, 389

Habsburg archives, I 86 pedigree, 74

Hacquet's Travels, 350

Haecken, Van, 248

Haghia Triada, 4 I

"Hail" or shot, I $2+$

Hakluyt, I I

Half Hags, 97 


\section{$I \mathcal{X} \mathcal{D} \& X$}

Hall, salt mines at, 72

Halse Hags, 97

Halzhalb's aurochs, 50, 336

Hamilton Smith picture, 50

Hampton Court, pictures in, 54, 110

Hamstringing stags, 33

Harbouring the hart, 15

Hardegg, Henry, Count, 70

Hardelling, 2 I

Hardes of hounds, 63,325

Hardouin de Fontaines-Guerin, 36

Hardwicke Hall, 52

Hare hunting, 24, 197, 23+

netting, 25

shooting, 25

Hariot, Thomas, 140

Haroun-al-Raschid, 38

Harting, J. E., I46, I49, 150, 268, $277,278,283$

Haussee Pied, 27

Hawking club, 122

Hayas, 4

Haywaggon, wood-blocks in, IoI

Hector, 9

Heiligenblut, $35^{\circ}$

Henry II of England, 205

IV, 52

$\mathrm{V}, 4^{1}$

VIII, I 26

II of France, 54, IIO

III, 192

IV, I $12,192,336$

Herberstein, Baron, 46

House, 47

Hercynian Woods, 38,42

Heristallum, 38

Heron hawking, 201, 277

Herrenhausen, I66, 235

d'Hertoginne-Dael, 82

Hesse-Darmstadt, stags of, 293

Hesse, Dukes of, 97, 186

Heures de Thurin, 55

Highland deer, 262

Hildegarde, 38

Hind's History of Engraving, 334 Italian Engravings, 53

Hinder-Riss chamois, 59, 72
Hipschmann, S. G., 195

Hirschjänger, 85, I 81

Hirschvogel, Augustin, 46, 47

Historia Animalium, 92

Historianl Indicarum, I 42

Historie of foure-footed Beastes, 50, 92

Hoecke, Van, i 89

Hogarth, 257

Hohberg, Baron, I9I

Hohenleyter, Wolfgang, 59, 68

Hohe $W$ and, 72

Hollar, W., 197-209, 258

Holstein, Duke of, 194

Hoops and Wigs, 167

Horace, 2, I 50

Horquilla, i 89

Horses in France, 328

how they were trained, 3 I 2

Houghton, 90

Hounds and peasantry, I 84

breeding of, 15

devouring their master, 337

names of, 196

number of, 196

of Gaston de Foix, 32

treatment of, 32

Hubertusburg, $25 \mathrm{I}$

Hufnagel, G., I 14

Hungary, King of, 42

Hunger's Prevention, 283

Hunt after Wealth, 169 breakfast, I05

Hunting Calendar, I 96

crops, 26, 330

diaries, 186

exhibition, $174,18 \mathrm{r}$

hall in Tratzberg, 74

train, 178

Hutten, Hans von, 186

IBEX HUNTING, 28, 62, I 2 I and lynx, 306

Iliad, 2

Illustrated London News, 38

Indian fishing, 158

stalking deer, I 56

$3 \mathrm{G}$
Instructions how to shoot, 192, 193

Irish hunters, 329

Italians good at shooting, 190

hunting, 220

Jacht Buch, 172

Jagdschaft, 62

Jaktorowka, 46, $4^{8}$

James I of England, I08, I09

Jarocki, $4^{8}$

Jerfalcon, 273

Jesuit father Moffe, ${ }^{4}{ }^{2}$

Jewel, i ro

Fevell for Gentrie, 283

Jews at Maximilian's court, 66

in Germany, 183

forced to buy wild boar, 290

make sewells, 304

Joachim, Dr. Erich, 42

Jode, de, I99

John Casimir, Duke, 172

George I and II of Saxony, 18I, I 86

le Valois, 52

Jordaens, 169

Joseph I, Emperor, I92

Joullain, F., 224

Juggling with wood-blocks, 108

Julius II, Pope, 290

Katzenellaogen, Count of, 42

Keller, Prof. Conrad, $4 \mathrm{I}$

Jörg, I I

Kellner of Geneva, 346

Kempenare, 146

Kessel, Van, I69

Killermann, Dr. Lib., 46

King Minos, 4I

Kirkall, 334

Kite, use of, 268

Klauber brothers, the, 85

Knossos, 4I

Kölderer, 57

Kracksen, $34^{8}$

Kukuck's Bad, 195

Küsel, Mel., 220 
La Cacio di Bilfori, it

La Cambre, 82

Le Chace doss Cerf, 36

Ladies riding astridc, $16_{3}$

Laisser courre, 20

Lake Leman, 293

La Liere de Chasse, 5 et seq.

La Mouthe grotto, 2

Lampooning spore, $231-4$

La Nuctic, 80

Lamy, J. P., $3+6$

Lancret, $2 f^{S}$

Landau, 294

Landsecr, 262

Landsknechec, 6

Lappen or sewells, 183,304

Large Riding School, 311

L'art le voulait, 330

Laudonnière, 153

La Vallée, 6, 248

Leaps of the ibex, 29

Leblond, 80

Leeds, Duke of, 122

Lefevre, Jean, 36

Le Moyne, Morgues, 153

Leopard for hunting, 130

Leopold, Archduke, 195

I, Empcror, 132, 220

Lco X, Pope, 290

Le Ruises Inroecut, 216

Les belles Chasses de Maximilien, 76

Lessons in riding, 312

Le Théâtre dès Nains, 231

Le Tros, 3 a

L'Evique, Henri, 3+t

Library of St. Marks, 55

Libro de Monteria, 37

Lichtenstcin, U. ron, 175

Lienz in Ty'rol, 68

Lignivilic, 112

Line of Pride, 188

Liniers, Castle of, 100

Link, J. A., 350

Lissabon, 91

Litcraturc on hawking, 277

Lirhuania, + I

Little Passion, +5

4 I 8

\section{SPORT IX ART}

Listle Turtle Doe'e, +6

Livonia, 334

Livre de Chasse, when written, 9

Lieres d'heures, 86

Locked drives, 293

Long Meadow, the, 66

Sir Robert, 192

Lonicer, 267

Loo, 122

Van, $2+8$

Low-bells for hare hunting, 33

Louis of France, 229

$\mathrm{XI}, 6,54$

XII, 300

XIII, 191, 325

$X[V, 6,126,192,223,22+$

$\mathrm{XV}, 248,328$

XVI, I 28, 336

VIII of Hesse, 297

Louviterie, 26

Louvre, the, 79,246

Love scenes in Flemish pictures, $S_{t}$

Lucas Cranach, 87, 92, 94 van Leyden, 102

Lucerne Lake, 332

Lufischiessen, 190

Lure, the, 278

Lusus naturee, 289

Lycurgus, 2, 3

Lydekker's The $O x$ and its Kindred, $; 1$

Lymer, the, 15, 20, 28, 32, 63

Ly'nx attacking stag, 332 crushed to dearh, 306

Mabuse, Jan DE, 55

Macedonian regulations, 2

Madrid, sport near, 189

Magdeburg Muscum, 37

Main morte, $33 \mathrm{I}$

Maison Gobelin, 247

Maitre d'Equipage, 326

Major, Thomas, 255

Mander, Karel van, 137, 1 46

Manege, 312

Mantegna, $5+, 102$

Mappenonde, $1+2-4$

Marc Antonio, the "pro," 192
Margaret, Regent, 76

Maricourt, I I 2

Marie Antoinette, 336

Marienburg, +2

Markham, G., 216

Marre], Peter, $34^{\circ}$

Martinez de Espinar, I 89, 191

Marx Treizsauerwein, 57

Mary, Queen, 97 of Burgundy, death of, 82 of the Joyous Spirit, $\delta_{1}$

Regent, 76

Stuart, 99

Masked a nimals, $2+2$

Maso Finiguerra,

Master of Game, 13, 14, 15, 22,; 73, end of book

of Werden, 85

Mastiffs, 32

Matins, artists at, 146

Matterhorn of Austria, $35^{\circ}$

Matthew, Emp., 194

Maurer, Ch., IOI

Maurice of Orange, I 70, 194

Mauvais pas, $34^{8}$

Mayr, Dr. M., 58

Maximilian, Emperor, 45, 46, 55, 59, $60,63,66,67,69,70,72$, $82,83,86,132$

assumption of imperial title, 59

as writer, 55

crossbow, 67

escapes, 72

financial straits, 66

fishing book, 132

hunts near Brussels, 82

marksmanship, 69

mountaineer, 70

passion for sport, 60

Pray'er Book, $45,76,86$

relations with Dürer, 86

stag hunting, methods of, 63

sword for boar hunting, 83

winter d̀ress, 82

Duke of Bavaria, I 7 I

Mechel, Ch. de, 339

Medirval hunting, It 
Mediæval I.O.U., 66

Medici, Catherine de, 164 Marshal, I 9

Meersburg, 293

Meeting place, I 5

Megaceros Hibernicus, I

Meissner mark, 25 I

Memling, Hans, 55

Mendez, 153

Merian, M., 1 53, 167

Metternich, Count, 258

Meulen, Van der, 223

Meutte d"attaque, 326

Michael Angelo, I 15

Mielle, Jan, 220

Miniatures, 5

Ministers burnt alive, I 86 quartered, 174

Minorca, 128

Minos, King, 4I

Mochly of Basle, 346

Modern M.S.H., 3 I 9

Moffe, 142

Moitte, A., $35^{\circ}$

Mongrel breeds, 32

Monk of St. Gall, 3

Montaigne, 138

Montagne Maudite, 338

Montagnier, Henry F., 338, 342, 357

Monsanvert, 340

Mont Blanc, story of, 338-35 I

Montmerque, 80

Monument to stag, 284

Moritzburg, 92, 299, 300

Morpurgo, Salomone, 55

Morte, blowing the, 22, 185,208

Most Wonderful Stags, the, 284

Mountaineers, early, 338-35 I

Mousterian art, 1, 38

Moyen Duc, the, 283

Moyreau, 223

M.S. 616 , when written, 6

Mucante, $4^{8}$

Müller, J. S., 50, 334

Munich, 94, 98, 171, 190

Musée Condé, 55

Musical notes, 219

\section{$I \mathcal{X} \mathcal{D} \& X$}

Muziano, Gir., 85

Muzzle-peg, 267

National Gallery, London, 85, I 89

Natural history notes, $7 \mathrm{I}$

Needles, 26

Negkers, Jost de, 57

Netting hares, 33 quails, 126

New Art of Riding, 310 Riding School, 311

Nimrod's procession, 195

Noble Realme of England, I08

Noirmont, I 26

Noort, Van, 169

Normandie, Guillaume de, 3

Norman hunting, 22

Nürnberg, Count of, 42

Oatland Park, I 3

Odericus Vitalis, 164

Odyssey, 2

Ognissanti, Church of, I $4+$

Oliphant, carved, 35

Oppian, 2, 92

Order of St. George, 86

Organ-lofts, use of, 70

Oriental literature, 2

Orleans, Duke of, 42 Louis of, 35

Orley, Bernard van, 76

Orthez, Castle of, 9

Ostrich hunting, 132

Otter hunting, 26, 203

spears, 205

traps, 268

Otto prints, 53

Oudry, Baptiste, 245

Ovid, 2

Paccard, Dr., 338

Palæolithic age, 1

Palazzo Vecchio, I 37

Palimpsest, 108

Pampeluna, 6

Pannemaker, 80

Paradise, the, $3 \mathrm{I} 6$
Parchment discharge, 256

Par Force hunting, 318, 332

Park, 183

Parma, Don Ph. of, tragic end of, 337

Parthey, I97

Partridge hawking, 149,202 setters, 317

Partridges, shot at Versailles, I92

Passe, de, I 70

Pathetic complaints, 183

Pavia, battle of, 6

Pavillon des Chasses, 99

Pearching Pheasants, 202, 2 I 5

Pepys, Mr., 192, 347

Perigord caves, 2

Pernau, Baron, 192

Persian literature, 2

Pesate, 315

Peter the Great, 247

Petrikau, 46

Pezold's poem, I 94

Pheasant hawking, 202 pearching, 202, 215

Philip IV of Spain, I 89, 195 Payne, 254

the Bold, Io

the Handsome, 72, 73

Phillipps, Sir Thomas, Io

Physiologus, 3

Pike catching a fox, 305

fishing, 199

Pillement, Jean, 256

Pineapple, 142

Pirkner, W., 172

Pisano, Vittore,

Piscator, I 50

Plantagenet hunting, 205

Pleasures of hunting, I4

Plessis, 54

Pliny, 92, 127

Pluvinel's Art of Riding, 170

Poachers' punishments, I 85

Pointer, book on the, 192

Poitiers, Aymar de, 5

Diana de, 6

Jean de, 6

Pol de Limbourg, 55 
Pollainolo, 99

Pompcian relic, 90

Pont, Guillaume de, 36

Pope Leo X, 77

Portraits by Ridinger, 333

Potoki, Baron, $t^{S}$

Powerscourt, Lord, 94

Prado, I Sg

Prague, gallcry' at, 195

Prater near Vienua, 220

Prajer Book by Dürcr, $76,86,88$

Prehistoric art, 1

Prescot, It+

Presenting the Antlers, 179

the Fercmets, 19, 105, 324

Presents of wild animals, 194

Printsellers' tricks, 161

Probst, J. B., 3II

Professional gunner, 267

Püffel, $t^{2}$

Pulecrin, $12+$

Punishments for poachers, 18 ;

Pürschrohr, 98

Pusey horn, 35

Putting up a Substitute, 329

QualL netring, 126

Quails, slaughter of, 283

Outotre Vents, 122

Queen Mathilda,

Quête, 63, 322

RabBit hunting, 126

warrens, 128

Raby Pack, $25+$

Radziwill, Prince, 194

Raleigh, I 53

Rambouillet, $2+8$

Rambouts, 169

Randall and Bcans' party, 351

Raphacl's cartoons, 76 , So

Razzoli, I 44

Reindecr hunting, $3 \mathbf{I}$

Reise-Jäger, 267

Relcis volant, 326

Relay"s, 19

Réné, King, 80

420

\section{SPORT IX ART}

Rent2, M., 195

Rerum Moscoviticarum, 48

Resch, 258

Retour de Chasse, $22+$

Reviewing the victims, 180

Rewarding the hounds, 22, 179

Rhinoceros by Dürer, 9 I

Ribault, 153

Richenthal, Ulrich von, $f 1$

Richmond Palace, 153

Riding astride, 163

Ridinger, J. E., 16\%, $25 \%-336$

birth, 257

hawking, 268

horses, 309

mezzotints, 332

mistakes about, 263

portrait, 335

Martin, 297, 335

Rink, 192

River-fishing, 199

Roanoke, 1+1, 153

Rochefoucauld, Duke of, $3+0$

Rocky Mountain goat, 29

Mountains, 306

Rogers, William, 102

Rolland, 9

Roman Campagna, the, 283

Romans, King of, $t^{2}$

Ronsard, 126

Rope, use of the, $34^{8}$

Rothschild, Baron, IIt

Rotterdam, V'an Stolk, 23 I

Rouge Cloitre, $\mathbf{S}_{2}, 8_{4}$

Royal sportswomen, 220

Roy Modus, 22, 36, +2, 20 ;

Rubens, 80, 195

Rugendas, 258

Running hounds, 21,32

Runnymede, 182

Ryckaert, 160

Ryc's publication, 109

SADELER, 137

Saenredam, I., 170

St. Germain, 3

-en-Lay'e, 80
St. Hubert, 3, 210,248

St. Martin, 3

St. Ravy, 112

Salaman, A., 102

Salmon fishing, 199

Salnove, 329

Salzburg, Bishop of, 185

Samuel Clarke's Fulius Casar, jo

Sandrart, 258

Satirical prints, $166,230-+$

Saussure, de, and Mont Blanc, $338-$ 51

Sautuola, Marcelino de, 38

Savoy, Princesses of, 165, 219, 220

Saxe-Weimar, Duke of, 109

Saxony, Electors of, 42, 186, 238, $28+$

stag-hunting in, 92, 299

Scato de Vries, 55

Schäuffelein, 57

Schönsperger, 57, 86

Schrottbüchse, 235

Schwarzburg, Count, 92

Schwaz, silver mines at, 72

Schrueinsfeder, 68

Schwerdt collection, 223

Science of horn-blowing, 35

Scoring appliance, 196

Scotch deer, i 87

Scotland, fire-arms in, 97

Scott, Walter, mistake by, 122

Scrope, 187

Secret Book of the Chase, 57

Selwyn, John, 1 I 3

Septfontaines, 82

Sermons of the chase, 185

Servia, stags of, 303

Services of the chase, 182

Serwout, 150

Sererall W'ayes of Hunting, 197, 209

Sewells, 304

Shirley's Deer Parks, 30

Shooting diary, 98

flying, 189,267

Show hunts, 236

Shrewsbury, Lord Gilbert, 98

Sibmacher, Johann, 49 
Siege of Rome, 96

Sienese school, 53

Sigismund, Augustus, of Poland, 46 Duke of Tyrol, 68

Sigismundswaid, 68

Silva Hectorea, 46

Sinister habits, 162

Sixty-six pointer, 284

Size of tapestry panels, 80

"Skieggers," 200

Slauper cave, I

Sloth, $x_{42}$

Snodham, Th., 283

Snow blindness, 349

cornice, 350

Snyders, I69, 195

Sobieski, 224

Soigne, forest of, $8 \mathrm{I}$

Solis, Virgil, 98

Sollas, Prof. W. J., 2

Soly, Arthur, 2 I 4

Sotheby, 155,156

Southern-mouthed hounds, 198

South Kensington Museum, 77, 80

Spangenberg, 18 ;

Spaniels, 32

Spanish Pointer, 256

Spaur, Carl von, 57, 59

Spears, length of, 62

Spork, Count, 195

Sport in the Alps, 188

of Princes, 318

Sporting Ladies, 166

Sportsman devoured, 337

Sportsman's Bible, 100

dress, 306

Spotted red deer, 303

Stadthalterei Archiv, 57,67

Staedel Institute, 52

Stag, despatching the, 223, 33 I

and four lynx, 332

heads, 188

hunting, 36, 1 22, 206

pictures of, $284-304$

shooting out of season, 98

stalking, rutting, 290

weights, 22, 176, 332

\section{$I \mathcal{X} \mathcal{D} \in X$}

Stalking big game, 30

carts, 30

cow, I 25

horse, use of, 267

Standing of Queen Elizabeth, 105

Staremberg lake, 244

Steinitzer, Alfred, $3 t^{\circ}$

Stevens, Henry, I 55

Stimmer, C. and T., IOI

Stouder, G. S., $35^{\circ}$

Strabo, 92

Stradanus, 3I, 48, 1 I 5-145, I90, Tracks of game, 308 $192,223,230,257$

Straet, Van der, see Stradanus

Strassburg, Bishop of, 38

Strecke, the, I 80

Stubbs, 256

Suber or bison, 48

Superiority of French shots, 193

Suppressed plates, 339

Suttele, 90

Swift English dog, 126

Sybilla of Cleve, 92

Sykes, Sir M. M., 254

Sympson, 2 I3

TACitus, 2

Tacul Glacier, 345

Tahillaud, 328

Taking eAssay, 106, 208

Tancarville, Count, 36

Tapestry works in Brussels, $77,78,80$

in Munich, 17

by Oudry, 246

Tapir, 142

Tarantus or Buffe, 50

Tempesta, Ant., 50, 146, 16I-4, Utrecht, Van, I 69 190

Teniers, David, I69, 255

Terra terra, 315

Tertullian, 92

Ter Vueren, 84

Teutonic knights, 31,42

Thaun, Philippe de, 3

The Byrrth of Mankind, 102

The Dearh of the Elk, 90

Theobalds, 109

Tyrolese art, II 4
Theuerdank, 55, 61, 66, 76, 83, го 3

Thielen, Van, I69

Thienemann, G., 257 et seq., 388

Thirty-two pointers, 294

Thoman, the brothers, 229

Thomson's History of Tapestry, 52

Thulden, Van, I69

Tirasse nets, I 26, 306

Topsell, Edward, 50, 92

Torgau, 94

Trab, Count Oswald, I 14

"Traitor" ducks, I 49

Tratzberg, Castle of, 74

Treasury of Venery, 36

Tresslerbuch, $4^{2}$

Tribute of the High Alps, 50

Tristan, 9

Trois Fontaines, 82

Tur or aurochs, 48

Turbervile, George, 104, 216,283

Nicholas, 105

Turenne, 6, 57

Turin, Book of Hours at, 55

hunting box near, 220

Turkish ambassador, 66

Turner, Charles, 254

Turning tail to tail, 283

Tweedmouth, Lord, I 14

Twici, 113,294

ULDEN, Van, 169

Ulm, 257

Undescribed coloured print, 346

Ursus Spelous,

Valets de Chiens, 324

$V$ alois, Duchess of, 220

Duke of, ${ }^{6} 62$

John le, 52

Val Verd, 82

Van Dyck, 150

Vanhaecken, 248

Van Stolk collection, 231

Varlet des foulcons, 51 
Vasari, I 20, 137

Vatican Library, 86

Velasquez, I 89

Veltres, 22

Venabulum, 198

Venaria Reale, 165, 219

Venationes; by Stradanus, 118, I 26, I 32

$V$ Vnationis, by $\mathrm{H}$. Bol, I +6

$V$ endée, forests of the, 336

Venetian noblemen, I 90

$\checkmark$ erard, 32

Vermenton, Madame de, 224

Versailles, bag of partridges at, 192

Vespucci's family, I $+5-6$ landfall, $138-145$

Veste at Coburg, 174

Victims of the Alps, 350

Vieilleville, Marshal, 110

Vienna, 83, 86, 92, I 74

Vigneau, Count, 6

Vincboons, 159

Vincennes, 229

Virgil, 2

Virginia, I 53

$V$ isscher, family of, I 50

Vitrey, M. de, I I 2

Vogelheerd, 283

Vos, Martin de, I69, I 70

Simon de, 169

Vouters, Dirk, I 71

\section{SPORT IX ART}

Wachsmuth, M. B., 256

Waddesdon Bequest, I 96

Waidblatt, 178

Waldseemüller, $142-4$

Walpole, Sir Horace, 90

Walton-on-Thames, i 3

Ward, William, 90, 254

Warsaw, 46

Water hunts, 236

Watteau, 224, 248

Wauchoppe, I

Wauters, Alphonse, 80

Weale's book on the Van Eycks, 52

Weidlitz, Hans, 82

Weighing stags, I 76

Weight of antlers, 332

Weisskunig, 55, 61

White, John, 141, I 53 stags, 294

Widt, de, 170

Wieser, F. von, I 42, 379

Wilczek, Count, $58,173,369,389$

Wild-fowling, I 24

Wild See, 68

Wildungen, 304

William the Conqueror, 4 present Emperor, 30, 289

Winchilsea, Lord, 30

Windhetz, 63

Windsor, 57, 109

Winendael, 82
Wisent, 38

Wisest jool of Europe, 329

Wiskitki forest, 46

Wittenweyer, battle of, $\mathrm{I}_{4}$

Witte, Pieter de, 223

Wocher, Marquard, $34^{2}$

Wodehouse, 149

Wolf hunting, 26 traps, 26

Wolff, Jeremias, 3 I I

Wolfsgabel, 189

Woodcock, flighting of, I 86

Woollett, William, 256

Wouverman, 220

Wřesniowski, 48

Württenberg, 42 , I 09, I 85, I 86,256 , 289,303

Wynkyn de Worde, I32

XENOPHON, 2, 3

YAuviLle, d', 326, 328

Yeates, Nic., $21+$

Yellow sash of Jews, 66

York, Duke Edward of, I , I 5, 24, 35,37

Z.APATA, Bart., 2 I 9

Zehender, C. L., 344

Zoologist, The, $\mathrm{I}_{4} 6$

Zubry or bison, 48 


\title{
THE MASTER OF GAME. By Edward, Second
}

Duke of York. (Written between $\mathrm{r}_{4} 06-\mathrm{x}_{4} \mathrm{r} 3$, and now printed for the first time.) Edited by $W . \Lambda$. and F. BAILLIE-GROHMAN, with a Preface by THEODORE ROOSEvElT.

\begin{abstract}
With 44 Facsimile Photogravure Plates ( 4 with original text) and Frontispiece reproduced in Colours and Gold, from the Miniatures in the famous MS. f. fr. 616 in the Bibliotheque Nationale, Paris. Monotint reproductions of the drawings in the Bodleian ". Mlaster of Game" (MS. Bodl. 546), and other reproductions, transcripts of bitherto unpublished MSS. and Docunents, Literary and Historical Notes, a Bibliography of MSS. and Printed Books on Hunting in the principal Languages of Europe up to the end of the sixteenth century, and a Glossary of Ancient English Hunting Terms, with Index.
\end{abstract}

Published for the Editors by BALLANTYNE \& CO., r4 TAvistock Street, Covent Garden, London, W.C. Price £6.

Their Majesties the late King and the present King were pleased to subscribe for copies; Emperor William of Germany, Archduhe Francis Ferdinand, future Emperor of Austria, and other royalties also obtaining copies.

\section{EXTRACTS FROM THE PRESS}

". THE Oldest English Book on Hunting renews its youth in a superb and massive volume, elabcrately illustrated with reproductions of the quaintest of medixval drawings. The archaic text of the original English is happily modernised in parallel columns appendix is a treasury of research. . . and the bibliographical catalogue is exhaustive "-Times.

"A more sumptucusly prepared edition than this stately folio produced under the tender care of Mr. Baillie-Grohman, with it wealth of introduction and apper dix, and its admirably written wealth of introduction and apper dix, and its admirably written
introduction by that ol ber prince of sfortsmen, Mr. Ihecdore Roosevelt, it would be difficulin to find. Tfortsmen, Mr. 'I hecdore publication must have been immense, but it has been spent to good publication must have been immense, but it has been spent to good
purpose. A great classic has been rescued from ot livic n."-Fort nightly Rezicui, November Iço5.

"There can be no hesitation in ascribing to the magnificently produced volume the first place in the classics of bunting of a earlier date ever given to the public of our day. Some of the attractions of this splendid volume... the illustrations which are as interesting as the text. . absolutely a masterpiece - . the endurance of a scholarly and rational enthusiasm in the history and pursuit of sport has its monument in the fine work now tresented."-Spectator.

"In many respects this is a remarkable book. It is the oldest treatise on hunting in the English language. It was written jus five centuries ago, and, strange to say, until the present time it has never been printed. As the treatise is from many points of view of considerable importance, one would bave supposed that long ere this some enthusiastic scholar with a love for the chase would have been found both able and willing to undertake its publication. On the other hand, we have only to look at the text as now presented to us to see that its preparation implies an enormous amount of labour, involving a collation of the various MSS, a verbatim literatim transcription of the text, a modern English translation in parallel columns, critical and explanatory notes, and a glossary of ancient hunting terms ; in a word, a thorough mastery of the subject. All this Mr. and Mrs, Baillie-Grohman have accomplished and indeed much more, for they have yiven an account of the existing MISS. of the work, a bibliography of the medizenal literature of the chase. In the way of reproduction nothing could be better . : the tout ensemble is a model of good taste and fine printing." -Field.

"This beautiful book ... in such sumptuous orm . . . bears evidence of wide research and of care in preparation. The sumptuous production it is and the jlluminations from old MSS. have been reproduced as well as it was possible to reproduce them." - Baily's Magazine.
"This is really an extremely interesting book, and if Mr. Baillie. Grobman is as painstaking and accurate with his rifle as be is with his pen, it is small wonder that he is in the front rank of contemporary sportsmen."-Land and Water.

"A notable possession ... fine work ... a MS. of extraordinary pictorial merit."-Countrn Life.

"Singularly interesting and amusing .... sumptuous book ... an immense amount of hibliographical information .... Nhr authority will he generally recognised."-Standord.

"Magnificent folio ... the editor"s notes on the text are full of far-sougbt infermation, and, what is more, are delight fully written ... Excellent reproductions of the beautifu] minialuses of hunting scenes ... Every detail of the workmanship of the folio is as near perfection as the medern prirter's craft can bring it. Happy is the perfection as the mcdern prirter's craft can bring it. Happy is
sportsman and scholar who has a copy of it." - Mrornins Post.

"Mr. and Mrs. Baillie-Grohman have done their wolk as editcrs admirably. . . notbing could be better than the general 'get up" of this cbarning volume.-Country Gentleman.

"One can hardly speak too highly or the loving and enthusiastic care which the editors have manifested in preparing the work for publication."-Nation (Neze York).

"Magnificent edition of the 'Master of Game," eoited with a loving care that makes it a literary marvel. No labour, no expense has been too great for the editors of this truly splendid edition of a singularly interesting work." -New York Herald.

"Sumpluous folio of the first importance to students... it must ever be considered a classic of its kind.-Chicago Tritune.

President PoOSEvelt, in his Forezurd to the book, says: such. Baillie-Grohman, in reproducing The such beautiful form has rendered a real service allows of of nature and of books-and no one can get the highest enjoyment out of sport unless be can live over again in the library the keen pleasure be experienced in the wilderness. ... It is a good thing for a man to be forced to show self-reliance, resourcerulness in emergency, willingness to endure fatigue end bunger, and at ne to face risk. Hunting is praisek ortby very much in proportion as it tends to develop these qualities. Mr. Bailhe-Grobman has himself followed in its most manly forms this, the manliest of sports. He bas hunted the tear, the wapiti, and the mountain-ran in the wildest regions of the Rockies, and also by fair stalking the chamois and the red deer in the Alps. Whoever babitually follows which it is a good thing for any nation to see brougbt out in its sons." 



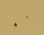

. 

$1-9$

$\because$

[1]

. 
